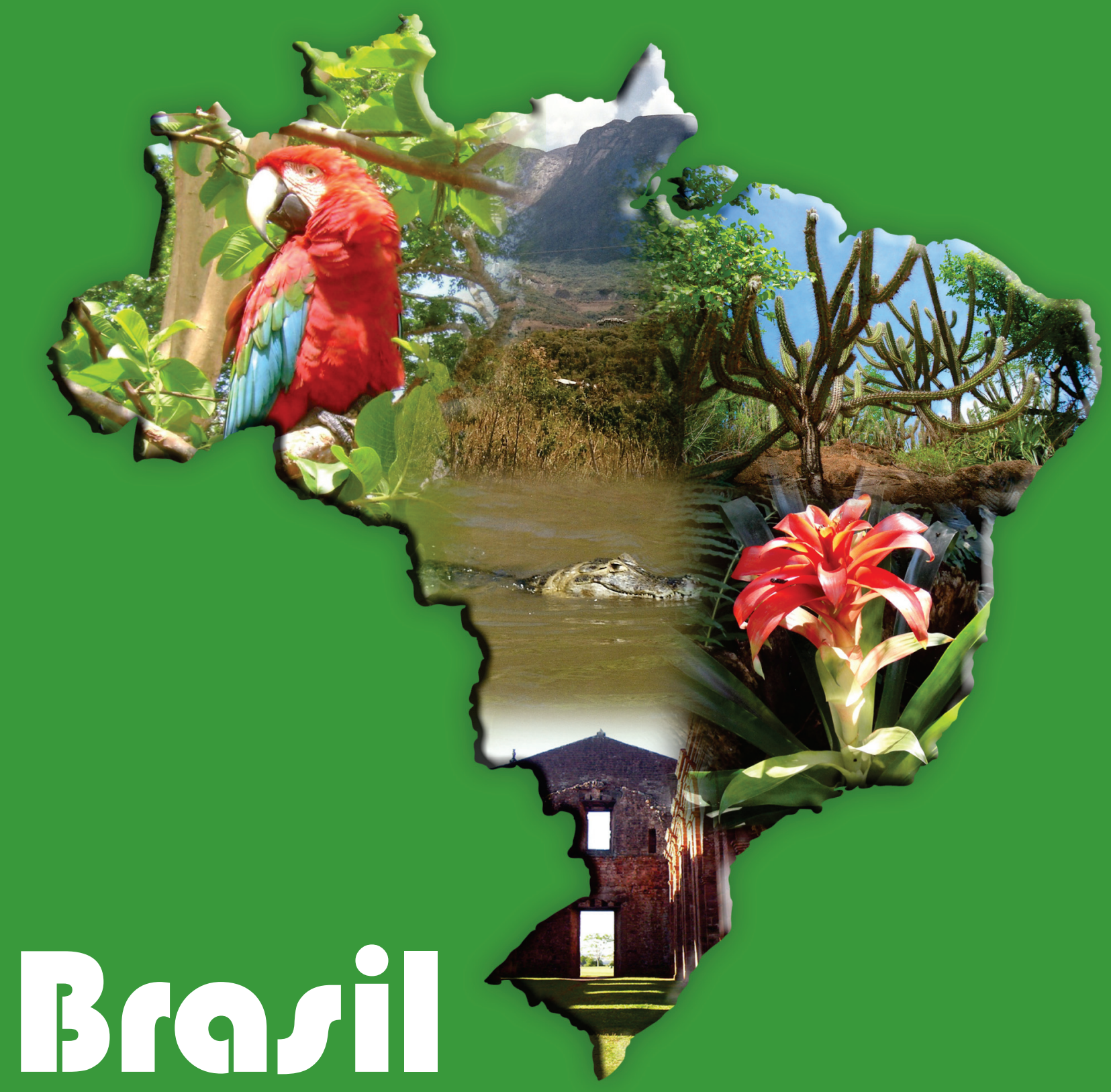

\title{
Uma visão geográfica e ambiental no início do século XXI
}

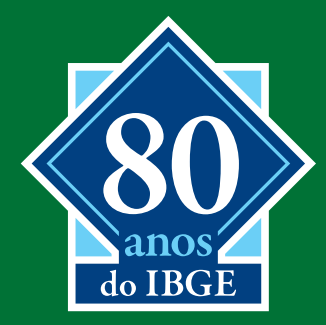

Adma Hamam de Figueiredo

Organizadora

\section{BIBCE}


Vice-Presidente da República no Exercício do Cargo de Presidente da República Michel Miguel Elias Temer Lulia

Ministro do Planejamento, Desenvolvimento e Gestão

Dyogo Henrique de Oliveira (interino)

INSTITUTO BRASILEIRO

DE GEOGRAFIA E

ESTATÍSTICA - IBGE

\author{
Presidente \\ Paulo Rabello de Castro \\ Diretor-Executivo \\ Fernando J. Abrantes
}

\title{
ÓRGÃOS ESPECÍFICOS SINGULARES
}

Diretoria de Pesquisas

Roberto Luís Olinto Ramos

Diretoria de Geociências

Wadih João Scandar Neto

Diretoria de Informática José Sant Anna Bevilaqua

Centro de Documentação e Disseminação de Informações David Wu Tai

Escola Nacional de Ciências Estatísticas Maysa Sacramento de Magalhães

UNIDADE RESPONSÁVEL

Diretoria de Geociências

Coordenação de Geografia

Claudio Stenner 

Ministério do Planejamento, Desenvolvimento e Gestão Instituto Brasileiro de Geografia e Estatística - IBGE
Diretoria de Geociências
Coordenação de Geografia

\section{Brasil}

\section{Uma visão geográfica e ambiental no início do século XXI}

Adma Hamam de Figueiredo

Organizadora 


\section{Instituto Brasileiro de Geografia e Estatística - IBGE}

Av. Franklin Roosevelt, 166 - Centro - 20021-120 - Rio de Janeiro, RJ - Brasil

ISBN 978-85-240-4386-4 (meio impresso)

(C) IBGE. 2016

\section{Produção do e-book}

Roberto Cavararo

\section{Capa}

Marcelo Thadeu Rodrigues - Gerência de Editoração /Centro de Documentação e Disseminação de Informações - CDDI

Brasil : uma visão geográfica e ambiental no início do século XXI / Adma Hamam de Figueiredo, organizadora. - Rio de Janeiro : IBGE, Coordenação de Geografia, 2016.

435p. -

Conteúdo: Formação territorial / Adma Hamam Figueiredo - Breve histórico do processo demográfico / Celso Cardoso Silva Simões - A Delimitação legal dos espaços urbanos / Maria Helena Palmer Lima - Padrões espaciais de serviços avançados de apoio às empresas na rede urbana brasileira / Marcelo Paiva da Motta e Ronaldo Cerqueira Carvalho - Evolução do espaço rural brasileiro / Luiz Sérgio Pires Guimarães - Recursos naturais e questões ambientais / Judicael Clevelário Júnior e Rosangela Garrido Machado Botelho - Uma Contribuição à geografia dos recursos hídricos / Eugênio Antônio de Lima Hellen Cano e José Antônio Sena do Nascimento - Desenvolvimento local sustentável e governança ambiental / Denise Kronemberger e Valéria Grace Costa - Diversidade e patrimônio cultural / Ana Maria Goulart Bustamante e Jorge Kleber Teixeira Silva

ISBN 978-85-240-4386-4

1. Geografia econômica - Brasil 2. Geografia política. 3. Demografia. 4. Divisões territoriais e administrativas. 5. Disparidades econômicas regionais. 6. Geografia urbana. 7. Recursos naturais 8. Desenvolvimento sustentável. 9. Patrimônio cultural. 10. Geografia rural. 11. Recursos hídricos I. Figueiredo, Adma Hamam II. IBGE. Coordenação de Geografia.

Gerência de Biblioteca e Acervos Especiais RJ/IBGE/2016-14
CDU 911.3:33(81)

GEO

Impresso no Brasil/Printed in Brazil 


\section{Sumário}

\section{Apresentação}

\section{Introdução}

\section{Formação territorial}

Adma Hamam de Figueiredo

Breve histórico do processo demográfico

Celso Cardoso Silva Simões

\section{A delimitação legal dos espaços urbanos}

Maria Helena Palmer Lima

Padrões espaciais de serviços avançados de apoio às empresas na rede urbana brasileira

Marcelo Paiva da Motta

Ronaldo Cerqueira Carvalho

\section{Evolução do espaço rural brasileiro}

Luiz Sérgio Pires Guimarães 


\section{Recursos naturais e \\ questões ambientais}

Rosangela Garrido Machado Botelho (Coord.)

Judicael Clevelário Júnior (Coord.)

\section{Uma contribuição à geografia dos recursos hídricos}

Eugênio Antônio de Lima

Hellen Cano

José Antônio Sena do Nascimento

\section{Desenvolvimento local sustentável e governança ambiental}

Denise Kronemberger

Valéria Grace Costa

\section{Diversidade e patrimônio cultural}

Ana Maria Goulart Bustamante

Jorge Kleber Teixeira Silva

\section{Convenções}

Dado numérico igual a zero não resultante de arredondamento;

Não se aplica dado numérico;

Dado numérico não disponível;

Dado numérico omitido a fim de evitar a individualização da informação; Dado numérico igual a zero resultante de arredondomento de um dado numérico originalmente positivo; e

$-0 ;-0,0 ;-0,00$

Dado numérico igual a zero resultante de arredondamento de um dado numérico originalmente negativo. 


\section{Apresentação}

Com o lançamento desta obra, o Instituto Brasileiro de Geografia e Estatística - IBGE se propõe a atualizar informações contempladas na publicação Brasil: uma visão geográfica nos anos 80, que, divulgada originalmente em 1988, trouxe a público uma interpretação multitemática da realidade socieconômica do País, privilegiando sua dimensão espacial.

O presente trabalho visa ampliar o conhecimento das expressivas alterações verificadas no território brasileiro como resultado das transformações econômicas, demográficas, políticas e ambientais ocorridas nas últimas décadas.

Se, durante o período que compreende as primeiras décadas até os anos 1980 do século passado, o grande movimento de estruturação do espaço nacional foi marcado pela articulação dos processos acelerados de industrialização e urbanização e pela constituição de um sistema econômico nacionalmente integrado, a dinâmica territorial, no presente, passa por diversas vertentes analíticas, algumas das quais tratadas nos capítulos desta obra. Embora ainda não consensualmente identificadas, as perspectivas de análise ora abordadas marcam a geografia do Brasil contemporâneo, rearticulando e, ao mesmo tempo, fragmentando o Território Nacional, a partir de interesses consolidados, desde a escala global à local.

Desse modo, no centro do debate acerca da atualização da geografia do Brasil, está a focalização do processo de reestruturação contemporânea de seu território, cuja natureza e significado das transformações não são o mero aprofundamento de tendências já anteriormente verificadas. Elas representam, antes, mudanças fundamentalmente distintas em sua origem e manifestação, cuja análise impõe a releitura de uma realidade geográfica em constante transformação.

Wadih João Scandar Neto

Diretor de Geociências 


\section{Introdução}

A obra Brasil: uma visão geográfica e ambiental no início do século XXI é composta de nove capítulos que abordam pontos relevantes da realidade nacional contemporânea reinterpretados pela análise geográfica.

Os dois capítulos iniciais contextualizam historicamente a formação territorial e demográfica do País, ressaltando os processos e as contingências que formataram a geografia do Brasil contemporâneo, observados sob o ponto de vista de sua inserção no mundo e da dinâmica demográfica que irá sustentar o movimento de povoamento de seu imenso território. Desse modo, enquanto o primeiro capítulo, Formação territorial, resgata as circunstâncias geopolíticas e geoeconômicas que estiveram fortemente entrelaçadas na formação territorial da Colônia, do Império e da República brasileira, o segundo, Breve histórico do processo demográfico, realiza uma síntese da dinâmica demográfica, tendo como pano de fundo o movimento socioeconômico e as diferenças regionais presentes no território brasileiro.

Seguem-se dois capítulos referenciados à geografia urbana brasileira e associados a um dos processos básicos pelos quais se pode analisar o Brasil na atualidade, qual seja, o da urbanização de seu território. Com efeito, eles abordam questões ligadas à formação político-administrativa da federação brasileira e à diferenciação da rede urbana nacional. Assim, enquanto o terceiro capítulo, A delimitação legal dos espaços urbanos, se concentra nas determinações legais que definiram os contornos do rural, do urbano e da divisão político-administrativa da federação, o quarto, Padrões espaciais de serviços avançados de apoio às empresas na rede urbana brasileira, aborda a presença das firmas de serviços avançados às empresas na rede urbana, em escala nacional, enquanto atividades essenciais para garantir a aceleração da circulação e acumulação de capital no Brasil contemporâneo. 
Os três capítulos seguintes descrevem o Território Nacional, seja pelo prisma de sua ocupação pela agropecuária, seja pelo ângulo de sua diversidade ambiental, vista esta última segundo o recorte territorial dos biomas e das bacias hidrográficas brasileiras. Nesse sentido, o quinto capítulo, Evolução do espaço rural brasileiro, fornece uma visão abrangente da trajetória da agropecuária de um país cuja dimensão continental sustentou historicamente o processo de contínua expansão de seu espaço produtivo. O sexto, Recursos naturais e questões ambientais, oferece uma longa análise ambiental integrada, permitindo não só o conhecimento da dinâmica do meio físico e das inter-relações entre seus elementos como também a compreensão da relação entre a sociedade e a natureza. Os elementos do meio físico-biótico são apresentados segundo os biomas brasileiros - Amazônia, Cerrado, Caatinga, Mata Atlântica, Pantanal e Pampa -, nos quais os diversos aspectos ambientais são tratados. A análise busca identificar as inter-relações que a ocupação humana imprime no espaço geográfico - ações, pressões, alterações e repercussões que se alteram continuamente ao longo do tempo histórico. O sétimo, Uma contribuição à geografia dos recursos hídricos, enfoca algumas diferenças geográficas relacionadas ao uso e à disponibilidade de um recurso natural essencial à vida no País, incluindo seu aproveitamento para os abastecimentos doméstico, agrícola e industrial, assim como para a geração de energia e irrigação, entre outros.

Os últimos capítulos reafirmam a importância de dois temas interligados que renovam a agenda e a geografia política contemporânea, tanto em escala global como nacional, ressaltando a relevância do desenvolvimento local e da diversidade cultural. O oitavo capítulo, Desenvolvimento local sustentável e governança ambiental, enfatiza o processo recente de consolidação de um novo padrão de relação entre o Estado e a sociedade, baseado na participação social, na formação de parcerias, na busca de integração das ações, bem como nas articulações inter e intragovernamentais. Finalmente, o nono, Diversidade e patrimônio cultural, analisa uma das chaves de entendimento da geografia do Brasil, no presente e no futuro, referente ao tema da diversidade sociocultural e ao conjunto de direitos a ela relacionados, expressos em uma ampla variedade de fontes normativas - leis, decretos, tratados e convenções internacionais, que são absorvidos pela legislação nacional. 


\title{
Formação territorial ${ }^{*}$
}

\author{
Adma Hamam de Figueiredo
}

Atributo fundamental de caracterização da sociedade e do Estado brasileiro, o território representou, ao longo da história do Brasil, um dos fundamentos e símbolo de sua identidade nacional.

Nesse sentido, a análise da formação territorial brasileira está intrinsecamente comprometida com uma visão interligada dos processos e circunstâncias que moldaram, no tempo e no espaço, seu povoamento, a ocupação econômica de seu território e a ação do Estado no Brasil. Com efeito, pode-se afirmar que, no caso brasileiro, as histórias geopolítica e geoeconômica estiveram fortemente entrelaçadas na sua formação territorial, pautadas pela própria continentalidade e diversidade regional características do País ${ }^{1}$.

Nos dias atuais esse entrelaçamento assume novos contornos através do potencial de expansão que o território e o desenvolvimento tecnológico oferecem no sentido da ampliação da bioenergia, derivando daí as chances de o País se inserir, de forma mais ou menos intensa, nos fluxos econômicos e na geopolítica mundial.

Tal visão não comporta uma compreensão reducionista do poder, nem do Estado, e, muito menos, do território. Ao contrário, ela implica a necessidade de se buscar novos ângulos de entendimento de uma realidade territorial que apresenta enorme capacidade de se transformar acompanhando as inúmeras transições pelas quais passa o poder político-econômico e a nacionalidade na contemporaneidade.

\footnotetext{
Esse capítulo contou com a revisão crítica de Ailton Antonio Baptista de Oliveira, geógrafo do IBGE.

1 Além da geopolítica preceder, até mesmo, o período colonial pela divisão do mundo desconhecido, através do Tratado de Tordesilhas, de 1492, a própria independência política e inserção da economia brasileira na órbita do capitalismo inglês estão, também, atreladas a um fenômeno geopolítico singular na história mundial que foi o da transmigração da sede de um grande império - o Império Português - para o seu maior espaço colonial (TAVARES, 1999).
} 
Essa transformação ocorre não só no sentido da sempre renovada tensão existente na repartição interna do poder entre os membros da federação (União, estados e municípios), como no de novas articulações engendradas na face externa do poder perpassadas pelo processo de globalização².

Segundo Tavares (1999), os fatos relevantes para a história social e política do Brasil e, portanto, para o entendimento de seu território, parecem ter sido, desde o Século XIX, além da apropriação privada do território e das migrações da população, em busca de terra e trabalho, a centralização e descentralização do próprio domínio do Estado Nacional sobre um pacto federativo que se revelou precário desde a nossa constituição como país independente. Essa precariedade está relacionada, entre outros motivos, com a continentalidade do País e com a enorme diversidade que comporta seu vasto território.

Com efeito, a dimensão e diversidade natural-cultural constituem a diferença fundamental do território brasileiro, residindo aí, em grande parte, as chances reais e potenciais de seu desenvolvimento e inserção, com relativa autonomia, no mundo globalizado atual.

Esse território apresenta, assim, posição singular nos planos externo e interno. A primeira, associada à visão do País no mundo como reserva de recursos naturais tradicionais e, hoje, também, enquanto detentor da biodiversidade da maior floresta equatorial do planeta e de seu banco genético de potencial ainda desconhecido. A segunda, ligada, internamente, à incorporação técnica, econômica e política do território, exigida pela expansão produtiva do espaço nacional, liderada, hoje, em termos de incorporação extensiva do território, pelo setor agroindustrial e o processo de ocupação a ele associado.

Nesse contexto, o presente capítulo pretende abordar a formação territorial brasileira em sintonia com o processo de povoamento e construção regional, para, em seguida, apontar os caminhos que levaram à unidade territorial do País, através da noção de modernização, desenvolvimentismo e de projeto nacional e, finalmente, desembocar no complexo mosaico territorial contemporâneo marcado pela globalização e pelas incertezas que rondam o Estado Nacional e seu espaço de regulação.

\section{Povoamento e construção regional}

Quinto país em extensão territorial do planeta, com uma superfície de 8515 767,049 quilômetros quadrados $\left(\mathrm{km}^{2}\right)$, o Brasil ocupa quase a metade do continente sul-americano, possuindo uma vasta região fronteiriça com todas as nações da América do Sul, à exceção do Chile e do Equador.

Por um lado, essa superfície física permite ao País compartilhar suas maiores bacias hidrográficas - a Amazônica e a do Prata - com os demais países sul-americanos, possuindo,

\footnotetext{
2 Se por um lado ocorrem mudanças profundas no interior do Estado, ou melhor, nas relações estabelecidas entre suas esferas administrativas e entre estas e a sociedade civil, enfatizando sua função mediadora mais do que a de detentor único do poder; por outro lado, os Estados-nação passam, externamente, a transitar de entidades fundamentalmente separadas, retendo o controle administrativo de seu território, para o fortalecimento de padrões de interdependência entre eles.
} 
desse modo, a plataforma natural para liderar o processo de integração econômica regional e se fortalecer frente aos blocos hegemônicos mundiais, sejam eles articulados pela frente americana, europeia ou asiática.

Com efeito, o capital de recursos naturais, representado pela biodiversidade, pela relativa abundância de recursos hídricos e minerais e pela existência de uma fronteira agrícola e mineral ainda passível de expansão, via incorporação de novas terras ao processo produtivo, conferem ao Brasil posição singular frente aos países mais industrializados do mundo, colocando, em novos termos, sua participação geopolítica em relação ao núcleo central da economia mundial ${ }^{3}$.

Por outro lado, a continental idade e a localização geopolítica do Brasil faz com que seu extenso litoral tenha seu valor estratégico e econômico desdobrado não somente nas inúmeras ilhas que possui, como, principalmente, em uma nova fronteira territorial submersa ${ }^{4}$ crescentemente valorizada pelas modernas tecnologias de exploração dos recursos da plataforma continental e das camadas mais profundas do pré-sal, desenvolvidas em um momento histórico pautado pela ameaça de escassez de fontes energéticas que ronda o mundo contemporâneo.

A vastidão do território brasileiro, tanto em latitude (entre os paralelos de $5^{\circ} 16^{\prime} 20^{\prime \prime}$ de latitude norte e $33^{\circ} 45^{\prime} 03^{\prime \prime}$ de latitude sul) quanto em longitude (entre os meridianos de $34^{\circ} 47^{\prime} 30^{\prime \prime}$ e $73^{\circ} 59^{\prime} 32^{\prime \prime}$ a oeste de Greenwich), abriga um extraordinário mosaico de ecossistemas, produzido por uma ampla diversidade climática e topográfica.

Essas características contingenciaram as diversas formas de ocupação e uso pela sociedade dos espaços moldados pela natureza tropical e subtropical do País, conformando, em linhas gerais, uma diferenciação regional que se altera à medida que o movimento de ocupação vai construindo, dinamicamente, o Território Nacional através do tempo.

O processo de ocupação e as atividades econômicas desenvolvidas no Brasil estiveram fortemente relacionadas com a exploração de seus recursos e, portanto, das potencialidades naturais contidas em seu território ${ }^{5}$. Pode-se afirmar, assim, que este último nunca traiu o desenvolvimento nacional, fornecendo a base de recursos necessária à expansão da fronteira econômica, sempre que foi solicitado nos momentos de aceleração do processo de crescimento, de consolidação do mercado interno e, mais recentemente, de competição no mercado externo.

A noção de economia de fronteira, baseada no pressuposto de que a natureza constituía uma reserva infinita de recursos, foi dominante desde as formas coloniais de ocupação "a

\footnotetext{
3 A participação do Brasil no G-20 frente ao bloco mais restrito dos sete países mais ricos do planeta (G-7) constitui, de certa forma, o deslocamento do País de sua histórica inserção periférica nos contextos econômico e político mundial.

4 O Brasil possui várias ilhas oceânicas, destacando-se as de Fernando de Noronha, Abrolhos e Trindade, de enorme valor enquanto patrimônio natural, além de uma vasta e rica fronteira submersa constituída pela plataforma marítima de mais de quatro milhões de quilômetros quadrados sob soberania do Estado brasileiro com a ratificação do limite exterior da plataforma continental brasileira e Zona Econômica Exclusiva - ZEE pela Convenção das Nações Unidas sobre o Direito do Mar.

5 Segundo Bacelar (2006), o Brasil engatou no Século XVI no velho movimento de internacionalização do capital comercial como colônia de exploração dentro de um processo que deixa sua marca até os dias atuais. Desse modo, afirma a autora, pedaços do território brasileiro foram articulados nesse movimento, montando bases produtivas e estruturas socioculturais diferenciadas que, ainda hoje, marcam nossas distintas regiões.
} 
ferro e fogo" da terra no Brasil (PÁDUA, 2002), projetando espaços geográficos diferenciados à medida que o mercado mundial demandava produtos com possibilidades e vantagens concretas de exploração.

Nesse contexto, a Coroa portuguesa teve uma política contínua de defesa utilitarista das matas brasileiras, tentando regular, através de inúmeros regimentos expedidos até início do Século XIX, o desmatamento provocado pela atividade agropecuária próxima ao litoral, uma vez que a madeira era particularmente necessária para a construção naval e civil, assim como servia de combustível para os engenhos.

Assim, é importante compreender que a existência de uma extensa base territorial e de uma fronteira econômica a ser desbravada fez com que a destruição ambiental constituísse um elemento central da própria lógica de ocupação colonial do Brasil, não sendo, portanto, algo fortuito nesse longo processo, embora, em termos espaciais, a degradação ocorresse em manchas descontínuas associadas às regiões diretamente impactadas pelo mercado ultramarino.

Tal lógica estaria vinculada, a demais, ao sentido aventureiro, destacado por Holanda (1971), para descrever a instabilidade, imprevidência e imediatismo característicos do pragmatismo que presidiu grande parte da ação humana portuguesa em sua colônia sul-americana, levando um pequeno e pouco habitado país europeu a estender seu domínio sobre um vasto território tropical.

Nesse sentido, pode-se afirmar que muitas das determinações coloniais permaneceram vigentes no processo de ocupação não só do Brasil, como de grande parte dos países periféricos, mesmo após os movimentos de autonomia política, uma vez que a nova ordem advinda com a independência foi construída sobre o arcabouço econômico e social gerado no período colonial.

Com efeito, em um país de formação colonial, como o Brasil, a dimensão espacial adquire singular importância na explicação dos processos sociais e da vida política tendo impacto direto em sua conformação territorial. Nesse contexto, a divisão político-administrativa do território brasileiro faz parte das heranças coloniais que se mantiveram mesmo após o processo de independência dos países periféricos, uma vez que a nova ordem político-territorial foi construída sobre o arcabouço econômico e social gerado no período colonial ${ }^{6}$.

Segundo Dória (1953), o Brasil não nasceu com a federação e nem seus membros federados constituíam Estados autônomos que abdicaram de sua soberania pactuando a federação, como no caso clássico da nação norte-americana. Ao contrário, o governo central no Brasil preexistia à federação e esta foi por ele, em grande parte, construída dentro de uma tensão constante que contrapunha forças políticas legitimadoras da centralização e da descentralização do poder que remontam ao período colonial.

\footnotetext{
6 De acordo com Tavares (1999, p. 84), "o novo império brasileiro, nascido à sombra de dois Impérios, um decadente (português) e outro no auge de sua expansão mundial (inglês), manteve sob seu domínio político a expansão das oligarquias regionais em sua ocupação do espaço e estabeleceu-se aos poucos sobre um território continental unificado" sobre o qual construiria seu mapa político intranacional.
} 
A configuração territorial dos estados retroage, assim, às antigas capitanias hereditárias cujas fronteiras foram limitadas pela extensão de terras concedidas na costa a partir daí se estendendo para o interior, isto é, para o sertão, na medida da capacidade de exploração dos donatários. As províncias imperiais (Mapa 1)e, posteriormente, os estados federados, herdariam, desse modo, uma divisão territorial profundamente desigual, cabendo a algumas, "grandes vastidões incultas", enquanto a outras restariam "diminutas nesgas de terra" (DÓRIA, 1953, p. 16).

Nesse contexto, como resultado de um povoamento que teve na expansão e na posse espontânea do seu território a base de sua dominação política, os estados brasileiros herdariam dos períodos colonial e imperial uma divisão político-administrativa profundamente desigual em termos de sua dimensão territorial, de seu aproveitamento econômico e grau de ocupação. Desse modo, pode-se afirmar que, ainda hoje, essa herança marca a construção profundamente diferenciada do território brasileiro.

O automatismo que marcou a passagem das províncias do Império em estadosmembros da República Federativa acabou por reafirmar os mesmos limites territoriais cujos contornos, segundo Octávio e Vianna (1927), não haviam sido determinados por qualquer princípio metódico ou sistemático.

O imediato aproveitamento das províncias imperiais em estados federados sem qualquer alteração na configuração territorial original deixa entrever, assim, que, em termos geopolíticos, a passagem do centralismo imperial para a República e o federalismo não chegaria a ser, de imediato, portadora de forças transformadoras na organização territorial da nação, embora se deva evitar, no caso brasileiro, a transposição direta da ideia de uma maior fragmentação territorial como um projeto necessariamente descentralizador do poder.

Ao contrário, muitos dos que defenderiam, posteriormente, a necessidade de uma divisão equilibrada do mapa político nacional em termos da dimensão territorial dos estados federados buscavam, antes de tudo, afirmar o poder central frente à ameaça de acirramento das desigualdades e de legitimação de autonomias regionais. 


\section{Mapa 1 - Províncias imperiais - 1840-1882}

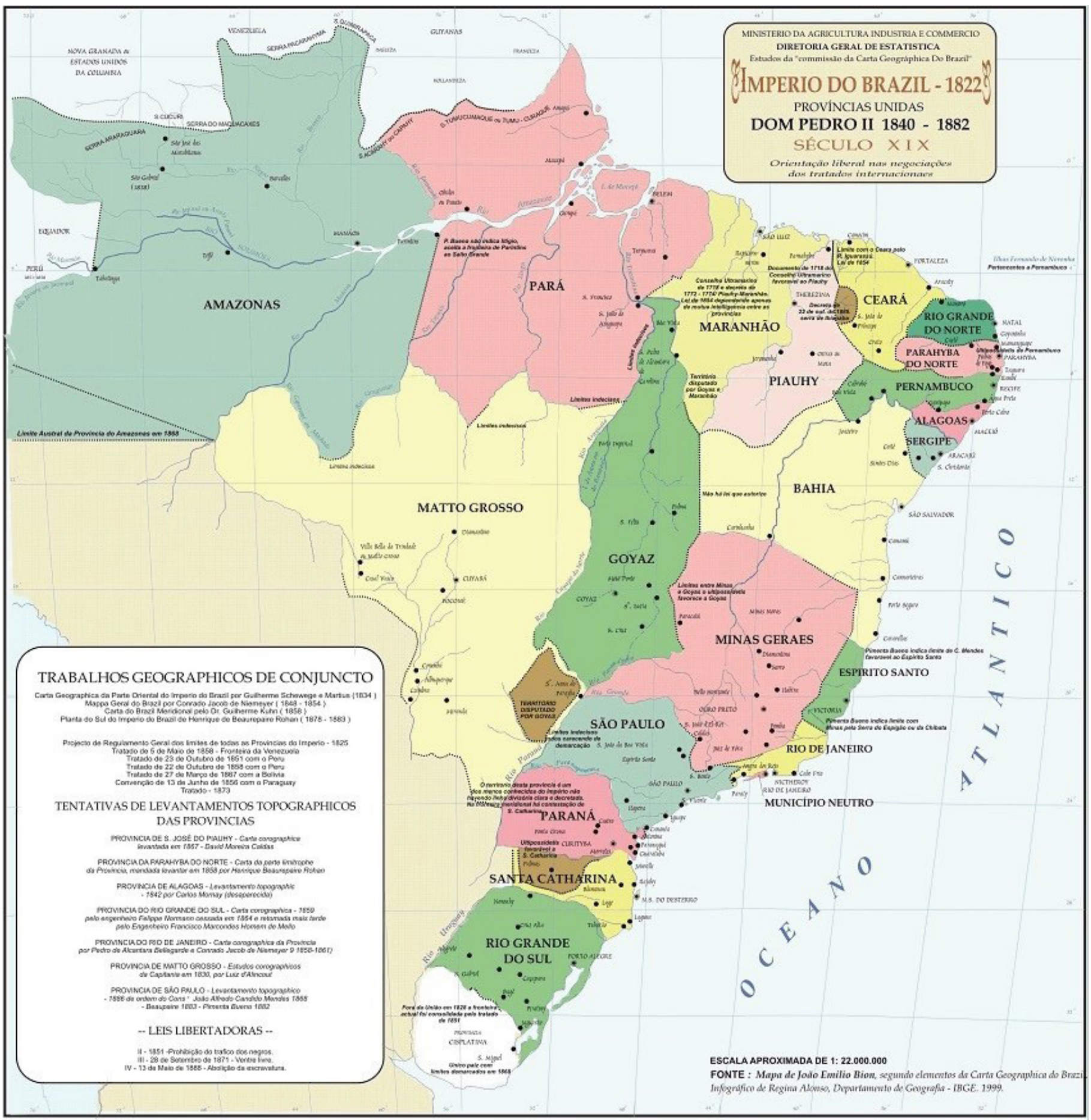

Fonte: Evolução da divisão territorial do Brasil: 1872-2010. Rio de Janeiro: IBGE, 2011. (Documentos para disseminação. Memória institucional, 17). Disponível em: <http://www.ibge.gov.br/home/geociencias/geografia/default_evolucao.shtm>. Acesso em: jan. 2016. 
De qualquer forma, a alegação de tradições históricas justificadoras da manutenção dos recortes territoriais preexistentes descartou qualquer iniciativa oficial no sentido de diminuir as desigualdades entre as unidades federadas através de uma distribuição territorial mais equitativa entre elas (BOMFIM, 1996) ${ }^{7}$.

Além da divisão política do território, a manutenção do escravismo, como relação de produção herdada do passado colonial, constitui-se, seguramente, no principal elemento de continuidade na vida social e econômica do novo país e está na raiz, inclusive, da própria forma predatória de exploração da terra, juntamente com a disponibilidade infinita desse recurso $^{8}$ que respaldou a marcha para frente sempre que o aumento da produção ou um novo produto era demandado pelo mercantilismo europeu.

A implantação, em diferentes momentos históricos, de várias atividades exportadoras, explica, assim, não somente as formas diferenciadas de ocupação do Brasil, como, simultaneamente, está na base da construção de sua diferenciação regional. Nesse sentido, pode-se afirmar, com Santos e Silveira (2001), que a história da formação do território brasileiro é, a um só tempo, una e diversa, na medida em que ela representa, simultaneamente, a soma e a síntese das histórias de suas regiões.

Desse modo, ao lado da via centralizada que possibilitou a manutenção da integridade territorial e a formação do Estado Nacional ${ }^{9}$, a continentalidade do Brasil irá impor uma feição diferenciada à exploração econômica dos seus recursos naturais, consolidando variadas identidades regionais no interior da colônia, do Império e, posteriormente, da República brasileira, apesar dos grandes projetos políticos catalisadores de sua unidade territorial.

Nesse contexto, fatos marcantes de transferência do poder político no período colonial, como a mudança da capital de Salvador para o Rio de Janeiro e da sede do Império português, em 1808, para essa cidade e, até mesmo, a independência ocorrida 14 anos depois, não foram suficientes para criar, no domínio da economia, fluxos capazes de articular o Território Nacional. A administração pública servia, assim, para preservar e ampliar as fronteiras, manter o regime e a ordem, assegurar a coleta de impostos e, com a ajuda da Igreja ${ }^{10}$, unificar a língua.

A estrutura espacial nas primeiras décadas do Século XIX, refletia, desse modo, um País de ocupação concentrada na faixa litorânea, cuja base econômica agrária, espacialmente descontínua e comandada pelo mercado externo, era marcada por dinâmicas pontuais que

\footnotetext{
7 Vale lembrar que, ainda no período colonial, as capitanias (maiores unidades político-administrativas do período) já se dividiam em principais e subalternas, consagrando, institucionalmente, relações de sujeição e de dependência entre elas.

8 Autores como José Bonifácio não só atribuíram à escravidão uma importância central no uso destrutivo dos recursos naturais brasileiros, como fizeram da defesa da natureza um instrumento teórico na luta pela emancipação política de um país de dimensões continentais (PÁDUA, 2002).

9 Para Becker e Egler (1993) os condicionantes históricos da relação Estado-território no Brasil repousam, em grande parte, numa via autoritária desde os tempos coloniais, em que a apropriação, o controle, a unidade e a integração do território serviram para a construção do Estado. Nesse sentido, concluem os autores, a construção do Estado e de seu território à frente da construção da nação constitui a marca da via brasileira para a modernidade.

${ }^{10}$ Cabe observar que, até o final do Império, bispos e sacerdotes eram funcionários da Coroa e a Igreja achava-se numa situação razoavelmente similar à de outras corporações do Estado, como o Exército (MARTINS, 1994).
} 
se reproduziam em diferentes áreas de seu território, de forma desintegrada, conforme as condições naturais reagiam à participação do Brasil no mercado internacional enquanto produtor de bens primários diferenciados.

Composto, ainda em meados do Século XX, de ilhas de adensamento econômico isoladas entre si e voltadas para o exterior, o País revelava a feição espacial herdada de um processo de ocupação que deixou marcas diferenciadas no extenso Território Nacional conforme se desdobravam, com grandes descontinuidades temporais e geográficas, os diversos ciclos econômicos voltados para exportação.

Nesse processo, diversas economias litorâneas, como a do açúcar, construiriam, na sua retaguarda, atividades subsidiárias à produção exportada, formando o embrião de uma divisão territorial do trabalho e da diferenciação regional no interior do País.

Com efeito, ao articular, ainda no início do Século XVII, o litoral açucareiro com o interior, através da rápida ocupação das margens do Rio São Francisco pela atividade criatória ${ }^{11}$, esse rio iria realizar a primeira grande experiência de ocupação efetiva do interior da colônia.

Nesse processo ele serviria, simultaneamente, tanto de hinterlândia para o abastecimento do litoral dominado pela monocultura canavieira (FURTADO, 1971), como de elemento consolidador de uma forma de ocupação territorial que iria marcar o povoamento do interior nordestino e brasileiro, na medida em que a criação de gado constituía em si uma atividade de subsistência de enorme capacidade de reprodução, mesmo nos períodos de refluxo da demanda externa e de crise da produção comercial.

De acordo com Furtado (1971), numa economia cuja expansão estava intrinsecamente assentada na disponibilidade de terras, dada a baixíssima capacidade natural de suporte prevalecente no sertão, a possibilidade de avanço da fronteira, facilitada no interior pelos caminhos naturais existentes, tornou possível a enorme velocidade com que os rebanhos penetraram naquela remota extensão setentrional do interior do País, traçando as linhas gerais de definição do território brasileiro, através da criação de novas vilas e fronteiras administrativas então criadas e que chegavam até o Piauí e Maranhão.

Nesse período, os rios constituíram os caminhos naturais de penetração do interior brasileiro, conformando um padrão dendrítico tradicional de ocupação do território brasileiro, modelado pela distribuição em suas margens dos núcleos urbanos assim como das áreas agrícolas com maior intensidade de uso.

No litoral, a presença de numerosas cidades e portos, que serviam de conexão com o exterior, geravam, contudo, frágeis articulações no plano interno, contrastando o espaço costeiro, mais denso, de caráter mercantil agroexportador, com o espaço interiorano, de ocupação rarefeita e acentuadamente dispersa, que apresentava, ademais, inexpressiva base econômica.

\footnotetext{
11 Além da perenidade de seu fluxo d'água, que lhe confere situação singular na Região Semiárida nordestina, ou nos sertões, como era identificado genericamente o interior do País em contraposição ao litoral, a rápida consolidação da ocupação nas margens do Rio São Francisco fazendo com que ele fosse reconhecido como um condensador tão importante de fazendas de gado, deveu-se, de acordo com Prado Júnior (1945), não só à vegetação pouco densa da Caatinga, como à localização, próxima às suas margens, de afloramentos salinos que forneciam ao gado os bebedouros necessários à sua alimentação.
} 
A evolução do povoamento do território brasileiro entre 1872 e 2010 (Mapa 2) deixa evidenciada, ainda nos dias atuais, a marca da clivagem inicial estabelecida entre o litoral e o interior. Nesse contexto, o ciclo do ouro em Minas Gerais representou, a seu tempo, a experiência mais concreta de indução do processo de articulação do interior do território e de afirmação da própria nacionalidade brasileira. Cabe observar que, anteriormente à expansão cafeeira, a mineração constituiu, seguramente, o primeiro movimento territorial com força suficiente não só para promover a ocupação do interior em bases mais estáveis ${ }^{12}$ como para abalar a hegemonia econômica e política da exploração da cana-de-açúcar no litoral nordestino.

De acordo com Moraes (2002), até o início do Século XX, em termos geográficos e políticos, o Brasil não constituía, plenamente, um território, sendo mais bem caracterizado como um conjunto disperso de regiões fragilmente articuladas em meio a vastos fundos territoriais ${ }^{13}$, genericamente associados aos sertões ou às extensas áreas de fronteira, que permaneciam, em grande parte, desconhecidos e precariamente revelados pela cartografia, em meados da década de 1930.

Da mesma forma, Cano (apud PACHECO, 1998) observa que, em termos econômicos, até meados da década de 1920, era pequena a integração do mercado nacional, com o comércio inter-regional perfazendo cerca de $1 / 4$ do total do comércio externo de todos os estados e regiões do País. Nesse contexto, a demanda por bens de consumo, industrializados ou não, era suprida por produção local ou por importações do exterior ${ }^{14}$.

\footnotetext{
12 De acordo com Tavares (1999, p. 86), a partir da economia do ouro em Minas Gerais "começava a ocupação extensiva do nosso vasto território interior, com os negócios de gado e muares constituindo o primeiro movimento de integração nacional à margem dos negócios metropolitanos". Ainda segundo Tavares (1999, p. 86), "Minas serve de ponte interna para o Século XIX, tanto de ocupação territorial quanto como precursora da Independência".

13 A noção de fundo territorial traduz um certo potencial de expansão sobre novas áreas que marcou no passado, e continua a marcar de forma determinante, no presente o processo de ocupação do País.

14 Para esse autor, a questão principal é que a produção industrial do País não apresentava, então, suficiente dinâmica de crescimento para romper o arquipélago nacional e cativar para si o mercado nacional.
} 
Mapa 2 - Evolução da população - 1872/2010

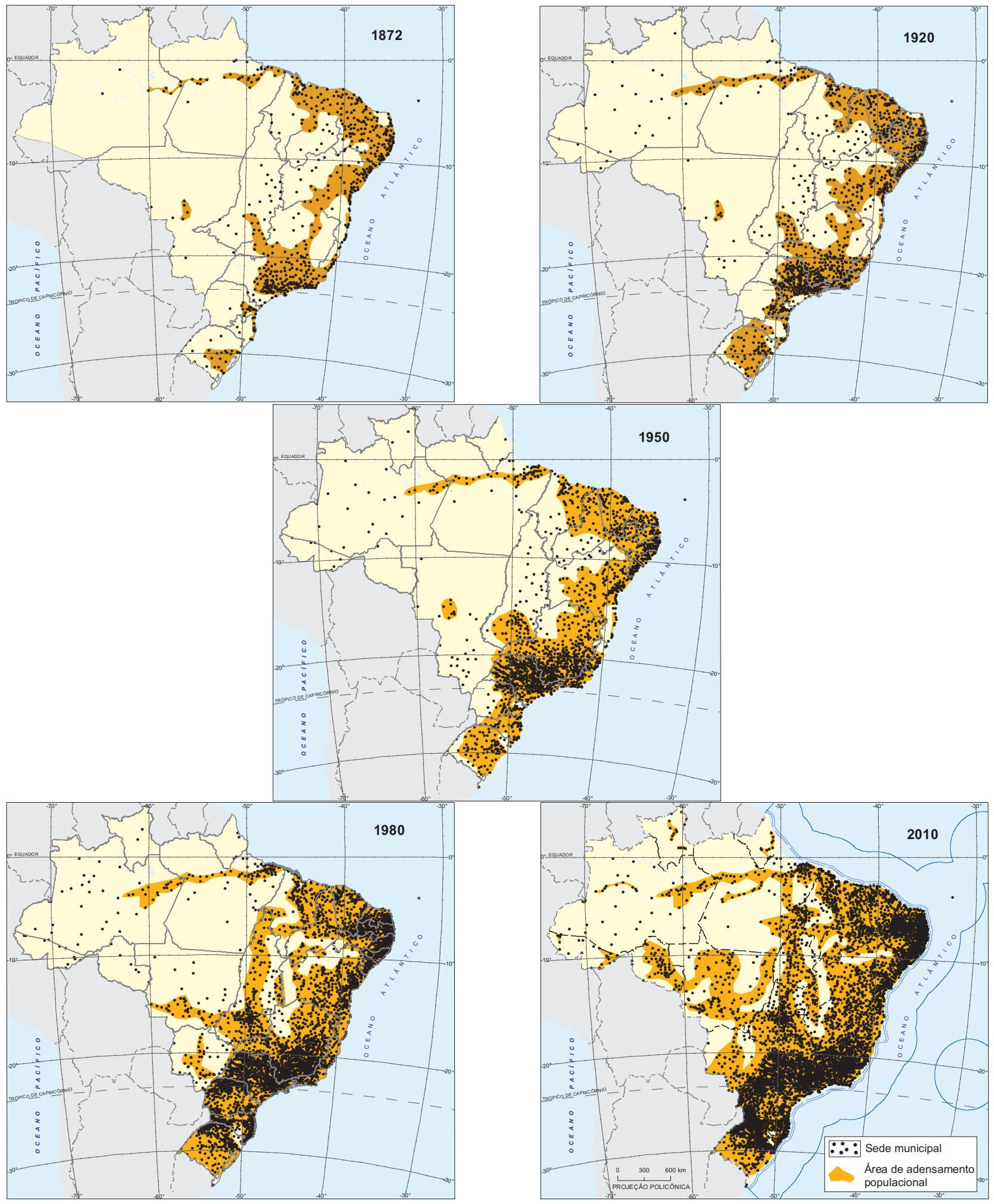

Fonte: Evolução da divisão territorial do Brasil: 1872-2010. Rio de Janeiro: IBGE, 2011. (Documentos para disseminação. Memória institucional, 17). Disponível em: <http://www.ibge.gov.br/home/geociencias/geografia/default_evolucao.shtm>. Acesso em: jan. 2016. 
Com efeito, no interior, a rarefação das atividades econômicas, característica tanto do extrativismo praticado na imensa Planície Amazônica recoberta pela Floresta Tropical Úmida ${ }^{15}$ como da pecuária e da mineração, dominante no Cerrado do Planalto Central, na Caatinga da Região Semiárida nordestina e nos campos subtropicais da Região Sul do País, só foi quebrada, de forma contínua e duradoura, pela interiorização do cultivo do café no oeste paulista e das demais atividades agrícolas e industriais induzidas, direta e indiretamente, pela expansão da cafeicultura.

Para o País como um todo, a consolidação da economia cafeeira, no Século XIX, servirá de suporte para o encaminhamento da centralização monárquica, alterando sua estrutura política e social, ao consolidar o deslocamento do eixo econômico do Império do "norte" para o "sul", numa mudança que iria legitimar a supremacia política com a supremacia econômica, pondo fim a um longo processo de ajuste quanto ao polo geográfico do poder, a partir do qual se reestruturariam as relações políticas e econômicas no território brasileiro.

O deslocamento do café pelo Vale do Paraíba Fluminense, até atingir o Planalto Paulista, representou não somente o grande movimento inicial de desmatamento contínuo em direção ao interior do País ${ }^{16}$, como a primeira diferença regional no Brasil que ia além da mera exploração das potencialidades naturais do território, apesar de encontrar aí condições excepcionais quanto à temperatura, pluviosidade e tipo de solo.

Transposta a barreira da Serra do Mar, a expansão dessa cultura pelo Planalto Paulista, em meados do Século XIX; ao induzir, com êxito, a diversificação produtiva de outras atividades agrícolas e não agrícolas, constitui um dos vetores do processo de urbanização/ industrialização de São Paulo, passando a depender, também, da ampliação do mercado interno e da modernização do processo produtivo para a própria reprodução da complexa economia e dos interesses que se articulavam a partir da atividade cafeeira.

Com efeito, em menos de um século, os espaços econômicos decadentes da exploração colonial (extrativa, canavieira e mineral) cederam lugar a um espaço dominante de acumulação, tendo como centro interno o próprio complexo cafeeiro e como inserção internacional a economia mundial.

Com a hegemonia econômica conquistada através da consolidação dessa atividade, reforçava-se, a partir de São Paulo, o pacto de poder político em tomo de interesses comprometidos, crescentemente, com atividades articuladas nas esferas financeira e industrial e cuja expansão pressupunha, agora, a formação de um mercado interno e o uso intensificado dos recursos naturais em escala nacional. Esses últimos atuariam, assim, como passos iniciais da efetiva consolidação da unidade territorial do País, uma vez superado o desafio inicial da manutenção de sua integridade política dentro da diversidade regional brasileira.

\footnotetext{
15 Longe de representar uma lógica menos perversa de povoamento do interior, o extrativismo da borracha pautava-se em um processo desequilibrado de ocupação territorial que enriquecia os distantes pontos de comercialização da borracha em detrimento da exploração da mão de obra dispersa nos seringais da Amazônia ocidental, impedindo, desse modo, o surgimento de um povoamento estável e organizado da extensa fronteira amazônica e, principalmente, impedindo a formação de uma sociedade menos desigual nessa região.

${ }^{16}$ Segundo Vianna (RECENCEAMENTO..., 1922, p. 5) "São os imensuráveis sertões do oeste paulista, compreendidos nas Bacias do Paranapanema, do Tietê, do Mogi-Guaçu e do Pardo, onde se está travando a nossa grande batalha do homem contra a floresta tropical".
} 


\section{Consolidando a unidade territorial brasileira: a unificação do mercado nacional}

A estrutura socioeconômica tradicional de base rural começa a ser modificada a partir de 1930 com a implantação da industrialização que representou um novo e dinâmico movimento na formação territorial brasileira de natureza diferenciada e capaz de promover a inexistente integração produtiva e a complementaridade inter-regional, consolidando os contornos atuais do mapa político do Brasil.

Com efeito, as condições criadas no âmbito do complexo exportador cafeeiro, de geração de lucros e demanda por bens de consumo, aliadas à infraestrutura instalada, viabilizaram um processo de industrialização substitutivo de importações, deslocando, geográfica e politicamente, o eixo dinâmico da economia e marcando o ingresso do País em um padrão de acumulação urbano-industrial polarizado pela capital paulista.

De acordo com Oliveira (1981), o desenvolvimento econômico de São Paulo começou, desde então, a definir a divisão regional do trabalho nacional em substituição ao arquipélago das economias regionais até então existentes, determinadas, sobretudo, por suas relações com o exterior ${ }^{17}$.

Nesse contexto, no bojo da crise internacional de 1929, assumindo uma forma centralizadora e autoritária, o Estado brasileiro começa a investir na indústria de base e a operar políticas de integração de seu vasto território e, simultaneamente, de estruturação do próprio mercado nacional de alimentos, de trabalho e de matérias-primas. Para Cano (apud PACHECO, 1998), a crise de 1929 e sua recuperação iriam acelerar a integração do mercado nacional, ocupando a capacidade produtiva da indústria paulista, instalada nos anos 1920.

Simbolicamente, no que diz respeito à integração territorial, as imagens do oeste e do centro, formuladas política e ideologicamente durante o Estado Novo, faziam do interior, ou melhor, do sertão, o lugar da destinação natural e do reconhecimento da unidade e da identidade nacional, fazendo de suas baixas densidades demográficas e de seu isolamento traços associados à preservação de valores genuinamente nacionais. Desse modo, em 1939, Getúlio Vargas ao convocar a nação para a marcha para o Oeste, isto é, rumo ao sertão, afirmava que "caminhamos para o centro não pela força de preconceitos doutrinários, mas pelo fatalismo de nossa definição racial" (CHAUÍ, 2000, p. 47).

No final dos anos 1930 caminhava-se, desse modo, para a formulação de uma nova síntese territorial na qual ao mesmo tempo que se valorizava e se exaltava o interior e sua capacidade de preservação do caráter nacional, começava a ser reconhecido o dinamismo econômico das metrópoles litorâneas, para onde se dirigia um crescente contingente populacional.

\footnotetext{
17 Cabe observar com Pacheco (1998) que a integração do mercado nacional não suprime por si só as diferenças regionais, mas, antes, representa uma subordinação que se expressa, inclusive, em termos tecno-materiais, na diferenciação das estruturas produtivas das diversas regiões, cujo desdobramento vai configurar complementariedades econômicas definidas com base em uma nova divisão regional do trabalho comandada a partir de São Paulo.
} 
De acordo com Bacelar (2006), nos anos 1940 e 1950 ocorreu um modesto movimento de desconcentração espacial da produção nacional, via ocupação da fronteira agropecuária, primeiro no sentido da Região Sul e mais tarde na direção das Regiões Centro-Oeste, Norte e parte oeste do Nordeste do País.

Cabe observar que é a partir dessa década que a decadência do café impôs a diversificação das atividades agrícolas e a dinamização do processo de industrialização pelas novas possibilidades que se abriam com o processo paulatino de substituição de importações, reestruturando, desse modo, tanto o campo como as cidades mais diretamente envolvidas com essa cultura.

Trazendo à luz novos atores, o operariado, ainda em princípio sem identidade política definida, e sua contraparte no processo produtivo, o empresariado, a economia urbano-industrial irá desdobrar-se no País via setor público, mediando o ordenamento da competição no segmento privado, a partilha da população em categorias profissionais e o atendimento à agenda básica do movimento operário (SANTOS, 1993), onde buscava legitimação para a sua ação política.

A emergência do setor industrial, a expansão do terciário, a urbanização e os progressos da divisão social do trabalho, simultaneamente às sucessivas crises da economia primário-exportadora, puseram em evidência, nesse período, tanto os limites como as possibilidades do sistema econômico e político brasileiro, abrindo caminho a uma percepção estratégica do Território Nacional.

Esse foi o contexto histórico em que o nacionalismo, de acordo com lanni (1979), passou a ser um componente mais explícito do universo sociocultural, político e econômico, na condução dos rumos do País, e que terá profunda influência na percepção e na ação política do Estado em relação ao interior do Brasil.

Os próprios militares, segundo lanni (1979) foram levados a reelaborar suas concepções sobre defesa e segurança nacionais, em relação ao grau de desenvolvimento das forças produtivas do País, engajando-se, crescentemente, em um projeto mais amplo de sua transformação modernizadora. ${ }^{18}$

Esse projeto seria solidário com o avanço industrial do País e com a eliminação dos últimos focos alternativos de poder armado - as milícias estaduais - e efetivado, simultaneamente, ao enquadramento legal da divisão/hierarquização da base territorial nacional, este último tomado necessário à medida que o Estado central passava a conduzir, de forma crescentemente centralizada, a ocupação do interior, com suas variadas adaptações locais quanto à delimitação/hierarquização do espaço político, que se tentava, agora, homogeneizar.

De fato, o predomínio da União vai atuar como o fator mais importante de integração nacional no comando da economia controlada e da burocracia em expansão, (FAORO, 1991-1993), aí incluído aquele segmento da burocracia estatal voltado especificamente para o conhecimento e organização do Território Nacional.

\footnotetext{
${ }^{18}$ O Estado, segundo visão de lideranças militares na ocasião, "deve ter poder para intervir e regular toda a vida coletiva e disciplinar a nação, criando os órgãos e aparelhos próprios para organizar a nossa economia, obrigar todos ao trabalho e satisfazer o mínimo das necessidades morais e materiais de todo o cidadão brasileiro que sirva, realmente, à sua pátria" (IANNI, 1979, p. 207).
} 
Nesse contexto, a redefinição do mapa político nacional, tanto no que diz respeito às fronteiras internas das unidades político-administrativas, como às fronteiras externas, entra na agenda política do País.

Quanto às fronteiras internas, a racionalização da divisão territorial do Brasil, visando a normatização administrativa e judiciária da República, de acordo com o Decreto Lei n. 311, de 02.03.1938, insere-se no contexto de se tentar reorganizar o espaço político-administrativo do País de maneira uniforme, uma vez que este ainda estava marcado por graves discordâncias quanto aos critérios de fixação das competências territoriais, notadamente no nível municipal, que se ressentiam de absoluta falta de delimitação ${ }^{19}$.

A criação do Conselho Nacional de Estatística, em 1937, e do Conselho Nacional de Geografia, um ano depois, visavam, assim, estabelecer o plano de registro regular da divisão territorial do País, assim como o da organização do Atlas Corográfico Municipal, instrumentos necessários, também, na classificação da população do País em urbana e rural, através da fixação dos limites e áreas dos municípios e da notificação obrigatória de seus desmembramentos.

Quanto às fronteiras externas, a criação dos Territórios Federais, em 1943, insere-se no processo mais amplo não só de definição externa dos limites territoriais do País como de ocupação e valorização de seu espaço interior, notadamente a Amazônia e o Centro-Oeste, sobre o qual recairia, de forma mais direta, a ação governamental através de programas de colonização rural e de extensão do telégrafo.

Cabe observar que ao longo dos anos 1930 a noção de unidade nacional estava associada, no debate político nacional, ao próprio sentido de modernização, isto é, de superação do atraso histórico do Brasil frente às nações europeias e aos Estados Unidos ${ }^{20}$. Assim, a modernização, para autores de influência como Oliveira Vianna, se traduz na consolidação da unidade nacional e de um poder central forte capaz de garantir a unidade e o desenvolvimento do País.

Debate-se intensamente, nessa ocasião, a necessidade de expansão da infraestrutura física, enquanto elemento central de promoção da unidade territorial de um País continental precariamente articulado pela navegação de cabotagem, por linhas interioranas de navegação a vapor, pelo telégrafo ${ }^{21} \mathrm{e} / \mathrm{ou}$ por redes ferroviárias de âmbito regional.

A modernização teria, assim, um sentido concreto, passível de ser sistematizada numa agenda de medidas e reformas, de caráter político-institucional, voltada para a implantação da ordem, isto é, da organização política e social e da unidade nacional, contra a desordem, esta última traduzida na desorganização política e na descentralização, identificadas com o atraso.

\footnotetext{
19 Tais imprecisões eram, em geral, decorrentes de limites assentados arbitrariamente em propriedades particulares ou em circunscrições eclesiásticas muito antigas, além dos problemas atinentes à extraterritorialidade, isto é, relacionados à ausência de contiguidade entre subdivisões territoriais componentes de uma mesma unidade político-administrativa, devido à extensão da jurisdição sobre fazendas ou povoados encravados em circunscrições diferentes.

${ }^{20}$ O federalismo americano constituía um ponto de discórdia entre aqueles que propunham a descentralização federativa, consagrada na Constituição da República dos Estados Unidos do Brazil de 1891, e os que apoiavam uma via centralizadora de organização do poder político (e territorial) considerada mais adaptada e realista para promover a modernização de uma federação hesitante, de dimensões continentais, como a do Brasil.

21 Inovação técnica presente no Brasil desde meados do Século XIX, a expansão da linha telegráfica pelas expedições lideradas pelo "Marechal-sertanista" Cândido Rondon foi responsável pela integração efetiva do Mato Grosso ao País.
} 
A agenda modernizadora confunde-se, nesse sentido, com a própria organização e unificação do Território Nacional sob a ação de um poder central forte, que constrói a dimensão pública e institucional no País necessárias à sua efetivação. A discussão sobre a organização do espaço brasileiro, diante do esforço do governo em modernizar e integrar o País, nos anos 1930, adquire forma mais agressiva durante o Estado Novo, quando se amplia a burocracia federal voltada para o conhecimento do Território Nacional, conforme visto anteriormente.

Desse modo, a modernização se consubstanciava, no campo político-institucional, em torno da questão da organização e da unidade nacional, com a consolidação do poder central e do Estado Nacional, sendo apontada como providência necessária à superação da desordem e à adoção de políticas civilizatórias (PIVA, 2000) entre as quais se incluía o enquadramento político-administrativo das áreas de fronteira em Territórios Federais sob domínio direto da União.

Enquanto, no campo político, a centralização iria constituir a necessidade da substituição das elites dirigentes locais pela autoridade nacional, no campo estritamente territorial era necessário substituir a desordem, então imperante na regulação e na divisão do território, pela organização do mapa político do País no qual o interior e, especificamente, a região de fronteira, mais do que qualquer outro segmento do Território Nacional, encarnava a afirmação da soberania e da autoridade sobre a unidade nacional.

Para Alcir Lenharo (apud CHAUÍ, 2000, p. 215), definia-se ali uma "geografia do poder em que o espaço físico unificado constitui o lastro empírico sobre o qual os outros elementos constitutivos da nação se apoiam". Dentre esses elementos, a consolidação do mercado nacional constitui, seguramente, a base sobre a qual irá se reestruturar, dinamicamente, o extenso território brasileiro.

Quanto à integração do mercado nacional, um dos pilares do processo de substituição de importações, ao se firmar como organizador da acumulação industrial, superando as economias agrárias regionais e se responsabilizando pela abertura de sucessivas fronteiras de acumulação, o Estado assume o planejamento e a formulação da política econômica.

Nesse sentido, além da regulação do mercado de trabalho, o Estado sinaliza na direção do estabelecimento de uma nova dinâmica socioespacial e na superação dos pontos de estrangulamento existentes na infraestrutura de transporte e energia, que impediam o avanço territorial a um processo mais intenso de acumulação capitalista.

Como afirma Cano (apud BACELAR, 2006), antes do processo de integração do mercado nacional o capital comercial dominava o padrão de acumulação nas diversas células exportadoras regionais, o que não consegue ser rompido no momento em que se compete com a economia de São Paulo, de base capitalista mais avançada, mantendo, assim, seu atraso relativo ao longo de todo o período da industrialização até que o potencial de acumulação do capital industrial leve-o a invadir aquele espaço, aí incluídas as áreas agrícolas mineiras, goianas e sul-mato-grossenses, mais próximas a São Paulo, que iriam passar por um intenso processo de expansão da fronteira agropecuária a partir dos anos 1960. 
Com efeito, para aquele autor a crescente diferenciação regional ocorrida no País nesse período teria sido a contrapartida do processo de integração do mercado nacional comandado a partir de São Paulo.

Nesse contexto, a criação de Brasília, em 1960, altera não apenas o mapa político do Brasil, como promove o redesenho da rede de circulação nacional, que a partir daquele momento passava a subordinar-se, crescentemente, à integração/ampliação do mercado interno, além de servir de plataforma de penetração ao espaço amazônico dentro da geopolítica de desenvolvimento e segurança, consagrada na década de 1970, com a qual se promoveu a incorporação daquela remota fronteira de recursos; impactando, diretamente, sua frágil cobertura florestal.

Cabe observar que, no início desse período, o Plano de Metas (1956-1961) significou mais do que algumas obras viárias na incorporação do interior do País mas, principalmente, a articulação dessa infraestrutura num processo mais amplo, que envolvia a concepção de um novo padrão de industrialização, elevadas taxas de crescimento econômico, unificação do mercado nacional e o binômio indústria automobilística-rodoviarismo, responsável pelo aumento da capacidade de transporte, que, até meados dos anos 1950, representava um grande entrave ao desenvolvimento do imenso interior do País.

Com efeito, conforme anteriormente mencionado, o padrão de uso e ocupação do território brasileiro reproduzia, ainda, até esse período, uma estrutura espacial que se organizava quase que exclusivamente ao longo da faixa litorânea e em regiões econômicas pouco articuladas entre si, voltadas mais para suas respectivas áreas de influência.

Nesse contexto, a integração territorial era bastante frágil, o que resultava em uma ocupação dispersa caracterizada por ilhas econômicas, um padrão também comum a outros países latino-americanos no mesmo período. O Plano de Metas veio, assim, romper com o isolamento das Regiões Central e Norte do País por meio da transferência da capital federal para o Planalto Central e da construção de rodovias de penetração no interior do País.

O discurso da integração nacional fundamentou o nacional-desenvolvimentismo, assumindo forma elaborada e ação política agressiva a partir da década de 1970, quando a aceleração do processo associado de urbanização-industrialização, passa a alterar, de forma radical, o ritmo e a forma de articulação e uso do Território Nacional, aí incluídas as áreas menos densas de sua fronteira agropecuária.

Para Becker, Bandeira e Torres (2000), no projeto nacional-desenvolvimentista conduzido pelo Estado (1930-1980), cuja atuação culminou, além do Plano de Metas (1956-1961), com o "milagre econômico brasileiro" (1968-1972) e o Programa de Integração Nacional (1970), através dos: I Plano Nacional de Desenvolvimento - I PND (1972-1974); II PND (1975-1979); e III PND (1980-1985), a lógica do projeto nacional e do planejamento territorial apresentava-se nitidamente no sentido de se concretizar a modernização acelerada da sociedade e do Território Nacional, capaz de elevar o Brasil à condição de potência, conforme pretendia, explicitamente, o II PND.

Com efeito, segundo Fiori (2001), o Brasil foi o único país latino-americano que durante o auge da sua era desenvolvimentista (1950-1980) foi capaz de ocupar economicamente o 
território, construindo uma infraestrutura relativamente complexa e integrada de transportes, energia e comunicações modernizadas, além de industrializar-se e manter durante 30 anos a segunda taxa média anual mais alta de crescimento econômico do mundo.

A partir de meados da década de 1970, apesar das dificuldades enfrentadas com os choques do petróleo, o Estado brasileiro empreendeu vultosos investimentos particularmente no setor energético (Programa Nacional do Álcool - ProÁlCOOL, Programa Nuclear Brasileiro, Usina Hidrelétrica de Itaipu, prospecção de petróleo, etc.), dentro dos marcos do II PND que procurava completar a montagem da estrutura industrial brasileira iniciada no pós-guerra e lançar um projeto nacional de longo prazo em torno da ideia do "Brasil potência".

$\mathrm{Na}$ agricultura, a substituição de importações de insumos e máquinas significou a superação de históricas restrições externas à expansão do processo de modernização. Nesse sentido, enquanto a modernização dependia da importação de insumos químicos, equipamentos e máquinas, ela tinha um limite definido pela capacidade de importar, o que, em termos territoriais, impunha, também, algum modo de restrição frente ao potencial de expansão física da fronteira agrícola nacional. Assim, como a modernização dependia, no seu início, dessa capacidade a fim de poder se generalizar, a internalização da produção de insumos e máquinas para a agricultura rompe esse limite.

A partir daí a modernização da agricultura caminha com mais independência e os limites agora são colocados por ela mesma, isto é, pelo próprio capital assim como pela base territorial disponível no Brasil para desenvolver a atividade agrícola ${ }^{22}$.

Nesse sentido, o processo de substituição de importações, tal como ocorreu no Brasil, ao internalizar ou alavancar inúmeras atividades consumidoras de espaço, teve um forte componente territorial, notadamente no que se refere à expansão espacial da agroindústria possibilitada pela dimensão continental do País.

Nesse contexto, a incorporação dos recursos naturais constituirá mais uma vez a condição central de ampliação da fronteira econômica do Brasil, após atingida a escala de concentração industrial e financeira em torno do núcleo paulista. Nesse sentido, embora obedecendo a lógicas e momentos diferenciados de expansão/inserção no mercado interno e externo, tanto as regiões periféricas mais próximas, como as mais distantes, foram sendo incorporadas à fronteira de recursos do País.

O período que se iniciava teria, portanto, enorme significado na história recente do Brasil pelos efeitos dinamizadores do novo modelo econômico. Este último, ao buscar a ampliação do mercado interno presidido pela indústria, estimulava a demanda por alimentos e matérias-primas, criando vínculos mais intensos com as áreas de produção agropecuária e promovendo a integração de uma nova fronteira dinâmica. 22 De acordo com Tavares (1999), a expansão das fronteiras econômicas, periodicamente fechadas e reabertas, pelos negócios de
produção e exportação do agribusiness e da exploração de recursos naturais, mantém-se ao longo de toda a história econômica brasileira. 
O movimento de integração do espaço geográfico nacional, necessário à formação e ampliação do mercado interno ${ }^{23}$ é componente intrínseco ao processo de substituição de importações, foi viabilizado, portanto, pela construção de uma rede técnica pautada na expansão de rodovias e na geração/distribuição de energia a partir da segunda metade da década de $1950^{24}$ e, mais intensamente, nos anos 1970, quando se avolumam, também, os incentivos fiscais e creditícios necessários à expansão de projetos produtivos fora das áreas de maior desenvolvimento.

Em termos espaciais, tal movimento ocorreu não só pela expansão horizontal de extensas fronteiras agrícolas modernizadas - como no caso do oeste do Paraná, da Região Centro-Oeste e, mais recentemente, dos chapadões do oeste da Bahia e sul do Maranhão e Piauí, expandindo o padrão modernizado de ocupação dos cerrados do Centro-Oeste, tanto em direção à Região Nordeste, como, até mesmo, ao Bioma Amazônico - assim como através de pontos e manchas deixados na paisagem pela extração mineral e pelos projetos de agricultura irrigada na Região Semiárida nordestina.

A base sobre a qual consolidou-se a inserção produtiva da Região Centro-Oeste teve como característica principal a direção definida pelo traçado das rodovias e a adoção do modal rodoviário que, por prescindir de escala concentrada, permitiu aos agentes econômicos o desenvolvimento de atividades produtivas em diferentes espaços, gerando uma configuração espacial que resultou na consolidação de poucos e diferenciados pontos de concentração dos fluxos econômicos.

Privilegiou-se, assim, os entroncamentos rodoviários, provocando o adensamento populacional ao longo das principais vias de integração comercial com a Região Sudeste, especialmente nos núcleos que tiveram a experiência da atividade mineradora e/ou foram alvos de programas de colonização, além de equidistantes da polarização direta dos núcleos urbanos do Centro-Sul.

Nesse contexto, a histórica herança de desigualdades socioeconômicas que se reflete nas desigualdades regionais, demonstrada pela alta concentração da renda e das atividades na Região Sudeste e, mais especificamente, em São Paulo, atinge novos contornos na década de 1970, na qual se projeta, de forma nítida, a hegemonia alcançada por esse estado e sua capital sobre um espaço econômico nacional grandemente ampliado, alterando, radicalmente, o desarticulado quadro regional herdado do período histórico anterior.

A esse movimento de incorporação de áreas ao espaço econômico nacional associou-se um processo de urbanização e de industrialização que significou, simultaneamente, a desconcentração econômica e demográfica rumo ao interior, resultando na expansão e adensamento da rede urbana nacional que passa a contar com a presença de cidades grandes e de numerosas cidades médias fora do eixo litorâneo de ocupação histórica do território brasileiro.

\footnotetext{
${ }^{23}$ Segundo Galvão (apud PACHECO, 1998, p. 113), “a impressionante expansão dos fluxos do comércio inter-regional, a partir dos anos 1950 [...] testemunha o notável avanço no processo de integração econômica do país e a formação de um mercado nacional virtualmente unificado".

${ }^{24}$ Com efeito, para Fiori (2001), o núcleo da primeira agenda desenvolvimentista desenhada nos anos 1950 propunha um crescimento econômico acelerado, com base na integração e interiorização do mercado interno, organizado a partir da expansão da infraestrutura, da indústria e do agribusiness.
} 
Nesse contexto, a criação do Estado de Mato Grosso do Sul, em 1979, e do Estado do Tocantins, pela Constituição Federal do Brasil de 1988, constitui, além da legitimação de identidades e de grupos de interesse regionais, o testemunho político da incorporação e do uso mais intenso da remota fronteira agropecuária ao mercado nacional.

Com efeito, se no período inicial de construção do nacional-desenvolvimentismo (1930 a 1980) os Territórios Federais foram traçados no mapa político do Brasil enquanto afirmação dos limites fronteiriços da Região Norte do País, a mudança da capital para o Planalto Central, em 1960, e a criação dos Estados de Mato Grosso do Sul e Tocantins ${ }^{25}$, no final desse período, embora em circunstâncias diferenciadas, constitui o registro territorial de consolidação do processo de integração (do mercado) nacional.

A passagem de um período histórico, como o do nacional-desenvolvimentismo, marcado por um modelo de substituição de importação que promoveu a integração do Território Nacional, para outro período, pautado pela globalização e pela construção de um mosaico territorial que hoje em dia, caracteriza a federação brasileira, põe em evidência que a transição dos anos 1980 para a década seguinte constitui um marco no que se refere à dinâmica de ocupação do território brasileiro.

\section{O mosaico territorial contemporâneo}

Se na escala mundial não há como duvidar de que em fins da década de 1980 e início da década de 1990 uma era se encerrou e outra nova começou (HOBSBAWM, 1995), esse período também constitui, na escala nacional, um momento único de reversão de tendências no que diz respeito à dinâmica de ocupação do território brasileiro.

Em meados da década de 1980, esgotado o projeto nacional-desenvolvimentista, à crise do Estado correspondeu a crise no planejamento centralizado e no território, com a entrada em cena de novos atores que, no campo político, se fortaleceram com a redemocratização do País e, no campo econômico, com a abertura comercial e a reestruturação industrial, acompanharam a reorientação estratégica que se vai implementar no início dos anos 1990, com ênfase no comércio exterior e no aumento da competitividade.

Nesse contexto, se, internamente, com a consolidação da federação, cresce o poder político e a competição de estados e municípios e, com a abertura democrática, aumenta a participação da sociedade civil na vida política do País, no plano externo, o peso da globalização repercute na inserção competitiva de importantes segmentos da economia, aumentando a influência e a autonomia das grandes corporações na reestruturação do Território Nacional segundo seus interesses específicos.

Com efeito, para Bacelar (2006), as grandes mudanças no ambiente econômico brasileiro, com impacto na dinâmica regional e na construção do mosaico territorial contemporâneo, ocorrem nos anos 1990 num contexto mundial marcado por transformações profundas que influenciam diretamente as estratégias econômicas e locacionais das corporações, tais

\footnotetext{
25 A Constituição do Brasil de 1988 ao mesmo tempo que criou o Estado do Tocantins, criou os Estados do Amapá e de Roraima, extinguindo, desse modo, os Territórios Federais ainda preexistentes.
} 
como uma política de rápida abertura comercia ${ }^{26}$, a priorização à integração competitiva e as reformas profundas na ação do Estado, paralelamente à reestruturação produtiva promovida pelo setor privado executada com enorme intensidade e rapidez.

No plano econômico, tais movimentos, associados a um contexto de crescente disputa interestadual e intermunicipal por investimentos, embasam a ideia de fragmentação da economia, da sociedade e do território (PACHECO, 1998), relacionada com o risco de se promover a articulação direta de diversas regiões e setores industriais do País com o mercado e a economia global, sem passar pela mediação do Estado e do mercado nacionais.

Contudo, tem que se levar em consideração que os países continentais e que contam com grandes contingentes populacionais, como o Brasil, possuem, de acordo com Teixeira (apud PACHECO, 1998), uma vocação inequívoca para possuir padrões de industrialização baseados na expansão de seus mercados internos, alavancando, a partir dessa expansão e do aumento de produtividade correspondente, posições que lhe permitam obter uma inserção internacional adequada.

Para esse autor, o fato de o Brasil ser uma nação de dimensões continentais faz dela, por sua própria natureza, uma economia estruturalmente fechada ou, ao menos, que possa comportar atividades voltadas para os mercados interno e externo.

No que se refere à dinâmica espacial, vários são os processos que induzem, na contemporaneidade, à desconcentração ou, ao menos, à construção de um mosaico territorial mais complexo, ampliando as heterogeneidades internas às macrorregiões brasileiras em um momento histórico em que se está construindo, segundo Oliveira (apud BACELAR, 2006), uma economia nacional, regionalmente localizada em substituição às ilhas regionais da fase primário-exportadora.

Nesse contexto, tanto a distensão operada na alocação de investimentos, como aquela ocorrida no marco regulatório dos serviços públicos, assim como o próprio contingenciamento ambiental imposto pela legislação e, mesmo, a acomodação de interesses diversos que gravitam no mundo globalizado atual, deverão promover uma desconcentração espacial das redes físicas e dos investimentos produtivos, ainda fortemente adensadas no Centro-Sul do País ${ }^{27}$.

O ritmo dessa desconcentração será ditado, contudo, por força da interiorização do povoamento e da rede urbana, associadas direta e indiretamente à expansão do agronegócio e do setor de serviços que, historicamente, acompanha o processo de ocupação pela via da multiplicação de centros urbanos e que, hoje em dia, começa a caracterizar e a alavancar, também, uma economia e um meio rural cada vez mais dinamizados pelas forças indutoras da mudança técnica e, portanto, da industrialização e da urbanização do território em escala nacional.

\footnotetext{
${ }^{26}$ A abertura comercial constitui um dos vetores mais fortes de indução da desconcentração espacial das atividades e setores econômicos servindo de favorecimento aos focos exportadores e ao crescente papel da logística nas decisões de localização dos estabelecimentos.

27 Vale observar que grande parte da infraestrutura física do País é ainda o resultado dos investimentos e projetos provenientes do II Plano Nacional de Desenvolvimento - II PND, que ainda hoje conformam, grosso modo, a ossatura territorial do Brasil.
} 
O grau e ritmo de integração do espaço brasileiro no processo de globalização da economia, acompanhado da inserção diferenciada de suas regiões e/ou de cadeias produtivas a esse processo configura, portanto, um fator importante para se entender a nova dinâmica de crescimento e o grau de desconcentração espacial que deverá acompanhar a expansão da infraestrutura de transporte e energia no País, submetidos, agora, a um novo enquadramento normativo ${ }^{28}$.

Cabe observar que tal regulamentação deverá, também, ter profundas implicações na integração do espaço brasileiro no futuro próximo, tanto internamente quanto em relação à articulação regional sul-americana, base natural de fortalecimento do Estado Nacional para enfrentar o desafio da globalização de modo mais competitivo ${ }^{29}$.

Até o momento tal desconcentração ${ }^{30}$ tem ocorrido, grosso modo, no interior do próprio segmento Sul-Sudeste, ora em benefício de áreas localizadas no interior do Estado de São Paulo, ora daquelas situadas nos Estados do Rio de Janeiro e de Minas Gerais, reduzindo a participação relativa do núcleo metropolitano em favor dos municípios de sua periferia imediata ou, mesmo, do interior desses estados. Tanto o Paraná como o Rio Grande do Sul tiveram, também, sua participação relativa aumentada no que se refere a setores industriais específicos.

Nesse sentido, a expansão da agroindústria na Região Centro-Oeste reposicionou a situação relativa dessa região no contexto econômico nacional dado o forte peso de sua produção primária, atualmente, em grande parte, articulada ao mercado externo.

Quanto às Regiões Norte e Nordeste, apesar de crescentemente inseridas nos circuitos econômicos, tanto internos como externos, a descontinuidade espacial continua a caracterizar sua feição regional mais ampla.

Com efeito, uma das principais características do espaço regional nordestino na atualidade constitui a grande diversidade e crescente heterogeneidade de suas estruturas econômicas (BACELAR, 2000), introduzindo focos de dinamismo tanto no litoral como em áreas agropastoris tradicionais do interior e acelerando, desse modo, as forças fragmentadoras da coesão territorial de uma região historicamente marcada pela desigualdade socioeconômica.

\footnotetext{
${ }^{28}$ Nesse sentido, observa-se, na atualidade, a multiplicação de forças sociais às quais o Estado tem dado autonomia de ação e, mesmo, a possibilidade de autonormatização, abrindo espaço à coexistência de vários grupos ou centros de poder públicos, semipúblicos e privados, dotados de autonomia regulatória, tais como as Agências Reguladoras, atuando dentro ou paralelamente à estrutura do Estado em geral e do Estado brasileiro, em particular, que levam ao enfraquecimento do modelo de organização centralizado surgido com a modernidade.

${ }^{29}$ A integração sul-americana encontra-se, contudo, permanentemente ameaçada dada a histórica instabilidade institucional e geopolítica que marcam as relações internas e externas nesse continente.

30 Para Pacheco (1998), a rápida mudança ocorrida no desenho regional brasileiro nos últimos 20 anos assenta-se, preponderantemente, no deslocamento das fronteiras agrícola e mineral, no processo de integração produtiva do mercado nacional, no perfil relativamente desconcentrado do sistema urbano brasileiro, no surgimento de deseconomias de aglomeração e em pressões ambientais nas áreas mais intensamente industrializadas, nas políticas de governo, como a política econômica, as diversas diretrizes setoriais e as políticas de desenvolvimento regional, e no investimento do setor produtivo estatal. Por fim, esse autor ressalta que, mais recentemente, a desconcentração regional é decorrente, em grande parte, dos impactos diferenciados que a crise econômica e a orientação exportadora, bem como do ajuste microeconômico que as novas formas de organização da grande empresa assumiram em cada região.
} 
Nessas áreas, o movimento de expansão e intensificação do turismo no litoral nordestino tem se revelado um poderoso vetor de transformação desse espaço regional, portador de novos riscos e oportunidades à sociedade e ao meio ambiente, enquanto no interior dessa macrorregião os perímetros irrigados conferem uma nova dinâmica à expansão do agrorregional.

As alterações verificadas na dimensão espacial do desenvolvimento brasileiro não deixam dúvidas quanto à crescente heterogeneidade ocorrida no interior das regiões brasileiras, com o surgimento de espaços descontínuos de alta produtividade convivendo com áreas tradicionais, de forte estagnação econômica.

Com efeito, o movimento de integração do mercado nacional, bloqueando as possibilidades de industrializações autônomas, forçava, de acordo com Cano (apud BACELAR, 2006), o surgimento de complementaridades inter-regionais, desenvolvendo, assim, especializações regionais importantes.

Para Pacheco (1998), a crescente especialização das economias regionais na contemporaneidade parece ser a contraface do processo de integração comandado a partir de São Paulo, uma vez que estavam bloqueadas, durante a estruturação daquele processo, as possibilidades de industrializações regionais autônomas, capazes de configurar estruturas produtivas à imagem e semelhança da indústria paulista.

Desse modo, da perspectiva territorial, o que caracteriza o espaço produtivo brasileiro, é a presença de um centro, comandado por São Paulo, no qual se localiza uma estrutura produtiva que contempla a quase totalidade dos segmentos produtivos estratégicos da economia nacional. Segundo Guimarães (apud PACHECO, 1998), com a integração comercial e produtiva ocorrida na fase histórica recente, essa região se articula com as demais, ajustando e consolidando estruturas econômicas complementares e especializadas nas regiões periféricas, inclusive através da implementação de grandes unidades produtivas privadas ou estatais ${ }^{31}$.

Nesse contexto, na atualidade o que parece prevalecer em termos da dinâmica espacial é a tensão existente entre forças centralizadoras e descentralizadoras na qual irão conviver a dinamização de diversos focos de atividades agroindustriais e mineradoras, além de outros decorrentes da presença de mão de obra barata, contrabalançando a concentração do complexo industrial/terciário, aí incluído o setor financeiro, articulado pelo capital paulista.

Nesse contexto a expansão recente da bioenergia, convertendo terras não só no Estado de São Paulo, mas também nos Estados de Goiás, Mato Grosso e Mato Grosso do Sul ${ }^{32}$, além da expectativa de expansão na Região Nordeste, deixa antever um reforço no sentido da descentralização do espaço produtivo nacional que seguramente irá acirrar as discussões em

\footnotetext{
31 Leonardo Guimarães (apud PACHECO, 1998) chama atenção para o fato de que as consequências das novas formas de articulação entre Unidades da Federação e sub-regiões têm induzido alguns estudos a repensar uma nova divisão do território brasileiro. Ele observa, contudo, que apesar de a divisão regional do País ter ficado obsoleta, pela produção de novos espaços e pela fragmentação de outros, as diferentes análises sugerem, segundo o autor, que não há, até o momento, uma percepção profunda do significado, da continuidade e, sequer, de uma nova regionalização a partir da qual se percebem, mais claramente, os aspectos fundamentais do processo de reestruturação territorial e de desconcentração em curso.

32 Nos Estados de Mato Grosso do Sul e Goiás o impulso inicial de expansão da cana-de-açúcar para a fabricação do etanol parece ser o de avançar sobre áreas de pastos degradados e/ou de pecuária extensiva.
} 
torno dos limites da expansão agropecuária vis-à-vis as limitações naturais impostas, entre outras, pelos cenários traçados pelas mudanças climáticas, que parecem reverter expectativas de uso do território em diversas partes do planeta e, em especial, nas áreas de fronteira agrícola no Brasil.

É na perspectiva de um aproveitamento cada vez mais seletivo do Território Nacional, tanto do ponto de vista espacial como setorial, que a inserção no comércio internacional tende a acirrar a desarticulação dos espaços regionais. Além dessa perspectiva estritamente econômica, um novo contingenciamento, agora, de ordem ambiental, parece impor-se, também, na contemporaneidade, na ampliação das diferenças quanto ao uso do território e de seus recursos naturais que acrescentam heterogeneidade nas diversas estruturas produtivas ${ }^{33}$ e territoriais das regiões brasileiras.

Com efeito, quanto à importância do território entendido como reserva do patrimônio natural, cabe observar que no Brasil contemporâneo os recursos naturais, longe de perderem sua importância relativa, vêm adquirindo, inclusive, uma importância fundamental na própria divisão política do País.

$\mathrm{Na}$ atualidade, o Estado e a sociedade brasileira, crescentemente comprometidos com a questão ambiental contemporânea, confrontam-se com um leque de interesses bem mais imbricados, redefinidor da divisão político-administrativa de enormes extensões do Território Nacional, notadamente na Região Amazônica.

Nesse sentido, a velha questão territorial em torno da redefinição do mapa político brasileiro ganha novos contornos a partir dos anos 1980, não só devido à descentralização federativa, que promoveu o crescimento acelerado do número de municípios em todo o País, como devido à delimitação de numerosas Terras Indígenas e Unidades de Conservação (Mapas 3 e 4) que tornaram mais complexa a própria gestão do território brasileiro na atualidade.

Pode-se afirmar que a mesma legislação constitucional que abraçou o projeto descentralizador do poder pela via da divisão tributária, servindo a uma acelerada fragmentação territorial em nível subnacional, ampliou, simultaneamente, as condições de criação de uma outra malha territorial, constituída pelas Terras Indígenas e Unidades de Conservação, regulada por legislação própria, justaposta à divisão político-administrativa preexistente.

Esta malha, apesar de não reivindicar o domínio da representação político-administrativa, acabou adquirindo legitimidade, por via da força política alcançada na contemporaneidade pela questão ambiental e indígena, para atuar na regulação voltada ao controle e uso da terra, isto é, para atuar, politicamente, por meio de restrições impostas ao uso de espaços delimitados, agindo, portanto, enquanto instância territorial efetiva ${ }^{34}$.

\footnotetext{
33 A continuidade da desconcentração industrial dos anos 1970, a retração dos investimentos, o surgimento de ilhas de produtividade, muitas voltadas para o comércio exterior estimularam uma maior heterogeneidade interna da estrutura produtiva (PACHECO, 1998).

${ }^{34} \mathrm{Na}$ Amazônia, tal fato ganhou expressão política concreta na medida em que muitos municípios têm grande parte de seus territórios submetidos a contingenciamentos específicos derivados da necessidade de se conservar seja a natureza, seja a cultura indígena, gerando situações novas e ainda maldefinidas quanto à legitimidade do domínio sobre o território, que renovam, no presente, a tensão centralização-descentralização nessa região.
} 
Mapa 3 - Terras indígenas - situação fundiária - 2010

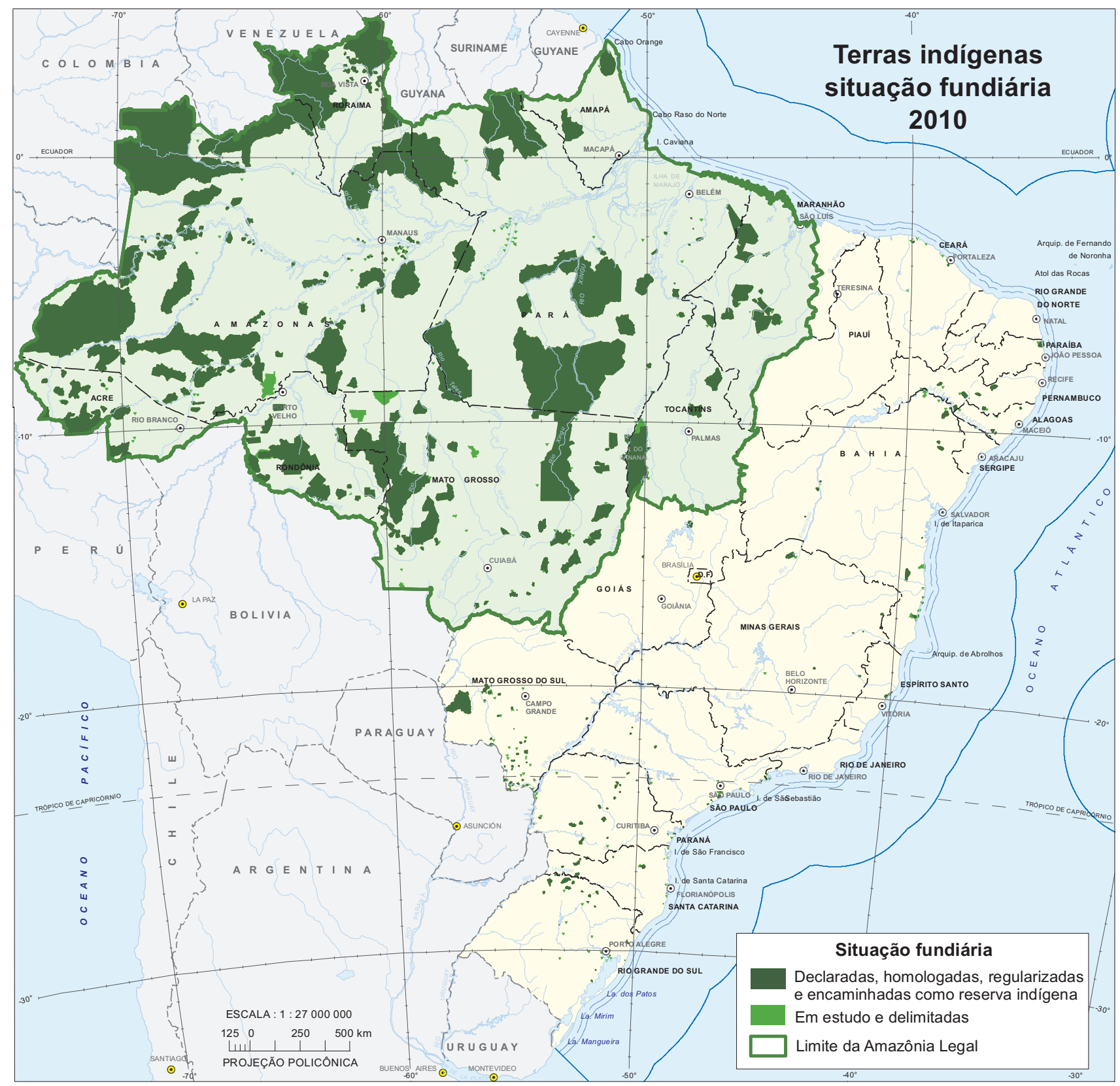

Fonte: Censo Demográfico 2010. Características gerais dos indígenas: resultados do universo. Rio de Janeiro: IBGE, 2010. Disponível em: <http://www.ibge.gov.br/home/estatistica/populacao/censo2010/default_resultados_universo.shtm>. Acesso em: jan. 2015.

Com efeito, a análise do mapa político da Amazônia contemporânea contrapõe a lógica tradicional da divisão política do espaço associada à repartição de competências políticas e de encargos tributários, que define a malha municipal, a uma outra (e nova) lógica de divisão territorial, de viés não necessariamente utilitarista, pautada numa apreciação do valor intrínseco e, portanto, não instrumental, da natureza e de formas culturais a serem preservadas. 
Tal lógica, torna difícil negar os conflitos entre crescimento econômico e proteção ambiental, uma vez que eles irão se impor ao longo do processo político assim como da ação do Estado sobre o território, apesar de as condições de fraca densidade econômica e demográfica, presentes em extensas porções dessa região, amortecerem, de alguma forma, o confronto de interesses presentes nas diferentes formas de dividir e de se apropriar, politicamente, essa região nos dias atuais.

Mapa 4 - Unidades de conservação - 2010

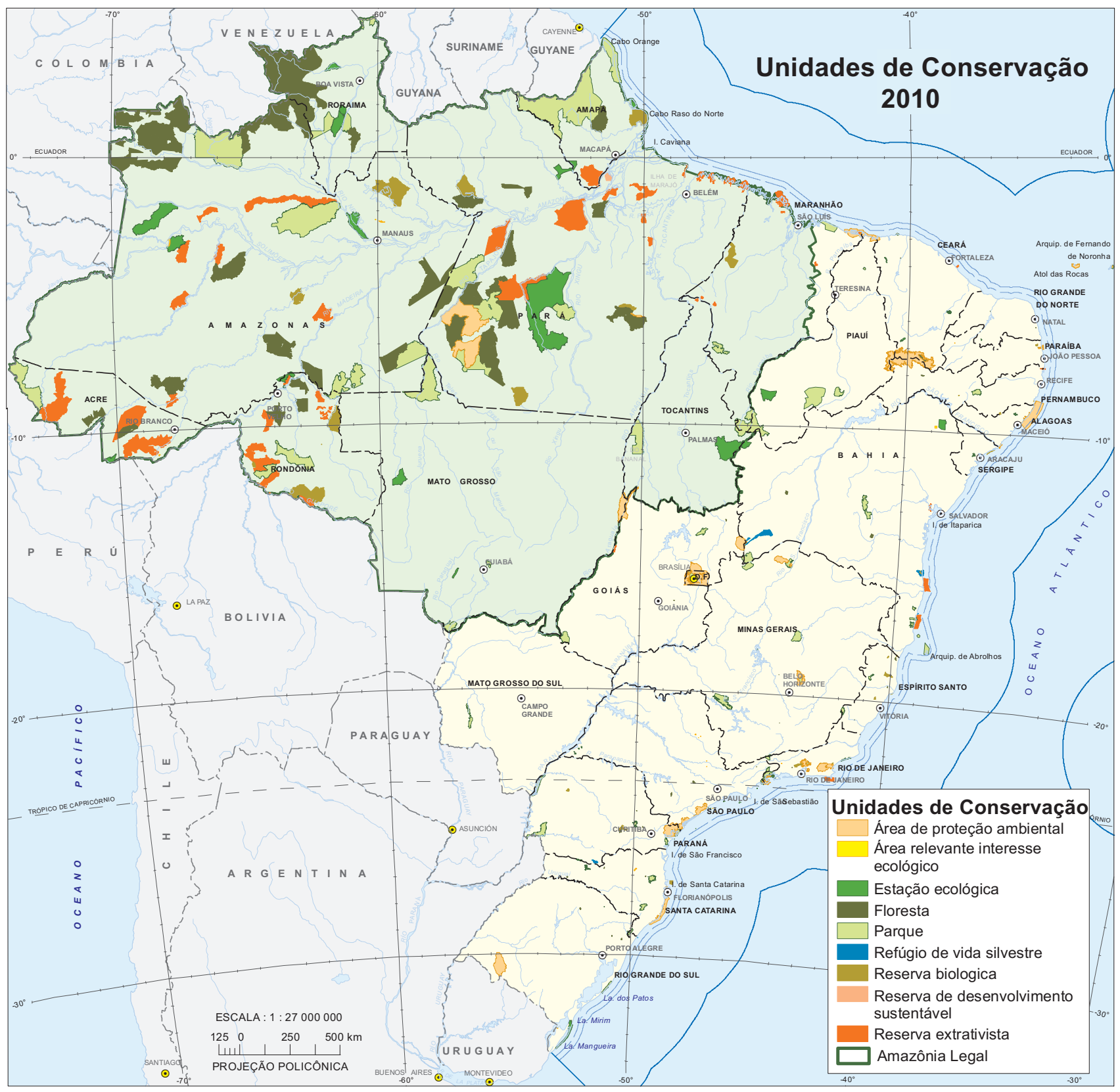

Fonte: Censo Demográfico 2010. Características gerais dos indígenas: resultados do universo. Rio de Janeiro: IBGE, 2010. Disponível em: <http://www.ibge.gov.br/home/estatistica/populacao/censo2010/default_resultados_universo.shtm>. Acesso em: jan. 2015. 
Na Amazônia constata-se, pois, no presente, um desajuste, real ou potencial, entre a regulação político-administrativa tradicional e a dinâmica e configuração territoriais emergentes da proposta ambiental. Dito de outra maneira, pode-se afirmar que entre os recortes territoriais decorrentes da ordenação federativa do País - estados e municípios - e aqueles contingenciados pela conservação ambiental - Terras Indígenas e Unidades de Conservação - existe uma tensão constante que se expressa de diferentes maneiras, tanto entre as escalas de poder, quanto em sua coerência interna.

Em um momento de valorização da dimensão local, seja devido à consolidação constitucional do sistema federativo no País, seja apoiada na afirmação da escala local, enquanto base obrigatória de referência para a ação sobre o território e, especificamente sobre o meio ambiente, como se verá em outros capítulos, recontextualiza-se, uma vez mais, a tensão centralização-descentralização no País.

Novas formas de exercício do poder (e de controle) sobre as atividades dos diferentes segmentos sociais ali presentes são projetadas, colocando em discussão a necessidade de ajuste no pacto federativo, visando atender às injunções e complexidades da dinâmica territorial contemporânea, com implicações diretas nas formas de organizar a administração e a regulação do espaço político nacional.

Enfim, a tendência atual da dinâmica da ocupação territorial aponta na direção do acirramento da complexidade e da fragmentação no uso do território brasileiro e dos riscos advindos de aprofundamento das desigualdades daí derivadas. Com efeito, segundo Furtado (1971), a partir do momento em que o motor do crescimento deixa de ser a formação do mercado interno para ser a integração à economia internacional, os efeitos de sinergia gerados pela interdependência das distintas regiões do País desaparecem, enfraquecendo consideravelmente os vínculos de solidariedade entre elas.

Um dos grandes desafios postos, desse modo, diz respeito aos limites da capacidade regulatória do Estado Nacional sobre a sociedade, a economia e o território em um mundo globalizado, no qual já se convive com inúmeros fatores de abrandamento da soberania nacional, notadamente em momentos históricos, como o atual, em que a superação das crises financeiras e ambientais colocam novamente o Brasil, e seu território, no centro de interesses estratégicos que movem a política e a economia no mundo.

Nesse sentido, o território, enquanto última fronteira da soberania nacional, constitui uma das poucas defesas concretas existentes contra os riscos inerentes à globalização, aí incluídos aqueles advindos da própria ampliação do bloco econômico regional sul-americano, com o qual o Brasil terá, necessariamente, que compartilhar uma infraestrutura física.

De acordo com Coutinho (2014), sejam quais foram as escolhas e os desafios postos à federação brasileira no volátil e interligado ambiente global, a territorialização da política, isto é, o ajuste possível das ações pública e privada à diversidade contida no território e na sociedade nacional, constitui uma estratégia a ser seguida.

Manter a coesão interna e ampliar a democracia social pela gestão participativa da sociedade sobre o território e seus recursos parecem temas definitivamente postos na agenda política do Brasil no Século XXI. 


\section{Referências}

ANDRADE, M. C. de; ANDRADE, S. M. C. de. A federação brasileira: uma análise geopolítica e geo-social. São Paulo: Contexto, 1999. 127 p. (Repensando a geografia).

BACELAR, T. O Brasil ainda precisa se consolidar como nação. Boletim Regional: informativo da política nacional de desenvolvimento regional, Brasília, DF: Ministério da Integração Nacional, n. 2, p. 14-22, maio/ago. 2006. Entrevista concedida ao jornalista Eduardo Ferreira. Disponível em: <http://www.integracao.gov.br/c/document_library/get_ file?uuid=42638937-4b59-4e82-a3a8-43e436d899ea\&groupld=24915>. Acesso em: jun, 2015.

A "questão regional" e a "questão nordestina". In: TAVARES, M. da C. (Org.). Celso Furtado e o Brasil. São Paulo: Ed. Fundação Perseu Abramo, 2000. p. 71-92. Disponível em: $<$ http://www.fpa.org.br/uploads/Celso_Furtado_e_o_Brasil.pdf>. Acesso em: jun. 2015.

BANDEIRA, P. S. Reflexões sobre a redefinição das políticas territoriais e regionais no Brasil. Brasília, DF: Ministério da Integração Nacional, 2000. 47 p.

BASTOS, A. C. T. O vale do Amazonas: a livre navegação do Amazonas, estatística, produções, comércio, questões fiscais do vale do Amazonas. Belo Horizonte: Ed. Itatiaia, 2000. 204 p. (Reconquista do Brasil, v. 216).

BECKER, B. K.; BANDEIRA, P. S.; TORRES, H. Reflexões sobre políticas de integração nacional e de desenvolvimento regional. Brasília, DF: Ministério da Integração Nacional, 2000. $177 \mathrm{p}$.

BECKER, B. K.; EGLER, C. A. G. Brasil: uma nova potência regional na economia-mundo. Rio de Janeiro: Bertrand Brasil, 1993. 267 p. (Geografia).

BENEVIDES, M. de A. Os novos territórios federais (Amapá, Rio Branco, Guaporé, PontaPorã e Iguaçu): geografia, história e legislação. Rio de Janeiro: Impr. Nacional, 1946. 264 p.

BOMFIM, M. O Brasil nação: realidade da soberania brasileira. Rio de Janeiro: Topbooks, 1996. $630 \mathrm{p}$.

CAMARGO, A. Federalismo e identidade nacional. In: SACHS, I.; WILHEIM, J.; PINHEIRO, P. S. (Org.). Brasil: um século de transformações. São Paulo: Companhia das Letras, 2001. p. 306-347.

CAVAGNARI FILHO, G. L. Debate calha norte: defesa com democracia e desenvolvimento. Teoria e Debate, São Paulo: Fundação Perseu Abramo, n. 24, p. 9-11, mar./maio 1994. Disponível em: <http://www.teoriaedebate.org.br/materias/nacional/debate-calha-nortedefesa-com-democracia-e-desenvolvimento>. Acesso em: jun. 2015.

CENSO DEMOGRÁFICO 2010. Características gerais dos indígenas: resultados do universo. Rio de Janeiro: IBGE, 2010. Disponível em: <http://www.ibge.gov.br/home/estatistica/ populacao/censo2010/default_resultados_universo.shtm>. Acesso em: jan. 2015.

CHAUÍ, M. de S. Brasil: mito fundador e sociedade autoritária. São Paulo: Ed. Fundação Perseu Abramo, 2000. 103 p. (História do povo brasileiro). Disponível em: <http://www.usp. 
br/cje/anexos/pierre/brasil_mitofundador_e_sociedade_autoritaria_marilena_chaui.pdf >. Acesso em: jun. 2015.

COSTA, W. M. da. O estado e as políticas territoriais no Brasil. 9. ed. São Paulo: Contexto, 2000. 83 p.

Políticas territoriais brasileiras no contexto da integração sul-americana. Território, Rio de Janeiro: Universidade Federal do Rio de Janeiro - UFRJ, Laboratório de Gestão do Território, ano 4, n. 7, p. 25-41, jul./dez. 1999. Disponível em: <http://www.revistaterritorio. com.br/pdf/07_3_costa.pdf>. Acesso em: jun. 2015.

COUTINHO, L. A crise e as múltiplas oportunidades de retomada do desenvolvimento industrial do Brasil. In: MONTEIRO FILHA, D.; PRADO, L. C. D.; LASTRES, H. M.M. (Org.). Estratégias de desenvolvimento, política industrial e inovação: ensaios em memória de Fabio Erber. Rio de Janeiro: Banco Nacional de Desenvolvimento Econômico e Social - BNDES, 2014. p. 81-101. Disponível em: <http://www.bndes.gov.br/SiteBNDES/bndes/bndes_pt/ Institucional/Publicacoes/Paginas/livro_fabio_erber.html>. Acesso em: jun. 2015.

COUTINHO, M. C.; SZMRECSÁNYI, T. As finanças públicas no Estado Novo, 1937-45. Revista de Economia Política, São Paulo: Centro de Economia Política: Ed. 34, v. 10, n. 2 (38), p. 67-81, abr./jun. 1990. Disponível em: <http://www.rep.org.br/PDF/38-5.PDF>. Acesso em: jun. 2015.

DINIZ, C. C. Capitalismo, recursos naturais e espaço: análise do papel dos recursos naturais e dos transportes para a dinâmica geográfica da produção agropecuária e mineral no Brasil e seus efeitos no padrão regional brasileiro. Tese (Doutorado)-Programa de Pós-Graduação em Economia Aplicada, Universidade Estadual de Campinas, Campinas, 1987.

DÓRIA, A. de S. Formas de estado. In: Direito constitucional: curso e comentários à Constituição. 3. ed. São Paulo: Ed. Nacional, 1953. v. 2, p. 5-30.

DREIFFUS, R. O ocaso das fronteiras. Problemas brasileiros, São Paulo: Conselho Regional do Serviço Social do Comércio, Serviço Nacional de Aprendizagem Comercial, n. 328, p. 4-11, jul./ago. 1998.

EVOLUÇÃO da divisão territorial do Brasil: 1872-2010. Rio de Janeiro: IBGE, 2011. (Documentos para disseminação. Memória institucional, 17). 261 p. Disponível em: <http:// www.ibge.gov.br/home/geociencias/geografia/default_evolucao.shtm>. Acesso em: jan. 2016.

FAORO, R. Os donos do poder: formação do patronato político brasileiro. 9. ed. São Paulo: Globo, 1991-1993. 2 v.

FIGUEIREDO, A. H. de. A divisão da floresta: uma (re)interpretação do mapa político da Amazônia Brasileira. 301 p. 1998. Tese (Doutorado)-Universidade Federal do Rio de Janeiro - UFRJ, Rio de Janeiro, 1998.

FIORI, J. L. Brasil no espaço. Petrópolis: Vozes, 2001, 268 p.

FURTADO, C. Formação econômica do Brasil. São Paulo: Ed. Nacional, 1971. 248 p. 
HOBSBAWM, E. J. A era dos extremos, o breve século XX: 1914-1991. São Paulo: Cia. das Letras, 1995. $598 \mathrm{p}$.

HOLANDA, S. B. Raízes do Brasil. 6. ed. Rio de Janeiro: José Olympio, [1971].

IANNI, O. Estado e planejamento econômico no Brasil: 1930-1970. 3 ed. Rio de Janeiro: Civilização Brasileira, 1979. 316 p.

LEAL, V. N. Coronelismo, enxada e voto: o município e o regime representativo no Brasil. 3. ed. Rio de Janeiro: Nova Fronteira, 1997. 440 p.

LEONARDI, V. P. de B. Fronteiras amazônicas do Brasil: saúde e história social. São Paulo: Marco Zero; Brasília, DF: Paralelo 15, 2000. 181 p.

LEUZINGER, M. D. Meio ambiente: propriedade e repartição constitucional de competências. Rio de Janeiro: Esplanada, 2002. 150 p.

LIMA, A. C. S. Militares, índios e fronteiras políticas. In: LÉNA, P.; OLIVEIRA, A. E. de (Org.). Amazônia: a fronteira agrícola 20 anos depois. Belém: Museu Paraense Emílio Goeldi; [Marseille]: Office de la Recherche Scientifique et Technique Outre-Mer - ORSTOM, Institut de Recherche pour le Développement - IRD, 1991. (Coleção Eduardo Galvão). p. 59-82.

MAGNAGO, A. A. A divisão regional brasileira: uma revisão bibliográfica. Revista Brasileira de Geografia, Rio de Janeiro: IBGE, v. 57, n. 4, p. 65-9, out./dez. 1995. Disponível em: $<$ http://biblioteca.ibge.gov.br/visualizacao/periodicos/115/rbg_1995_v57_n4.pdf >. Acesso em: jun. 2015.

MARTINS, J. de S. Clientelismo e corrupção no Brasil contemporâneo. In: O poder do atraso: ensaios de sociologia da história lenta. São Paulo: Hucitec, 1994. (Ciências sociais, 34). p. 19-51.

MIRANDA, P. de. Comentários à constituição de 1946. Rio de Janeiro: H. Cahen, [1947]. 4 v. 1.

MORAES, A. C. R. Território e história no Brasil. São Paulo: Hucitec: Annablume, 2002. $198 \mathrm{p.}$

OCTAVIO, R.; VIANNA, P. D. Elementos de direito público e constitucional brasileiro. 3. ed. rev. e aum. Rio de Janeiro: F. Briguiet, 1927. 423 p.

OLIVEIRA, F. de. Elegia para uma re(li)gião: SUDENE, Nordeste: planejamento e conflitos de classes. 3. ed. Rio de Janeiro: Paz e Terra, 1981.

PACHECO, C. A. Fragmentação da nação. Campinas: Universidade Estadual de Campinas - Unicamp, Instituto de Economia, 1998. 291 p. Originalmente apresentada como tese de Doutorado na Universidade, Campinas, 1996, sob o título: A questão regional brasileira pós-1980: desconcentração econômica e fragmentação da economia nacional.

PÁDUA, J. A. Um sopro de destruição: pensamento político e crítica ambiental no Brasil escravista (1786-1888). Rio de Janeiro: Zahar, 2002. 318 p. 
PIVA, L. G. Ladrilhadores e semeadores: a modernização brasileira no pensamento político de Oliveira Vianna, Sérgio Buarque de Holanda, Azevedo Amaral e Nestor Duarte. São Paulo: Ed. 34, 2000. 264 p.

PRADO JÚNIOR, C. Formação do Brasil contemporâneo. 2. ed. São Paulo: Brasiliense, 1945.

RECENSEAMENTO do Brazil: realizado em 1 de setembro de 1920. Rio de Janeiro: Typ. da Estatistica, 1922-1930. 5 v.

RIBEIRO, L. C. Q. Transformação geofísica e explosão urbana. In: GARCIA, A. et al. Brasil: um século de transformações. São Paulo: Companhia das Letras, 2001. p. 132-161.

RÜCKERT, A. A. O processo de reforma do estado e a política nacional de ordenamento territorial. In: OFICINA SOBRE A POLÍTICA NACIONAL DE ORDENAMENTO TERRITORIAL, 1., 2003, Brasília, DF. Anais... Brasília, DF: Ministério da Integração Nacional, Secretaria de Políticas de Desenvolvimento Regional, 2005. p. 31-39. Disponível em: <http://www.mi.gov.br/c/document_library/get_file?uuid=3fc31d16-e5f7-46fb-b8ccOfb2ae176171\&groupld=24915>. Acesso em: jan. 2016.

SANTOS, M.; SILVEIRA, M. L. O Brasil: território e sociedade no início do século XXI. Rio de Janeiro: Record, 2001. 474 p.

SANTOS, W. G. dos. A gênese da ordem. In: Razões da desordem. Rio de Janeiro: Rocco, 1993. p. 11-27.

SILVA, E. B. da. Infrastructure for sustainable development and integration of South America: a report to Business Council for Sustainable Development - Latin America (BCSD - LA). [S.I.], 1996. 84 p.

TAVARES, M. C. Império, território e dinheiro. In: FIORI, J. L. (Org.). Estados e moedas no desenvolvimento das nações. Petrópolis: Vozes, 1999. (Coleção Zero à esquerda). 492 p. 


\title{
Breve histórico do processo demográfico
}

\author{
Celso Cardoso Silva Simões
}

O presente capítulo tem como objetivo realizar uma síntese do processo de transição demográfica no Brasil, considerando as tendências, os padrões e os ritmos das principais variáveis demográficas, em especial a fecundidade e a mortalidade, tendo, como pano de fundo, o contexto socioeconômico e as diferenças regionais presentes no Território Nacional.

Procurou-se ainda, avaliar, ao longo desse processo, as alterações relacionadas com a esperança de vida ao nascer, a mortalidade infantil, a fecundidade e os impactos decorrentes sobre as estruturas etárias e suas consequências na redefinição das políticas públicas, levando em conta o peso de grupos populacionais específicos (crianças, jovens e idosos).

O capítulo está desmembrado em subitens, de forma a apresentar um panorama integrado do processo demográfico brasileiro, com ênfase a partir dos anos 1940, quando a produção de informações estatísticas e demográficas no País passa a ser mais consistente, incorporando, na medida do possível, as alterações observadas nos processos demográficos com os eventos considerados mais importantes na história do País.

Serão focados os seguintes aspectos relacionados com a dinâmica demográfica brasileira:

- Processo demográfico brasileiro; e

- Decomposição do crescimento demográfico brasileiro: a natalidade e a mortalidade; a esperança de vida ao nascer; a mortalidade infantil; as taxas de fecundidade total; e os impactos da queda da fecundidade sobre a estrutura etária e suas implicações sociais. 
Para que tal objetivo seja alcançado, serão utilizadas informações das Projeções da População do Brasil e das Unidades da Federação por Sexo e Idade, realizadas pelo IBGE (PROJEÇÃO..., 2013), até o ano 2050, obtidas pelo Método das Componentes Demográficas, levando em consideração hipóteses sobre o comportamento futuro das principais componentes da dinâmica demográfica: fecundidade, mortalidade e migrações ${ }^{1}$

\section{Aspectos demográficos}

\section{Evolução da população brasileira e suas componentes demográficas}

A população do Brasil atingiu, em 1ํ de agosto de 2010, 190732694 habitantes. A taxa média geométrica de crescimento anual, no período de 2000-2010, foi de apenas $1,17 \%$, a mais baixa já observada, refletindo a continuidade do declínio da fecundidade, que se vem verificando no decorrer dos últimos 40 anos. Este declínio é generalizado no País, isto é, ocorre em todas as regiões, exprimindo-se na queda relativa e, em diversos casos, na redução até absoluta do número de nascimentos.

A maior aceleração no aumento da população brasileira ocorreu durante a década de 1950. Naquele período, a população cresceu a uma média de 3,0\% ao ano, correspondendo a um acréscimo relativo de $34,9 \%$ no efetivo populacional. Nessa época, enquanto a mortalidade acentuava seu processo de declínio, a fecundidade mantinha-se em patamares extremamente elevados. Posteriormente, inicia-se a desaceleração do crescimento em função de uma queda inicialmente tímida da fecundidade, o que fez com que a taxa de crescimento fosse inferior a 2,5\% ao ano na década de 1970. Entretanto, nas décadas seguintes, em consonância com a transição para níveis de fecundidade mais baixos, intensifica-se o declínio na taxa de crescimento, chegando-se aos patamares atuais, com taxas de crescimento, em torno de 1,2\% (Tabela 1 e Gráfico 1).

Outro aspecto importante da evolução da população brasileira está relacionado com o processo de urbanização. Até 1960, a maioria da população residia na área rural do País, à exceção da Região Sudeste que, nessa data, já apresentava $57,0 \%$ de sua população residente na área urbana. O fenômeno da urbanização no Brasil está estreitamente associado à questão das migrações internas que se intensificam a partir do início dos anos 1960 e tendo, inicialmente, como principal área de atração a Região Sudeste, que concentrava as maiores oportunidades de emprego, em decorrência da concentração das principais atividades econômicas então existentes no País. Já em 1970, a taxa de urbanização, nessa região, chega a $73,0 \%$, enquanto, nas demais, esse valor ainda é inferior a 50,0\%.

1 Nas Projeções realizadas para o Brasil, deixou de ser contemplada a variável migração. 
Tabela 1 - População nas datas dos recenseamentos gerais, taxas médias de crescimento anual e variação da taxa de crescimento - Brasil - 1872/2010

\begin{tabular}{|c|c|c|c|}
\hline Data & População residente & $\begin{array}{c}\text { Taxa média } \\
\text { geométrica de } \\
\text { crescimento anual } \\
(\%)\end{array}$ & $\begin{array}{c}\text { Variação da } \\
\text { taxa de crescimento } \\
(\%)\end{array}$ \\
\hline \multirow[t]{2}{*}{01.08 .1872} & 9930478 & & \\
\hline & & 2,01 & \\
\hline \multirow[t]{2}{*}{31.12 .1890} & (1) 14333915 & & (-) 1,49 \\
\hline & & 1,98 & \\
\hline \multirow{2}{*}{31.12 .1900} & (1) 17438434 & & 46,97 \\
\hline & & 2,91 & \\
\hline \multirow[t]{2}{*}{01.09 .1920} & (1) 30635605 & & (-) 48,80 \\
\hline & & 1,49 & \\
\hline \multirow[t]{2}{*}{01.09 .1940} & 41165289 & & 60,40 \\
\hline & & 2,39 & \\
\hline \multirow[t]{2}{*}{ 01.07.1950 } & 51941767 & & 25,10 \\
\hline & & 2,99 & \\
\hline \multirow[t]{2}{*}{01.09 .1960} & 70070457 & & (-) 3,34 \\
\hline & & 2,89 & \\
\hline \multirow[t]{2}{*}{01.09 .1970} & 93139037 & & (-) 14,19 \\
\hline & & 2,48 & \\
\hline \multirow[t]{2}{*}{ 01.09.1980 } & 119002706 & & (-) 22,18 \\
\hline & & 1,93 & \\
\hline \multirow[t]{2}{*}{ 01.09.1991 } & 146825475 & & (-) 15,03 \\
\hline & & 1,64 & \\
\hline \multirow[t]{2}{*}{01.08 .2000} & 169799170 & & (-) 28,66 \\
\hline & & 1,17 & \\
\hline 01.08 .2010 & 190755799 & & \\
\hline
\end{tabular}

Fontes: 1. Directoria Geral de Estatística, Recenseamento do Brazil 1872/1920. 2. IBGE, Censo Demográfico 1940/2010.

(1) O efetivo populacional até o Censo de 1920 refere-se à população presente.

As Regiões Sul e Centro-Oeste, a partir de meados da década de 1970, também começam a se urbanizar de forma intensa, apesar da expansão das atividades agrícolas nestas áreas. O crescimento urbano coexiste com uma atividade agrícola muito intensa, passando por um processo de modernização no transcorrer das últimas décadas e favorecendo o processo de expulsão populacional do campo para as cidades, inclusive em áreas que até os anos 1960 e 1970 representavam espaços de expansão da fronteira agrícola.

Por outro lado, nas Regiões Norte e Nordeste, os níveis de urbanização ainda em 2010 são relativamente mais baixos $(73,0 \%)$, quando confrontados com os das Regiões Sudeste $(92,9 \%)$, Centro-Oeste $(88,8 \%)$ e Sul $(84,9 \%)$ (Tabela 2 e Gráfico 1$)$. 
Tabela 2 - Taxas de urbanização, segundo as Grandes Regiões - 1940/2010

\begin{tabular}{l|r|r|r|r|r|r|r|r}
\hline \multirow{2}{*}{ Grandes Regiões } & \multicolumn{7}{c}{ Taxa de urbanização (\%) } \\
\cline { 2 - 9 } & 1940 & 1950 & 1960 & 1970 & 1980 & 1991 & 2000 & 2010 \\
\hline \multirow{2}{*}{ Brasil } & $\mathbf{3 1 , 2}$ & $\mathbf{3 6 , 2}$ & $\mathbf{4 4 , 7}$ & $\mathbf{5 5 , 9}$ & $\mathbf{6 7 , 6}$ & $\mathbf{7 5 , 6}$ & $\mathbf{8 1 , 2}$ & $\mathbf{8 4 , 4}$ \\
Norte & 27,7 & 31,5 & 37,4 & 45,1 & 51,6 & 59,0 & 69,9 & 73,5 \\
Nordeste & 23,4 & 26,4 & 33,9 & 41,8 & 50,5 & 60,7 & 69,1 & 73,1 \\
Sudeste & 39,4 & 47,5 & 57,0 & 72,7 & 82,8 & 88,0 & 90,5 & 92,9 \\
Sul & 27,7 & 29,5 & 37,1 & 44,3 & 62,4 & 74,1 & 80,9 & 84,9 \\
Centro Oeste & 21,5 & 24,4 & 34,2 & 48,0 & 67,8 & 81,3 & 86,7 & 88,8 \\
\hline
\end{tabular}

Fonte: IBGE, Censo Demográfico 1940/2010.

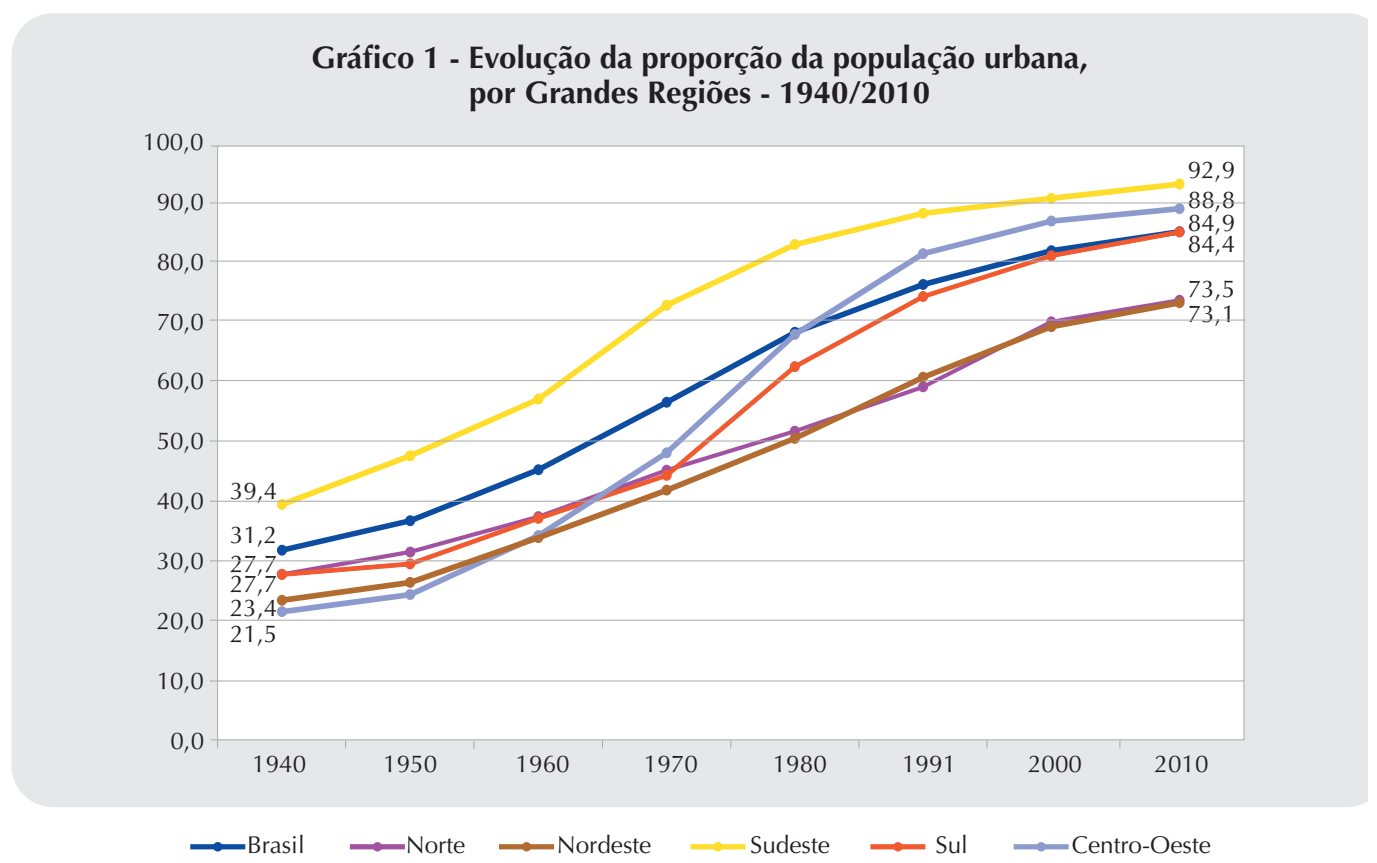

Fonte: IBGE, Censo Demográfico 1940/2010.

Em síntese, pode-se assegurar que o Brasil passou por profundas alterações durante as últimas décadas, ao deixar de ser um País predominantemente rural, situação que prevaleceu até meados da década de 1960, para uma condição atual em que $84,4 \%$ de sua população já reside em áreas urbanas.

Uma análise mais detalhada do comportamento demográfico, no Brasil, leva-se a concluir que o mesmo se manteve estável até meados do Século XX, com leves declínios da mortalidade e períodos de elevação cíclica da imigração estrangeira. Os níveis de natalidade e de mortalidade permaneceram, com pequenas oscilações, em patamares elevados, com a mortalidade apresentando tênues e graduais reduções, já a partir do final do Século XIX, enquanto que os níveis de fecundidade iniciavam declínios, embora menos expressivos, em algumas regiões específicas, a partir do início do século seguinte.

Vale ressaltar que os valores mais elevados das taxas brutas de natalidade, que oscilavam entre 45 e 50 nascimentos por 1000 habitantes, e das taxas de fecundidade total, 
que variavam, em média, entre sete e nove filhos, por mulher, refletiam a prevalência, no período, de uma visão de família numerosa, típica de sociedades agrárias precariamente urbanizadas e industrializadas.

Transformações mais consistentes no padrão demográfico só se iniciam a partir de meados da década de 1940, decorrentes, num estágio inicial, de uma relativa aceleração do declínio da mortalidade, conforme será detalhado a seguir.

Acompanhando ao longo do tempo as variáveis componentes da decomposição da taxa de crescimento demográfico ${ }^{2}$ - taxas brutas de natalidade e de mortalidade - estimadas para o Brasil, chama a atenção o fato de a mortalidade registrar declínio consistente a partir de 1940, apresentando-se estável nos períodos anteriores e com leves reduções no início do Século XX. Fundamental ressaltar o papel dos antibióticos nesse processo de queda, influenciando, num primeiro momento, na redução da mortalidade adulta, e, posteriormente, na redução da mortalidade dos grupos etários infantis e infantojuvenis.

A natalidade, por outro lado, inicia de forma mais consolidada seu declínio somente a partir dos anos 1960, acompanhando as grandes transformações socioeconômicas que vinham acontecendo no País, principalmente nas regiões do Centro-Sul, além da intensificação do processo de urbanização decorrente, em parte, dos intensos deslocamentos populacionais de origem rural, para os centros urbanos. Além do mais, esse período foi coincidente com a introdução da pílula anticoncepcional que operou como importante ferramenta na redução do tamanho da família e, posteriormente, a partir do final da década de 1970, com a prática da esterilização, iniciada especialmente nos estados da Região Sudeste e estendida aos da Região Nordeste, a partir de meados da década de 1980.

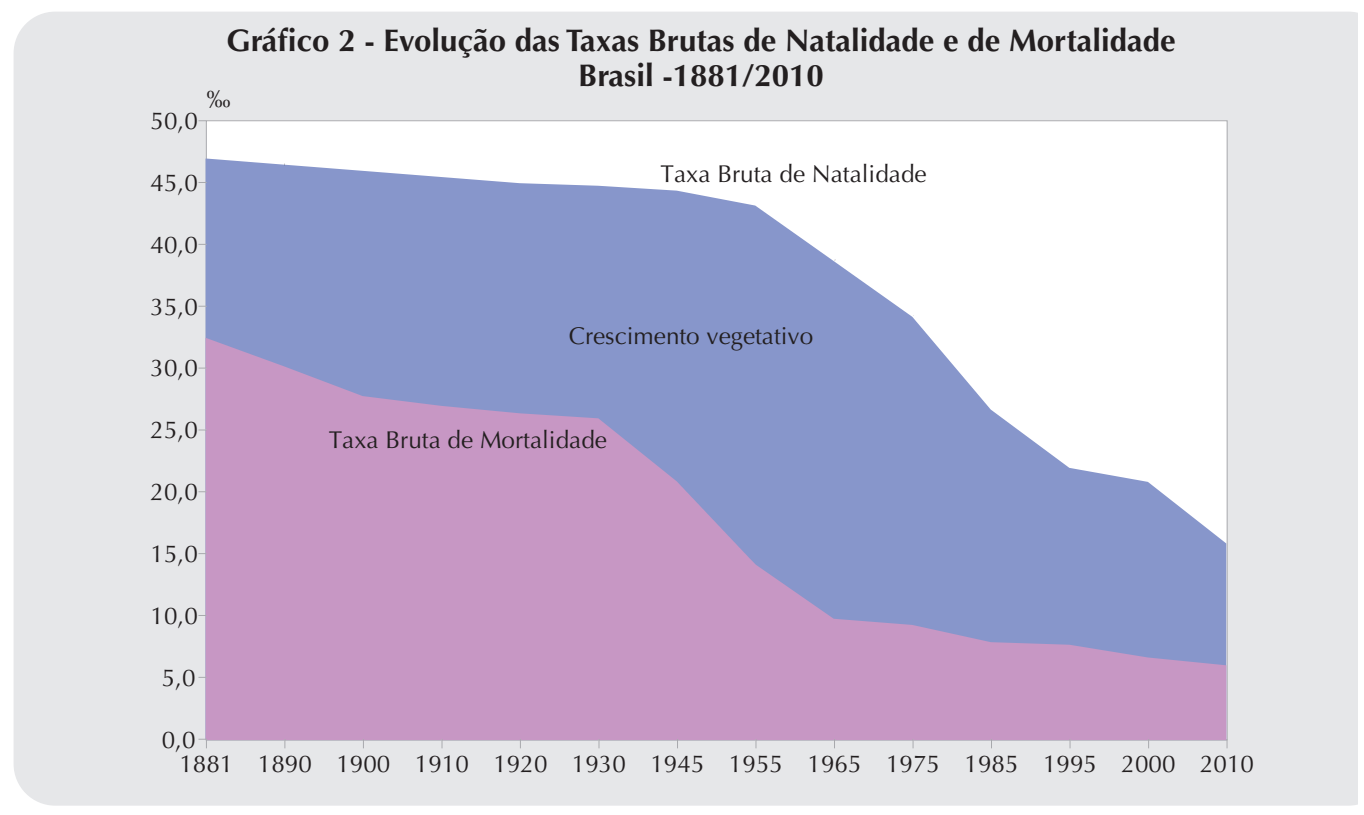

Fontes: 1. Directoria Geral de Estatística, Recenseamento do Brazil 1872/1920. 2. IBGE, Censo Demográfico 1940/2010 e Projeção da População do Brasil por Sexo e Idade 2000-2060.

\footnotetext{
2 Em termos conceituais, crescimento demográfico é resultante da diferença entre nascimentos e óbitos, mais os efeitos líquidos dos saldos migratórios.
} 
O auge do crescimento demográfico brasileiro ocorreu na década de 1950, quando foi mais elevada a diferença entre a natalidade e a mortalidade, com o País crescendo cerca de $3,0 \%$ ao ano.

A partir da análise do Censo Demográfico 1991, observa-se que, na década anterior, foi intensificado o declínio dos níveis de natalidade. Nesse período, a estimativa da taxa bruta de natalidade, que era, em média, de 29,0 nascimentos por 1000 habitantes (1985), declina para, percentualmente, 20,9\%, no ano 2000, e 15,9\%, em 2010. Em paralelo, as taxas brutas de mortalidade decaem mais lentamente, nas últimas décadas, pois seus patamares já eram relativamente baixos, oscilando apenas em função de comportamentos específicos por idade 3 .

Em síntese, a componente natalidade e os padrões correlatos de fecundidade são os principais agentes de mudanças no padrão demográfico brasileiro. O seu movimento de declínio é que explica a razão pela qual a taxa de crescimento demográfico registrada no Brasil é inferior, atualmente, a 1,2\% ao ano, de acordo com os resultados da população recenseada em 2010, quando comparados com os de 2000 (Tabela 1).

Uma análise mais detalhada dos parâmetros demográficos possibilita uma avaliação qualificada dos indicadores de mortalidade, especificamente, aqueles relativos à esperança de vida ao nascer, além de indicadores do comportamento reprodutivo (taxas de fecundidade total). Dada a grande diferenciação regional que caracteriza o Brasil, um entendimento correto dos processos demográficos, não pode deixar de incorporar a diversidade regional, conforme será visto no decorrer dos próximos capítulos.

\section{Esperança de vida ao nascer}

Raros são os estudos realizados no Brasil que permitem avaliar os níveis de sobrevivência até o início do Século XX, caso se considerar o indicador esperança de vida ao nascer. Cabe destacar, contudo, o estudo desenvolvido por Santos (1978) que, utilizando o modelo de populações estáveis, estimou a esperança de vida ao nascer da população brasileira para os anos de 1900, 1910, 1920 e 1930, cujas estimativas são apresentadas na Tabela 3.

De acordo com os resultados, pode-se concluir que, durante os primeiros 30 anos do Século XX, a população brasileira teve um aumento na sua sobrevivência de aproximadamente três anos, ou seja, um incremento de apenas $8,0 \%$, refletindo, portanto, uma elevada incidência de mortalidade, que só começou a diminuir a partir dos anos 1940. É importante também destacar a maior sobrevivência entre as mulheres, quando comparada com a dos homens. Ou seja, as diferenças que eram menores de 1 ano no início do Século XX, sobem para 1,6 ano, até 1930. Esta maior sobrevivência entre as mulheres continuará aumentando, conforme se verá mais adiante.

\footnotetext{
3 Tais como os relativos à redução da mortalidade infantil e infantojuvenil e o novo perfil epidemiológico, como, por exemplo, o aumento da mortalidade por causas externas etc.
} 
Tabela 3 - Evolução da esperança de vida ao nascer, por sexo - Brasil - 1900/1930

\begin{tabular}{|c|c|c|c|c|}
\hline \multirow{2}{*}{ Ano } & \multicolumn{3}{|c|}{ Esperança de vida ao nascer $\left(\mathrm{e}_{0}\right)$} & \multirow{2}{*}{$\begin{array}{c}\text { Diferença na }\left(\mathrm{e}_{0}\right) \\
\text { entre mulheres e homens }\end{array}$} \\
\hline & Total & Homens & Mulheres & \\
\hline 1900 & 33,65 & 33,28 & 34,05 & 0,77 \\
\hline 1910 & 34,08 & 33,55 & 34,62 & 1,07 \\
\hline 1920 & 34,51 & 33,84 & 35,21 & 1,37 \\
\hline 1930 & 36,49 & 35,72 & 37,29 & 1,57 \\
\hline
\end{tabular}

Fonte: Santos, J. L. F. Demografia: estimativas e projeções: medidas de fecundidade e mortalidade para o Brasil no século XX. São Paulo: Universidade de São Paulo - USP, Faculdade de Arquitetura e Urbanismo: Fundação para Pesquisa Ambiental, 1978. (Cadernos de estudo e pesquisa do Prodeur).

A Tabela 4 e o Gráfico 3 exibem os valores desse indicador para os anos posteriores a meados da década de 1930 até 2014, para o País como um todo e suas Grandes Regiões. É indiscutível a melhoria nos níveis de sobrevivência da população brasileira a partir de meados da década de 1930, quando a média de anos de vida foi estimada em 41,5 anos, passando para 45,5 anos, em meados da década de 1940. Ou seja, os ganhos foram de quatro anos, elevando-se para mais de seis anos no período de 1945 a 1955. Entre 1955 e 1965, observou-se desaceleração no número de anos de vida (1,8 ano).

As diferenças regionais já se refletiam nos distintos níveis de sobrevivência entre as populações residentes no País. Enquanto a Região Nordeste, durante a década de 1930/1940, apresentava os menores valores de esperança de vida ao nascer (36,7 anos), este indicador era de 49,2 anos, na Sul; 47,9 anos, na Centro-Oeste, e 43,5 anos, na Sudeste. Estas diferenças regionais refletem, entre outros fatores, a prioridade dos investimentos econômicos então norteados para as Regiões Sudeste e Sul do País, em detrimento da Região Nordeste, que, em decorrência, se transforma em área de expulsão populacional.

Tabela 4 - Esperança de vida ao nascer, segundo as Grandes Regiões - 1930/2014

\begin{tabular}{l|c|c|c|c|c|c|c|c|c}
\hline \multirow{2}{*}{$\begin{array}{c}\text { Grandes } \\
\text { Regiões }\end{array}$} & \multicolumn{10}{c}{ Esperança de vida ao nascer (anos) } \\
\cline { 2 - 11 } & $\begin{array}{c}1930 / \\
1940\end{array}$ & $\begin{array}{c}1940 / \\
1950\end{array}$ & $\begin{array}{c}1950 / \\
1960\end{array}$ & $\begin{array}{c}1960 / \\
1970\end{array}$ & 1980 & 1991 & 2000 & 2010 & 2014 \\
\hline \multicolumn{1}{c}{ Brasil } & $\mathbf{4 1 , 5 3}$ & $\mathbf{4 5 , 5 1}$ & $\mathbf{5 1 , 6 4}$ & $\mathbf{5 3 , 4 6}$ & $\mathbf{6 2 , 5 2}$ & $\mathbf{6 6 , 9 3}$ & $\mathbf{7 0 , 4 4}$ & $\mathbf{7 3 , 8 6}$ & $\mathbf{7 5 , 4 4}$ \\
Norte & 40,69 & 44,59 & 53,36 & 54,63 & 60,75 & 66,92 & 69,53 & 70,79 & 72,00 \\
Nordeste & 36,68 & 38,94 & 40,98 & 45,54 & 58,25 & 62,83 & 67,15 & 71,23 & 72,51 \\
Sudeste & 43,53 & 48,95 & 57,18 & 57,30 & 64,82 & 68,83 & 71,99 & 75,55 & 76,89 \\
Sul & 49,19 & 52,82 & 60,32 & 60,03 & 66,01 & 70,40 & 72,74 & 75,87 & 77,19 \\
Centro-Oeste & 47,92 & 51,11 & 56,65 & 58,93 & 62,85 & 68,55 & 71,75 & 73,69 & 74,67 \\
\hline
\end{tabular}

Fonte: IBGE, Censo Demográfico 1940/2010 e Projeção da População das Unidades da Federação por Sexo e Idade $2000-2030$. 
Importante também mencionar o impulso dado ao sistema de saúde pública, à previdência social, à infraestrutura urbana e à regulamentação do mercado de trabalho, observado principalmente nas regiões do Centro-Sul do País, e relacionado com o processo de urbanização nestas áreas, iniciado a partir dos anos 1930. Esses fatores institucionais, agregados aos avanços da indústria químico-farmacêutica, permitiram o controle e a redução de várias doenças, sobretudo as infectocontagiosas e pulmonares que até então tinham forte incidência sobre a população, com altos níveis de letalidade. Este conjunto de ações atuou positivamente na melhoria da qualidade de vida da população, elevando seus anos de vida média ao nascer. Ou seja, até meados da década de 1950, a esperança de vida ao nascer aumentou cerca de 10 anos para o País como um todo, ao passar de 41,5 anos (1930/1940) para 51,6 anos (1950/1960), porém, de forma menos acentuada na Região Nordeste, que teve um incremento de apenas 4,3 anos, enquanto, nas regiões do Centro-Sul, os ganhos alcançaram a cifra de 13,7 anos, a exemplo da Região Sudeste. Estes maiores ganhos, certamente, são decorrentes das ações anteriormente descritas.

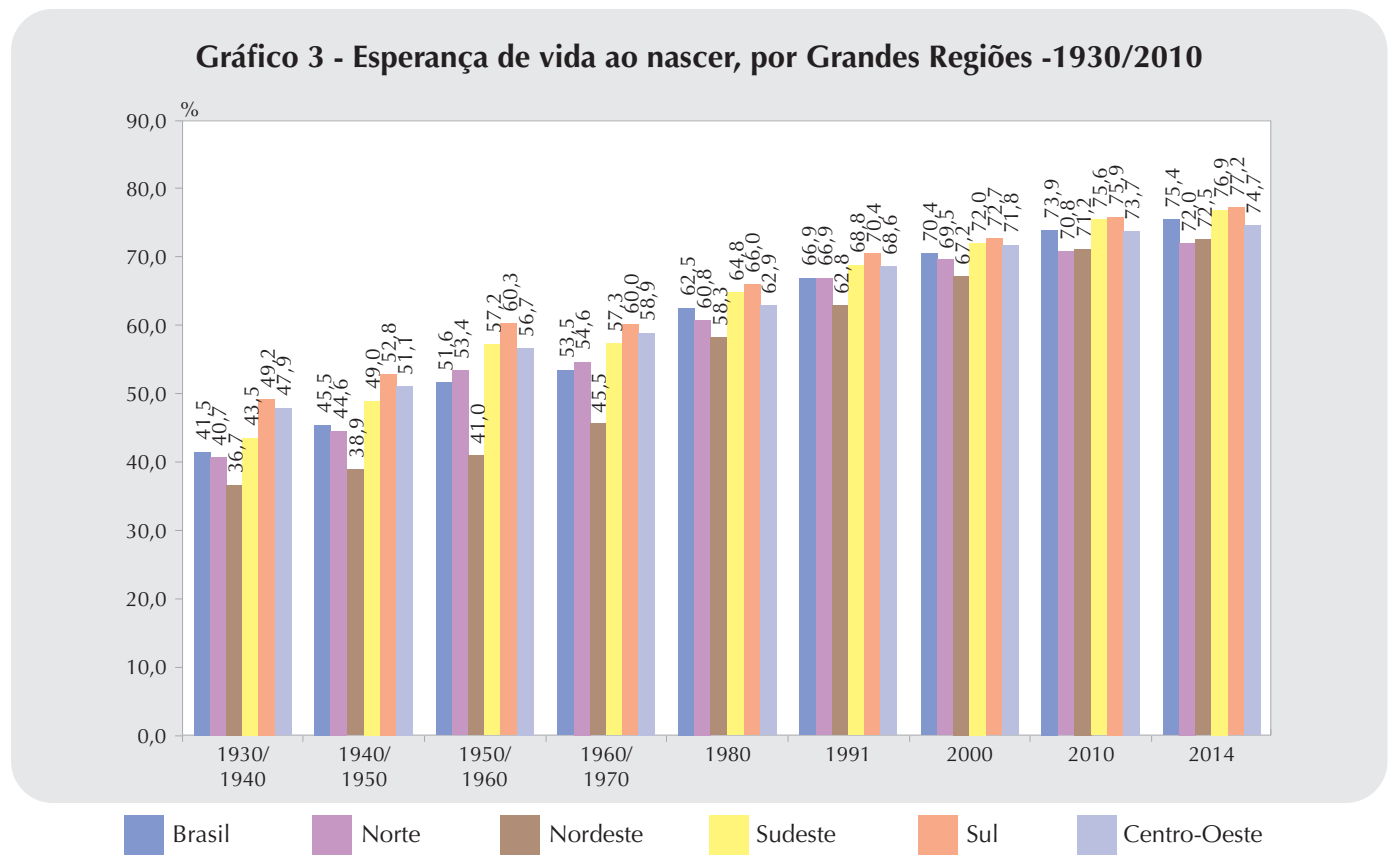

Fonte: IBGE, Censo Demográfico 1940/2010 e Projeção da População das Unidades da Federação por Sexo e Idade $2000-2030$.

Ainda com base nas informações da Tabela 4 e do Gráfico 3, constata-se que, de 1955 até o início da década de 1970, esse processo de aumento da esperança de vida ao nascer prossegue, todavia, de forma mais lenta, o que mostra a sensibilidade desse indicador ao contexto socioeconômico mais amplo. Ou seja, na ausência de políticas estruturadas e compensatórias direcionadas para a melhoria e a preservação das condições de saúde da população, em particular, a infantil, os agravos econômicos impactam, de maneira mais acentuada, exatamente aqueles segmentos populacionais que se encontram fragilizados. Em 
termos regionais, observa-se que, nas Regiões Sudeste e Sul, a esperança de vida ao nascer, praticamente, se manteve inalterada, em torno de 57 e 60 anos, respectivamente. Durante esse mesmo período, melhoraram as condições de sobrevivência da população nordestina, com incrementos de cinco anos, embora mantendo ainda valores bem abaixo dos observados para aquelas mesmas regiões.

No período de 1965 a 1975, foram constatados os menores ganhos na mortalidade, sobretudo, nas Regiões Sudeste e Sul, justamente por serem essas regiões o núcleo hegemônico da economia nacional e, portanto, diretamente mais expostas aos efeitos das flutuações na conjuntura econômica.

A crise estrutural, notadamente em suas dimensões econômico-institucional, pela qual passava a sociedade brasileira naquele período, foi talvez a principal causa da interrupção do processo de declínio da mortalidade. Cabe lembrar ainda que o grande êxodo populacional rural e a pressão demográfica sobre os grandes centros urbanos foram muito marcantes durante a década e representaram uma pressão adicional sobre os serviços de infraestrutura e de atendimento público (O PROCESSO..., 1998).

Foi a partir de meados da década de 1970, contudo, que se retomou a tendência de queda da mortalidade, tanto a geral como a infantil, em todos os países da América Latina. No caso específico do Brasil, a retomada do processo de declínio da mortalidade esteve associada, no âmbito das políticas centralizadoras do regime militar, às ações representadas pela expansão da rede assistencial e à ampliação da infraestrutura de saneamento básico, sobretudo, da rede de abastecimento d'água, a qual teve o papel principal na continuidade do processo (VETTER; SIMÕES, 1981).

Em decorrência da ampliação da oferta dos serviços de saúde e de saneamento básico e do avanço da escolarização, iniciou-se redução significativa nos padrões históricos da desigualdade regional diante da morte no País. A Região Nordeste apresentou os maiores aumentos da esperança de vida ao nascer durante o período de 1975 a 2014. A ampliação dos serviços de saneamento básico, em áreas até então excluídas, os programas de saúde materno-infantil, sobretudo os voltados para o pré-natal, parto e puerpério, a ampliação da oferta de serviços médico-hospitalares, as campanhas de vacinação, os programas de aleitamento materno e reidratação oral, em muito contribuíram para a continuidade da redução dos níveis de mortalidade infantil e infantojuvenil, principalmente a partir dos anos 1980 (SIMÕES, 1997).

Este conjunto de ações, que atuaram no sentido de reduzir a mortalidade infantil e na infância, foi um dos fatores centrais relacionados com o incremento da esperança de vida ao nascer, principalmente na Região Nordeste, conforme estudo desenvolvido no âmbito da Rede Interagencial de Informações para a Saúde - RIPSA, divulgado pela Organização Pan-Americana da Saúde - OPAS (SIMÕES, 2002). Ou seja, considerando o indicador esperança de vida ao nascer, as diferenças regionais, que eram elevadas durante a maior parte do período analisado, reduziram-se significativamente até o início da segunda década do Século XXI. Exemplificando, as diferenças entre as Regiões Nordeste e Sul, que eram de 19,3 anos, no período de 1950-1960, baixam para 4,7 anos, em 2014 (Tabela 4). 
Outro aspecto relacionado com este indicador refere-se aos diferenciais de sobrevivência por sexo (Tabela 5). Historicamente, essas diferenças não eram importantes, mas, a partir dos anos 1980, passam a adquirir significância em praticamente todas as regiões brasileiras, resultado da tendência de aumento das causas violentas que passam a afetar prioritariamente o sexo masculino, de tal forma que sua incidência chega a ser mais que o triplo, em relação ao sexo feminino (SIMÕES, 2016).

Em 1980, enquanto a esperança de vida ao nascer para o sexo feminino era de 65,7 anos, para o masculino, o valor foi de 59,6 anos. Ou seja, em nível nacional, as mulheres tinham uma sobrevida de seis anos em relação aos homens.

Em decorrência do agravamento da violência no sexo masculino, durante os períodos seguintes, particularmente nas faixas etárias que compõem o grupo de jovens-adultos (15 a 29 anos de idade), a diferença na esperança de vida ao nascer entre os sexos, para o Brasil, aumentou para 7,9 anos, em 2000, sendo que, na Região Sudeste, esse valor era de 8,6 anos inferior à das mulheres, seguida pelas Regiões Norte ( 8,3 anos), Nordeste ( 7,8 anos) e Sul (7,0 anos). Entre 2000 e 2010, enquanto, nas Regiões Nordeste e Centro-Oeste, observaram-se tendências de aumento dessas diferenças, nas demais regiões ocorreu o oposto. Entretanto, é importante chamar a atenção para o fato de que, na Região Sudeste, apesar da diminuição observada na esperança de vida ao nascer, as diferenças ainda continuam elevadas.

Tabela 5 - Esperança de vida ao nascer, por sexo, segundo as Grandes Regiões - 1980/2014

\begin{tabular}{|c|c|c|c|c|c|c|c|c|c|}
\hline \multirow{3}{*}{$\begin{array}{l}\text { Grandes } \\
\text { Regiões }\end{array}$} & \multicolumn{9}{|c|}{ Esperança de vida ao nascer } \\
\hline & \multicolumn{3}{|c|}{1980} & \multicolumn{3}{|c|}{1991} & \multicolumn{3}{|c|}{2000} \\
\hline & Total & Homens & Mulheres & Total & Homens & Mulheres & Total & Homens & Mulheres \\
\hline Brasil & \multicolumn{3}{|l|}{62,52} & \multicolumn{2}{|l|}{66,93} & 70,90 & 70,44 & 66,71 & 74,35 \\
\hline Norte & 60,75 & 58,18 & 63,74 & 66,92 & 63,67 & 70,33 & 69,53 & 66,82 & 72,38 \\
\hline Nordeste & 58,25 & 55,40 & 61,27 & 62,83 & 59,56 & 66,27 & 67,15 & 63,60 & 70,88 \\
\hline Sudeste & 64,82 & 61,68 & 68,23 & 68,83 & 64,46 & 73,42 & 71,99 & 67,90 & 76,28 \\
\hline Sul & 66,01 & 63,26 & 69,07 & 70,40 & 66,69 & 74,30 & 72,74 & 69,39 & 76,26 \\
\hline Centro-Oeste & 62,85 & 60,51 & 65,60 & 68,55 & 65,22 & 72,04 & 71,75 & 68,36 & 75,31 \\
\hline & & & oerança de $\mathrm{V}$ & da ao nasc & & & & & \\
\hline $\begin{array}{l}\text { Grandes } \\
\text { Regiões }\end{array}$ & & 2010 & & & 2014 & & varra & اçao 1980/2 & 014 \\
\hline & Total & Homens & Mulheres & Total & Homens & Mulheres & Total & Homens & Mulheres \\
\hline Brasil & 73,86 & 70,21 & 77,60 & 75,14 & 71,57 & 78,78 & 12,62 & 11,95 & 13,09 \\
\hline Norte & 70,79 & 68,58 & 74,44 & 71,77 & 68,45 & 75,53 & 11,02 & 10,27 & 11,79 \\
\hline Nordeste & 71,23 & 67,17 & 75,47 & 72,51 & 68,40 & 76,75 & 14,26 & 13,00 & 15,48 \\
\hline Sudeste & 75,55 & 72,06 & 79,00 & 76,89 & 73,62 & 80,10 & 12,07 & 11,94 & 11,87 \\
\hline Sul & 75,87 & 72,46 & 79,33 & 77,19 & 73,80 & 80,60 & 11,18 & 10,54 & 11,53 \\
\hline Centro-Oeste & 73,69 & 70,44 & 77,20 & 74,67 & 71,39 & 78,17 & 11,82 & 10,88 & 12,57 \\
\hline
\end{tabular}

Fonte: IBGE, Censo Demográfico 1980/2010 e Projeção da População das Unidades da Federação por Sexo e Idade $2000-2030$. 
Todavia, apesar das perdas observadas no indicador, particularmente entre os homens, é importante ressaltar os ganhos nos valores da esperança de vida ao nascer, em cada sexo, durante o período de 1980 a 2014, alcançando 12,0 anos para os homens e 13,1 anos entre as mulheres, no País como um todo. As Regiões Nordeste (13,0 anos), Sudeste (11,9 anos) e Centro-Oeste (10,9 anos) foram as Grandes Regiões onde se notaram os maiores ganhos na esperança de vida ao nascer, entre os homens. Por outro lado, entre as mulheres, os maiores incrementos foram verificados na Região Nordeste (15,5 anos), seguida pela Centro-Oeste (12,6 anos), Sudeste (11,9 anos) e Norte (11,8 anos). Não obstante, apesar de os maiores avanços na esperança de vida ao nascer terem se verificado nas Regiões Nordeste e Norte, é, contudo, fundamental salientar que as Regiões Sudeste, Sul e Centro-Oeste ainda exibem os valores mais elevados da esperança de vida ao nascer, independentemente do sexo ${ }^{4}$.

Em síntese, os dados sobre o aumento da esperança de vida ao nascer e os impactos da forte redução da fecundidade, conforme será discutido no próximo tópico, apontam claramente para um processo de envelhecimento populacional no País, o que vai exigir novas prioridades na área das políticas públicas. Como exemplo dessas prioridades, destaca-se, dentro de um plano, a formação urgente de recursos humanos para o atendimento geriátrico e gerontológico, além de providências a serem adotadas com relação à previdência social, que deverá se adequar a essa nova configuração demográfica, além de melhorias urgentes nas redes de atendimento hospitalar, ajustando-as a esta nova configuração populacional que tende a um crescimento cada vez mais intenso.

A não adequação da estrutura de saúde e econômica a essa nova realidade, por certo, trará efeitos negativos sobre a qualidade de vida da população brasileira que está vivenciando o processo de transição, onde, em curto e médio prazos, os idosos serão a grande maioria, com necessidades altamente diferenciadas em relação à situação anterior.

Paralelamente ao aumento da esperança de vida ao nascer, também serão discutidas as alterações que vêm se sucedendo nos níveis de reprodução das mulheres brasileiras, que vêm apresentando fortes declínios no decorrer das últimas duas décadas e que também são responsáveis pelo processo de envelhecimento por que vem passando a sociedade brasileira. No entanto, antes de se focar esse tema específico, relacionado com o processo de reprodução da mulher brasileira, será analisado o histórico da mortalidade infantil observado no Brasil, tendo em vista sua vinculação com a esperança de vida ao nascer.

\section{A evolução das taxas de mortalidade infantil $\left.\right|^{5}$}

Outra variável que vem experimentando alterações intensas, no Brasil, numa perspectiva altamente positiva, é a mortalidade infantil.

\footnotetext{
4 Para maiores detalhes do impacto da violência sobre a mortalidade em jovens, ver texto de Simões (1997).

5 Conceitualmente, a taxa de mortalidade infantil é a relação entre o número de óbitos de menores de 1 ano de idade, por 1000 nascidos vivos, na população residente em determinado espaço geográfico, no ano considerado. Estima o risco de morte dos nascidos vivos durante o seu primeiro ano de vida.
} 
Uma visão geral do quadro da evolução da mortalidade infantil é apresentada na Tabela 6 e no Gráfico 4, considerando o País como um todo e cada uma das Grandes Regiões, a partir dos anos 1930. A configuração de distintas trajetórias da mortalidade infantil entre as regiões brasileiras é um fato incontestável. Enquanto as Regiões Centro-Oeste, Sudeste e Norte mostravam, já antes de 1940, tendências lentas de declínio da mortalidade, a Região Nordeste e, principalmente, a Região Sul apresentavam níveis estáveis, com a diferença fundamental de que, nesta última, por razões históricas relacionadas com a colonização, com a importante contribuição dos fluxos de imigrantes europeus na sua estrutura populacional, seus níveis eram significativamente menores.

Na Região Nordeste, por exemplo, somente ao final da década de 1940, começa a se observar tendências na redução da mortalidade infantil, mesmo assim, num ritmo inferior ao das demais regiões.

Pode ser notada, com pequenas variações, a estabilidade dos níveis de mortalidade durante o período de 1955 a 1970, reflexo da crise estrutural, em suas dimensões econômica e institucional, passada pela sociedade brasileira, durante aquele período.

Tabela 6 - Taxas de mortalidade infantil, por Grandes Regiões - 1930/2014

\begin{tabular}{|c|c|c|c|c|c|c|}
\hline \multirow{2}{*}{ Ano } & \multicolumn{6}{|c|}{ Taxas de mortalidade infantil } \\
\hline & Brasil & Norte & Nordeste & Sudeste & Sul & Centro-Oeste \\
\hline 1930 & 162,4 & 193,3 & 193,2 & 153,0 & 121,0 & 146,0 \\
\hline 1935 & 152,7 & 170,0 & 188,0 & 145,0 & 120,0 & 133,0 \\
\hline 1940 & 150,0 & 166,0 & 187,0 & 140,0 & 118,0 & 133,0 \\
\hline 1945 & 144,0 & 156,0 & 185,0 & 130,0 & 113,0 & 123,0 \\
\hline 1950 & 135,0 & 145,4 & 175,0 & 122,0 & 109,0 & 119,0 \\
\hline 1955 & 128,2 & 127,5 & 169,6 & 108,0 & 94,7 & 114,0 \\
\hline 1960 & 124,0 & 122,9 & 164,1 & 110,0 & 96,0 & 115,0 \\
\hline 1965 & 116,0 & 111,3 & 153,5 & 96,0 & 84,0 & 99,0 \\
\hline 1970 & 115,0 & 104,3 & 146,4 & 96,2 & 81,9 & 89,7 \\
\hline 1975 & 100,0 & 94,0 & 128,0 & 86,0 & 72,0 & 77,0 \\
\hline 1980 & 80,1 & 68,4 & 116,3 & 53,8 & 46,0 & 54,2 \\
\hline 1985 & 64,1 & 57,8 & 98,0 & 41,7 & 36,4 & 44,1 \\
\hline 1990 & 48,0 & 45,9 & 75,8 & 31,4 & 28,3 & 34,3 \\
\hline 1995 & 35,7 & 35,4 & 55,5 & 24,2 & 22,5 & 26,8 \\
\hline 2000 & 29,0 & 31,0 & 45,2 & 20,1 & 16,9 & 22,6 \\
\hline 2005 & 22,2 & 25,2 & 32,0 & 16,1 & 14,0 & 19,7 \\
\hline 2010 & 17,2 & 21,1 & 23,1 & 13,0 & 11,6 & 17,0 \\
\hline 2014 & 14,4 & 18,6 & 18,4 & 11,5 & 10,1 & 15,2 \\
\hline
\end{tabular}

Fonte: IBGE, Censo Demográfico 1940/2010 e Projeção da População das Unidades da Federação por Sexo e Idade $2000-2030$.

As Regiões Sudeste e Sul foram as mais afetadas, inclusive com aumentos da mortalidade infantil, durante o período de 1955 a 1960 e de 1965 a 1970, decorrente dos seguintes fatores:

- Substancial redução do poder de compra do salário mínimo, que caiu em cerca de $45 \%$ durante o período de 1959 a 1974; 
- Profunda concentração de renda, que foi uma característica que acompanhou a evolução da economia brasileira; e

- Deterioração de certos serviços básicos, a exemplo do saneamento, relacionados com o forte impacto do aumento dos deslocamentos populacionais das áreas rurais para as urbanas.

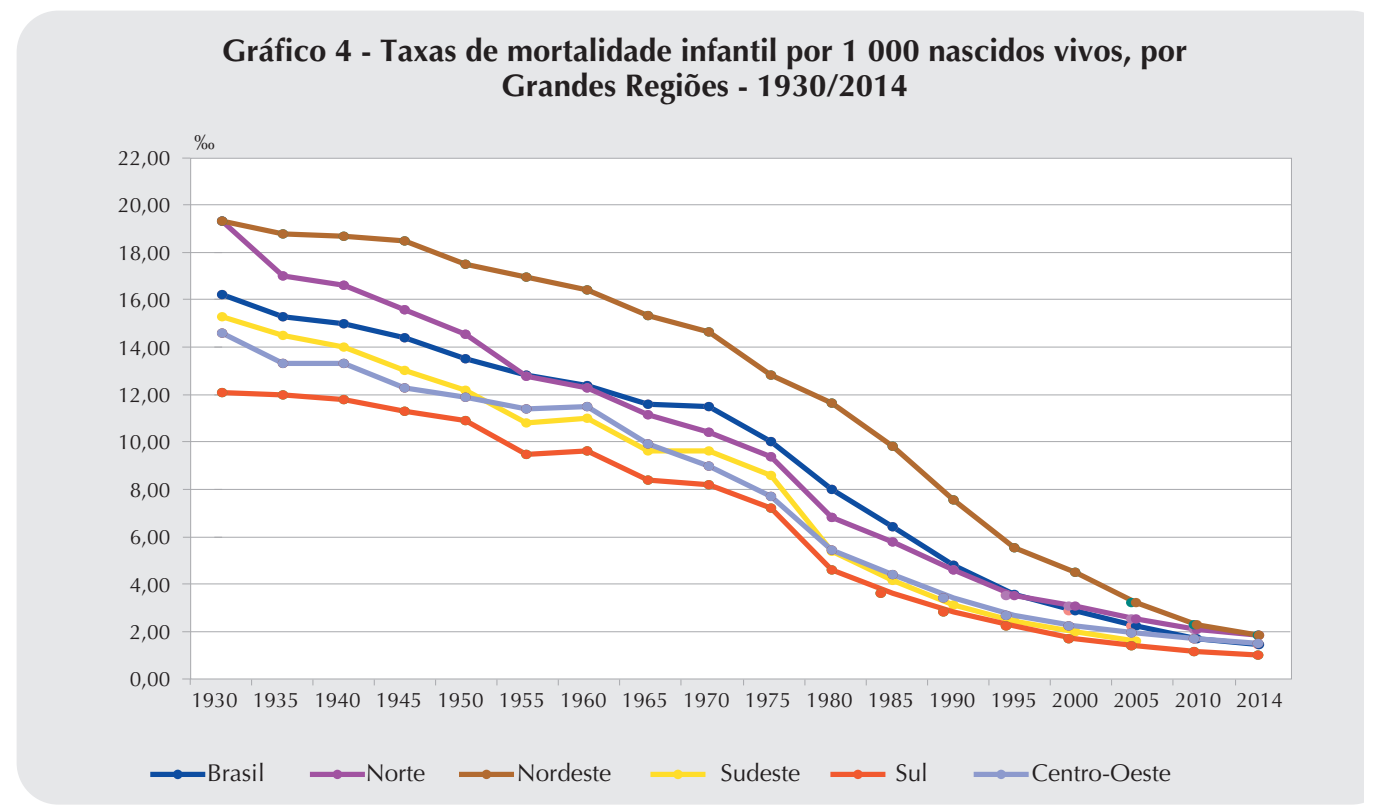

Fonte: IBGE, Censo Demográfico 1940/2010 e Projeção da População das Unidades da Federação por Sexo e Idade $2000-2030$.

É importante destacar que as diferenças regionais entre a mortalidade infantil não eram muito acentuadas no passado, mantendo-se os diferenciais à medida que se evoluía ao longo do tempo. Entretanto, a trajetória da mortalidade nordestina, por apresentar velocidade de queda inferior à observada nas demais regiões, principalmente até o final da década de 1980, foi um dos principais fatores relacionados com o aumento do diferencial entre elas, indicando um afastamento, cada vez maior.

Só para exemplificar, ao se comparar os valores da mortalidade infantil nordestina com os valores referentes à Região Sul, os mais baixos do País, constata-se que as diferenças que eram de 60,0\%, em 1930, e mantidas próximas a esse patamar durante as décadas seguintes, começam a elevar-se (150,3\%), a partir dos anos 1980, chegando a 170,0\% até o final dessa mesma década. A Região Norte, embora, com intensidade menor, seguiu tendência similar, provavelmente, em decorrência dos intensos fluxos migratórios que se dirigiram inicialmente para sua área de fronteira, sobretudo, a partir dos últimos anos da década de 1970 e início de 1980. Posteriormente, com a saturação dessas áreas, tem início um processo de deslocamentos para as capitais e periferias urbanas da região, que, na ausência de investimentos na infraestrutura urbana, gerou uma deterioração dessas áreas, agravados pela ausência de criação de empregos na economia formal, com fortes implicações nas condições de vida e sobrevivência desses grupos populacionais. 
Por outro lado, em 1990, embora ainda elevados, se se considerar a média existente em países desenvolvidos, os indicadores das demais regiões do País já tendiam a níveis similares da mortalidade infantil, com valores em torno de 30,0\%. Todavia, durante a década de 1990, dá-se início a mudanças no quadro da mortalidade infantil, quando começam a se observar reduções importantes nos diferenciais entre as regiões. Para o Brasil como um todo, a mortalidade infantil declina de 48 óbitos por 1000 menores de 1 ano de idade (1990) para, percentualmente, 29,0\%, em 2000; 17,2\%, em 2010; declinando para 14,4\%o, em 2014, de acordo com as novas Projeções da População por Sexo e Idade, divulgadas pelo IBGE em 2013, ou seja, uma queda de aproximadamente 64\%, durante o período de 1990 a 2014.

Para um melhor entendimento do processo de redução da mortalidade infantil no País, importante mencionar que, após a divulgação dos resultados do Censo Demográfico 2000, foi realizado um amplo trabalho de pesquisa sobre as atividades que estavam sendo desenvolvidas pela Pastoral da Criança, da Conferência Nacional dos Bispos do Brasil - CNBB; pelo Programa Saúde da Família, do Ministério da Saúde; ee pelo Fundo das Nações Unidas para a Infância (United Nations Children's Fund - UNICEF), além de programas como Bolsa Família, do governo federal, junto às comunidades mais carentes, principalmente nos municípios da Região Nordeste, onde os níveis de mortalidade infantil apresentavam patamares mais elevados, quando comparados com as demais regiões brasileiras. O monitoramento das crianças desde o nascimento é um fato concreto e prioritário, concluindo-se, a partir das informações disponíveis, que começaram a ocorrer melhorias inquestionáveis nas condições de saúde e sobrevivência nas faixas etárias de crianças em idade infantil e na infância.

Um exemplo dessas melhorias foi retratado no inquérito designado Chamada Nutricional, realizado em 2005, pelo então Ministério do Desenvolvimento Social e Combate à Fome, em parceria com o Ministério da Saúde, prefeituras, governos estaduais, 12 universidades públicas e o UNICEF, que deu origem ao relatório Chamada nutricional: um estudo sobre a situação nutricional das crianças do semi-árido brasileiro, publicado em 2006. O resultado do inquérito mostrou que a desnutrição infantil na Região Semiárida, uma das mais pobres do País, vinha caindo de forma expressiva. O estudo revelou que 6,6\% das crianças com até 5 anos de idade que viviam na região sofriam de desnutrição crônica (déficit de altura). O índice era 11 pontos percentuais menor que o registrado em 1996, em pesquisa semelhante efetuada na Região Nordeste, quando o percentual era de 17,9\%. Foram avaliadas 17 mil crianças com até 5 anos de idade, de 307 municípios da Região Semiárida, composta por oito estados da Região Nordeste e do norte do Estado Minas Gerais. De acordo com a pesquisa, quanto maior a renda da família, menor era o índice de desnutrição infantil. Enquanto na classe " $E$ ", 10,0\% das crianças apresentavam quadro de desnutrição crônica, na classe " $D$ ", esse índice era de 6,8\% e, na classe " $\mathrm{C}$ ", de 2,5\%. Entre as crianças das famílias que faziam menos de três refeições por dia, o índice de desnutrição crônica chegava a 16,4\%, três vezes maior do que o observado entre as crianças que faziam três refeições ou mais $(5,8 \%)$.

Os resultados dessas ações, sem dúvida, tiveram importantes impactos na redução dos níveis da mortalidade infantil, evidenciados quando se estima o indicador para o período de 1990 a 2014. 
A Região Nordeste, que apresentava uma taxa de mortalidade infantil altíssima, 75,8\%, no início da década de 1990, em 2000, o valor dessa taxa se reduz para 45,2\%, mantendo a tendência de queda durante a década $(23,1 \%$ ) , sendo que o valor projetado do indicador para 2014 é de 18,4\%, ou seja, um declínio de 40,4\%, entre 1990 e 2000; de 48,9\%, entre 2000 e 2010; e de 20,3\%, entre 2010 e 2014 (Tabela 7).

Cabe observar que, apesar das maiores reduções nos níveis de mortalidade infantil se verificarem na Região Nordeste, esta ainda continua exibindo as maiores taxas do País, quando comparadas às demais. Por conseguinte, com vistas a nortear ações de políticas públicas com o objetivo de intensificação de uma maior velocidade na redução da mortalidade infantil na região como um todo, são exibidos na Tabela 8, para os anos de 1990, 2000, 2010 e 2014, os valores desse indicador para o Brasil e as Unidades da Federação, além de suas variações relativas (\%) para cada período decenal considerado.

Tabela 7 - Variação relativa das taxas de mortalidade infantil, segundo as Grandes Regiões 1990/2010

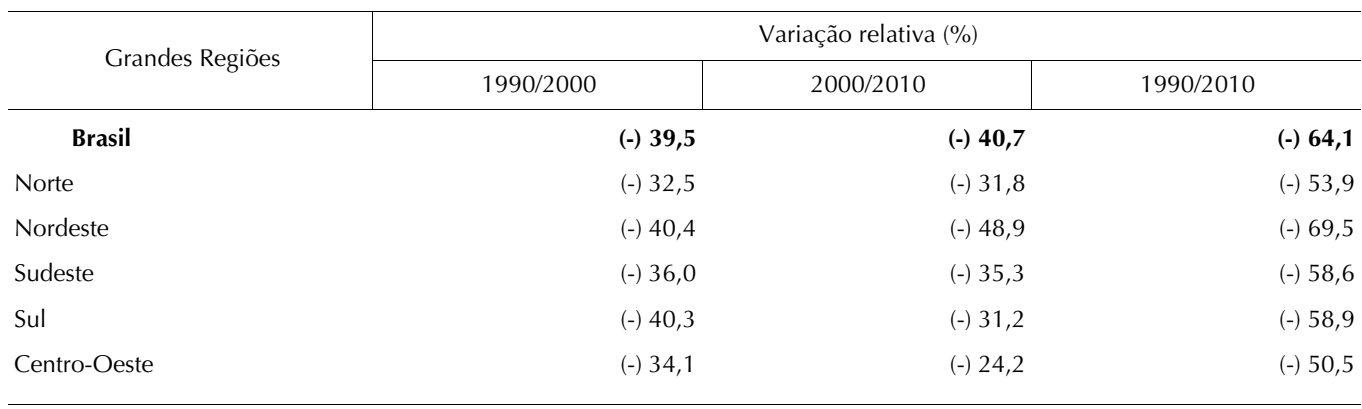

Fonte: IBGE, Censo Demográfico 1991/2010 e Projeção da População das Unidades da Federação por Sexo e Idade $2000-2030$.

Percebe-se que todas as Unidades da Federação que fazem parte das Regiões Norte e Nordeste, apesar de apresentarem intensa redução na mortalidade infantil no transcorrer das últimas duas décadas, revelam ainda níveis superiores à média nacional, sendo que os índices mais elevados, observados no ano de 2014, estão localizados no Amapá $(23,0 \%$ ), Rondônia $(20,8 \%$ ) e Acre $(18,4 \%)$, estados da Região Norte; além do Maranhão $(23,5 \%$ ), Alagoas $(22,4 \%$ ), Piauí $(20,4 \%$ ) e Bahia (19\%o), da Região Nordeste. Já as demais Unidades da Federação desta região apresentam valores abaixo desse patamar, a exemplo da Paraíba $(18,0 \%)$, Rio Grande do Norte (16,1\%o), Ceará (15,8\%o) e Pernambuco (14,0\%o).

Por outro lado, Espírito Santo (9,6\%), Santa Catarina (9,8\%), Paraná $(10,1 \%)$, Rio Grande do Sul (10,2\%o), São Paulo (10,5\%o), Distrito Federal (11,0\%o), Minas Gerais $(12,0 \%)$ e Rio de Janeiro $(12,50 \%$ ) se destacam como as Unidades da Federação de menor mortalidade infantil, enquanto, em patamares intermediários, levemente acima da média nacional $(14,4 \%)$, as demais.

Uma visão deste quadro mais recente dos diferenciais de mortalidade infantil é sintetizada no Gráfico 5, que apresenta, para o ano de 2014, uma ordenação das taxas de mortalidade infantil por Grandes Regiões e Unidades da Federação. 
Tabela 8 - Taxas de mortalidade infantil, segundo as Unidades da Federação - 1990/2014

\begin{tabular}{|c|c|c|c|c|c|c|c|}
\hline \multirow{2}{*}{ Unidades da Federação } & \multicolumn{4}{|c|}{ Taxas de mortalidade infantil ( \%o) } & \multicolumn{3}{|c|}{ Variação relativa (\%) } \\
\hline & 1990 & 2000 & 2010 & 2014 & $1990 / 2014$ & $2000 / 2010$ & $2010 / 2014$ \\
\hline Rondônia & 42,6 & 29,2 & 22,8 & 20,8 & 51,2 & 28,6 & 8,5 \\
\hline Acre & 56,5 & 38,0 & 22,1 & 18,4 & 67,5 & 51,7 & 16,8 \\
\hline Amazonas & 44,5 & 32,3 & 22,2 & 19,4 & 56,4 & 39,9 & 12,7 \\
\hline Roraima & 39,6 & 19,7 & 18,4 & 17,6 & 55,7 & 10,8 & 4,4 \\
\hline Pará & 46,2 & 30,1 & 20,3 & 17,7 & 61,8 & 41,4 & 13,0 \\
\hline Amapá & 38,1 & 29,4 & 24,6 & 23,7 & 37,9 & 19,6 & 3,7 \\
\hline Tocantins & 44,9 & 33,6 & 19,4 & 16,9 & 62,5 & 49,8 & 13,0 \\
\hline Maranhão & 76,6 & 49,9 & 29,0 & 23,5 & 69,3 & 52,9 & 19,0 \\
\hline Piauí & 65,0 & 36,4 & 23,4 & 20,4 & 68,6 & 44,1 & 13,1 \\
\hline Ceará & 79,5 & 38,1 & 19,7 & 15,8 & 80,1 & 58,5 & 19,7 \\
\hline Rio Grande do Norte & 75,7 & 44,8 & 20,6 & 16,1 & 78,7 & 64,0 & 21,6 \\
\hline Paraíba & 81,9 & 48,6 & 22,9 & 18,0 & 78,1 & 63,0 & 21,4 \\
\hline Pernambuco & 77,0 & 48,8 & 18,5 & 14,0 & 81,8 & 71,3 & 24,4 \\
\hline Alagoas & 102,2 & 63,7 & 30,2 & 22,4 & 78,1 & 64,9 & 26,0 \\
\hline Sergipe & 65,5 & 43,1 & 22,6 & 17,9 & 72,6 & 58,4 & 20,5 \\
\hline Bahia & 66,0 & 41,3 & 23,1 & 19,0 & 71,3 & 54,2 & 18,1 \\
\hline Minas Gerais & 39,0 & 25,6 & 14,6 & 12,0 & 69,3 & 53,3 & 18,2 \\
\hline Espirito Santo & 33,2 & 23,5 & 12,0 & 9,6 & 71,0 & 58,9 & 19,5 \\
\hline Rio de Janeiro & 32,3 & 19,8 & 14,1 & 12,3 & 62,0 & 38,0 & 12,6 \\
\hline São Paulo & 30,8 & 17,3 & 12,0 & 10,5 & 65,9 & 39,3 & 12,4 \\
\hline Paraná & 35,1 & 18,9 & 12,1 & 10,1 & 71,1 & 46,5 & 15,9 \\
\hline Santa Catarina & 33,6 & 15,9 & 11,2 & 9,8 & 70,8 & 38,2 & 12,5 \\
\hline Rio Grande do Sul & 26,2 & 15,3 & 11,4 & 10,2 & 61,3 & 33,5 & 10,8 \\
\hline Mato Grosso do Sul & 32,3 & 24,2 & 17,0 & 14,9 & 53,8 & 38,3 & 12,3 \\
\hline Mato Grosso & 37,5 & 25,1 & 19,5 & 17,7 & 52,8 & 29,3 & 9,3 \\
\hline Goiás & 35,1 & 23,2 & 17,7 & 15,8 & 55,0 & 32,0 & 10,9 \\
\hline Distrito Federal & 28,9 & 15,2 & 12,0 & 11,0 & 62,0 & 27,5 & 8,3 \\
\hline
\end{tabular}

Fonte: IBGE, Censo Demográfico 1991/2010 e Projeção da População das Unidades da Federação por Sexo e Idade 2000-2030.

As estimativas encontradas para a mortalidade infantil corroboram resultados já analisados em outros estudos, divulgados anteriormente e que apontavam a associação existente entre esse indicador e o status socioeconômico da mulher, no sentido de que crianças menores de 1 ano de idade, cujas mães estão inseridas nos estratos sociais de menor instrução, ainda exibem as taxas mais elevadas, enquanto os grupos de crianças de mães de estratos sociais intermediários e os de maior instrução, em escala ordenada, apresentam menores valores (SIMÕES, 1997, 2002, 2016). 


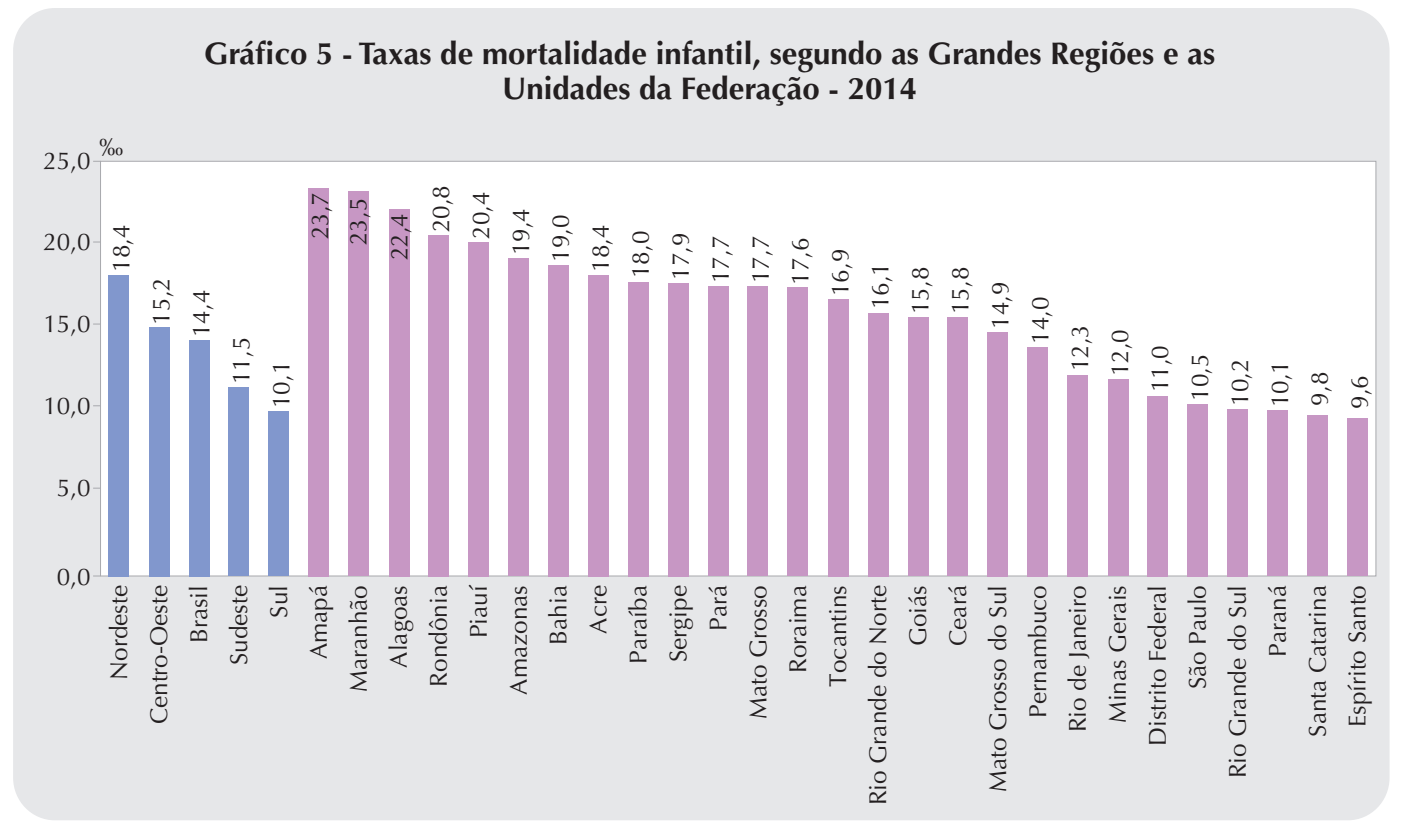

Fonte: IBGE, Projeção da População das Unidades da Federação por Sexo e Idade 2000-2030.

Em síntese, o Brasil, apesar das importantes reduções observadas no indicador, no decorrer dos últimos 25 anos, ainda exibe heterogeneidades internas, não só do ponto de vista geográfico, mas igualmente quando se leva em consideração a inserção das crianças nos distintos estratos sociais. Se, por um lado, no caso das Regiões Norte e Nordeste, apesar do importante declínio observado na mortalidade infantil, vale salientar, conforme já exposto, que, em alguns estados dessas regiões, seus valores permanecem relativamente elevados quando comparados aos das regiões do Centro-Sul do País. Ou seja, a insuficiência de oferta de importantes serviços que foram responsáveis pela queda da mortalidade infantil nas áreas mais dinâmicas do País e a sua estrutura econômica mais rígida, ao excluir contingentes significativos da população dos benefícios sociais, continua sendo um obstáculo que deve ser removido, para que se intensifique, ainda mais, o processo de queda que vem se observando na mortalidade infantil nessas áreas.

Saliente-se que, mesmo na maioria das regiões do Centro-Sul, onde se verificam valores relativamente baixos da mortalidade infantil, os índices apresentados são elevados quando comparados com os encontrados em países mais desenvolvidos e/ou naqueles que apresentam menores desigualdades sociais (abaixo de 5\%), a exemplo do Japão, Canadá, França e Portugal, dentre outros.

Por fim, enfatize-se que o nível médio da mortalidade infantil brasileira, estimado para o ano 2014, de 14,4 óbitos infantis por 1000 nascidos vivos, está fortemente influenciado pelos níveis ainda relativamente elevados que predominam em algumas das Unidades da Federação das Regiões Norte e Nordeste. Nesse sentido, para suavizar esses efeitos, num curto prazo de tempo, as políticas sociais, econômicas e de saúde deverão ser, em grande medida, fortalecidas, reorientadas e monitoradas, concentrando-se esforços nessas regiões. 


\section{Histórico do processo de evolução das taxas de fecundidade total ${ }^{6}$}

Um dos componentes mais importantes da dinâmica demográfica é a fecundidade, que afeta de maneira profunda as estruturas etárias das populações. Níveis elevados das taxas de fecundidade total estão associados a estruturas etárias muito jovens e baixa proporção de pessoas idosas.

Até meados da década de 1960, apesar do processo de urbanização e industrialização que vinha ocorrendo a partir de 1930, os níveis de fecundidade mantiveram-se elevados e estáveis, ainda que os diferenciais regionais e sociais fossem crescentes. Nos Estados do Rio de Janeiro e de São Paulo, e em parte da Região Sul, desde 1940, a fecundidade já vinha passando por um processo de declínio, com patamares ligeiramente mais baixos ano a ano, tendência esta que antecipava a diminuição acelerada, verificada, posteriormente, em todo o País.

A partir de 1960, constata-se a intensificação, cada vez mais generalizada e rápida, do declínio da fecundidade, que se consolida durante as décadas de 1970 e 1980, em todas as regiões brasileiras, inclusive nas áreas rurais e em grupos sociais mais pobres. A literatura especializada comumente contempla uma série de causas e motivações com vistas a explicar a súbita mudança no comportamento reprodutivo da população brasileira. Entre elas, vale destacar fatores econômicos, sociais, político-institucionais e as chamadas variáveis intermediárias, inibidoras da fecundidade, como determinadas características de natureza demográfica e o conhecimento e uso de métodos anticoncepcionais.

Os primeiros fatores assinalados, de natureza estrutural, respondem pela determinação, em última instância, dos padrões de dinâmica demográfica. Isto, necessariamente, porque o significado histórico das relações entre a dinâmica populacional e a formação social concreta somente pode ser apreendido quando se situa a variável população em sua interação com as transformações e a dinâmica específica das relações sociais e da organização produtiva.

É importante chamar a atenção para o fato de que, a partir da década de 1960, se inicia, no País, a difusão dos métodos anticonceptivos, particularmente nas regiões do Centro-Sul. Até essa década, a taxa de fecundidade total, que era levemente superior a seis filhos por mulher, declina, em 1970, para 5,8 filhos, em decorrência da redução mais forte observada na Região Sudeste (Tabela 9 e Gráfico 6).

Segundo a publicação Nupcialidade e fecundidade: resultados da amostra do Censo Demográfico 2000 (2003, p. 55):

\footnotetext{
6 Conceitualmente, a taxa de fecundidade total representa o número médio de filhos nascidos vivos, tidos por uma mulher ao final de seu período reprodutivo, na população residente, em determinado espaço geográfico. Esse indicador é o principal determinante da dinâmica demográfica, não sendo afetado pela estrutura etária da população. Expressa a situação reprodutiva de uma mulher pertencente a uma coorte hipotética, sujeita às taxas específicas de fecundidade por idade, observadas na população em estudo, supondo-se a ausência de mortalidade nesta coorte.
} 
Por se tratar da região mais urbanizada do País, proporcionando um maior acesso aos meios existentes para evitar uma gravidez não desejada, e dispor de um parque industrial e de uma rede de comércio e serviços, impulsionadores da economia nacional, que absorvia um número cada vez maior de mão de obra feminina, a Região Sudeste do Brasil foi a primeira a experimentar a maior redução no nível da fecundidade: quase 2 filhos de 1960 a 1970.

Já, nas Regiões Sul e Centro-Oeste, o início da transição da fecundidade se processa a partir dos primeiros anos da década de 1970, enquanto, nas Regiões Norte e Nordeste, este fato se verifica a partir do início da década de 1980, em decorrência da prática de uma política não "oficializada" de esterilização, uma vez que a grande maioria das mulheres que "optavam" por este procedimento, realizava-o na rede pública hospitalar.

Tabela 9 - Taxas de Fecundidade Total, segundo as Grandes Regiões - 1940/2014

\begin{tabular}{l|r|r|r|r|r|r|r|r|r}
\hline \multirow{2}{*}{ Grandes Regiões } & \multicolumn{10}{c}{ Taxas de Fecundidade Total (TFT) } \\
\cline { 2 - 11 } & 1940 & 1950 & 1960 & 1970 & 1980 & 1991 & 2000 & 2010 & 2014 \\
\hline \multirow{2}{*}{ Brasil } & $\mathbf{6 , 1 6}$ & $\mathbf{6 , 2 1}$ & $\mathbf{6 , 2 8}$ & $\mathbf{5 , 7 6}$ & $\mathbf{4 , 3 5}$ & $\mathbf{2 , 8 5}$ & $\mathbf{2 , 3 9}$ & $\mathbf{1 , 8 7}$ & $\mathbf{1 , 5 7}$ \\
Norte & 7,17 & 7,97 & 8,56 & 8,15 & 6,45 & 4,15 & 3,18 & 2,40 & 2,16 \\
Nordeste & 7,15 & 7,50 & 7,39 & 7,53 & 6,13 & 3,75 & 2,72 & 2,02 & 1,85 \\
Sudeste & 5,69 & 5,45 & 6,34 & 4,56 & 3,45 & 2,36 & 2,11 & 1,70 & 1,61 \\
Sul & 5,65 & 5,70 & 5,89 & 5,42 & 3,63 & 2,50 & 2,17 & 1,70 & 1,60 \\
Centro-Oeste & 6,36 & 6,86 & 6,74 & 6,42 & 4,51 & 2,69 & 2,25 & 1,83 & 1,72 \\
\hline
\end{tabular}

Fonte: IBGE, Censo Demográfico 1940/2010 e Projeção da População das Unidades da Federação por Sexo e Idade 2000-2030.

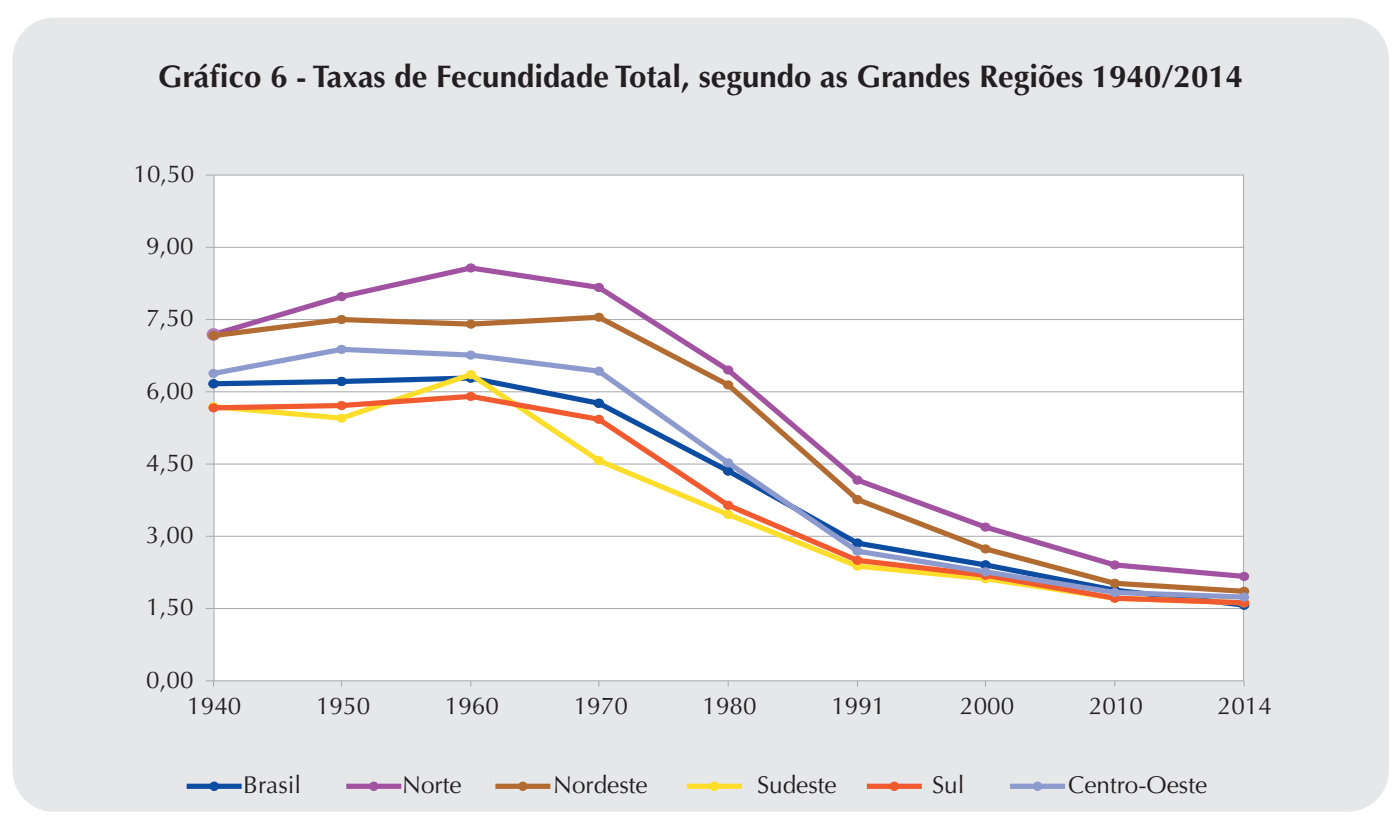

Fonte: IBGE, Censo Demográfico 1940/2010 e Projeção da População das Unidades da Federação por Sexo e Idade $2000-2030$. 
Durante a década de 1980, manteve-se o ritmo de declínio, chegando, em 2000, à estimativa da ordem de 2,39 filhos por mulher e de 1,87 filho, em 2010. De acordo com as Projeções da População por Sexo e Idade, divulgadas pelo IBGE em 2013, a estimativa cai para 1,57 filho, indicativo de que a fecundidade no País já se encontra bem inferior ao nível de reposição (2,1 filhos por mulher). Trata-se de um rápido e espetacular declínio, num espaço de tempo bastante reduzido (34 anos), quando comparado à experiência vivenciada pelos países desenvolvidos, cujo processo teve uma duração superior a um século para atingir patamares similares.

Considerando as diferenças regionais, verifica-se que as Regiões Norte e Nordeste, justamente as mais ruralizadas do País, lideravam o ranking da fecundidade mais elevada. Em 1970, essas duas regiões apresentavam taxas de fecundidade superiores a sete filhos por mulher, enquanto a Região Sudeste já apresentava valores bem abaixo (4,6 filhos por mulher). O processo de declínio da fecundidade, sobretudo a partir dos anos 1980, generalizou-se por todas as regiões e grupos sociais, de tal forma que, em 2010, mesmo as regiões que antes tinham fecundidade elevada, com exceção da Região Norte $(2,40)$ já apresentavam taxas reduzidas, inferiores aos níveis de reposição $(2,02)$, conforme é exibido na Tabela 9. Vale salientar que, em 2000, as taxas de fecundidade total estimadas para as Regiões Sudeste e Sul, cujos valores estavam em torno de 2,1 filhos por mulher, já podiam ser consideradas como tendo atingido níveis de reposição. As demais regiões também continuaram mantendo a tendência de queda, a ponto de que, para o ano de 2014, todas as regiões já apresentam valores inferiores a 2,1 filhos por mulher, com exceção da Região Norte, que estaria no limite.

Os resultados confirmam a associação entre posição socioeconômica da população e níveis de fecundidade, no sentido de que os grupos menos instruídos ainda apresentam taxas de fecundidade mais elevadas, enquanto os grupos intermediários e os mais instruídos, em escala ordenada, detêm menores valores. Todavia, cabe esclarecer que as diferenças entre as taxas de fecundidade total do primeiro e último estrato educacional vêm se reduzindo de maneira acentuada nas últimas décadas (Tabela 10), independentemente da região de residência.

Tabela 10 - Diferença entre o número de filhos de mulheres com até 3 anos de instrução e de mulheres com 8 anos e mais de instrução, por Grandes Regiões -1970/2014

\begin{tabular}{|c|c|c|c|c|c|c|}
\hline \multirow{2}{*}{ Ano } & \multicolumn{6}{|c|}{$\begin{array}{c}\text { Diferença entre o número de filhos de mulheres com até } 3 \text { anos de instrução e } \\
\text { de mulheres com } 8 \text { anos e mais de instrução }\end{array}$} \\
\hline & Brasil & Norte & Nordeste & Sudeste & Sul & Centro Oeste \\
\hline 1970 & 4,54 & 5,51 & 5,28 & 4,03 & 3,98 & 4,56 \\
\hline 1980 & 4,16 & 4,34 & 3,94 & 2,79 & 2,67 & 2,88 \\
\hline 1991 & 2,15 & 3,20 & 2,77 & 1,44 & 1,70 & 1,61 \\
\hline 2000 & 1,81 & 2,76 & 2,08 & 1,35 & 1,53 & 1,36 \\
\hline 2010 & 1,56 & 2,18 & 1,58 & 1,12 & 1,31 & 1,15 \\
\hline 2014 & 1,31 & 1,96 & 1,25 & 1,06 & 1,23 & 1,08 \\
\hline
\end{tabular}

Fontes: 1. IBGE, Censo Demográfico 1970/2010 e Projeção da População das Unidades da Federação por Sexo e Idade 2000-2030. 2. Simões, C. C. da S. Relações entre as alterações históricas na dinâmica demográfica brasileira, políticas públicas e impactos futuros decorrentes do processo de envelhecimento da população. Rio de Janeiro: IBGE, Departamento de Pesquisas, 2016. No prelo. 
No Brasil, o diferencial que era, em 1970, de 4,5 filhos por mulher, declina para 1,3 filho, em 2014, relacionado, de acordo com o estudo desenvolvido por Simões (2016), com a acentuada queda da taxa de fecundidade total estimada para mulheres com até 3 anos de escolaridade, que passa de 7,2 filhos para 2,5 filhos, durante o período analisado (Gráfico 7).

Importante destacar que, a partir de 1980, as mulheres mais instruídas começaram a ter taxas de fecundidade total abaixo do nível de reposição, sendo que, em 2010, de acordo com o estudo anteriormente citado, esse valor situava-se em 1,4 filho, reduzindo-se, ainda mais, em 2014 (1,2 filho), indicativo de um maior controle da reprodução por parte destes segmentos populacionais mais instruídos. Também dentro da perspectiva regional, podem-se constatar mudanças nos padrões reprodutivos da mulher brasileira.

Ressalte-se que os decréscimos nacional e regional da fecundidade vêm ocorrendo em todos os estratos sociais. Vale chamar a atenção para o fato de que o nível de instrução da mãe tem sido uma das principais variáveis socioeconômicas a receber atenção especial nos estudos, tanto de mortalidade como de fecundidade, por ser um fator determinante na transformação de conduta da mulher frente à reprodução, além de ser proxy de condição socioeconômica. Além disso, a educação influencia a conduta da mãe desde a gravidez até a criação e o desenvolvimento dos filhos. A adoção de práticas mais sadias e a maior percepção quanto ao cuidado e o trato de higiene e de saúde dos filhos, e um maior poder de decisão da mãe mais instruída dentro do domicílio, sobretudo em relação à proteção das crianças, estariam por detrás do papel da educação da mãe, na melhoria, não só das condições de sobrevivência das crianças, mas também na redução dos níveis de fecundidade.

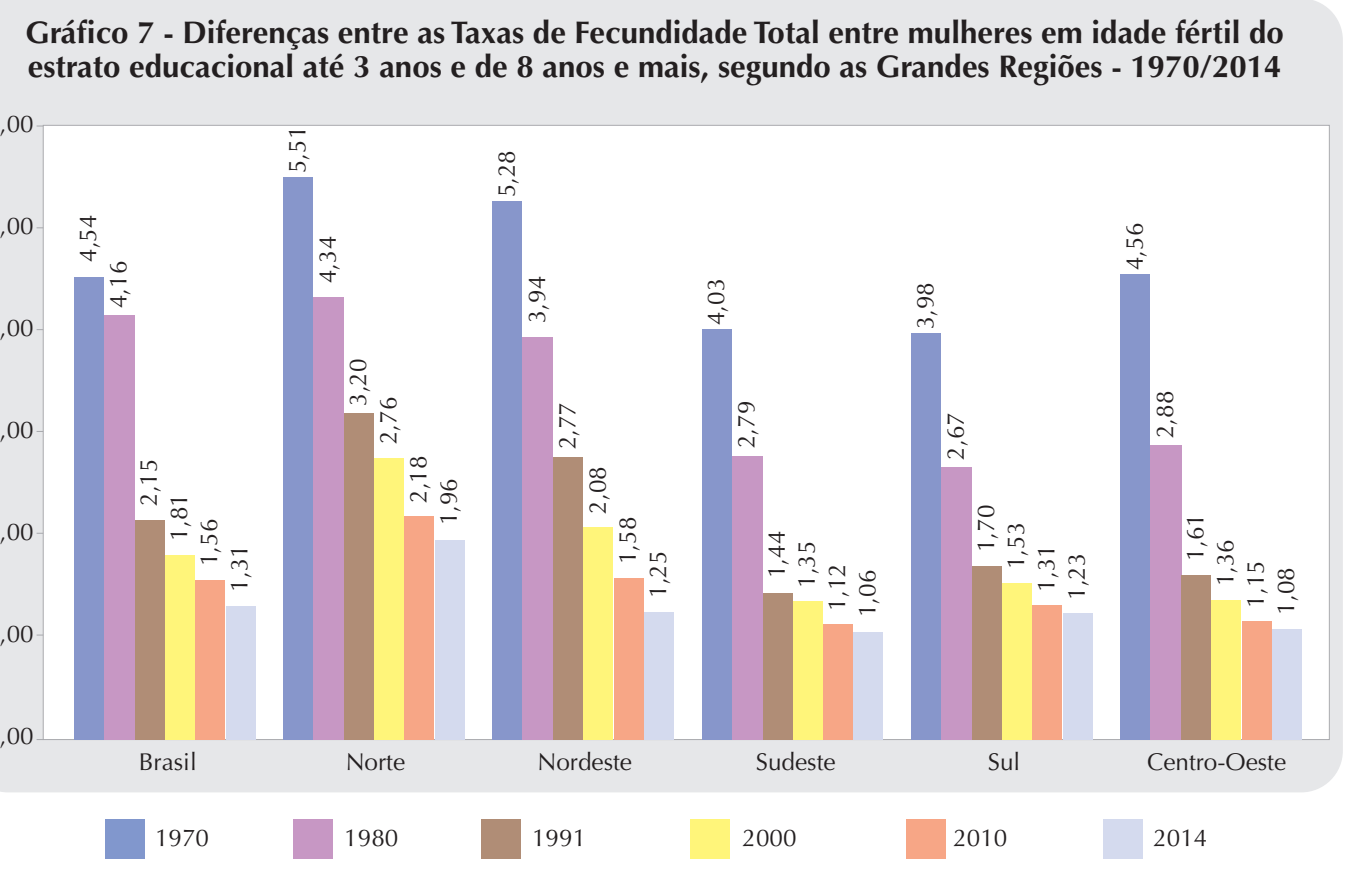

Fonte: IBGE, Censo Demográfico 1970/2010 e Projeção da População das Unidades da Federação por Sexo e Idade $2000-2030$. 
Em síntese, em decorrência dos resultados apresentados, pode-se inferir que o avanço na escolaridade por parte das mulheres, observado no decorrer das últimas décadas, tem sido um importante condicionante que operou e vem agindo no sentido da redução do número de filhos, numa perspectiva de um melhor posicionamento na estrutura da sociedade, uma vez que o custo de uma família numerosa é cada vez mais elevado.

Por outro lado, independentemente da melhoria da escolaridade, como fator de redução da fecundidade, o que vem se notando é que, mesmo nos segmentos menos instruídos, os níveis de fecundidade também se reduziram intensamente, indicativo de que expressivas parcelas da população pobre também vêm, no decorrer das últimas décadas, incorporando padrões de comportamento reprodutivo típicos de segmentos da classe média moderna. Aspectos culturais, relativos às mudanças na organização familiar e no papel desempenhado pelas mulheres, igualmente, apresentam um peso na consolidação de um comportamento reprodutivo em níveis reduzidos de fecundidade.

Um resultado relevante da mudança nos níveis de fecundidade, com a consequente redução do número de nascimentos, refere-se a seus efeitos sobre as estruturas etárias da população ${ }^{7}$ e seus impactos que já vêm sendo vivenciados pela sociedade brasileira na formulação de novas políticas públicas sociais, objeto de análise da próxima seção.

\section{Os efeitos das alterações da dinâmica demográfica brasileira sobre as estruturas etárias e os impactos nas políticas públicas}

No decorrer do capítulo, foram apresentadas evidências sobre as profundas mudanças na dinâmica demográfica brasileira, particularmente no que se refere aos aspectos relacionados com a fecundidade. Constatou-se que o processo de transição da fecundidade, apesar de ter principiado em momentos diferentes do tempo, foi resultante dos distintos aspectos estruturais das transformações sociais apresentadas entre as regiões brasileiras. Essas alterações, por terem tido início retardado nas Regiões Norte e Nordeste, em relação às do Centro-Sul, fizeram com que o ritmo de queda da fecundidade obedecesse a um movimento com temporalidade própria.

Por exemplo, mesmo apresentando taxas de fecundidade mais altas, o declínio relativo naquelas regiões durante a década de 1970 foi inferior ao das regiões mais desenvolvidas. Contudo, a partir dos anos 1980, o declínio da fecundidade das Regiões Nordeste e Norte começa a ser proporcionalmente maior do que o das Regiões Sudeste e Sul, evidenciando a tendência generalizadora do processo de transição de fecundidade pelo conjunto das regiões do País, alcançando as áreas e os grupos sociais, em que a fecundidade era, até então, mais elevada.

\footnotetext{
7 Na elaboração da pirâmide, foram utilizadas as informações dos Censos Demográficos e as Projeções da População do Brasil por Sexo e Idade até o ano 2050, realizadas pelo IBGE. Chama-se a atenção para a convergência das estruturas etárias implícitas do Censo Demográfico 2010 e as derivadas das Projeções para esse mesmo ano.
} 
Exibir as implicações das mudanças nos padrões demográficos, particularmente nas questões relacionadas com o comportamento reprodutivo, as estruturas etárias e a redefinição de políticas públicas direcionadas a grupos sociais específicos, é o foco dos tópicos seguintes.

\section{Os impactos do novo processo demográfico nas alterações das estruturas etárias da população brasileira}

Uma consequência relevante das alterações verificadas nos padrões demográficos no Brasil, sobretudo nos níveis de fecundidade, que resultou na redução do número de nascimentos, refere-se a seus efeitos sobre as estruturas de distribuição etária da população.

Se, até o final dos anos 1970, a estrutura etária da população brasileira era predominantemente jovem, em decorrência dos níveis então elevados da fecundidade, a partir da década de 1980, inicia-se um estreitamento da base da pirâmide, com reduções significativas do número de crianças e adolescentes no total da população. Essa tendência reflete claramente o processo de declínio da fecundidade, quando se consideram as estimativas do indicador, levando em conta as informações do Censo Demográfico 1980, que se intensifica no decorrer das décadas seguintes. Quanto à diminuição relativa do número de crianças, acrescenta-se, inicialmente, um aumento em termos absolutos, em decorrência da inércia demográfica e uma posterior diminuição a partir do ano 2000 (Gráfico 8).

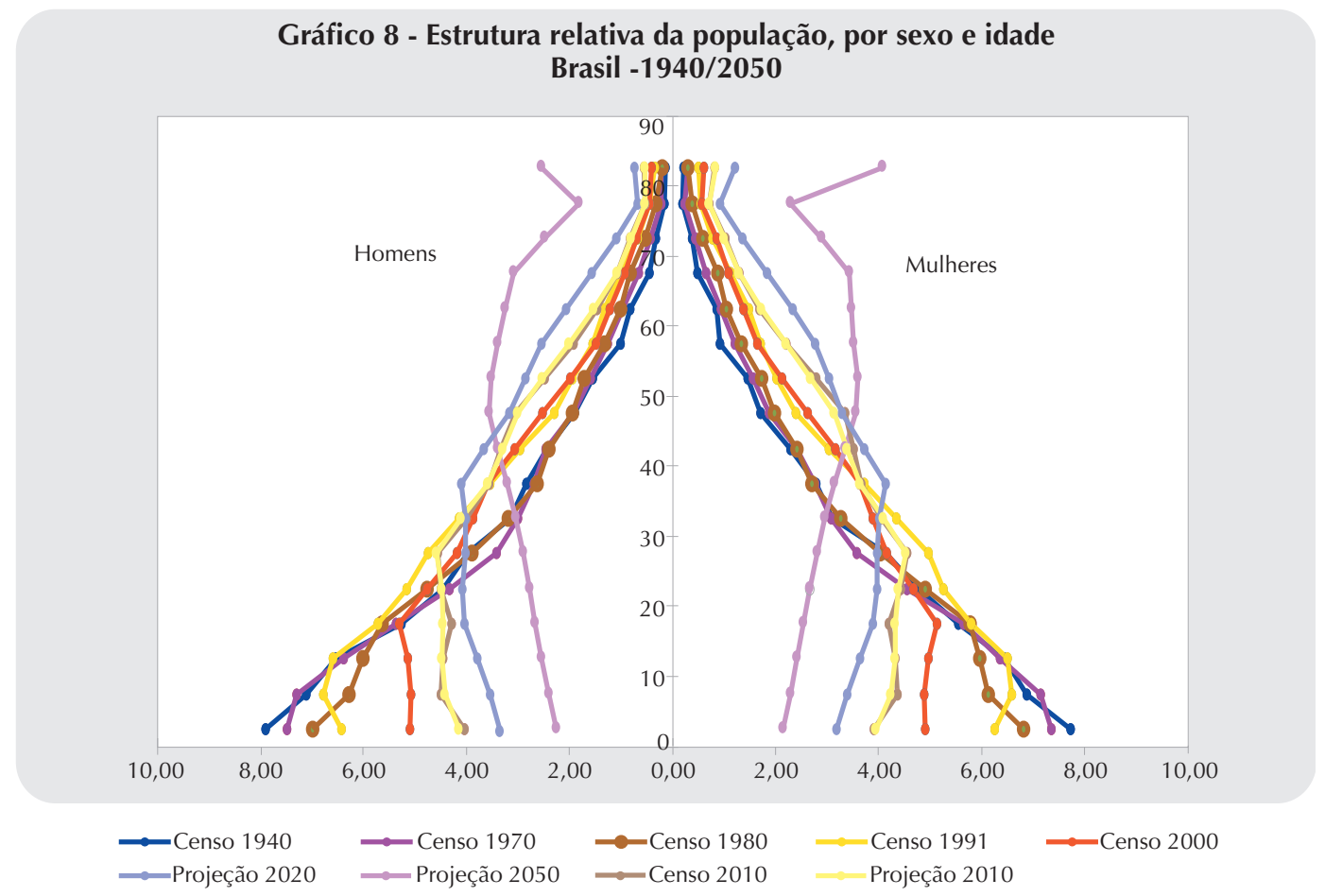

Fonte: IBGE, Censo Demográfico 1940/2010 e Projeção da População do Brasil por Sexo e Idade 2000-2060. 
As estruturas das pirâmides ainda revelam o peso de coortes etárias provenientes de nascimentos de períodos em que a fecundidade ainda era elevada. Desse modo, a partir de 1991, percebe-se nitidamente o salto no crescimento, em termos relativos e absolutos, da população em idade ativa (15 a 59 anos), ou seja, os chamados jovens e adultos. Em termos absolutos (Tabela 11), o total da população deste grupo etário pulou de 85,1 milhões para 126,0 milhões, em 2010. Ou seja, um incremento de 22,0 milhões, durante 19 anos, numa fase que coincide com mudanças cíclicas na economia e reestruturação do mercado de trabalho. Nesse período, o crescimento do número de idosos 8 já se faz notar, de forma mais nítida, com um incremento absoluto de 8,9 milhões, enquanto, entre as crianças e adolescentes de 0 a 14 anos de idade, o valor foi negativo $(-1,1$ milhão).

Tabela 11 - População residente, total e proporção, por grupos de idade - Brasil - 1940/2050

\begin{tabular}{|c|c|c|c|c|c|c|c|}
\hline \multirow{3}{*}{ Ano } & \multicolumn{7}{|c|}{ População residente } \\
\hline & \multicolumn{4}{|c|}{ Total } & \multicolumn{3}{|c|}{ Proporção (\%) } \\
\hline & Total & $\begin{array}{l}\text { De } 0 \text { a } \\
14 \text { anos }\end{array}$ & $\begin{array}{l}\text { De } 15 \text { a } \\
59 \text { anos }\end{array}$ & $\begin{array}{c}\text { De } 60 \text { anos } \\
\text { e mais }\end{array}$ & $\begin{array}{l}\text { De } 0 \text { a } \\
14 \text { anos }\end{array}$ & $\begin{array}{l}\text { De } 15 \text { a } \\
59 \text { anos }\end{array}$ & $\begin{array}{c}\text { De } 60 \text { anos } \\
\text { e mais }\end{array}$ \\
\hline 1940 & 41132884 & 17523641 & 21942119 & 1667124 & 42,60 & 53,34 & 4,05 \\
\hline 1950 & 51784603 & 21670246 & 27916906 & 2197451 & 41,85 & 53,91 & 4,24 \\
\hline 1960 & 69957865 & 29854870 & 36790575 & 3312420 & 42,68 & 52,59 & 4,73 \\
\hline 1970 & 92955059 & 39130433 & 49108418 & 4716208 & 42,10 & 52,83 & 5,07 \\
\hline 1980 & 118874665 & 45460763 & 66197885 & 7216017 & 38,24 & 55,69 & 6,07 \\
\hline 1991 & 146825475 & 50988432 & 85114338 & 10722705 & 34,73 & 57,97 & 7,30 \\
\hline 2000 & 173448346 & 52107064 & 107105551 & 14235731 & 30,04 & 61,75 & 8,21 \\
\hline 2010 & 195497797 & 49934121 & 125961822 & 19601854 & 25,54 & 64,43 & 10,03 \\
\hline 2020 & 212077375 & 44315024 & 138471689 & 29290662 & 20,90 & 65,29 & 13,81 \\
\hline 2030 & 223126917 & 39256945 & 142328209 & 41541763 & 17,59 & 63,79 & 18,62 \\
\hline 2040 & 228153204 & 35441110 & 138507200 & 54204894 & 15,53 & 60,71 & 23,76 \\
\hline 2050 & 226347688 & 31849189 & 128040929 & 66457570 & 14,07 & 56,57 & 29,36 \\
\hline
\end{tabular}

Fonte: IBGE, Censo Demográfico 1940/2010 e Projeção da População do Brasil por Sexo e Idade 2000-2060.

O aumento contínuo do grupo populacional que compõe a cognominada terceira idade é uma realidade, que já dá para ser percebida no cotidiano da sociedade brasileira. Só para reforçar essa questão, tendo como base as informações disponíveis da Tabela 11, observa-se que, entre 2010 e 2050, a previsão é que o grupo populacional de 60 anos e mais de idade triplique em termos absolutos, passando de 19,6 milhões para 66,5 milhões. Estas transformações nas estruturas etárias já começam a afetar a configuração das pirâmides etárias (Gráfico 8), com diminuições sucessivas de contingentes populacionais na sua base, em paralelo a aumentos contínuos nas idades posteriores, até atingir a forma de uma estrutura piramidal mais estável.

\footnotetext{
8 A definição de idoso como pessoa de 60 anos ou mais de idade é estabelecida na legislação brasileira, por meio da Lei n. 8.842, de 4 de janeiro de 1994, regulamentada pelo Decreto n. 1.948, de 3 de julho de 1996, que dispõe sobre a política nacional do idoso (BRASIL, 1994, 1996). A Organização Mundial da Saúde - OMS (World Health Organization - WHO) também vem adotando esse critério para esse grupo específico.
} 
Por outro lado, observa-se, em âmbito nacional, que a participação do grupo de crianças e adolescentes de 0 a 14 anos de idade, apesar do aumento observado, em valores absolutos, em termos relativos, manteve-se estável $(42,0 \%)$ até 1970 , quando se inicia um processo de declínio, atingindo, em 2010, uma proporção de 25,5\%. Essa redução se contrapõe não só aos grupos populacionais em idade de trabalhar ( 15 a 59 anos), mas também ao de idoso (60 anos e mais), que tiveram majoradas suas participações proporcionais na composição etária da população, conforme mostrado na Tabela 11 e no Gráfico 9. Em 2030, o número de idosos já superará o de crianças e adolescentes em cerca de 2,28 milhões, diferença que tenderá a aumentar para 34,6 milhões, em 2050 (66,5 milhões contra 31,8 milhões, respectivamente). Nesse ano, os idosos já representarão $29,4 \%$ contra $14,1 \%$ de crianças e adolescentes no total da população.

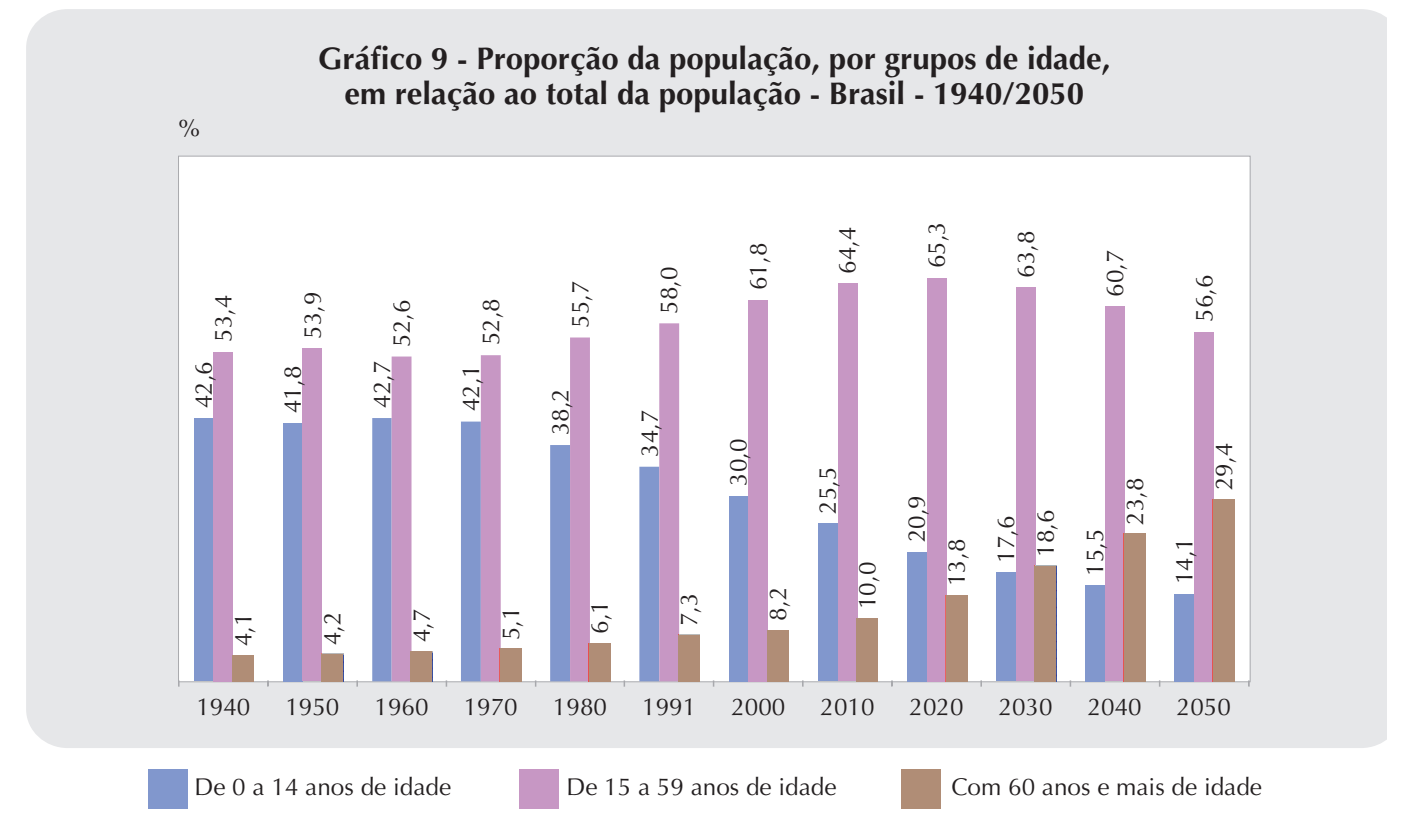

Fonte: IBGE, Censo Demográfico 1940/2010 e Projeção da População do Brasil por Sexo e Idade 2000-2060.

Uma visualização mais clara das mudanças desses grupos populacionais específicos é exibida no Gráfico 10, durante o período de 1940 a 2050. Até 2030, as Projeções da População por Sexo e Idade apontam para uma igualdade no número de crianças e adolescentes de 0 a 14 anos e de idosos de 60 anos e mais de idade. Entretanto, a tendência é que, enquanto o número de crianças e adolescentes tende a uma redução, o número de idosos, ao contrário, siga um comportamento oposto, com aumentos expressivos no decorrer das décadas seguintes. Exemplificando, de acordo com as Projeções, em 2050, a previsão é que, enquanto a tendência da proporção de crianças e adolescentes em relação ao total da população continue a se reduzir (14,01\%), a tendência da proporção de idosos de 60 anos e mais de idade é aumentar (29,36\%). Ou seja, o dobro da observada para as crianças e adolescentes de 0 a 14 anos de idade. 
Nesse sentido, a partir das informações exibidas no Gráfico 10, é importante atentar que se observa uma tendência do aumento progressivo de pessoas em idade ativa previsto para o País até 2030, consubstanciando o fenômeno denominado "bônus demográfico". A expressão vem sendo muito usada na área da demografia, procurando chamar a atenção dos gestores, na área das políticas públicas, para o momento que se está processando na dinâmica populacional brasileira, devido a seus feitos sobre a inserção de novos e velhos contingentes populacionais no mercado de trabalho, os custos da previdência social e sobre os indicadores relacionados com a violência, dentre outros. Portanto, além da busca de soluções para problemas histórico-estruturais existentes na sociedade brasileira, há que se encarar os novos obstáculos que começam a surgir decorrentes do processo de envelhecimento da população brasileira.

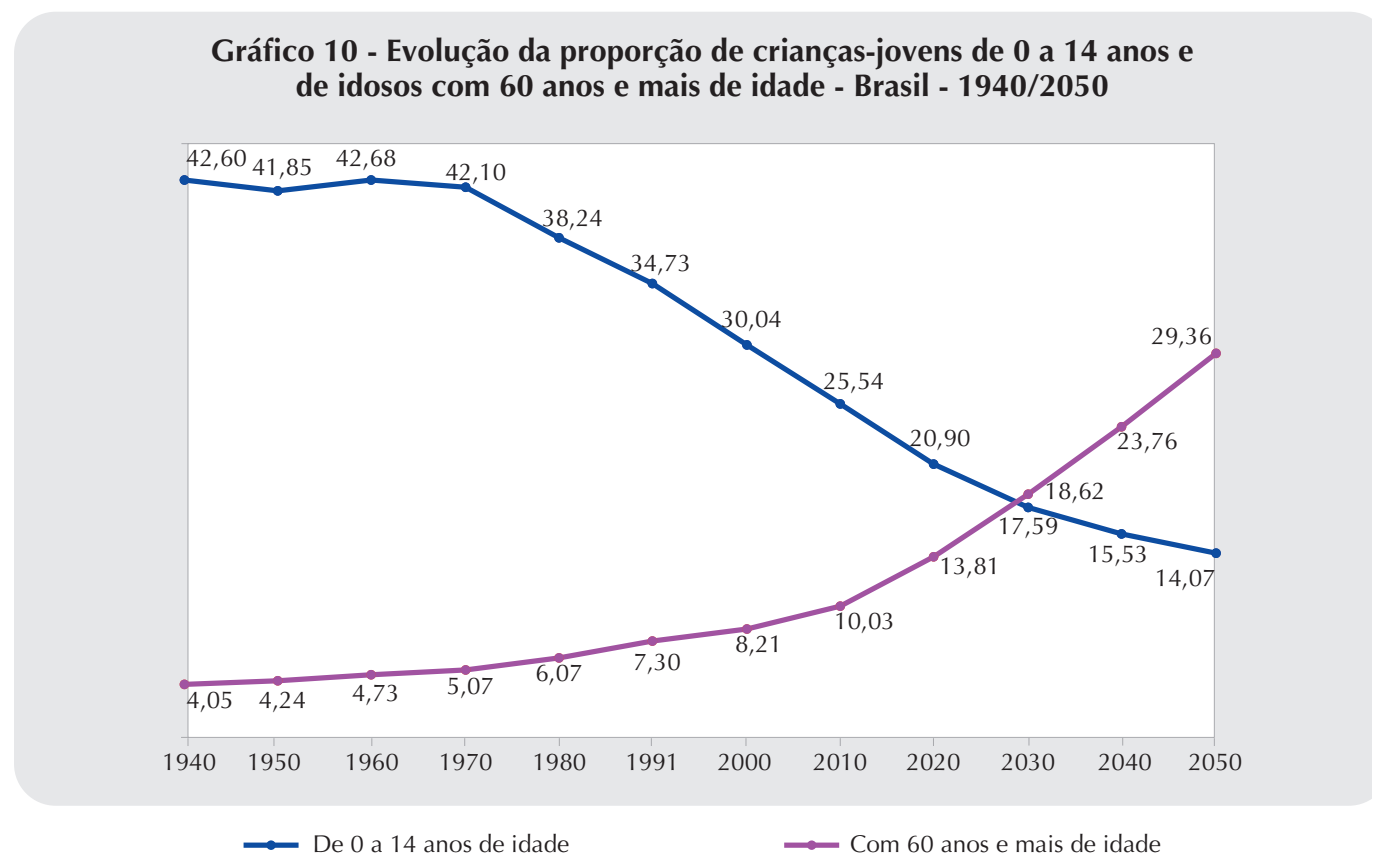

Fonte: IBGE, Censo Demográfico 1940/2010 e Projeção da População do Brasil por Sexo e Idade 2000-2060.

Cabe também destacar que as mudanças no perfil demográfico brasileiro têm sido intensivamente investigadas e retratadas nas pesquisas do IBGE, além de amplamente discutidas em seminários e congressos de especialistas em estudos de população. Ou seja, a discussão da nova realidade demográfica brasileira é cada vez mais urgente, no sentido destas questões serem levadas em consideração no planejamento e reformulação das políticas sociais, econômicas e de saúde. 
Sem dúvida, o processo de envelhecimento da população que se está vivenciando deve ser encarado, não só como um dos maiores triunfos do País, mas também como um desafio, uma vez que vem originando aumento das demandas socioeconômicas e, sobretudo, na área de saúde.

É oportuno chamar a atenção para o fato de que o impacto dos efeitos das alterações que vêm se verificando no padrão demográfico sobre as estruturas etárias, é extremamente relevante para a identificação das características das distintas gerações e coortes populacionais no País. Em decorrência, as gradativas mudanças que vão se produzindo, no decorrer do tempo, nas faixas etárias, se refletem na magnitude das mesmas e apontam para novas questões e demandas, principalmente, em relação aos serviços que as instâncias governamentais e a sociedade, de um modo geral, devem proporcionar aos distintos grupos de cidadãos, sejam eles crianças/adolescentes, jovens, adultos e idosos. Todavia, o que se percebe é que segmentos relevantes da sociedade brasileira concebem as pessoas que atingem a terceira idade, como ineficientes, quando na verdade, deveriam ser visualizadas como precioso recurso da estrutura da própria sociedade. Vale registrar que a Organização Mundial da Saúde - OMS (World Health Organization - WHO) defende a ideia de que os países têm obrigação de custear o envelhecimento. Nesse sentido, os governos, as organizações internacionais e a sociedade civil deveriam programar políticas e programas de "envelhecimento ativo", possibilitando, dessa forma, o melhoramento da saúde, a participação mais ativa e a segurança dos cidadãos mais envelhecidos.

Em decorrência da rapidez que vem se registrando, no País, o processo de enveIhecimento e as ponderações apresentadas, é de fundamental relevância adquirir, o mais rápido possível, consciência de que este é o momento oportuno para se planejar e atuar na concretização dessas ações.

Só para reforçar, na Tabela 12, é apresentado, para o conjunto nacional, regional e estadual, alguns subsídios que reforçam essas questões, a partir da comparação das faixas etárias da população de 0 a 14 anos e de 60 anos e mais de idade, para o ano 2010, considerando os seguintes indicadores: proporção de internações; gasto médio das internações (reais); e média de permanência (dias) na rede hospitalar. Assim, por exemplo, se se levar em consideração o indicador proporção de internações para cada grupo etário focado, observa-se que a média de internações de idosos é o triplo da observada no grupo de crianças e adolescentes até 14 anos de idade, para o conjunto do País. Ou seja, 12,5\% contra 4,1\%, respectivamente. Este é um padrão geral, mas com maior incidência nos estados das Regiões Sul e Centro-Oeste, quando o número de internações entre os idosos é mais de três vezes superior ao observado para o grupo etário de 0 a 14 anos. Cabe ressaltar, no entanto, que o Paraná apresenta a maior relação $(5,3)$, mas alguns estados que não fazem parte dessas regiões exibem também valores significativos, a exemplo de Amazonas $(5,0)$, Acre $(4,0)$ e Minas Gerais $(3,8)$.

O mesmo sucede com os indicadores gasto médio das internações (reais) e média de permanência (dias) na rede hospitalar. Para o Brasil como um todo, apesar de a proporção 
de crianças e adolescentes ser, em média, de 25,5\% contra 10,0\% da de idosos, devido à maior complexidade dos problemas relacionados com a saúde entre as pessoas de 60 e mais de idade, o gasto médio das internações (reais) atinge cifras superiores a $40 \%$, quando comparadas com o observado no grupo de crianças e adolescentes de 0 a 14 anos de idade.

Quanto ao indicador média de permanência (dias) na rede hospitalar, os valores também são mais expressivos no grupo de idosos de 60 e mais anos de idade, em todas as áreas espaciais focadas, sendo a média nacional de 7,6 dias, contra 4,8 dias no grupo de crianças e adolescentes de 0 a 14 anos de idade. Ou seja, uma diferença de $60,0 \%$. Na Região Sudeste, a média de dias de internação entre os idosos atinge a cifra de 9,4 dias, sendo que o grupo de idosos residentes no Rio de Janeiro apresenta os valores mais elevados, em comparação com o observado nas demais Unidades da Federação (13,6 dias). Ou seja, uma diferença de $140,0 \%$ em relação às crianças e adolescentes.

Conveniente enfatizar que essas diferenças tendem a se acentuar no transcorrer dos anos, uma vez que o processo de envelhecimento da população é um processo irreversível, conforme pode ser deduzido das Projeções da População por Sexo e Idade, realizadas pelo IBGE, que apontam para uma quantidade cada vez mais volumosa de idosos que, de acordo com as projeções, apontam para um valor estimado de 66,0 milhões, em 2050, enquanto o número de crianças e adolescentes é estimado em 31,8 milhões. Igualmente, é oportuno chamar a atenção para o fato de que estas informações espelham uma tendência oposta entre as duas faixas etárias extremas, uma vez que, em 2010, o quantitativo de crianças e adolescentes era de 49,9 milhões contra 19,6 milhões de idosos.

Tendo em vista este novo perfil demográfico, que, cada vez mais, apresenta a tendência de um crescimento contínuo e acentuado no número de idosos, a sociedade civil e, sobretudo, os órgãos públicos devem, urgentemente, tomar consciência sobre as consequências dessas transformações, no aceleramento nas despesas relacionadas com esse grupo populacional específico. Só para exemplificar, na Tabela 12, conforme já exposto, é constatado um diferencial expressivo nos indicadores gasto médio das internações (reais) e média de permanência (dias) na rede hospitalar no grupo populacional de idosos, em virtude da crescente complexidade das doenças e de novos procedimentos médicos que terão de ser implementados, implicando custos financeiros crescentes.

Além disso, apesar de importantes avanços verificados na área das políticas públicas e sociais, durante as últimas duas décadas, o Brasil ainda evidencia graves desigualdades sociorregionais, devendo-se, portanto, ao se pensar em planejamento de políticas públicas, considerar as especificidades peculiares de cada região, uma vez que as mesmas exibiram ritmos diferenciados de transição demográfica, que irão se refletir nas novas demandas. 
Tabela 12 - Estrutura relativa da população de 0 a 14 anos de idade e de 60 anos e mais de idade, idade média, proporção e gasto médio das internações e média de permanência na rede hospitalar, segundo as Grandes Regiões e as Unidades da Federação - 2010/2030

\begin{tabular}{|c|c|c|c|c|c|c|}
\hline \multirow{3}{*}{$\begin{array}{c}\text { Grandes Regiões } \\
\text { e } \\
\text { Unidades da Federação }\end{array}$} & \multicolumn{4}{|c|}{ Estrutura relativa (\%) } & \multirow{2}{*}{\multicolumn{2}{|c|}{$\begin{array}{l}\text { Idade média } \\
\text { (anos) }\end{array}$}} \\
\hline & \multicolumn{2}{|c|}{2010} & \multicolumn{2}{|c|}{2030} & & \\
\hline & $\begin{array}{c}\text { De } 0 \text { a } \\
14 \text { anos }\end{array}$ & $\begin{array}{c}\text { De } 60 \\
\text { anos e mais }\end{array}$ & $\begin{array}{c}\text { De } 0 \text { a } \\
14 \text { anos }\end{array}$ & $\begin{array}{c}\text { De } 60 \\
\text { anos e mais }\end{array}$ & 2010 & 2030 \\
\hline Brasil & 25,5 & 10,0 & 17,6 & 18,6 & 30,8 & 37,9 \\
\hline Norte & 32,7 & 6,0 & 21,5 & 11,8 & 26,2 & 33,2 \\
\hline Rondônia & 28,6 & 6,4 & 18,9 & 13,8 & 27,9 & 35,3 \\
\hline Acre & 35,7 & 5,7 & 23,6 & 10,6 & 25,1 & 31,7 \\
\hline Amazonas & 34,5 & 5,2 & 22,5 & 10,6 & 25,2 & 32,2 \\
\hline Roraima & 35,1 & 4,5 & 22,4 & 10,3 & 24,8 & 31,8 \\
\hline Pará & 32,5 & 6,4 & 21,4 & 12,1 & 26,4 & 33,4 \\
\hline Amapá & 36,2 & 4,4 & 22,6 & 10,1 & 24,3 & 31,7 \\
\hline Tocantins & 30,5 & 7,4 & 20,1 & 13,9 & 27,6 & 34,7 \\
\hline Nordeste & 28,4 & 9,1 & 19,2 & 16,0 & 29,1 & 36,2 \\
\hline Maranhão & 33,2 & 7,5 & 21,9 & 12,4 & 26,6 & 33,4 \\
\hline Piauí & 28,8 & 9,0 & 19,0 & 16,0 & 28,9 & 36,4 \\
\hline Ceará & 28,1 & 9,5 & 19,0 & 16,2 & 29,3 & 36,3 \\
\hline Rio Grande do Norte & 26,8 & 9,8 & 18,4 & 17,0 & 29,9 & 36,8 \\
\hline Paraíba & 27,0 & 10,6 & 18,9 & 16,8 & 30,2 & 36,7 \\
\hline Pernambuco & 27,4 & 9,5 & 18,8 & 16,7 & 29,8 & 36,7 \\
\hline Alagoas & 31,0 & 7,9 & 20,3 & 14,9 & 27,8 & 35,2 \\
\hline Sergipe & 28,8 & 8,0 & 19,4 & 14,8 & 28,5 & 35,5 \\
\hline Bahia & 26,9 & 9,3 & 18,5 & 17,0 & 29,7 & 37,2 \\
\hline Sudeste & 23,1 & 11,2 & 16,1 & 21,1 & 32,5 & 39,5 \\
\hline Minas Gerais & 23,7 & 11,1 & 16,3 & 20,8 & 32,0 & 39,4 \\
\hline Espírito Santo & 24,4 & 9,6 & 16,9 & 19,2 & 31,2 & 38,4 \\
\hline Rio de Janeiro & 22,5 & 12,5 & 15,99 & 22,26 & 33,5 & 40,0 \\
\hline São Paulo & 22,9 & 11,0 & 15,98 & 21,01 & 32,4 & 39,5 \\
\hline Sul & 23,0 & 11,5 & 16,19 & 21,94 & 32,6 & 39,7 \\
\hline Paraná & 24,1 & 10,7 & 16,56 & 20,91 & 31,8 & 39,2 \\
\hline Santa Catarina & 22,9 & 10,1 & 16,60 & 20,14 & 31,9 & 38,8 \\
\hline Rio Grande do Sul & 22,0 & 13,2 & 15,51 & 24,27 & 33,9 & 41,0 \\
\hline Centro-Oeste & 25,6 & 8,2 & 17,8 & 16,5 & 29,9 & 36,9 \\
\hline Mato Grosso do Sul & 26,5 & 9,0 & 18,5 & 17,4 & 30,1 & 36,9 \\
\hline Mato Grosso & 27,0 & 7,4 & 18,7 & 16,0 & 29,0 & 36,3 \\
\hline Goiás & 25,3 & 8,7 & 17,4 & 16,5 & 30,3 & 36,9 \\
\hline Distrito Federal & 24,1 & 7,5 & 17,2 & 16,4 & 29,8 & 37,3 \\
\hline
\end{tabular}


Tabela 12 - Estrutura relativa da população de 0 a 14 anos de idade e de 60 anos e mais de idade, idade média, proporção e gasto médio das internações e média de permanência na rede hospitalar, segundo as Grandes Regiões e as Unidades da Federação - 2010/2030

\begin{tabular}{|c|c|c|c|c|c|c|}
\hline \multirow{3}{*}{$\begin{array}{c}\text { Grandes Regiões } \\
\text { e } \\
\text { Unidades da Federação }\end{array}$} & \multicolumn{4}{|c|}{ Internações (1) } & \multirow{2}{*}{\multicolumn{2}{|c|}{$\begin{array}{l}\text { Média de dias internados na } \\
\text { rede hospitalar (3) }\end{array}$}} \\
\hline & \multicolumn{2}{|c|}{ Proporção (\%) } & \multicolumn{2}{|c|}{ Gasto médio (R\$) (2) } & & \\
\hline & $\begin{array}{l}\text { De } 0 \text { a } \\
14 \text { anos }\end{array}$ & $\begin{array}{c}\text { De } 60 \\
\text { anos e mais }\end{array}$ & \begin{tabular}{|c|} 
De 0 a \\
14 anos \\
\end{tabular} & $\begin{array}{c}\text { De } 60 \\
\text { anos e mais }\end{array}$ & $\begin{array}{c}\text { De } 0 \text { a } \\
14 \text { anos }\end{array}$ & $\begin{array}{c}\text { De } 60 \\
\text { anos e mais }\end{array}$ \\
\hline Brasil & 4,1 & 12,5 & 911,1 & 1245,8 & 4,8 & 7,6 \\
\hline Norte & 4,7 & 13,1 & 630,6 & 864,2 & 4,5 & 5,9 \\
\hline Rondônia & 5,1 & 15,9 & 548,8 & 650,4 & 3,5 & 5,0 \\
\hline Acre & 3,4 & 14,9 & 505,0 & 864,8 & 5,0 & 7,8 \\
\hline Amazonas & 3,0 & 15,2 & 687,0 & 1117,4 & 5,9 & 8,5 \\
\hline Roraima & 4,5 & 16,8 & 777,4 & 817,0 & 6,3 & 7,8 \\
\hline Pará & 5,6 & 12,8 & 607,7 & 818,9 & 4,2 & 5,4 \\
\hline Amapá & 2,5 & 11,8 & 658,7 & 899,9 & 6,9 & 7,6 \\
\hline Tocantins & 5,6 & 16,2 & 752,0 & 966,5 & 4,3 & 4,8 \\
\hline Nordeste & 4,3 & 11,9 & 723,9 & 958,7 & 4,5 & 6,3 \\
\hline Maranhão & 4,1 & 11,9 & 628,7 & 717,6 & 4,9 & 5,7 \\
\hline Piauí & 4,7 & 15,8 & 590,7 & 700,7 & 4,3 & 4,8 \\
\hline Ceará & 3,7 & 11,7 & 857,7 & 1051,5 & 5,0 & 6,0 \\
\hline Rio Grande do Norte & 3,4 & 10,4 & 859,6 & 1293,6 & 5,1 & 7,1 \\
\hline Paraíba & 4,6 & 12,9 & 716,0 & 1012,2 & 4,4 & 5,6 \\
\hline Pernambuco & 4,0 & 11,9 & 773,7 & 1074,8 & 4,8 & 8,3 \\
\hline Alagoas & 4,6 & 10,1 & 767,8 & 953,5 & 4,7 & 5,9 \\
\hline Sergipe & 2,6 & 7,1 & 1039,6 & 1193,3 & 5,0 & 6,6 \\
\hline Bahia & 5,0 & 12,2 & 656,0 & 889,3 & 3,9 & 6,0 \\
\hline Sudeste & 3,7 & 11,4 & 1094,9 & 1434,3 & 5,2 & 9,4 \\
\hline Minas Gerais & 3,5 & 13,3 & 1210,4 & 1374,2 & 4,7 & 7,1 \\
\hline Espírito Santo & 3,6 & 11,6 & 1107,2 & 1249,3 & 5,3 & 6,8 \\
\hline Rio de Janeiro & 3,4 & 7,9 & 766,9 & 1380,8 & 5,6 & 13,6 \\
\hline São Paulo & 3,8 & 11,9 & 1148,1 & 1495,1 & 5,4 & 9,4 \\
\hline Sul & 4,5 & 15,7 & 1146,4 & 1346,7 & 4,9 & 6,5 \\
\hline Paraná & 4,9 & 26,2 & 1038,4 & 1334,3 & 4,5 & 5,5 \\
\hline Santa Catarina & 3,8 & 15,0 & 1131,4 & 1473,5 & 4,7 & 7,2 \\
\hline Rio Grande do Sul & 4,5 & 14,4 & 1280,4 & 1300,4 & 5,4 & 7,0 \\
\hline Centro-Oeste & 4,5 & 15,2 & 892,1 & 1075,6 & 4,6 & 6,0 \\
\hline Mato Grosso do Sul & 4,5 & 15,5 & 1007,5 & 1175,7 & 4,5 & 5,8 \\
\hline Mato Grosso & 4,4 & 14,3 & 908,5 & 1032,6 & 4,3 & 5,3 \\
\hline Goiás & 4,5 & 16,4 & 794,7 & 988,2 & 4,2 & 5,5 \\
\hline Distrito Federal & 4,6 & 12,9 & 989,3 & 1297,4 & 6,2 & 10,0 \\
\hline
\end{tabular}

Fontes: IBGE, Projeção da População das Unidades da Federação por Sexo e Idade 2000-2030. 2. Internações hospitalares. In: Brasil. Ministério da Saúde. Sistema de Informações Hospitalares do SUS - SIH/SUS: arquivos dissemináveis para tabulação. Brasília, DF: Ministério da Saúde, Departamento de Informática do Sistema Único de Saúde - SUS - Datasus, [2014]. Disponível em: <http://www2.datasus.gov.br/DATASUS/index.php?area=0901>. Acesso em: mar. 2014.

(1) Refere-se às internações realizadas no Sistema Único de Saúde - SUS. (2) O gasto médio é obtido através da despesa total com internações SUS, dividido pelo número total de internações. (3) Refere-se aos dias de internação. 
Neste aspecto, variações e flutuações quanto aos valores populacionais projetados são factíveis de ocorrer em decorrência das distintas transições verificadas por cada uma das áreas consideradas.

\section{Considerações finais}

Em decorrência das análises realizadas, são claras as evidências de que o Brasil iniciou o Século XXI com uma nova configuração de padrão demográfico, decorrente das profundas transformações nos níveis e padrões de fecundidade e mortalidade verificados ao longo das últimas décadas, sobretudo, do aceleramento do declínio da fecundidade, observado a partir da década de 1970. Este processo aconteceu de forma generalizada, atingindo indistintamente todas as Grandes Regiões, Unidades da Federação e estratos sociais, a ponto de, a partir de 2000, já existirem poucas diferenças entre os valores das taxas encontradas para as regiões brasileiras, principalmente, em relação à fecundidade.

Nesse sentido, a recente configuração demográfica traz à luz novos fundamentos relacionados com a discussão acerca de futuras políticas públicas direcionadas a segmentos etários específicos, não só em relação às crianças e adolescentes, particularmente nos aspectos vinculados à saúde, educação e atenção materno-infantil, como também aos jovens, adultos e idosos, sobretudo no que concerne às políticas de emprego, previdência social e serviços de saúde, que assumem, cada vez mais, um grau crescente de complexidade.

As questões apresentadas, de certa forma, expõem evidências a respeito das causas que deveriam nortear a sociedade brasileira, em especial os gestores responsáveis pela formulação das políticas públicas, a adquirir consciência sobre o real significado das novas realidades demográficas e seus desdobramentos sobre a formulação de políticas públicas direcionadas a grupos sociais específicos. Essa tomada de consciência, caso tivesse se verificado no decorrer do processo de transição, poderia, por exemplo, ter norteado decisões, na área das políticas socioeconômicas, com desdobramentos positivos como maior oferta de emprego e melhorias na distribuição da renda. Além disso, há que se chamar a atenção para o fato de que se, na questão relacionada com os idosos, ainda existem dúvidas quanto ao encaminhamento de soluções relativas ao conjunto de medidas para a seguridade social e atenção a novas necessidades de saúde, devido a seu grau de complexidade, dúvidas de natureza similar também existem em relação às crianças e adolescentes.

Se se partir do princípio de que a população, independentemente de sua estrutura etária, deva usufruir os direitos de cidadania, é lícito considerar que os sistemas públicos envolvidos com a seguridade e a assistência sociais devam ser regidos por regras de contribuição, critérios de benefícios e transferências de fundos públicos que possam proteger e sustentar as condições materiais de vida desses contingentes populacionais, sobretudo os componentes de famílias mais carentes.

No caso específico do grupo dos idosos, a questão fundamental será garantir um sistema previdenciário que permita uma qualidade de vida e sobrevivência digna, num país, em que, ser idoso ainda é um risco, uma vez que a sociedade, de um modo geral, ainda não está organizada, pelo fato de ainda não ter tomado plena consciência do processo de mudança profunda que se vem processando no perfil demográfico brasileiro, em que a tendência é de aumento contínuo da participação deste grupo etário específico na estrutura populacional, 
conforme apresentado neste capítulo. Consequentemente, mudanças de cultura e educação direcionadas à valorização dos idosos são fundamentais, sendo, portanto, precondições para decisões em várias áreas importantes, como a de saúde - ampliação e melhoria no atendimento, preparação de quadros técnicos e profissionais especializados em geriatria, fisioterapia, terapia ocupacional etc. -, e de infraestrutura urbana, adequando o espaço urbano e moradias a esse grupo específico que, conforme observado, vem tendo, cada vez mais, um peso crescente na estrutura populacional brasileira, pressupondo, também, a necessidade de fortalecimento dos programas previdenciários.

No tocante à situação específica do grupo de crianças e adolescentes de 0 a 14 anos de idade, as tendências demográficas parecem assinalar em direções mais favoráveis, uma vez que se vem observando uma tendência de declínio, tanto em termos absolutos como relativos.

Conhecendo-se a nova realidade demográfica, passa-se a dispor de novos elementos suscetíveis de convergir para um melhor equacionamento de problemas crônicos que vêm afetando esses grupos etários, sobretudo os pertencentes a famílias mais carentes. Contudo, é importante alertar que a redução dos níveis de fecundidade não é garantia, por si só, da solução automática dos problemas sociais com os quais o País ainda se defronta. É imprescindível que haja objetividade na demarcação das populações que serão foco das políticas sociais, tendo-se bem claro sua dimensão, características e tendências evolutivas, elementos fundamentais para o dimensionamento e a seleção correta dos grupos de risco e/ou das populações-alvo.

Tendo em vista as questões especificadas, é conveniente chamar a atenção para uma importante variável, que é a educação, e que afeta, sobretudo, as crianças. Pesquisas têm mostrado a existência de grandes distorções entre a série frequentada versus idade, pondo em evidência as deficiências do sistema e, em última análise, sua capacidade de absorção, retenção e progressão da oferta de vagas aos alunos. Há que levar em consideração também as causas de natureza social, visto que muitas famílias, como fonte de ajuda para a sobrevivência familiar, são forçadas a utilizar seus filhos como força de trabalho infantojuvenil, ainda não inteiramente eliminada no País, apesar da legislação vigente, proibindo tal prática.

De qualquer forma, é imperativo reforçar e monitorar as estratégias em curso (programas do governo federal na área da educação, Bolsa Família etc.), para reter estas crianças na escola e criar as infraestruturas escolares em municípios do País, onde elas ainda são inexistentes, apesar das melhorias que vêm se observando nos níveis de alfabetização, no decorrer dos anos. Além disso, deve-se ficar atento para a melhoria da qualidade do ensino, elemento cada vez mais importante, numa economia globalizada e competitiva.

Para atingir tal objetivo, tornam-se cada vez mais necessários investimentos na qualificação do corpo docente e remuneração condizente. Tais questões não podem deixar de ser focadas e enfrentadas, num momento em que o número de crianças em idade escolar começa a diminuir significativamente, na maioria dos municípios brasileiros não afetados por movimentos migratórios maciços. No caso dos municípios onde as taxas de analfabetismo são ainda elevadas, deve-se ter presente que esses são provavelmente municípios que expulsam população para centros mais urbanos dotados, em geral, de serviços de natureza pública. 
Resumindo, desperdiçar esta situação, extremamente favorável do ponto de vista demográfico, para solucionar de vez problemas desse tipo, é jogar fora algumas das chances futuras desta nação realmente vir a solucionar seus imensos problemas de pobreza e exclusão social (O PROCESSO..., 1998).

Finalmente, importante registrar que, ao se pensar em planejamento de políticas públicas, não se pode deixar de considerar as especificidades próprias de cada região que, no caso do Brasil, apresentou trajetórias distintas de transição demográfica, as quais vêm se refletindo, portanto, nas novas demandas dos distintos grupos sociopopulacionais abordados.

Em decorrência das informações apresentadas, não deixa de ser evidente que o processo de transição demográfica que o País atravessa, afeta diversamente os distintos grupos etários, para os quais deverão ser oferecidas soluções específicas:

- Melhorias de programas de qualidade relacionados com a saúde e a educação, no caso de crianças e adolescentes, na medida em que o número de beneficiários está em processo de redução;

- Aumento na oferta de empregos, no caso de jovens e adultos; e

- Atenção médico-psicológica, adequação da infraestrutura urbana e domiciliar, e fortalecimento dos programas previdenciários, dentre outros, no caso dos idosos.

Quanto a este último segmento populacional, ressalte-se que o processo de envelhecimento é muito mais amplo que uma modificação de pesos de uma determinada população, pois altera a vida dos indivíduos, as estruturas familiares, a demanda por políticas públicas e a distribuição de recursos na sociedade. A questão que está sendo colocada está relacionada com o impacto da nova dinâmica demográfica recente na demanda por cuidados de longa duração para a população idosa, sejam estes formais ou informais. Isto, porque, menos trabalhadores significa menos produção de riqueza, menos gente para consumir e, o que é mais perturbador, menos contribuintes para manter o sistema de previdência social, sobrecarregado pelo volume crescente de aposentados.

Há de tomar consciência de que, como o Brasil começa a enfrentar os problemas que atualmente afetam os países europeus, ainda existe algum tempo para observar e analisar as possíveis soluções, porventura, encontradas, de forma a subsidiar a solução de problemas relacionados com os impactos do envelhecimento e o declínio futuro da população. Mas já se podem vislumbrar algumas saídas para essa problemática e adotadas por esses países, a exemplo da existência de uma boa estrutura de creches e de leis que facilitam o retorno da mulher ao trabalho após a licença-maternidade. Além disso, é fundamental destacar que as medidas que podem permitir a muitos países conviver com o envelhecimento populacional passam por mudanças culturais. Nesse aspecto, uma das soluções, apesar de fortes resistências de segmentos importantes da sociedade seria, gradualmente, ir aumentando a idade para a aposentadoria que, possivelmente, evitaria a falência dos sistemas previdenciários. Como a tendência é envelhecer com cada vez mais saúde e, portanto, com maior disposição para continuar trabalhando, é possível que, mantendo a contribuição do trabalhador por mais três a cinco anos, por si só, geraria impactos altamente positivos no alívio das contas da previdência social. 
Em síntese, conforme exposto, a tendência é que os idosos tenham um peso cada vez mais expressivo na estrutura populacional brasileira em decorrência das alterações na dinâmica demográfica. Contudo, a questão que se coloca é saber se a sociedade brasileira tem consciência das implicações dessa nova pressão populacional sobre a estrutura de serviços que terá de ser gerada, de forma a atender adequadamente a esse "novo" estrato populacional.

\section{Referências}

BRASIL. Decreto n. 1.948, de 6 de julho de 1996. Regulamenta a lei n. 8.842, de 4 de janeiro de 1994, que dispõe sobre a política nacional do idoso, e dá outras providênicas. Diário Oficial [da] República Federativa do Brasil, Brasília, DF, ano 134, n. 128, 4 jul. 1996. Seção 1, p. 12277-12279. Disponível em: <http://www.presidencia.gov.br/legislacao>. Acesso em: jan. 2016.

. Lei n. 8.842, de 4 de janeiro de 1994. Dispõe sobre a política do idoso, cria o conselho nacional do idoso e dá outras providências. Diário Oficial [da] República Federativa do Brasil, Brasília, DF, ano 132, n. 3, 5 jan. 1994. Seção 1, p. 77-79. Disponível em: <http:// www.presidencia.gov.br/legislacao>. Acesso em: jan. 2016.

BRASS, W. Métodos para estudiar la fecundidad y la mortalidad en poblaciones con datos limitados. Santiago de Chile: Centro Latinoamericano de Demografía - Celade, 1974. 240 p. (Serie E, n. 4).

CHAMADA nutricional: um estudo sobre a situação nutricional das crianças do semi-árido brasileiro. Brasília, DF: Ministério do Desenvolvimento e Combate à Fome, 2006. 114 p. (Cadernos de estudos: desenvolvimento social em debate, n. 4). Disponível em: <http:// acervodigital.mds.gov.br/xmlui/handle/123456789/191>. Acesso em: jun. 2015.

CENSO DEMOGRÁFICO 2000. Nupcialidade e fecundidade: resultados da amostra. Rio de Janeiro: IBGE, 2003. Disponível em: <http://www.ibge.gov.br/home/estatistica/populacao/ censo2000/nupcialidade_fecundidade/tabela_regioes.shtm>. Acesso em: jun. 2015.

FARIA, V. E.; POTTER, J. E. Television, telenovelas, and fertility change in northeast Brazil. Austin: University of Texas at Austin, Texas Population Research Center, 1995. 30 p. (Texas population research center paper, n. 94-95-12). Artigo posteriormente traduzido para o português, por Heloísa Buarque de Almeida.

GWATKIN, D. R. Indications of change in developing country mortality trends: the end of an era? Population and Development Review, New York: Population Council, v. 6, n. 4, p. 615644, Dec. 1980.

INTERNAÇÕES hospitalares. In: BRASIL. Ministério da Saúde. Sistema de Informações Hospitalares do SUS - SIH/SUS: arquivos dissemináveis para tabulação. Brasília, DF: Ministério da Saúde, Departamento de Informática do Sistema Único de Saúde - SUS - Datasus, [2014]. Disponível em: <http://www2.datasus.gov.br/DATASUS/index. php?area=0901>. Acesso em: mar. 2014. 
MORTALIDADE infantil e na infância e riscos de mortalidade associados ao comportamento reprodutivo. In: PESQUISA nacional sobre demografia e saúde 1996: Brasil. Rio de Janeiro: Sociedade Civil Bem-Estar Familiar no Brasil - Bemfam, 1997. cap. 7, p. 95-102. Disponível em: <http://www.measuredhs.com/pubs/pdf/FR77/FR77.pdf>. Acesso em: mar. 2015.

O PROCESSO demográfico brasileiro. In: A INFÂNCIA brasileira nos anos 90. Brasília, DF: Fundo das Nações Unidas para a Infância - Unicef, 1998. p. 13-27.

PROJEÇÃO da população do Brasil por sexo e idade para o período 2000-2060; Projeção da população das unidades da federação por sexo e idade 2000-2030. Rio de Janeiro: IBGE, 2013. Disponível em: <http://www.ibge.gov.br/home/estatistica/populacao/projecao_da_ populacao/2013/default.shtm>. Acesso em: jun. 2015.

SANTOS, J. L. F. Demografia: estimativas e projeções: medidas de fecundidade e mortalidade para o Brasil no século XX. São Paulo: Universidade de São Paulo - USP, Faculdade de Arquitetura e Urbanismo: Fundação para Pesquisa Ambiental, 1978. 71 p. (Cadernos de estudo e pesquisa do Prodeur).

SIMÕES, C. C. da S. A mortalidade infantil na transição da mortalidade no Brasil: um estudo comparativo entre o nordeste e o sudeste. 1997. 178 p. Tese (Doutorado)-Centro de Desenvolvimento e Planejamento Regional, Universidade Federal de Minas Gerais, Belo Horizonte, 1997.

Perfis de saúde e de mortalidade no Brasil: uma análise de seus condicionantes em grupos populacionais específicos. Brasília, DF: Organização Pan-Americana da Saúde - OPAS, 2002. 141 p. Disponível em: <http://gestaocompartilhada.pbh.gov.br/sites/ gestaocompartilhada.pbh.gov.br/files/biblioteca/arquivos/mortalidade_no_brasil.pdf>. Acesso em: jun. 2015.

Relações entre as alterações históricas na dinâmica demográfica brasileira, políticas públicas e impactos futuros decorrentes do processo de envelhecimento da população. Rio de Janeiro: IBGE, Departamento de Pesquisas, 2016. No prelo.

A transição da fecundidade no Brasil: análise de seus determinantes e as novas questões demográficas. Brasília, DF: Fundo de População das Nações Unidas Brasil UNFPA; São Paulo: Arbeit Factory, 2006. 140 p. Disponível em: <http://www.unfpa.org.br/ Arquivos/transicao.pdf>. Acesso em: jun. 2015.

VETTER, D. M.; SIMÕES, C. C. da S. Acesso à infra-estrutura de saneamento básico e mortalidade. Revista Brasileira de Estatística, Rio de Janeiro: IBGE, v. 42, n. 165. p. 17-35, jan./mar. 1981. Disponível em: <http://biblioteca.ibge.gov.br/pt/biblioteca-catalogo?view=d etalhes\&id=7111>. Acesso em: jun. 2015. 


\title{
A delimitação legal dos espaços urbanos
}

\author{
Maria Helena Palmer Lima
}

Uma das linhas de pesquisa tradicional da geografia, os critérios que delimitam os espaços urbanos e rurais constituem tema central de uma visão geográfica do Brasil na contemporaneidade.

Com efeito, a delimitação de espaços urbanos no Brasil tem implicações no controle do território, o que faz com que seu estabelecimento ocorra por meio de legislação específica nas diversas esferas do poder constituído.

Historicamente, o ordenamento do Território Nacional produziu os primeiros resultados ao oferecer consistência aos recenseamentos gerais da população, que passaram a ser periódicos e padronizados para todo o País, fornecendo informações importantes para o conhecimento do Brasil e a elaboração de políticas públicas.

A determinação legal dos espaços urbanos no Brasil, contudo, vem recebendo críticas de importantes estudiosos ligados principalmente à geografia. O texto, a seguir, recupera a evolução dessa legislação e apresenta as críticas a ela dirigida.

\section{Questões empíricas e conceituais em torno da delimitação legal do espaço urbano no Brasil}

A primeira orientação para delimitação do território brasileiro em espaços urbanos e rurais foi apresentada pela Convenção Nacional de Estatística, em 11 de agosto de 1936, na qual ficou estabelecido pelos governos federal e das Unidades da Federação que todas as municipalidades fixariam, naquele ano, "os limites e a área do 'quadro urbano' da cidade ou vila sede do município" (CONVENÇÃO...,1936, p. 22). 
Ainda em 1936, as sedes municipais podiam ser cidades ou vilas, categorias atribuídas no momento de suas criações e cuja origem remonta ao Brasil Colônia. As cidades só podiam ser constituídas pelo poder real, enquanto que aos donatários das capitanias era permitido apenas criar as vilas (ABREU, 2010).

Como o desenvolvimento socioeconômico ocorreu de forma diferenciada, muitas vilas progrediram e cresceram mais acentuadamente em relação a várias outras cidades. Independentemente da designação e do seu porte populacional ou econômico, em todas, o governo, com suas evidências formais, se fazia presente.

O Decreto-Lei n. 311, de 02.03.1938, como será visto adiante no tópico intitulado A legislação brasileira e sua origem, determinou que as sedes de municípios seriam classificadas como cidades, e as sedes de distritos, como vilas. As Unidades Federadas deveriam indicar os municípios e os distritos existentes naquele momento e os que fossem criados a partir de então deveriam obedecer ao estabelecido no referido Decreto-Lei (BRASIL, 1938).

Essa legislação organizou a estrutura territorial brasileira atribuindo-lhe forte sentido político-administrativo, uma vez que as cidades e vilas, além de serem, respectivamente, as sedes de municípios e distritos, passaram também a ser os únicos espaços urbanos, cujos limites são, desde o início, determinados por leis municipais.

A despeito de todas as críticas, essa legislação vem se mantendo por quase oito décadas, resistindo a quatro especiais oportunidades de alteração como foram as Constituições Federais do Brasil de 1946; 1967; 1988 (BRASIL, 1986, 2009); e ainda o Estatuto das Cidades de 2001 (BRASIL, 2001), Lei n. 10.257, de 10.07.2001, significando sua aprovação pelo Estado brasileiro.

Deve-se admitir que algumas situações, como é o caso da classificação de espaços urbanos e rurais, requerem permanência para efeitos de comparação temporal. Nesse caso específico, há a manutenção da definição geral; entretanto, as delimitações de cada um dos perímetros urbanos de todas as cidades e vilas são estabelecidas pelos governos municipais e podem variar conforme a necessidade local, a depender de suas leis.

Rosa e Ferreira (2006) apresentam o exemplo do Município de Araraquara, no Estado de São Paulo, onde loteamentos que, na avaliação das autoras, deveriam constar da área urbana, foram incluídos na área rural pelo Censo Demográfico 2000 por falta de atualização da legislação municipal. Para outros autores, como Veiga (2002a), há, ao contrário, populações que no seu entender deveriam estar entre as rurais, mas são legalmente urbanas.

Os Gráficos 1 e 2 apresentam, respectivamente, o aumento do número de municípios e o da população urbana no Brasil para os mesmos momentos na linha do tempo. Observa-se que, enquanto a curva dos municípios apresenta comportamentos diferentes nos períodos, a curva de população urbana é permanentemente crescente. O incremento da população urbana está, portanto, muito mais ligado ao adensamento das áreas urbanas já consolidadas do que ao surgimento de novas áreas urbanas por meio das emancipações municipais. 


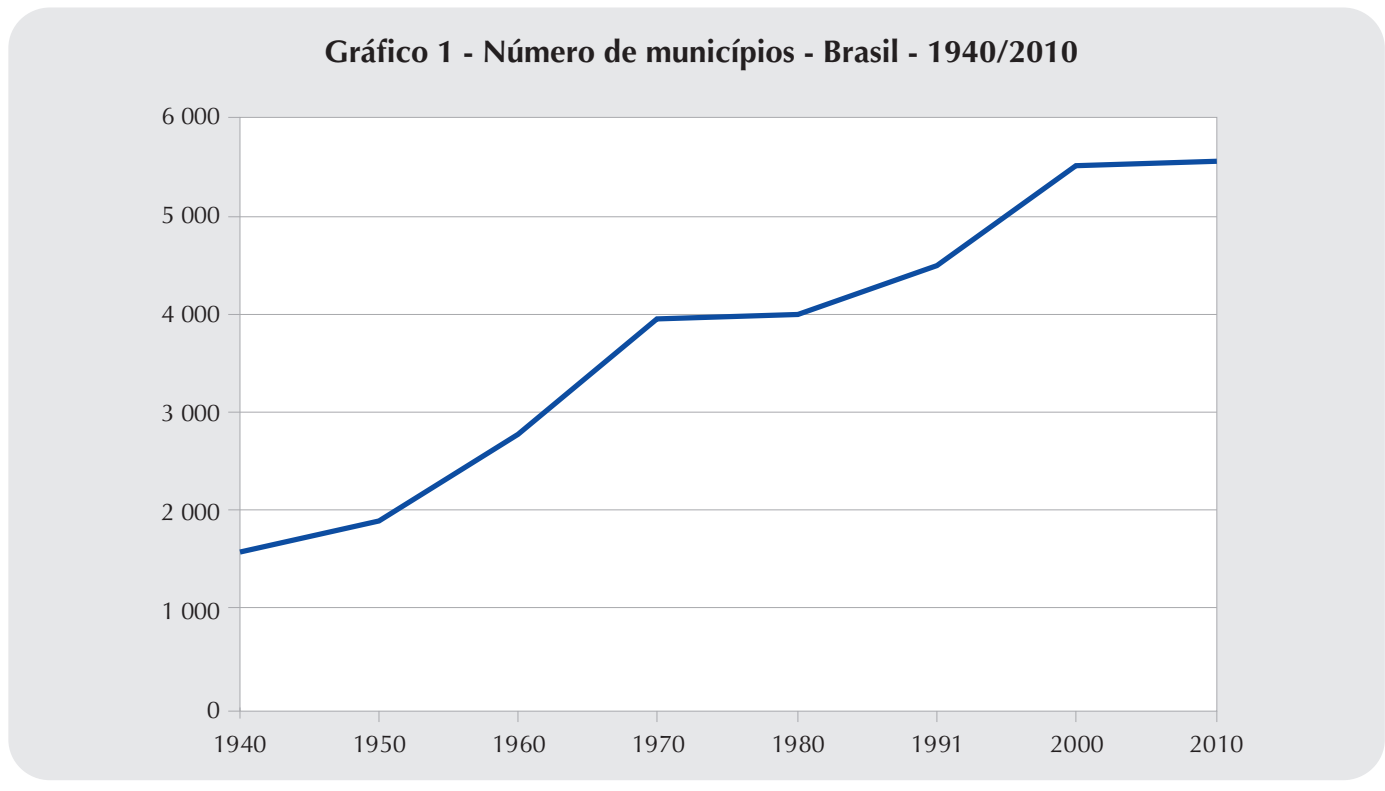

Fonte: IBGE, Censo Demográfico 1940/2010.

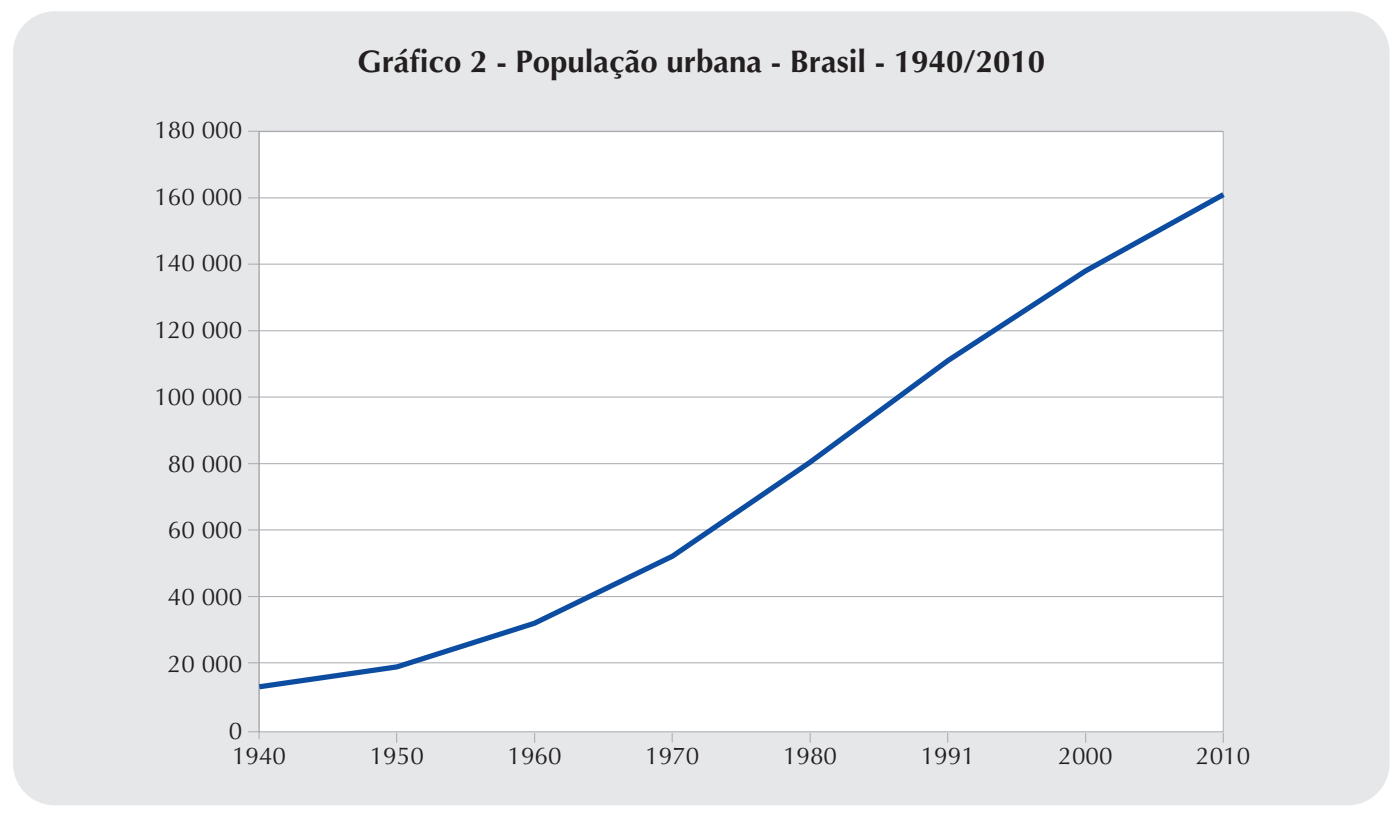

Fonte: IBGE, Censo Demográfico 1940/2010.

Os mapas, a seguir, apresentam momentos da distribuição da população urbana brasileira em municípios, deixando evidenciada a intensa urbanização da população, decorrente não apenas do aumento do número de municípios e, consequentemente, de áreas urbanas, vale dizer de cidades e vilas, mas, principalmente, do adensamento da população em áreas urbanas consolidadas como as atuais metrópoles, como mostraram os Gráficos 1 e 2. 
Mapa 1 - Evolução da população urbana - 1940

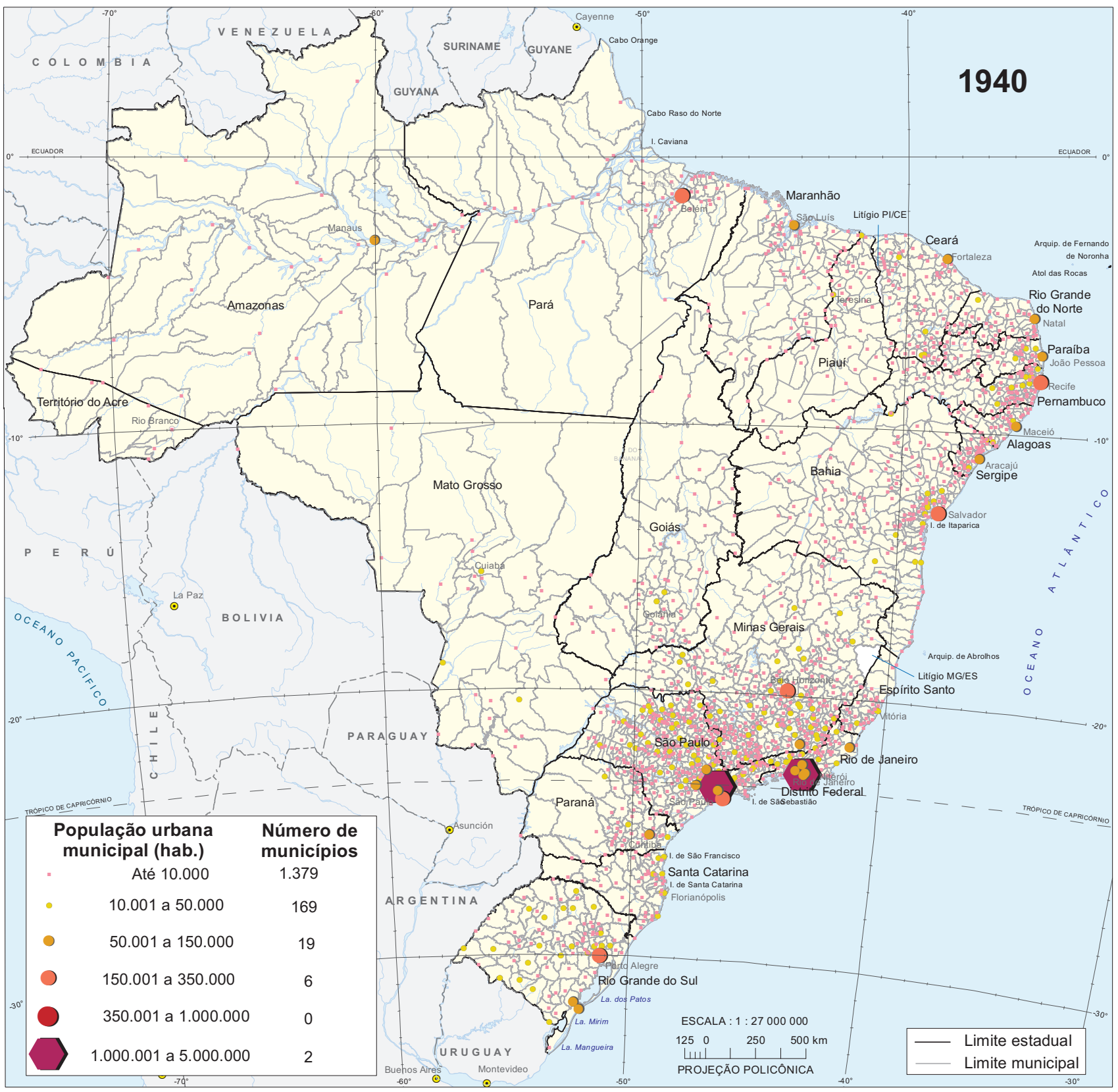

Fonte: IBGE, Censo Demográfico 1940.

Notas: 1. Primeiro censo realizado pelo IBGE quando a população passou a ser legalmente dividida entre urbana e rural.

2. Surgiram os litígios entre Minas Gerais e Espírito Santo e entre Piauí e Ceará.

3. A capital do Estado de Goiás foi transferida para Goiânia. 
Mapa 2 - Evolução da população urbana - 1960

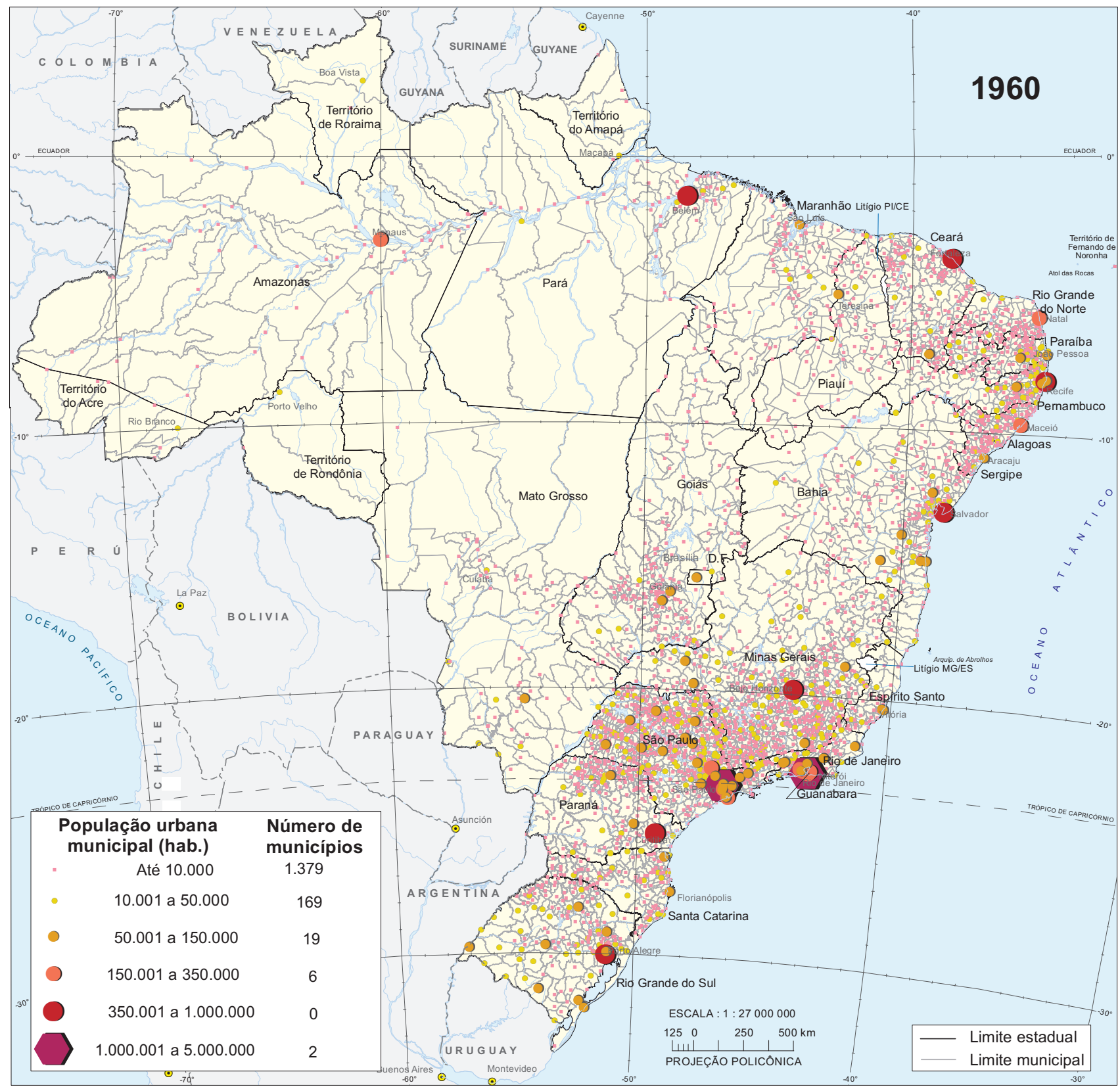

Fonte: IBGE, Censo Demográfico 1960.

Notas: 1. O território federal de Guaporé passou a ser denominado Rondônia e o de Rio Branco passou a Roraima.

2. Outra parte do litígio entre Minas Gerais e Espírito Santo foi solucionada. 
Mapa 3 - Evolução da população urbana - 1991

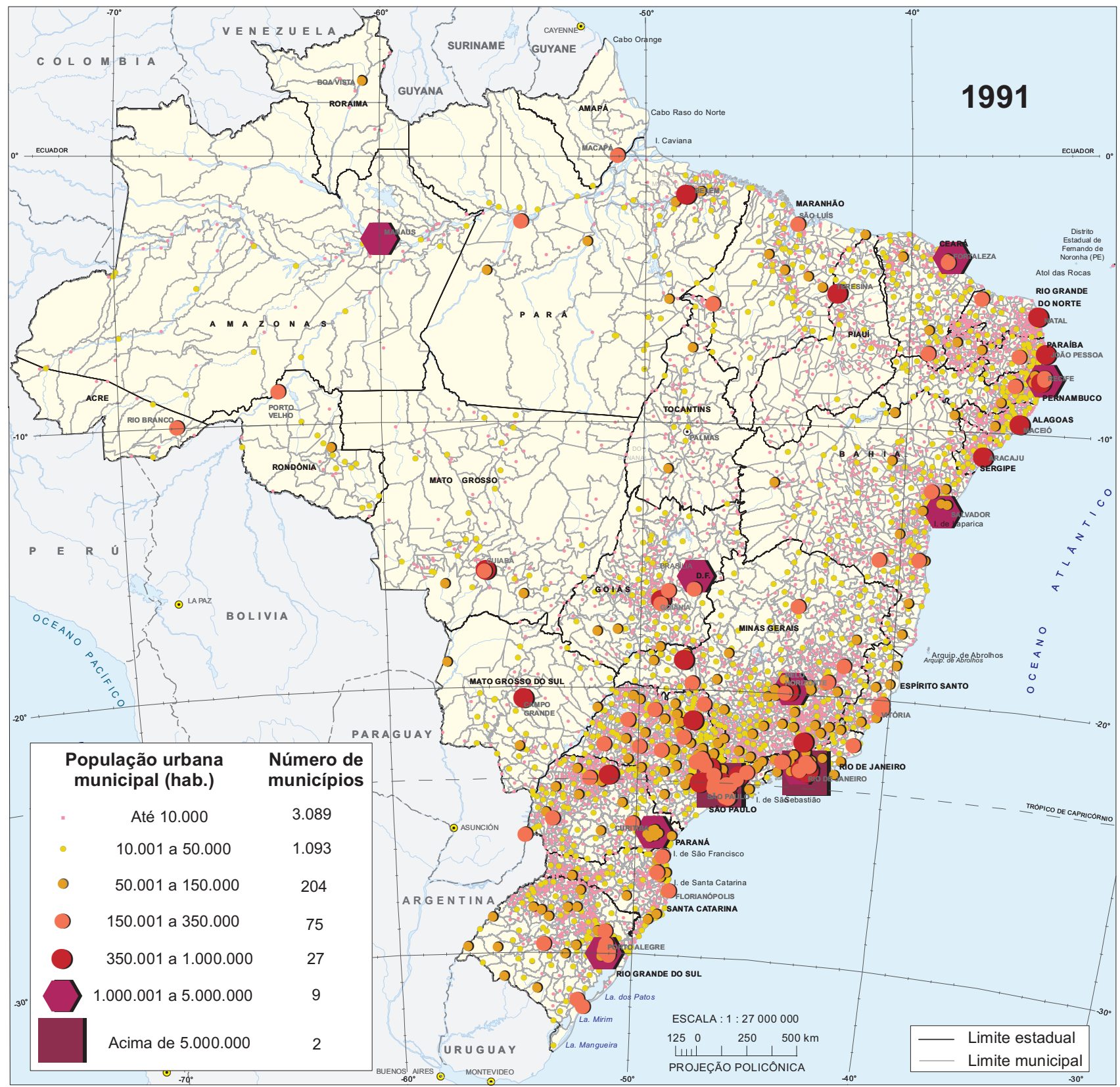

Fonte: IBGE, Censo Demográfico, 1991.

Notas: 1. Rondônia foi elevado à categoria de estado em 1982.

2. Pela Constituição Federal de 1988, o antigo Estado de Goiás foi dividido para formar os estados de Goiás e Tocantins. Os territórios de Roraima e Amapá foram elevados a estado e Fernando de Noronha passou a ser território estadual de Pernambuco. 
Mapa 4 - Evolução da população urbana - 2010

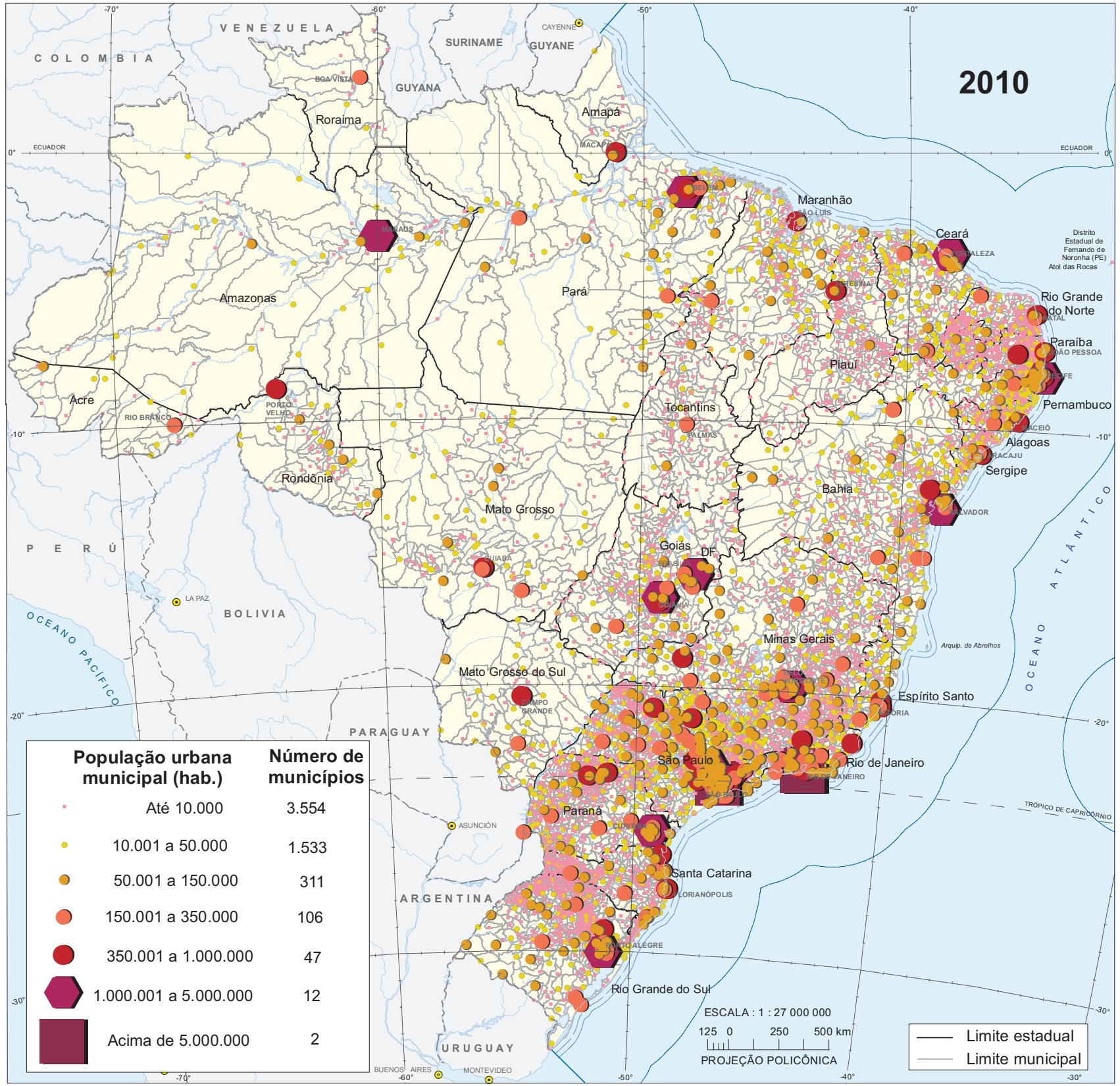

Fonte: IBGE, Censo Demográfico 2010.

Nota: A linha divisória entre os estados do Acre e Amazonas foi alterada. 
O critério brasileiro para estabelecer a situação urbana legal de determinado espaço pode parecer excessivamente político e tecnicamente frágil, posto que se restringe a que a área "seja sede de distrito ou município"; entretanto, como será apresentado, adiante, no tópico $\mathbf{O}$ processo de emancipação de municípios, há uma série de requisitos a cumprir, que envolvem um número expressivo de pessoas, com cargos políticos ou não, para que essa situação seja alcançada.

Conforme mencionado anteriormente, esses critérios vêm recebendo críticas por parte de estudiosos há muitos anos, como será analisado no tópico Críticas ao critério brasileiro de determinação de espaços urbanos.

O conceito de urbano, atrelado que está à sociedade na qual se insere, varia, conforme afirmam autores como Beaujeu-Garnier (1983), Ledrut (1971) e Castells (1983), conforme o país e a sociedade. O Brasil, com sua diversidade inscrita em sua sociedade e em todos os níveis da Federação, é formado por grupos sociais diferentes em muitos aspectos; assim, a atual legislação, ao delegar aos estados e municípios que estabeleçam eles próprios seus espaços urbanos, respeita suas diferenças.

\section{A legislação brasileira e sua origem}

A determinação legal para a diferenciação de espaços urbanos e rurais no Brasil é o Decreto-Lei n. 311, de 02.03.1938. Sua redação foi oriunda do projeto de decreto-lei proposto pela Junta Executiva Central do Conselho Nacional de Estatística, encaminhado por seu presidente José Carlos de Macedo Soares ao Presidente da República Getúlio Vargas, junto a uma exposição de motivos. Nesse último documento, eram solicitadas providências no sentido de reparar "a desordem e a confusão que sempre reinaram no quadro territorial do Brasil" (SOARES, 1939, p. 149).

Os documentos encaminhados à Presidência da República foram elaborados a partir da Convenção Nacional de Estatística de 1936, realizada com membros dos governos federal e estaduais. Um dos objetivos da Convenção era "aprovar as bases da constituição e regulamentação do Conselho Nacional de Estatística e assentar as medidas necessárias à integração do quadro federativo do Instituto Nacional de Estatística", e, ainda, estabelecer "cláusulas de compromisso entre os altos Poderes representados". A cláusula 14ª estabelecia, dentre outras providências atinentes aos estados, a "atribuição da categoria e foros de cidade e vila segundo critérios específicos claramente fixados em lei" (INSTITUTO NACIONAL DE ESTATÍSTICA, 1936, p. 21).

A cláusula 15a enfatizava a necessidade de identificação das populações urbana e rural, observava o respeito às diferenças entre os estados federados e destacava a urgência na delimitação das áreas urbanas e rurais, mantendo a possibilidade de que a sede municipal fosse uma cidade ou uma vila.

Embora não tenha sido expresso, está subentendido que, para essa Convenção, as cidades e vilas, sede de municípios, eram espaços urbanos, sendo os demais rurais. Assim, 
o atendimento a interesses estatísticos e administrativos, ensejava que os estados determinassem, por ato do respectivo governo, os limites dessas cidades e vilas que comporiam o quadro urbano do município.

A importância em estabelecer um ordenamento territorial, no que se referia aos municípios, fez com que o tema voltasse à pauta da Assembleia Geral Ordinária do Conselho Nacional de Estatística, em julho de 1937.

Em dezembro de 1937, o Presidente José Carlos de Macedo Soares, do Instituto Nacional de Estatística, encaminhou ao Presidente da República o documento por meio do qual solicitava que as cláusulas 14a e 15a da Convenção Nacional de Estatística de 1936 fossem transformadas em lei federal, junto a um projeto de decreto-lei. O encaminhamento do pleito a Getúlio Vargas mostra que Macedo Soares duvidava da capacidade de atendimento, no tempo necessário, às cláusulas pactuadas pelos representantes dos governos estaduais presentes à Convenção Nacional de Estatística de 1936, que as tinham assumido como compromisso a ser honrado (CONSELHO NACIONAL DE ESTATÍ́STICA, 1943, p. 166).

O documento enfatizava a necessidade de que fosse implementada rígida racionalidade na delimitação territorial por meio da sistematização e padronização, tanto dos limites jurisdicionais e de suas sedes quanto das denominações e classificações de ambas. Os principais pontos a carecer de solução eram os seguintes: limites municipais inexistentes ou impossíveis de serem seguidos; áreas municipais descontínuas; problemas relativos à toponímia, como repetições, e diversidade entre a jurisdição e sua sede; diferentes malhas para as jurisdições dos distritos administrativos, judiciários e policiais; e,ainda, incoerência quanto aos foros de cidades, vilas, comarcas e termos.

O Conselho defendia que algum montante populacional fosse estabelecido como critério diferenciador entre cidades e vilas que deveriam sediar circunscrições administrativas e judiciárias, com um "espírito de sistema". Para fins estatísticos e administrativos, Macedo Soares defendia também o estabelecimento de critérios que delimitassem e classificassem o espaço em urbano, suburbano e rural.

Também, em dezembro de 1937, foi enviado ao Ministério da Justiça um projeto de decreto-lei sem número, que seguiu anexo à Resolução n. 26, de 15.12.1937, e redigido pela Junta Executiva Central do Conselho Nacional de Estatística, afirmando que, segundo a Constituição em vigor, era da competência da União realizar o recenseamento geral da população e que, para tanto, era preciso "promover a efetiva e racional delimitação das circunscrições administrativas e judiciárias, a identificação das zonas urbanas e rurais e a classificação das localidades segundo categorias padronizadas" (CONSELHO NACIONAL DE ESTATÍ́STICA, 1937, p. 1).

As considerações iniciais do projeto indicavam que o município seria a base da organização administrativa e judiciária, tendo a cidade como sede, e que cada município seria dividido em distritos, cuja sede seria a vila. Estabelecia também um mínimo de duzentas moradias para as sedes dos novos municípios a serem instalados e de trinta para as novas sedes distritais, além da delimitação dos quadros urbano, suburbano e rural mapeados em planta própria (CONSELHO NACIONAL DE ESTATÍ́STICA, 1937). 
A criação de distritos deveria ser da competência estadual, apenas seu parcelamento em subdistritos caberia aos governos municipais. Objetivando consolidar as malhas de distritos administrativos e judiciários em uma única, o projeto propunha a manutenção de todos os distritos então existentes, mesmo os que tivessem sido criados por atos dos governos municipais, desde que não houvesse intercessão de suas circunscrições.

O Conselho Nacional de Estatística obteve a confirmação do sucesso de sua empreitada, em 07 de março, quando foi publicado, o Decreto-Lei n. 311, de 1938, dispondo sobre a divisão territorial do País. As considerações iniciais se referem à execução do recenseamento geral da população e às demandas da Convenção Nacional de Estatística e da Assembleia do Conselho Nacional de Estatística, dizendo textualmente:

Considerando que o Art. 15ํ da Constituição confere à União a competência de resolver definitivamente sobre os limites do território nacional e fazer o recenseamento geral da população;

$[\ldots]$

Considerando, ainda, os compromissos assumidos nas cláusulas XIV e XV da Convenção Nacional de Estatística, a Resolução n. 59, de 17 de julho de 1937, da Assembléia Geral do Conselho Nacional de Estatística, e, finalmente, o critério por este firmado na Resolução n. 60, de 17 de julho de 1937, da Assembléia Geral, para o cômputo das unidades do quadro territorial da República,

Decreta:

[...]

Art. 3ํ A sede do município tem a categoria de cidade e lhe dá o nome.

Art. 4ㅇ O distrito se designará pelo nome da respectiva sede, a qual, enquanto não for erigida em cidade, terá a categoria de vila.

Parágrafo único. No mesmo distrito não haverá mais de uma vila.

Art. 5 Um ou mais municípios, constituindo área contínua, formam o termo judiciário, cuja sede será a cidade ou a mais importante das cidades compreendidas no seu território e dará nome à circunscrição.

Art. $6^{\circ}$

Observado, quanto à sede e à continuidade do território, o disposto no artigo anterior, um ou mais termos formam a comarca.

[...]

Art. 11Nenhum novo distrito será instalado sem que previamente se delimitem os quadros urbano e sub-urbano da sede, onde haverá pelo menos trinta moradias.

Art. 12 Nenhum município se instalará sem que o quadro urbano da sede abranja no mínimo duzentas moradias.

Art. 13ำ Dentro do prazo de um ano, contado da data desta lei, ou da respectiva instalação, se ulterior, os municípios depositarão na Secretaria do Diretório Regional de Geografia, em duas vias autenticadas, o mapa do seu território.

$[\ldots]$

Parágrafo 2을 $\mathrm{O}$ município que não der cumprimento ao disposto neste artigo terá cassada a autonomia e o seu território será anexado a um dos municípios vizinhos, ao qual fica deferido o encargo, aberto novo prazo de um ano, com idêntica sanção (BRASIL, 1938). 
O Decreto-Lei n. 311, de 1938 regulamentou a distinção entre cidade e vila, garantiu que seus nomes fossem os mesmos do município e distrito que sediavam, hierarquizou as divisões territoriais administrativa e judiciária, estabeleceu número mínimo de moradias para novas cidades e vilas e garantiu o mapeamento de todos os municípios.

Poucas foram as determinações dessa legislação que deixaram de viger no País, a saber: embora proibidos, ainda há alguns poucos casos de municípios com áreas descontínuas; o número mínimo de moradias para cidades e vilas foi substituído pelo o de população na Constituição Federal do Brasil de 1967, que atualmente varia conforme a legislação estadual; e os municípios nunca mais foram responsabilizados pelo próprio mapeamento. Embora a extinção de municípios seja ainda prevista em lei, não costuma acontecer, houve casos de municípios extintos no ano de 1964, os quais, segundo Lordello de Mello (1992)', foram justos em sua maioria.

Esse mesmo Decreto-Lei proporcionou avanços concretos para o conhecimento e a organização padronizada do Território Nacional. Sua implantação conferiu uma base espacial sistematizada, não apenas para apoiar as estatísticas, o que em si já guarda grande importância, mas também para proporcionar maior consistência às informações sobre o ordenamento territorial e sua administração. Pela primeira vez foram mapeados todos os municípios do País, possibilitando a visualização dos seus limites, assim como dos limites entre os espaços urbanos e rurais.

Nenhum outro documento legal, incluindo três Constituições Federais, alterou o estabelecido quanto ao significado de urbano e de rural, conservando-se o entendimento de que todas as cidades e vilas são urbanas, e que o espaço rural é o que lhes é externo (BRASIL, 1986; BRASIL, 2009). Quanto ao número de moradias para novas cidades e vilas, há legislação específica e atualizada nas duas últimas Constituições Federais.

A Constituição Federal de 1967 estabeleceu, da Lei Complementar n. 1, de 09.11.1967, os requisitos para emancipação de novos municípios, o que implicou em determinar o tamanho mínimo para que uma nova cidade fosse criada. Eram exigidos: população superior a 10 mil habitantes na área pretendida para o novo município, sendo $10 \%$ eleitores, cinco milésimos da receita estadual de impostos, e 200 casas na futura cidade.

Esse critério único para todo o Brasil era, antes de tudo, a negação das enormes e conhecidas desigualdades existentes, uma vez que a reunião de 10 mil pessoas encerra realidades totalmente distintas a depender da fração do território em que ocorre. Do mesmo modo, a geração de cinco milésimos da receita estadual oriunda de impostos apresenta distribuição tão ou mais desigual que a referente à população. Entretanto, esta legislação vigorou até o final da década de 1980 quando foi substituída por leis que ainda vigem atualmente.

A Constituição Federal do Brasil de 1988 delegou aos estados o poder de estabelecer os requisitos à emancipação de seus municípios, o que proporcionou diferenças quantitativas e qualitativas entre os estados (BRASIL, 2009). Manteve a competência estadual, que sempre

\footnotetext{
1 O caso mais contundente relatado pelo autor é o de uma sede de município localizada no barco do prefeito, ancorado próximo a Manaus.
} 
houve, de determinar os requisitos e os procedimentos necessários à criação de distritos, atribuição que, em alguns estados, foi delegada aos próprios municípios.

Todos os estados mantiveram o critério de valor mínimo para a população de um novo município; alguns adotaram valores percentuais da população do estado; outros passaram a considerar o valor do município de menor população e a associar o mínimo populacional à distância da sede do município de origem.

Manteve-se, também, como critério, o percentual de eleitores na população. Exige-se, ainda, a geração de renda mínima na área a ser emancipada, geralmente, um percentual sobre o valor da receita tributária ou da oriunda de impostos do estado.

Em praticamente todos os estados, há exigências com relação à futura sede municipal quanto a número mínimo de casas, moradias, ou prédios; construções disponíveis para abrigar a Prefeitura e a Câmara de Vereadores; escolas de primeiro grau; posto de saúde; serviço público de água, dentre muitas outras.

Essa legislação expressa a autonomia estadual para a criação de novos municípios conquistada com a redemocratização política do País na década de 1980. Sua análise não permite associações entre maiores facilidades para emancipar o maior ou menor desenvolvimento econômico do estado. As inúmeras desigualdades, que caracterizam o Brasil, são também identificadas no fracionamento dos territórios estaduais, tanto pelos recortes herdados de períodos passados, quanto pelos desmembramentos que continuam a acontecer de maneira muito diferenciada, sugerindo, mesmo, tratar-se de uma estratégia estadual que transcende seus governos.

Embora expressos de forma clara e inequívoca, nem sempre esses requisitos legais são respeitados pelas próprias Assembleias Legislativas que os estabeleceram. Veiga e outros (2001) apontam alguns exemplos de municípios que, não obstante de emancipação recente, não atendem aos requisitos previstos em lei, contribuindo para a conclusão do autor de que toda a estrutura de determinação de espaços urbanos no País deva ser alterada. Nesse sentido, pode-se afirmar que o maior apreço à legislação vigente seria suficiente para evitar emancipações municipais indevidas e, portanto, passíveis de críticas estruturais.

Conforme visto anteriormente, alguns estados estabelecem critérios para a criação de distritos, outros delegam essa atribuição aos municípios, dado o seu caráter exclusivamente administrativo. Sua sede com categoria de vila é, entretanto, delimitada por perímetro urbano, estabelecido em lei municipal, fazendo com que seu território, economias e população sejam legalmente urbanos.

Os requisitos para a criação de distritos, em termos populacionais, são muito díspares, assim como o número de construções na sede. São muito restritas as exigências que visam ao atendimento básico das necessidades da população, como a oferta de escolas e postos de saúde, por exemplo.

Em 1996, houve a reinterpretação da Emenda Constitucional n. 15, de 12.09.1996, que implementou duas mudanças importantes quanto à emancipação municipal: a primeira trata da lei estadual de criação, que passou a depender de prazo a ser estipulado por lei complementar federal, que nunca foi elaborada, o que, a rigor, passou a impedir qualquer 
emancipação; a segunda alteração foi quanto à realização de plebiscito, requisito básico à criação de um município, que passou a ser realizado também na área remanescente do(s) município(s) de origem (BRASIL, 1996).

O Projeto de Lei do Senado n. 98, de 23.04.2002, transformado no Projeto de Lei Complementar n. 416, de 17.10.2008, estabeleceu critérios gerais para a emancipação de municípios, dentre outras alterações territoriais, a saber: determinou $10 \%$ de eleitores subscrevendo o requerimento inicial; montante mínimo de população variando de 5 mil a 10 mil habitantes, conforme a Grande Região do País; eleitorado igual ou superior a 50\% da população; núcleo urbano constituído, dotado de infraestrutura compatível com a condição de município e com 10\% a mais de imóveis que a média dos municípios do estado; e arrecadação estimada $10 \%$ maior que a média dos municípios do estado. Cumpridas essas exigências, ainda estabeleceu a necessidade de realização de estudos de viabilidade econômico-financeira, político-administrativa, socioambiental e urbana, indicando os órgãos que devem ser consultados. Esse Projeto de Lei Complementar, aprovado no Congresso, foi vetado, em 2013, pelo poder Executivo, com o argumento de que haveria ônus excessivo ao erário (BRASIL, 2008).

Em 2014, novo projeto de lei foi apresentado com critérios semelhantes ainda mais rigorosos. O Projeto de Lei do Senado n. 104 de 26.03.2014 elevou para 20\% o total de eleitores da área a ser emancipada a subscreverem o requerimento inicial; aumentou o montante populacional mínimo em valores regionais, variando de 6 mil a 20 mil habitantes; manteve a exigência quanto ao núcleo urbano consolidado com número de imóveis maior que a média dos menores municípios do estado; e estabeleceu área mínima para o futuro município, segundo a Grande Região a que pertence. E, ainda, conservou a exigência acerca dos estudos de viabilidade econômico-financeira, político-administrativa, socioambiental e urbana com maior detalhamento, determinando que fossem contratados e custeados pelos governos estaduais. Além disso, reiterou que os novos municípios contemplassem todos esses requisitos sem que os municípios de origem deixassem de atendê-los. Apesar de todas essas exigências, esse Projeto de Lei Complementar foi igualmente vetado pelo poder Executivo (BRASIL, 2014).

Desde 1996, quando houve a reinterpretação da Emenda Constitucional n. 15, de 12.09.1996, não deveria ter havido sequer uma emancipação municipal, ficando os projetos estaduais no aguardo da lei federal, mas não foi o que aconteceu. Muitos municípios que de fato existem foram emancipados de forma juridicamente irregular, pois a lei complementar federal que deveria determinar o período para apresentação das leis estaduais nunca foi formalizada, criando uma situação complexa, que está a depender de parecer do Supremo Tribunal Federal.

A emancipação de municípios é uma das formas de incremento dos espaços urbanos; as demais são a criação de um distrito com sua vila, a expansão de uma cidade ou vila por meio da ampliação do perímetro urbano, ou o adensamento populacional de uma cidade ou vila já existente.

Em termos de mudanças na vida cotidiana da população, a primeira forma, isto é, a emancipação de novos municípios é, certamente, a que causa maior impacto no curto prazo. 
Cada novo município significa o surgimento de uma nova cidade, com o aparato institucional correspondente, produzindo efetiva mudança local no ordenamento do território por meio do redirecionamento dos fluxos da população próxima para atendimento às necessidades básicas e de acesso ao Estado.

Cigolini (2009), analisando diversos trabalhos acerca do tema, identificou aqueles que defendem a emancipação municipal, ao contrário dos que não a apoiam. Para os primeiros, a melhora da qualidade de vida local, em razão da implantação de serviços essenciais como agências bancárias, escolas de nível médio, postos de saúde e outros, justifica as despesas com a instalação de uma nova prefeitura e Câmara de Vereadores. Para aqueles que julgam indevidas as emancipações municipais, as despesas financeiras se sobrepõem aos ganhos da população.

\section{O processo de emancipação de municípios}

A emancipação de um município passa pelo cumprimento de uma série de requisitos e exige o envolvimento de um grande número de pessoas e instituições. O processo começa com a formação de uma Comissão de Emancipação composta por pessoas do local que deseja se tornar município. Em alguns estados, esse pleito só pode ser encaminhado se a área pretendente já for um distrito.

Essa Comissão de Emancipação encaminha documento à Assembleia Legislativa do seu estado, com assinatura e, em alguns casos, firma reconhecida de um número legalmente determinado de eleitores residentes na área a ser emancipada. Além da manifestação dos eleitores, há estados em que o pleito depende da assinatura de um ou mais deputados ou do governador.

No documento elaborado pela Comissão de Emancipação e encaminhado à Assembleia Legislativa, são informados os limites ou, pelo menos, as vilas e povoados que formarão o município e também a localidade que abrigará a sede do futuro município. Na Assembleia Legislativa, uma comissão interna, que pode ser a Comissão de Constituição e Justiça ou a Comissão de Revisão Territorial, dependendo do estado, verifica o cumprimento dos primeiros requisitos e acompanha toda a tramitação do processo.

O projeto de criação do município é elaborado, apresentando o limite detalhado por meio de memorial descritivo e de mapa, e encaminhado a alguns órgãos que prestarão informações necessárias ao processo. Ao órgão responsável pela geografia ou cartografia do estado compete a verificação dos limites quanto ao fechamento do polígono, à observação de inexistência de área descontínua no futuro município e nos de origem, e à estabilidade e identificação das linhas e pontos constituintes do limite.

Ao IBGE, na maioria dos casos, é solicitado que informe, com base no Censo Demográfico mais recente, a população residente na área apresentada pelo projeto de criação, assim como o número de casas ou construções no aglomerado indicado para abrigar a sede 
do futuro município. O número de eleitores é solicitado à Justiça Eleitoral, e as informações sobre arrecadação são solicitadas às Secretarias Estaduais de Fazenda.

Cumpridos todos os requisitos pelo pretenso município, sem que os de origem tenham deixado de atender a nenhum deles, a comissão responsável, na Assembleia Legislativa, solicita ao Tribunal Regional Eleitoral a realização de plebiscito, consultando tanto a população da área do futuro município quanto da área remanescente dos municípios de origem, conforme determina a Emenda Constitucional n. 15, de 12.09.1996.

Após a aprovação pelas populações envolvidas, o projeto de criação é votado em plenário da Assembleia Legislativa, e, se aprovado, a lei de criação é publicada, no Diário Oficial do Estado, com os limites do município, o nome e a indicação da sede. Essa publicação, entretanto, não consagra ao município o direito de existência para quaisquer fins, apenas a sua instalação, que se dará com a posse do prefeito, é que determina o nascimento real de uma nova unidade político-administrativa. Nas eleições seguintes, independentemente de a quais cargos se destinem, o Tribunal Regional Eleitoral inclui a votação, no novo município, que escolherá também seu primeiro prefeito, vice-prefeito e vereadores. Em primeiro de janeiro do ano consecutivo, ocorrem a posse dos eleitos e a assinatura da Ata de Instalação do Município, dando início à sua efetiva existência.

Todo o processo de emancipação de um município é, portanto, determinado por legislações estadual e federal e conta, necessariamente, com a aprovação dos deputados estaduais e das populações envolvidas, tanto daquela que reside na área a ser emancipada, quanto a da área remanescente dos municípios de origem. A importância dessa explanação é mostrar que esse processo envolve muitas pessoas, apresenta regras claras e legalmente estabelecidas, e que, se por vezes essas não são cumpridas, a deficiência não está no processo, mas na falta do correto cumprimento às leis.

Enquanto a legislação federal e/ou estadual tem estabelecido os critérios quanto ao tamanho das novas cidades e vilas desde 1938, a legislação municipal tem sido a responsável pela determinação de seus limites. Cabe à Prefeitura e à Câmara de Vereadores estabelecer o perímetro urbano da cidade e das vilas em lei municipal, que pode não ser específica para esse fim. A área contida pelo perímetro urbano é legalmente urbana, assim como tudo o que dela constar. Por exclusão, as áreas não urbanas são legalmente rurais, conservando-se, portanto, o preceito estabelecido pelo Decreto-Lei n. 311, de 02.03.1938.

O estabelecimento do limite da cidade concretamente identificado no terreno é bem mais simples no discurso do que na prática. Todas as proposições teóricas acerca do urbano e da cidade mostram que, desde que as muralhas em torno da cidade deixaram de existir, nem sempre é fácil identificar, no terreno, uma linha que identifique o início das manifestações da vida urbana ou da cidade. Frequentemente, a transição entre a cidade e o campo ocorre em uma zona de transição, uma franja rural-urbana que já foi qualificada de suburbana, termo que com o tempo adquiriu outro significado. Entretanto, a lei estabelece que a divisa seja feita em linha e não em área. 
Mas como conciliar a linha exigida pela lei com a área na qual mais frequentemente ocorre a transição? Ambas precisam ser respeitadas, uma por ser legalmente determinada, e a outra por ser a expressão da organização daquela sociedade. Essa conciliação é especialmente importante nos momentos em que é necessário classificar cada fração do espaço, cada casa, cada pessoa.

Visando contornar esse problema, o IBGE, que é um órgão usuário desse recorte espacial, construiu uma classificação que, sendo mais complexa que a legal, possibilita o respeito e a preservação mais acurada das características de vida das populações residentes nessas zonas de transição. Essa classificação, proposta por Fredrich, Brito e Rocha (1983), foi adotada a partir do Censo Demográfico 1991 e, além de incluir os setores, que são as unidades espaciais de coleta, nas situações urbana ou rural, estabelece oito tipos que distinguem as áreas urbanizadas das não urbanizadas, assim como diferenciam os aglomerados rurais (X RECENSEAMENTO..., 2005).

Como visto anteriormente, os critérios de determinação do caráter urbano a certas áreas do território brasileiro têm recebido críticas contundentes por parte de profissionais que se dedicam quer a estudos da organização espacial, como os geógrafos, quer a informações oriundas de levantamentos baseados nesses recortes espaciais. As críticas identificadas por este trabalho foram oferecidas principalmente por geógrafos e se dirigem aos fundamentos da opção brasileira de basear, na estrutura político-administrativa, a identificação de espaços urbanos.

\section{Críticas ao critério brasileiro de determinação de espaços urbanos}

A crítica mais antiga foi divulgada já na publicação dos resultados do Recenseamento Geral do Brasil de 1940. Nas páginas introdutórias, onde são apresentadas as definições dos termos empregados no levantamento, criticava-se a inclusão de aglomerados muito pequenos na categoria de cidades, em decorrência de serem sedes municipais, conforme estabelecido pelo Decreto-Lei n. 311, de 02.03.1938 (RECENSEAMENTO..., 1950-1952).

A decisão governamental de que todas as sedes municipais passassem a ser cidades foi considerada inadequada por parte do corpo técnico da Instituição, mesmo considerando que o referido Decreto-Lei tenha sido elaborado a partir de documentos do Conselho Nacional de Estatística.

Alguns anos mais tarde, em 1956, Aroldo de Azevedo, em seu clássico estudo "Vilas e cidades do Brasil colonial", apresentou também sua crítica ao estabelecido pelo Decreto-Lei n. 311, de 1938. Nas palavras do autor:

Evidentemente, seria um erro afirmar que esses 1.890 centros urbanos devem ser considerados verdadeiras cidades, de acordo com o conceito geográfico desta palavra, pois a grande maioria não apresenta as características culturais e sociais, a estrutura, as características demográficas e as funções geralmente apontadas pelos geógrafos para que possam ser como tais classificados. 
Acreditamos estar mais próximos da realidade se tomarmos como limite mínimo para a conceituação das cidades (na falta de outro critério) a população urbana de 10.000 hab. Nesta hipótese, existiriam, em 1950, apenas 204 aglomerados urbanos que mereceriam aquela designação, no ponto de vista da Geografia (AZEVEDO, 1956, p. 5-6, grifo do autor).

Em 1963, Pedro Geiger publicou sua discordância quanto à legislação brasileira que, para o autor, considerava as cidades aglomerados que não se caracterizavam como tal. Geiger (1963, p. 8) questionava que se atribuísse categoria de cidade às sedes de municípios com "menos de 1000 habitantes, casario tosco, baixo e disperso".

O limite inferior de 1 mil habitantes para as cidades sugerido por Geiger se coaduna com o Decreto-Lei n. 311, de 1938, que estabeleceu 200 moradias para as novas sedes municipais. O problema grave era quanto às sedes já existentes e com valores de população e/ ou de construções muito aquém do legal e do conceitualmente razoável.

Do mesmo modo, o "casario tosco e baixo" devia ser corriqueiro nas pequenas cidades, com casas feitas de pau-a-pique e recobertas com folhagem da vegetação local, condizentes com as precárias condições econômicas da maioria da população brasileira. O problema da dispersão, destacado por Geiger (1963), possivelmente o de maior relevância na determinação de uma cidade, não foi enfrentado sequer pela legislação de 1967, ao não incluir nenhuma exigência quanto à densidade.

Em 1983, a Fundação Carlos Chagas Filho de Amparo à Pesquisa do Estado do Rio de Janeiro - FAPERJ publicou um trabalho, coordenado por Lysia Maria Cavalcanti Bernardes (1983), sobre aglomerados fluminenses de pequeno porte, assim considerados as "cidades (até 30000 habitantes), vilas e outros aglomerados populacionais", em cuja primeira página criticava o critério político-administrativo de classificar como urbanas todas as sedes municipais e distritais.

Dentre as cidades e vilas do interior do Estado do Rio de Janeiro, 89\% possuíam, segundo o Censo Demográfico 1980, menos de 30 mil habitantes, e muitas, menos de 10 mil habitantes. Segundo esse levantamento, "tais localidades, oficialmente reconhecidas como urbanas, correspondem, via de regra, a pequenos embriões urbanos ou simples povoados rurais, na maioria das vezes dotados de funções e equipamentos urbanos mínimos" (BERNARDES, 1983, p. 13).

A crítica dirigia-se, portanto, às mínimas dimensões, assim como às parcas funcionalidades oferecidas pelas localidades, que, muitas vezes, sequer constituíam aglomerados visivelmente percebidos. A interpretação da palavra urbano nesse trabalho da FAPERJ parece guardar o conceito ligado à reunião de pessoas, casas e funções, não ao de dinamismo e modernidade que já se construía no período.

Naquele ano de 1983, a legislação em vigor para a emancipação de novos municípios era a Lei Complementar n. 1, de 9 de novembro de 1967, da Presidência da República, que determinava a todas as áreas que almejassem se tornar municípios, que possuíssem ao menos 10 mil habitantes em seu território, incluindo as populações urbanas da cidade e das vilas e a população rural. 
Fany Davidovich e Olga Fredrich (1988), analisando a urbanização brasileira na década de 1980, mostraram as altas taxas de crescimento da população urbana, chamaram a atenção para a estratégia de ocupação urbana de áreas de fronteira e perceberam tendências de homogeneização do comportamento social segundo o modo de vida urbano. Discordaram, assim como os autores anteriormente apresentados, do critério administrativo para o estabelecimento de espaços urbanos no Brasil.

As autoras apresentaram exemplos tanto de cidades que pela pequena população não deveriam dispor da condição de espaço urbano, quanto da situação oposta exemplificada pela cidade de São Luís, no Estado do Maranhão, em que a ocupação com características urbanas expandia-se para muito além dos limites legais da cidade. Embora o referido trabalho tivesse como objetivo "analisar as características da urbanização no Brasil", com destaque para "o decênio 1970-1980" (DAVIDOVICH; FREDRICH, 1988, p. 15), não houve, por parte das autoras, a intenção de apresentar sugestões para o aperfeiçoamento da definição utilizada e por elas reconhecida como inadequada.

Outras críticas foram identificadas avançando para além das anteriormente apresentadas, no sentido de contribuírem com propostas concretas para solucionar, ou ao menos minimizar, as reconhecidas dificuldades quanto ao estabelecimento de critérios objetivos para a determinação de espaços urbanos no Brasil. A primeira, também na década de 1980, foi formulada por Lysia Bernardes, Sergio Lordello dos Santos e Fernando Nalcacer e publicada à época pelo Instituto Paranaense de Desenvolvimento Econômico e Social - IPARDES - Fundação Édison Vieira. (BERNARDES; SANTOS; NALCACER, 1983); a segunda, apresentada, no ano 2000, por Ricardo Abramovay (2000), em publicação do Instituto de Pesquisa Econômica Aplicada - IPEA; e a terceira, divulgada, nos anos 2001 e 2002, por José Eli da Veiga (2002a), em artigos no jornal O Estado de São Paulo, alguns dos quais foram posteriormente reunidos em livro.

No ano de 1983, o trabalho do então Instituto Paranaense de Desenvolvimento Econômico e Social - IPARDES - Fundação Édison Vieira em associação com Ministério do Interior, coordenado por Lysia Bernardes (BERNARDES; SANTOS; NALCACER, 1983), discutiu o conceito de determinação de espaços urbanos no Brasil, analisado sob os aspectos tributário e urbanístico, comparou-o aos de outros países e elaborou propostas concretas e politicamente factíveis para o aperfeiçoamento da legislação brasileira.

Os autores começavam o texto mostrando que a inadequação da definição de urbano era reconhecida por todos. Destacavam também a dificuldade de adequação que teria qualquer critério que viesse a ser adotado no Brasil em face de enormes diferenças entre a maioria das cidades e as grandes metrópoles.

A simetria atribuída aos municípios, embora fosse considerada indevida pelos autores, era percebida como parte integrante da história municipal brasileira, tendo sido mantida tanto por todas as Constituições Federais, quanto pelas legislações estaduais, que poderiam, conservando a igualdade no que se refere à autonomia municipal, ter estabelecido algumas diferenças, por exemplo, quanto a procedimentos de administração financeira.

Admitiam a existência de municípios que era contestada quer por terem sido indevidamente criados sob a inobservância da legislação, quer por terem deixado de atender 
a essa última, em face de reduções populacionais ou de perdas de agentes econômicos. A resolução desse problema possuía duas alternativas:

A primeira solução, aparentemente mais simples, mas reconhecidamente inviável, seria a extinção daqueles municípios de extensão territorial pequena e de recursos escassos, que tem como sede núcleos de dimensão populacional também pequena, que melhor se enquadrariam como vilas. A fusão de pequenos municípios desse tipo [...] poderia resultar em melhor racionalização na utilização dos recursos disponíveis, sem dúvida, mas não encontraria qualquer apoio político pois implicaria, para a população local, em perda de sua autonomia (BERNARDES; SANTOS; NALCACER, 1983, p. 38)

Considerando impossível a implementação da extinção de municípios, os autores indicavam, como segunda proposta de solução, estudos do Instituto Brasileiro de Administração Municipal - IBAM; do IBGE; e do Conselho Nacional de Desenvolvimento Urbano - CNDU. Nesses estudos, haviam sido apresentadas propostas de "criação de categorias diferentes de municípios" sem, entretanto, alterar suas autonomias, mas considerando principalmente as diferenças na complexidade de suas sedes. O estudo do IBAM se detivera na maior ou menor concentração urbana; o do IBGE, por meio de técnicas estatísticas, classificara os municípios em rural, rural/urbano, urbano/rural e urbano; e o do CNDU distribuíra-os entre as categorias rural, de capital, de interesse de segurança nacional e geral ou padrão. Dentre os problemas que a implementação de sistemas como esses acarretaria, os autores destacavam sua aceitação em termos políticos. Apontavam para o perigo do autoritarismo, memória viva na época da elaboração do estudo, e da transitoriedade da classificação, indicando exemplos de municípios que, em poucos anos, tinham deixado de ter economias eminentemente agrícolas passando a industriais, ou que se transformaram em centros turísticos, o que requereria periódica revisão da classificação. Ainda no sentido de apontar dificuldades, lembravam que um número expressivo de cidades de grande porte tinha suas economias voltadas principalmente para a agropecuária e questionavam se, ainda assim, seriam classificados como urbanas.

Concluíam que a única alternativa para diminuir os efeitos negativos da "uniformização do critério administrativo" seria o estabelecimento, por parte dos estados, de alguma classificação de cidades, não de municípios, de modo a, garantindo a autonomia destes, diferenciá-las em termos de "atuação e exigências", proporcionando "maior racionalidade no tratamento do urbano" (BERNARDES; SANTOS; NALCACER, 1983, p. 44).

Mesmo reconhecendo que os critérios referentes ao montante populacional e à densidade eram os mais utilizados como indicadores de áreas urbanas, julgavam que os ligados à funcionalidade seriam mais adequados, não apenas em termos conceituais, mas principalmente para a aplicação em países como o Brasil, que apresenta enormes desigualdades regionais.

Para os autores, o que propiciava o caráter urbano a um aglomerado era a implantação de infraestrutura mínima que garantisse a permanência e o bem-estar das famílias. Reconheciam a dificuldade de estabelecer esse limite, mas identificavam que o montante de 1 mil habitantes ou 200 moradias seria suficiente para assegurá-la. Avaliavam que um aglomerado dessas dimensões seria capaz de gerar demandas por infraestrutura, comércio e serviços em volume suficiente para ser considerado urbano. A consecução desses investimentos dependeria de um certo aparato administrativo, proporcionado pelo governo municipal, 
e de receitas próprias que tivessem sido geradas no município ou para ele transferidas por outro ente federativo.

Lembravam que a desigualdade da distribuição espacial da população no Brasil exigiria que à União coubesse apenas fornecer as linhas gerais de caracterização dos espaços urbanos, enquanto aos estados deveria competir a fixação dos critérios objetivos estabelecendo limites mínimos na determinação de suas cidades e vilas.

Admitiam a existência de áreas urbanas externas às cidades e vilas, assim como vilas sem o caráter urbano. Não incluíam as cidades, por menos populosas que fossem, nessa categoria não urbana, por avaliar que a presença do aparato político-administrativo era capaz, por si só, de propiciar a complexidade necessária e suficiente à inclusão da cidade no conjunto dos aglomerados urbanos.

Alguns anos depois, embora a referida "inadequação da definição de urbano" ainda permanecesse, ao menos parte das recomendações desse trabalho do IPARDES - Fundação Édison Vieira foi atendida pela Constituição Federal do Brasil de 1988, com a delegação aos estados do estabelecimento de requisitos mínimos para que novos municípios fossem emancipados.

Em todos os estados, são exigidos o valor mínimo de população para o futuro município, assim como os elementos de infraestrutura para a futura sede. O aspecto referente à densidade foi o único, dentre os sugeridos pelos autores, a ser enunciado pela lei de poucos estados, embora seja frequente a referência à ocorrência de "unidade do território" para a criação de cidades.

Ricardo Abramovay (2000) apresentou suas críticas ao método brasileiro de estabelecimento de espaços rurais. Julgava inadequados tanto o critério administrativo de identificação de espaços urbanos, quanto a determinação de espaços rurais feita por exclusão. Propunha que o País fosse dividido em regiões urbanas e regiões rurais, foco principal do seu trabalho, que incluiriam campos e cidades. As regiões rurais não seriam estabelecidas a partir da predominância da ocupação da mão de obra em atividades agropecuárias, as quais, no entender do autor, não representam as áreas rurais, dado o estabelecimento cada vez mais frequente de outras atividades. Discorda também da utilização de critério calcado no estabelecimento de patamar mínimo de população das localidades, embora o considere o menos inadequado.

Para o autor, há três características indicadas para determinar as áreas que devam ser consideradas rurais: 1 ) as fortes relações com a natureza em termos éticos, afetivos e como fonte de rendimento; 2) a baixa densidade demográfica no campo aberto e nas pequenas cidades, nos quais são maiores as probabilidades de se desenvolverem relações de vizinhança que nas grandes cidades; e 3) a dependência ao sistema urbano, mostrando que as áreas rurais mais prósperas são as que possuem maior interação com os grandes centros urbanos (ABRAMOVAY, 2000).

Nos anos 2001 e 2002, José Eli da Veiga manteve uma coluna no jornal O Estado de São Paulo, na qual publicou diversos artigos, posteriormente reunidos em livro (VEIGA, 2002a), criticando os resultados do Censo Demográfico 2000 que, mesmo preliminares, apontavam para o aumento, em termos absolutos e relativos, da população urbana brasileira.

O autor apresentava duas discordâncias acerca do critério brasileiro para a determinação dos espaços urbanos: a primeira, e mais fundamental, era a de que, na mesma linha de Abramovay (2000), os municípios não deveriam possuir parte urbana e parte rural, mas, 
sim, serem classificados por inteiro em municípios urbanos ou municípios rurais; e a segunda crítica, decorrente da primeira, referia-se ao limite mínimo de população e densidade que deveriam ter os municípios a serem classificados como urbanos (VEIGA, 2002a). Ele distinguia, de início, os municípios brasileiros sobre os quais não havia dúvida quanto ao caráter urbano:

Não há habitantes mais urbanos do que os residentes nas 12 aglomerações metropolitanas, nas 37 demais aglomerações e nos outros 77 centros urbanos identificados pela pesquisa que juntou excelentes equipes do IBGE - Instituto Brasileiro de Geografia e Estatística, do Ipea - Instituto de Pesquisas Econômicas Aplicadas, e da Unicamp - Universidade de Campinas: Caracterização e Tendências da Rede Urbana do Brasil (1999). Nessa teia urbana, formada pelos 455 municípios dos três tipos de concentração, estavam 57\% da população em 2000. Esse é o Brasil inequivocamente urbano (VEIGA, 2002a, p. 32, grifos do autor).

Para classificar todos os demais municípios, apontava como o ideal um "índice de pressão antrópica", que ainda estava por ser construído, e que determinaria, como mais rurais, os municípios de território mais intocado, enquanto, no extremo oposto, estariam os municípios mais urbanos que seriam, portanto, os mais artificializados. Em não havendo tal índice, utilizava informações de montante populacional e densidade demográfica para considerar

de pequeno porte os municípios que têm simultaneamente menos de 50 mil habitantes e menos de 80 hab/km2 e de médio porte os que têm população no intervalo de 50 a 100 mil habitantes, ou cuja densidade supere os 80 hab/km², mesmo que tenham menos de 50 mil habitantes (VEIGA, 2002a, p. 34).

Dessa classificação resultava, segundo o autor, que cerca de $80 \%$ dos municípios brasileiros, nos quais residiam aproximadamente $30 \%$ da população, seriam percebidos como "essencialmente rurais", e 10\% dos municípios que abrigavam cerca de $13 \%$ da população estariam em posição intermediária entre os essencialmente urbanos e os essencialmente rurais, os quais seriam denominados "intermédios" (VEIGA, 2002a, p. 34).

Em artigo posterior à publicação do livro, o autor afirma que deveriam ser consideradas urbanas apenas as aglomerações que dispusessem de livraria, funcionalidade que, no seu entender, garantiria a existência de outras que propiciariam ao aglomerado o verdadeiro caráter urbano. Nas palavras do autor, "povoações que não chegam a ter livraria também não costumam cumprir as funções exigidas para que uma aglomeração seja cidade" (VEIGA, 2002b, p. 1).

O trabalho de Veiga (2002a), embora trate enfaticamente das questões relativas à divisão e classificação do território, tem por objetivo principal defender o desenvolvimento das regiões por ele identificadas como rurais por meio da diversificação das atividades. Como afirmado em várias passagens, a população dessas regiões há muito já não tem seu trabalho restrito à agricultura, pecuária e pesca; ao contrário, dedica-se cada vez mais à prestação de serviços que, em geral, propicia melhor remuneração. 


\section{Considerações finais}

As críticas aos critérios brasileiros de determinação de espaços urbanos fixam-se, como foi visto, no limite inferior do conjunto das cidades e vilas. Não há argumentação contrária ao fato de que os grandes aglomerados sejam cidades e urbanos; a discussão centra-se nas pequenas cidades. A principal questão é a identificação mais precisa das categorias de cidade e de espaço urbano.

As críticas propostas em Recenseamento geral do Brasil 1940 (1950); Azevedo (1956); Geiger (1963); Bernardes (1983); Santos e Nalcacer (1983); Davidovich e Fredrich (1988); Bernardes e Abramovay (2000); e Veiga (2002a; 2002b) apontam para a inadequação de que seja atribuído a pequenas cidades tal título, assim como que lhes seja imputado caráter urbano. Estariam esses autores, a partir de suas criticas, sugerindo o fim da diferenciação entre os pequenos aglomerados, sendo ou não legalmente cidades, e o campo? Abramovay (2000) e Veiga (2002a) afirmam que sim, ao propor a divisão do Território Nacional em áreas urbanas e rurais, homogeneizando-as em grandes conjuntos.

As demais críticas, entretanto, apontam para a deficiência no limite mínimo do que se deva considerar cidade, aspecto que, quanto a novas cidades, provavelmente seria resolvido com o simples respeito à legislação vigente. A proposta de Bernardes, Santos e Nalcacer (1983), embora mantenha a atual estrutura básica, contempla ajustes referentes à retirada de vilas, cuja pequena complexidade socioeconômica não justifique sua permanência entre os espaços urbanos, e, pela via oposta, a inclusão nesses espaços de povoados, que, portanto, sequer são sedes de distritos, avaliados como suficientemente complexos. Apenas esses autores se debruçaram sobre a complexa situação que é criada diante da redução de montante populacional e de atividade econômica ocorrida em municípios já consolidados, que deixam, assim, de atender aos requisitos mínimos aceitos para se manterem como tal.

O estabelecimento de espaços urbanos no Brasil segue, há muitos anos, regras legalmente estabelecidas; respeita, desde o final da década de 1980, as diferenciações estaduais; e envolve grande número de agentes locais, de instâncias políticas estaduais e de instituições públicas das esferas federal e estaduais. Se, ainda assim, são verificadas emancipações indevidas, a falha não está no sistema, mas sim nas inadequações inseridas em seu cumprimento por aqueles a quem cabe fiscalizar sua implementação.

Os projetos de legislação recentemente propostos pelo Senado e vetados pelo poder Executivo contemplavam, além de exigências já previstas em legislações anteriores como as relativas ao montante mínimo de população, construções, rendimento e infraestrutura, estudos prévios de viabilidade econômico-financeira, político-administrativa, socioambiental e urbana.

Finalmente, o argumento divulgado pelo Executivo para o veto destaca a persistência da centralidade das questões financeiras nas decisões políticas em torno desse tema ao apontar apenas para o aumento de despesas, deixando em aberto, para a análise geopolítica, o impacto da criação de município sobre as condições objetivas de vida dos pequenos aglomerados populacionais do País. 
Com efeito, a transformação de uma vila em cidade pode representar tanto a universalização do acesso a uma agência bancária, a uma escola de nível médio e/ou aos recursos para transporte de pacientes em consultas, exames e internações, como, em termos institucionais, o ethos urbano, mesmo da pequena cidade, pode representar para a organização da vida socioeconômica do interior. Isso não é pouco, e a pesquisa geográfica tem muito a contribuir e avançar nesse debate.

\section{Referências}

X RECENSEAMENTO geral do Brasil: GR-7.01: manual de delimitação dos setores e das zonas de trabalho de 1990. Rio de Janeiro: IBGE, Diretoria de Geociências, 1990. 78 p. Disponível em: <http://biblioteca.ibge.gov.br/visualizacao/instrumentos_de_coleta/ doc0207.pdf>. Acesso em: mar. 2016.

ABRAMOVAY, R. Funções e medidas da ruralidade no desenvolvimento contemporâneo. Brasília, DF: Instituto de Pesquisa Econômica Aplicada - IPEA, 2000. 28 p. (Texto para discussão, n. 702). Disponível em: <http://www.ipea.gov.br/agencia/images/stories/PDFs/ TDs/td_0702.pdf>. Acesso em: mar. 2016.

ABREU, M. de A. Geografia histórica do Rio de Janeiro (1502-1700). Rio de Janeiro: A. Jakobson Estúdio: Rio Prefeitura, 2010. 2 v.

AZEVEDO, A. de. Vilas e cidades do Brasil colonial: ensaio de geografia urbana retrospectiva. Boletim da Faculdade de Filosofia, Letras e Ciências Humanas da Universidade de São Paulo, São Paulo, 1956.

BEAUJEU-GARNIER, J. Geografia urbana. Lisboa: Fundação Calouste Gulbenkian, 1983. $525 \mathrm{p}$.

BERNARDES, L. M. C. (Coord.). Urbanização do interior fluminense: análise dos aglomerados de pequeno porte. Rio de Janeiro: Fundação de Amparo à Pesquisa do Estado do Rio de Janeiro - FAPERJ, Coordenadoria de Geografia e Estatística, 1983. 204 p.

BERNARDES, L. M. C.; SANTOS, S. R. L. dos; NALCACER, F. C. (Org.). Redefinição do conceito de urbano e rural. Curitiba: Ipardes-Fundação Édison Vieira; Ministério do Interior, Conselho de Desenvolvimento Urbano, 1983. 84 p. Disponível em: <http://www.ipardes. gov.br/biblioteca/docs/redefinicao_urbano_rural_12_83.pdf>. Acesso em: mar. 2016.

BRASIL. Congresso. Câmara dos Deputados. Projeto de Lei Complementar n. 416, de 16 de outubro de 2008. Dispõe sobre o procedimento para a criação, a incorporação, a fusão e o desmembramento de Municípios, para regulamentar o parágrafo 4o do Art. 18, da Constituição Federal; tendo pareceres: da Comissão de Desenvolvimento Urbano e Interior, pela aprovação dos Projetos de Lei Complementar ns 130/96, 138/96 e 151/97, apensados, com substitutivo... Disponível em: <http://www.camara.gov.br/proposicoesWeb/prop_most rarintegra;jsessionid=821AAB046C7E5E8E44208C0EBF9969E3. node2 codteor $=1022562 \&$ filename=Avulso+-PLP+416/2008>. Acesso em: mar. 2016. 
Projeto de Lei Complementar n. 416-A, de 4 de junho de 2013. Dispõe sobre o procedimento para a criação, a incorporação, a fusão e o desmembramento de municípios, nos termos do parágrafo $4^{\circ}$ do artigo 18 da Constituição Federal. Disponível em: $<$ http://www.camara.gov.br/proposicoesWeb/prop_mostrarintegra?codteor $=1096917 \& f$ ilename $=$ Tramitacao-RDF+1+\%3D\%3E+PLP+416/2008>. Acesso em: mar. 2016.

Senado Federal. Projeto de Lei n. 104, de 31 de março de 2014. Dispõe sobre o procedimento para a criação, a incorporação, a fusão e o desmembramento de municípios, nos termos do parágrafo 4o do artigo 18 da Constituição Federal e dá outras providências. Disponível em: <http://www.senado.leg.br/atividade/materia/getPDF.asp?t=147713\&tp=1>. Acesso em: mar. 2016.

Constituição (1988). Constituição da República Federativa do Brasil. Brasília, DF, [2009]. Disponível em: <http://www.presidencia.gov.br/legislacao> Acesso em: mar. 2016.

[Constituição]. Constituições do Brasil: (de 1824, 1891, 1934, 1937, 1946, 1967 e suas alterações). Brasília, DF: Senado Federal, 1986. 2 v.

. Emenda Constitucional n. 15, de 12 de setembro de 1996. Dá nova redação ao parágrafo 4 o Art. 18 da Constituição Federal. Diário Oficial [da União], Brasília, DF, n. 179, 13 set. 1996. Seção 1, p. 18110-18111. Disponível em: <http://www.presidencia.gov. br/legislacao>. Acesso em: mar. 2016.

Decreto-Lei n. 311, de 2 de março de 1938. Dispõe sobre a divisão territorial do país e dá outras providências. Coleção de leis da República Federativa do Brasil de 1938, Rio de Janeiro: Imprensa Nacional, v. 1, p. 438-440, 1938. Disponível em: <http:// www2.camara.leg.br/legin/fed/declei/1930-1939/decreto-lei-311-2-marco-1938-351501publicacaooriginal-1-pe.html>. Acesso em: mar. 2016.

Lei Complementar n. 1, de 9 de novembro de 1967. Estabelece os requisitos mínimos de população e renda pública e a forma de consulta prévia às populações locais para a criação de novos municípios, e dá outras providências. Diário Oficial da União, Brasília, DF, 10 nov. 1967. Seção 1, p. 11391. Disponível em: <http://www4.planalto.gov. br/legislacao/legislacao-1/leis-complementares-1/leis-complementares-1/1967\#content $>$. Acesso em: mar. 2016.

. Lei n. 10.257, de 10 de julho de 2001. Regulamenta ao arts. 182 e 183 da Constituição Federal, estabelece diretrizes gerais da política urbana e dá outras providências. Diário Oficial [da] República Federativa do Brasil, Brasília, DF, ano 138, n. 133, 11 jul. 2001. Seção 1, p. 1. Disponível em: <http://www.presidencia.gov.br/legislacao>. Acesso em: mar. 2016.

CASTELLS, M. A questão urbana. 3. reimpr. São Paulo: Paz e Terra, 1983. 590 p. (Pensamento crítico, v. 48).

CIGOLINI, A. A. Território e criação de municípios no Brasil: uma abordagem históricogeográfica sobre a compartimentação do espaço. 2009. 210 f. Tese (Doutorado)-Programa de Pós-Graduação em Geografia, Universidade Federal de Santa Catarina - UFSC, Florianópolis, 2009. Disponívelem:<https://repositorio.ufsc.br/bitstream/handle/123456789/92531/268885. pdf? sequence=1>. Acesso em: jun. 2015. 
CONSELHO NACIONAL DE ESTATíSTICA (Brasil). Junta Executiva Central. Resolução n. 26, de 15 de dezembro de 1937. Sugere ao Governo Federal a decretação de disposições orgânicas relativas à divisão administrativa e judiciária do território nacional. Diário Oficial [dos] Estados Unidos do Brasil, [Rio de Janeiro], ano 76, n. 296, 28 dez. 1937. Seção 1, p. 25656.

DAVIDOVICH, F. R.; FREDRICH, O. M. B. de L. Urbanização no Brasil. In: SILVA, S. T. (Coord.). Brasil: uma visão geográfica nos anos 80. Rio de Janeiro: IBGE, Departamento de Geografia, 1988. p. 13-85. Disponível em: <http://biblioteca.ibge.gov.br/visualizacao/ livros/liv80970.pdf>. Acesso em: mar. 2016.

EVOLUÇÃO da divisão territorial do Brasil: 1872-2010. Rio de Janeiro: IBGE, Diretoria de Geociências, 2011. 261 p. (Documentos para disseminação. Memória institucional, 17). Disponível em: <http://biblioteca.ibge.gov.br/visualizacao/livros/liv55077.pdf>. Acesso em: mar. 2016.

FREDRICH, O. M. B. L.; BRITO, S. R. de; ROCHA, S. Conceituação e operacionalização da categoria de aglomerados rurais como situação de domicílio para fins censitários. Revista Brasileira de Estatística, Rio de Janeiro: IBGE, v. 44, n. 173-174, p. 199-225, jan./jun. 1983. Disponível em: <http://biblioteca.ibge.gov.br/visualizacao/periodicos/111/rbe_1983_v44_ n173_n174.pdf>. Acesso em: mar. 2016.

GEIGER, P. P. Evolução da rede urbana brasileira. Rio de Janeiro: Centro Brasileiro de Pesquisas Educacionais - CBPE, 1963. 462 p. (Sociedade e educação).

INSTITUTO NACIONAL DE ESTATÍSTICA (Brasil). Convenção Nacional de Estatística. Rio de Janeiro: Ministério do Trabalho, Indústria e Commercio, Departamento de Estatística e Publicidade, 1936. 32 p. Disponível em: <http://biblioteca.ibge.gov.br/visualizacao/livros/ liv14968.pdf>. Acesso em: mar. 2016.

LEDRUT, R. Sociologia urbana. Rio de Janeiro: Forense, 1971. 208 p.

MELLO, D. de L. A multiplicação de municípios no Brasil. Revista de Administração Municipal, Rio de Janeiro: Instituto Brasileiro de Administração Municipal - IBAM, v. 39, n. 203, p. 23-38, abr. 1992.

RECENSEAMENTO geral do Brasil: 1ำ de setembro de 1940. Rio de Janeiro: Serviço Gráfico do Instituto Brasileiro de Geografia e Estatística, 1950-1952. 3 v.; 22 partes. (Série Nacional). Disponível em: <http://biblioteca.ibge.gov.br/pt/bibliotecacatalogo?view=detalhes\&id=765>. Acesso em: mar. 2016.

ROSA, L. R.; FERREIRA, D. A. de O. As categorias rural, urbano, campo, cidade: a perspectiva de um continuum. In: SPÓSITO, M. B. E.; WHITAKER, A. M. (Org.). Cidade e campo: relações e contradições entre urbano e rural. São Paulo: Outras Expressões, 2006. 409 p.

SOARES, J. C. de M. Exposição dirigida ao senhor presidente da republica [sic] pelo presidente do Instituto Brasileiro de Geografia e Estatistica [sic]. Revista Brasileira de Geografia, Rio de Janeiro: IBGE, ano 1, n. 2, p. 148-154, abr. 1939. Disponível em: <http://biblioteca.ibge. gov.br/visualizacao/periodicos/115/rbg_1939_v1_n2.pdf>. Acesso em: mar. 2016. 
VEIGA, J. E. Cidades imaginárias: o Brasil é menos urbano do que se calcula. Campinas: Autores Associados, 2002a. 304 p.

VEIGA, J. E. Dos povoados, aldeias, vilas, cidades e municípios. O Estado de São Paulo, São Paulo, 20 maio 2002b. Economia, p. 17.

VEIGA, J. E. et al. O Brasil rural precisa de uma estratégia de desenvolvimento. 2. Reimpr. Brasília, DF: Ministério do Desenvolvimento Agrário, Conselho Nacional de Desenvolvimento Rural Sustentável - CNDRS, Núcleo de Estudos Agrários e Desenvolvimento Rural - NEAD, 2001. 108 p. (Textos para discussão, n. 1). Texto provisório para discussão. Disponível em: $<$ http://www.mda.gov.br/sitemda/pagina/nead-textos-para-discuss\%C3\%A3o $>$. Acesso em: mar. 2016. 


\title{
Padrões espaciais de serviços avançados de apoio às empresas na rede urbana brasileira
}

\author{
Marcelo Paiva da Motta \\ Ronaldo Cerqueira Carvalho
}

O presente capítulo visa caracterizar a presença das firmas de serviços avançados de apoio às empresas na rede urbana em escala nacional, tanto vistas por sua localização absoluta, quanto pelas redes de sedes e filiais em que operam. É preciso sempre ter em conta que este tipo de firma é aquele com o propósito de garantir a aceleração da circulação e acumulação de capital, sendo, portanto, centrais para se entender a geografia do Brasil contemporâneo.

Promotoras ativas do city-ness, isto é, o conjunto de relações que as atividades de uma cidade realizam com seus pares em longa distância (TAYLOR; HOYLER; VERBRUGGEN, 2010), as firmas de serviços avançados funcionam como um "termômetro" do grau de sofisticação das economias locais, ligando-se às empresas mais dinâmicas, sendo em si atividades inovadoras e de alto valor agregado. Nesse contexto, o sistema de cidades não é concebido simplesmente como hierarquias baseadas em hinterlândias estanques, mas como conjunto de nós críticos para o funcionamento da economia de mercado.

\section{Breves observações conceituais}

Toda rede urbana possui uma natureza dupla, com duas dimensões invariavelmente presentes em sua estrutura. A primeira está associada ao papel econômico das cidades de fornecer bens e serviços para a população dispersa no território e nos demais centros urbanos. Nessa dimensão, o sistema urbano forma áreas de influência baseadas na contiguidade, no espaço contínuo - a partir do alcance que as funções urbanas possuem - e no deslocamento 
da população que as adquire. Via de regra, quanto maior o tamanho demográfico de uma cidade, mais ela acumula funções urbanas e maior é sua área de influência ou hinterlândia, formando um encadeamento de subordinações entre os centros urbanos. Essa dimensão possui um longo histórico de estudos (BROWN, 1994) e é bem caracterizada pela teoria clássica das localidades centrais de Christaller (1966).

Contudo, nos escalões superiores da hierarquia urbana, os processos econômicos baseados na fricção da distância - quanto mais os indivíduos têm que se deslocar para adquirir um bem ou serviço, maior será seu custo e raridade - e na contiguidade perdem importância em face dos relacionamentos à longa distância que as atividades lá localizadas realizam. Nesse sentido, as redes urbanas podem ser descritas como estruturas espaciais formadas tanto por ligações locais (CHRISTALLER, 1966), quanto por não locais, como preconizado pela teoria dos fluxos centrais de Taylor, Hoyler e Verbruggen (2010).

De acordo com a teoria dos fluxos centrais, as metrópoles e as grandes cidades não se tornaram o que são apenas a partir das relações locais do centro urbano com sua área de influência, pois estas últimas são insuficientes para explicar seu funcionamento.

Com efeito, enquanto o modelo das localidades centrais é essencialmente estático e não inclui mecanismos de expansão da atividade econômica e o surgimento de "novo trabalho" - atividades inovadoras que criam uma divisão do trabalho mais complexa -, o ambiente econômico das cidades, bem como sua função, só são explicáveis a partir de um modelo transacional mais amplo. Tal modelo leva em conta as interações entre os diferentes centros urbanos operacionalizados pelas atividades neles localizadas, através de distâncias e em escalas as mais distintas.

Nesse sentido, as firmas de serviços avançados de apoio às empresas constituem um dos grandes agentes das ligações a distância, uma vez que para atender seus mercados diversas empresas de variados ramos e escalas de produção - necessitam buscar recursos localizados em pontos diversos do espaço.

As redes de escritórios, sedes e filiais que realizam as conexões dessas firmas são construídas, majoritariamente, por meios eletrônicos, entre as cidades. Concretamente, são empresas de advocacia, consultoria legal, financiamento, propaganda e marketing, instituições bancárias, desenvolvimento tecnológico etc. Embora essas firmas pertençam a diferentes ramos de negócio e cada qual tenha sua estratégia particular, ao analisar os padrões espaciais agregados de suas atuações, é possível definir os grandes centros emissores de ordens em que se localizam as sedes, os polos de atração de escritórios, filiais e os padrões espaciais de interação entre as cidades, que não se comportam necessariamente de maneira hierárquica, como na busca por bens e serviços clássica.

Nas ligações entre cidades estabelecidas por essas empresas, caracterizadas como facilitadoras, portadoras e mesmo geradoras de inovação, intensivas em informação e conhecimento em seus processos de trabalho (HERTOG, 2000), são importantes também as conexões "transversais", complementares, entre cidades cuja hierarquia clássica é semelhante. 
As duas vertentes dessa natureza dual do fato urbano estão presentes em maior ou menor grau em todos os centros urbanos, embora uma delas seja dominante, governando os processos de urbanização. Nas cidades de maior porte, sobretudo nas metrópoles ${ }^{1}$, há a hegemonia dos processos baseados em redes, onde sua economia se explica mais pelo amálgama de relacionamentos a distância suscitados pelas aglomerações de firmas ali presentes, ao que Taylor (2012) denomina city-ness. Isto não quer dizer que a formação de hinterlândias esteja ausente, apenas que, na essência dessas cidades, a tradicional busca por bens e serviços adquire uma importância secundária.

As cidades menores, por sua vez, tendem a se organizarem antes pelo town-ness - a capacidade de polarização de suas funções urbanas - do que pelas relações de longa distância que, igualmente, não estarão totalmente ausentes, como é o caso das pequenas cidades da Região Centro-Oeste do Brasil cujo agronegócio é profundamente articulado aos mercados globais.

\section{Notas metodológicas}

Este estudo é um desdobramento de análise da publicação Gestão do território 2014, divulgada pelo IBGE no âmbito do projeto Redes e Fluxos do Território, onde foi destacada a diversidade na oferta de serviços avançados de apoio às empresas² (GESTÃO..., 2014, p. 98-102).

O presente capítulo procura enfatizar o quantitativo de empresas envolvidas neste segmento de mercado, seu padrão de localização e seu posicionamento em diversos recortes espaciais.

Como, dentre esses objetivos, buscou-se também avaliar espacialmente a distribuição de serviços avançados de apoio às empresas nas cidades, os dados foram agregados por Área de Concentração de População (ACP) $)^{3}$, elaboradas de acordo com a metodologia de Castello Branco (2006), de forma a se trabalhar o mais próximo possível com as reais unidades urbanas, descontando os recortes político-administrativos. Os municípios, entretanto, também foram considerados como forma de se obter uma análise mais apurada do padrão de localização das empresas que são objeto deste estudo, bem como para os casos onde as Áreas de Concentração de População não se apliquem.

A fonte de dados primária, cujo ano de referência é 2011, foi obtida do Cadastro Central de Empresas - CEMPRE, do IBGE, considerando somente as entidades empresariais (ESTATÍSTICAS..., 2013). Desta base de dados não foram incluídos os registros de microempreendedores individuais, empresas da administração pública, entidades empresariais sem fins

\footnotetext{
1 As metrópoles são aqui entendidas como os centros urbanos de grande porte que se encontram no topo da hierarquia urbana nacional, cuja unidade seja constituída de diversas entidades municipais, com complexidade interna e grande população.

2 Os termos "empresa", "firma" e "companhia" são tratados como sinônimos no presente estudo.

3 As Áreas de Concentração de População (ACP) são definidas como grandes manchas urbanas de ocupação contínua, identificadas por características ligadas à densidade populacional, urbanização e coesão interna de sua área. A Área de Concentração de População de São Paulo é considerada o maior conjunto urbano do País, alocada no primeiro nível da gestão territorial (REGIÕES..., 2008).
} 
lucrativos, pessoas físicas com Cadastro Nacional de Pessoas Jurídicas - CNPJ, organizações internacionais e outras instituições extraterritoriais. Selecionou-se, do CEMPRE, um conjunto de empresas classificadas como possuindo uma natureza administrativa, contábil, jurídica, financeira e de publicidade ${ }^{4}$ (GESTÃO..., 2014), em consonância com as categorizações de Sassen (1998) e Taylor (2001), de forma a se manter o mais próximo possível do tema de serviços avançados.

Para a identificação das cidades onde ocorrem aglomerações de firmas de serviços avançados, foi utilizada a metodologia desenvolvida por Crocco e outros (2006), que se baseia na geração do Índice de Concentração normalizado (ICn).

O ICn é constituído pela soma ponderada de três outros indicadores, sendo o primeiro o quociente locacional (QL), técnica de uso clássico na identificação de aglomerações produtivas. Este índice compara o peso da atividade em questão em cada município, no caso o número de empresas de serviços avançados, com a média nacional, de acordo com a fórmula:

$$
Q L=\frac{\frac{E_{j}^{s a}}{E_{j}}}{\frac{E_{B R}^{s a}}{E_{B R}}}
$$

onde:

$E_{j}^{\text {sa }}{ }_{j}$ corresponde ao número de empresas de serviços avançados no município ou ACP $j$;

$E_{j}$ é o número total de empresas no município ou ACP $j$.

$E_{B R}^{s a}$ significa o total de empresas de serviços avançados no Brasil; e

$E_{B R}$ corresponde ao total de empresas no País.

Esse índice possui a vantagem de ter como parâmetro a média nacional, estando as cidades acima de 1 como possíveis candidatos a abrigarem um cluster de empresas. Também tem a desvantagem de sobrevalorizar os locais com pequenos números de empresas, estando muito sujeito à variação dos pequenos números. A título de exemplo, um pequeno município com quatro empresas e, eventualmente, uma de serviços avançados, se encontrará muito acima da média nacional, porém não possuirá uma aglomeração produtiva. Simultaneamente, as grandes cidades, com importante diversidade produtiva, são relativamente desvalorizadas, pois o setor em questão terá um peso menor dentro da grande massa de empresas locais.

Portanto, torna-se necessário ponderar o peso do QL com outros índices. O segundo passo é estabelecer o índice denominado de Hirschman-Herfindahl modificado, que compara o peso do setor de serviços avançados nas cidades com o peso de cada cidade no total na estrutura produtiva do País:

\footnotetext{
4 A informação sobre a atividade econômica exercida pelas unidades locais presentes no CEMPRE tem como base a Classificação Nacional de Atividades Econômicas - CNAE 2.0. Este padrão é utilizado no Sistema Estatístico Nacional e na administração pública, sendo o IBGE o órgão responsável por sua manutenção e gestão.
} 


$$
H H m=\left(\frac{E_{j}^{s a}}{E_{B R}^{s a}}\right)-\left(\frac{E_{j}}{E_{B R}}\right)
$$

O terceiro indicador é a simples porcentagem de empresas de serviços avançados de cada município no total de empresas de serviços avançados do País, ou participação relativa (PR).

$$
P R=E_{j}^{s a} \div E_{B R}^{s a}
$$

Para se obter o ICn de cada cidade, soma-se os três indicadores anteriores:

$$
I C n_{j}=\theta_{1} Q L_{j}+\theta_{2} H H m_{j}+\theta_{3} P R_{j}
$$

Cada indicador possui um peso $(\theta)$ que é dado pela variância da dispersão total da nuvem de pontos, obtida pela aplicação de uma técnica multivariada de análise de dados, nomeadamente a análise dos componentes principais dos três indicadores. A partir do software estatístico SAS/STAT, da empresa norte-americana Statistical Analysis System - SAS, são utilizados os valores intermediários obtidos a partir dos autovalores e autovetores e não os valores dos componentes principais em si desta análise multivariada ${ }^{5}$.

Uma vez de posse dos indicadores de concentração normalizados, um filtro foi aplicado nos resultados de maneira a só considerar os municípios e Áreas de Concentração de População relevantes economicamente, que possuem uma escala que justifique a presença de uma aglomeração produtiva, evitando resultados idiossincráticos. Como é impossível falar em aglomerações produtivas sem um número mínimo de empresas, aplicou-se um filtro nos resultado de maneira a excluir os municípios muito pequenos. Com o auxílio do algoritmo de Jenks, que agrupa os dados de valor semelhante o mais possível, categorizou-se a distribuição do número absoluto de empresas em seis classes, sendo excluída a inferior, isto é, os municípios ou Áreas de Concentração de População com menos de 9521 empresas.

Especialmente quanto ao trato das relações multilocalizadas (sede e filial situadas em municípios distintos), empregou-se uma tipologia classificatória que distingue a existência ou não da estrutura de rede, baseada na proposta de Rabino e Occelli (1997). Com a identificação positiva de padrões de rede pelo método do fluxo dominante, estabeleceu-se, em sequência, os níveis hierárquicos dos municípios que constituem os nós. Em seguida, selecionou-se os fluxos dominantes no sentido do município da unidade auxiliar (filial) para o município que abriga a sua respectiva unidade central (sede). Caso a localidade participante da ligação pertença a uma Área de Concentração de População, considerou-se, para efeito de tabulação, evidenciar a ACP, na qual o município está circunscrito.

Uma ligação entre uma filial localizada em Niterói (RJ) e sua sede em Camaçari (BA) foi computada, por exemplo, como sendo entre a ACP do Rio de Janeiro (RJ) e a ACP de Salvador (BA). Além disso, agregaram-se as ligações, resumindo os dados agrupados pelo somatório das empresas envolvidas em cada par de localidades. Finalmente, para a espacialização do tema, considerou-se o décimo superior da distribuição em ordem decrescente do total de empresas compreendido em cada fluxo.

\footnotetext{
5 Para informações detalhadas sobre essa metodologia, consultar a publicação: CROCCO, M. A. et al. Metodologia de identificação de aglomerações produtivas locais. Nova Economia, Belo Horizonte: Universidade Federal de Minas Gerais - UFMG, Faculdade de Ciências Econômicas - FACE, v. 16, n. 2, p. 211-241, maio/jun. 2006. Disponível em: <http://www.scielo.br/scielo. php?script=sci_arttext\&pid=S0103-63512006000200001\&lng=pt\&nrm=iso\&tlng=pt>. Acesso em: out. 2015.
} 
Nos mapeamentos desenvolvidos neste estudo, quando aplicável, de forma a melhor adequar a classificação da variável em evidência, empregou-se o método analítico de otimização de Jenks que identifica as quebras entre classes. O algoritmo utiliza fórmula estatística que consiste basicamente na minimização da soma de variância dentro de cada grupo. Em sequência, procedeu-se a ajustes manuais para melhor acomodação dos valores às faixas de classificação.

Por último, ainda em se tratando da espacialização do tema, estabeleceu-se no Mapa 1 o corte do número abaixo de 500 estabelecimentos-sede de serviços avançados, objetivando destacar os centros de maior relevância.

\section{A geografia das aglomerações produtivas de serviços avançados de apoio às empresas no Brasil}

A localização dos serviços avançados de apoio às empresas - denominadas doravante como empresas de serviços avançados - em termos absolutos pouco se diferencia da distribuição das empresas em geral no Brasil. A falta de um padrão específico à primeira vista deixa evidenciada, assim, que a configuração espacial daquelas empresas reproduzem os processos de concentração econômica na Região Sudeste e, particularmente, no Estado de São Paulo.

Com efeito, ao se realizar uma análise bivariada dos dados, tomando como variável independente o número total de empresas nos municípios e, como variável dependente, a quantidade de empresas de serviços avançados, obtém-se um $\mathrm{R}^{2}$ de 0,98 , isto é, uma correlatividade muito alta das duas variáveis, como evidência por se tratar, em realidade, de um mesmo fenômeno.

Esta situação é um indicativo de que as atividades que compõem os serviços avançados estão bem-inseridas na estrutura produtiva do País, correspondendo aos processos sociais que levam à concentração histórica nas áreas do Centro-Sul. A relativa escassez de infraestrutura logística e de mão de obra qualificada faz com que o leque de localizações possíveis a este tipo de atividade seja restrita, de maneira parecida a outros ramos de negócios, contribuindo para a semelhança encontrada nos padrões gerais de distribuição espacial.

Como o período histórico contemporâneo é marcado pela formação de aglomerações produtivas, especialmente naqueles setores da economia marcados pelo forte componente informacional e de conhecimento nos processos produtivos e na natureza dos produtos, muitas vezes intangível, como é o caso dos serviços avançados, faz-se necessário verificar os pontos no Território Nacional onde se formam concentrações desse tipo de atividade.

Assim, para se obter uma medida mais apurada da configuração espacial das empresas de serviços avançados, aplicou-se o Índice de Concentração normalizado (ICn), que se caracteriza como uma técnica relevante para a identificação de aglomerações produtivas desses serviços em virtude da extrema semelhança entre a localização absoluta dos dados e as das firmas em geral. O ranking de cidades segundo o ICn é exibido na Tabela 1, na qual 41 cidades, dentre as de maior relevância econômica, qualificam-se como possuindo uma concentração significativa de firmas deste setor. 
Como esperado, é notável a hegemonia da Cidade de São Paulo (SP), seguida pela do Rio de Janeiro (RJ), no contexto do País, que condiz com a presença em números absolutos deste tipo de empresa nessas duas metrópoles. A Região Sul também se destaca tendo cinco cidades entre as 10 maiores aglomerações produtivas concentradoras de serviços avançados: Porto Alegre (RS), Blumenau (SC), Curitiba (PR), Florianópolis (SC) e Joinville (SC). Isto é, a região possui três de suas capitais entre as principais cidades caracterizadas como aglomerações de serviços avançados.

Tabela 1 - Principais aglomerações produtivas de serviços avançados, com indicação da posição ocupada, em ordem decrescente do Índice de Concentração normalizado - ICn, segundo as Unidades da Federação

\begin{tabular}{|c|c|c|c|c|c|c|c|}
\hline $\begin{array}{l}\text { Posi- } \\
\text { ção } \\
\text { ocu- } \\
\text { pada }\end{array}$ & $\begin{array}{c}\text { Unidades } \\
\text { da } \\
\text { Federação }\end{array}$ & $\begin{array}{l}\text { Principais aglome- } \\
\text { rações produtivas } \\
\text { de } \\
\text { serviços avançados }\end{array}$ & Icn & $\begin{array}{l}\text { Posi- } \\
\text { ção } \\
\text { ocu- } \\
\text { pada }\end{array}$ & $\begin{array}{c}\text { Unidades } \\
\text { da } \\
\text { Federação }\end{array}$ & $\begin{array}{l}\text { Principais aglome- } \\
\text { rações produtivas } \\
\text { de } \\
\text { serviços avançados }\end{array}$ & Icn \\
\hline & São Paulo & São Paulo & 1,20 & 22 & Paraná & Londrina & 0,47 \\
\hline & Rio de Janeiro & Rio de Janeiro & 0,83 & 23 & São Paulo & Sorocaba & 0,47 \\
\hline & Rio Grande do Sul & Porto Alegre & 0,76 & 24 & Rio Grande do Sul & Caxias do Sul & 0,46 \\
\hline & Santa Catarina & Blumenau & 0,74 & 25 & Goiás & Goiânia & 0,46 \\
\hline 5 & Paraná & Curitiba & 0,72 & 26 & Amazonas & Manaus & 0,45 \\
\hline 6 & Minas Gerais & Belo Horizonte & 0,71 & 27 & Paráraná & Maringá & 0,44 \\
\hline 7 & Distrito Federal & Brasília & 0,66 & 28 & Sergipe & Aracaju & 0,42 \\
\hline 8 & Santa Catarina & Florianópolis & 0,64 & 29 & Ceará & Fortaleza & 0,42 \\
\hline 9 & Santa Catarina & Joinville & 0,62 & 30 & São Paulo & Piracicaba & 0,42 \\
\hline 10 & São Paulo & Campinas & 0,60 & 31 & São Paulo & São José do Rio Preto & 0,42 \\
\hline 11 & São Paulo & Jundiaí & 0,57 & 32 & Rio Grande do Norte & Natal & 0,41 \\
\hline 12 & Minas Gerais & Uberlândia & 0,56 & 33 & Pará & Belém & 0,41 \\
\hline 13 & São Paulo & São José dos Campos & 0,55 & 34 & Alagoas & Maceió & 0,40 \\
\hline 14 & Rio Grande do Sul & Novo Hamburgo & 0,55 & 35 & Paraíba & João Pessoa & 0,38 \\
\hline 15 & Bahia & Salvador & 0,54 & 36 & Minas Gerais & Juiz de Fora & 0,38 \\
\hline 16 & Espírito Santos & Vitória & 0,53 & 37 & Maranhão & São Luís & 0,36 \\
\hline 17 & Mato Grosso & Cuiabá & 0,53 & 38 & Piauí & Teresina & 0,31 \\
\hline 18 & Pernambuco & Recife & 0,53 & 39 & Rio Grande do Sul & Pelotas & 0,31 \\
\hline 19 & Mato Grosso do Sul & Campo Grande & 0,51 & 40 & São Paulo & Franca & 0,27 \\
\hline 20 & São Paulo & Santos & 0,48 & 41 & Bahia & Feira de Santana & 0,23 \\
\hline 21 & São Paulo & Ribeirão Preto & 0,48 & & & & \\
\hline
\end{tabular}

Fonte: Estatísticas do cadastro central de empresas 2011. Rio de Janeiro: IBGE, 2013. Disponível em: <http://www.ibge.gov. br/home/estatistica/economia/cadastroempresa/2011/default.shtm>. Acesso em: out. 2015. 
Em nível macrorregional, percebe-se uma hierarquia na qual as Regiões Sudeste e Sul ocupam uma posição de destaque no terço superior e do meio da distribuição de cidades com os maiores ICn, tendo centros urbanos com portes diferenciados. A Região Centro-Oeste apresenta-se apenas com suas capitais em posições mais medianas, enquanto que as Regiões Nordeste e Norte situam-se em grande parte nos menores ICns. É interessante observar que o comportamento espacial dos serviços avançados nessa escala é condizente com o conceito de espaço de fluxos (CASTELLS, 1999), caracterizado pela presença de certos locais altamente conectados às redes produtivas e vastos espaços excluídos.

Nesse sentido, a Região Sudeste, seguida pela Sul, destacam-se como as macrorregiões mais integradas do ponto de vista da inclusão em redes produtivas com serviços avançados. Embora de forma seletiva e desigual, estas atividades estão mais presentes em seus territórios. Já as outras regiões se caracterizam por uma conectividade mais fraca, limitadas, via de regra, a poucos pontos, quase sempre as capitais estaduais.

Observando as cidades individualmente, a correspondência do ICn com a hierarquia urbana é menor. Brasília (DF) se mostra apenas na sétima posição, sugerindo que o papel desta aglomeração urbana é menos relevante na distribuição dos serviços avançados, ao mesmo tempo que Porto Alegre (RS) apresenta uma concentração deste ramo de negócios superior à Curitiba (PR) e Belo Horizonte (MG). Também há cidades médias que se mostram como forte atrativo para o setor, possuindo um ICn maior que diversas capitais, como os casos de Blumenau e Joinville, ambas do Estado de Santa Catarina.

A região difusa da metrópole paulista, com os Municípios de Campinas, Jundiaí, Santos, São José dos Campos e Sorocaba, possui concentração de serviços avançados de maneira consistente com o conceito de cidade-região, uma ampla área, de fronteiras pouco claras, incorporando diversos núcleos urbanos, periurbanos e mesmo áreas fracamente urbanizadas, mas que formam uma área polinucleada, constituindo um complexo de atividades econômicas diversificadas, com alto grau de integração interna (SCOTT et al., 2001).

Levando em conta que as cidades-regiões cada vez mais funcionam como os nós espaciais essenciais da economia global, sendo o ponto de interconexão da economia doméstica com a global, os serviços avançados são o tipo de atividade capaz de realizar as conexões a longa distância que caracteriza o papel das cidades no período contemporâneo, sobretudo nas de maior porte.

A existência maciça de aglomerações produtivas de serviços avançados na ACP de São Paulo e seu entorno constitui em mais um indicador de que essa área constitui um exemplo emblemático dessa nova modalidade urbana no Brasil $^{6}$. Além disso, o fato de São Paulo estar

\footnotetext{
6 Neste sentido, cabe observar que a Cidade-Região de São Paulo apresenta-se igualmente coerente em termos de integração interna quando analisada sob o ponto de vista do deslocamento para trabalho e estudo, a formação de conurbações e o Produto Interno Bruto - PIB dos municípios que a compõem, conforme observado na publicação Arranjos populacionais e concentrações urbanas do Brasil, divulgada pelo IBGE em 2015.
} 
muito acima das outras cidades como local de concentração das empresas de serviços avançados quer dizer, exatamente por ter como clientes outras empresas, de diversas naturezas, que é fundamental estarem onde existam grandes quantidades de atividades econômicas distintas, cadeias produtivas, polos de atração de força de trabalho, fluxos monetários, pontos de operações de transações internacionais etc., formando redes em diferentes escalas e que atravessam as fronteiras nacionais.

Nesse contexto, pode-se afirmar que os serviços avançados constituem o tipo de atividade que se nutre desse complexo ambiente econômico globalizado contemporâneo, ao mesmo tempo em que contribuem para reproduzi-lo.

\section{A rede de empresas de serviços avançados no Brasil}

No Brasil, foram identificadas 323508 empresas de serviços avançados em 2011 (ESTATÍSTICAS..., 2013). Essas firmas estão representadas por 361418 unidades locais, correspondendo a $7,0 \%$ do total de estabelecimentos dedicados a todo o tipo de atividade econômica. Quanto às conexões entre os endereços de uma mesma empresa, 91,0\% dizem respeito a ligações intramunicipais (locais). Nesta contagem, também fazem parte os registros oriundos de empresas de unidade local única (sem filial). Em termos da quantidade de unidades locais, 98,3\% das empresas contam com um único endereço para o desenvolvimento das suas atividades.

Valendo-se de outra perspectiva de análise, observa-se que pouco menos da metade das empresas de serviços avançados (49,1\%) estão sediadas nos municípios-núcleo das metrópoles, conforme conceituados na pesquisa Regiões de Influência das Cidades - REGıc 2007 (REGIÕES..., 2008). O resultado é consistente com outros estudos sobre a estruturação das aglomerações urbano-metropolitanas, deixando clara a supremacia do nível metropolitano na oferta de serviços deste gênero, com ênfase na concentração de vantagens competitivas de centralidade, em conjunto com empresas parceiras e firmas especializadas em um ambiente de concentração de competências, tanto informacionais quanto de infraestrutura (ANÁLISE..., 2004; GESTÃO..., 2014).

Quando se compara a estrutura das ligações de sedes e filiais das empresas de serviços avançados com a hierarquia urbana (REGIÕES..., 2008), é possível observar que 23,0\% do total dessas empresas corresponde ao nível local, isto é, às unidades sem filiais ou com filial e sede no mesmo município. Esta primeira categorização está concentrada na Grande Metrópole Nacional, topo da hierarquia, atribuída à ACP de São Paulo, maior conjunto urbano do País, contando com 83094 estabelecimentos de serviços avançados (Tabela 2). 
Tabela 2 - Dez principais tipos de ligação entre filiais e seus estabelecimentos-sede de serviços avançados de apoio às empresas, segundo a hierarquia dos centros urbanos e as unidades locais envolvidas - 2011

\begin{tabular}{rlr}
\hline \multicolumn{1}{c|}{ Tipo de ligação (1)/cidade da filial -> cidade da sede (2) } & $\begin{array}{r}\text { Percentual de } \\
\text { unidades locais (\%) }\end{array}$ \\
\hline 1 & Âmbito local/filial e sede alocadas na Grande Metrópole Nacional (São Paulo/SP) & 23 \\
2 & Âmbito local/(sem classificação hierárquica identificada) & 16,3 \\
3 & Âmbito local/Capital Regional -> Capital Regional & 14,3 \\
4 & Âmbito local/Metrópole -> Metrópole & 13,2 \\
5 & Âmbito local/Metrópole Nacional -> Metrópole Nacional & 8,4 \\
6 & Âmbito local/Centro Local -> Centro Local & 5,6 \\
7 & Âmbito local/Centro Sub-Regional -> Centro Sub-Regional & 4,9 \\
8 & Âmbito local/Centro de Zona -> Centro de Zona & 4,5 \\
9 & Multilocalizada/Centro Local -> Metrópole Nacional & 0,7 \\
10 & Multilocalizada/Capital Regional -> Grande Metrópole Nacional & 0,6 \\
\hline
\end{tabular}

Fontes: 1. Estatísticas do cadastro central de empresas 2011. Rio de Janeiro: IBGE, 2013. Disponível em: <http://www.ibge.gov. br/home/estatistica/economia/cadastroempresa/2011/default.shtm>. Acesso em: out. 2015. 2. Regiões de influência das cidades 2007. Rio de Janeiro: IBGE, 2008. Disponível em: <http://www.ibge.gov.br/home/geociencias/geografia/regic.shtm>. Acesso em: out. 2015.

(1) As ligações em Âmbito local também contemplam empresas contando com unidade local única (sem filial). Ligações multilocalizadas fazem referência à localização de cada filial e de sua respectiva unidade gestora, ambas situadas em municípios distintos. (2) O fluxo cidade da filial -> cidade da sede diz respeito à ligação da filial para com sua matriz, quando aplicável, segundo a classificação hierárquica dos centros urbanos segundo a pesquisa Regiões de Influência das Cidades - REGIC 2007, nos quais os estabelecimentos estão localizados.

Em segundo lugar, também em nível local, 16,3\% couberam às ligações sem classificação hierárquica identificada, em virtude de o município se situar dentro de uma Área de Concentração de População ou de ter sido criado após 2007, ano de referência do estudo REGIC (REGIÕES..., 2008). Na sua maioria, são localidades pertencentes à Região Sudeste e em termos das Unidades da Federação, 65,5\% delas situadas no Estado de São Paulo. Com efeito, muitos destes municípios estão no bojo das grandes aglomerações metropolitanas, com uma média de 205,4 unidades locais computadas para cada centro urbano.

A terceira posição remete aos limites das Capitais Regionais (14,3\%), sinalizando vigor além da concentração nas metrópoles. Deste modo, as ligações internas nos centros classificados como Capitais Regionais superam as conexões também locais envolvendo metrópoles, com exceção da ACP de São Paulo (SP). Os 10,0\% desta categoria com maior número de estabelecimentos envolvidos nas ligações entre sedes e filiais se atém a municípios do Centro-Sul. A propósito, Campinas (SP) lidera o grupamento com 8,4\% das unidades de empresas de serviços avançados (4 365 endereços).

No tipo de ligação 4, isto é, o das ligações locais em metrópoles (Tabela 2) com 13,2\% das unidades locais, sobressaem Belo Horizonte (MG) com 11031 unidades produtivas, seguida de Curitiba (PR), com 10422 unidades e Porto Alegre (RS) com 10 011. No quinto lugar (8,4\%), têm-se as ligações locais envolvendo Rio de Janeiro (RJ) e Brasília (DF) - Metrópoles Nacionais, sendo que a metrópole fluminense centraliza $72,6 \%$ dos endereços, considerando a classe isolada. 
Outras categorizações em âmbito local se sucedem dos tipos de ligação 6 a 8. Interrompendo este padrão, surge no tipo 9, que reúne $0,7 \%$ das unidades locais, ligações multilocalizadas oriundas das filiais situadas em centros locais se reportando a estabelecimentos-sede localizadas nas Metrópoles Nacionais. A grande capilaridade de empresas, como o Banco do Brasil, vinculadas a Brasília (DF), por exemplo, justifica o maior valor absoluto nesta categoria (932 firmas). Encerrando a tabela, com o percentual de 0,6\%, verifica-se a comunicação das filiais em Capitais Regionais com a Metrópole de São Paulo (SP). Cabe observar que 40,6\% destas sucursais pertencem ao mesmo estado da Grande Metrópole Nacional.

Comparando o quantitativo de empresas com outros recortes espaciais, constata-se em termos das Grandes Regiões um predomínio da Região Sudeste sobre o restante do País, concentrando $65,8 \%$ das empresas, vindo em seguida a Região Sul com 17,7\%. A Região Nordeste fica na terceira colocação, atingindo $8,4 \%$, enquanto em quarto e quinto lugares vêm as Regiões Centro-Oeste e Norte, reunindo, respectivamente, 6,2\% e 1,9\% das empresas.

Com base nas Unidades da Federação, São Paulo exibiu as maiores participações relativas, contando com o percentual de $46,3 \%$ de todas as empresas de serviços avançados, enquanto o Rio de Janeiro chegou ao segundo lugar com 9,9\% e Minas Gerais, em terceiro, obteve o percentual de $8,1 \%$.

Em outra escala, isto é, no nível de Área de Concentração de População (REGIÕES..., 2008), a ACP de São Paulo, que abrange o Município de São Paulo e os municípios vizinhos de Barueri, Guarulhos, Osasco, São Caetano do Sul, dentre outros, a participação relativa das empresas de serviços avançados no total nacional alcança 35,0\%, reforçando seu alto grau de concentração geográfica no Território Nacional, reafirmando o conceito de cidade-região.

Quanto ao Município de São Paulo, sua centralidade é manifesta em termos quantitativos pela maior participação relativa no total dos municípios brasileiros. Apenas dentro do município se encontram 25,2\% das empresas de serviços avançados, 81453 em valores absolutos. Neste sentido, a capital paulista figura na primeira classificação do Mapa 1. O Município do Rio de Janeiro, com 21827 empresas, aparece na segunda classificação. No terceiro nível têm-se oito municípios, todos do Centro-Sul. Cinco deles são metrópoles: Belo Horizonte (MG), 10912 empresas; Curitiba (PR), 10338 empresas; Porto Alegre (RS), 9829 empresas; Brasília (DF), 8027 empresas e Salvador (BA), 3935 empresas. Os municípios que não são centros metropolitanos pertencem ao Estado de São Paulo e às ACPs desta Unidade da Federação: Santana do Parnaíba (6 052 empresas); Poá (4 523 empresas) e Campinas (4 359 empresas).

As ligações entre filiais e respectivas sedes, estabelecidas em municípios não coincidentes, estão representadas também no Mapa 1. Desta forma, os fluxos exibidos simbolizam a atuação das empresas de serviços avançados em mais de um endereço. Em se tratando do percentual de 10,0\% das maiores interações, constata-se que quase todos os registros se manifestam na forma de ligações hierárquicas ascendentes diretas, ou seja, convergindo das unidades auxiliares alocadas nos centros menores para os centros hierarquicamente superiores na rede urbana, onde se encontram seus estabelecimentos-matriz. 
Nesse contexto, o fluxo mais intenso, em relação ao total de empresas envolvidas, parte da ACP do Rio de Janeiro para a ACP de São Paulo. A única exceção ao padrão hierárquico ascendente se encontra no segundo maior fluxo, inverso do primeiro. Este último contém filiais alocadas na ACP de São Paulo que convergem para suas matrizes na ACP do Rio de Janeiro, sendo classificado como hierárquico descendente direto.

Além disso, consolidando a condição de centro polarizador de São Paulo (SP), constata-se que $77,5 \%$ do total de ligações dos fluxos dominantes no País se dirigem para a capital paulista. Por sua vez, 41,2\% dos centros que abrigam estabelecimentos-sede são os municípios-núcleo pertencentes às Metrópoles de Porto Alegre (RS), Belém (PA), Curitiba (PR), Rio de Janeiro (RJ), Brasília (DF) e Belo Horizonte (MG).

No que concerne ao raio de ação das ligações do Mapa 1, a média da distância dos fluxos que convergem para São Paulo (SP) é a segunda maior (935,2 km), superando à média geral $(784,1 \mathrm{~km})$. Este valor se coaduna com os resultados apresentados no parágrafo anterior, denotando a comunicabilidade da Grande Metrópole Nacional com centros distribuídos por todo o Território Nacional nas diversas hierarquias constantes da REGIC 2007 (REGIÕES..., 2008). As maiores distâncias estão atreladas aos pares formados com Brasília (DF) que alcançam 1 034,7 km em média. A localização estratégica da Capital Federal no interior do Território Nacional gerindo filiais situadas notadamente na Região Nordeste e na região do Triângulo Mineiro, explica, em grande parte, sua posição de destaque.

Em contraposição à geografia dos centros de gestão de serviços avançados que segue, grosso modo, distribuição demográfica e econômica do País, observam-se os municípios que não apresentamm sedes (unidades centrais) de serviços avançados alocadas em seus limites. Conforme o Mapa 2, a localização de tais municípios não permite a identificação de um padrão espacial que possa ser representativo em escala nacional.

Contudo, em nível regional, algumas observações podem ser feitas. Assim, se por um lado na franja litorânea da região sul do Estado da Bahia até a região do sudeste catarinense, praticamente todos os municípios possuam empresas do gênero, por outro lado, na parte setentrional do Estado do Amazonas, no centro-oeste paraense e, em inúmeras áreas dos Estados do Acre, Roraima, Amapá, Piauí, Rio Grande do Norte, Paraíba, Alagoas e Tocantins, grandes vazios são observados quanto à ocorrência de municípios com a presença de serviços avançados. Finalmente, pode-se observar que, de forma mais fragmentada, porém quantitativamente significante, são observadas áreas desconectadas nas demais Unidades da Federação. 


\section{Mapa 1 - Total de empresas de serviços avançados de apoio às empresas por município e principais ligações multilocalizadas entre filiais e sedes - 2011}

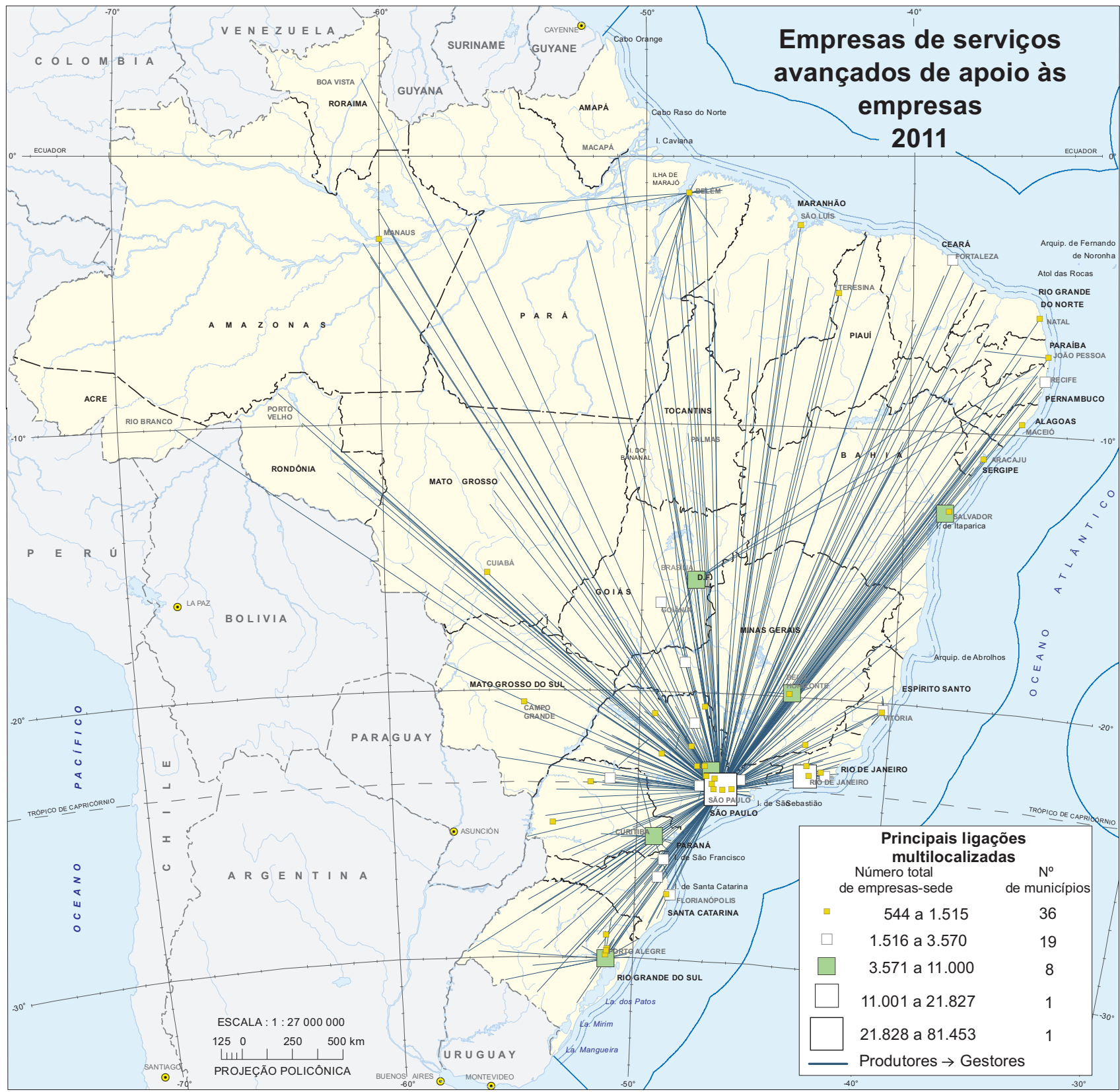

Fontes: 1. Estatísticas do cadastro central de empresas 2011. Rio de Janeiro: IBGE, 2013. Disponível em: <http://www.ibge.gov.br/home/estatistica/ economia/cadastroempresa/2011/default.shtm>. Acesso em: out. 2015. 2. Classificação nacional de atividades econômicas - CNAE: versão 2.0. Rio de Janeiro: IBGE, 2007. Disponível em: <http://concla.ibge.gov.br/classificacoes/por-tema/>. Acesso em: out. 2015.

Notas: 1. No tocante ao "número total de empresas-sede", foram considerados somente os municípios que abrigam um número superior a 500 estabelecimentos-sedes de serviços avançados de apoio às empresas em sua localidade.

2. Nas "principais ligações multilocalizadas", no sentido das unidades produtoras de cada empresa (filiais) para suas matrizes, situadas em outro município, foram espacializados somente os fluxos de pares de municípios contemplando o décimo superior da distribuição, em ordem decrescente da quantidade de empresas associadas a cada par. 
Mapa 2 - Municípios sem matrizes de serviços avançados - 2011

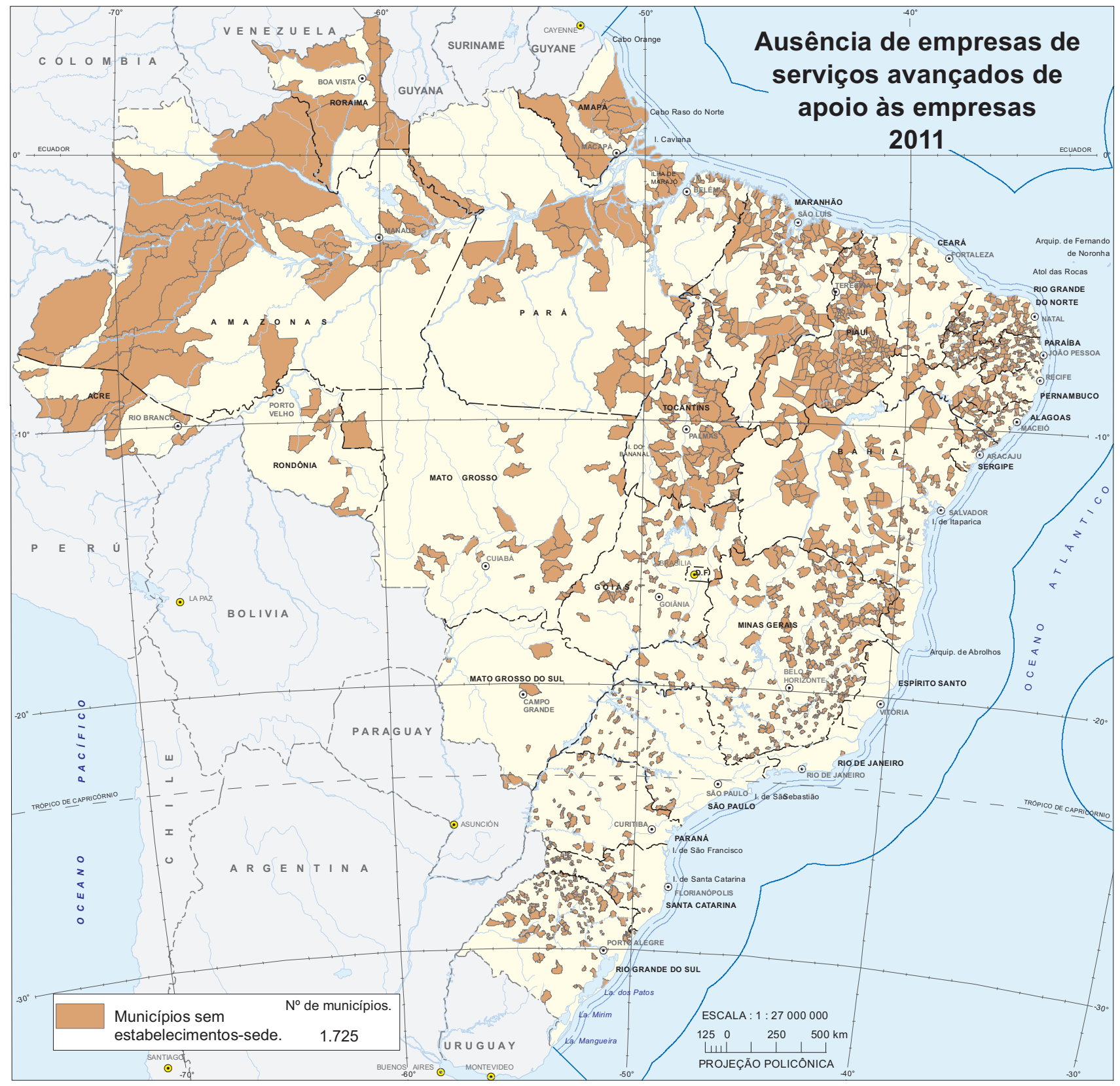

Fontes: 1. Estatísticas do cadastro central de empresas 2011. Rio de Janeiro: IBGE, 2013. Disponível em: <http://www.ibge.gov.br/home/estatistica/ economia/cadastroempresa/2011/default.shtm>. Acesso em: out. 2015. 2. Classificação nacional de atividades econômicas - CNAE: versão 2.0. Rio de Janeiro: IBGE, 2007. Disponível em: <http://concla.ibge.gov.br/classificacoes/por-tema/>. Acesso em: out. 2015. 


\section{Considerações finais}

Os indicativos deste estudo confirmam o quadro delineado na publicação Gestão do território 2014, onde as Metrópoles de São Paulo (SP) e Rio de Janeiro (RJ) chamam atenção ao oferecer quase todo o leque de variedades de serviços avançados de apoio às empresas, seguidos, em um segundo grupo, pelas demais metrópoles.

A pesquisa atual, de maneira análoga, permite observar que os municípios-núcleo das metrópoles brasileiras apresentam o maior quantitativo de empresas de serviços avançados. A pesquisa serviu, em particular, para reafirmar a percepção da centralidade inerente à capital paulista, seja tomando o Município de São Paulo isoladamente, seja fazendo sua análise articulada à metrópole. A hegemonia da capital paulista é ademais indicada pela própria desproporção verificada entre os índices de concentração de serviços avançados nessa cidade em relação às demais. Este motor de polarização também adensa o seu entorno, sobrepondo em números o Estado de São Paulo perante as demais Unidades da Federação.

Além disso, do ponto de vista sugerido por Hanssens e Derudder (2011), que observa as cidades belgas sob o binômio cidades que produzem versus cidades que consomem serviços avançados empresariais, pode-se traçar um paralelo no presente estudo.

Nesse sentido, apesar de não haver pretensão em replicar a metodologia dos autores e verificar a relação produção-consumo, como a maior parte dos endereços dos estabelecimentos-sede e de suas filiais está no mesmo município (91,0\%), a proporção sugere que o emprego do serviço avançado ocorre majoritariamente na mesma localidade da sua elaboração, reforçando a ideia de polos de produção e de preferência pela cidade-região brasileira, nomeadamente São Paulo. Diante do fato, importa dizer que as condições de operação das empresas de serviços avançados, no caso brasileiro, se encontram espacialmente limitadas e concentradas.

Entretanto, a existência de aglomerações secundárias, como no eixo Curitiba (PR), Blumenau (SC), Joinville (SC) e Florianópolis (SC), com índices de aglomeração semelhantes ou mesmo superiores a algumas metrópoles, mostra uma situação mais complexa do que previsto pela teoria clássica das localidades centrais, sugerindo o peso das instituições locais em atrair serviços avançados e uma maior importância do city-ness nesses centros urbanos.

Além dessa zona secundária de concentração de serviços avançados, a apreciação das ligações dominantes entre sedes e filiais, também ajuda a perceber importantes especificidades locais, como é o caso do peso de Belém em comandar diversas cidades no Estado do Pará; Porto Alegre em relação ao Estado do Rio Grande do Sul, estado tradicionalmente centralizado em sua capital; e Brasília (DF), com uma relação mais forte com alguns municípios na Região Nordeste. Entretanto, deve-se chamar a atenção que as ligações das firmas multilocalizadas, isto é, cujas espacialidades traduzem estratégias intrafirma, fazem-se esmagadoramente com São Paulo, o que é consistente com a grande presença de empresas e de comando desta Grande Metrópole Nacional.

A maciça concentração na Metrópole de São Paulo e o fato de as sedes aí localizadas possuírem um alcance espacial que praticamente incorpora todo o Território Nacional, torna plausível, de acordo com Rossi, Beaverstock e Taylor (2007) e Tolosa (2005) que essa aglomeração urbana constitua um gateway, isto é, um ponto de interconexão do Brasil com a economia mundial, se constituindo assim em uma cidade global. 
Embora a interconexão entre as cidades brasileiras não seja, em geral, negligenciável, no que tange os serviços avançados de apoio às empresas, o papel central dessa metrópole é único e as informações estatísticas, analisadas à luz da teoria dos fluxos centrais, reforçam o papel de São Paulo como um relé entre os níveis nacional e internacional.

Nesse sentido, verifica-se que $34,6 \%$ das 1000 maiores corporações identificadas pelo periódico Valor Econômico estão situadas nos Municípios de São Paulo (SP) e Rio de Janeiro (RJ) (RANKING..., 2012). Ademais, 52,8\% são empresas atuando em metrópoles. Esses percentuais elevados no âmbito metropolitano se coadunam com os resultados até aqui verificados quanto aos serviços empresariais. Portanto, recapitulando a argumentação de Hertog (2000) quanto à sinergia entre as empresas de serviços avançados de apoio às empresas e sua clientela, reforça-se o entendimento de que estes serviços intensivos em conhecimento se prestam tanto como facilitadores, quanto como carreadores, ou mesmo como fonte primária de práticas de inovação. Deste modo, a dinâmica promovida no cerne do terciário avançado propaga conhecimento e insumos, incorporando setores de ponta envolvidos no processo.

Resumindo, os padrões espaciais ligados às empresas de serviços avançados possuem um caráter metropolitano, mostrando que suas condições de operação parecem estar profundamente conectadas com as economias urbanas.

A elevadíssima concentração no Município de São Paulo, em patamares bem superiores aos demais núcleos urbanos do País, indica que os serviços avançados não podem fugir do círculo que reúne as empresas que são seus clientes e da concentração de serviços, mão de obra qualificada, know-how, bem como das redes sociais que compõem um complexo de empresários e força de trabalho especializada e qualificada que constroem um conhecimento coletivo sobre esse segmento, fazendo com que este arranjo de competências sistêmicas encontre naquela metrópole seu ponto de funcionamento fundamental.

\section{Referências}

ANÁLISE das regiões metropolitanas do Brasil: relatório da atividade 1: identificação dos espaços metropolitanos e construção de tipologias. Rio de Janeiro: Observatório das Metrópoles, 2004. 93 p. Disponível em: <http://www.observatoriodasmetropoles.ufrj.br/ produtos/produto_mc_1.pdf>. Acesso em: out. 2015.

ARRANJOS populacionais e concentrações urbanas do Brasil. Rio de Janeiro: IBGE, 2015. 167 p. Disponível em: <ftp://geoftp.ibge.gov.br/organizacao_territorial/arranjos_ populacionais/arranjos_populacionais.pdf>. Acesso em: out. 2015.

BROWN, S. Central place theory: sixty years on. In: CONFERENCE ON HISTORICAL RESEARCH IN MARKETING AND MARKETING THOUGHT, 6.,1993, Atlanta. Proceedings... East Lansing: Michigan State University, 1994. p. 69-87. Disponível em: <http://learn. quinnipiac.edu/charm/CHARM\%20proceedings/CHARM\%20article\%20archive\%20 pdf\%20format/Volume\%206\%201993/69\%20brown.pdf>. Acesso em: out. 2015. 
CASTELLO BRANCO, M. L. G. Áreas de concentração de população. 2006. Trabalho apresentado na mesa-redonda "Áreas de concentração de população: regiões metropolitanas, cidades médias, cidades gêmeas, cidades de fronteiras", no II Encontro Nacional de Produtores e Usuários de Informações Sociais, Econômicas e Territoriais, realizado no Rio de Janeiro, 2006.

CASTELLS, M. A sociedade em rede. Tradução de RoneideVenancio Majer com a colaboração de Klauss Brandini Gerhardt. In: A era da informação: economia, sociedade e cultura. São Paulo: Paz e Terra, 1999. v. 1.

CHRISTALLER, W. Central places in southern Germany. Englewood Cliffs: Prentice-Hall, 1966. $230 \mathrm{p}$.

CLASSIFICAÇÃO nacional de atividades econômicas - CNAE: versão 2.0. Rio de Janeiro: IBGE, 2007. 425 p. Acompanha 1 CD-ROM. Disponível em: <http://concla.ibge.gov.br/ classificacoes/por-tema/>. Acesso em: out. 2015.

CROCCO, M. A. et al. Metodologia de identificação de aglomerações produtivas locais. Nova Economia, Belo Horizonte: Universidade Federal de Minas Gerais - UFMG, Faculdade de Ciências Econômicas - FACE, v. 16, n. 2, p. 211-241, maio/jun. 2006. Disponível em: $<$ http://www.scielo.br/scielo.php?script=sci_arttext\&pid=S0103-63512006000200001 \&lng $=$ pt\&nrm=iso\&tlng=pt $>$. Acesso em: out. 2015.

ESTATÍSTICAS do cadastro central de empresas 2011. Rio de Janeiro: IBGE, 2013. 193 p. Acompanha 1 CD-ROM. Disponível em: <http://www.ibge.gov.br/home/estatistica/ economia/cadastroempresa/2011/default.shtm>. Acesso em: out. 2015.

GESTÃO do território 2014. Rio de Janeiro: IBGE, 2014. 118 p. Acompanha 1 CD-ROM. Acima do título: Redes e fluxos do território. Disponível em: <http://www.ibge.gov.br/home/ geociencias/geografia/redes_fluxos/gestao_do_territorio_2014/default.shtm?c=11>. Acesso em: out. 2015.

HANSSENS, H.; DERUDDER, B. The urban geography of advanced producer service transaction links in Belgium. Belgeo: revue belge de géographie, Bruxelles: Belgian National Committee for Geography: Société Royale Belge de Géographie - SRBG, n. 1-2, p. 17-28, 2011. Disponível em: <https://belgeo.revues.org/6345>. Acesso em: out. 2015.

HERTOG, P. D. Knowledge-intensive business services as co-producers of innovation. International Journal of Innovation Management, Singapore: World Scientific, v. 4, n. 4, p. 491-528, Dec. 2000.

RABINO, G. A.; OCCELLI, S. Understanding spatial structure from network data: theoretical considerations and applications. Cybergeo: european journal of geography, Marseille: Revues.org, n. 29, June 1997. Disponível em: <http://cybergeo.revues.org/2199?lang=pt>. Acesso em: out. 2015.

RANKING das 100 maiores. In: VALOR ECONÔMICO. Valor 1000. São Paulo, 2012. Disponível em: <http://www.valor.com.br/empresas/2801254/ranking-das-1000-maiores>. Acesso em: fev. 2014. 
REGIÕES de influência das cidades 2007. Rio de Janeiro: IBGE, 2008. 201 p. Acompanha 1 CD-ROM. Disponível em: <http://www.ibge.gov.br/home/geociencias/geografia/regic. shtm>. Acesso em: out. 2015.

ROSSI, E. C.; BEAVERSTOCK, J. V.; TAYLOR, P. J. Transaction links through cities: 'decision cities' in outsourcing by leading Brazilian firms. Geoforum, Amesterdam: Elsevier, v. 38, n. 4, p. 628-642, July 2007. Disponível em: <http://www.sciencedirect.com/science/article/pii/ S0016718506001771? np=y\#>. Acesso em: out. 2015.

SASSEN, S. As cidades na economia mundial. Tradução Carlos Eugênio Marcondes de Moura. São Paulo: Studio Nobel, 1998. 190 p. (Megalópolis).

SCOTT, A. J. Regions and the world economy: the coming shape of global production, competition and political order. Oxford: Oxford University Press, 1998. 177 p.

SCOTT, A. J. et al. Global city-regions. In: SCOTT, A. J. (Ed.). Global city-regions: trends, theory, policy. Cambridge: Oxford University Press, 2001. p. 11-30.

TAYLOR, P. J. History and geography: Braudel's 'extreme longue durée' as generics? In: LEE, R. E. (Ed.). The longue durée and world-system analysis. New York: State University of New York Press, 2012. p. 35-64. Disponível em: <http://www.lboro.ac.uk/gawc/rb/rb284.html>. Acesso em: jan. 2016.

Specification of the word city network. Geographical Analysis, Columbus: Ohio State University Press, Department of Geography; Hoboken: Wiley, v. 33, n. 2, p. 181-194, Apr. 2001. Disponível em: <http://onlinelibrary.wiley.com/doi/10.1111/j.1538-4632.2001. tb00443.x/pdf>. Acesso em: out. 2015.

TAYLOR, P. J.; HOYLER, M.; VERBRUGGEN, R. External urban relational process: introducing central flow theory to complement central place theory. Urban Studies, Thousand Oaks: SAGE, v. 47, n. 13, p. 2803-2818, Nov. 2010. Disponível em: <http://usj.sagepub.com/ content/47/13/2803.short>. Acesso em: jan. 2016.

TOLOSA, H. The Rio/São Paulo extended metropolitan region: a quest for global integration. In: RICHARDSON, H. W.; BAE, C.-H. C. (Ed.). Globalization and urban development. Berlin: Springer, c2005. (Advances in spatial science). p. 125-146. 


\title{
Evolução do espaço rural brasileiro
}

\author{
Luiz Sérgio Pires Guimarães
}

As condições naturais do território brasileiro favorecem o desenvolvimento de uma atividade agropecuária em larga escala. Com um relevo predominantemente plano, uma significativa diferenciação climática e sendo detentor das maiores reservas de água doce conhecidas, o Brasil se consolidou no mercado internacional como um dos grandes produtores de grãos, carnes e bioenergia do mundo contemporâneo. Essa trajetória da agropecuária nacional, embora tenha seu desenvolvimento ligado a condições naturais favoráveis, é, igualmente, indissociável dos condicionantes históricos, políticos, sociais e geográficos que traçaram o processo de construção do espaço rural brasileiro.

Com a quase totalidade do seu território situado na zona tropical e subtropical, o espaço rural brasileiro começa efetivamente a se estruturar a partir da introdução da monocultura da cana-de-açúcar, na Região Nordeste, no Século XVI (VALVERDE, 1985). Destinada ao mercado externo, essa lavoura era cultivada em larga escala, em grandes latifúndios, com uso extensivo do solo, emprego de técnicas rudimentares e utilização de mão de obra escrava. Como esse sistema de produção era reconhecidamente predatório, ele demandava uma constante incorporação de novas terras, causando contínua expansão de seu espaço produtivo.

Outra atividade extensiva de grande importância na conformação do espaço rural foi a pecuária, principal atividade do período colonial, que não se destinava à exportação. Ela se localizou no sertão interior, próxima a áreas de produção para o mercado externo, como o açúcar na Região Nordeste, o extrativismo na Região Norte, e a mineração na Região Sudeste. Esse deslocamento dos rebanhos para o interior se deve à proibição, no Século $\mathrm{XVI}$, de sua criação num perímetro de até 10 léguas da costa. "Essa medida foi prenhe de 
consequências, das quais a mais importante foi a separação econômica e espacial da agricultura e da pecuária, fazendo com que uma e outra adotassem obrigatoriamente práticas extensivas" (VALVERDE, 1985, p. 194)'.

Posteriormente, além da atividade pecuária e da lavoura da cana-de-açúcar, foram introduzidas outras lavouras que tiveram importância na estruturação do espaço rural do Brasil, como o algodão, o cacau e o tabaco, já exportados no Século XVIII, e o café, de enorme significado socioeconômico e geográfico para a sociedade brasileira.

Embora o café tivesse sido introduzido no Brasil, em 1727, essa lavoura só ganha importância comercial com a decadência das culturas da cana-de-açúcar, algodão e tabaco ${ }^{2}$.A partir de então, a cafeicultura, em consonância com o aumento de sua participação na economia, apresentou uma grande expansão espacial. De início, o café foi produzido na região do Vale do Paraíba, no sul de Minas Gerais e no Espírito Santo. Dali chega a Campinas, no "Oeste Velho Paulista", para então se expandir em sentido ao "Oeste Novo" (Ribeirão Preto e Araraquara) e, posteriormente, para as áreas de terra roxa do norte do Paraná e em Mato Grosso. É relevante destacar que, desde 1870/1880, o café suplantou o açúcar como principal produto agrícola de exportação, posição mantida até a década de 1930.

Esse quadro é alterado com a Grande Depressão, crise econômica em 1929, iniciada a partir da quebra da Bolsa de Valores de Nova York. Devido à superprodução da agricultura no período, aliada à forte dependência da economia brasileira com as exportações de café e agravada pelo fato de os Estados Unidos serem o maior comprador da produção cafeeira, o governo se vê na contingência de atuar mais diretamente no setor agropecuário, por meio de políticas públicas regulatórias. Foram criadas autarquias como o Instituto do Açúcar e do Álcool (1932) e o Departamento Nacional do Café (1933), que deu origem ao Instituto Brasileiro do Café (1952), com o objetivo de mediar conflitos de interesses dos diferentes subsetores produtivos e controlar a produção por meio da compra e estocagem dos excedentes. Além disso, o Banco do Brasil desempenha um papel fundamental no financiamento do setor. O Estado passa a atuar então como agente regulador, imprimindo um novo padrão de desenvolvimento econômico ao setor agropecuário, que se mantém até os dias atuais, com similitudes e diferenças significativas, conforme o período analisado.

Este trabalho abrange um período histórico/geográfico longo, em que a estrutura e a configuração do processo produtivo agropecuário se consolidam no território brasileiro, sob a regência de diversas políticas públicas. Apesar de essas políticas variarem de acordo com os diferentes governos, de comum em todo esse período foi a persistência de uma estrutura fundiária de concentração extrema, em que a grande produção monocultora predominou, a despeito de diversas iniciativas de apoio à pequena produção.

\footnotetext{
1 Segundo Valverde (1985), até meados do Século XIX, constituíram-se no Brasil três zonas principais de criação: o sertão do Nordeste; o sul de Minas Gerais; e as planícies e planaltos da Região Sul.

2 A produção da cana-de-açúcar entra em decadência a partir da concorrência das Antilhas e do açúcar de beterraba europeu. Também o algodão entra em decadência devido à produção norte-americana e, o Tabaco, com a Lei Euzébio de Queiroz, que proibia o tráfico de escravos. (BRASIL, 1850).
} 
Esta análise tem por objetivo traçar um amplo panorama da trajetória geográfica do processo de ocupação do espaço rural brasileiro. O tempo investigado varia da década de 1940, quando, após a Segunda Guerra Mundial, o Estado se redefine como principal agente de fomento da acumulação capitalista no campo e passa a atender, de modo definitivo e sistemático, demandas específicas do setor, até os dias atuais, quando o País se afirma no mundo como uma grande economia agroindustrial. Examina-se a maneira como algumas dessas transformações se concretizaram no setor agropecuário brasileiro, no intervalo entre os Censos Agropecuários 1940/2006. Para tanto, foram identificadas variáveis passíveis de serem comparadas no período em estudo: a evolução dos estabelecimentos rurais em número e área; a utilização das terras destes, considerando as áreas das principais atividades produtivas; o total de pessoal ocupado; o número de tratores e os efetivos da pecuária, sobretudo o dos bovinos.

Apesar de a análise comparativa de dados censitários por um período tão longo ficar restrita a um número limitado de variáveis estruturais, e de ser realizada em uma escala por Unidades da Federação, sua escolha deve-se ao fato de identificar padrões regionais de transformações estruturais no setor agropecuário, que levam tempo para se materializar no espaço rural brasileiro.

Desde meados dos anos 1940, a agricultura brasileira vem passando, de forma ininterrupta, por um profundo reajustamento produtivo, visando a sua modernização. Esse processo, caracterizado por diferentes etapas, ocorre por meio de uma contínua melhoria e ampliação do sistema logístico de infraestrutura de transporte e armazenagem, e, institucionalmente, por meio de políticas visando ao aumento e à diversificação das exportações e, principalmente, pela transformação da base técnica de produção do setor agropecuário. Com isso, em seu decorrer, o processo de modernização vai sendo permeado por um crescente aumento das trocas intersetoriais, o que implica a ampliação e a intensificação das condições de produção agrícola e, no limite, na transformação deste setor em um complexo agroindustrial mais completo, agora envolvendo um articulado sistema de interesses e de ações intersetoriais.

Todas essas transformações decorrem de um rearranjo técnico-econômico e territorial em que, necessariamente, não só há uma concentração da produção em determinados produtos, como, simultaneamente, ocorre uma especialização dinâmica dos lugares em que esta se realiza no espaço e no tempo. A sua forma de concretização no território varia em função da época em que ocorre, do padrão técnico-científico disponível, bem como do modo de como se dá a inserção dos diferentes países na economia-mundo e, sobretudo, das políticas públicas adotadas na consecução dos objetivos almejados.

Entre 1940 e 1950, era inquestionável a primazia das atividades agropecuárias sobre o conjunto da economia brasileira, aí compreendida não só o domínio econômico, como social, político e cultural. Nesse período, e sem se considerar os produtos pecuários, o valor da produção dos 20 principais produtos agrícolas, segundo Bernardes (1961), equivalia a $54 \%$ do valor de toda a produção industrial do País ${ }^{3}$.

3 O valor da produção agrícola considerada foi de 136,2 milhões de cruzeiros, enquanto o da produção industrial foi de 116,7 milhões, ano-base 1950. Ressalte-se que, nos cálculos da agricultura, não foram incluídos valores da atividade pecuária e que $29 \%$ do valor industrial provêm de indústrias alimentares. 
Apesar de sua importância, a economia agropecuária era, contudo, extremamente frágil, mantendo-se, de acordo com esse autor, em grande medida deficitária, com baixos rendimentos e instabilidade da produção tanto no tempo como no espaço.

Nas décadas de 1940 e 1950, a principal área onde ocorriam atividades agropecuárias no País formava um espaço contínuo correspondente às atuais Regiões Nordeste (com exceção dos Estados do Maranhão, Piauí e Sergipe), Sudeste e Sul. A sua produção estava concentrada, sobretudo, nestas duas últimas, sendo que, a Região Sudeste, isoladamente, detinha $42 \%$ de todas as áreas de lavouras. Só o Estado de São Paulo concentrava em torno da metade das áreas de cultivo do algodão (47\%) e do café (52\%), este último, o principal item da pauta de exportações (ANUÁRIO ESTATÍ́STICO DO BRASIL 1950, 1951). (Mapa 1).

Mapa 1 - Evolução da lavoura temporária - 1940/2006
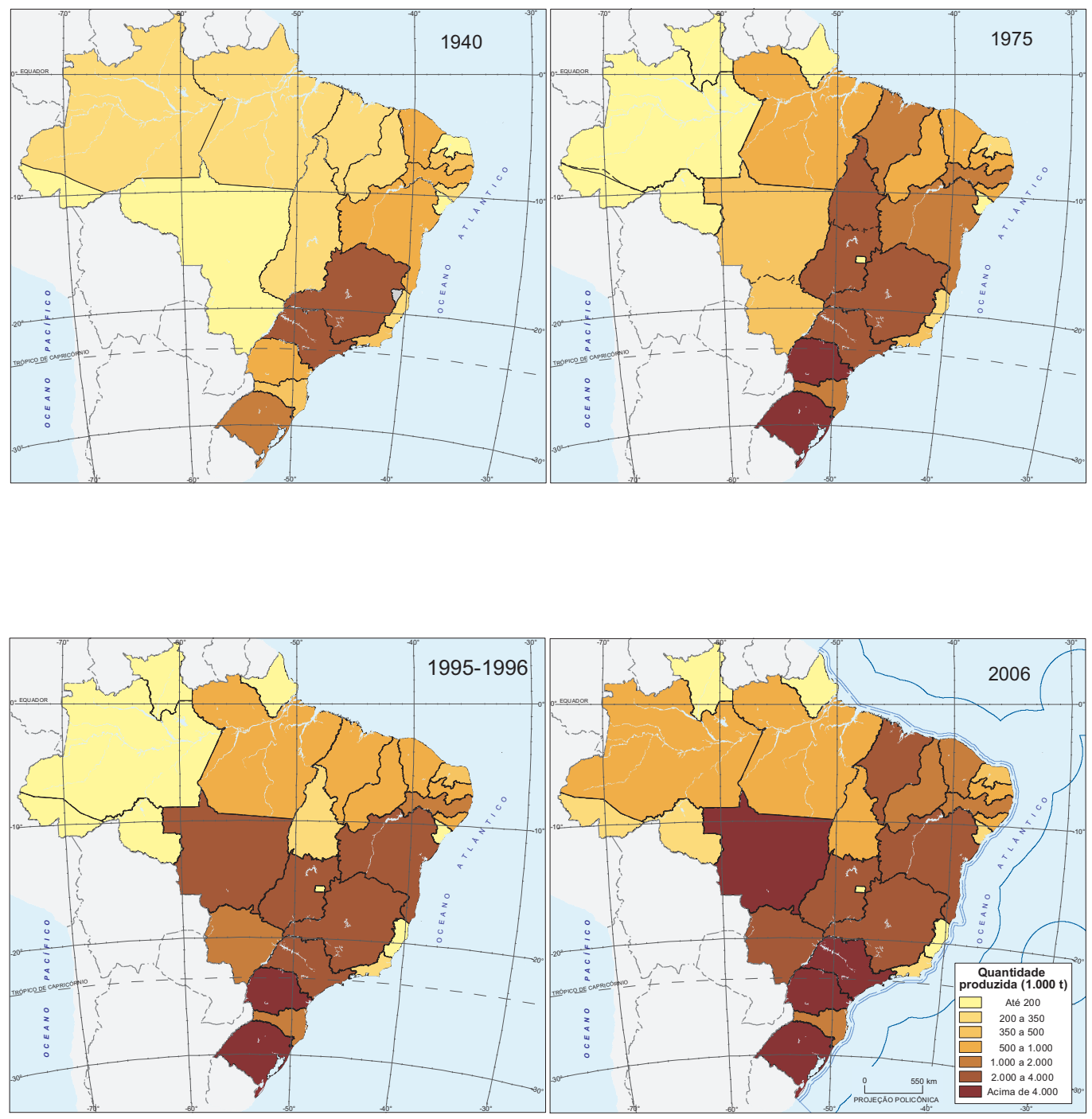

Fonte: IBGE, Censo Agropecuário 2006. 
Outras lavouras de importância comercial à época eram a cana-de-açúcar, o cacau, o arroz e o trigo. Estas culturas, ao lado das de feijão, mandioca e milho, cujo objetivo principal era a subsistência, formavam a base da atividade agrícola brasileira. Cabe destacar a importância econômica da pecuária bovina, cujo rebanho, já naquele período, era considerado o quarto maior do mundo, com um total de 44600159 de cabeças em 1950 (CENSO AGROPECUÁRIO, 1970; 2006) (Mapa 2).

\section{Mapa 2 - Evolução do número de bovinos - 1940/2006}
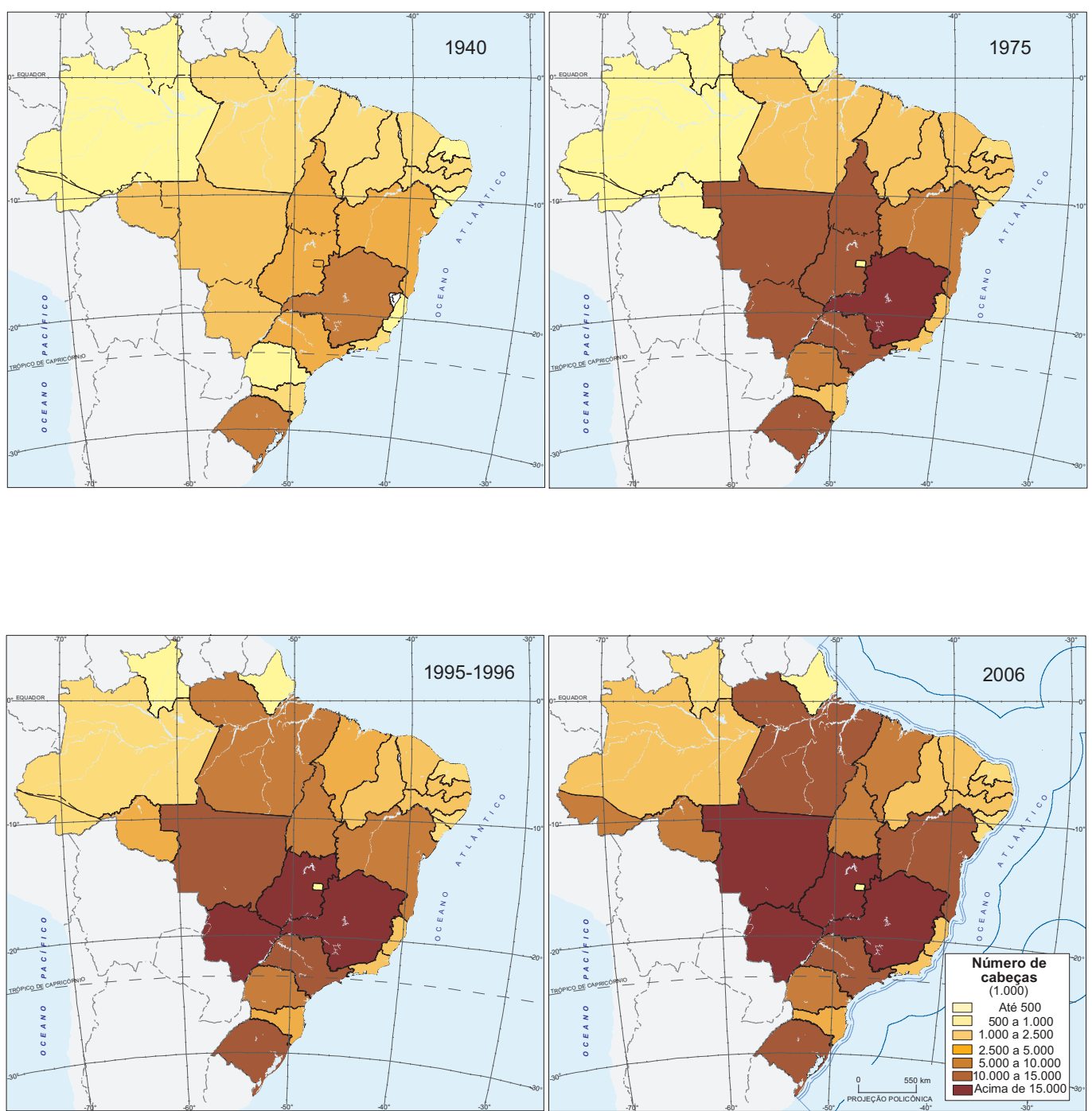

Fonte: IBGE, Censo Agropecuário 2006.

A abertura de novas áreas de pastagens foi uma das principais causas do aumento da área dos estabelecimentos verificado no período. Em "zonas de ocupação mais antiga", como Rio de Janeiro, São Paulo, Minas Gerais e Rio Grande do Sul, esse processo se deu por "um recuo da área já cultivada" com lavouras. A grande expansão da atividade pecu- 
ária, no entanto, se deu em áreas de fronteira agrícola, sobretudo, pela "incorporação aos estabelecimentos rurais de grandes trechos de campos de cerrado na Região Centro-Oeste [...], onde se verificou o maior acréscimo relativo de área total" (BERNARDES, 1961, p. 103).

Apesar de a expansão da pecuária predominar, havia também uma preocupação, por parte do governo brasileiro, de ocupar essas áreas da Região Centro-Oeste com colônias agrícolas para a produção de alimentos e matérias-primas a baixo custo. Com isso, criava-se, nos "sertões brasileiros", um mercado para produtos industrializados, direcionando-se um expressivo contingente populacional, sobretudo da Região Nordeste, para o interior do País e, ao mesmo tempo, ocupando espaços até então vazios. Visando à implantação desse projeto, foram criadas, em 1943, por iniciativa estatal, as Colônias Agrícolas Nacionais de Goiás e de Mato Grosso, que, embora não atingissem seu objetivo de criar núcleos de pequenos produtores, deram origem, respectivamente, aos municípios de Ceres e Dourados.

Outra região de fronteira agrícola, cuja ocupação se baseou na criação de colônias, foi a do Paraná. Diferentemente da Região Centro-Oeste, o projeto de colonização nesse estado, que tinha um caráter empresarial, foi, em princípio, bem-sucedido. A sua ocupação se deu com base no estabelecimento de descendentes de italianos e alemães procedentes do Rio Grande do Sul e Santa Catarina, que ocuparam pequenos lotes de terra no sudoeste e oeste do Paraná. Cabe ressaltar que, além de uma pequena policultura de alimentos, eles cultivavam a hortelã, destinada a empresas compradoras, a menta e a soja, esta última utilizada apenas como forragem verde para alimentação de animais.

Outra área de fronteira agrícola existente, na década de 1940, localizava-se no Maranhão. Diferentemente do Paraná e da Região Centro-Oeste, contudo, a frente de ocupação naquele estado apresentou um caráter "espontâneo", absorvendo um excedente populacional proveniente do semiárido nordestino. Nessas áreas, estabeleceu-se um sistema de produção agroextrativista em que se alia a agricultura de queima e o pousio com o extrativismo das amêndoas de babaçu, principal base econômica do estado. Nesse período, começa também a se intensificar a produção de arroz, cujo cultivo precedia, em parte, a formação dos pastos para a pecuária em estabelecimentos maiores.

Assim, seja em áreas consolidadas ou de expansão, a produção agropecuária dos anos 1940-1950 estava estruturada sobre uma malha fundiária extremamente desigual, na qual, ao lado de grandes estabelecimentos dedicados à pecuária e a lavouras de alto valor comercial, coexistiam pequenos estabelecimentos que praticavam uma agricultura destinada à subsistência e ao abastecimento do mercado interno. A maior parte dessa produção era obtida por meio das diferentes formas do sistema de "meação", relação de trabalho então predominante na agricultura. O trabalho assalariado, quando empregado, restringia-se a algumas grandes lavouras, sendo mais comumente utilizado nos períodos em que a safra demandava um contingente mais elevado de mão de obra.

Devido ao uso disseminado de práticas agrícolas extensivas e à ausência de uma infraestrutura de apoio, entre outros fatores, o setor agropecuário brasileiro apresentava ainda baixos rendimentos e instabilidade de sua produção, tanto no tempo como no espaço. 
Isso num período em que o País vivia um processo de urbanização e industrialização, que dependia fortemente da economia agrária.

A importância da agropecuária nesses anos estava atrelada, em grande parte, à política de substituições de importações, na qual cabia a este setor produzir alimentos para uma crescente população urbana, suprir com matérias-primas importantes setores da indústria, além de gerar divisas cambiais que viessem a financiar o desenvolvimento da própria indústria nacional. No entanto, apesar de seu papel central para o financiamento do modelo de desenvolvimento então vigente, a agricultura mantinha-se ainda atrelada a estruturas tradicionais de produção. Somente no período pós-guerra, quando há uma recuperação dos mercados internacionais, o Estado procura implementar, de forma mais decisiva, um processo de modernização de sua base técnica, pela importação de tratores e fertilizantes (GRAZIANO, 1996).

Na década de 1950, com a manutenção do modelo de substituição das importações, a agricultura permanece com o objetivo principal de abastecer os centros urbanos e, ao mesmo tempo, gerar divisas para o financiamento dos produtos importados necessários à consolidação do projeto de industrialização. No entanto, mesmo tendo ocorrido um crescimento acelerado da indústria neste período, o setor agropecuário ainda apresentava uma baixa produtividade, com as suas exportações mantendo-se calcadas na cafeicultura, cujo valor da produção exportada, entre 1949 e 1959, aumentou em 331,74\% (CENSO AGROPECUÁRIO, 1950; 1960).

Como nos anos 1950 ainda havia um predomínio amplo das tradicionais práticas de cultivo, o aumento da produção alimentar e de matérias-primas primárias dependia, em grande medida, da incorporação de novas terras ao espaço produtivo dos estabelecimentos, o que ocasionou uma significativa expansão das áreas de fronteira agrícola. Comparativamente, enquanto, no Brasil, o número e a área dos estabelecimentos aumentaram em 61,6\% e 7,6\%, respectivamente, no Paraná, este aumento foi de $200 \%$, no número, e de $41,7 \%$, na área dos estabelecimentos rurais. Em Goiás, onde a expansão da fronteira se deu, sobretudo, pelo crescimento da atividade pecuária, o aumento da área total de pastagens foi superior a $23 \%$, enquanto, no Brasil, foi de $13 \%$.

Com o distanciamento entre as áreas produtoras e os centros consumidores, surge a questão da infraestrutura de transportes, armazenamento e comercialização das safras, que tinham perdas calculadas em até $25 \%$ da produção embarcada (MELLO, 1979). As políticas públicas de então passam a focar seus objetivos na melhoria das condições de transporte, com a construção de grandes eixos rodoviários como a Belém-Brasília. Outra preocupação era quanto à melhoria das condições de produção. Para tanto, ampliou-se o sistema de crédito rural, de assistência técnica e os subsídios à importação de insumos modernos. Além disso, abriu-se uma linha de crédito oficial, visando à aquisição de máquinas agrícolas de fabricação nacional, sobretudo de tratores. Com efeito, entre 1950 e 1960, o número de tratores utilizados no setor agropecuário passou de 8372 para um total de 61345 unidades (FERNANDES, 2006). 
Foi, sobretudo, esse aumento do uso de tratores e a ampliação da infraestrutura de transportes o que viabilizou a continuidade da expansão das fronteiras agrícolas na década de 1950. Apesar de esses fatores de modernização terem proporcionado o alargamento de um mercado interno nacional interligado, o crescimento da agricultura manteve-se assentado na ampliação das áreas de cultivo, com a predominância de formas tradicionais de produção e trabalho ${ }^{4}$.

Nos anos 1960, época de fortes mudanças sociais e políticas no País, o projeto da industrialização com base na substituição de importações se esgota. Isso se deveu, por um lado, pela incapacidade estrutural da própria indústria nacional em atender a sua crescente demanda interna por bens de capital e matérias-primas e, por outro lado, pela incapacidade da agricultura em financiar e abastecer as necessidades de um setor urbano e um parque industrial em expansão.

Com isso, em meados dessa década, prevalecem políticas que preconizavam um modelo de "desenvolvimento associado", no qual a participação de capitais internacionais tem um papel fundamental no financiamento do desenvolvimento econômico do País. Neste contexto, adotam-se, para o setor agropecuário, políticas de modernização conservadoras, com o objetivo de estender, de forma definitiva, a dinâmica capitalista de produção ao campo, sem se alterar a estrutura fundiária preexistente.

Esse projeto, que tinha a intenção de modernizar a agricultura, aumentando e diversificando a sua produção, pela introdução e disseminação de tecnologias de ponta, apresentava dois grandes eixos para a sua concretização: primeiro expandir e ocupar os espaços ainda não integrados ao mercado nacional, por meio da criação de incentivos fiscais em favor do grande empreendimento agropecuário capitalista nacional ou estrangeiro; e segundo ampliar a concessão de créditos subsidiados, direcionados para a grande monocultura de alto valor comercial destinada à exportação ${ }^{5}$.

Graças a essas políticas, o desempenho da agricultura nos anos 1960 foi superior ao verificado na década de 1950 . Isso se traduz pelo aumento superior a $170 \%$ no número de tratores utilizados no setor, naquele decênio, onde foram empregados principalmente nas áreas de lavouras da Região Sul e do Estado de São Paulo.

Foi nesse espaço contínuo que a agricultura moderna mais se desenvolveu nos anos 1960, no contexto nacional. Além das tradicionais monoculturas de exportação do algodão e do café, nele se intensificaram e se expandiram as lavouras do milho e da soja, em caráter empresarial.

A expansão do grande empreendimento agropecuário moderno afetou muitas áreas de pequena produção agrícola, estando estas em áreas já colonizadas ou em áreas de expansão da fronteira. Isso porque o modelo de modernização conservador, ao direcionar sua política de crédito subsidiado para a mecanização, a utilização de insumos e os implementos

\footnotetext{
4 Segundo Graziano (1996), até 1960, quase 70\% do pessoal ocupado na agricultura ainda era mão de obra familiar e de parceiros, agregados e outras formas tradicionais de relações de trabalho.

5 A Lei n. 4.829, de 05.11.1965, instituiu o Sistema Nacional de Crédito Rural, principal instrumento político de incentivo à produção agropecuária.
} 
industriais, fez com que o desenvolvimento da agricultura dependesse cada vez mais de investimentos de capital. Nesse sentido, o alto custo da utilização de insumos modernos inviabilizava os pequenos agricultores, uma vez que a eles foram impostas condições de produção semelhantes às dos grandes proprietários. Em consequência da modernização da agricultura, extensas porções do espaço rural sofreram transformações na sua malha fundiária e na produção agrícola, como é o caso de diversas áreas do Paraná, onde a policultura de subsistência foi substituída por lavouras temporárias, cultivadas em grande escala, para fins de comercialização, como, por exemplo, a da soja ${ }^{6}$.

Até mesmo espaços rurais de pequena produção, distantes da principal área de agricultura moderna formada pela Região Sul e o Estado de São Paulo, sofreram modificações em seu processo de produção tradicional. Este é o caso do Maranhão, onde, nos anos 1960, projetos governamentais favoreciam a apropriação da terra por grandes empreendimentos pecuários. Com a pecuarização e a privatização das terras, extensas áreas de mata e capoeira foram transformadas em pastagens, destruindo, desse modo, o sistema agroextrativo prevalecente nesta área, ao qual estavam ligados os pequenos produtores estabelecidos há décadas nos vales dos Rios Grajaú e Pindaré.

A atividade pecuária também se expande significativamente para a Região Centro-Oeste, com as áreas de pastagens em Mato Grosso e Goiás aumentando em mais de 13000000 hectares, entre 1960 e 1970. Além dessa atividade, houve também, nesses estados, um incremento das áreas de lavouras temporárias, sobretudo no Estado de Goiás. Embora, em parte, a expansão dessas áreas esteja atribuída à lavoura do arroz, cultivo que precede a formação de pastos em áreas de fronteira agrícola, registrou-se também um aumento das áreas de milho, soja e da cotonicultura.

Essa expansão do grande empreendimento agropecuário moderno, ao mesmo tempo em que provocava uma expropriação dos pequenos produtores em diferentes áreas, rearranjava as relações de produção existentes no campo. Muitos dos antigos produtores, embora morando na periferia das cidades, são realocados no mercado de trabalho rural, na condição de trabalhadores assalariados. Isso ocorreu, sobretudo, em estados de agricultura já consolidada, como o Paraná e São Paulo. Um outro contingente de pequenos produtores, ao perder suas terras nos locais de origem, migra para áreas de expansão de fronteiras agrícolas, onde volta a se inserir, no processo produtivo, como ocupantes, pequenos arrendatários ou mesmo empregados parceiros de grandes estabelecimentos. Neste último caso, encontram-se os Estados de Goiás, Mato Grosso e Pará, que, entre 1960 e 1970, receberam um intenso fluxo migratório.

\footnotetext{
6 Embora a soja fosse conhecida, na Região Sul, antes do processo de modernização agrícola da década de 1970, ela era uma cultura secundária naquela região, sendo utilizada como alimento na suinocultura.
} 


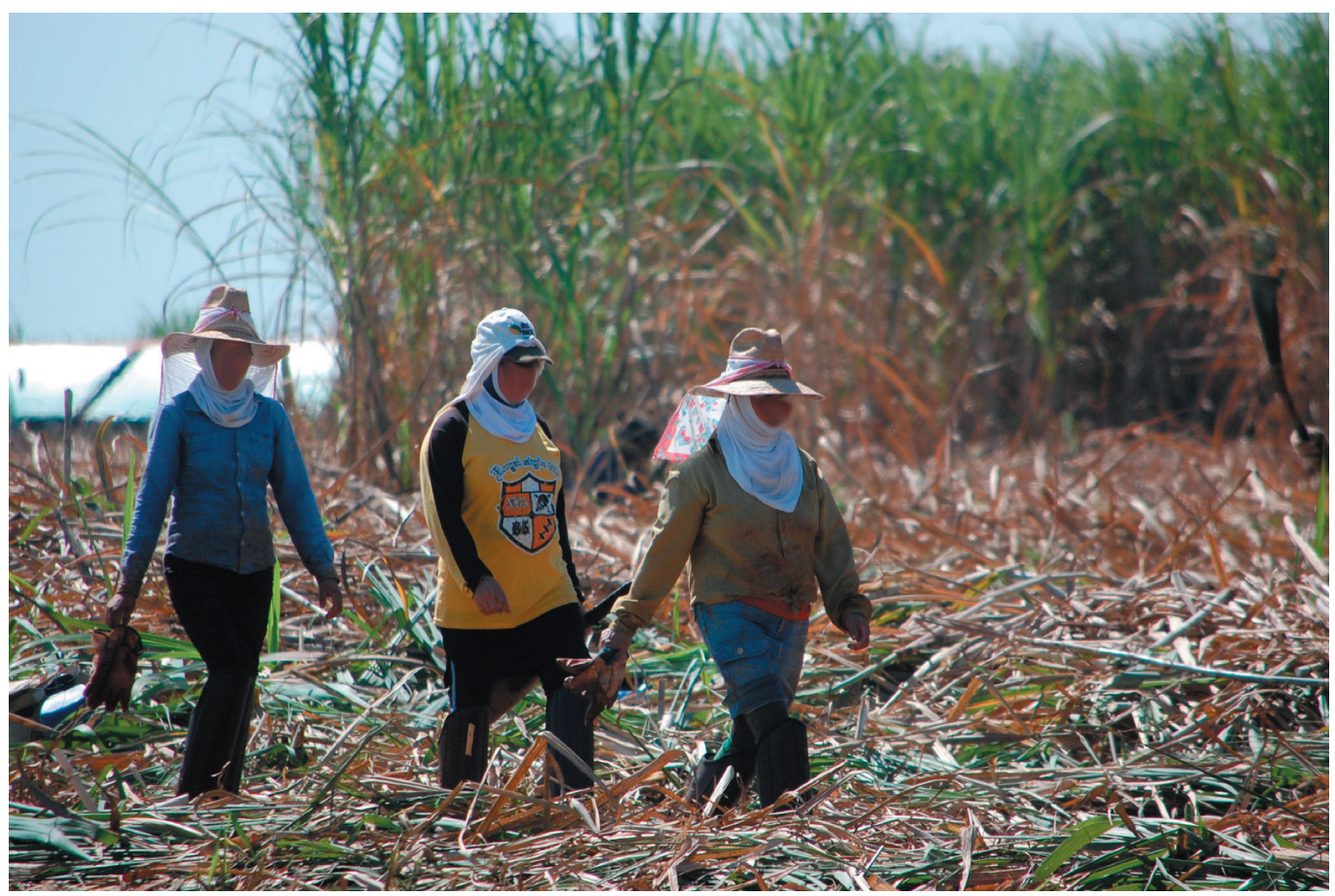

Foto 1 - Trabalhadores assalariados temporários, na colheita da cana-de-açúcar, em Ribeirão Preto, SP (2013). Foto: Luiz Sérgio Pires Guimarães.

Assim, em meados da década de 1960, a adoção de uma série de políticas públicas específicas para a chamada "modernização conservadora" da agricultura provocou importantes transformações no setor, consolidando a grande agricultura comercial, por meio da tecnicização de seus processos produtivos e de uma maior abertura ao mercado internacional. Nesse contexto, a produção agropecuária apresentou um desempenho muito superior a de décadas anteriores, devido tanto ao aumento da sua produtividade como da diversificação de suas exportações agrícolas. Ao final desse período, a situação do mercado continuava favorável, com abundância de créditos baratos, preços de insumos e bens de capital em declínio e os das commodities em alta.

Esse quadro em que o setor agropecuário se estrutura, com base na expansão e na modernização tecnológica da produção de commodities de alto valor comercial, foi consolidado ao longo da década de 1970. Nesse período, foram ampliados os investimentos públicos na infraestrutura, no armazenamento e na modernização da produção agropecuária em larga escala. Chama a atenção o aumento da mecanização do setor agropecuário entre os anos 1970 e 1980, quando a maioria dos estados mais que dobrou o número de tratores utilizados. Estados com grande produção de grãos, como, Paraná, Goiás e Mato Grosso que quintuplicaram as suas frotas nessa década. Só Mato Grosso (incluída a área do atual Mato Grosso do Sul, para efeitos de comparação) passa de um total de 4386 tratores, em 1970, para 44320 unidades, em 1980. 
Como os preços das commodities internacionais eram ainda mais favoráveis que na década anterior, ampliou-se a participação do Brasil, no mercado internacional, com o aumento das exportações de vários produtos agrícolas, entre os quais se destacam a soja, o café, o milho, a laranja (em suco), o açúcar e as carnes. Essas atividades modernizadas aumentaram, inicialmente, suas áreas na Região Sul, nos Estados de Minas Gerais e São Paulo, para, posteriormente, em meados da década, se expandirem sistematicamente por toda a Região Centro-Oeste, e, por fim, atingindo o Estado do Pará, ampliando a fronteira agrícola para áreas até então só parcialmente integradas à dinâmica de produção capitalista. Todo esse dinamismo, baseado na grande oferta de capitais existentes no mercado internacional e em uma política de crédito altamente subsidiada, deteriora-se a partir da crise do petróleo de 1979, quando ocorre uma forte retração da economia internacional.

Nos anos 1980 e até meados da década seguinte, o crescimento da dívida externa do Brasil e das taxas de juros internacionais provocou uma significativa redução dos recursos para o financiamento rural. Isso se refletiu de imediato na redução das áreas de lavouras, pastagens e pessoal ocupado na agricultura, verificada no período. Gradativamente, a política de crédito vai sendo substituída pela Política de Garantia de Preços Mínimos - PGPM, que passa a ser o principal instrumento de incentivo à expansão e ao desenvolvimento do setor agropecuário. Apesar disso, o quadro de hiperinflação obrigou o governo a elaborar um conjunto de políticas de ajustamento macroeconômico que, materializadas em uma série de planos econômicos, restringiram a plena expansão do setor agropecuário nessa década ${ }^{7}$.

Com a manutenção de um cenário macroeconômico desfavorável no Brasil, delineou-se, na década de 1990, sobretudo a partir do segundo quinquênio, a necessidade de se construir um novo quadro institucional, que permanece até o período atual e que redefiniu o espaço entre o público e o privado nos mercados agroalimentares, alinhando as novas diretrizes às exigências da Organização Mundial do Comércio - OMC. O Estado deixa, em grande medida, de ser o gestor das políticas públicas para o setor, passando a exercer o papel de principal coordenador e fiscal destas. Isso implicou a "retirada do governo de controles diretos na forma de preços ou compras e, em muitos casos, implicou no desmantelamento de serviços de extensão e, também, na eliminação de políticas setoriais mais ativas" (WILKINSON, 2003, p. 12). "Tais medidas vieram acompanhadas de uma menor proteção tarifária e de uma maior abertura ao comércio internacional, levando em vários casos a um aumento no ritmo de importação de alimentos". Visando aumentar o volume de investimentos diretos vindos do exterior, procedeu-se, conforme complementa este autor, a uma "modificação da legislação sobre os níveis de participação de capitais estrangeiros em empresas nacionais e a uma maior tolerância à remessa de lucros". (WILKINSON, 2003, p. 27). Com isso, torna possível intensificar ainda mais a modernização da agricultura, o que provocou um aumento da competitividade da produção brasileira no comércio internacional, alavancando as exportações. As consequências desse novo quadro foi a exacerbação das características do processo de modernização.

\footnotetext{
Nesse período foram sete planos de ajuste: Planos Cruzado I e II; Plano Bresser; Plano Verão; Planos Collor I e II; e finalmente, o Plano Real.
} 
Diante da nova escala mínima de capitais necessários para repor as condições da produção agropecuária, há um aumento ainda maior da concentração e da centralização dos capitais em uma gama de empresas que têm como características a forte interdependência com outros setores econômicos, não só nacionais, mas também, e cada vez mais, em nível internacional.

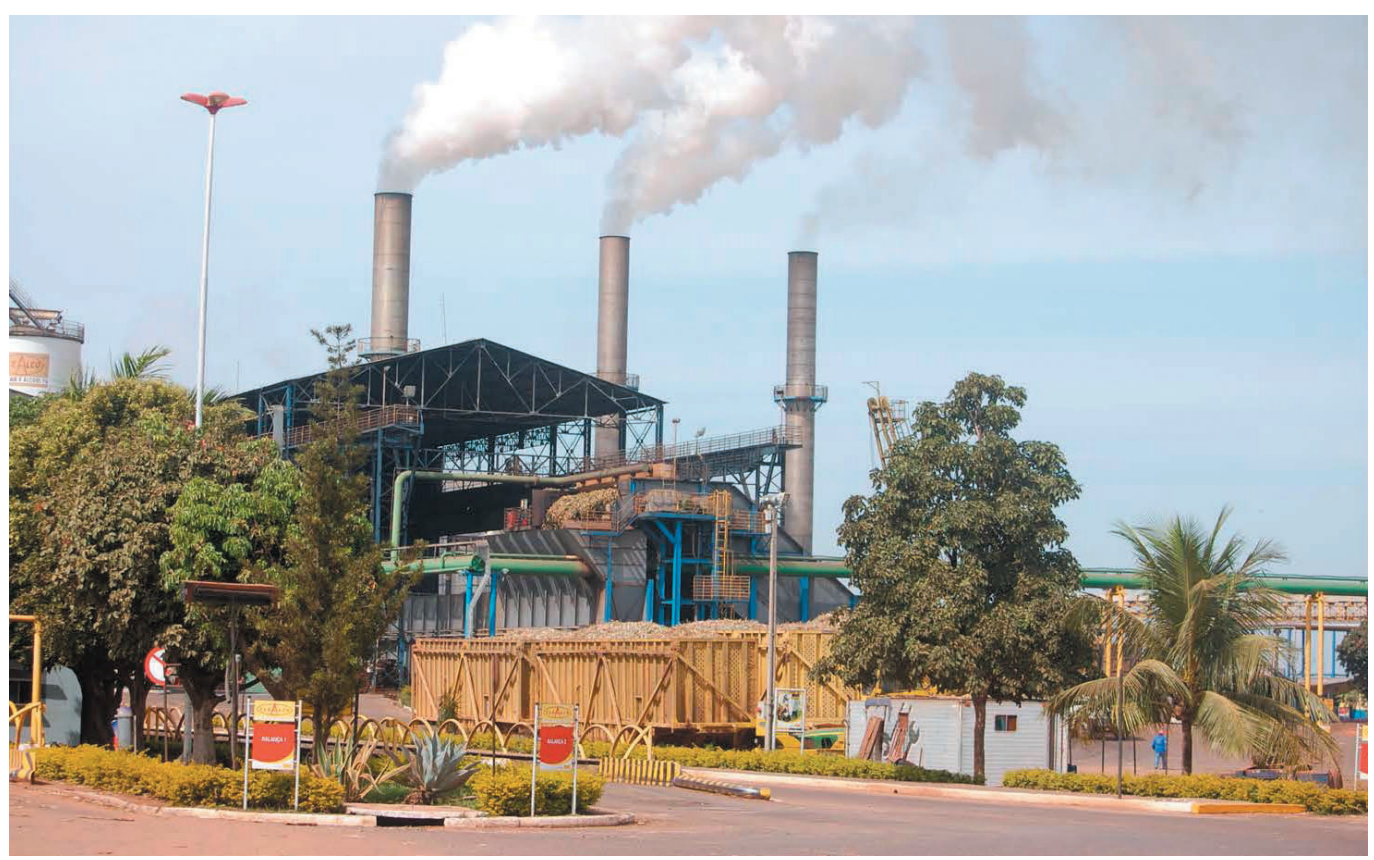

Foto 2 - Usina de cana-de-açúcar em atividade, Assaí, PR (2013).

Foto: Luiz Sérgio Pires Guimarães.

Com esse novo quadro econômico e institucional, as mudanças registradas na dinâmica da produção agropecuária entre 1996 e 2006 se refletiram no aumento do desempenho e produtividade da grande produção, notadamente das commodities. Nesse segmento de estabelecimentos, houve um grande aumento da produtividade, tanto pela disseminação do uso de tecnologia como pela expansão da área produtiva dos estabelecimentos. Registre-se que o Censo Agropecuário 2006 constatou que os estabelecimentos muito grandes, com 1000 hectares ou mais, representavam apenas $1 \%$ de todas as unidades produtivas, ocupando $45 \%$ da área destes, enquanto mais da metade dos estabelecimentos agropecuários (52,7\%) tinham menos de 10 hectares, ocupando uma área equivalente a 2,3\% da área total.

Nesse período em análise, consolida-se um dos principais objetivos do processo de modernização conservadora, iniciado nos meados dos anos 1960: a estruturação de um setor agropecuário com base em grandes estabelecimentos modernos, com uma produção de alto valor comercial, fundamentada no desenvolvimento técnico-científico, cuja lógica de investimentos varia primordialmente com as necessidades dos mercados externos. Esse modelo, com significativas diferenças regionais, se concretiza por todo o espaço rural brasileiro, transformando tanto áreas de agricultura consolidada como áreas de fronteiras agrícolas. 
Estas últimas, que vinham, desde a década de 1970, avançando pelas Regiões Centro-Oeste e Norte, formaram, em época mais recente, um grande espaço contínuo de produção no Tocantins, sul do Maranhão, sul-sudeste do Piauí e oeste da Bahia.

Diante de um cenário internacional favorável à comercialização de produtos agrícolas, observa-se, entre 1996 e 2006, um incremento das atividades produtivas, refletido na grande expansão das áreas de lavouras temporárias $(42,8 \%)$ e permanentes $(54,8 \%)$ e no aumento do rebanho bovino (15,1\%), que, em 2006, tinha um total de 176147501 cabeças, em uma área de 160042062 hectares em pastos.

Nesse último período censitário, constatou-se que áreas selecionadas do Território Nacional começam a se tornar especializadas no cultivo de determinados produtos, como a soja, a cana-de-açúcar, o milho e o algodão, obedecendo a uma dinâmica espacial que extrapola estritamente a produção agrícola e se projeta na modernização e na expansão de redes de fluxos materiais (a montante e a jusante da produção propriamente dita) e imateriais (ordens, informação, capital, serviços).

Considerando-se a cadeia produtiva da carne bovina, constata-se que o Brasil era, em 2012, o segundo maior produtor e exportador de carne bovina, além de ter o maior rebanho bovino do mundo com um total de 211279082 cabeças (CARVALHO; DEZEN; FERREIRA, 2008). A atividade pecuária no Brasil é responsável por $1 / 3$ do Produto Interno Bruto - PIB do setor agrícola, sendo o segmento destinado ao corte destacado por sua presença em um grande número de estabelecimentos distribuídos em todo o Território Nacional. Atividade tradicional no Brasil, a pecuária era, até meados da década de 1960, produzida em moldes extensivos (Mapa 3).

A partir desse período, a pecuária começa a se modernizar, incorporando tecnologia ao seu processo produtivo. Associada a áreas de expansão de fronteira agrícola, essa atividade se encontra, hoje, disseminada por quase todo o território brasileiro, principalmente nas Regiões Sul, Sudeste e Centro-Oeste, sobretudo no Estado de Mato Grosso do Sul. A concentração dessa atividade nessas regiões se deve a inúmeros fatores, entre os quais: a proximidade do principal mercado consumidor do País; e a maior presença de frigoríficos, empresas de comércio atacadista de carnes e os principais portos de exportação do País.

A rápida expansão da pecuária sobre áreas da Região Norte, em especial do Estado do Pará, tem contribuído para o agravamento da questão do desmatamento das áreas de mata na Amazônia Oriental, fazendo com que uma série de medidas e ações públicas sejam implementadas no sentido da construção de um pacto entre o setor público e os diversos segmentos que compõem a cadeia produtiva da carne, visando evitar novas frentes de expansão da pecuária sobre áreas ainda cobertas pela vegetação de florestas naquela região.

Quanto à cadeia produtiva da soja, o Brasil tem uma posição estabelecida no mercado mundial de matérias-primas agrícolas como o maior produtor de soja, tendo colhido 65848857 toneladas em uma área total de 24975258 hectares, em 2012 (PRODUÇÃO AGRíCOLA MUNICIPAL, 2013) (Gráfico 1). 
Mapa 3 - Evolução do rebanho bovino - 2000/2012
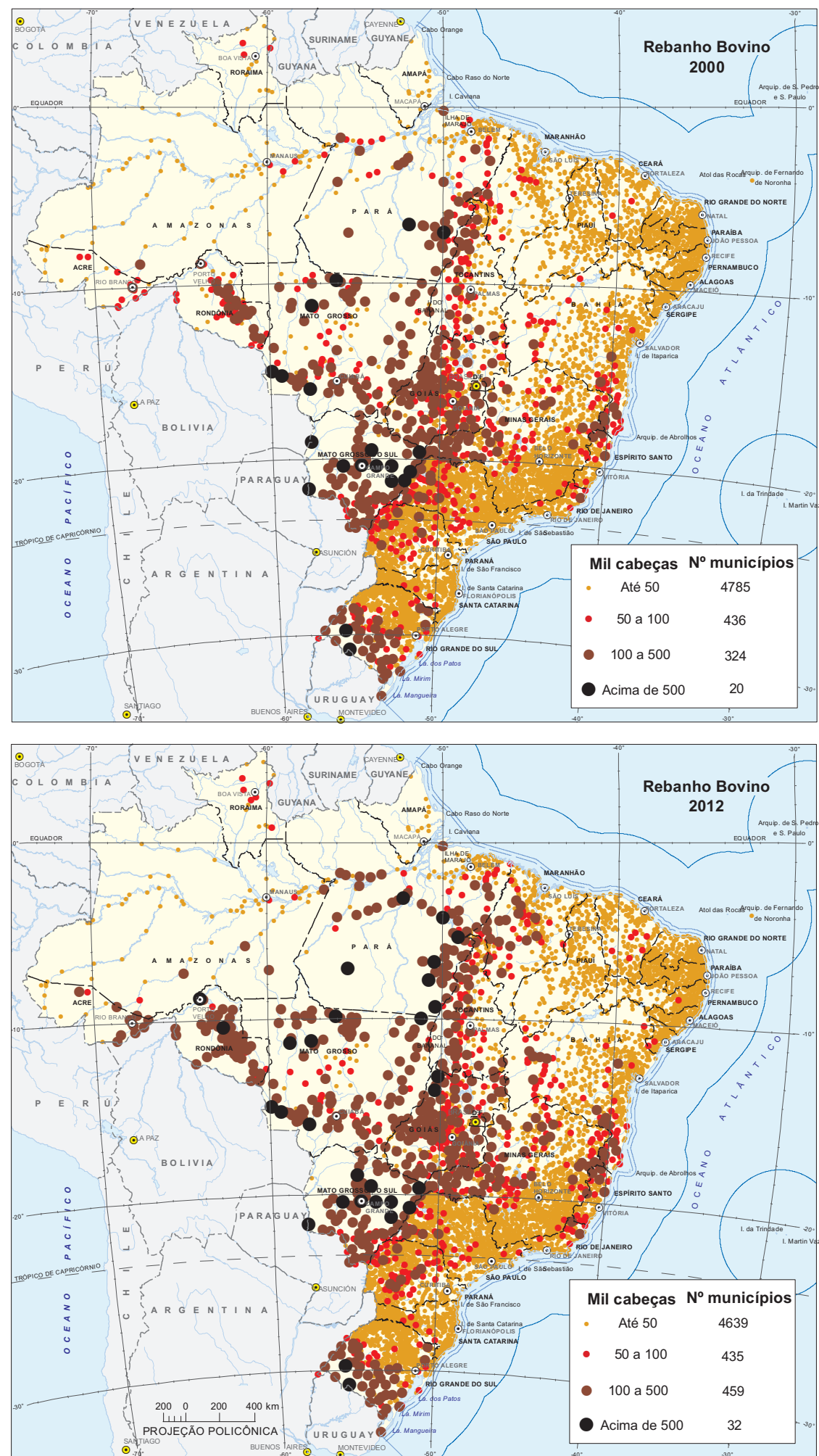

Fonte: IBGE, Censo Agropecuário 2006 


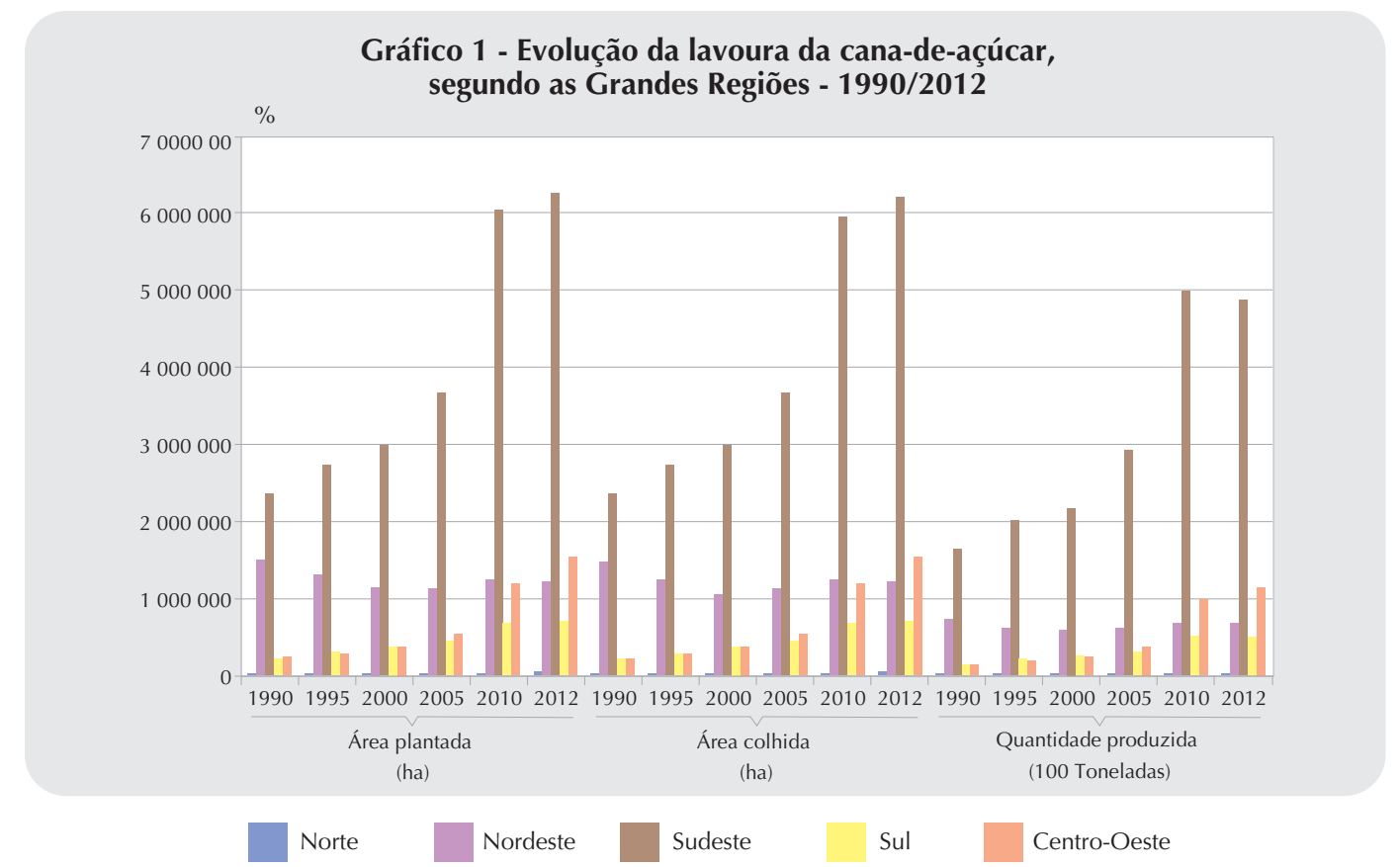

Fonte: IBGE, Produção Agrícola Municipal 1990/2012.

Conforme observado anteriormente, no Brasil, a soja foi introduzida na Região Sul, no início do Século XX, permanecendo, até os anos 1940, como uma lavoura de pouca significância, sendo cultivada por colonos do Estado do Rio Grande do Sul, com o objetivo de complementar a ração do rebanho suíno. De uma lavoura de pouca expressão, foi adquirindo importância na década de 1960, como opção de rotação ao trigo, em uma época em que políticas governamentais incentivavam a expansão da triticultura. A partir desse período, seu cultivo se expande para os Estados de Santa Catarina, Paraná e São Paulo. É, no entanto, em meados da década de 1970, com o processo de modernização da agricultura, que a soja se consolida definitivamente como a principal commoditie do agronegócio nacional, elevando seu patamar de produção e produtividade, quando se expande em direção à Região Centro-Oeste.

Apesar de sua importância, por ser uma planta originária de clima temperado, a grande expansão de sua área plantada só se concretizou quando a Empresa Brasileira de Pesquisa Agropecuária - EMBRAPA, do Ministério da Agricultura, Pecuária e Abastecimento, ao desenvolver variedades de soja que se adequavam ao clima tropical, introduziu uma ruptura tecnológica, que possibilitou a ampliação da fronteira agrícola para áreas antes consideradas inadequadas. O seu cultivo passa a ser realizado em vastas áreas da Amazônia Legal ${ }^{8}$, onde sobressaem as áreas plantadas com soja de Mato Grosso, principal produtor, Tocantins e Maranhão. Neste último estado, a área com soja localiza-se principalmente ao sul, onde forma

\footnotetext{
8 A primeira definição de Amazônia Legal foi feita pela Lei n. 1.806, de 06.01.1953, que criou a Superintendência do Plano de Valorização Econômica da Amazônia - SPVEA e definiu sua área de atuação. Atualmente, a Amazônia Legal abrange os Estados do Amazonas, Pará, Rondônia, Acre, Roraima, Amapá, Tocantins e Mato Grosso, além da porção ocidental do Maranhão limitada pelo meridiano de $44^{\circ}$.
} 
um grande espaço contínuo que atualmente já alcança o sudoeste do Piauí, que, por sua vez, é contíguo à extensa área produtora do oeste da Bahia. Embora relativamente recente, a região de sojicultura na Bahia constitui, na atualidade, uma região consolidada, com uma significativa produção. Portanto, a possibilidade de se ocuparem novos solos, com atividades agrárias rentáveis em grande escala, viabilizou a expansão da cadeia produtiva da soja para espaços regionais que, até então, em sua grande maioria, ainda mantinham sua cobertura vegetal original ou apresentavam estruturas de produção arcaicas.

A sustentabilidade econômica da cultura da soja nessas áreas de expansão foi garantida pela implantação de novas estruturas de produção viárias e energéticas, que modificaram profundamente os arranjos espaciais preexistentes.

Finalmente, juntamente com as cadeias produtivas da soja e da carne, a cadeia produtiva da cana-de-açúcar se constitui, historicamente, em uma das mais importantes do Brasil. O setor sucroalcooleiro que, em 1990, tinha produzido uma safra de 262674150 toneladas, em 2012, produziu 721077287 toneladas de cana-de-açúcar. Dada a dimensão de sua produção, a cana-de-açúcar deve ser considerada a principal lavoura geradora de biomassa energética.

Introduzida no Brasil, no Século XVI, na Região Nordeste, a cana-de-açúcar é a lavoura mais tradicional do País. Atualmente, apesar de a Região Nordeste ainda manter um importante setor sucroalcooleiro, a sua produção, em relação ao total do Brasil, era apenas de 9,4\%, em 2012. Nesse mesmo ano, a produção de cana-de-açúcar das Regiões Sudeste e Centro-Oeste, somadas, equivaliam a $83,2 \%$ da safra brasileira. Ressalte-se que, em 2012, aproximadamente $15,7 \%$ da safra de cana-de-açúcar foi colhida na Região Centro-Oeste, região para onde tem se expandido esse cultivo, sobretudo a partir de São Paulo e do Triângulo Mineiro (Gráfico 2).

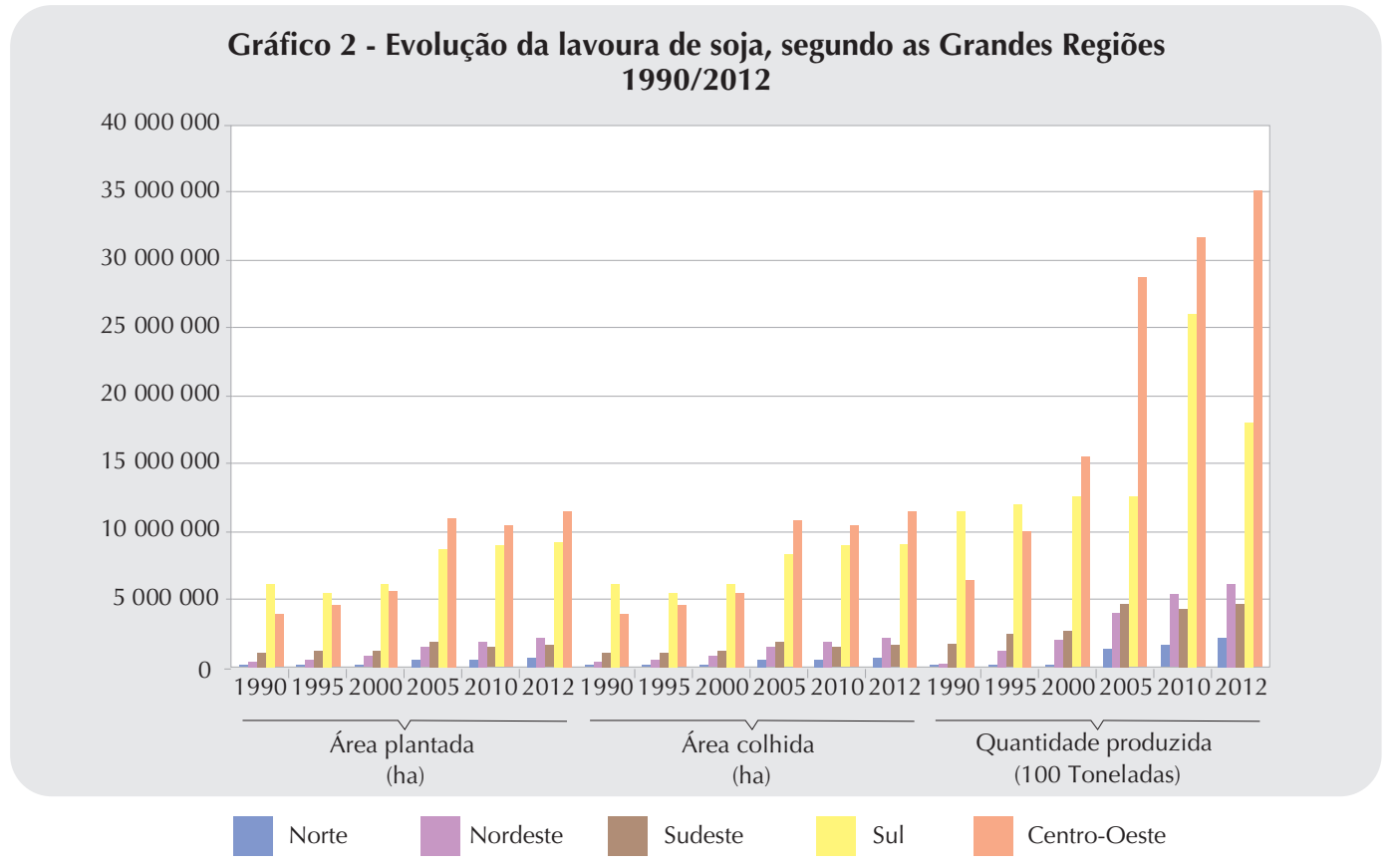

Fonte: IBGE, Produção Agrícola Municipal 1990/2012. 
Esse rearranjo espacial do setor sucroalcooleiro foi uma das transformações mais significativas no uso e na ocupação do território brasileiro no último período censitário. Essa mudança vem ocorrendo, especialmente no Centro-Sul do País, com o processo de introdução, expansão e concentração de grandes plantações de cana-de-açúcar. São Paulo, que, em 1996, já era o maior produtor nacional de açúcar e álcool, registrou a maior expansão de área plantada com esta lavoura em direção a áreas contíguas ao território paulista como as do Triângulo Mineiro, mas também as do centro-leste de Mato Grosso do Sul e, em menor escala, as do noroeste do Paraná, com um aumento expressivo da área ocupada com a lavoura canavieira.

O dinamismo do setor sucroalcooleiro nesse espaço, que forma, a partir de São Paulo, uma grande área agroindustrial consolidada, está em consonância com as demandas do mercado. A crescente procura pelo álcool combustível da cana-de-açúcar, no decênio 19962006, fez com que esse setor intensificasse o processo de centralização de sua produção nesta área, que apresenta uma excelente infraestrutura de produção, circulação e informação, potencializando, com isso, os seus ganhos de escala.

A análise dos dados censitários no período 1996-2006 indica, ainda, que a Região Centro-Oeste vem se constituindo em uma nova área de expansão da cana-de-açúcar, dentro de uma dinâmica espacial que parece não comportar mais a "esgotada fronteira" do litoral nordestino, enquanto espaço de crescimento dessa lavoura. Nesse sentido, mesmo se mantendo como importante região produtora, a tendência geral verificada para a Região Nordeste foi a de diminuição de sua participação no total do Brasil, uma vez que, com a reestruturação do setor, registrou-se uma queda da produção da agroindústria nordestina, em favor daquela localizada no Centro-Sul. Essa dinâmica provocou um recuo da área ocupada pela cultura da cana-de-açúcar na Região Nordeste, fazendo com que, nessa região, em algumas áreas, essa cultura fosse substituída por outras (mandioca, milho, frutas etc.).

Desse modo, pode-se afirmar que, na década de 2000, a reestruturação organizacional e produtiva do setor sucroalcooleiro brasileiro teve como principal estratégia a concentração e a centralização de sua produção na região Centro-Sul do País, formando e expandindo uma grande área produtora a partir de São Paulo. Essa dinâmica regional está consolidada em uma estratégia de mercado que ocasionou uma maior desigualdade entre as regiões, intensificando a desestruturação da produção do açúcar e do álcool em áreas de forte tradição no desenvolvimento da cultura da cana-de-açúcar. Esse é o caso da Região Nordeste, mas também de outras regiões, como o norte fluminense.

Com efeito, os espaços que concentraram a moderna infraestrutura do setor sucroalcooleiro tendem a se especializar na produção da cana-de-açúcar, por seu alto valor econômico, contribuindo, com isso, para o desenvolvimento de grandes monoculturas. Estas, por sua vez, desestruturam os sistemas agrícolas preexistentes, limitam as oportunidades de inserção no mercado de trabalho, contribuem para a redução da biodiversidade e concentram outros impactos ambientais, decorrentes da expansão dessas lavouras.

Nesse contexto, a análise censitária do período 1996-2006 refletiu uma realidade agropecuária marcada pela abertura da economia à concorrência internacional, pela redução e alteração das políticas públicas de apoio ao setor, por um maior aporte de capital 
estrangeiro - mas também nacional - e pelo uso de um padrão tecnológico de ponta, tanto biológico como mecânico. Destaque-se que, neste quadro, foram identificadas diversas características que marcaram a continuidade do processo de transformação técnico-econômica da agropecuária brasileira, iniciado em meados da década de $1960^{9}$.

Assim, apesar de variações locais pouco significativas, o nível de concentração da estrutura fundiária manteve-se elevado em todo o espaço agropecuário. Mesmo tendo sido reduzida a área total dos estabelecimentos, estes intensificaram suas produções. Apesar de a intensificação produtiva ter caracterizado o período, registraram-se também o avanço e a abertura de novas áreas de fronteira agrícola, no sentido norte/nordeste.

Com a valorização da atividade agropecuária, o predomínio dos estabelecimentos dirigidos pelos próprios proprietários aumentou. Apesar de o Brasil estar posicionado como um grande produtor mundial de alimentos e de matéria-prima, tendo por base uma produção agropecuária capitalista altamente tecnificada, era o trabalho familiar, e não o assalariado, a principal forma de emprego da mão de obra em 2006. Essa mão de obra, que representava $77 \%$ do total de trabalhadores rurais, de um modo geral, mantinha-se ligada à pequena produção. Esta última, apesar da heterogeneidade de situações no que diz respeito ao nível de modernização de seu processo produtivo, mantinha-se, em grande parte, atrelada ao mercado interno, voltando sua produção, basicamente, aos alimentos que compõem a cesta básica nacional.

Por fim, a série histórica da informação censitária, entre 1940 e 2006, revela que a agropecuária brasileira vem se modernizando a partir de diferentes modelos produtivos que, em comum, têm o fato de privilegiar a grande produção monocultora de alto valor comercial, destinada à exportação, enquanto a pequena produção de fraca inserção no mercado e/ou voltada à comercialização continua a ter papel relevante na produção alimentar para mercado interno. Se, em princípio, adotou-se um modelo de "substituições de importações", a partir de meados dos anos 1960, o setor rural passa a ser reconfigurado no padrão clássico da modernização conservadora, cujos princípios e estratégias locacionais definem, em grande parte, a geografia do espaço rural brasileiro na contemporaneidade.

\section{Referências}

ANUÁRIO ESTATÍSTICO DO BRASIL 1950. Rio de Janeiro: IBGE, ano XI, 1951. Disponível em: <http://biblioteca.ibge.gov.br/pt/biblioteca-catalogo?view=detalhes\&id=720>. Acesso em: fev. 2016.

BERNARDES, N. Características gerais da agricultura brasileira no século XX. Revista Brasileira de Geografia, Rio de Janeiro: IBGE, ano 49, p. 363-420, abr./jun. 1961. Disponível em: <http:// biblioteca.ibge.gov.br/visualizacao/monografias/GEBIS\%20-\%20RJ/RBG/RBG\%201961\%20 v23_n2.pdf>. Acesso em: jan. 2016.

\footnotetext{
9 Segundo Delgado (2012), esta transformação ocorreu principalmente no período de 1965 a 1980, caracterizado auge da "modernização conservadora".
} 
BRASIL. Lei n. 581, de 4 de setembro de 1850. (Vide Decreto n. 731, de 14 de novembro de 1850). Estabelece medidas para a repressão do trafico de africanos neste Império. Disponível em: <http://www.planalto.gov.br/ccivil_03/Leis/LIM/LIM581.htm>. Acesso em: fev. 2016.

CARVALHO, T. B.; DEZEN, S.; FERREIRA, P. C. caracterização da atividade pecuária de engorda nos principais países produtores de carne bovina. Trabalho apresentado no XLVI Congresso da Sociedade Brasileira de Economia, Administração e Sociologia Rural - SOBER, realizado em Rio Branco, 2008. Disponível em: <http://www.sober.org.br/palestra/9/571. pdf>. Acesso em: fev. 2016.

CENSO AGROPECUÁRIO 1940-2006. Rio de Janeiro: IBGE, 1940-2009. Disponível em: $<$ http://www.ibge.gov.br/home/estatistica/economia/agropecuaria/censoagro/default.shtm>. Acesso em: fev. 2016.

DELGADO, G. C. Do capital financeiro na agricultura à economia do agronegócio: mudanças cíclicas em meio século (1965-2012). Porto Alegre: Ed. da Universidade Federal do Rio Grande do Sul - UFRGS, 2012. 144 p.

FERNANDES, A. D. A dinâmica da fronteira agrícola em Goiás (1970-1985). 2006. 142 p. Dissertação (Mestrado em História)-Universidade Federal de Goiás, Goiânia, 2006.

GASQUES, J. G. et al. Desempenho e crescimento do agronegócio no Brasil. Brasília, DF: Instituto de Pesquisa Econômica Aplicada - IPEA, fev. 2004. (Textos para Discussão n, 1009). Disponível em: <http://www.ipea.gov.br/portal/images/stories/PDFs/TDs/td_1009. pdf>. Acesso em: fev. 2016.

GRAZIANO, J. da S. A Nova dinâmica da agricultura brasileira. Campinas, SP: Universidade Estadual de Campinas - UNICAMP, Instituto de Economia, 1996. 217 p.

MELLO, F. B. H. Políticas de desenvolvimento agrícola no Brasil. In: SAYAD, J. (Org.). Resenha de economia brasileira. São Paulo: Saraiva, 1979. p. 56.

MOTTA, M. Dicionário da terra. Rio de Janeiro: Civilização Brasileira, 2005. 515 p.

PORRO, R.; MESQUITA, B. A. de; SANTOS, I. de J. P. Expansão e trajetórias da pecuária na Amazônia: vales dos Rios Mearim e Pindaré - Maranhão. Brasília, DF: Ed. UnB, 2004.

PRODUÇÃO AGRÍCOLA MUNICIPAL: culturas temporárias e permanentes 2012. Rio de Janeiro: IBGE, v. 39, 2013. Acompanha 1 CD-ROM. Disponível em: <http://www.ibge.gov. br/home/estatistica/economia/pam/2012/default.shtm>. Acesso em: fev. 2016. 2014.

VALVERDE, O. Estudos de geografia agrária brasileira. Petrópolis: Vozes, 1985.

WILKINSON, J. A pequena produção e sua relação com os sistemas de distribuição. Trabalho apresentado no Seminário sobre políticas de Seguridad Alimentaria y Nutrición em América Latina, realizado em Campinas, SP, 2003. 


\title{
Recursos naturais e questões ambientais
}

\author{
Rosangela Garrido Machado Botelho (Coord.) \\ Judicael Clevelário Júnior (Coord.) $)^{1}$
}

A crescente preocupação com as questões ambientais no Brasil e no mundo, não só por parte dos pesquisadores e especialistas no assunto, mas também dos governantes e da população em geral, tem levado a uma reavaliação constante das formas de análise e, principalmente, de intervenção do homem no ambiente.

A constatação cada vez maior da ocorrência de danos ambientais e do comprometimento da quantidade e qualidade dos recursos naturais, essenciais à vida no planeta e ao desenvolvimento das sociedades, tem propiciado maior conscientização dos efeitos da ação humana sobre o meio e uma mudança gradativa na postura dos planejadores e agentes tomadores de decisão. Medidas protetoras e preventivas têm ganhado maior importância na avaliação e instalação de novos empreendimentos e atividades exploradoras. Contudo, há ainda muito a ser feito.

Neste capítulo, dedicado aos recursos naturais e às questões ambientais no Brasil, busca-se uma análise ambiental integrada dos mesmos de forma a permitir não só o conhecimento da dinâmica do meio físico e das inter-relações entre seus elementos, mas também da compreensão da relação entre sociedade e natureza.

\footnotetext{
1 A lista completa dos autores do capítulo se encontra na Equipe técnica ao final da publicação.
} 
Nesse sentido, o presente capítulo utiliza uma abordagem que ressalta a unidade presente da natureza e que é reconhecível por meio, inclusive, dos diversos mapeamentos temáticos amplamente realizados no País. Essa unidade, fruto da inter-relação entre os elementos naturais em uma dada área, reflete-se no aspecto do visível e pode ser identificada, e se manifesta também no espectro invisível, onde circulam matéria e energia, atuam processos e se estabelecem interações das mais diversas.

Assim, os diferentes elementos do meio físico-biótico são abordados, apresentados e discutidos de forma integrada segundo os biomas brasileiros (MAPA..., 2004a), onde os diversos aspectos ambientais são tratados buscando associações e inter-relações entre si e entre eles e a ocupação humana ao longo do tempo, que imprimiu no espaço geográfico ações, pressões, alterações e repercussões.

O bioma, palavra derivada do grego bio- (vida) + -oma (sufixo que pressupõe generalização; grupo, conjunto), deve ser entendido como um conjunto de vida (vegetal e animal) constituído pelo agrupamento de tipos de vegetação contíguos e identificáveis em escala regional, com condições geoclimáticas similares e história compartilhada de mudanças, resultando em uma diversidade biológica própria (MAPA..., 2004a).

A adoção do bioma como recorte territorial de análise reflete a preocupação com o conhecimento da biodiversidade e a conservação da biota no Brasil. Nos últimos 10 anos, houve um aumento considerável, na literatura, de referências sobre os biomas brasileiros. Por outro lado, inúmeras iniciativas voltadas para a indicação de áreas prioritárias para conservação ocorreram neste período, tendo como temática os biomas enfocados regionalmente. Ao mesmo tempo, o Ministério do Meio Ambiente tem atuado por meio de políticas que visam à conservação e utilização sustentável da diversidade biológica brasileira, evitando a destruição dos habitats naturais.

Ressalta-se, ainda, que a relevância na adoção dos biomas está direcionada para vários aspectos práticos, como constituir uma base sistematizada e uniforme de informações como referência para o estabelecimento de políticas públicas diferenciadas; o acompanhamento, pela sociedade, das ações a serem implementadas; e a análise de cenários e tendências em cada um desses conjuntos. Por outro lado, nesta publicação, cada bioma é apresentado e discutido segundo uma condição ou característica marcante, mas que ao mesmo tempo garante diversidade e aspectos particulares inerentes a cada unidade.

Ao apresentar cada bioma com suas unidades espaciais identificadoras, sejam elas as formações vegetacionais, as unidades morfoestruturais, os tipos de relevo ou as bacias hidrográficas, propicia-se ao leitor o reconhecimento da variabilidade interna existente em cada um deles e a possibilidade de estudos mais detalhados sobre os mesmos. 
Neste capítulo, busca-se, ainda, ressaltar o potencial ecológico de cada bioma, as transformações ocorridas e em curso, sejam elas de ordem natural ou relacionadas com as atividades antrópicas e, por fim, as implicações ambientais decorrentes da utilização social dos seus recursos naturais.

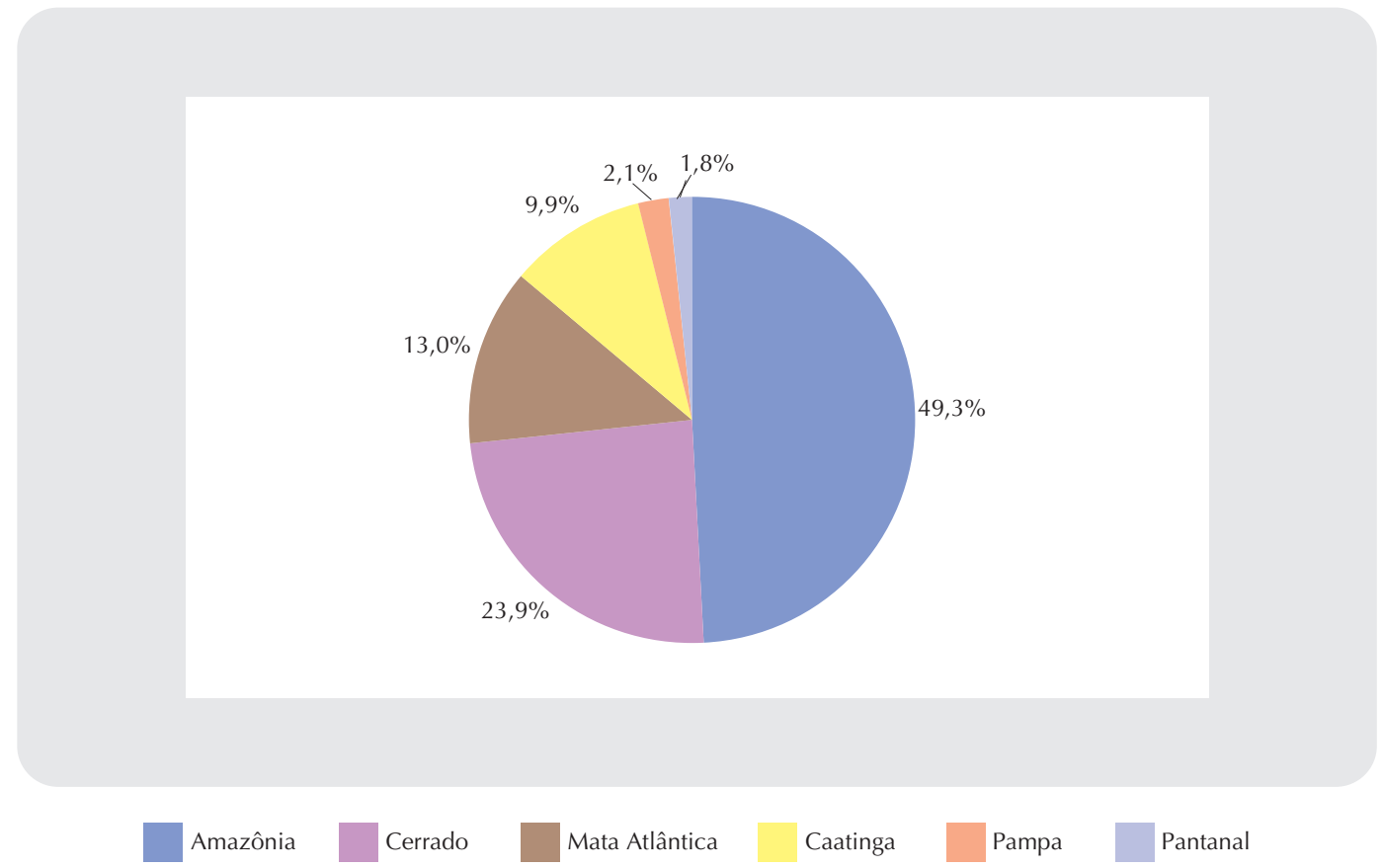

Figura 1 - Biomas brasileiros e área ocupada por cada um no Território Nacional. Gráfico elaborado pelos Autores com base no Mapa de biomas do Brasil: primeira aproximação (2004).

Nota: Ressalta-se, ainda, que a relevância na adoção dos biomas, enquanto vetor de diferenciação do território brasileiro (Figura 1), está direcionada para vários aspectos práticos, como constituir uma base sistematizada e uniforme de informações como referência para o estabelecimento de políticas públicas diferenciadas; o acompanhamento, pela sociedade, das ações a serem implementadas; e a análise de cenários e tendências em cada um desses conjuntos.

É preciso reconhecer que os elementos do meio físico-biótico estão em constante transformação, resultante das dinâmicas naturais e sociais que neles atuam, o que sugere a necessidade de constante atualização do seu conhecimento e funcionamento. Muitas das desigualdades socioeconômicas, verificadas hoje no território brasileiro, ou sucessos e insucessos de políticas públicas, por exemplo, podem ser melhor compreendidos à luz do conhecimento dos diferentes biomas e de suas particularidades, suas limitações e potencialidades de uso. 


\section{Amazônia: unidade e diversidade}

\section{Mapa 1 - Bioma Amazônia - Vegetação}

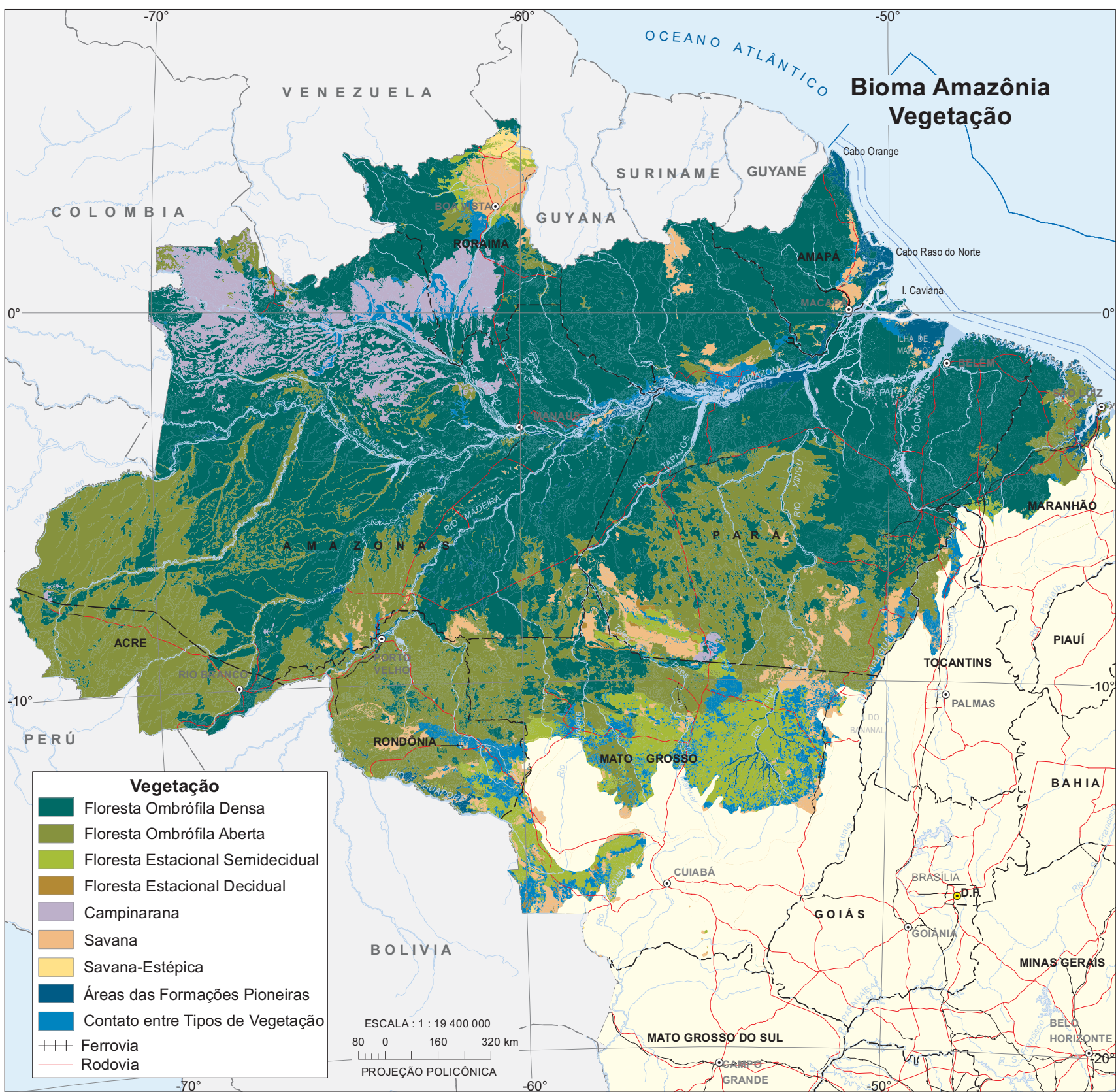

Fonte: IBGE, Diretoria de Geociências, Coordenação de Recursos Naturais e Estudos Ambientais.

O Bioma Amazônia, com uma área de 4196942 quilômetros quadrados, corresponde a 49,0\% do território brasileiro. Os fatores que o caracterizam e lhe conferem unidade são o clima dominante quente e úmido, a predominância da fisionomia florestal, a condição periequatorial e o próprio contexto da Bacia do Rio Amazonas, que possui a maior rede hidrográfica do planeta. A área desta bacia, de 7008370 quilômetros quadrados, desde as nascentes nos 
Andes peruanos até sua foz no Oceano Atlântico, corresponde a 5,0\% da superfície terrestre, equivalendo a $2 / 5$ da América do Sul, abrangendo, além do território brasileiro, terras da Colômbia, da Bolívia, do Equador, da Guiana, do Peru e da Venezuela. O Bioma Amazônia se estende por dois grandes domínios estruturais do continente sul-americano: a vasta área que constitui a Plataforma Sul-americana, a leste, e a Cordilheira dos Andes, a oeste. A geomorfologia do Bioma Amazônia é bastante variada, apresentando planaltos, planícies e depressões.

A Bacia Amazônica é delimitada ao norte pelo Maciço das Guianas, ao sul pelo Brasil Central, e a oeste pela Cordilheira dos Andes. Está situada na zona intertropical e recebe precipitações médias anuais de cerca de 2460 milímetros, com descarga líquida média estimada em 209000 metros cúbicos por segundo (AMORIM et al., 2005).

Num contexto sul-americano, o Bioma Amazônia se estende para além da Bacia do Rio Amazonas, abrangendo também parte da Bacia do Orinoco (sul e oeste) e da região das Guianas. Em território brasileiro, o Bioma Amazônia e a Bacia Amazônica se confundem, sendo quase sobrepostos em termos espaciais, com algumas diferenças, como é o caso do oeste do Maranhão, do norte do Amapá, do leste do Pará e do noroeste do Tocantins, que estão fora da Bacia Amazônica, e de parte do Estado de Mato Grosso, que pertence ao Bioma Cerrado.

Aproximadamente 65,0\% da Bacia Amazônica, que escoa cerca de 1/5 do volume de água doce do mundo, está em território brasileiro, área compartilhada por sete estados: Acre, Amazonas, Amapá, Rondônia e Roraima, em sua totalidade; 76,2\% do Pará; e $67,8 \%$ de Mato Grosso. Vale lembrar que, tradicionalmente, no Brasil, o nome Amazonas é dado ao rio a partir da junção com o Rio Negro (encontro das águas), próximo à Cidade de Manaus (Figura 2). Antes deste ponto, desde a fronteira com o Peru, o rio recebe a denominação de Solimões. Trata-se, entretanto, apenas de denominações diferentes, pois o curso de água é o mesmo.

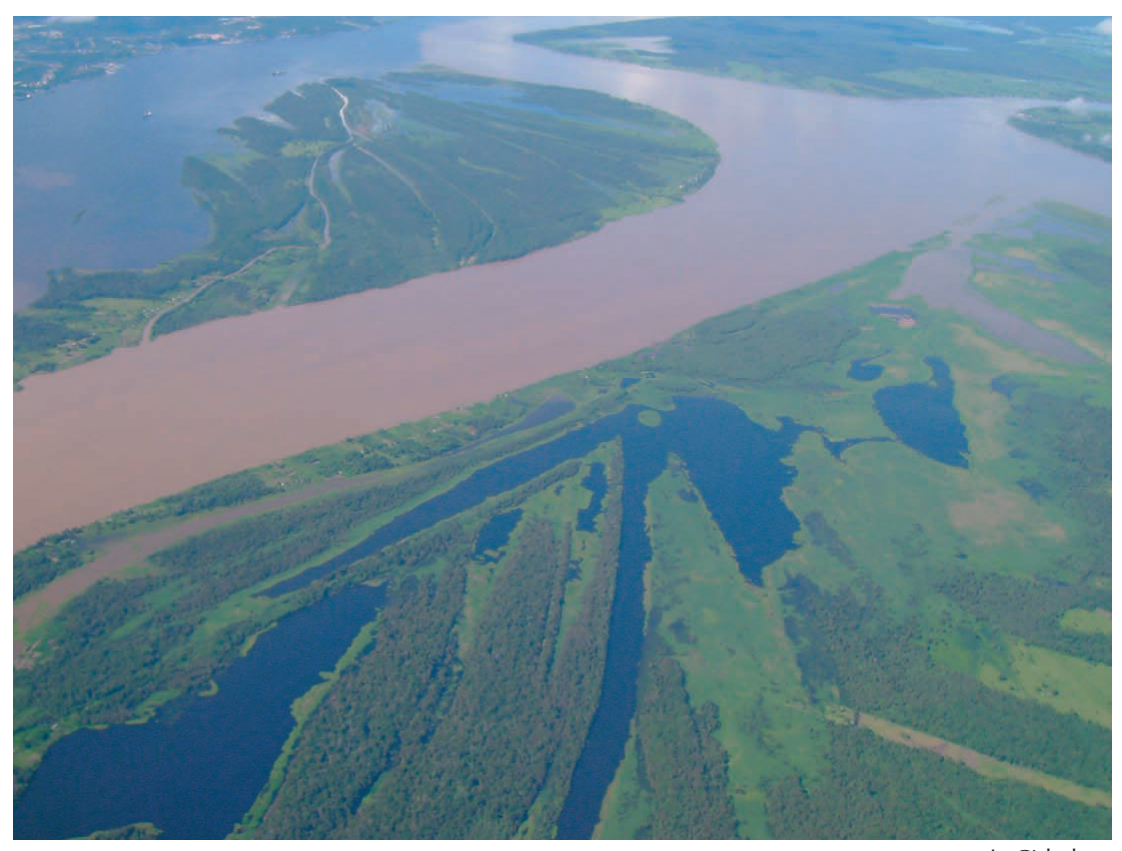

Figura 2 - Encontro das águas dos Rios Negro (à esquerda) e Solimões (à direita), às margens da Cidade de Manaus.

Foto: Rosangela Garrido Machado Botelho. 
Os rios permanentemente caudalosos são condicionados pelo regime das chuvas que caem na região, as quais, por sua vez, dependem da circulação atmosférica dentro da zona intertropical sul-americana e dos deslocamentos das massas de ar. A temperatura média oscila em torno de $25^{\circ}$ Célsius, com chuvas torrenciais bem-distribuídas por todo o ano. $\mathrm{O}$ período de chuvas ou de forte atividade convectiva, na maior parte da região amazônica, é compreendido entre novembro e março, e o período de seca (sem grande atividade convectiva) ocorre entre os meses de maio e setembro. Abril e outubro são meses de transição entre um regime e outro (FISCH et al., 2005 apud AMAZONAS, 2005).

Na Amazônia, 50,0\% da chuva é água que foi absorvida e transpirada pela floresta (SALATI; MARQUES; MOLION, 1978). Estima-se que, para a manutenção do atual regime de chuvas, seja necessário manter cerca de 70,0\% da cobertura florestal original (DIAS; COHEN; GANDU, 2005). Este dado mostra a importância que a floresta tem sobre os climas regional e continental e alerta para os riscos que o desmatamento pode trazer para a Amazônia. Alguns cientistas acreditam que a destruição maciça da floresta pode alterar o regime das precipitações nas áreas limítrofes do bioma, acentuando a sazonalidade das mesmas, com intensificação do período seco. Neste cenário, haveria uma contração da área de florestas remanescentes (especialmente das Ombrófilas) e expansão das áreas de Cerrado.

Nos últimos anos, a Amazônia tem experimentado um aumento de eventos climáticos extremos, com alternância, em curto espaço de tempo, de secas e cheias acentuadas. Em 2005 e 2010, ocorreram duas das secas mais severas já registradas na Amazônia Ocidental, com o ano de 2010 apresentando a vazante recorde do Rio Negro, desde 1902, quando foram iniciados os registros de vazão desse rio em Manaus (SERVIÇO GEOLÓGICO DO BRASIL, 2014). Segundo Carlos Nobre, pesquisador do Instituto Nacional de Pesquisas Espaciais - INPE, a seca de 2005 ocorreu devido a três fatores: aquecimento do oceano Atlântico, redução da transpiração das árvores e produção de fumaça pelas queimadas (MACEDO, 2005). A principal razão teria sido um aumento entre um e $2^{\circ}$ Celsius da temperatura das águas do Atlântico, ao norte da América do Sul, o que teria acarretado grande concentração de chuvas nesta região. O resultado seria um movimento descendente do ar em regiões próximas, como a Amazônia, e, consequentemente, a diminuição da formação de nuvens (SOUZA; ZANCHETTA, 2005).

Na seca de 2005, a pluviosidade teve redução de 8,47\%,27,86\% e 29,94\%, em relação aos anos anteriores, nos meses de maio, junho e julho, respectivamente (AMAZONAS, 2005). Segundo a Capitania dos Portos, essa foi a maior seca do Rio Madeira desde que se iniciaram as medições da vazão do rio, em 1960. Antes desta, a maior seca tinha sido a de 1968, quando a profundidade desse rio atingiu 2,14 metros em Porto Velho. Em 2005, atingiu 1,64 metro (AMAZONAS, 2005). Em outubro desse ano, o governo estadual decretou estado de calamidade pública nas cidades amazonenses.

Por sua vez, em 2012, foi registrada a maior cheia do Rio Negro em Manaus (SERVIÇO GEOLÓGICO DO BRASIL, 2014). Em 2004, foi a vez do Rio Madeira registrar uma cheia histórica, que inundou grandes extensões de terra na Bolívia e nos Estados de Rondônia e do Amazonas.

Vale ressaltar que a alta variabilidade das precipitações na Amazônia dificulta a identificação e caracterização de tendências de longo prazo, inclusive sobre a possível ocorrência de mudanças climáticas e sobre a influência das ações antrópicas (queimadas, desmatamento, represamento de rios etc.) no clima regional. Essa variabilidade, refletida nas vazões dos rios, pode ser observada na Figura 3, que mostra os picos de cheias e vazantes anuais para o Rio Negro na estação de Manaus. 


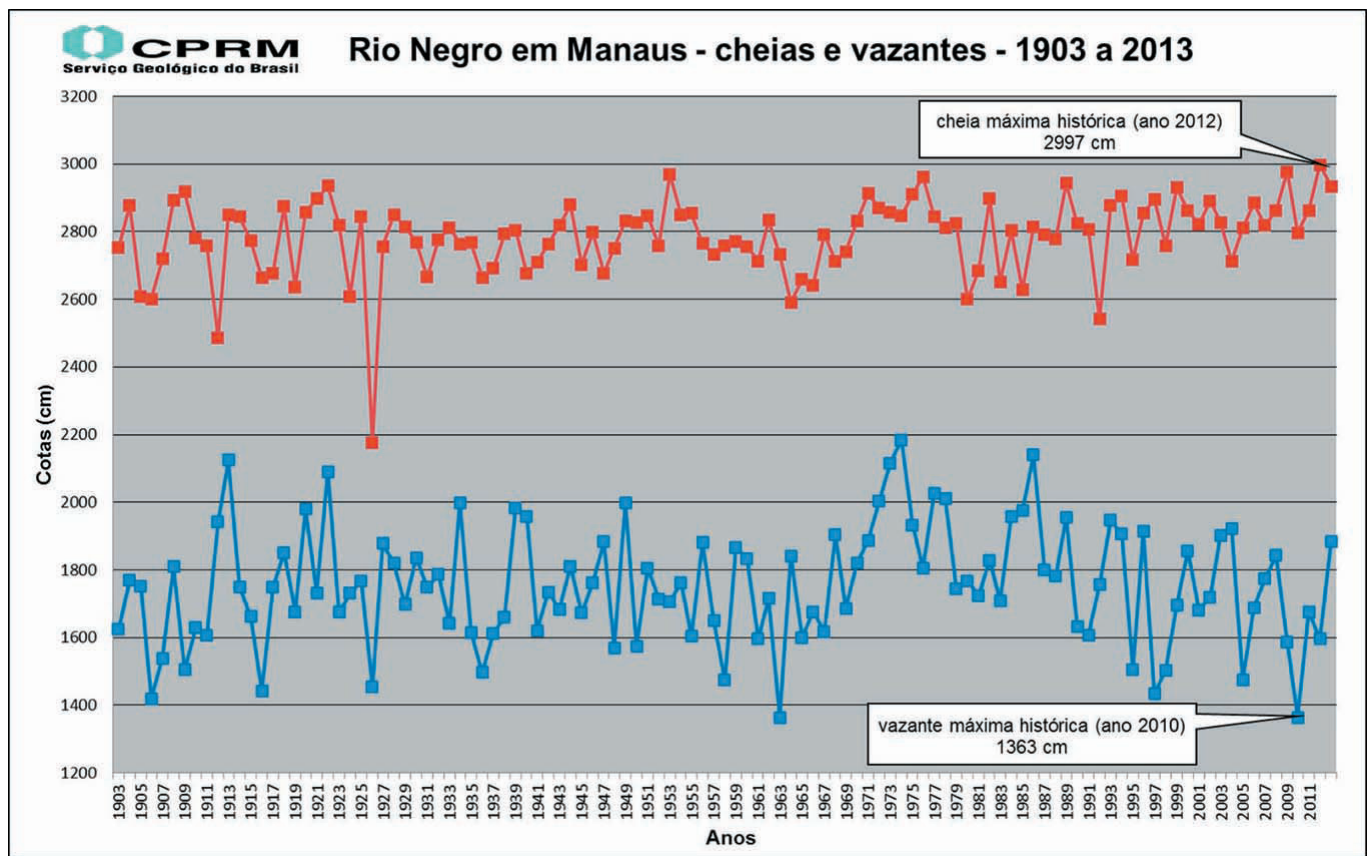

Figura 3 - Cotagrama com as cheias e vazantes em Manaus no período 1903-2013. Serviço Geológico do Brasil (2013)

A dinâmica ecológica conhecida como "pulso de inundação", caracterizada pela alternância de aproximadamente oito meses de águas altas e quatro meses de águas baixas, é a principal força motriz responsável pela produtividade das águas e pela complexidade espacial e sazonal dos ecossistemas aquáticos amazônicos e de suas zonas de transição terrestre-aquáticas (JUNK; BAYLEY; SPARKS, 1989).

A Bacia Amazônica é formada pelo Rio Amazonas, seus tributários e os lagos de várzea que interagem com os rios. Os rios e a várzea do Amazonas constituem um complexo de canais, rios, lagos, ilhas e depressões. Fazem parte deste complexo grandes extensões de terras alagadas e alagáveis, recobertas por variados tipos de vegetação (florestas inundadas, inundáveis, Campinaranas, campos etc.). O termo várzea é utilizado para caracterizar as planícies de inundação ao longo dos rios, enquanto o termo "terra firme" é usado para designar a área que está acima do limite de inundação e sustenta uma floresta específica e característica.

Com diferentes propriedades químicas e físicas, os rios da Amazônia são classificados de acordo com a cor de suas águas, distinguindo-se rios de águas claras, rios de águas brancas e rios de águas pretas. Sua diferença está relacionada, principalmente, com a quantidade de sedimentos transportados e com a composição química das águas, que, por sua vez, estão relacionadas a geologia, a geomorfologia e com os solos das bacias por elas drenadas.

2 Alguns autores (SIOLI, 1984) utilizam o termo várzea para planícies de inundação de rios de águas brancas, enquanto o termo igapó é usado para planícies de inundação de rios de águas claras e de águas pretas. 
Os rios de águas brancas drenam regiões geológicas jovens. Nascem nos contrafortes dos Andes, sob forte declive, como o Rio Solimões-Amazonas; ou no sopé dos Andes, como os Rios Juruá e Purus, com seus inumeráveis meandros e interminável construção/desconstrução de seu curso principal, e o Madeira, que recebe tributários de águas claras (AGÊNCIA NACIONAL DE ÁGUAS, 2012). Os rios de águas brancas têm cor barrenta e trazem sedimentos e nutrientes carreados dos solos relativamente recentes dos Andes, que são depositados ao longo do percurso, originando as várzeas. As águas brancas possuem visibilidade de 0,1 a 0,5 metro e pH 6,5 a 7,0.

Os rios de águas pretas nascem no Planalto das Guianas sobre rochas mais antigas e resistentes, ou na própria planície Amazônica, em áreas de baixíssima declividade e solos arenosos, ácidos e ricos em matéria orgânica, extremamente pobres em nutrientes, e escoam na direção sul. São rios escassos em sedimentos, com visibilidade entre 1,5 a 2,5 metros, com águas ácidas $(\mathrm{pH}<4,0)$ e coloração semelhante a uma infusão de chá forte, por causa da grande quantidade de matéria orgânica dissolvida, oriunda do solo e da vegetação de suas bacias. São exemplos de rios de águas pretas o Negro e seus tributários, o Uatumã e o Manacapuru, entre outros. Ao longo dos extensos igapós de rios de águas pretas é comum a presença da vegetação de Campinarana.

Os rios de águas claras têm sua origem em regiões geologicamente antigas dos Planaltos Central e das Guianas. Particularmente, os que descem do Planalto Central na direção norte são pobres em sedimentos, com visibilidade superior a 4 metros e pH entre 4,0 e 7,0, mas, em certos trechos, assumem uma composição intermediária entre os rios de águas brancas e os de águas pretas. São exemplos de rios de águas claras o Xingu, o Tapajós e o Tocantins-Araguaia.

Situada na Região Neotropical ${ }^{3}$, a vegetação do Bioma Amazônia é predominantemente, e não exclusivamente, florestal (Figura 4). Abriga uma surpreendente diversidade de plantas, animais, fungos, bactérias e uma gama de outros microrganismos que contribuem para o balanço ecológico desse bioma e que, em integração com o meio físico, representam, para a humanidade, um dos recursos naturais de maior importância ecológica, cultural e socioeconômica.

A manutenção dessa biodiversidade é importante tanto no plano global quanto local, com efeitos significativos para a região, para o País e para o planeta, funcionando como um verdadeiro estoque de material genético para o campo biotecnológico, para o desenvolvimento de produtos alimentícios, aromáticos, cosméticos, oleaginosos e medicinais. A importância desse bioma em termos globais é reforçada pelo seu estoque e sua capacidade de fixação de carbono, que contribui para amenizar o aquecimento global, e pelo papel que exerce no ciclo hidrológico. Pela transpiração da floresta, grandes quantidades de vapor d'água e calor são transferidas para a atmosfera, tornando-se fundamentais para a manutenção das características atuais do clima regional da América do Sul e mundial.

\footnotetext{
3 Segundo Magalhães (2007, p. 108), Neotropical é a "região que compreende a América Central, incluindo a parte sul do México e da península da Baixa Califórnia, o sul da Florida, todas as ilhas do Caribe e a América do Sul. Apesar do seu nome, esta região inclui, não só sub-regiões de clima tropical, mas também de climas temperado e de altitude".
} 


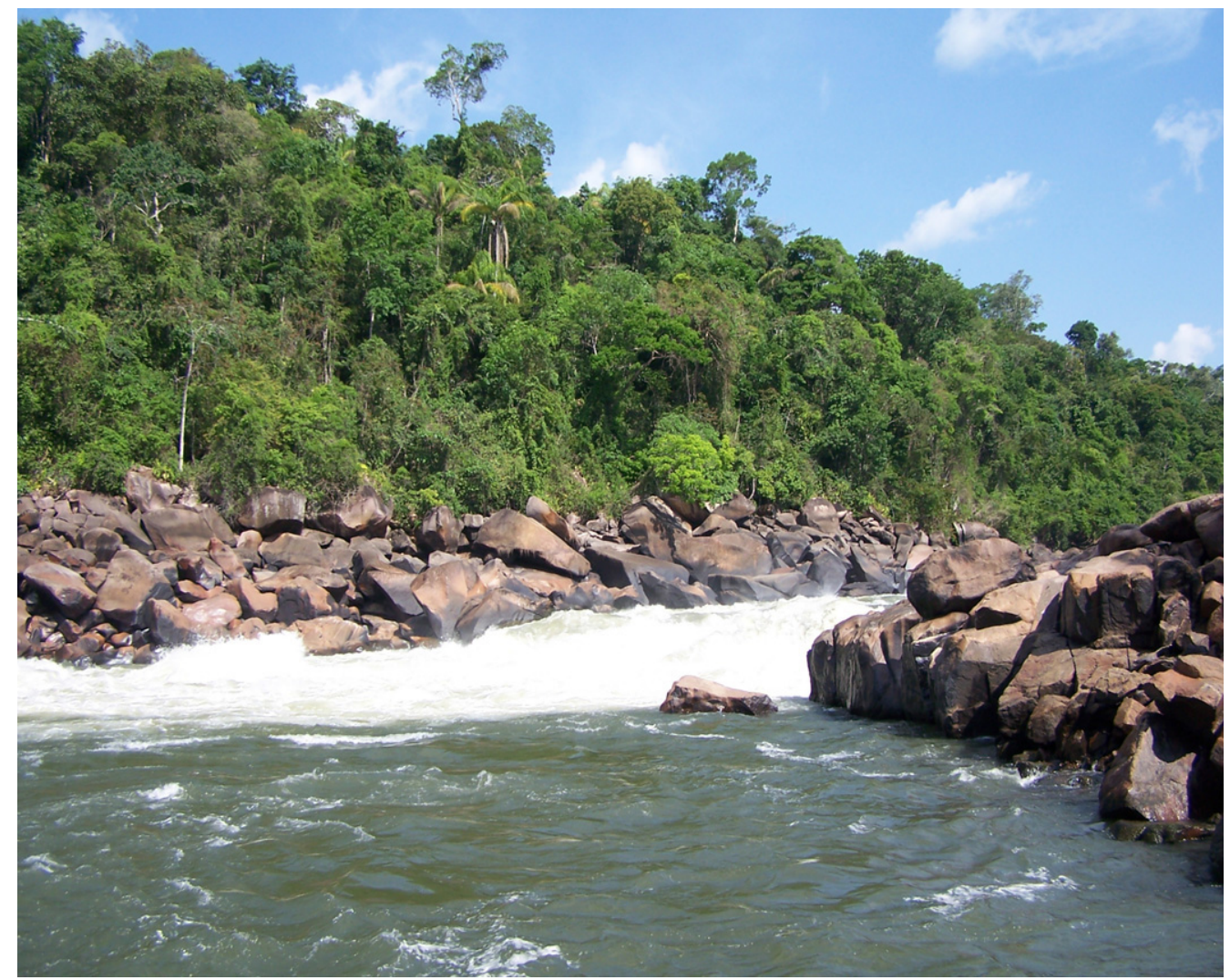

Figura 4 - Floresta Ombrófila Densa, às margens do Rio Teles Pires, na divisa entre os Estados de Mato Grosso e do Pará. Foto: José Carlos Louzada Morelli.

Dentro do Bioma Amazônia estão presentes as seguintes tipologias vegetacionais (ver Quadro 1): Floresta Ombrófila Densa; Floresta Ombrófila Aberta; Floresta Estacional Sempre-Verde; Floresta Estacional Semidecidual; Floresta Estacional Decidual; Campinarana; Savana; Savana Estépica; Formações Pioneiras; e Refúgio Vegetacional. No bioma, também se encontram as seguintes Áreas de Tensão Ecológica: Contato Floresta Ombrófila/Floresta Estacional, Contato Campinarana/Floresta Ombrófila, Contato Savana/Floresta Ombrófila, Contato Savana/Floresta Estacional, Contato Savana Estépica/Floresta Estacional. Ressalta-se, contudo, que as fisionomias vegetais usadas para delimitar o Bioma Amazônia foram as Florestas Ombrófilas e as Estacionais. As demais fitofisionomias presentes no bioma foram incluídas por estarem circundadas por áreas florestais ou por apresentarem predominância florestal, como é o caso das áreas de tensão ecológica.

Entretanto, historicamente, o Bioma Amazônia vem sofrendo um processo de descaracterização, devido ao desmatamento decorrente do modo de ocupação e de uso da terra. Assim, parte das fisionomias vegetais originais, especialmente as Florestas Estacionais, encontra-se devastada ou alterada, sendo considerada área sob antropismo (Tabela 1). Verifica-se, portanto, que na virada do milênio, o Bioma Amazônia apresentava 82,0\% de sua área coberta com a vegetação original, 16,0\% constituíam área antropizada e 2,0\% correspondiam à superfície coberta com água. 
Tabela 1 - Áreas remanescentes e áreas antropizadas, no Bioma Amazônia, segundo os tipos de vegetação

\begin{tabular}{|c|c|c|c|c|c|c|}
\hline \multirow{3}{*}{ Tipos de vegetação } & \multicolumn{6}{|c|}{ Bioma Amazônia } \\
\hline & \multicolumn{2}{|c|}{ Total no Bioma } & \multicolumn{2}{|c|}{ Área remanescente } & \multicolumn{2}{|c|}{ Área antropizada } \\
\hline & $\begin{array}{c}\mathrm{Em} \\
\mathrm{km}^{2}\end{array}$ & $\begin{array}{c}\text { Percentual } \\
(\%)\end{array}$ & $\begin{array}{c}\mathrm{Em} \\
\mathrm{km}^{2}\end{array}$ & $\begin{array}{c}\text { Percentual } \\
(\%)\end{array}$ & $\begin{array}{c}\mathrm{Em} \\
\mathrm{km}^{2}\end{array}$ & $\begin{array}{l}\text { Percentual } \\
(\%)\end{array}$ \\
\hline Área total do bioma & 4196942 & 100,0 & 3424169 & 82,0 & 671503 & 16,0 \\
\hline Floresta Ombrófila Densa & 2101804 & 50,0 & 1770131 & 84,0 & 331673 & 16,0 \\
\hline Floresta Ombrófila Aberta & 960201 & 23,0 & 801179 & 83,0 & 159022 & 17,0 \\
\hline Floresta Estacional Semidecidual & 68154 & 2,0 & 13794 & 20,0 & 54360 & 80,0 \\
\hline Floresta Estacional Decidual & 6104 & $<0,5$ & 4491 & 74,0 & 1613 & 26,0 \\
\hline Campinarana & 107173 & 3,0 & 107173 & 100,0 & - & - \\
\hline Savana & 102755 & 2,0 & 97637 & 95,0 & 5118 & 5,0 \\
\hline Savana estépica & 10042 & $<0,5$ & 10042 & 100,0 & - & - \\
\hline Formações pioneiras & 89498 & 2,0 & 89498 & 100,0 & - & - \\
\hline Contatos entre tipos de vegetação & 646752 & 15,0 & 527035 & 81,0 & 119717 & 19,0 \\
\hline Refúgios vegetacionais & 3190 & $<0,5$ & 3190 & 100,0 & - & - \\
\hline Superfície com água & 101270 & 2,0 & - & - & - & - \\
\hline
\end{tabular}

Fonte: Mapa de biomas do Brasil: primeira aproximação. Rio de Janeiro: IBGE, 2004. 1 mapa. Escala 1:5 000 000. Disponível em: <ftp://geoftp.ibge.gov.br/informacoes_ambientais/vegetacao/mapas/brasil/biomas.pdf>. Acesso em: jul. 2016.

Notas: 1 . Corresponde a 49,0\% da área total do País.

2. Data média de referência: ano 2000.

3. Exclusive a Floresta Estacional Sempre-Verde que ainda não teve sua área delimitada.

A vegetação mais característica do Bioma Amazônia é a Floresta Ombrófila Densa, um dos tipos de mata de terra firme. Ocorre em toda a área central do bioma, ao longo da calha do Rio Solimões-Amazonas e principais afluentes, sendo composta, em geral, por árvores altas, sempre verdes, perenifólias, com dossel que pode ou não apresentar árvores emergentes. A maioria das plantas de porte baixo, quando ocorrem, constitui-se de árvores imaturas, em crescimento, resultantes de matrizes próximas. Apesar da exuberância da vegetação, há predomínio absoluto de solos das classes Latossolo e Argissolo (ver Quadro 2), majoritariamente com baixa fertilidade natural (PROJETO..., 1990; MAPA..., 2001). Solos de textura superficial média são predominantes, seguidos pelos de textura argilosa e arenosa, merecendo destaque a textura cascalhenta de ocorrência significativa nos solos do Estado de Roraima (BOTELHO; MACEDO, 2009). Os Latossolos Amarelos, associados a litologias da Formação Alter do Chão, principalmente, ocupam extensas áreas ao longo do Rio Amazonas. O processo de subsidência termal que se seguiu à fragmentação do Gondwana, originou a Bacia Mesozoica Alter do Chão, desenvolvida sobre a Bacia do Amazonas, e a Bacia Mesozoica Ramon sobre a Bacia do Solimões. Na Formação Alter do Chão formaram-se, por alteração supergênica, magníficos depósitos de bauxita e caulim, com grandes jazidas e minas no Pará. As Bacias Geológicas do Amazonas e Solimões formam a grande Província Sedimentar que separa o Cráton Amazônico em dois grandes escudos: ao norte, o Escudo das Guianas e, ao sul, o Escudo do Brasil Central. A Bacia Sedimentar do Amazonas, que deve seu nome ao Rio Amazonas, artéria principal da bacia hidrográfica homônima, ocupa uma área de cerca de 500000 quilômetros quadrados nos Estados do Amazonas, do Pará e do Amapá. 


\section{Quadro 1 - Caracterização dos tipos de vegetação que ocorrem nos biomas brasileiros, de acordo com o Mapa de biomas do Brasil (2004) e Manual de técnico da vegetação brasileira (2012)}

FLORESTA OMBRÓFILA DENSA - ocorre sob clima tropical quente e úmido, sem período biologicamente seco, com chuvas bemdistribuídas durante o ano e temperaturas médias variando entre $22^{\circ}$ e $25^{\circ}$ Celsius. É caracterizada pela presença de árvores de grande e médio portes, além de trepadeiras e epífitas em abundância.

FLORESTA OMBRÓFILA ABERTA - ocorre em áreas com período seco entre dois a quatro meses e temperaturas médias entre $24^{\circ} \mathrm{e}$ $25^{\circ}$ Celsius. É caracterizada pela fisionomia florestal composta por árvores mais espaçadas e estrato arbustivo pouco denso. Apresenta quatro faciações decorrentes da presença de palmeiras, cipós, bambus e sororocas (planta semelhante à bananeira).

FLORESTA OMBRÓFILA MISTA - ocorre nos planaltos do sul do Brasil, cujas temperaturas médias anuais estão em torno de $18^{\circ}$ Celsius, alcançando menos de $15^{\circ}$ Celsius em um período que varia de três a seis meses. É caracterizada por uma rica mistura florística na qual se destacam as duas únicas coníferas brasileiras, a araucária e o pinheirinho.

FLORESTA ESTACIONAL SEMPRE-VERDE - apresenta alto verdor no período de estiagem. Ocorre no Estado de Mato Grosso e se estende por toda a região da Bacia Sedimentar dos Parecis, parte das depressões do Guaporé, do Paraguai, do Araguaia e do Planalto de Tapirapuã. A vegetação é constituída por espécies essencialmente amazônicas que revelam ausência ou baixa decidualidade durante o período de estiagem.

FLORESTA ESTACIONAL SEMIDECIDUAL - ocorre sob clima estacional menos chuvoso, ou seja, marcado por alternância de períodos quente e úmido/quente e seco, na zona tropical, e quente e úmido/frio e seco, na zona subtropical. Esta estacionalidade atinge os elementos arbóreos dominantes, levando, no período desfavorável, à perda de 20,0 a $50,0 \%$ das folhas do conjunto florestal.

FLORESTA ESTACIONAL DECIDUAL - seu conceito é idêntico ao da Floresta Estacional Semidecidual, porém com o período desfavorável mais acentuado, podendo a seca atingir mais de cinco meses (com temperaturas médias inferiores a $15^{\circ}$ Celsius) na região subtropical. Tais condições resultam em que mais de 50,0\% das árvores do conjunto florestal percam as folhas.

CAMPINARANA - condicionada pelo clima quente e superúmido com chuvas torrenciais (cerca de 4000 milímetros anuais) e altas temperaturas (médias superiores a $25^{\circ}$ Celsius). É caracterizada por agrupamentos de vegetação arbórea fina e alta, cuja fisionomia raquítica é resultante da baixa concentração de nutrientes minerais no solo.

SAVANA (Cerrado) - ocorre predominantemente em climas estacionais tropicais com período seco entre três a sete meses. Sua distribuição está relacionada também a solos, na maioria profundos e pobres em nutrientes. Em geral, apresenta dois estratos distintos: um arbóreo lenhoso xeromorfo, formado por árvores de pequeno e médio portes, troncos e galhos tortuosos, folhas rígidas e brilhantes ou revestidas por densa camada de pelos, e raízes profundas. O outro estrato é gramíneo-lenhoso composto predominantemente por ervas e arbustos baixos. Apresenta variedade estrutural alta, com grandes diferenças em porte e densidade, influenciadas inclusive pela intensidade da ação antrópica (uso do fogo).

SAVANA ESTÉPICA - tipologia vegetal estacional decidual aberta, com espécies lenhosas espinhosas, entremeadas de plantas suculentas, sobretudo cactáceas, que crescem sobre solos rasos e quase sempre pedregosos. As árvores são baixas, raquíticas, com troncos finos e esgalhamento profuso. Muitas espécies são microfoliadas, e outras possuem espinhos (adaptações à escassez de água).

ESTEPE - ocorre no sul do Brasil, onde as plantas são submetidas a uma dupla condição de estacionalidade, uma pelo frio outra pela seca. O termo estepe tem origem russa e sua adoção no Brasil baseia-se na fisionomia da vegetação, homóloga à estepe daquele país, embora com florística diversa daquela. É caracterizada por uma vegetação essencialmente campestre em que predominam as gramíneas, com ocorrência de espécies lenhosas deciduais espinhosas.

FORMAÇÕES PIONEIRAS - relacionam-se às áreas pedologicamente instáveis submetidas aos processos de acumulação fluvial, lacustre, marinha e fluviomarinha. Estas áreas são cobertas por uma vegetação de primeira ocupação, condicionada pelo tipo de solo, formada por plantas adaptadas às condições ecológicas locais. Entre as pioneiras estão incluídas a vegetação da restinga, do mangue, dos campos salinos e das várzeas.

REFÚGIOS VEGETACIONAIS - tipologia vegetal diferente da vegetação regional dominante, nos aspectos florísticos e fisionômicos, por condições ecológicas especiais existentes em determinados locais, sendo considerada como "refúgio ecológico". Constitui, às vezes, uma "vegetação relíquia", que persiste em situações muito especiais (caso das comunidades de plantas situadas em altitudes acima de 1800 metros).

ÁREAS DE TENSÃO ECOLÓGICA - contatos entre tipos de vegetação, que podem ocorrer na forma de ecotono, quando a transição se dá por uma mistura florística, ou na forma de encrave, quando existe uma interpenetração em "mosaico" dos tipos de vegetação.

Fonte: Mapa de biomas do Brasil: primeira aproximação. Rio de Janeiro: IBGE, 2004. 1 mapa. Escala 1:5 000 000. Disponível em <ftp://geoftp.ibge.gov.br/informacoes_ambientais/vegetacao/mapas/brasil/biomas.pdf>. Acesso em: jul. 2016. 


\section{Quadro 2 - Caracterização sucinta dos principais solos brasileiros de acordo com o Sistema brasileiro de classificação de solos (2013)} ARGISSOLOS - solos com movimentação de argila no perfil, do horizonte superficial A para o subsuperficial (B textural),
geralmente acompanhada de boa diferenciação de cores. As cores do horizonte B variam de acinzentadas a avermelhadas, e as do
A são sempre mais escurecidas. A profundidade destes solos é variável, mas, comumente, não ultrapassa os 200 centímetros.

CAMBISSOLOS - solos em estado inicial de desenvolvimento e, por isso, apresentam grande variação quanto à profundidade demais características. Podem apresentar qualquer tipo de horizonte A sobre um horizonte B incipiente (pouca alteração física e química). Muitas vezes são pedregosos, cascalhentos e mesmo rochosos. Ocorrem preferencialmente em regiões serranas ou montanhosas.

CHERNOSSOLOS - solos com pequena ou média profundidade, caracterizados pela presença de horizonte superficial A do tipo chernozêmico (teores consideráveis de matéria orgânica, cores escurecidas e boa fertilidade), sobre horizontes subsuperficiais avermelhados ou escurecidos, com argila de alta atividade.

ESPODOSSOLOS - solos com diferenciação significativa entre os horizontes e presença de horizonte espódico (de acumulação de ferro e/ou matéria orgânica) de cores escurecidas ou avermelhadas/amareladas, precedido de um horizonte eluvial E (de cores claras) ou A. O horizonte espódico ocorre a profundidades variáveis. Em geral, são solos de baixa fertilidade e com textura arenosa.

GLEISSOLOS - solos característicos de áreas alagadas ou sujeitas a alagamento (margens de rios, ilhas, planícies etc.). Apresentam cores acinzentadas, azuladas ou esverdeadas, dentro de 50 centímetros da superfície. Podem ser de alta ou baixa fertilidade natura e drenagem deficiente.

LATOSSOLOS - solos, em geral, muito intemperizados, profundos, de boa drenagem e com argila de baixa atividade. Apresentam grande homogeneidade de características ao longo do perfil. Diferenciam-se entre si principalmente pela coloração e teores de óxidos de ferro em Latossolos Brunos, Amarelos, Vermelhos e Vermelho-Amarelos.

LUVISSOLOS - solos de profundidade média, com cores desde vermelhas a acinzentadas, horizonte B textural (sob horizonte A ou E), com argila de alta atividade e boa fertilidade. A mineralogia das argilas condiciona certo fendilhamento em alguns perfis nos períodos secos.

NEOSSOLOS - solos pouco evoluídos, com reduzida expressão dos atributos diagnósticos e exígua diferenciação de horizontes, com horizonte A sobre C ou R (rocha). Congregam solos rasos, Neossolos Litólicos; ou profundos e arenosos, Neossolos Quartzarênicos; ou com presença considerável de minerais primários de fácil intemperização, Neossolos Regolíticos; ou ainda, solos constituídos por sucessão de camadas aluvionares, sem relação pedogenética entre si, Neossolos Flúvicos.

NITOSSOLOS - caracterizados pela presença de horizonte B nítico, com moderado ou forte desenvolvimento estrutural, em prismas ou blocos, e com as superfícies dos agregados reluzentes, relacionadas à presença de cerosidade ou superfícies de compressão. São argilosos ou muito argilosos. Possuem argila de atividade baixa ou caráter alítico (associado a um expressivo teor de alumínio no solo)

ORGANOSSOLOS - solos pouco evoluídos, com predomínio de material orgânico, proveniente de acumulação de restos vegetais em variado grau de decomposição, em ambientes mal drenado, ou ambientes úmidos de altitude elevada, que ficam saturados por poucos dias no período chuvoso. Têm coloração preta, cinzenta muito escura ou marrom.

PLANOSSOLOS - solos minerais mal drenados, com horizonte superficial A e/ou subsuperficial eluvial E, que contrasta abruptamente, em termos texturais, com o horizonte B subjacente, adensado, com acentuada concentração de argila e permeabilidade lenta.

PLINTOSSOLOS - solos com presença expressiva de plintita, com ou sem petroplintita (concreções de ferro ou cangas). Estes solos apresentam drenagem restrita, identificada principalmente por mosqueado ou variegado de cores, de tons desde vermelhos a acinzentados. Parte desses solos (Plintossolos Pétricos) apresentam horizonte diagnóstico concrecionário ou litoplíntico (presença de petroplintita)

VERTISSOLOS - solos minerais com horizonte vértico, comumente argiloso ou muito argiloso, com presença de fendas no perfi como consequência da expansão e contração das argilas, superfícies de fricção (slickensides) e estrutura fortemente desenvolvida, do tipo prismática. Apresentam cores de escuras a amareladas, acinzentadas ou avermelhadas.

Fonte: Sistema brasileiro de classificação de solos. 3. ed. rev. e ampl. Brasília, DF: Empresa Brasileira de Pesquisa Agropecuária Embrapa Informação Tecnológica; Rio de Janeiro: Embrapa Solos, 2013.

O conjunto rochoso que compõe a borda sul da Bacia do Amazonas, sob influência do clima predominantemente úmido, favoreceu o desenvolvimento do manto de alteração, resultando em formações superficiais geralmente profundas. Esses fatores propiciaram a evolução de modelado de feições de topos aguçados e convexos com vertentes convexas ravinadas. Os processos mais eficazes na esculturação da convexidade das vertentes foram o escoamento superficial difuso e o rastejamento. 
Vários trabalhos técnico-científicos (SOMBROEK, 1962; FOLHA..., 1976; FUNDAÇÃO CENTRO TECNOLÓGICO DE MINAS GERAIS, 1986) têm mostrado particularidades desses Latossolos Amarelos, dentre elas o fato de serem alguns dos solos mais argilosos do Brasil (chegando, em alguns platôs, a teores de argila superiores a 90,0\%) e apresentarem, em certos locais, horizonte A do tipo antrópico, desenvolvido pela ação de povos indígenas muito antigos, no qual a presença de fragmentos de cerâmica e os teores de matéria orgânica e fósforo elevados são características distintivas. Solos com esse tipo de horizonte superficial receberam, por muito tempo, a denominação "Terra Preta de Índio" (Figura 5) e eram cobiçados pelos primeiros colonizadores da Amazônia devido à sua maior fertilidade, em contraste com a pobreza em nutrientes dos solos amazônicos mais comuns. A chamada Terra Preta de Índio é um testemunho claro de que as populações pré-colombianas da Amazônia manejavam eficientemente os recursos naturais, favorecendo as atividades humanas, com um mínimo de dano ao ambiente. O resgate e a procura de tecnologias desse tipo, que favorecem a ocupação humana e causam baixo impacto ambiental, devem nortear o processo de ocupação e de desenvolvimento da Amazônia no Século XXI.

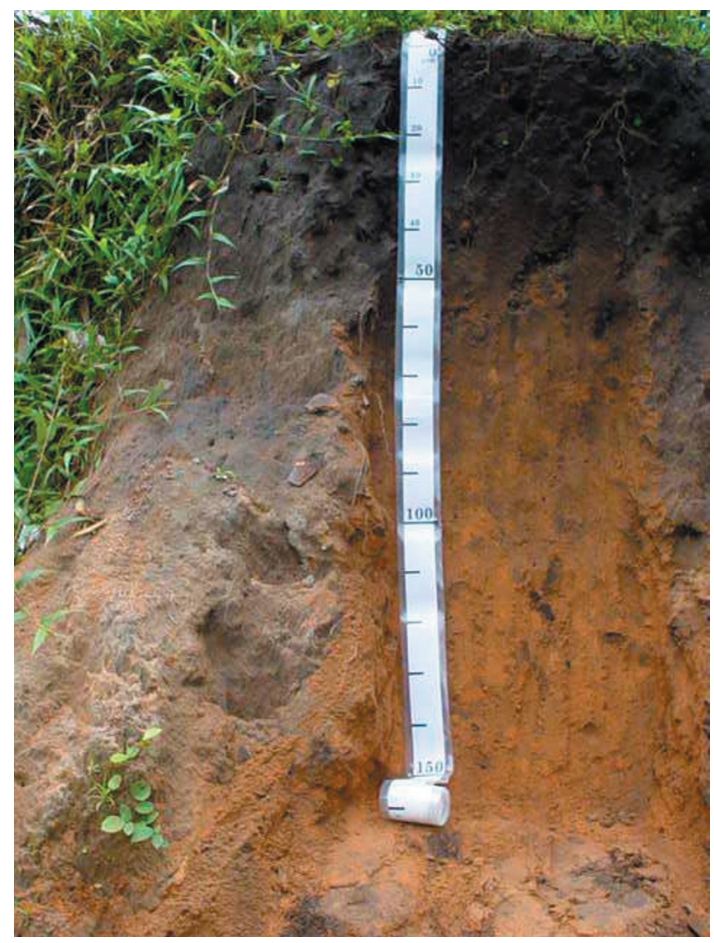

Figura 5 - Perfil de Latossolo Amarelo Distrófico típico (Terra Preta de Índio), Parintins (AM).

Foto: Virlei Álvaro de Oliveira.

Os Argissolos, outra classe comum nas áreas de floresta ombrófila, são predominantemente alumínicos e alíticos, ou seja, com teores muito elevados de alumínio trocável $(>4 \mathrm{cmol} / \mathrm{cg}$ ), ocorrendo na altura do médio e baixo curso dos Rios Solimões, Juruá e Purus. Vale ressaltar que o excesso de alumínio trocável no solo é prejudicial ao desenvolvimento da maior parte das plantas cultivadas. 
As variações mais marcantes da tipologia florestal ocorrem nas planícies que acompanham o Rio Amazonas e seus grandes afluentes, onde se encontram as formações regionalmente conhecidas como mata de várzeas e mata de igapó. Ambas têm como condicionante a flutuação cíclica do nível dos rios, que pode atingir até 17 metros no Rio Madeira e 15 metros em Manaus, entre as estações de seca e de enchente, resultando em inundações de grandes áreas ao longo de suas margens. Sob essas matas, encontram-se solos hidromórficos e semi-hidromórficos, que ocorrem nas inúmeras ilhas fluviais e imensas planícies de inundação posicionadas ao longo de praticamente todos os rios, inclusive na llha de Marajó, na foz do Amazonas. A respeito destes solos, é importante destacar a grande riqueza química de alguns, mormente daqueles posicionados ao longo dos rios que têm o seu curso no sentido oeste-leste, cujos sedimentos formadores provêm da Região Andina (rios de águas brancas).

Ao longo dos cursos de água, também são encontrados terraços fluviais, que representam planícies antigas (subatuais) emersas. Morfologicamente, os terraços fluviais se distinguem das planícies fluviais, que são áreas mais baixas, sujeitas a inundações periódicas pelas chuvas e enchentes dos rios, quando há grandes aportes de sedimentos, formando faixas de deposição atual. Eventualmente, a delimitação entre esses dois tipos de feição torna-se difícil por não ocorrerem quebras significativas de declividade. As planícies mais expressivas ocorrem ao longo dos rios maiores, como o Solimões e seus tributários da margem direita. Também neste caso, as interferências neotectônicas desempenham um papel relevante, determinando a formação de extensas e largas planícies nas áreas rebaixadas, com estreitamento nas soerguidas. A planície do Rio Solimões na região da Reserva de Mamirauá, margem esquerda do Solimões, a oeste de Manaus, chega a apresentar 80 quilômetros de largura devido à adaptação a uma estrutura do tipo graben ${ }^{4}$, cujas falhas, ainda ativas, determinam a migração do curso principal para sudoeste e a formação de terraços a nordeste. Nessas áreas, a planície fluvial adquire características fluviolacustres, situação que se repete no Rio Amazonas a montante de áreas soerguidas, como entre Santarém e Gurupá. Nessas áreas, há registros recentes de atividade sísmica.

Nas áreas sujeitas à inundação, os processos hidrodinâmicos são bastante atuantes, o que restringe sua utilização. Aliado a este fato, torna-se conveniente lembrar que a proteção dessas áreas é garantida por lei. Quando localizadas às margens de rios que drenam as rochas do Cráton Amazônico, apresentam grande importância do ponto de vista econômico, pois geralmente abrigam acumulações de minerais pesados de alto valor, como ouro, diamante e cassiterita, entre outros. Esta característica, no entanto, é a indutora de um dos grandes problemas ambientais verificados na Amazônia: a contaminação dos cursos de água pelo mercúrio utilizado na recuperação do ouro por garimpeiros. A atividade garimpeira provoca também o desbarrancamento das margens, causando assoreamento dos rios. Além disso, conflitos sociais decorrentes das atividades garimpeiras são muito comuns, como a ocupação desordenada das periferias dos centros urbanos por garimpeiros e seus familiares, a prostituição, inclusive infantil, alcoolismo, homicídios, invasão de terras indígenas e de áreas destinadas à preservação ambiental.

\footnotetext{
4 Graben ou fossa tectônica constitui um compartimento da crosta terrestre afundado entre falhas ou degraus de falhas geológicas (PENTEADO, 1980).
} 
Os terraços, por sua vez, são muito importantes do ponto de vista social, pois sobre eles se assenta a maior parte da população ribeirinha, que depende da caça, da pesca e do plantio de culturas de ciclo curto (arroz, milho, mandioca). São importantes também porque constituem excelentes indicadores de movimentação neotectônica, evidenciada pela retilineidade de canais e pela ocorrência de terraços em apenas uma das margens dos grandes rios. Os exemplos mais notáveis de basculamentos são encontrados nos Rios Purus e Juruá, que por todo o curso apresentam notáveis assimetrias de vertentes, com grande distribuição de terraços na margem direita, onde os afluentes são extensos (BEZERRA et al., 1986), enquanto na margem esquerda os afluentes são curtos ou inexistentes.

Ainda na área de ocorrência da Floresta Ombrófila Densa, sobressaem relevos topograficamente elevados de caráter residual que, localmente, funcionam como dispersores de água e sedimentos, reunidos em várias unidades de relevo. No setor norte do Cráton Amazônico, domínio da Província Amazônia Central, no Pará, os relevos mais elevados estão esculpidos em rochas provenientes de um extenso episódio de vulcanoplutonismo ocorrido no Paleoproterozoico e representado pelo Supergrupo Uatumã, que compreende rochas vulcânicas ácidas e diversas suítes intrusivas graníticas (Mapuera, Abonari, Água Branca, entre outras). Essas unidades graníticas têm grande importância econômica por serem potencialmente portadoras de mineralizações de cassiterita (estanho), wolframita (tungstênio), columbita (nióbio), tantalita (tântalo) e molibdenita (molibdênio), presente em quantidades apreciáveis nas jazidas e minas em exploração nas cabeceiras do Rio Pitinga, afluente do Rio Uatumã. Na busca pela energia elétrica destinada a suprir as necessidades da mina, e, subsidiariamente, da Cidade de Manaus, foi construída no início da década de 1980, no Rio Uatumã, a Hidrelétrica de Balbina, cujo lago desencadeou sérios danos ambientais, tanto pela considerável extensão de floresta densa recoberta pelas águas quanto pelo desaparecimento de uma rica paisagem de cachoeiras e corredeiras, dentre elas a Cachoeira da Balbina.

Alguns relevos residuais do Amapá são hospedeiros de concentrações de manganês, por mais de três décadas exploradas pela Indústria e Comércio de Minérios - Icomı. Esta companhia dispunha de um complexo formado por mina-ferrovia-porto, além de uma outrora importante cidade, Serra do Navio, onde residiam os mineradores e seus familiares. Com a exaustão das jazidas lavráveis, percebe-se que a exportação do minério in natura, com pouco ou nenhum valor agregado, não trouxe qualquer benefício para a população residente, que hoje convive com o abandono das instalações, inclusive da ferrovia. Ressalte-se que as unidades geológicas presentes nessa área são potencialmente mineralizadas com ouro e podem eventualmente vir a constituir jazidas de interesse econômico e alternativas para a recuperação econômica da região.

Na região do Vale do Tapajós, a mineralização de ouro parece se relacionar com as intrusões dos granitos do tipo Parauari e Maloquinha. Desde a década de 1950, o ouro vem sendo explorado por meio de garimpagem, acompanhada de graves problemas sociais e ambientais. Dentre estes, merece ser ressaltada a preocupante contaminação das bacias de drenagem por mercúrio utilizado para retirada do ouro. Há registros de que o mercúrio metálico está em progressiva incorporação à cadeia trófica, se transformando em mercúrio orgânico (metil-mercúrio), forma em que atinge o homem, bem como as plantas e animais que formam aquele habitat. 
Estudos têm apontado altos teores de mercúrio $(\mathrm{Hg})$ em peixes e nas populações ribeirinhas da Amazônia (HACON et al., 1997; DOREA; BARBOSA; SILVA, 2006; KASPER et al., 2007; SILVA et al., 2009). Aparentemente, uma conjugação de fatores naturais e antrópicos condiciona este resultado. Entre os fatores antrópicos, os mais importantes são a queima de florestas, que leva à volatilização do mercúrio contido na vegetação, com seu posterior retorno, por meio das chuvas, aos solos e rios, e, principalmente, o garimpo, que usa o mercúrio para separar o ouro dos outros materiais (WASSERMAN; HACON, WASSERMAN, 2001). Segundo estes autores, estima-se que, nas décadas de 1980 e 1990, mais de 2000 toneladas de mercúrio foram lançadas no ambiente pela atividade garimpeira na Amazônia.

Merece ser igualmente ressaltado o significativo descaminho de grande parte do ouro recuperado dos aluviões do Bioma Amazônia que, em face de uma deficiente fiscalização por parte dos órgãos competentes, é exportado sem que nenhum tributo seja recolhido aos cofres públicos. Finalmente, chamam atenção os problemas sociais trazidos pelos garimpeiros que não alcançam sucesso com sua empreitada, e que formam a grande maioria do contingente populacional. Estes migram para as periferias das cidades, como Itaituba, Trairão, Novo Progresso, onde, em condições subumanas, integram-se ao círculo de marginalidade (prostituição, inclusive infantil, drogas, alcoolismo) há muito estabelecido.

Outra área de grande ocorrência de minérios está representada pelos maciços montanhosos que constituem as serras do sul do Pará, onde se encontra delineada a maior província mineral do Brasil, com concentrações de uma variada gama de bens minerais, como ferro, manganês, ouro, cobre, níquel, prata, paládio, platina, com destaque para o ouro, o cobre e o ferro, este último com potencial de exploração em Carajás por, no mínimo, 500 anos. Em decorrência deste potencial, opera, na região, um complexo sistema de exploração que inclui mina, ferrovia e porto, seguindo o modelo implantado há décadas no Quadrilátero Ferrífero, em Minas Gerais. O projeto inclui a implantação de siderúrgicas (também chamadas de guseiras) ao longo do eixo da ferrovia, visando à transformação do minério bruto hematítico em ferro-gusa, com a utilização maciça de carvão vegetal, a princípio proveniente de florestas plantadas (como em Minas Gerais), mas, efetivamente, retirado da floresta natural a uma razão de duas toneladas de carvão para cada tonelada de ferro-gusa, no que, certamente, se configura em mais um desastre social (indústria carvoeira e seus problemas sociais) e ambiental (exploração maciça da floresta com essa finalidade) para a Amazônia. Além do ferro, grandes quantidades de ouro provenientes primariamente dessas sequências vulcanossedimentares já foram retiradas via garimpagem, com destaque para os garimpos de Serra Pelada e Cumaru, palco de sérios conflitos entre garimpeiros e mineradoras, e de uma rica história de bamburros (sucessos) e, principalmente, blefes (insucessos) protagonizados pela população garimpeira.

Vale ressaltar também que as Serras e Patamares dos Rios Tocantins e Araguaia, que formam o divisor entre essas bacias hidrográficas, encontram-se esculpidas em litologias (basicamente biotita xistos e biotita gnaisses) do Grupo Estrondo, onde existem acumulações de gemas, principalmente ametista e cristal de rocha em veios de quartzo, característica que, historicamente, representa um forte indutor do processo de ocupação populacional desta fração do Norte e do Centro-Oeste brasileiros. 
A vegetação de Floresta Ombrófila que recobria toda a área foi substituída por pastagem, tendo como resultado o aumento do escoamento das águas superficiais, que de difuso passa a concentrado, provocando ravinamentos consideráveis.

Em termos de extensão, dentro do Bioma Amazônia, a Floresta Ombrófila Densa é seguida pela Floresta Ombrófila Aberta e pelas Florestas Estacionais Semidecidual e Decidual (Tabela 1). A Floresta Ombrófila Aberta está presente no Acre, em Rondônia, no leste e no sul do Estado do Amazonas, no norte de Mato Grosso e no norte do Maranhão, formando uma espécie de arco ao sul e a leste da Floresta Ombrófila Densa, envolvendo-a. Estas áreas são, em sua maioria, parte do Escudo do Brasil Central, composto tanto por áreas sedimentares quanto por áreas cristalinas.

Por muito tempo a Floresta Ombrófila Aberta foi considerada como uma transição entre a Floresta Amazônica e as áreas extra-amazônicas. Apresenta quatro faciações florísticas que alteram a fisionomia da Floresta Densa, imprimindo-lhe claros, advindo daí o nome adotado: aberta com palmeiras, com cipós, com bambus, com sororocas. As comunidades florestais com palmeiras ou com bambu, em geral, revestem os terrenos areníticos (solos arenosos, muito pobres em nutrientes); as comunidades com sororocas (a Strelitziaceae Phenakospermum guyannense) e com cipós revestem preferencialmente as depressões do embasamento Pré-Cambriano e encostas do relevo dissecado dos planaltos. Vale ressaltar que as florestas aluviais (de várzea e de igapós) são ricas em palmeiras-açaí e buritis, plantas de elevado potencial nutricional.

Aproximadamente na região das cabeceiras dos Rios Juruá e Purus, contemplando praticamente todo o Estado do Acre e pequena porção do Estado do Amazonas, os estratos argilosos e argilo-arenosos da Formação Solimões propiciaram o desenvolvimento de solos mineralogicamente constituídos de argilas jovens (esmectíticas), que Ihes atribuem alta capacidade de troca de cátions (CTC) e alta capacidade de expansão e contração, em função de alternâncias dos regimes de umidade, classificados como Luvissolos (Figura 6), Argissolos e Cambissolos (SISTEMA..., 2006), ora saturados por cátions básicos (eutróficos) e ora por cátions ácidos (alumínicos). Ocorrências de Argissolos Eutróficos (região do embasamento cristalino em Rondônia e numa faixa ao norte do Estado de Mato Grosso) são os principais representantes dos solos de boa fertilidade natural e, portanto, com aptidão razoável para lavouras, sem requerer o emprego maciço de corretivos químicos.

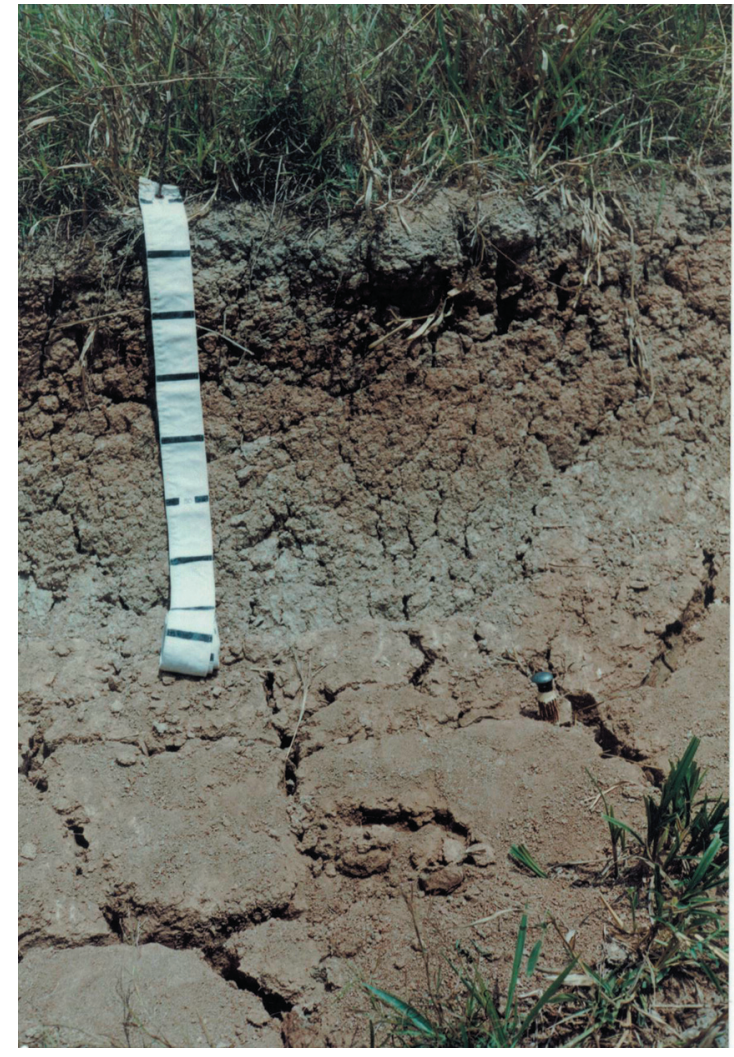

Figura 6 - Perfil de Luvissolo Háplico, Tarauacá (AC). Foto: Virlei Álvaro de Oliveira.

Em termos de bens minerais, destacam-se, nos terrenos cobertos pela Floresta Ombrófila Aberta, uma extensa área mineralizada em ouro que forma a Província Aurífera Alta Floresta, em Peixoto de Azevedo (MT), objeto de exploração por garimpagem, e, em Rondônia, uma série de corpos graníticos mineralizados em cassiterita, objeto de lavra por empresas de mineração. 
A Floresta Estacional Semidecidual, presente no sul de Rondônia e sudoeste de Mato Grosso, na Bacia do Rio Guaporé, está ligada à transição climática de úmido a seco. Latossolos mais amarelados (Latossolos Amarelos e Vermelho-Amarelos), junto a solos hidromórficos, particularmente Plintossolos Argilúvicos, são comuns e ocupam extensas áreas da Bacia do Rio Guaporé (MATO GROSSO, 2001).

A Floresta Estacional Decidual, presente na Serra do Cachimbo no sudoeste do Pará, tem sua ocorrência ligada a Neossolos Litólicos. Nas grandes estruturas residuais das Serras do Cachimbo e dos Caiabis, há ainda extensas ocorrências de Neossolos Quartzarênicos (MAPA..., 2001), solos muito arenosos, de baixíssima potencialidade agrícola, originados de arenitos diversos. É importante mencionar que, nestes casos, apesar de serem áreas contidas dentro dos limites do Bioma Amazônia, é comum a ocorrência de vegetação de cerrado em associação com formações florestais. Constituem algumas das denominadas "ilhas" de cerrado, em meio ao "mar" de florestas da Amazônia, que, no mapa de vegetação do Brasil (MAPA..., 2004b), estão caracterizadas como vegetação de contato entre Savana e floresta.

A Serra do Cachimbo, cuja borda sul estabelece grande parte do limite entre os Estados do Pará e do Amazonas com o de Mato Grosso, encerra promissoras, e ainda não convenientemente pesquisadas, ocorrências de mineralizações de fosfato e grandes concentrações de calcário, inclusive magnesiano, que podem vir a representar importantes insumos para as correções de acidez e fertilidade dos solos da região que vive a expectativa do asfaltamento total da Rodovia BR-163, em andamento, e a consequente expansão do cultivo de soja do norte de Mato Grosso para o sul do Pará.

Parte das Florestas Estacionais Semideciduais e dos contatos Floresta Estacional/Floresta Ombrófila, foram, recententemente, reclassificadas como Floresta Estacional Sempre-Verde (MANUAL..., 2012), uma nova tipologia florestal proposta para a Amazônia. Embora ainda não totalmente delimitada e quantificada, esta tipologia ocupa terras ao sul do Bioma Amazônia, especialmente em Mato Grosso, em áreas onde a litologia sedimentar garante a existência de grande e acessíveis reservas de água no subsolo. Esta disponibilidade permite que a floresta se mantenha sempre verde, sem ou quase sem perda de folhas durante o período seco do ano. A Floresta Estacional Sempre-Verde tem como área core o extenso Planalto dos Parecis, já na zona de transição entre as florestas amazônicas e os cerrados do Brasil Central.

Além das florestas, são encontradas no Bioma Amazônia tipologias vegetacionais de Savana, de Campinarana, de Formações Pioneiras e de Refúgio Vegetacional, e as diversas formas de contato das mesmas entre si e com as florestas. Estão incluídas também no Bioma Amazônia as formações costeiras adjacentes, restingas e manguezais da costa do Amapá, do Pará e do noroeste do Maranhão, bem como as formas de contato limítrofes com o Bioma Cerrado, nas quais predomina a tipologia Floresta Ombrófila. As áreas de transição vegetacional, em geral, coincidem com faixas de transição climática e, muitas vezes, com o contato entre duas formações geológicas.

A Campinarana (Figura 7) não constitui disjunção vegetacional, pois é uma formação própria do Bioma Amazônia, condicionada por clima superúmido e solos arenosos lixiviados e hidromórficos. Ocorre em Roraima e no norte do Estado do Amazonas, acompanhando o curso dos Rios Negro e Branco, sobre a bacia sedimentar do Rio Branco-Rio Negro. A bacia 
abriga um extenso pacote de sedimentos holocênicos inconsolidados depositados por sistemas fluviais e fluviolacustres, apresentando extensas áreas pantanosas e lagos interfluviais, constituindo a Depressão dos Rios Branco e Negro.

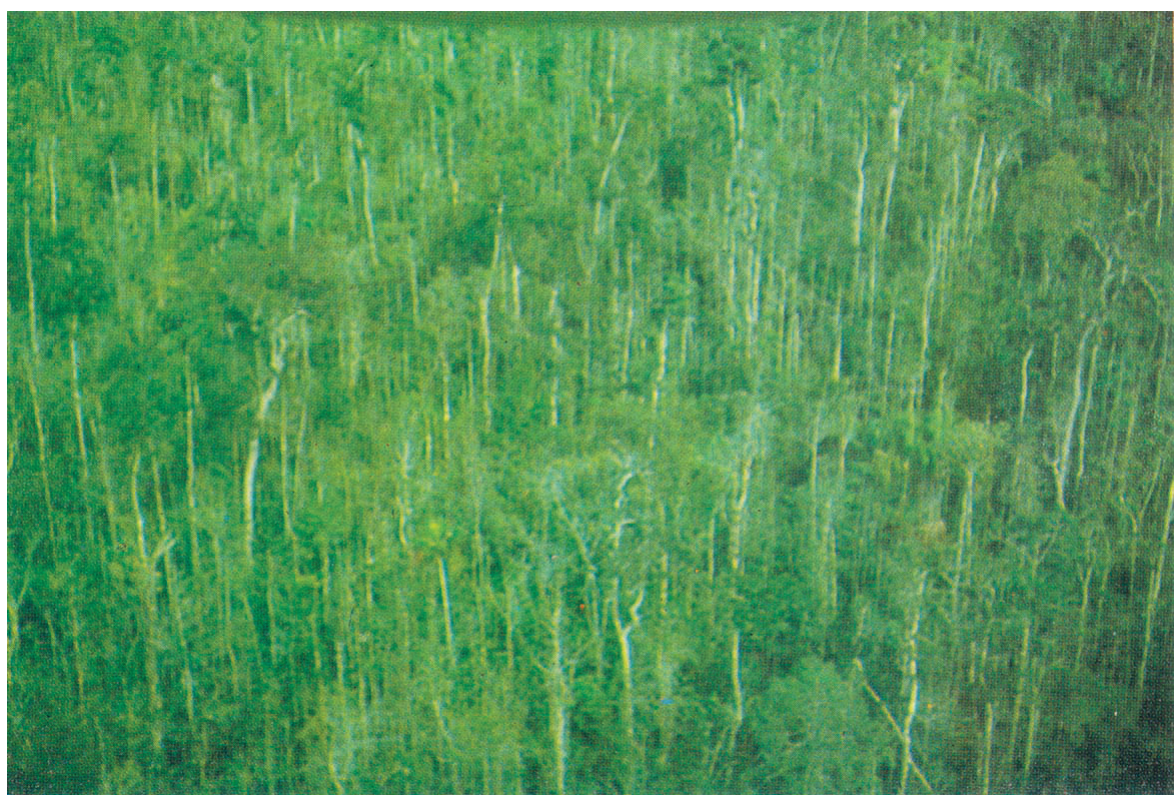

Figura 7 - Campinarana arbórea aberta das depressões da Amazônia. Acervo do Projeto RADAmBRASIL (incorporado ao patrimônio do IBGE, por força do art. $3^{\circ}$ do Decreto $n^{\circ}$ 92.925/85)

Na área de drenagem do Rio Negro, com maior concentração na região do seu alto curso, verifica-se grande domínio de Espodossolos, cujo horizonte diagnóstico de acumulação de matéria orgânica (Bh) e/ou matéria orgânica e ferro (Bhs) está situado muitas vezes a grandes profundidades ( $>2$ metros), caracterizando os Espodossolos Humilúvicos e Ferri-humilúvicos, ambos Hidro-hiperespessos (SISTEMA..., 2006). A Campinarana é dotada de florística típica, com gêneros endêmicos, e apresenta fisionomias que diferem no porte e na densidade dos elementos lenhosos, geralmente compostos por árvores sempre verdes, de troncos finos e esbranquiçados, com alturas variando de 5 a 20 metros, havendo ou não a ocorrência de palmeiras, sendo que na formação gramíneo-lenhosa é comum a presença de colônias do líquen Cladonia. As Campinaranas dos Rios Negro e Branco (AM e RR) ocupam áreas de relevo plano arrasado (peneplanos), com baixa declividade e, portanto, drenagem deficiente, do Escudo das Guianas. Os solos são extremamente pobres em nutrientes e ácidos, assim como os rios de águas pretas que cortam a região. Há acúmulo de matéria orgânica no solo, que se reflete na coloração e nas características das águas dos rios. As características gerais das áreas ocupadas por Campinaranas (solos hidromórficos, ácidos e pobres, rios pouco piscosos, árvores finas etc.) não recomendam a exploração econômica destas áreas, nem mesmo com atividades extrativistas, devendo-se destiná-las à conservação de sua fauna e flora e proteção ambiental.

As Savanas estão inseridas no Bioma Amazônia como disjunções, pois constituem fisionomia vegetal típica do Bioma Cerrado, apresentando-se com suas diversas formações e formas de contato. Ocorrem em Roraima, norte do Pará, Amapá, Ilha de Marajó, sul do 
Estado do Amazonas, Rondônia e Mato Grosso. Como exemplo, podem ser citadas as Serras de Cubencranquém, dos Caiabís, Chapada de Dardanelos, além de Chapada e Serras do Cachimbo, Apiacás, e os supracrustais da região de Carajás, que constituem relevos especiais tanto do ponto de vista da disposição espacial, quanto de suas próprias feições geomorfológicas, comportando modelados de dissecação ou de topos aplanados configurando formas relictuais de processos ou de sistemas morfogenéticos de fases mais secas que a atual. Os topos dos relevos revestidos com vegetação de Savana confirmam a extensão de um domínio morfoclimático pretérito. Os modelados de dissecação estão relacionados com as condições climáticas mais úmidas, sobre domínio morfoclimático dos planaltos amazônicos.

O Planalto dos Parecis, localizado na extremidade sul do Bioma Amazônia, caracteriza-se pela homogeneidade topográfica, interrompida pelas rupturas que delimitam as calhas fluviais e pela transição para o Bioma Cerrado. A área encontra-se recoberta por Florestas Estacionais Semidecidual e Sempre-Verde até atingir os rebordos do planalto, onde é muito nítida a transição floresta-savana, sugerindo tratar-se da área meridional da Floresta Amazônica, onde a mesma tem sido indiscriminadamente devastada e substituída por monocultura, com modificação da paisagem natural, ocasionando problemas ambientais.

Em alguns locais, como no Estado do Amapá, os topos dos interflúvios, em geral, contêm materiais concrecionários, que impõem resistência aos processos morfogenéticos. Contudo, percebe-se uma nítida evolução da frente de intemperismo, relacionada com as morfogênese úmida, favorecendo o desenvolvimento das formações superficiais, recobertas por vegetação de cerrado com trechos de floresta, denunciando o avanço desta formação sobre o cerrado sob a influência do clima atual. A fitoestabilidade dada pela cobertura vegetal de floresta tem sido rompida pela ação do homem, com a retirada de madeira e as queimadas indiscriminadas. Desse modo, o ambiente naturalmente estável passa a instável, com forte intensidade dos processos morfodinâmicos (erosão acelerada).

Nas áreas de Savana (Cerrado), devido às características campestres naturais, a atividade econômica geralmente se restringe à pecuária extensiva, com incipiente retirada de bens minerais de emprego na construção civil, caso das argilas acumuladas nos vales dos principais canais de drenagem, usadas para fabricação de cerâmica vermelha (tijolos e telhas), com impactos ambientais pouco significativos. Nas áreas de fronteira de ocupação, como no Vale do Guaporé, nos campos de Boa Vista e na região da llha do Bananal (área limítrofe entre os Biomas Cerrado e Amazônia) há introdução do cultivo de soja.

A tipologia Savana Estépica, presente no norte de Roraima, constitui igualmente uma disjunção no Bioma Amazônia. Em verdade, trata-se de uma vegetação relictual (herança) de um clima pretérito mais seco (semiárido).

Quanto às Formações Pioneiras, destacam-se os mangues, presentes no litoral do Amapá, no Pará, inclusive na Ilha de Marajó, e no Maranhão, e as formações com influência fluvial e/ou lacustre referentes às planícies aluviais que ocorrem ao longo dos cursos médio e baixo do Rio Amazonas, além de alguns afluentes, e no arquipélago marajoara. Na região correspondente à foz do Amazonas, que envolve o Arquipélago de Marajó, a influência marinha adentra o continente pelo Vale do Rio Amazonas, com os efeitos da maré se fazendo 
sentir até a altura do meridiano de Santarém (PA), a 600 quilômetros do litoral. Esta influência é marcante nas sizígias da lua nova, principalmente nos meses de março e setembro, quando, em função do equinócio, a amplitude de maré chega ao seu ponto máximo, acontecendo o fenômeno da pororoca, uma onda de maré de dimensões métricas cuja energia suplanta a da corrente fluvial e que, durante a preamar, invade os estuários com grande poder erosivo e destrutivo. Ressalte-se que o fenômeno não é restrito ao Rio Amazonas, ocorrendo em praticamente todas as bacias hidrográficas costeiras do bioma, com destaque para as Bacias do Rio Araguari, no Amapá, e do Rio Capim, no Pará. A intensidade do fenômeno enseja a realização de competições anuais de surfe, chamadas de "surfe na pororoca".

Na planície aluvial na llha de Marajó, que representa um fragmento do continente, ressalta-se o intenso processo de colmatação do Lago Arari, um dos principais elementos da fisiografia da ilha, com impactos sobre a fauna aquática e sobre a navegação, criando dificuldade de acesso à localidade de Santa Cruz do Arari. O Arquipélago de Marajó é um ecossistema extremamente frágil, em que as atividades econômicas são restritas à pecuária extensiva, mormente de bufalinos nos campos alagáveis, e à exploração predatória de madeira nas florestas inundáveis, onde também se encontra em expansão o extrativismo do açaí, embora sem qualquer tipo de manejo. Mais recentemente, antigas fazendas de gado vêm sendo transformadas em pousadas para atender a um turismo ecológico ainda incipiente, mas que, pelas belezas naturais ali existentes, apresenta um grande potencial de crescimento.

Na região costeira do Pará e do Maranhão assiste-se a um considerável processo de ocupação, em função, principalmente, das belas praias formadas na região entremarés. Os caminhos de acesso a tais paragens, via de regra, seccionam manguezais, impactando as funções essenciais que esses ecossistemas cumprem na reprodução da vida marinha. A ocupação das falésias vivas potencializa o processo erosivo sobre estas formas litorâneas, causando prejuízos não só ao ambiente, mas também àqueles que constroem suas residências sobre as falésias, que, em geral, veem seu patrimônio consumido pelas ondas de maré.

O Refúgio Vegetacional é uma tipologia que está presente em solos rasos nos pontos mais elevados das serras, ocorrendo no norte dos Estados do Amazonas e de Roraima (terras altas do Escudo das Guianas), nos pontos culminantes do País: o Pico da Neblina (2 994 metros) e o Pico 31 de Março (2 973 metros), na fronteira com a Venezuela, e também na Serra do Cachimbo, no sudoeste do Pará (Escudo do Brasil Central). Nos refúgios, é comum a presença de espécies endêmicas.

Nos contatos entre a Savana e a Floresta Ombrófila, a superfície ocupada pela floresta é interpenetrada pela Savana na forma de encrave ${ }^{5}$. Este tipo de contato vegetacional tem estreita ligação com as formas de dissecação do relevo em cristas e colinas. Os solos onde ele ocorre são, em geral, Neossolos Quartzarênicos e Argissolos Vermelho-Amarelos, ambos distróficos. Nos contatos entre a Floresta Ombrófila e a Floresta Estacional, o período sem chuvas é de aproximadamente quatro a cinco meses, e a porcentagem mínima dos indivíduos arbóreos que perdem folhas é 20,0\%. Nos meses sem chuvas, os espécimes deciduais

\footnotetext{
Mancha de ecossistema típico de outro bioma, encravada no interior de um domínio de natureza totalmente diferente.
} 
se distribuem por quase toda a superfície, caracterizando sua fisionomia, interrompida somente por raros grupamentos de cipós, situados geralmente onde o relevo toma forma mais dissecada ou nas proximidades dos cursos de água. Os contatos entre a Campinarana e a Floresta Ombrófila são frequentes na Bacia do Rio Negro, em áreas com relevo pouco dissecado e em algumas depressões. Por sua vez, os contatos entre a Savana e a Floresta Estacional ocorrem na forma de encraves com diferentes subformações das duas tipologias, em áreas condicionadas pelos fatores edáficos e pela transição climática. Já os contatos da Savana Estépica com a Floresta Estacional ocorrem sob a forma de interpenetrações florísticas, constituindo ecótono ou mistura.

Toda essa variedade fitofisionômica, contudo, não impede que a Amazônia se constitua na maior região de floresta tropical do mundo. Abriga uma surpreendente diversidade de plantas e animais que, em integração com o meio físico, representa, para a humanidade, um dos recursos naturais de maior importância ecológica, cultural e econômica - um verdadeiro celeiro de seres vivos.

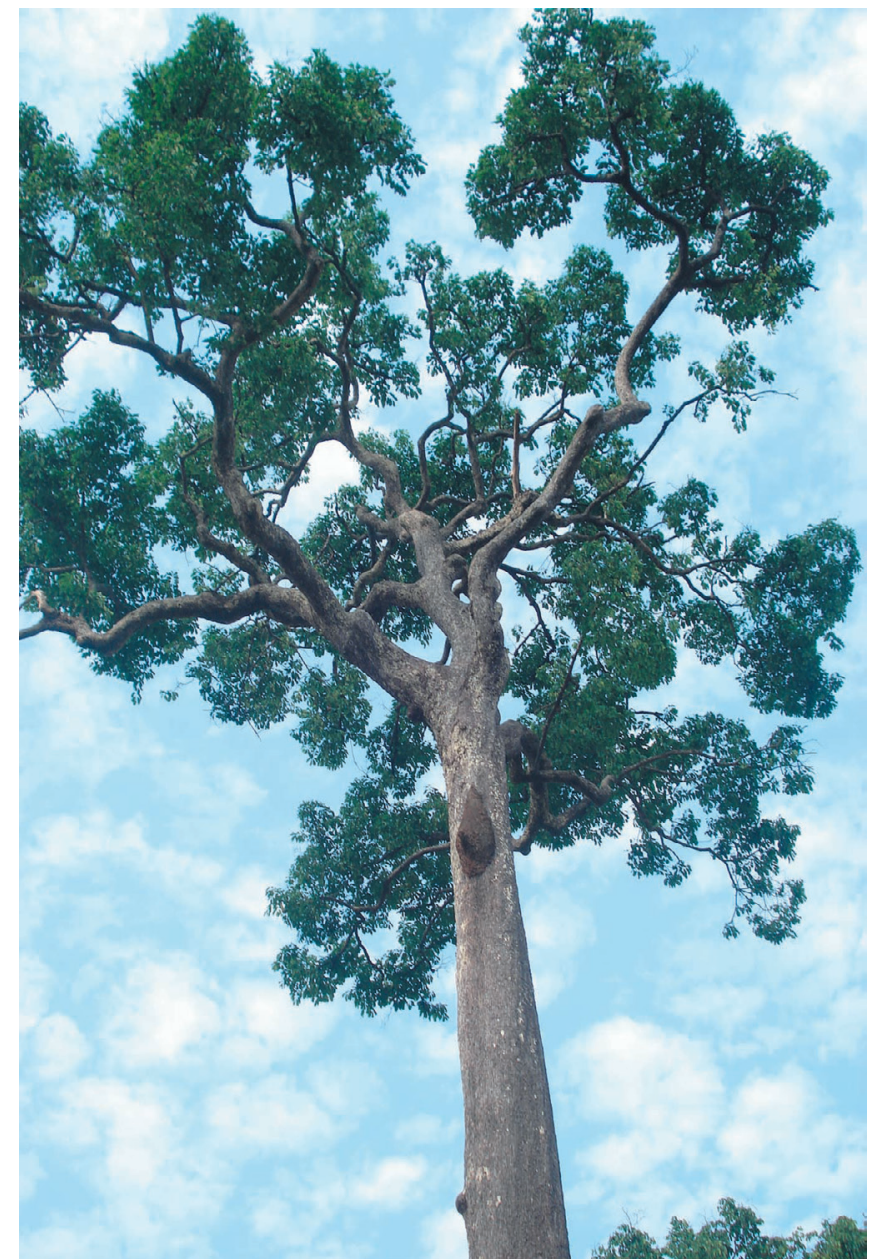

Figura 8 - Castanheira-do-pará.

Foto: José Carlos Louzada Morelli.
No que se refere à diversidade vegetal, a riqueza de plantas da Amazônia é estimada em 13229 espécies, sendo 2 956 endêmicas do bioma (LISTA..., 2010). Segundo Steege e outros (2000), ocorre maior diversidade florística na porção central do que na parte oriental da Amazônia. Se comparada com outras florestas pluviais dos trópicos, a Amazônia é a que apresenta também a maior diversidade de espécies de ampla distribuição. Entre as espécies vegetais que integram a rica diversidade amazônica, destacam-se árvores de grande porte, como a seringueira, a castanheira-do-pará (Figura 8), as maçarandubas, o jacarandá e o ipê-amarelo, que vivem entremeadas com um elevado número de trepadeiras, cipós, epífitas, musgos, liquens, pteridófitas etc. O Ministério do Meio Ambiente por meio da Secretaria de Biodiversidade e Florestas (BRASIL, 2002) identificou 61 áreas prioritárias para a conservação da vegetação da Amazônia. Os estudos mostram que as Unidades de Conservação existentes na área do Bioma Amazônia são maldistribuídas, não havendo conexão entre elas, o que coloca em vulnerabilidade a diversidade genética e as espécies endêmicas. 
Os invertebrados, distribuídos em vários filos, constituem 95,0\% das espécies existentes no planeta e dominam a fauna amazônica, especialmente na copa das árvores, centro de sua maior diversificação. Apesar de os número de espécies identificadas ser bastante expressivo (aproximadamente 13 000), estima-se que cerca de 70,0\% das espécies potencialmente existentes ainda não foram catalogadas pela ciência (BRASIL, 2002). Essa fauna assume importante papel no funcionamento dos ecossistemas, sendo responsável, entre outras funções, pelos processos de dispersão de sementes, polinização e controle biológico de pragas. Durante o Seminário Consulta de Macapá, realizado na Cidade de Macapá, no período de 20 a 25 de setembro de 1999, foram identificadas 28 áreas prioritárias para invertebrados na Amazônia. Entre elas, 25 (89,3\%) apresentavam alta riqueza de espécies raras/ameaçadas; 19 (67,9\%) tinham alta diversidade filética e abrigavam espécies de valor econômico; e 11 (39,3\%) registravam elevado grau de ameaça de degradação (BRASIL, 2002).

A Bacia Amazônica apresenta a maior diversidade de peixes do planeta. Somente no Rio Madeira, foram inventariados recentemente cerca de 1000 espécies (QUEIROZ et al., 2013), e o número estimado para a bacia deve superar 3000 espécies. Muitas espécies possuem ampla distribuição geográfica, como alguns grandes bagres que realizam migrações continentais de aproximadamente 3500 quilômetros entre o estuário do Rio Amazonas (área de cria dos jovens), o Rio Amazonas e seus tributários de águas brancas (áreas de dispersão e alimentação) e as cabeceiras do sistema no Peru ou Colômbia, onde se reproduzem (BARTHEM; RIBEIRO; PRETERE JUNIOR, 1991). Com base nos estudos sobre o tambaqui (Figura 9) (GOULDING, 1979) e jaraqui (RIBEIRO; PETRERE JUNIOR, 1990), espécies de porte médio, também realizam extensas migrações regionais ligadas à várzea, com deslocamentos ascendentes anuais de até 1000 quilômetros ao longo dos rios de águas brancas (dispersão) e tributários de águas claras ou águas pretas (tróficas), com desova nos seus respectivos "encontros de águas". Algumas

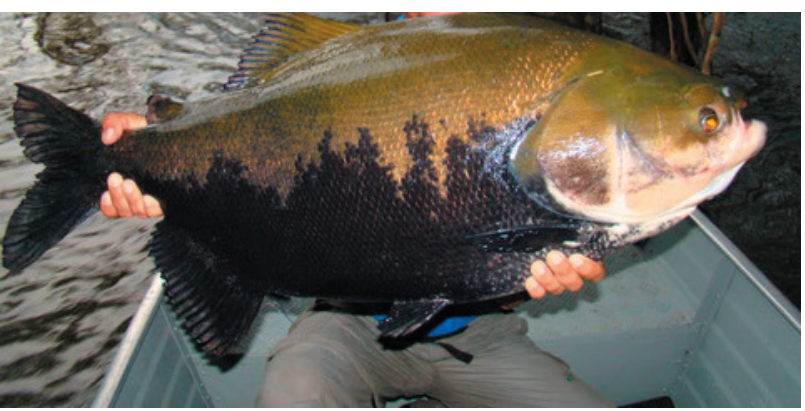

Figura 9 - Tambaqui, peixe comum na Amazônia. Foto: José Carlos Louzada Morelli. espécies migradoras têm seus movimentos restritos aos tributários de águas claras ou de águas pretas (RIBEIRO; PETRERE JUNIOR; JURAS, 1995). Muitas outras espécies possuem estratégias de vida bastante distintas, com deslocamentos laterais bem mais restritos entre as várzeas e o canal dos rios de águas brancas; entre os igapós e os canais de rios de águas pretas ou claras; espécies associadas às corredeiras e cachoeiras, espécies restritas aos igarapés de terra firme, a ambientes temporários ou mesmo ao estuário. Apesar de existirem muitos estudos e levantamentos da ictiofauna ${ }^{6}$ amazônica, ainda é bastante comum a descrição de espécies novas, e o número de espécies endêmicas ainda é incerto. As informações a respeito do grau de ameaça de extinção ou mesmo sobre o desaparecimento de espécies de peixes tampouco são muito precisas. Como

\footnotetext{
6 Conjunto de peixes de uma região ou ambiente.
} 
as Unidades de Conservação já implantadas na Amazônia são essencialmente de terra firme, poucos habitats-críticos, como as áreas inundadas e inundáveis, estão protegidos. Durante o Seminário Consulta de Macapá, foram identificadas 31 áreas prioritárias para biota aquática na Amazônia. Entre elas, 19 (61,3\%) apresentavam alta diversidade filética, 14 (45,2\%) tinham alta diversidade de espécies e 13 (41,9\%) abrigavam espécies de importância econômica e possuíam elevado grau de ameaça de degradação (BRASIL, 2002).

As estimativas para a pesca na Amazônia, embora precárias e subestimadas, apontam para 130000 toneladas em 2005 (BARTHEM; GOULDING, 2007). O pescado representa a principal fonte de proteína na alimentação das populações ribeirinhas. Além disso, a pesca é responsável pela geração de renda e empregos diretos e indiretos, sendo uma das atividades mais tradicionais da Amazônia, com aproximadamente 6 000-7 000 anos de existência registrada. Não obstante sua importância, a pesca também exerce pressão sobre as espécies explotadas. Em um raio de 500 quilômetros das principais cidades da Amazônia, há evidências de que o pirarucu e o tambaqui, juntamente com algumas outras espécies de porte médio, estejam sobre-explotados ou ameaçados de sobre-explotação. Alternativas para um manejo sustentável têm sido discutidas (BAYLEY; PETRERE JUNIOR, 1989; RUFFINO, 2004; BARTHEM; GOULDING, 2007). A captura de espécies ornamentais também representa uma alternativa econômica viável para áreas com poucas opções de sobrevivência. A principal área de produção ornamental é o Médio Rio Negro, onde a maior parte dos habitantes estão envolvidos na atividade. Corredeiras dos Rios Xingu e Tapajós também representam pesqueiros importantes. Espécies sedentárias de pequeno porte ou jovens de espécies migradoras são o principal alvo ornamental e podem também estar sendo sobre-explotadas por esta atividade.

A fauna de anfíbios e répteis da Amazônia brasileira perfaz um total de 713 espécies conhecidas, sendo 163 anfíbios e 550 répteis. Esses números, entretanto, representam o mínimo, no que diz respeito à avaliação da diversidade biológica da herpetofauna ${ }^{7}$. São grandes as dificuldades quanto à determinação taxonômica de muitas espécies, e os levantamentos científicos são insuficientes. Dados da Secretaria de Biodiversidade e Florestas, do Ministério do Meio Ambiente, indicam a existência de apenas 12 espécies endêmicas de anfíbios para o bioma (BRASIL, 2002). Apesar do pouco conhecimento que se tem sobre sua distribuição geográfica, cabe evidenciar a ocorrência da única espécie de salamandra conhecida no Brasil. As listas oficiais não registram espécies de anfíbios ameaçadas ou em perigo de extinção na Amazônia brasileira. No tocante a répteis, sabe-se que cerca de 60,0\% das espécies descritas para este bioma são endêmicas. Assim como os anfíbios, os répteis amazônicos não integram a listagem oficial brasileira de animais ameaçados de extinção. Entre os quelônios (tartarugas, cágados, tracajás etc.), ressalta-se a ocorrência da tartaruga-do-amazonas e, nas porções florestadas, algumas espécies de jabutis. Comuns, igualmente, são o jacaretinga, o jacaré-açu (o maior deles) e as cobras jiboia e surucucu, dentre inúmeras espécies de serpentes. Estão apontadas 46 áreas em toda a porção da Amazônia brasileira para a conservação da fauna de anfíbios e répteis, das quais 20 (cerca de 44,0\%) com alto valor biológico (BRASIL, 2002).

Conjunto de répteis e anfíbios de uma região ou ambiente. 
Outro grupo faunístico de importância considerável para a biodiversidade amazônica é o das aves. Segundo o Ministério do Meio Ambiente (BRASIL, 2002), na Amazônia estão registradas aproximadamente 1000 espécies de aves, sendo que 283 apresentam distribuição geográfica restrita ou são consideradas raras, e 32 podem ser apontadas como endêmicas da porção brasileira. As listas de animais ameaçados de extinção mostram 15 espécies de aves da Amazônia, destacando-se, a título de exemplo, a ararajuba (uma bela espécie de psitacídeo), considerada uma das aves-símbolo do Brasil, devido às cores amarela e verde de suas penas. A maioria das aves é bastante notável e exibe plumagens exuberantes, a exemplo do galo-da-serra e outras tantas variedades de araras (Figura 10), papagaios e tucanos, que ocupam os diferentes estratos arbóreos da floresta. Outras, de grande porte, como o gavião-real, habitam as copas das grandes árvores. Há, ainda, as que são encontradas no piso da floresta, entre a vegetação arbustiva e a herbácea, voando baixo, como os mutuns e o pavãozinho-do-pará, uma das aves amazônicas mais características. Em que pese a riqueza da fauna ornitológica ${ }^{8}$ e as grandes modificações ambientais, várias regiões desse bioma carecem de inventários e estudos pertinentes. Há indicação de 109 áreas prioritárias para a conservação das aves da região. Dentre estas, 39 apresentam-se como de alto valor biológico, e 32 possuem elevados níveis de endemismo (BRASIL, 2002).

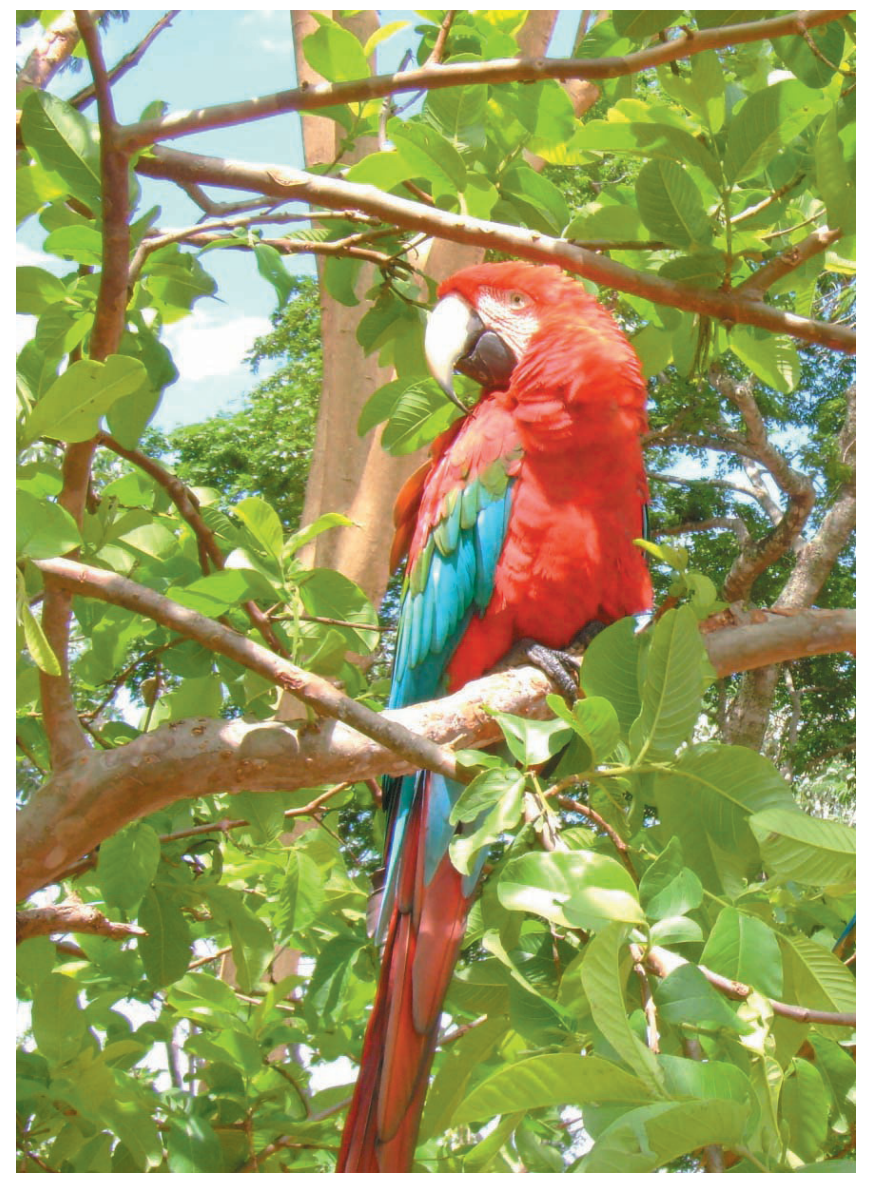

Figura 10 - Arara vermelha.

Foto: Rosangela Garrido Machado Botelho.

\footnotetext{
8 Referente às aves.
} 
Quanto à diversidade de mamíferos, pode-se dizer que existem 311 espécies conhecidas. Entre estas, seis podem ser classificadas como raras e 44 estão com sua sobrevivência de alguma maneira ameaçada (BRASIL, 2002). A exemplo do que ocorre com a avifauna amazônica, os vazios científicos para este grupo também são enormes. Amostragens e inventários mais exaustivos sobre a classe dos mamíferos são necessários, para que se possa definir, por exemplo, a distribuição geográfica das espécies, principalmente no que se refere à ordem dos roedores, dos marsupiais e dos morcegos. Segundo dados oficiais, a porção a oeste dos Rios Negro e Madeira deve apresentar maiores índices de diversidade biológica, enquanto, na região das Guianas, os índices devem ser mais baixos (BRASIL, 2002). A fauna de mamíferos do bioma é uma das mais variadas do mundo, citando-se, como exemplo, algumas espécies notáveis, como o tamanduá-bandeira, o cachorro-do-mato-vinagre, a ariranha, o peixe-boi-da-amazônia, a onça-pintada (e sua versão melânica) e outros felinos, além do macaco-aranha, todas integrando listas de espécies ameaçadas de extinção, em perigo, ou vulneráveis. Ainda entre os primatas, encontram-se, nas diferentes formações florestais, os bugios e o macaco-da-noite. Merece destaque, também, a anta, considerado o maior mamífero terrestre brasileiro. Por último, vale ressaltar a ocorrência, em seus rios, de duas espécies de botos. Visando à conservação da diversidade mamíferos amazônicos, foram identificadas 39 áreas, das quais seis apresentam grande valor biológico e outras seis se encontram com elevados graus de ameaça ambiental (BRASIL, 2002).

A existência de tamanha diversidade de espécies pode ser explicada pela teoria dos refúgios (HAFFER, 1969; PRANCE, 1973; VANZOLINI, 1992), segundo a qual, a cada período seco prolongado (da ordem de milhares de anos) durante as glaciações, formavam-se núcleos florestais isolados, e seus componentes, animais e vegetais, passando por diferenciações genéticas profundas, acabavam por gerar novas espécies. Considerando a extensão da Amazônia e suas barreiras hidrográficas, referidos processos evolutivos ocorriam com muita frequência, daí a alta diversidade biológica. Por também se referirem a uma longa extensão de tempo (Quaternário, Terciário e antes) e a eventos recorrentes de formação de barreiras (mudanças repetidas na distribuição de terra e mar, e dos tipos de vegetação úmidos e secos sobre áreas terrestres), as hipóteses Paleogeográfica (NORES, 1999) e da Densidade do Dossel (COWLING; MASLIN; SYKES, 2001) também possuem alto poder explanatório para a biodiversidade da Amazônia. Outras hipóteses, que se referem a eventos históricos únicos ou muito recentes, como no caso do Pleistoceno, têm poder explanatório bem mais baixo (HAFFER; PRANCE, 2002).

Contudo, a alta diversidade biológica da Amazônia encontra-se seriamente ameaçada. A destruição dos habitats, o contínuo processo de fragmentação florestal e dos rios, os diferentes tipos de uso da terra, as hidrelétricas e o extrativismo constituem os principais impactos responsáveis pela perda de biodiversidade.

Apesar de a taxa de desmatamento ter caído cerca de 30,0\% entre 2004 e 2012, após o lançamento, pelo governo federal em 2003, do Plano de Ação para Prevenção e Controle do Desmatamento na Amazônia Legal - PPCDAm, dados oficiais do sistema de informações 
geográficas do Projeto de Monitoramento do Desflorestamento na Amazônica Legal - PRODES, do Instituto Nacional de Pesquisas Especiais - INPE, mostram que há, na Amazônia brasileira, mais de 748 mil quilômetros quadrados de florestas derrubadas - cerca de 18,0\% da floresta da região (PLANO..., 2013).

Os desmatamentos em grandes proporções e suas consequências tiveram início no final da década de 1960 e, até os anos de 1980, foram induzidos por incentivos e políticas governamentais. A partir de então, entretanto, os desmatamentos passaram a ser impulsionados pela pecuária de média e grande escalas, que assim viabilizam também os lucros de outros agentes especulativos nas fronteiras mais avançadas do bioma (MARGULIS, 2003). Os danos são causados por queimadas e derrubadas de mata, originados, portanto, de um processo articulado de expansão da pecuária, da exploração madeireira predatória e das fronteiras agrícolas (Figura 11).

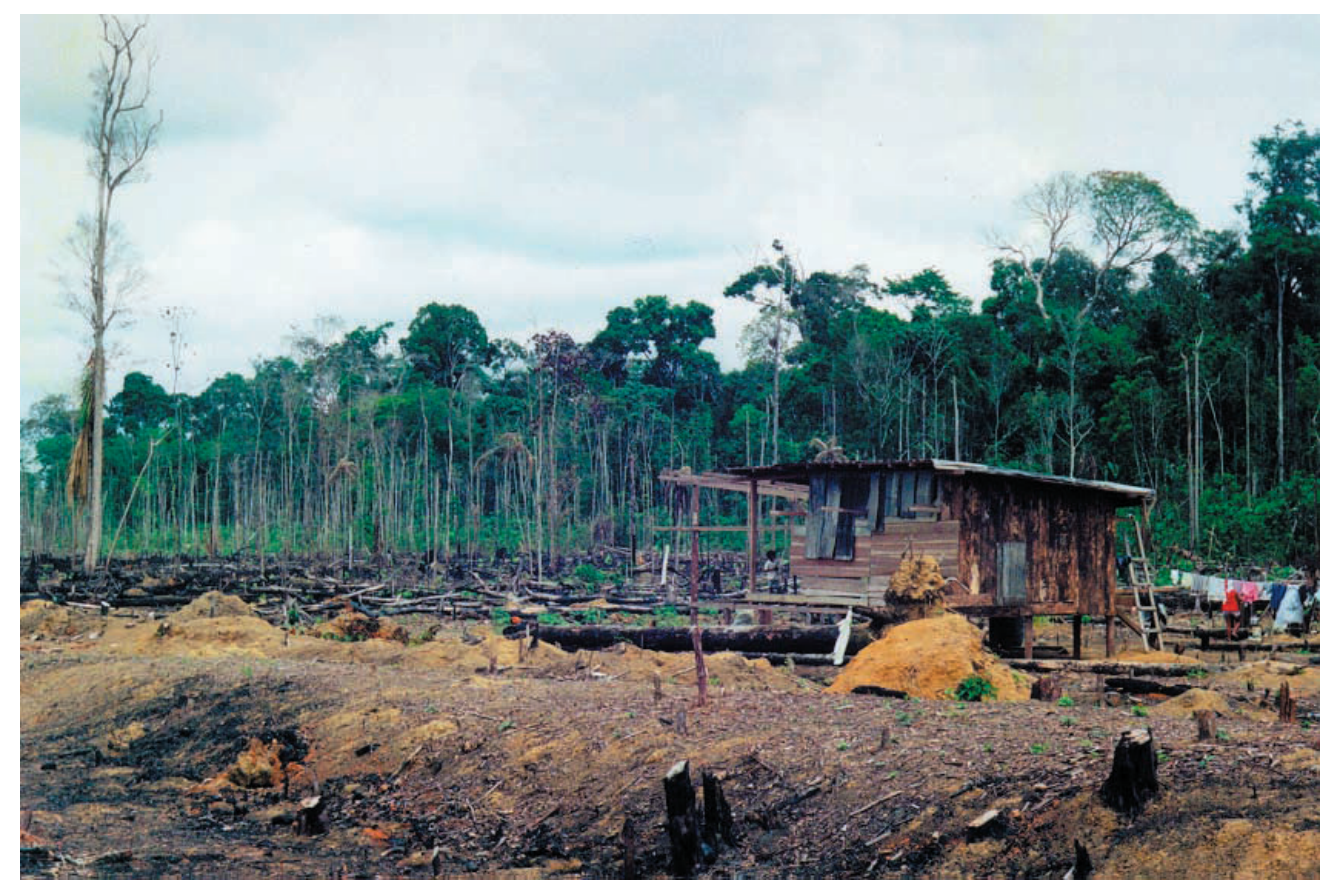

Figura 11 - Queimada na região do entorno de Manaus (AM). Foto: Cláudio Stenner. 
O agronegócio é um dos setores que mais tem contribuído para o crescimento econômico do Brasil nos últimos anos. A pecuária bovina, em particular, tem tido um papel de destaque nesse cenário. O Brasil tornou-se, em 2003, o maior exportador de carne bovina do mundo. Porém, grande parte do crescimento da pecuária tem ocorrido na Amazônia, o que contribuiu para o aumento nas taxas de desmatamento, usado para abrir novas áreas para a implantação de pastos. A pecuária na Amazônia é diversa, incluindo regiões e propriedades com produtividade alta e baixa. Segundo o IBGE, a pecuária mais produtiva utilizava uma lotação média de 1,4 animal por hectare em 1995, enquanto a de baixa produtividade utilizava apenas 0,50 cabeça por hectare (BARRETO; ARIMA; BRITO, 2005). O menor preço das pastagens é suficiente para compensar os preços mais baixos do gado na Amazônia. Além do elevado retorno do investimento, os pecuaristas contaram com vantagens adicionais para expandir suas atividades, como o acesso relativamente fácil a terras públicas e ao crédito, além da baixa aplicação de lei florestal, sobre a exploração ilegal de madeira.

A exploração e o processamento industriais de madeira estão entre as principais atividades econômicas na Amazônia, ao lado da mineração industrial e da agropecuária. $\mathrm{O}$ processamento madeireiro ocorre principalmente no Pará, em Mato Grosso e em Rondônia. A atividade madeireira está frequentemente associada à expansão agropecuária, antecedendo-a nas frentes de ocupação da Amazônia. A indústria madeireira localiza-se preferencialmente ao longo dos principais eixos de transporte (rodoviário e fluvial). A partir do final da década de 1990, houve um deslocamento da produção do leste para o oeste do Pará e do centro-norte para o noroeste de Mato Grosso. Em 2004, 28,0\% da madeira produzida era oriunda das madeireiras ao longo da Rodovia BR-163 (Santarém-Cuiabá). A Rodovia BR-364 (Cuiabá-Porto Velho-Rio Branco) era responsável por 16,0\% da produção, enquanto as indústrias situadas às margens do Rio Amazonas (Manaus-Estuário) produziam 14,0\% da madeira processada. Os eixos rodoviários do leste do Pará, PA-150 e BR-010, representavam cada um deles 12,0\% da produção. A Rodovia Transamazônica (de Marabá, no Pará, até Humaitá, no Amazonas) contribuía com 5,0\% da madeira processada. Os 13,0\% restantes estavam dispersos no noroeste de Mato Grosso, no sul de Rondônia e em Roraima (LENTINI; VERÍSSIMO; PEREIRA, 2005). Segundo dados do então Ministério do Desenvolvimento, Indústria e Comércio Exterior, entre 1998 e 2004, houve um drástico aumento no valor das exportações de madeira da Amazônia (FATOS..., 2006).

Em 2002, cerca de 47,0\% do bioma estava sob pressão humana. As áreas de pressão humana consolidada, que abrangem centros urbanos, assentamentos de reforma agrária e áreas desmatadas, cobriam 19,0\% da Amazônia. As áreas de pressão incipiente, notadamente as zonas em torno dos focos de incêndios em florestas, cobriam 28,0\% do Bioma Amazônia. A taxa de desmatamento é um indicador fundamental para avaliar a pressão humana sobre a cobertura vegetal na Amazônia (BARRETO et al., 2005).

As áreas desmatadas são mais expressivas no chamado "arco do desmatamento", no leste do Pará, oeste do Maranhão, norte de Mato Grosso e em Rondônia. O plantio de pastos para pecuária é o principal uso das áreas desmatadas no bioma, de acordo com os Censos Agropecuários 1996 e 2006, do IBGE. Entretanto, em anos recentes, uma parte das 
pastagens degradadas tem sido convertida em cultivos agrícolas, como arroz, milho e soja, em algumas microrregiões, por exemplo, do leste do Pará e do centro-norte de Mato Grosso. Por outro lado, a expansão dos plantios de grãos no Bioma Amazônia tem sido limitada pelo excesso de chuvas ou pela presença de terrenos acidentados, como em Paragominas, no Pará (BARRETO et al., 2005).

No Bioma Amazônia, a urbanização também é importante em torno de polos de processamento de madeira, extração mineral, zonas francas (Manaus e Macapá), capitais e polos regionais. De 1970 a 2010, a população amazônica cresceu de 7,3 milhões para 24,1 milhões de habitantes, concentrando-se nas cidades. Em 2010, 71,0\% da população morava em cidades, com pouca infraestrutura, onde proliferam palafitas (Figura 12). Crescem especialmente as cidades com menos de 100000 habitantes. As zonas urbanas cobrem 5,6\% do Bioma Amazônia, considerando um raio de 20 quilômetros ao redor da sede de cada um dos 450 municípios. Esse raio permite fazer uma estimativa aproximada das zonas que sofrem pressão mais intensa, incluindo áreas desmatadas (menores que 6,25 hectares), construções, pavimentação, depósitos de lixo e resíduos industriais e emissão de esgoto sem tratamento. Além disso, essas zonas abrigam remanescentes de florestas submetidas à pressão de uso mais intensiva, por exemplo, extração de madeira e produtos não madeireiros e caça (BARRETO et al., 2005).

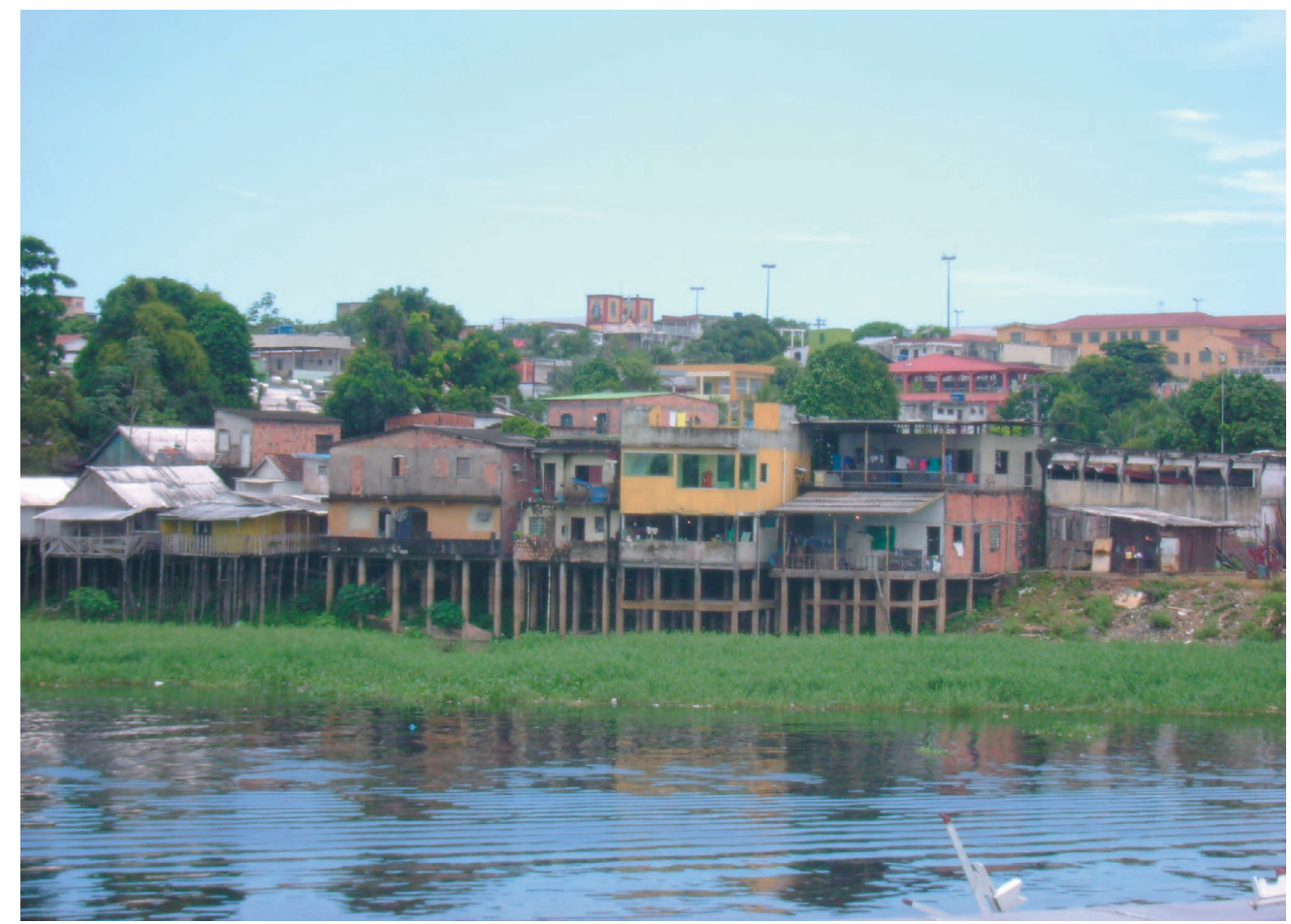

Figura 12 - Casas sobre palafitas, Manaus (AM). Foto: Rosangela Garrido Machado Botelho. 
Os assentamentos de reforma agrária cobrem 4,9\% do bioma, dos quais aproximadamente metade está em áreas florestadas sem sinais de pressão humana. De acordo com o Instituto Nacional de Colonização e Reforma Agrária - INCRA, do Ministério do Desenvolvimento Agrário, o número de famílias em assentamentos de reforma agrária na Amazônia Legal mais do que triplicou entre 1994 e 2002, passando de 161500 para 528571 (BARRETO et al., 2005). O Pará concentra um grande número de assentamentos, especialmente no sul e oeste do estado. Todos os outros estados também abrigam assentamentos em regiões florestadas.

Os focos de calor na floresta também são indicadores de zonas de pressão incipiente. Os incêndios florestais são mais comuns em florestas sujeitas à exploração de madeira, uma vez que essas últimas são mais abertas e secas, acumulando vegetação morta, altamente suscetível à combustão. Os incêndios florestais geralmente começam a partir de queimadas em terrenos agrícolas ou pastagens vizinhas (BARRETO et al., 2005). Segundo dados do Instituto Nacional de Pesquisas Espaciais - INPE (2014), a partir do ano de 2005, a taxa de desmatamento na região da Amazônia Legal decresce graduamente até 2013.

Há uma forte associação entre a pressão humana sobre a Floresta Amazônica e as estradas. Por exemplo, aproximadamente $80,0 \%$ da área total desmatada está localizada até 30 quilômetros das estradas oficiais. E 80,0\% dos centros urbanos, assentamentos de reforma agrária e focos de calor estão numa faixa de 70 quilômetros a partir dessas estradas. Por outro lado, é possível encontrar assentamentos de reforma agrária e centros urbanos até 210 e 450 quilômetros das estradas oficiais. A ocupação humana distante de estradas é propiciada principalmente por rios navegáveis e pela abertura de estradas não oficiais para dar acesso a recursos de alto valor como mogno (no sul do Pará) e ouro (no oeste do Pará). As estradas não oficiais geralmente partem de estradas oficiais (BARRETO et al., 2005). Estas são rodovias inter-regionais, construídas tanto pelos governos estaduais como pela União. As estradas não oficiais, conhecidas na região como ramais, são abertas pela iniciativa privada e têm abrangência local. Os principais responsáveis pela abertura dessas estradas são madeireiros, colonos, fazendeiros e garimpeiros, que as constroem para facilitar o acesso aos recursos naturais, principalmente a madeira e a terra (PERZ et al., 2005). Tal relação entre estradas pavimentadas e principais pressões antrópicas remete à necessidade de órgãos governamentais incorporarem áreas extensas no planejamento dos principais projetos de infraestrutura elaborados ou em elaboração no Bioma Amazônia, como está sendo feito no caso da pavimentação da Rodovia Santarém-Cuiabá (BR-163 Sustentável).

Outros empreendimentos de grande impacto na Amazônia são os projetos de aproveitamento hidrelétrico. A hidroeletricidade é a forma predominante de geração de energia do setor elétrico brasileiro e deverá, ainda, ser preponderante nas próximas duas décadas, segundo dados Plano nacional de energia 2030 (EMPRESA DE PESQUISA ENERGÉTICA, 2007). Muito embora, em 2005, a Amazônia participasse com apenas 16,8\% do total de hidroeletricidade em operação no País, parte importante da expansão hidroenergética $(53,4 \%)$ está prevista para a região. O potencial de geração se concentra sobretudo nos tributários de águas claras que 
drenam do Planalto Central do Brasil - Rios Tocantins-Araguaia, Xingu e Tapajós; nas bacias hidrográficas dos rios de águas pretas Trombetas e Negro, e nos tributários de águas brancas Madeira e Purus, entre outros. Existem ainda várias Pequenas Centrais Hidrelétricas ( $\mathrm{PCHs}$ ) em operação e/ou construção nas cabeceiras dos tributários, sobretudo em Rondônia, Pará e Mato Grosso. Não obstante sua importância estratégica e os benefícios socioeconômicos resultantes, o represamento dos rios para a construção de usinas hidrelétricas tem gerado passivos socioambientais de diferentes naturezas e magnitudes, que devem ser minimizados, mitigados e/ou compensados. Entre os principais impactos ambientais estão a perda de florestas por alagamento, a perda de habitats-críticos para a biota aquática, a interrupção de migrações de peixes que mantêm a pesca na região, alterações no regime hidrológico e possíveis influências sobre Unidades de Conservação. O deslocamento da população humana atingida pelas barragens e as interferências em povos tradicionais e indígenas estão entre os principais impactos sociais.

Ressalta-se que, diante do preocupante quadro de desequilíbrio ambiental na Amazônia, diversas ações prioritárias de proteção à biodiversidade vêm sendo implementadas nas últimas décadas.

Reconhecendo a importância da Floresta Amazônica (e de outras formações vegetais presentes no bioma), o Ministério do Meio Ambiente por meio da Secretaria de Biodiversidade e Floresta (BRASIL, 2007) identificou 824 áreas como prioritárias para a conservação e o uso sustentável da biodiversidade, das quais 490 já possuem algum tipo de proteção (Unidades de Conservação e Terras Indígenas), e 334 são áreas novas ainda não protegidas. No total, mais de $80,0 \%$ da área do Bioma Amazônia foi considerada prioritária para a conservação da biodiversidade (BRASIL, 2007). Este documento tem orientado as ações do poder público no Bioma Amazônia, inclusive a criação de novas áreas protegidas.

Outros Planos e iniciativas governamentais na área de revitalização e gestão ambiental com foco no Bioma Amazônia incluem: o Plano de Ação para Prevenção e Controle do Desmatamento na Amazônia Legal - PPCDAm; Projeto de Apoio ao Manejo dos Recursos Naturais da Várzea - ProVárzea; Programa Áreas Protegidas da Amazônia - ARPA, Programa Piloto para Proteção das Florestas Tropicais do Brasil - PPG7; Plano Amazônia Sustentável PAS; Projeto Gerenciamento Integrado e Sustentável dos Recursos Hídricos Transfronteiriços na Bacia do Rio Amazonas - Projeto GEF Amazonas; Projeto Manejo Integrado dos Recursos Aquáticos na Amazônia - AQuAbIo; Sistema de Vigilância da Amazônia - Projeto Sivam; Programa Brasileiro de Ecologia Molecular para o Uso Sustentável da Biodiversidade da Amazônia - Probem; Large Scale Biosphere-Atmosphere Experiment in Amazonia - LBA; entre outros.

A proteção da Floresta Amazônica justifica-se não só pela sua elevada biodiversidade, mas também pela existência de numerosos e diferentes grupos de populações tradicionais que habitam o Bioma Amazônia. Esses dependem da floresta e dos rios e tiram do seu espaço o seu sustento, entre os quais se destacam índios, seringueiros, castanheiros e pescadores, que demandam a implementação de políticas de apoio ao desenvolvimento humano. 


\section{Cerrado: berço das águas}

\section{Mapa 2 - Bioma Cerrado - Bacias Hidrográficas}

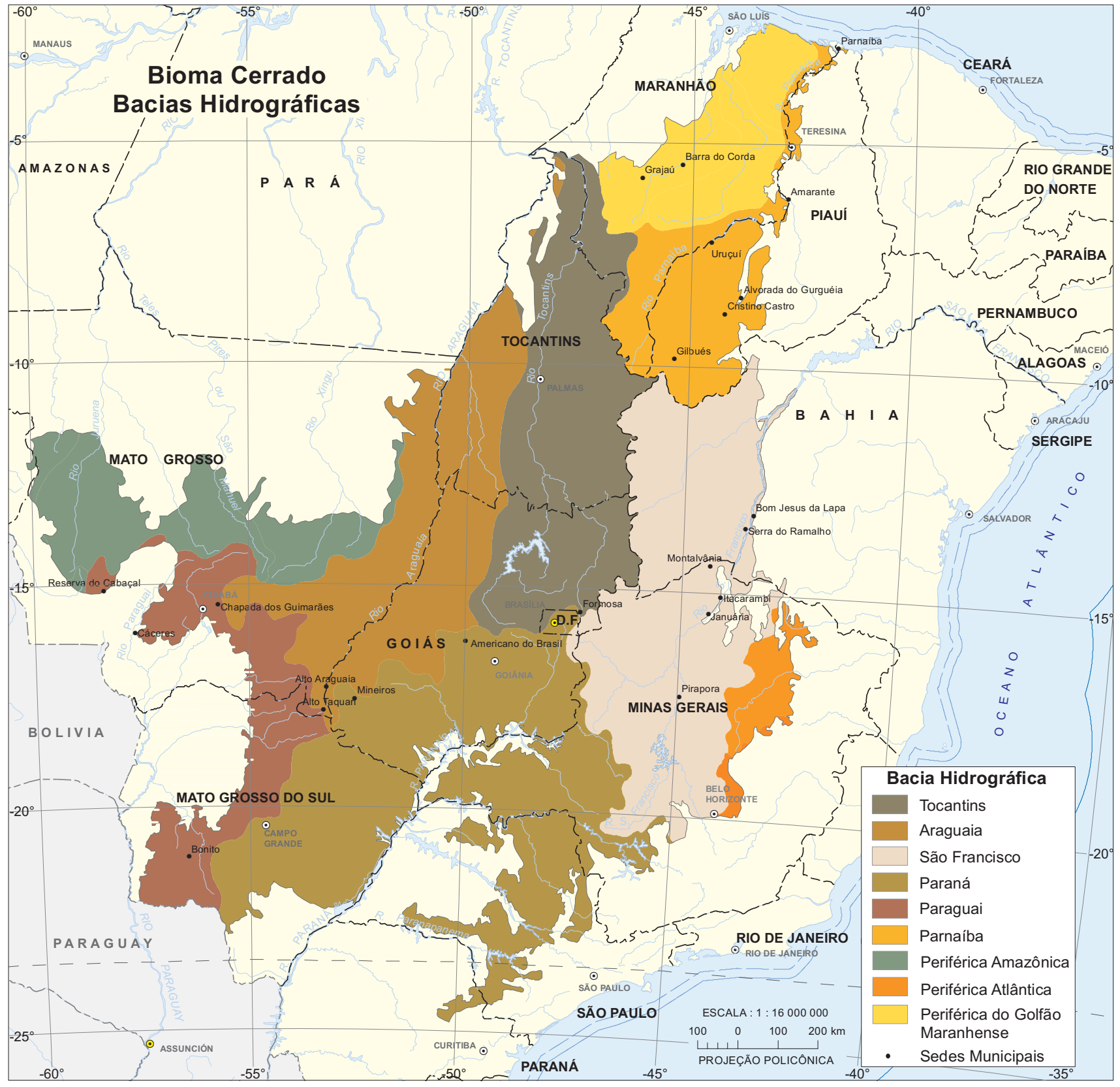

Fonte: IBGE, Diretoria de Geociências, Coordenação de Recursos Naturais e Estudos Ambientais. 
O Bioma Cerrado é o segundo do Brasil em tamanho e estende-se do Pantanal Mato-Grossense até a faixa litorânea maranhense, interpondo-se entre os Biomas Amazônia, Mata Atlântica, Pantanal e Caatinga. Os fatores determinantes para a predominância das fitofisionomias savânicas que caracterizam o Bioma Cerrado são o clima, os solos e o fogo, embora outras variáveis ambientais também contribuam para isso. Alterações climáticas foram responsáveis ao longo do tempo geológico por períodos alternados de expansão e retração geográfica do bioma (MARINHO-FILHO; MACHADO; HENRIQUES, 2010).

O clima dominante é tropical quente subúmido, com duas estações: a seca, geralmente de maio a setembro, e a chuvosa, de outubro a abril. A precipitação varia entre 600 a 2200 milímetros anuais, sendo que as áreas limítrofes com os Biomas Caatinga e Amazônia recebem, respectivamente, os mais baixos e os mais altos volumes anuais de chuva. As temperaturas médias anuais variam entre $27^{\circ}$ Celsius, na faixa situada acima dos $14^{\circ} \mathrm{de}$ latitude Sul, e $22^{\circ}$ Celsius abaixo deste paralelo. Neste último caso, estão as áreas de maior altitude ou sujeitas a frentes frias intensas, com temperaturas médias mais baixas. Durante o período seco, a umidade relativa do ar pode ficar muito baixa, com níveis comparáveis aos de regiões desérticas.

A geologia do Bioma Cerrado é das mais diversificadas e complexas do País, compreendendo rochas que remontam do Pré-Cambriano ao Cenozoico, com predominância das primeiras. O relevo exibe uma gama muito grande de feições morfológicas distribuídas em níveis altimétricos diferenciados, constituindo unidades bem-definidas, dentre as quais destacam-se planaltos, depressões e planícies. Os planaltos predominam, constituindo extensas chapadas com escassa rede de drenagem. As altitudes variam de cerca de 50 metros, no litoral do Maranhão, a 1670 metros, na Chapada dos Veadeiros, em Goiás, atingindo 2000 metros na Serra do Espinhaço, em Minas Gerais (Figura 13).

Os solos são, na maior parte da área, distróficos e ácidos, estando os Latossolos presentes em cerca de 65,0\% do Bioma, principalmente nos planaltos. Jacomine (1969) e Lopes (1983) chamam a atenção para os baixos valores absolutos de alumínio trocável, embora, por vezes, os solos tenham sido caracterizados como álicos em razão do nível muito baixo dos demais cátions do complexo sortivo. São, portanto, solos em sua maioria de baixa fertilidade química, exigindo para o desenvolvimento da atividade agrícola o emprego de sistemas de manejo tecnificados e capitalizados. 


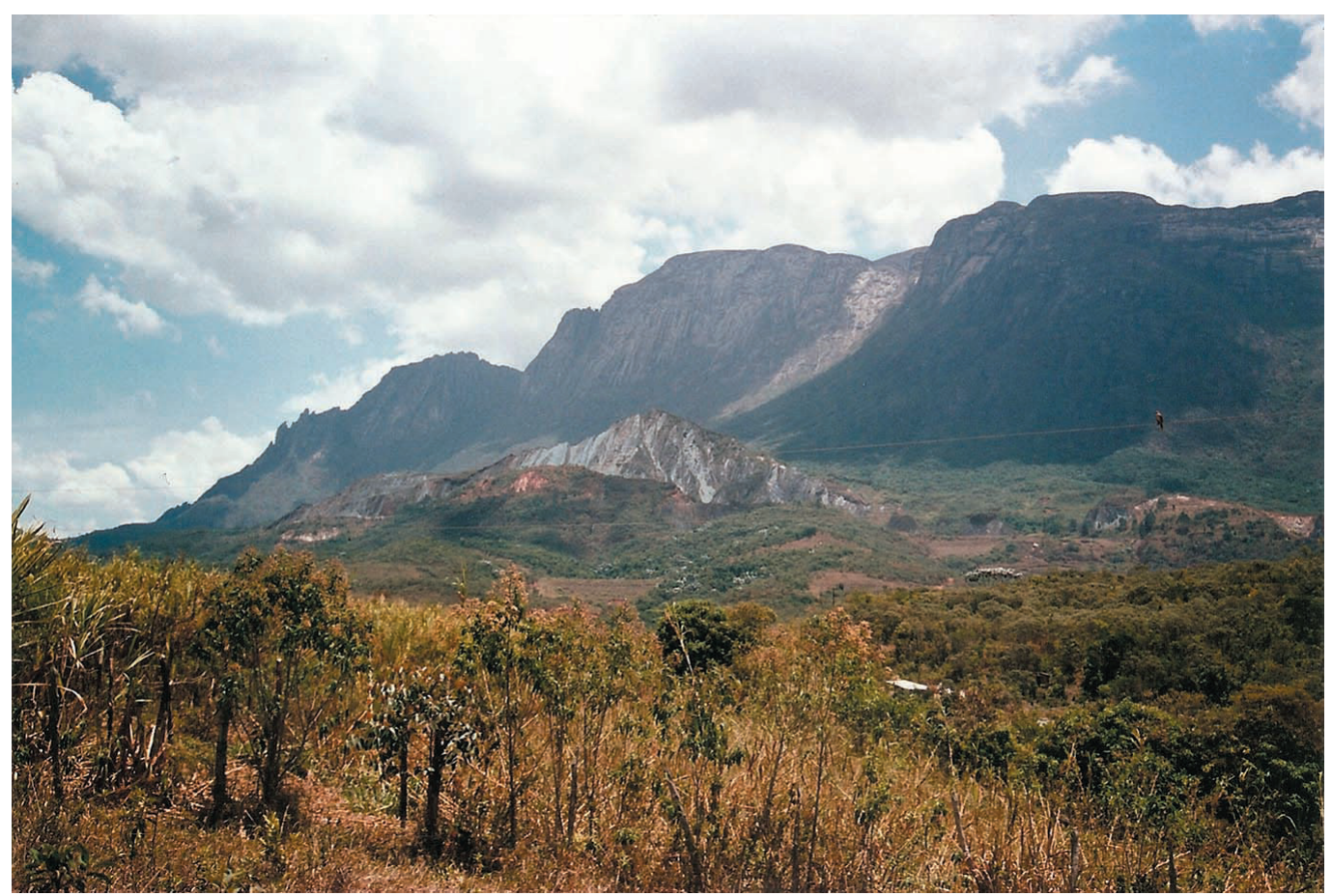

Figura 13 - Serra do Espinhaço (MG).

Foto: Rosangela Garrido Machado Botelho.

A maior parte dos Latossolos argilosos dos chapadões, mesmo os originados de basaltos, tem mostrado, além da baixa fertilidade, valores positivos para $\Delta \mathrm{pH}^{9}$ (OLIVEIRA; COSTA, 1995; OLIVEIRA et al., 2003). Logo, são solos que apresentam inversão no balanço de cargas, o que reduz a praticamente zero sua capacidade de reter cátions (CTC). Tal fato é responsável por seu enquadramento nos grandes grupos "ácricos ou acriférricos" do Sistema Brasileiro de Classificação de Solos (2013).

Vale destacar que os solos do Bioma Cerrado são bastante intemperizados. Se forem submetidos a uso indevido, perdem capacidade produtiva e podem apresentar degradação intensa, com efeitos diretos sobre os recursos hídricos.

O Bioma Cerrado apresenta fisionomias que englobam formações florestais, savânicas e campestres. A fisionomia mais comum é uma formação aberta de árvores e arbustos baixos coexistindo com uma camada rasteira graminosa (BRASIL, 2002, p. 178). As tipologias vegetacionais do Bioma Cerrado estão assim distribuídas: Savana, que ocupa expressivas áreas nos Estados de Goiás, Minas Gerais, Mato Grosso, Mato Grosso do Sul, Tocantins, Bahia, Maranhão, Piauí, São Paulo e uma pequena área no nordeste do Paraná; Savana Estépica, em pequenas áreas do sudoeste da Bahia e norte de Minas Gerais; Floresta Estacional Semidecidual, no Maranhão, Piauí, oeste da Bahia, norte, centro e oeste de Minas Gerais, norte e sul de Goiás, Mato Grosso e Mato Grosso do Sul; Floresta-de-Galeria, espalhada por toda a área

\footnotetext{
9 Diferença entre os valores de $\mathrm{pH}$ em cloreto de potássio e em água. O caráter aniônico do solo, quando o mesmo apresenta $\Delta \mathrm{pH}$ positivo, confere-lhe baixa fertilidade e até mesmo efeito nocivo às plantas (SISTEMA..., 2013).
} 
do bioma; Floresta Estacional Decidual, que ocorre em expressivas áreas, desde o Piauí até o norte de Minas Gerais, atravessando o oeste da Bahia, e chegando ao nordeste e centro de Goiás; Formações Pioneiras, representadas pelos mangues e restingas do litoral do Piauí e do Maranhão, incluindo os Lençóis Maranhenses; Refúgio Vegetacional, na porção central de Minas Gerais e de Goiás; e mais as Áreas de Tensão Ecológica (Tabela 2).

Tabela 2 - Áreas remanescentes e áreas antropizadas, no Bioma Cerrado, segundo os tipos de vegetação

\begin{tabular}{|c|c|c|c|c|c|c|}
\hline \multirow{3}{*}{ Tipos de vegetação } & \multicolumn{6}{|c|}{ Bioma Cerrado } \\
\hline & \multicolumn{2}{|c|}{ Total no Bioma } & \multicolumn{2}{|c|}{ Área remanescente } & \multicolumn{2}{|c|}{ Área antropizada } \\
\hline & $\begin{array}{c}\mathrm{Em} \\
\mathrm{km}^{2}\end{array}$ & $\begin{array}{l}\text { Percentual } \\
(\%)\end{array}$ & $\begin{array}{l}\mathrm{Em} \\
\mathrm{km}^{2}\end{array}$ & $\begin{array}{l}\text { Percentual } \\
(\%)\end{array}$ & $\begin{array}{l}\mathrm{Em} \\
\mathrm{km}^{2}\end{array}$ & $\begin{array}{l}\text { Percentual } \\
(\%)\end{array}$ \\
\hline Área total do bioma & 2036448 & 100,0 & 859765 & 42,0 & 1164757 & 57,0 \\
\hline Floresta Estacional Semidecidual & 36217 & 2,0 & 9012 & 25,0 & 27205 & 75,0 \\
\hline Floresta Estacional Decidual & 1390710 & 7,0 & 32864 & 24,0 & 106207 & 76,0 \\
\hline Savana & 1369699 & 67 & 608067 & 44,0 & 761631 & 56,0 \\
\hline Savana estépica & 653 & $<0,5$ & 653 & 100,0 & - & - \\
\hline Formações pioneiras & 9564 & $<0,5$ & 9564 & 100,0 & - & - \\
\hline Contatos entre tipos de vegetação & 464523 & 23 & 194813 & 42,0 & 269714 & 58,0 \\
\hline Refúgios vegetacionais & 4792 & $<0,5$ & 4792 & 100,0 & - & - \\
\hline Superfície com água & 11926 & 1,0 & - & - & - & - \\
\hline
\end{tabular}

Fonte: Mapa de biomas do Brasil: primeira aproximação. Rio de Janeiro: IBGE, 2004. 1 mapa. Escala 1:5 000 000. Disponível em: <ftp://geoftp.ibge.gov.br/informacoes_ambientais/vegetacao/mapas/brasil/biomas.pdf>. Acesso em: jul. 2016.

Notas: 1 . Corresponde a 24,0\% da área total do País.

2. Datas médias de referência: Regiões Norte e Centro-Oeste - 2000; Região Nordeste - 1996; Região Sudeste - 1982.

A cobertura vegetal predominante é constituída pelas formações da Savana, ocorrendo também formações florestais. A Savana Florestada (Cerradão) é dotada de fisionomia florestal e composta por espécies arbóreas semideciduais, com dossel entre 8 e 12 metros de altura. Caracteriza-se pela associação de espécies típicas do Cerrado com espécies das Florestas-de-Galeria Estacionais. Sua frequência no Bioma Cerrado é moderada, e sua ocorrência geralmente está relacionada com os Latossolos em relevo plano.

As formações com fisionomias campestres da Savana compõem-se de um estrato arbóreo sem dossel contínuo, acompanhado ou não de um estrato arbustivo e um herbáceo. São as formações que melhor caracterizam o Bioma Cerrado, recobrindo cerca de $3 / 4$ da sua superfície e abrigando a maior parte das espécies endêmicas. Dentre elas, a Savana Arborizada é a que ocupa a maior área e a que melhor reflete as condições ambientais predominantes (Figura 14). É uma formação semidecídua, rica em espécies adaptadas à seca e ao fogo, composta de um estrato arbóreo formado por elementos xeromorfos, de 3 a 10 metros de altura, um estrato arbustivo, também composto por elementos xeromorfos, e um estrato herbáceo dominado por gramíneas. Outra formação importante é a Savana Parque, também semidecidual, porém menos disseminada, com estrutura composta por agrupamentos de árvores e arbustos típicos da Savana e por um estrato herbáceo graminoso. A terceira formação é a Savana Gramíneo-Lenhosa, composta pela associação de ervas e arbustos de pequeno porte. 


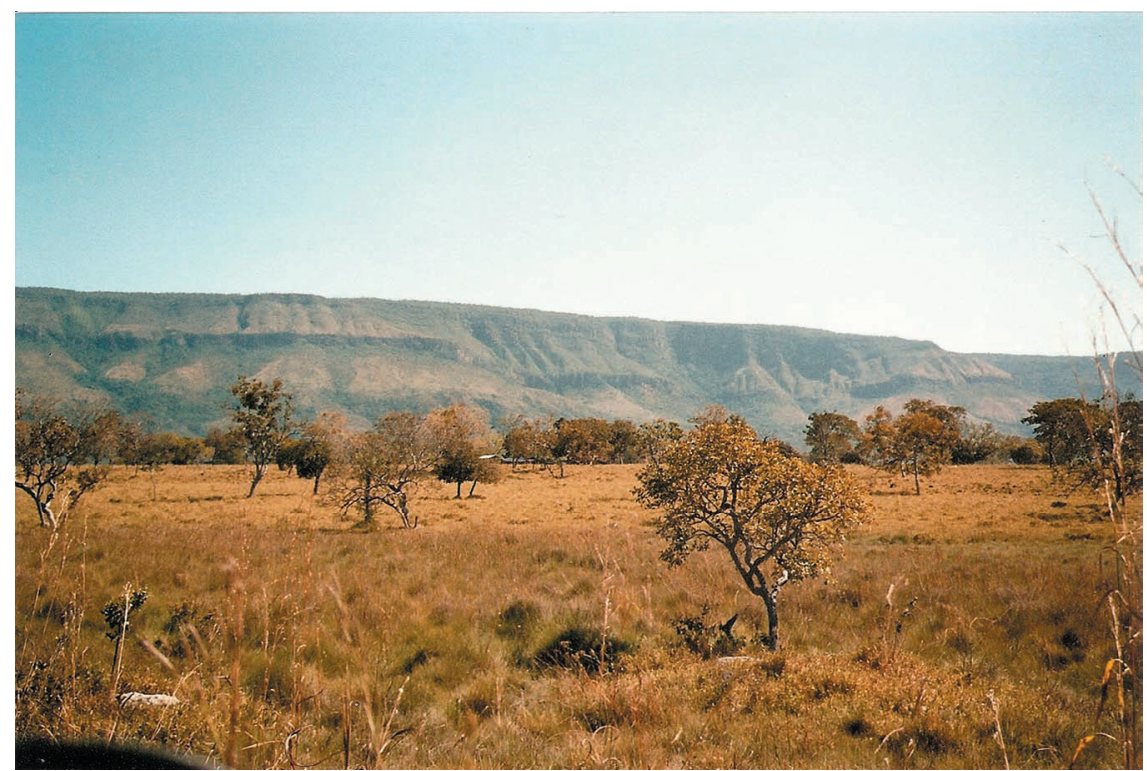

Figura 14 - Savana Arborizada (campo cerrado), Município de Formosa (GO). Foto: Rosangela Garrido Machado Botelho.

Associada à fisionomia da Savana, a Floresta-de-Galeria (também denominada mata ciliar, mata ripária, mata ripícola e mata ribeirinha) ocorre ao longo dos cursos de água, em terrenos relativamente férteis e sem déficit hídrico; é, em geral, perenifólia, sendo o tipo de floresta mais frequente no Bioma Cerrado. Outra fisionomia típica da Savana é a Vereda, que se caracteriza por ocorrer em vales ocupados por solos gleizados ou aluviais, encharcados, e por ser constituída de agrupamentos da palmeira buriti, misturada ou não com a buritirana, sobre um estrato herbáceo dominado por elementos graminoides. Trata-se de uma fitofisionomia frequente na maior parte do Cerrado, mas que não ocupa grande fração da área total (Figura 15).

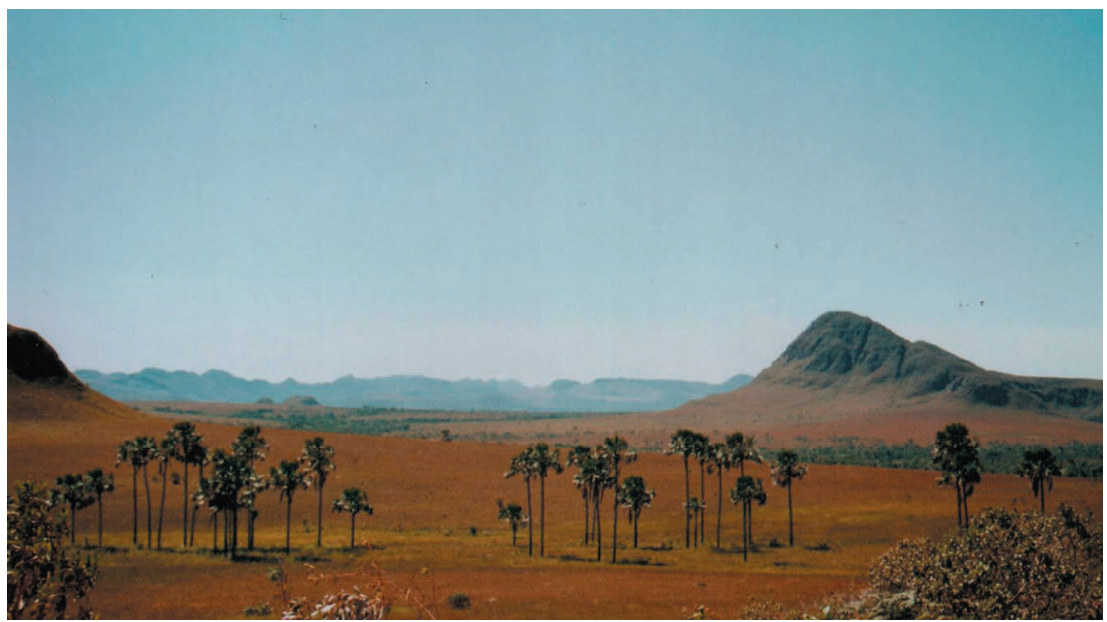

Figura 15 - Jardim de Maytrea, Parque Nacional da Chapada dos Veadeiros (GO). Foto: Rosangela Garrido Machado Botelho. 
A Floresta Estacional é menos frequente, mas é encontrada em todo o Bioma Cerrado, ocupando, por vezes, extensas áreas. A sua distribuição coincide com as áreas de solos com fertilidade alta e média que ocorrem nos interflúvios e ao longo de alguns segmentos da rede de drenagem, situações que condicionam as categorias decidual e semidecidual. A Floresta Estacional Semidecidual ocorre em solos profundos, férteis e de boa capacidade de retenção de umidade. Seu estrato arbóreo compartilha espécies com as demais florestas de solos bem-drenados e possui diversos elementos florísticos de ampla dispersão no Brasil. A Floresta Estacional Decidual ocorre em solos rasos e de baixa capacidade de retenção de água, em grande parte das vezes associados a afloramentos de calcário. Seu estrato arbóreo contém grande número de espécies de alto valor comercial e, em algumas áreas, apresenta elementos comuns à Savana Estépica.

Vale destacar a pequena área remanescente das Florestas Estacional Decidual e Semidecidual, ambas nas formações submontana e montana. No Bioma Cerrado, a Savana Estépica, as Formações Pioneiras e os Refúgios Vegetacionais têm áreas de ocorrência apenas pontuais.

Segundo Cochrane e outros (1985), o Bioma Cerrado engloba 25 grandes unidades fisiográficas, com mais de 70 sistemas de terras, que reúnem condições distintas de rochas, solos, relevos e climas. Como as coletas botânicas no Bioma Cerrado são insuficientes para inferir centros de diversidade florística, estudos fitossociológicos padronizados têm sido utilizados para quantificar diferenças fitogeográficas de composição, riqueza e diversidade (PROENÇA et al., 2010). Esses estudos atestam que esta heterogeneidade física do Bioma Cerrado está refletida em sua biota (OLIVEIRA FILHO; RATTER; 1995; FELFILI; SILVA JÚNIOR, 2001; RATTER; BRIDGEWATER; RIBEIRO, 2003).

Já foram catalogadas 12683 espécies de plantas e fungos, 58,0\% das quais endêmicas do Bioma Cerrado (LISTA..., 2010). Segundo Bertram (1994), há mais de 12 mil anos, as plantas nativas do Cerrado vêm sendo utilizadas pelo homem como alimento, remédio, forragem, material de construção, matéria-prima para artesanato, para obtenção de fibras, óleo, tanino e outros produtos, ou para fins ornamentais (Figura 16).

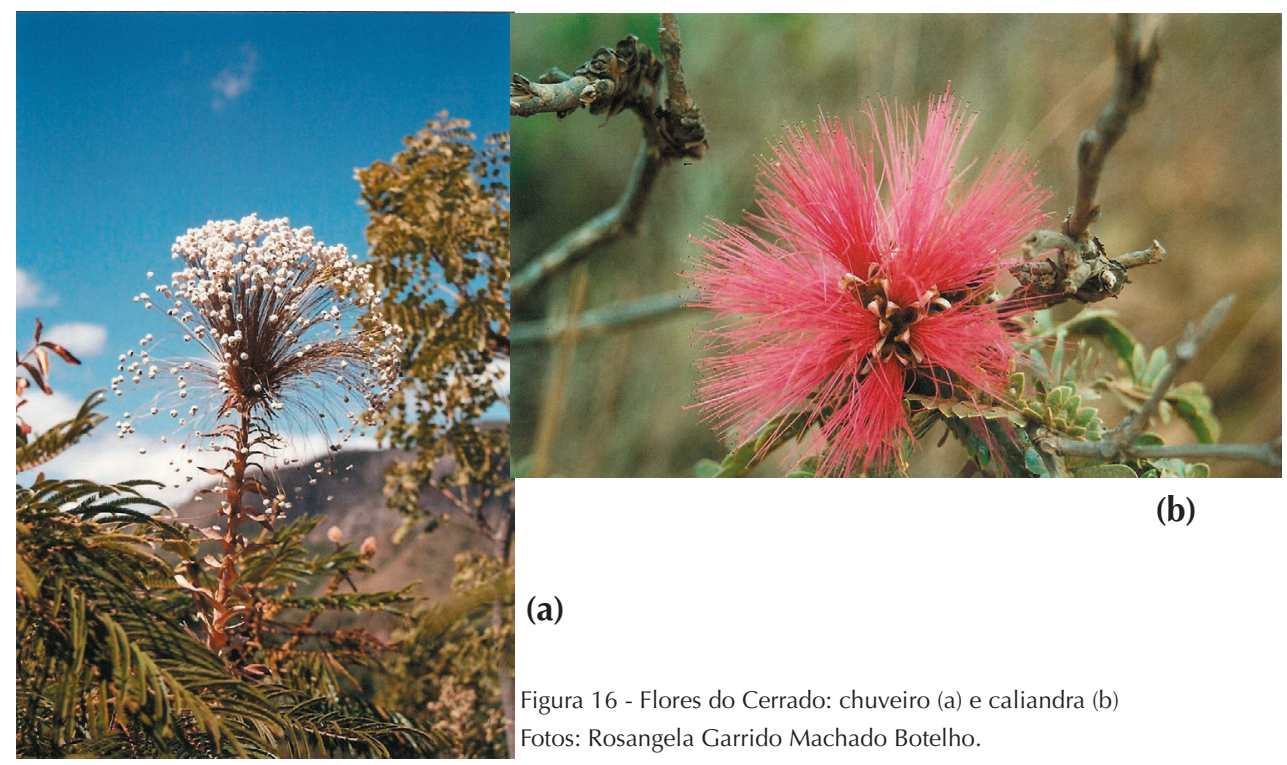


A exemplo das plantas, a fauna do Bioma Cerrado também é bastante rica e exibe número de espécies semelhante ao observado nas formações florestais. As primeiras análises sobre a fauna do Cerrado ocorreram a partir dos anos de 1960 e introduziram o paradigma de uma fauna "pouco característica, com baixo endemismo e praticamente sem adaptações específicas aos ambientes mais abertos e secos". Estudos posteriores ajudaram a consolidar essa ideia, ao associarem o baixo endemismo da fauna de vertebrados terrestres, especialmente de aves $(4,0 \%)$ e mamíferos $(9,0 \%)$, à manutenção de corredores florestais (Matas-de-Galeria) entre a Mata Atlântica e a Amazônia, que persistiram mesmo durante os climas mais frios e secos do Quaternário. Entretanto, estudos mais recentes demonstram que, para outros grupos menos associados às formações florestais, o grau de endemismo é bem mais expressivo: invertebrados (alta proporção de espécies típicas do Cerrado); anfíbios (30,0\%), anfisbênias (60,0\%), lagartos $(45,0 \%)$ e serpentes (30,0\%). Esses dados permitem questionar o modelo previamente estabelecido (MARINHO-FILHO; MACHADO; HENRIQUES, 2010).

Os invertebrados representam o grupo mais hipediverso do planeta, reunindo mais de $95,0 \%$ das espécies e 99,9\% dos indivíduos do reino animal (HADFIELD, 1993). A representatividade da fauna regional em relação à brasileira varia entre os grupos, com menos de $20,0 \%$ das abelhas e formigas, $43,0 \%$ das vespas sociais, $44,0 \%$ das aranhas e $54,0 \%$ dos cupins (DINIZ et al., 2010). Em três ordens de insetos, Lepidoptera, Hymenoptera e Isoptera, o número de espécies estimado para o Cerrado é de 14425 e representa $47,0 \%$ da fauna estimada para o Brasil (BRASIL, 2002). Outros grupos, como os besouros, também são muito diversificados e rivalizam com a fauna Amazônica. A meiofauna de Campos Úmidos do Bioma Cerrado apresenta a maior riqueza de copépodos conhecida em habitat inundado de água doce, com a excepcional marca de 95,0\% de endemismos. Os insetos são também especialmente abundantes no Bioma Cerrado, com valores surpreendentemente mais altos ( 2,5 vezes) do que os registrados para Florestas Úmidas na América Central e no Caribe. Além de sua extraordinária diversidade e abundância, os invertebrados, especialmente os insetos, ocupam um grande número de habitats e nichos, e desempenham funções ecológicas essenciais para a regulação dos ecossistemas, tais como polinização, dispersão, decomposição e ciclagem de nutrientes (MORAIS; DINIZ, 2011).

Pela relativa facilidade de estudo e alto grau de vulnerabilidade, anfíbios e répteis representam bons grupos-indicadores para a proposição de áreas e ações prioritárias para a conservação da biodiversidade e para o diagnóstico do valor de conservação de diferentes regiões do Bioma Cerrado (DINIZ-FILHO et al., 2006). As duas últimas décadas registraram um grande salto qualitativo e quantitativo na compreensão dos padrões de diversidade e de distribuição da fauna de anfíbios e répteis no Bioma Cerrado, bem como dos mecanismos evolutivos envolvidos e, ao contrário de interpretações anteriores, atestam a grande riqueza e endemismo desses grupos (NOGUEIRA et al., 2010). A síntese mais recente indica a ocorrência de 113 espécies de anfíbios (40,0\% endêmicas), 30 espécies de anfisbênia (60,0\% endêmicas), 74 espécies de lagartos (45,0\% endêmicas) e 156 espécies de serpentes (29,0\% endêmicas), além de cinco espécies de jacarés e 10 espécies de quelônios, totalizando 300 espécies conhecidas do Cerrado (COLLI et al., 2011).

A fauna aquática do Bioma Cerrado é muito diversificada e pode ser exemplificada por sua ictiofauna, para a qual, não obstante a falta de uma compilação recente, mais de 1000 
espécies podem ser estimadas. Em 1998, cerca de 780 espécies de peixes foram registradas para as bacias hidrográficas que drenam o Bioma Cerrado, $84,0 \%$ das quais pareciam exclusivas de alguma bacia da região, com menores dissimilaridades entre as ictiofaunas das Bacias dos Rios São Francisco-Paraná-Pantanal e dos Rios Tocantins-Parnaíba (RIBEIRO, 2007). Desde então, diversas espécies novas têm sido descritas em função de novos inventários e revisões taxonômicas. Somente no Distrito Federal, foram validadas recentemente para as cabeceiras dos Rios Corumbá (Bacia do Rio Paraná), Maranhão (Bacia do Rio Tocantins) e Preto (Bacia do Rio São Francisco) mais de 220 espécies, das quais mais de 20,0\% endêmicas e ainda desconhecidas da ciência (MELO; LIMA; RIBEIRO, 2014). Os sistemas ecológicos das cabeceiras, que drenam os chapadões do Planalto Central, abrigam uma grande variedade de espécies de pequeno porte, muitas das quais endêmicas daquelas regiões. Vale destacar ainda que, no Bioma Cerrado, ocorrem três importantes interconexões entre bacias hidrográficas ou "águas emendadas": duas no Distrito Federal (entre as Bacias do Tocantins-Paraná; São Francisco-Paraná) e outra no Chapadão Oeste da Bahia (entre as Bacias do Tocantins-São Francisco). As ictiofaunas atuais dessas "águas emendadas" são testemunhos de processos históricos de capturas entre aquelas drenagens e exibem poucas espécies compartilhadas entre suas respectivas bacias (RIBEIRO et al., 2008; LIMA; CAIRES, 2011).

O Bioma Cerrado apresenta uma extraordinária diversidade de aves, incluindo numerosas famílias e cerca de 850 espécies. Entre as espécies registradas, 777 (90,7\%) parecem se reproduzir na área do Cerrado, 26 são migrantes do hemisfério norte e 12 do hemisfério sul (SILVA; SANTOS, 2005). Dois fluxos migratórios sazonais foram reconhecidos para o Bioma Cerrado: (a) "espécies de inverno", tais como o príncipe, a andorinha-serradora e a andorinha-morena, deixam os rigores climáticos da região austral da América do Sul para alcançar o Planalto Central no início da estação seca (maio - junho), onde se alimentam das revoadas de dípteros; (b) "espécies de primavera", como a tesourinha, o bem-te-vi-peitica e o bem-te-vi-rajado chegam à região poucas semanas antes das primeiras chuvas, época de maior abundância de formigas e cupins alados (NEGRET, 1988). Exemplos de aves características do Bioma Cerrado e observadas em grande quantidade são as emas (Figura 17), a coruja-do-campo, a seriema e as perdizes. O raro urubu-rei, a arara-canindé (Figura 18), o tucano-de-bico-verde e o pato selvagem também são avistados com relativa frequência. Entre as aves endêmicas e campestres estão a codorna buraqueira, o inhambú-carapé e o andarilho, que figuram na lista nacional de espécies ameaçadas de extinção, o tapaculo-de-colarinho, o tapaculo-de-Brasília, o limpa-folha-do-brejo, o soldadinho e o pula-pula-de-sobrancelha, entre outras. A diversidade e abundância das aves do Bioma Cerrado variam de acordo com o tipo de vegetação e a época do ano. A maior riqueza de espécies foi encontrada na Mata-de-Galeria e a menor, no Campo Limpo. O Cerrado Típico apresenta maior abundância de aves, enquanto o Brejo registra os menores números de indivíduos. Aves de vegetações abertas procuram abrigo durante a seca nas Matas-de-Galeria adjacentes. Aves florestais também utilizam os cerrados adjacentes, avançando maiores distâncias na época não reprodutiva, sobretudo em bandos mistos guiados pela saíra-de-papo-preto e atraídos pela floração de pequizeiros, uma estratégia que parece diminuir os riscos de predação em ambientes mais abertos e, ao mesmo tempo, expandir sua área de distribuição e seu nicho ecológico (TUBELIS; COWLING; DONNELLY, 2006). 


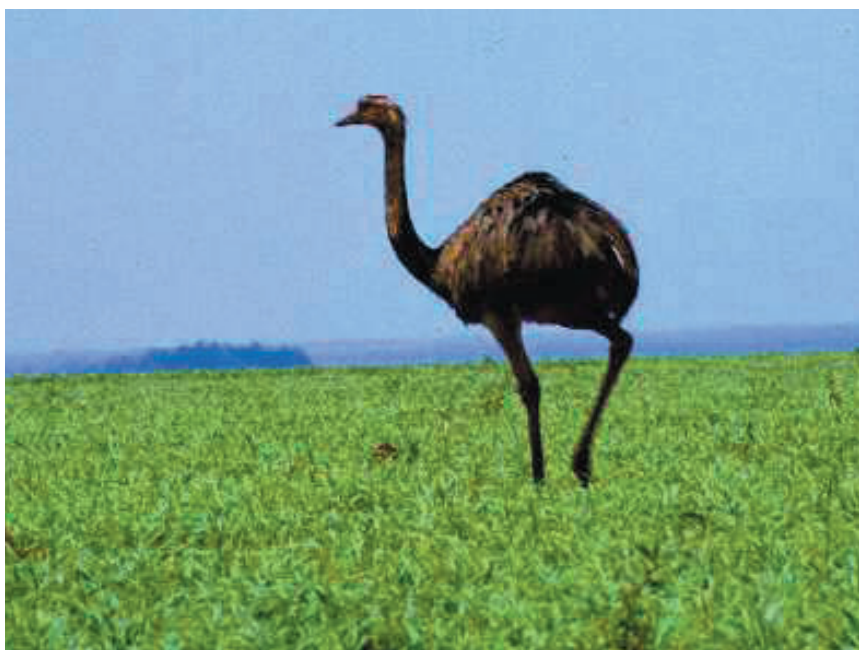

Figura 17 - Ema, ave comum no Bioma Cerrado. Acervo: Reserva Ecológica do IBGE.

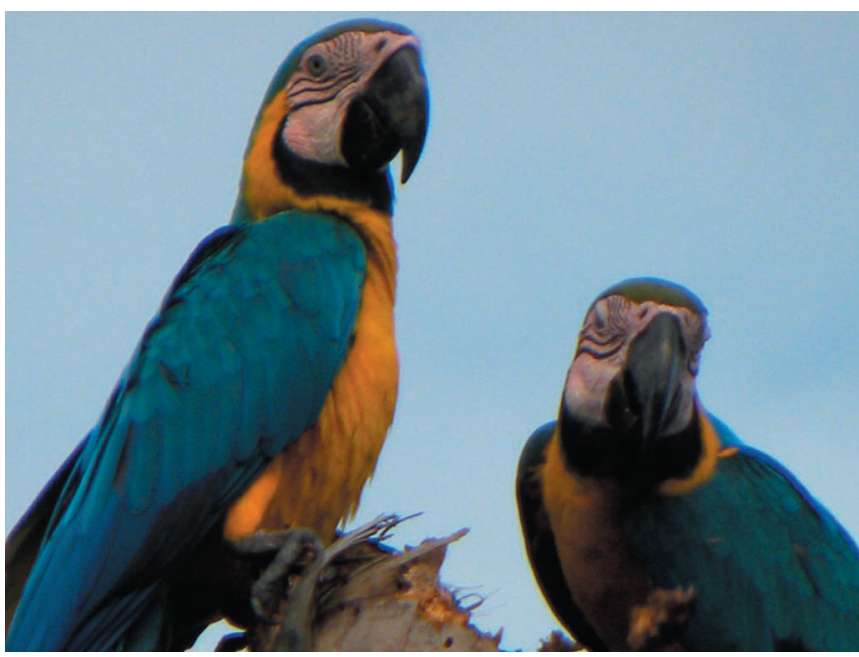

Figura 18 - Araras canindé.

Foto: José Carlos Louzada Morelli.

O Cerrado abriga uma expressiva fauna de mamíferos, com aproximadamente 252 espécies catalogadas, sendo os morcegos os mais diversificados, com 106 espécies (AGUIAR; MACHADO, 2010). A riqueza de espécies, a abundância e a estrutura das comunidades de mamíferos silvestres do Bioma Cerrado tendem, em geral, a refletir o tipo e a estrutura dos habitats, seus recursos ecológicos e o drástico regime sazonal de chuva e seca, com variações na oferta de alimentos e ritmo fenológico da vegetação, bem como na reprodução dos mamíferos. Alguns mamíferos típicos do Bioma Cerrado são o tamanduá-bandeira (Figura 19), o veado-campeiro, a onça-pintada, a suçuarana, o tatu-galinha (Figura 20), o tatu-canastra, o lobo-guará (Figura 21), o cachorro-do-mato, o coati e o tapetí, única espécie de lagomorfo brasileiro, além da anta, macacos-prego, bugios e capivaras mais frequentes nas áreas florestadas. Cerca de 18 espécies de mamíferos são endêmicas do Bioma Cerrado ou estão sob algum grau de ameaça, sendo os carnívoros topo de cadeia os mais vulneráveis à redução/ fragmentação de habitats ou caça (BRASIL, 2002). Não obstante sua diversidade e importância, pouco se conhece sobre os padrões de distribuição dos mamíferos nas diversas áreas do Bioma Cerrado (AGUIAR; MACHADO, 2010; RIBEIRO; BEZERRA; MARINHO-FILHO, 2010). 


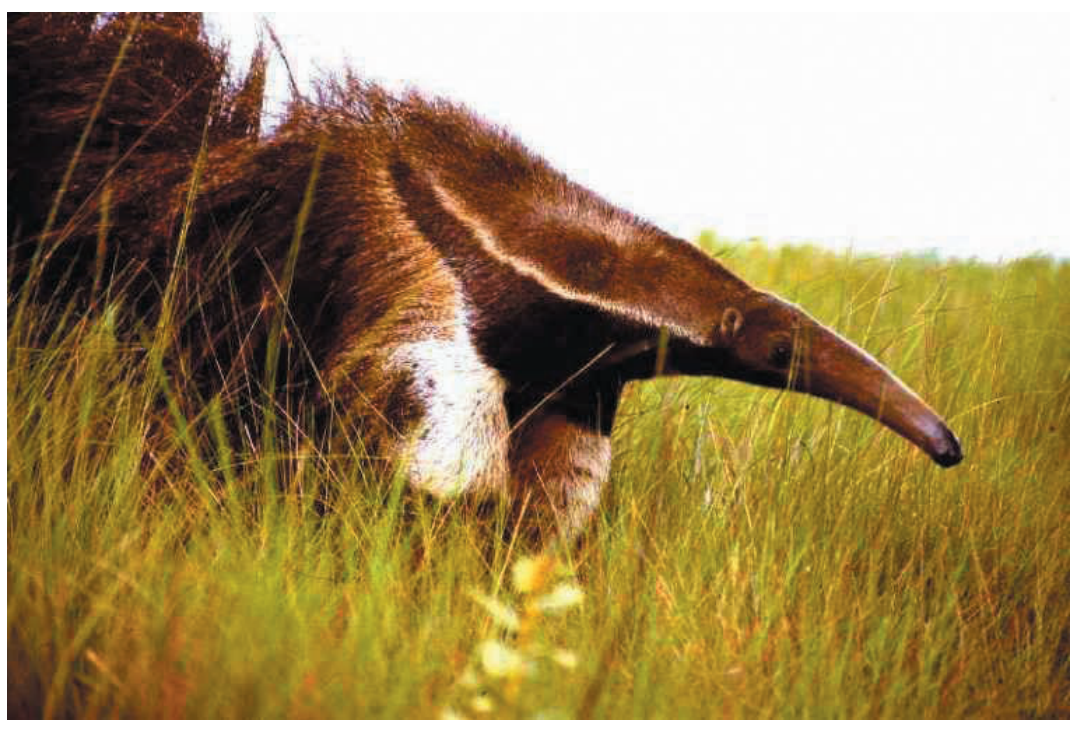

Figura 19 - Tamanduá-bandeira. Acervo: Reserva Ecológica do IBGE.
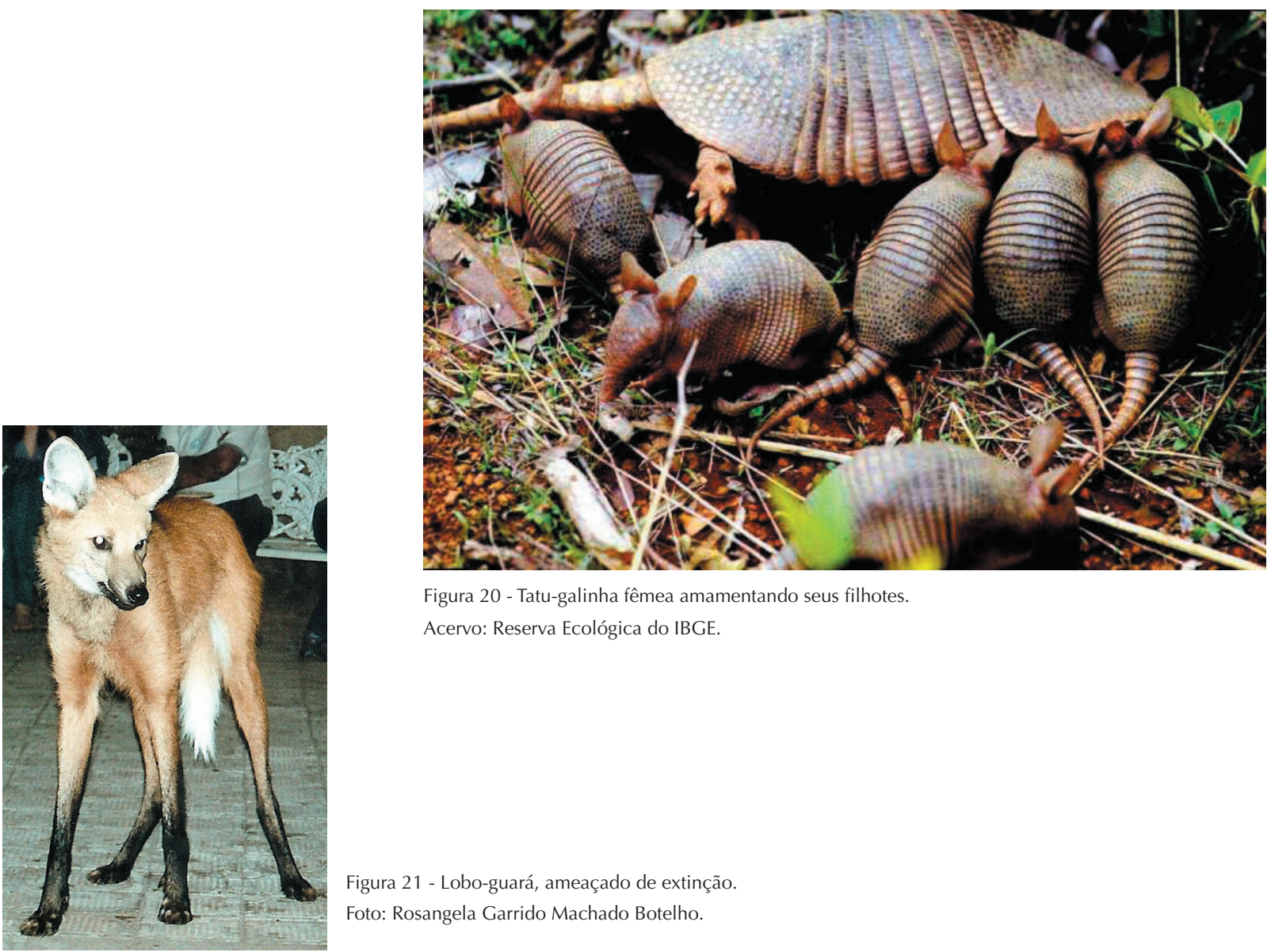

Figura 20 - Tatu-galinha fêmea amamentando seus filhotes.

Acervo: Reserva Ecológica do IBGE.

Figura 21 - Lobo-guará, ameaçado de extinção.

Foto: Rosangela Garrido Machado Botelho. 
Não obstante seu grande patrimônio biológico, estimado em cerca de $1 / 3$ de toda a biodiversidade brasileira, que representa mais de $15,0 \%$ de toda a biodiversidade conhecida pela ciência no mundo, o Bioma Cerrado está fortemente ameaçado: dados do Instituto Brasileiro do Meio Ambiente e dos Recursos Naturais Renováveis - IBAMA indicam que, até abril de 2011, 49,0\% da área total do bioma já havia sido desmatada e convertida para outros usos (pastagens, lavouras, hidrelétricas, áreas urbanas e de infraestrutura, mineração e terras degradadas). Da área remanescente, a maior parte era utilizada como pastagem, submetida à extração predatória de carvão vegetal e queimadas em frequências e intensidades acima da capacidade natural de recuperação, ou sofriam com a crescente expansão de espécies exóticas invasoras, com o crescimento da poluição, a erosão dos solos e assoreamentos dos rios. Como consequência imediata dessa situação, o Cerrado é o segundo bioma brasileiro com mais espécies ameaçadas de extinção, conforme as listas oficiais editadas pelo Ministério do Meio Ambiente, e apenas 8,0\% desse bioma está protegido, em graus variados, por Unidades de Conservação do Sistema Nacional de Unidades de Conservação da Natureza (DIAS, 2011).

Visando priorizar ações de conservação de importância mundial, áreas com alta biodiversidade e elevado nível de ameaça foram classificadas como hotspots ${ }^{10}$ de biodiversidade. No Brasil, a Mata Atlântica e o Cerrado estão entre os 34 hotspots mundiais, sendo o Cerrado a única savana do mundo incluída nessa categoria (MITTERMEIER et al., 2005). Este reconhecimento internacional torna o Bioma Cerrado uma das áreas primordiais para investimentos em conhecimento científico e conservação.

Nesse contexto, as Áreas Prioritárias para Conservação, Utilização Sustentável e Repartição dos Benefícios da Biodiversidade constituem um dos importantes instrumentos para o cumprimento dos compromissos assumidos na assinatura da Convenção sobre Diversidade Biológica, tratado da Orgazinação das Nações Unidas - ONU (United Nations - UN). No Cerrado, foram indicadas 68 áreas, em 1998, e 431, em 2006, totalizando, respectivamente, 686668 e 939753 quilômetros quadrados de áreas prioritárias. Houve um ganho significativo no volume de informações biológicas entre os levantamentos de 1998 e 2006, que resultou numa melhor caracterização do Cerrado. Além disso, o mapeamento realizado em 2006 seguiu uma metodologia sistematizada, com uma carga de subjetividade menor, contribuindo para um resultado mais preciso. O processo de revisão final em 2012 identificou 300 áreas prioritárias, sendo 69 de extrema prioridade, 152 de prioridade muito alta e 79 de prioridade alta (ÁREAS..., 2015).

Além da grande biodiversidade, o Bioma Cerrado destaca-se por ser o berço das águas que drenam para os diferentes biomas brasileiros. Com exceção do Bioma Pampa, todos os demais possuem nascentes no Bioma Cerrado, que acaba por ter sobre eles forte influência hidrológica e ecológica. A existência desses cursos de água contribui para a biodiversidade da região, pois os vales dos rios são rotas preferenciais de migração e dispersão para vários tipos de organismos.

\footnotetext{
${ }^{10}$ O conceito de hotspot foi criado em 1988 pelo ecólogo inglês Norman Myers e é atribuído a toda área prioritária para conservação, isto é, de alta biodiversidade e ameaçada no mais alto grau (HOTSPOTS, 2009).
} 
Dois fatores propiciam a presença de grande quantidade de nascentes e corpos hídricos no Planalto Central brasileiro: o fato de ser um divisor de bacias e ter altitude média elevada quando comparado ao restante do País.

Além dos abundantes recursos hídricos superficiais, o Cerrado apresenta também elevado potencial de águas subterrâneas, haja vista a presença do Aquífero Guarani em boa parte do bioma. O Sistema Aquífero Guarani é uma gigantesca unidade hidrogeológica da porção meridional da América do Sul e se estende por quatro países: Argentina, Brasil, Paraguai e Uruguai, totalizando mais de um milhão de quilômetros quadrados (CONGRESSO AQUÍFERO GUARANI, 2009).

As principais bacias hidrográficas do Cerrado ${ }^{11}$ são as dos Rios Tocantins, Araguaia, São Francisco, Paraná, Paraguai e Parnaíba, não só em função das suas maiores áreas, mas também por ocuparem a porção central ou área core do Bioma. Além destas, existem outras bacias menores, aqui denominadas periféricas, que embora apresentem nascentes neste bioma, drenam, em sua maioria, áreas de outros biomas, englobando pequenas extensões de terras no Cerrado. São elas: Bacia Periférica Amazônica, que engloba parte das bacias dos Rios Madeira, Tapajós e Xingu; Bacia Periférica Atlântica, que engloba parte das Bacias dos Rios Doce, Jequitinhonha e Pardo; e Bacia Periférica do Golfão Maranhense, que engloba parte das Bacias dos Rios Itapecuru, Mearim, Pindaré e Munim. A seguir, abordar-se-á a distribuição dos recursos naturais e as relações entre homem e natureza no Cerrado a partir destes diferentes sistemas hídricos.

\section{Bacia Hidrográfica do Rio Tocantins}

O Rio Tocantins nasce no Planalto de Goiás, a cerca de 1000 metros de altitude, e flui adaptado a falhas normais de direção norte-sul por 1960 quilômetros, até desaguar no estuário do Amazonas (Baía de Marajó), nas proximidades de Belém. Os principais formadores do Rio Tocantins são os Rios Paranã e Maranhão. Este último nasce na Estação Ecológica de Águas Emendadas, no Distrito Federal, onde as Bacias dos Rios Tocantins e Paraná estão em contato. Corredeiras e cachoeiras dominam a paisagem do curso superior e encontram-se espalhadas no curso médio. O principal tributário do Rio Tocantins é o Rio Araguaia. Além deste, destacam-se os Rios Itacaúnas, Bagagem e Tocantinzinho.

O Rio Tocantins drena terrenos elevados, o que garante boas possibilidades para geração de energia. O grande potencial hidrelétrico, aliado à localização próxima aos consumidores da Região Nordeste, tornam a Bacia do Tocantins prioritária para a implantação de aproveitamentos hidrelétricos. As principais usinas em operação no Rio Tocantins, no Bioma Cerrado, são: Serra da Mesa (GO), Cana Brava (GO) e Luís Eduardo Magalhães (TO).

Além da agricultura e da geração de energia, a região apresenta expressiva reserva de minérios, merecendo destaque as jazidas de ouro e de gemas, notadamente esmeralda,

\footnotetext{
11 As bacias hidrográficas aqui apresentadas não configuram uma divisão formal para o bioma nem tampouco substituem as classificações em bacias e regiões hidrográficas já existentes. Trata-se de uma estratégia de apresentação das informações com foco nos cursos de água e sua delimitação física.
} 
muitas delas responsáveis pela penetração dos colonizadores até o Centro-Oeste brasileiro, como as da região de Almas-Dianópolis, no sudeste do Tocantins, onde as mineralizações auríferas são conhecidas desde o Século XVII.

Os granitos de Serra Dourada, Serra do Encosto, Serra da Mesa e Serra Branca contêm jazidas de cassiterita (minério de estanho), que constituem a Província Estanífera de Goiás, com uma reserva de 25000 toneladas (DARDENNE; SCHOBBENHAUS, 2003). Os complexos máfico-ultramáficos encerram jazidas e minas de amianto (Cana Brava) e níquel (Niquelândia), com importantes concentrações desses recursos também em Barro Alto, no norte de Goiás.

Estudos de solos da região do Complexo Básico-Ultrabásico de Barro Alto e Niquelândia (OLIVEIRA, 2004b) têm revelado a presença de solos eutróficos. Entretanto, tais solos sempre apresentam outros fatores severamente limitantes ao desenvolvimento vegetal, como ocorrência de cascalhos, pedregosidade e pequena profundidade, entre outros. Tais fatos mostram que a teoria de baixa fertilidade química (estresse nutricional) para justificar a vegetação de Cerrado não se aplica de forma incondicional, pelo menos isoladamente.

Solos com alta fertilidade, provenientes da alteração dos basaltos, também podem ser encontrados na região conhecida como Bico do Papagaio, no extremo norte da Bacia do Rio Tocantins, palco, nas décadas de 1970 e 1980, de conflitos fundiários, fomentados de certa forma por essa condição.

O aproveitamento das águas subterrâneas, apesar de incipiente em termos regionais, é importante em pontos específicos, como na região nordeste do Estado de Goiás, Vale do Rio Paranã. Dentre os aquíferos encontrados nas bacias hidrográficas do Tocantins e do Araguaia, destacam-se o Motuca (Tocantins) e o Ponta Grossa (Araguaia) (BRASIL, 2006).

No Rio Tocantins, a época da cheia estende-se de outubro a abril, com pico em fevereiro, no curso superior, e março, nos cursos médio e inferior. As principais atividades impactantes sobre o regime hidrológico na bacia são a construção de hidrelétricas, a estruturação de hidrovias, o desmatamento, a adoção de práticas agropecuárias incorretas, a ocupação desordenada em centros urbanos, a falta de saneamento ambiental nos assentamentos humanos, a transposição de águas entre bacias e os projetos de irrigação. Estas atividades, se realizadas sem os devidos estudos, podem levar à perda de qualidade e quantidade de água. O conjunto das hidrelétricas construídas e projetadas para a bacia ameaçam transformar o Rio Tocantins numa sucessão de lagos artificiais.

\section{Bacia Hidrográfica do Rio Araguaia}

O Rio Araguaia é o principal afluente do Rio Tocantins e tem a maior parte de sua bacia $(81,0 \%)$ inserida no Bioma Cerrado, tendo apenas parte do seu baixo curso no Bioma Amazônia. Esse rio nasce a 850 metros de altitude na Serra do Caiapó, na divisa entre Goiás e Mato Grosso. Corre quase paralelamente ao Rio Tocantins e nele desemboca, após percorrer cerca de 2115 quilômetros, na divisa entre os Estados do Tocantins, Maranhão e Pará. Drena uma área de aproximadamente 380000 quilômetros quadrados, com descarga média de 6000 metros cúbicos por segundo, na estação hidrológica de Araguatins (AQUINO; LATRUBESSE; SOUZA FILHO, 2008). 
Por ser um rio de planície, o Araguaia possui amplas superfícies inundáveis e alguns trechos com cachoeiras e corredeiras. Nos trechos de planície, encontram-se a llha do Bananal e um número incontável de lagoas marginais. As áreas inundáveis, ou áreas de várzeas, mais expressivas estão em Mato Grosso, destacando-se o trecho da Ilha do Bananal, inclusive o chamado "Pantanal do Rio das Mortes".

A llha do Bananal, maior ilha fluvial do mundo, com 350 quilômetros de comprimento por 80 quilômetros de largura, é reconhecida como Zona Úmida de Importância Internacional (ou Sítio Ramsar), desde 1993 (O QUE SÃO..., 2009), além de ser território indígena. O Rio Javaés, braço menor do Rio Araguaia, com 556 quilômetros de extensão, constitui o limite oriental da Ilha do Bananal.

Assim como a Bacia do Rio Tocantins, Bacia do Araguaia apresenta dois períodos climáticos bem-definidos: o das chuvas, de outubro a abril; e o da seca, de maio a setembro. Entretanto, no Rio Araguaia, as cheias são maiores e um mês atrasadas em relação ao Rio Tocantins, em decorrência do extravasamento na Planície do Bananal. Ambos reduzem sua vazão entre maio e setembro, com mínimas em setembro (ESTUDO..., 2001).

O Rio Araguaia mantém os mais importantes sistemas de áreas úmidas (wetlands) do Brasil Central e uma enorme biodiversidade. A planície aluvial do Rio Araguaia e os seus ecossistemas aquáticos constituem uma das últimas fronteiras para conservação do Bioma Cerrado (AQUINO; LATRUBESSE; SOUZA FILHO, 2008).

O Rio Araguaia ficou intocado, como o Cerrado, até a década de 1960, e, nestes 50 anos, vem assistindo ao desaparecimento da maior parte de sua vegetação. Pesquisas realizadas pela Universidade Federal de Goiás indicam que, em território goiano, restam apenas cerca de $27,0 \%$ da vegetação original da bacia. O desmatamento, além de reduzir a biodiversidade, gera aumento dos processos erosivos e, consequentemente, da quantidade de sedimentos carregados para os cursos de água. Isso tem gerado alterações significativas nos padrões de canais e na paisagem.

As intervenções na bacia do Araguaia têm como foco principal a hidrovia Araguaia-Tocantins, que estimulará ainda mais a expansão da fronteira agropecuária, além de envolver intervenções diretas no canal, de forma a assegurar sua navegabilidade. Os projetos de geração de energia propostos, por sua vez, alagarão extensas áreas, com sérios impactos sobre a biodiversidade e as populações humanas.

Sérios problemas ambientais afetam ainda as nascentes do Rio Araguaia. Nas proximidades do Parque Nacional das Emas, nos Municípios de Mineiros (GO), Alto Araguaia (MT) e Alto Taquari (MT), o desmatamento e a ocupação pela agricultura e pela pecuária resultam em voçorocas e outros sinais erosivos.

A Bacia do Rio Araguaia possui cinco Unidades de Conservação federais: o Parque Nacional das Emas (266 000 hectares) e a Área de Proteção Ambiental Meandros do Araguaia (358 000 hectares), em Goiás; o Parque Nacional do Araguaia (2,23 milhões hectares), a Estação Ecológica Coco-Javaés (37 000 hectares) e a Reserva Extrativista do Extremo Norte do Tocantins (9 000 hectares), no Tocantins. Além delas, há também, na bacia, várias Unidades de Conservação mantidas pelos estados e municípios. 
Em termos de recursos minerais, destacam-se as esmeraldas da região de Campos Verdes, com importantes jazidas em unidades do chamado Arco Magmático de Goiás, próximo ao limite com a Bacia do Rio Tocantins, com destaque para as de Santa Terezinha de Goiás, por sua pureza e seu alto valor econômico.

\section{Bacia Hidrográfica do Rio São Francisco}

A Bacia do Rio São Francisco é a maior bacia hidrográfica totalmente brasileira. Drena uma área de 640000 quilômetros quadrados e ocupa 8,0\% do Território Nacional. Do total, 56,0\% estão inseridos no Bioma Cerrado, inclusive as nascentes, na Serra da Canastra (MG).

O Rio São Francisco percorre cerca de 2700 quilômetros, e sua bacia é dividida em quatro regiões: Alto São Francisco, das nascentes até Pirapora (MG); Médio São Francisco, entre Pirapora e Remanso (BA); Submédio São Francisco, de Remanso até a Cachoeira de Paulo Afonso (BA); e Baixo Rio São Francisco, de Paulo Afonso até a foz no oceano Atlântico. Quase todo o alto curso e parte do médio estão inseridos no Bioma Cerrado.

O Rio São Francisco tem 36 tributários de porte significativo, dos quais apenas 19 são perenes. Os principais contribuintes são os da margem esquerda (Rios Paracatu, Urucuia, Carinhanha, Corrente e Grande), que fornecem cerca de 70,0\% das águas num percurso de apenas 700 quilômetros. Na margem direita, os principais tributários são os Rios Paraopeba, das Velhas, Jequitaí e Verde Grande. Todos estes rios têm seus cursos total ou parcialmente inseridos no Bioma Cerrado.

Desde as nascentes, a Bacia do Rio São Francisco apresenta degradações, com sérios impactos sobre as águas. A maioria dos povoados não dispõe de tratamento de esgotos domésticos e industriais, lançando-os diretamente nos rios. Os despejos de garimpos, mineradoras e indústrias aumentam a carga de metais pesados, incluindo o mercúrio, metal altamente tóxico.

O assoreamento dos formadores e da calha do Rio São Francisco deve-se, em grande parte, ao desmatamento das nascentes da vertente esquerda da bacia, ou seja, das Chapadas do São Francisco. Estas situam-se no extremo leste goiano, com bordas escarpadas que servem de limite entre Goiás e Bahia e como divisor entre as bacias do Tocantins e São Francisco. Sua alta vulnerabilidade natural, em face da constituição dominantemente arenítica e friável, deve ser objeto de preocupação especial no contexto do planejamento de longo prazo. Sua recente ocupação por monoculturas, principalmente de soja, constitui um traço marcante no desenvolvimento econômico regional, de um lado; de outro, aponta para um cenário de problemas socioambientais de grande magnitude ainda contornáveis. Como constituem as cabeceiras de importantes bacias hidrográficas, sua ocupação predatória pode ser desastrosa para essas bacias. 
Na região do Alto São Francisco, nas áreas de modelado cárstico, Ramos, Nunes e Natali Filho (1984) observaram processos de dissolução em forma de lápies ${ }^{12}$ em algumas vertentes. Os processos morfodinâmicos relacionados com o escoamento superficial nessas áreas são pouco eficazes, em função da presença de fraturas e de formações superficiais arenosas, que facilitam o escoamento subsuperficial. A ocupação e a exploração dessas áreas requerem atenção, pois os riscos de contaminação do lençol de água subterrâneo são maiores.

Na região do Médio São Francisco, ainda em áreas de relevo cárstico (Figura 22), encontram-se importantes jazimentos de chumbo e zinco, próximos às cidades de Januária, Itacarambi e Montalvânia (MG) e Serra do Ramalho (BA), associados aos calcários dolomíticos, os quais, por si só, constituem insumos minerais para correção da acidez dos solos do Cerrado.

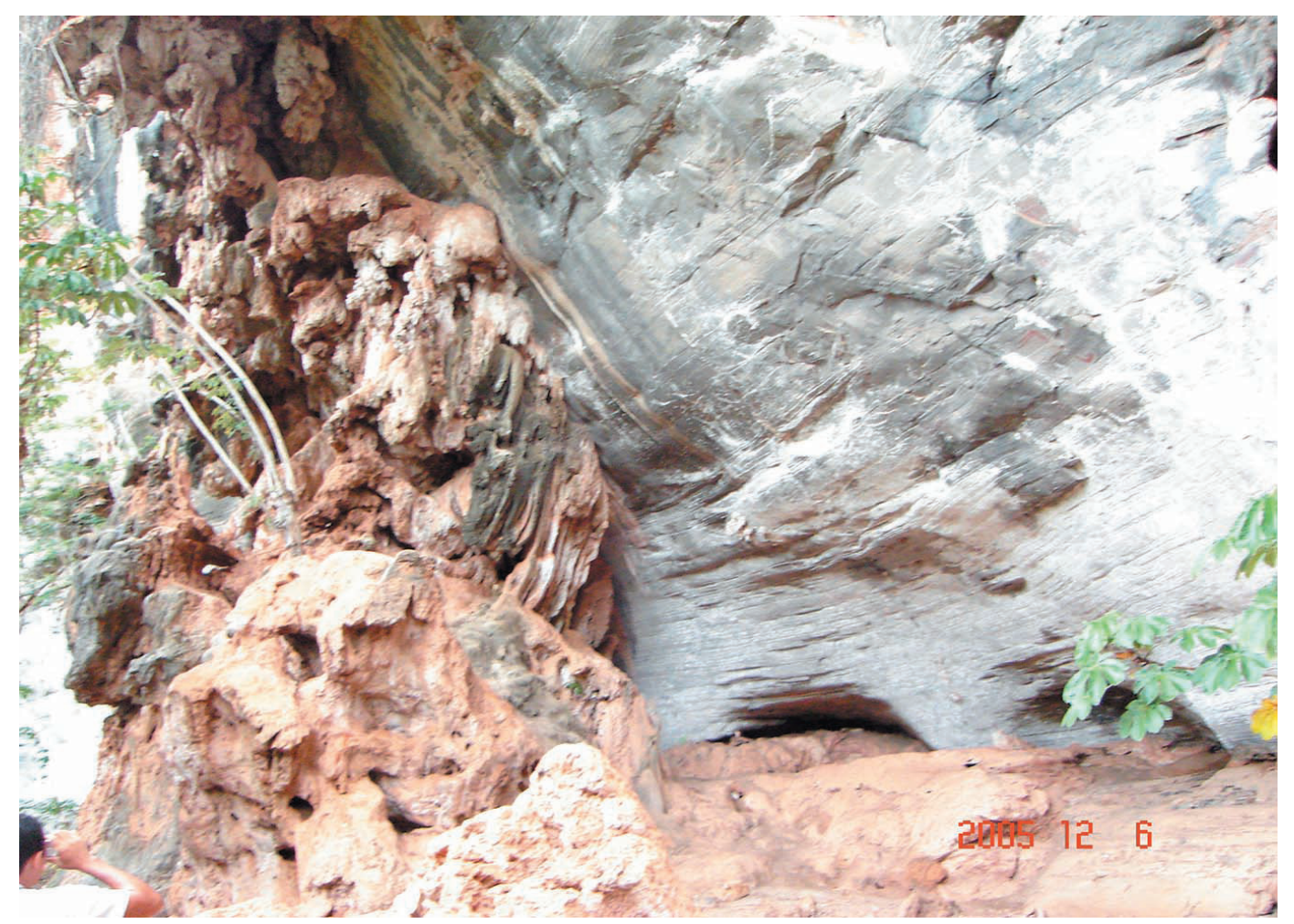

Figura 22 - Rochas calcárias, Parque Nacional Cavernas do Peruaçu, Município de Januária (MG). Foto: Rogério Botelho de Mattos.

Importantes depósitos minerais são encontrados em terras mineiras, próximo ao limite com a Bacia do Rio Paraná. São eles: cobre, ouro e esmeraldas (associados ao Arco Magmático de Goiás); fosfato de Rocinha, em Patos de Minas, e de Lagamar; chumbo e zinco de Morro Agudo, em Paracatu; e zinco de Vazante (DARDENNE; SCHOBBENHAUS, 2003).

\footnotetext{
12 Sulcos, ranhuras ou caneluras milimétricas a métricas que se formam na superfície intemperizada de rochas solúveis, como calcários, em regiões cársticas, pela dissolução dos carbonatos segundo linhas de escoamento de água superficial e que tendem a ser separados por cristas afiadas à medida que as lápies se interpenetram (WINGE et al., 2001).
} 
Nas cabeceiras, o maior problema é o desmatamento para a produção de carvão vegetal, utilizado pela indústria siderúrgica mineira, que tem reduzido as matas ciliares a $4,0 \%$ da área original (BRASIL, 2007). A produção de carvão vegetal a partir da destruição da vegetação nativa é uma das maiores ameaças à biodiversidade do Bioma Cerrado (Figura 23). O uso intensivo de fertilizantes e defensivos agrícolas também tem contribuído para a poluição das águas.

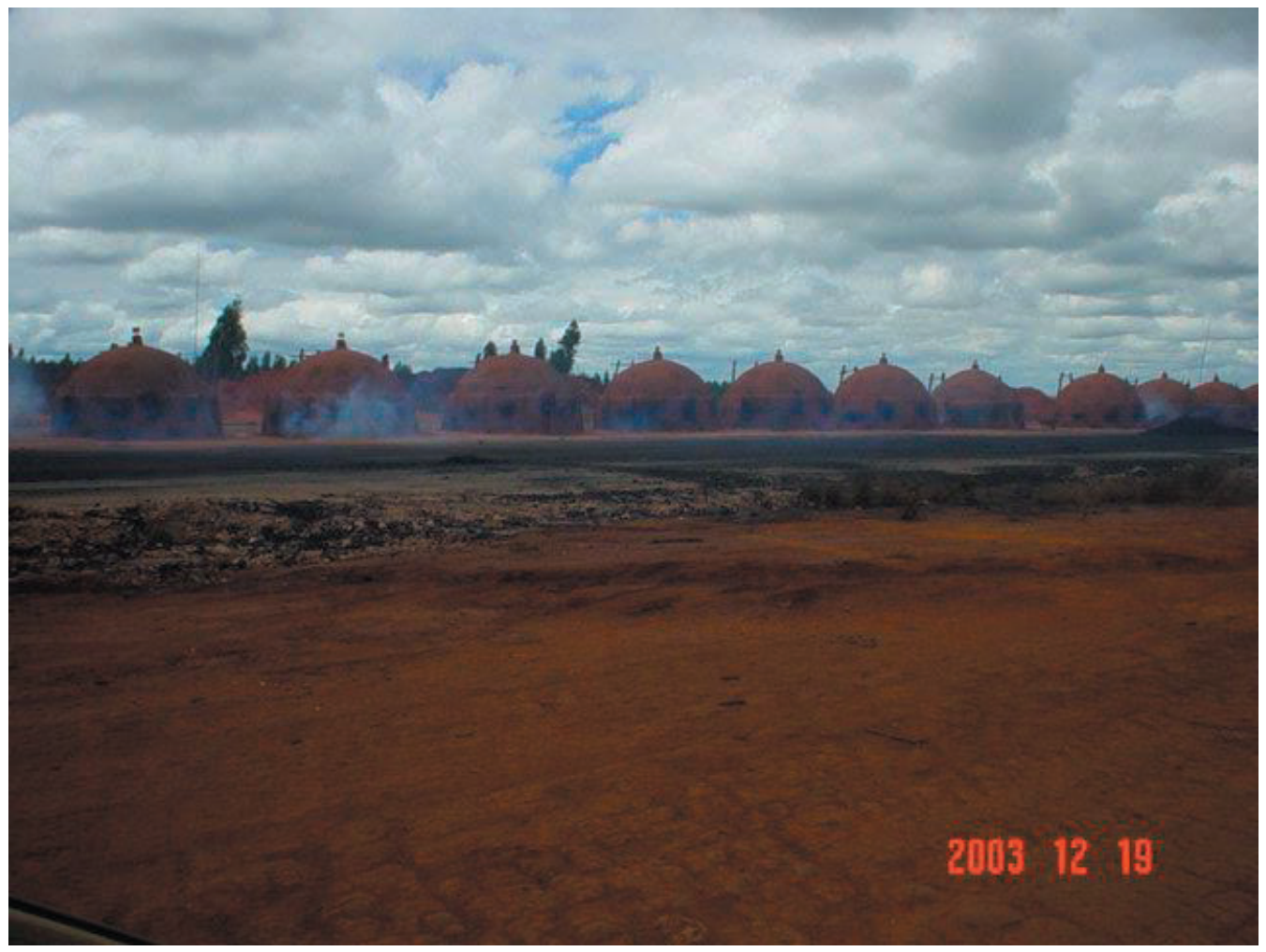

Figura 23 - Fornos para produção de carvão na região de Turmalina, norte de Minas Gerais.

Foto: Virlei Álvaro de Oliveira.

As barragens hidrelétricas e a irrigação transformaram o Rio São Francisco e alguns de seus tributários, pois alteraram a intensidade e a época das enchentes, transformaram rios em lagos etc., com impactos diretos sobre os recursos pesqueiros. Atualmente, o Rio São Francisco possui apenas dois trechos de águas correntes: 1100 quilômetros entre as Barragens de Três Marias e Sobradinho, com vários tributários de grande porte e inúmeras lagoas marginais; e 280 quilômetros da Barragem de Sobradinho até a entrada do Reservatório de Itaparica. Daí para baixo, transforma-se em uma cascata de reservatórios da Companhia Hidrelétrica do Rio São Francisco (Itaparica, Complexo Moxotó - com Paulo Afonso I, II, III, IV - e Xingó). Estes dois trechos e os grandes tributários, nos quais se encontram as lagoas marginais, ainda permitem a existência de espécies de peixes migradores, importantes para a pesca comercial e amadora. 


\section{Bacia Hidrográfica do Rio Paraná}

O Rio Paraná, juntamente com os Rios Paraguai e Uruguai, forma, em território argentino, o Rio da Prata, cuja bacia hidrográfica destaca-se por seus recursos naturais e numerosa população.

O Rio Paraná, principal formador do Rio da Prata, possui cerca de 4900 quilômetros de extensão, sendo formado pela junção dos Rios Grande e Paranaíba. Apresenta o maior aproveitamento hidrelétrico do Brasil, com destaque para os afluentes Tietê e Paranapanema. Sua navegabilidade e a de seus afluentes vem sendo aumentada pela construção da hidrovia Tietê-Paraná. A hidrovia serve para o transporte de cargas, pessoas e veículos, tornando-se uma importante ligação com os países do Mercosul. São 2400 quilômetros de percurso navegável, ligando as localidades de Anhembi e Foz do Iguaçu. Vale ressaltar que o Rio Paraná é o quarto do mundo em área de drenagem, drenando todo o centro-sul da América do Sul, desde as encostas dos Andes até a Serra do Mar. A maior parte da Bacia do Paraná se encontra hoje ocupada por cultivos e pastagens, restando pouco da vegetação nativa. Por sua vez, o intenso aproveitamento hidrelétrico faz com que poucos trechos do rio se mantenham na condição original.

O relevo é marcado por modelados do tipo tabular com formas muito amplas, esculpidos predominantemente em arenitos. Esses planos estão ocupados por monoculturas, onde o uso de máquinas pesadas provocou a compactação das camadas de solo, acentuando o escoamento superficial difuso e a erosão eólica em função da desagregação das partículas finas. Nos patamares estruturais, as exposições das rochas decorreram dos processos de ablação; nas vertentes, os processos morfogenéticos geraram desequilíbrio dinâmico. As sucessivas retomadas erosivas, pela dissecação fluvial, favoreceram a diversificação dos modelados e contribuíram para o transporte do material fino, tornando as formações superficiais pouco espessas. Nas áreas de pastagens, o pisoteio do gado, em relevos de declives acentuados, tem gerado movimentos lentos dos solos (creeping).

Importantes depósitos minerais de cobre, níquel e cobalto são encontrados em Americano do Brasil (GO), associados a complexos máfico-ultramáficos no extremo norte da bacia, em área do Planalto Central Brasileiro (DARDENNE; SCHOBBENHAUS, 2003).

\section{Bacia Hidrográfica do Rio Paraguai}

O Rio Paraguai é um típico rio de planície. Possui cerca de 2550 quilômetros de extensão ao longo dos territórios brasileiro e paraguaio, e sua bacia abrange 345000 quilômetros quadrados. A maior parte da área pertence ao Bioma Pantanal, onde o rio é muito utilizado para navegação. No entanto, as nascentes do Rio Paraguai e de seus principais afluentes, em território brasileiro - Miranda, Taquari, Apa e São Lourenço -, estão inseridas no Bioma Cerrado. O Rio Paraguai nasce na Serra de Araporé, a 100 quilômetros de Cuiabá (MT), e seus afluentes nascem nos planaltos da Bacia Sedimentar do Paraná, mais especificamente na Serra de Maracaju. 
Na porção da Bacia do Paraguai inserida no Cerrado, predominam os planaltos e depressões da Bacia Sedimentar do Paraná, compreendendo relevos desenvolvidos em estruturas monoclinais, representados por frentes de cuestas. Os vários conjuntos litológicos foram sucessivamente reafeiçoados, reativados e basculados ao longo do tempo. A morfogênese estimulou o processo de erosão diferencial, proporcionando a desagregação mecânica dos materiais rochosos em alguns locais e, em outros, a remobilização das formações superficiais. Na borda oeste-noroeste, envolvendo a região central de Mato Grosso do Sul e sul-sudoeste de Mato Grosso, os relevos estão compartimentados em Patamares e Depressões Interiores dos Rios Taquari e Itiquira, Patamares da Borda Ocidental da Bacia do Rio Paraná e Planalto dos Guimarães, que inclui a Chapada dos Guimarães, belíssimo acidente fisiográfico posicionado ao norte da escarpa da cuesta do Caiapó e que compreende uma extensa área de relevo aplanado, com cotas altimétricas entre 600 e 800 metros, cujo topo, bastante plano, encontra-se com relevo conservado, observando-se fraca densidade de drenagem (Figura 24).

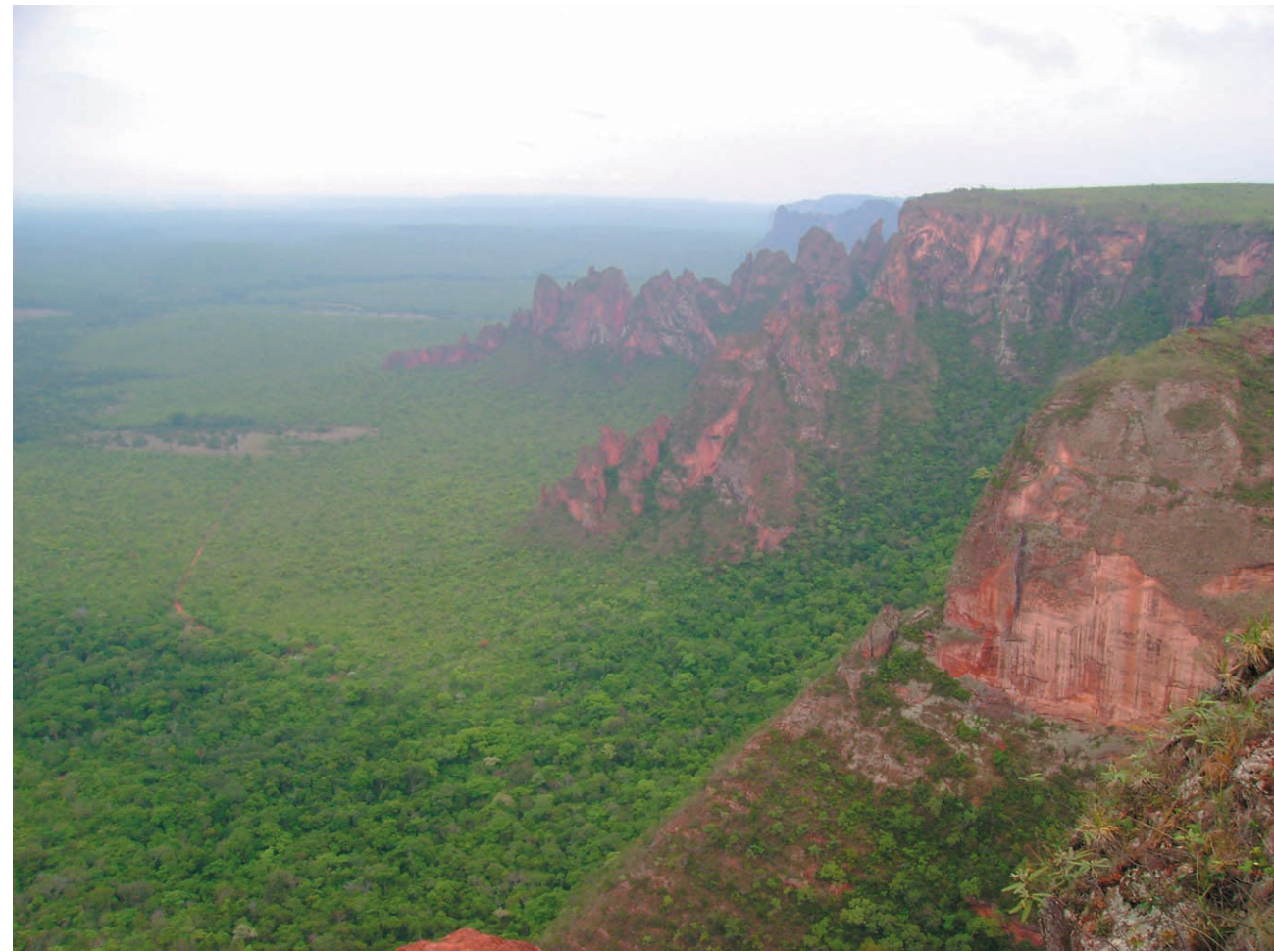

Figura 24 - Contato entre a Depressão Cuiabana e a Chapada dos Guimarães (MT). Foto: Rosangela Garrido Machado Botelho.

Outra formação que se destaca no trecho da Bacia do Rio Paraguai, inserida no Cerrado, é a Serra da Bodoquena. Esta compreende feições de relevos dobrados muito evoluídos e relevos cársticos, onde sobressaem paisagens de rara beleza, incluindo grutas, rios e lagos subterrâneos, como na Bacia do Rio Miranda, na região de Bonito (MS). 
Na porção da bacia situada sobre terrenos da Bacia Sedimentar dos Parecis, no contato com a Bacia Periférica Amazônica, há setores dissecados em cristas e colinas, em sequências vulcanossedimentares (Grupo Alto Jauru) mineralizadas em cobre, zinco e ouro, onde se encontra a jazida aurífera de Cabaçal (MT).

Concentrações de ouro na Baixada Cuiabana, em rochas do Grupo Cuiabá, são explorados por garimpeiros desde o Século XVIII e, mais recentemente, por empresas de mineração. O ouro está presente em veios de quartzo de rochas metassedimentares e nos aluviões da Bacia do Rio Cuiabá, o que favorece a contaminação da Bacia do Pantanal pelos resíduos da atividade mineradora, notadamente o mercúrio utilizado na recuperação do ouro. Além disso, a recente ocupação das áreas de cabeceiras dos rios por grandes plantações (soja e cana-de-açúcar) tem favorecido processos erosivos e contaminação dos cursos de água por pesticidas e fertilizantes.

\section{Bacia Periférica Amazônica}

A Bacia Periférica Amazônica ocupa a porção noroeste do Bioma Cerrado e engloba parte das Bacias dos Rios Madeira, Tapajós e Xingu, no Estado de Mato Grosso, predominantemente sobre terrenos da Bacia Sedimentar dos Parecis, e drena suas águas para o Rio Amazonas.

A parte da Bacia do Rio Madeira inserida no Bioma Cerrado é bastante pequena e inclui a nascente do Rio Aripuanã, afluente direto do Madeira. O Rio Aripuanã drena uma área aproximada de 10000 quilômetros quadrados, com trechos encachoeirados, de grande potencial hidrelétrico, a maioria em áreas indígenas. A maior parte desta bacia periférica é composta por rios da Bacia do Tapajós, que tem, no Cerrado, as nascentes dos seus dois formadores, Juruena e Teles Pires.

O Rio Juruena nasce nas encostas setentrionais da Serra dos Parecis, em altitudes próximas a 700 metros, e recebe grande número de tributários até sua confluência com o Rio Arinos, seu principal afluente. Tanto o Arinos quanto o Juruena não são considerados navegáveis, devido ao grande número de obstáculos ao longo de seus cursos.

O terço superior da Bacia do Tapajós, inserido no Bioma Cerrado, é atualmente cenário de uma importante frente de expansão da agricultura de soja (TRANCOSO et al., 2005). A crescente expansão do desmatamento sobre áreas de cabeceiras de drenagem pode, a médio prazo, se mantidos os incrementos atuais, causar impactos em toda a bacia. Avanços indiscriminados sobre as matas ciliares e cabeceiras podem assorear os canais e com isso provocar perturbações no ritmo de escoamento dos rios, com efeitos que se irradiam pela bacia. O inegável potencial do bioma para a produção agropastoril em larga escala deve ser realizado sem causar danos à biodiversidade e ao ambiente, tanto no próprio Cerrado quanto nos biomas vizinhos.

O Rio Xingu nasce nos contrafortes da Serra Azul, no Município de Chapada dos Guimarães (MT), com a denominação de Rio Culuene, a uma altitude de 600 metros. Possui extensão total de 2045 quilômetros e drena cerca de 509000 quilômetros quadrados. Apesar de sua extensão, o Rio Xingu não é apropriado para a navegação em larga escala. No curso superior, somente canoas podem navegar em trechos relativamente extensos. 
A degradação ambiental já destruiu boa parte da vegetação de cerrado das nascentes do Rio Xingu e de seus afluentes. Um dos principais fatores para o aumento da degradação é o modelo de atividade agropecuária, implantado a partir da década de 1960, de produção intensiva, em grandes extensões de terra e com uso maciço de tecnologia (agroquímicos, sementes melhoradas e maquinário). Neste contexto, cabe ressaltar que a pressão sobre as nascentes desse rio representa, simultaneamente, uma ameaça à própria integridade ambiental do Parque Indígena do Xingu.

\section{Bacia Periférica Atlântica}

A Bacia Periférica Atlântica ocupa a porção sudeste do Bioma Cerrado e engloba parte das Bacias dos Rios Doce, Jequitinhonha e Pardo, em terras do Estado de Minas Gerais. São bacias que drenam predominantemente o Bioma Mata Atlântica e deságuam, a primeira, no litoral capixaba, e as duas outras, no extremo sul da Bahia.

A Bacia do Rio Doce possui área bastante pequena no Bioma Cerrado, correspondente às nascentes do Rio Santo Antônio, afluente da margem esquerda.

A Bacia do Rio Jequitinhonha é a que ocupa a maior porção da Bacia Periférica Atlântica. O Rio Jequitinhonha nasce na Serra do Espinhaço, no Município de Diamantina, a uma altitude aproximada de 1200 metros, e percorre 920 quilômetros até a foz, no Município de Belmonte. Neste rio, entre os Municípios de Berilo e Grão Mogol, foi construída a Hidrelétrica Presidente Juscelino Kubitscheck, a Usina de Irapé, obra estratégica por sua importância socioeconômica.

A Bacia do Rio Jequitinhonha é propícia à ocorrência de minerais de interesse econômico. Nos aluviões do alto curso existem atividades de mineração, com garimpos de diamantes e ouro. No caso dos planaltos, destaca-se a Serra do Espinhaço Meridional, onde a busca e a exploração de diamantes nos tempos coloniais resultaram no surgimento de povoações (arraiais) que hoje são importantes cidades históricas, como Diamantina, em Minas Gerais.

No Alto Jequitinhonha, encontram-se grandes planaltos, as chapadas, entremeadas por vales profundos e estreitos, e as grotas, que possuem terras férteis e água. Contudo, o Vale do Jequitinhonha, em sua maior parte, apresenta solo árido, sendo castigado regularmente por secas e enchentes. Apesar disso, a agropecuária é uma das principais atividades econômicas, e a indústria, embora ocupe pequena parcela da população, tem a maior contribuição para o Produto Interno Bruto - PIB da região. O Vale do Jequitinhonha mineiro é hoje a porção mais pobre de Minas Gerais.

A produção agrícola é a segunda maior contribuinte do PIB da região. No Vale do Jequitinhonha, produz-se excelente artesanato em cerâmica, tecelagem, cestaria, esculturas em madeira, trabalhos em couro, bordados, pintura, desenho, música. Os principais polos da atividade em cerâmica desta bacia, no Cerrado, são as Cidades de Turmalina e Minas Novas.

A terceira bacia componente da Bacia Periférica Atlântica, e com menor área absoluta dentro do Bioma Cerrado, é a do Rio Pardo, que nasce no Município de Rio Pardo de Minas. Assim como os Rios Doce e Jequitinhonha, o Pardo é um rio de domínio federal, pois seu curso corta os Estados de Minas Gerais e da Bahia. 
A economia da parte alta da bacia está baseada principalmente na pecuária e na agricultura, tendo ocorrido, entretanto, crescimento de atividades industriais.

\section{Bacia Periférica do Golfão Maranhense}

A Bacia Periférica do Golfão Maranhense ocupa o extremo norte do Bioma Cerrado e engloba boa parte das Bacias dos Rios Itapecuru, Munim, Mearim e Pindaré, todas no Estado do Maranhão, que deságuam no Golfão Maranhense ${ }^{13}$, sendo os dois primeiros rios na Baía de São José, e os dois últimos na Baía de São Marcos. Junto com uma estreita faixa longitudinal da Bacia do Rio Parnaíba, esta é a porção do Bioma que chega ao litoral, indo da foz do Rio Parnaíba, no Piauí, à Ponta dos Mangues Secos, no Maranhão.

O Rio Itapecuru nasce nos limites dos Municípios de Mirador, Grajaú e São Raimundo das Mangabeiras na encosta setentrional do sistema formado pelas Serras das Croeiras, Itapecuru e Alpercatas, a cerca de 500 metros de altitude, e percorre 1450 quilômetros até a foz, drenando uma área de aproximadamente 52700 quilômetros quadrados (SEMATUR, 1991 apud POMPÊO; MOSCHINI-CARLOS; SILVA-FILHO, 2002).

O Vale do Itapecuru é uma das regiões de mais elevada densidade demográfica do Maranhão, sendo o Rio Itapecuru fonte estratégica de água para várias cidades, principalmente São Luís, onde abastece $75,0 \%$ da população. A navegação no Rio Itapecuru marcou época na história do Maranhão, trazendo desenvolvimento ao interior do estado.

A Bacia do Rio Mearim drena predominantemente terras do Bioma Cerrado, sobre terrenos da Bacia Sedimentar do Meio-Norte ou Parnaíba. Apenas seu terço inferior está inserido no Bioma Amazônico, que é denominado de "Izu", rio de águas pardacentas, devido à grande quantidade de seston ${ }^{14}$.

O Rio Mearim nasce na encosta setentrional da Serra da Menina, a uma altitude de 400 a 500 metros, com extensão de 930 quilômetros, e, juntamente com o Rio Pindaré, drena uma área de cerca de 97000 quilômetros quadrados. O rio está dividido em três trechos principais: Alto Mearim, entre as cabeceiras e a Barra do Rio das Flores, com extensão de 400 quilômetros, e elevado número de corredeiras; Médio Mearim, entre a barra do Rio das Flores e o Seco das Almas, com uma extensão aproximada de 180 quilômetros; e o Baixo Mearim, entre o Seco das Almas e a foz, na Baía de São Marcos.

O Rio Mearim, no Bioma Cerrado, é navegável até a Cidade de Barra do Corda (MA). Sua navegação é, atualmente, praticada por embarcações de madeira e lanchas, no transporte de cargas, como arroz, milho, feijão, babaçu, farinha de mandioca, pescado e gêneros diversos, bem como de passageiros entre os diversos povoados e as cidades existentes ao longo do rio. O Vale do Mearim também tem participação reconhecida no processo de ocupação do interior do Maranhão.

\footnotetext{
13 Área resultante do intenso trabalho de erosão fluvial do Quaternário antigo, posteriormente colmatada, originando uma paisagem de planícies fluviais, ilhas, lagoas e rios divagantes. Constitui o coletor principal do sistema hidrográfico do Maranhão.

${ }^{14}$ Conjunto de partículas, orgânicas ou não, que se encontram suspensas em corpos d'água.
} 
O Rio Grajaú, afluente da margem esquerda do Mearim, tem um curso de cerca de 770 quilômetros, estando o terço superior totalmente inserido no Bioma Cerrado, e o terço médio parcialmente inserido. O Rio Grajaú é navegável no trecho compreendido entre a sua foz e a Cidade de Grajaú (MA).

O Rio Pindaré nasce na Serra do Gurupi, nas elevações que formam o divisor entre as Bacias Hidrográficas dos Rios Mearim e Tocantins, nas proximidades da Cidade de Amarante (MA). O Rio Pindaré só não pode ser navegado com segurança em seu alto curso, que vai até a foz do Rio Buriticupu, numa extensão aproximada de 230 quilômetros. Dentre os rios maranhenses, destaca-se como o mais piscoso e de importância para a navegação, contribuindo no abastecimento de água das cidades ribeirinhas (LEITE, 1976 apud POMPÊO; MOSCHINI-CARLOS; SILVA-FILHO, 2002).

O Rio Munim nasce nos tabuleiros da Formação Barreiras, a nordeste de Caxias, na porção extremo leste do Estado do Maranhão, e deságua na Baía de São José, entre os Municípios de Axixá e Icatu, após um percurso de mais de 320 quilômetros, drenando aproximadamente 15800 quilômetros quadrados. Em sua bacia, encontra-se o Parque Nacional dos Lençóis Maranhenses, criado em 1981. Os Lençóis Maranhenses correspondem à faixa litorânea e sublitorânea, constituída por restingas, campos de deflação e dunas (Figura 25).

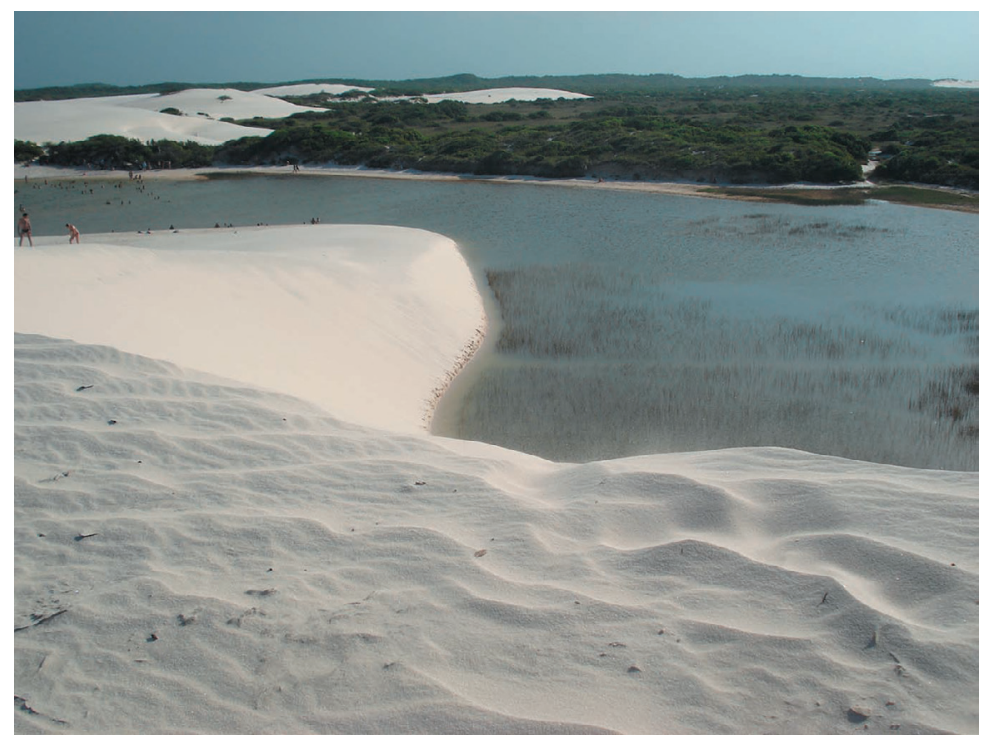

Figura 25 - Parque Nacional dos Lençóis Maranhenses (MA).

Foto: José Carlos Louzada Morelli.

É grande a ocorrência de minerais não metálicos, com a exploração econômica de argilas, para a produção de cerâmicas (telhas, tijolos etc.), e de pedreiras. Bastante assoreado, o Rio Munim sofre as consequências dos desmatamentos e do uso inadequado do solo, que tornam suas águas escassas e turvas, só adquirindo maior volume no baixo curso, já próximo à costa.

A rápida expansão dos cultivos de soja nas chapadas do sul do Maranhão, área das cabeceiras da maioria dos rios que deságuam no Golfão Maranhense, pode comprometer a quantidade e a qualidade de água destes, ameaçando o abastecimento humano e a navegação. 
O Bioma Cerrado possui duas grandes potencialidades intrinsecamente dependentes: a produção agropecuária e a produção de água. Se a primeira é fundamental para a economia do Brasil Central, a segunda é um serviço ambiental que esse bioma presta ao País e que é indispensável à sobrevivência humana e à manutenção dos ecossistemas. A expansão da atividade agropastoril não pode se dar às custas do comprometimento da mais antiga e também essencial potencialidade do Cerrado: a produção de água.

\section{Bacia Hidrográfica do Rio Parnaíba}

A Bacia do Rio Parnaíba é uma das maiores do País, estando 46,0\% dela no Bioma Cerrado, e o restante, no Bioma Caatinga.

O Rio Parnaíba nasce nos contrafortes da Chapada das Mangabeiras, em altitudes da ordem de 700 metros, percorrendo 1344 quilômetros até sua desembocadura no Oceano Atlântico, constituindo importante hidrovia para o transporte dos produtos agrícolas da região.

Antes de atingir o oceano, o Parnaíba forma um amplo e recortado delta, caracterizado por um conjunto de ilhas entrecortadas por estuários e baías. O delta é formado por três braços de rio na saída do mar. O intermediário, com rumo geral norte, desemboca na Baía das Canárias. Ele forma a divisa entre os Estados do Piauí e do Maranhão. O braço leste, chamado Rio Iguaçu, desemboca no oceano junto à Cidade de Luís Correia. O canal oeste, chamado Rio Santa Rosa é o mais comprido, subdividindo-se em vários braços distintos conhecidos como Igaraçu, Canárias, Caju, Melancieira e, por último, o de Tutoia, no extremo oeste.

O Rio Parnaíba possui um regime hidrológico semelhante ao do Rio São Francisco. Correndo numa região de transição entre os rios de regime equatorial e os da Região Nordeste, recebe, pela margem esquerda, afluentes perenes e, pela margem direita, tributários temporários, oriundos do Bioma Caatinga. Em janeiro ou fevereiro, ocorrem as cheias, e as águas transbordam, inundando as várzeas e possibilitando a alimentação das lagoas marginais.

É intenso o transporte de sedimentos pelo Rio Parnaíba, consequência da forte erosão que vem se processando em suas margens, relacionada com o seu regime torrencial e com a natureza arenosa do material encontrado nessas áreas.

O Rio Parnaíba é navegável da foz à Cidade de Santa Filomena, num percurso de 1176 quilômetros, em que os maiores obstáculos são constituídos por bancos de areia e afloramentos rochosos. A construção da Barragem de Boa Esperança, eliminou uma parte desses obstáculos e tornou possível a navegação a montante da barragem.

A Bacia do Rio Parnaíba comporta duas importantes Unidades de Conservação: o Parque Nacional das Nascentes do Rio Parnaíba e o Parque Estadual do Jalapão.

O Parque Estadual do Jalapão, criado em 2001 e localizado no Município de Mateiros, porção leste do Estado do Tocantins, na divisa entre Maranhão e Piauí, foi criado com o intuito de conservar as comunidades naturais contra a ação antrópica danosa e ordenar o desenvolvimento do ecoturismo. Suas paisagens mostram-se exuberantes por mesclarem cerrado, veredas, cachoeiras, serras e dunas (Figura 26). O Jalapão comporta, também, praias, cascatas, cachoeiras e corredeiras, ideais para a prática de esportes. 


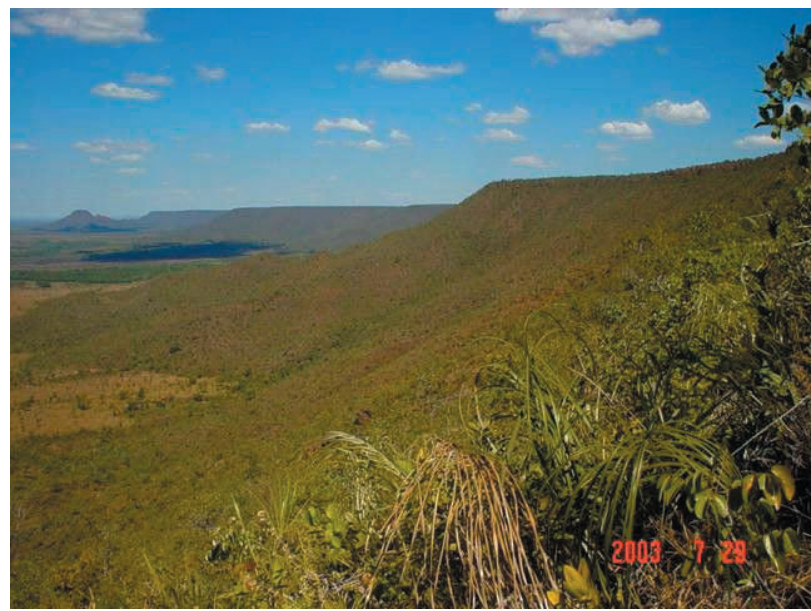

Figura 26 - Parque Estadual do Jalapão (TO).

Foto: Virlei Álvaro de Oliveira.

A estrutura econômica da porção da Bacia inserida no Bioma Cerrado é sustentada, basicamente, por atividades ligadas ao setor primário, no qual persiste a agricultura familiar, com atividades predominantemente de subsistência. Nesse contexto, a apicultura têm-se

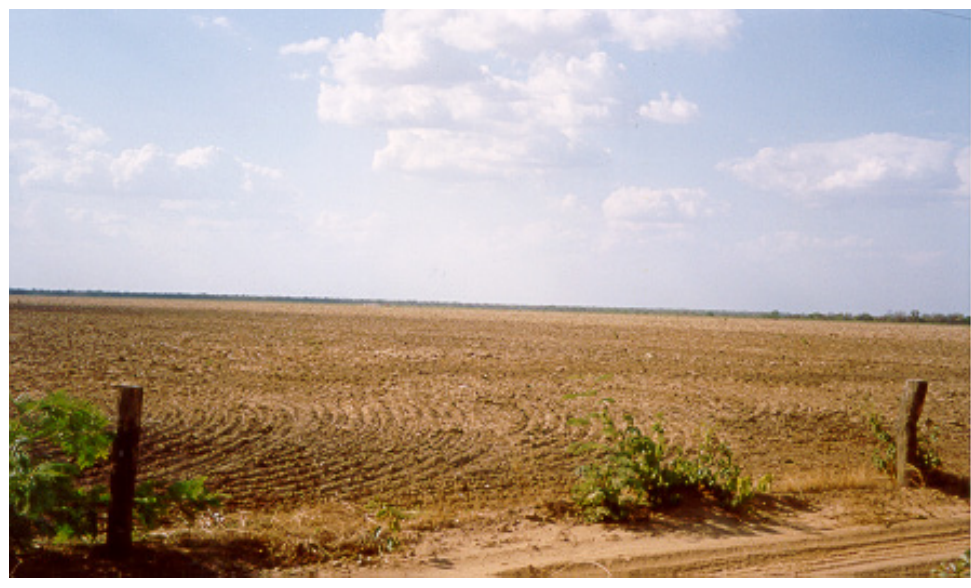

Figura 27 - Terreno preparado para o plantio da soja no Município de Uruçuí (PI) em área originalmente ocupada por vegetação do Cerrado.

Foto: Rosangela Garrido Machado Botelho. mostrado bastante profícua, gerando emprego e renda de forma sustentável. A pecuária de corte é outra atividade de tradicional importância, que tem sistematicamente se expandido. A região é uma das fronteiras agrícolas do Brasil, apresentando grande potencial na produção de grãos, em especial soja e milho, principal responsável pela supressão da vegetação de cerrado e de sua biodiversidade (Figura 27). Dos cerca dos 204 milhões de hectares de Cerrado originalmente existentes, apenas $42,0 \%$ permanecem, embora metade dessas áreas já esteja bastante degradada. Os principais municípios produtores de soja na Bacia do Rio Parnaíba são: Balsas e Tasso Fragoso, no Maranhão, e Uruçuí, no Piauí (ZONEAMENTO ECOLÓGICO-ECONÔMICO, 2005).

Num momento em que o Brasil vivencia uma intensificação de eventos meteorológicos e hidrológicos extremos (secas e enchentes recordes) em algumas bacias hidrográficas e regiões do País, observa-se a disputa entre setores econômicos (agricultura, indústria, geração hidrelétrica etc.) e entes federativos pelo uso da água, evidenciando sua escassez. O potencial para a produção agropastoril e mineral do Cerrado não pode comprometer sua vocação para a produção de água. Com esta premissa em mente, é preciso proteger mais e disciplinar melhor a ocupação e o uso das terras no Cerrado brasileiro. 


\section{Caatinga: sob o estigma da seca}

Mapa 3 - Bioma Caatinga - Domínios Morfoestruturais

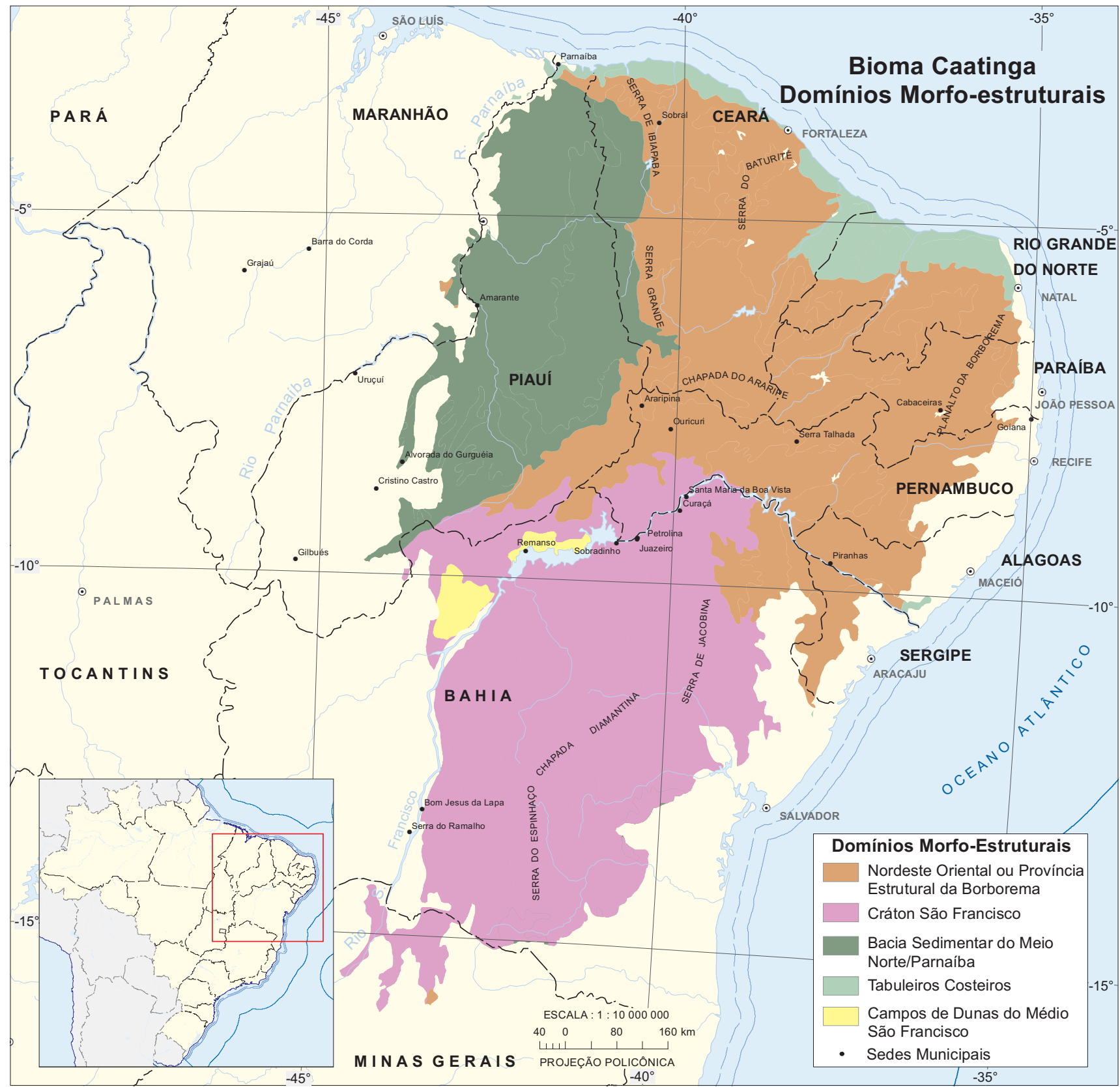

Fonte: IBGE, Diretoria de Geociências, Coordenação de Recursos Naturais e Estudos Ambientais. 
O termo caatinga é de origem indígena e significa mata clara e aberta. Aplica-se tradicionalmente ao conjunto paisagístico do Sertão Nordestino do Brasil, um importante espaço semiárido da América do Sul, exceção em um país com predominância de climas tropicais úmidos e subúmidos. Juntamente com o Chaco, a Patagônia argentina, os desertos da costa do Pacífico (Atacama, Sechura etc.) e as áreas secas dos altiplanos da Argentina, Chile, Bolívia e Peru compõem o conjunto de regiões áridas e semiáridas da América do Sul, continente mais conhecido pela abundância de umidade de algumas de suas regiões (Amazônia, Pantanal, costa tropical do Atlântico etc.).

Em largos traços, a existência deste espaço semiárido se deve à conjunção de fatores climáticos que pode ser traduzida, de um lado, pela presença de massas de ar equatoriais continentais nas depressões interplanálticas nordestinas e, de outro, pela influência de centros de alta pressão que, originados no Atlântico Sul durante o inverno austral, invadem os sertões secos. Isto debilita a ação da massa de ar tropical atlântica (inclusive os ventos alísios), atuante de leste para oeste, que vai alcançar apenas a parte costeira da Região Nordeste, domínio do Bioma Mata Atlântica. Comumente, são estes os fatores evocados para explicar a ocorrência do longo vazio de precipitações no Bioma Caatinga, frequentemente com dois períodos secos anuais: um de longo déficit hídrico, seguido de chuvas intermitentes, e outro, com seca curta, seguido de chuvas torrenciais, que podem faltar durante anos.

A originalidade dos sertões do Nordeste brasileiro reside num complexo feixe de atributos climático, hidrológico e ecológico e são esses atributos que servirão de fundamento à caracterização desse bioma, já que são eles condicionantes não só do ambiente natural como também das formas de ocupação humana nele presentes.

Na verdade, os atributos marcantes do Bioma Caatinga estão centrados no tipo de clima, muito quente e sazonalmente seco, com fortes reflexos sobre a hidrologia, a biodiversidade e a socioeconomia sertaneja. A grande variabilidade de deflúvios - maior característica dos rios na Caatinga - é decorrente das irregularidades interanuais nas chuvas e produz efeitos muitas vezes catastróficos, que se manifestam tanto por secas prolongadas como por inundações. Além disso, a região também está sujeita a elevadas taxas de evaporação, e este fato contribui para exaurir ainda mais os recursos hídricos - mormente os superficiais.

Se comparada com outras regiões áridas do mundo, a influência pluviométrica na questão da seca no Bioma Caatinga está mais relacionada com a distribuição irregular das chuvas do que propriamente com a falta das mesmas. Assim, a ocorrência de secas é uma condição comum à Caatinga e não uma excepcionalidade.

Sob este aspecto, há que se destacar o fenômeno da "seca verde", quando as chuvas ocorrem fora de sua época normal. Neste caso, embora a vegetação da Caatinga se apresente exuberante (verdejante, com folhas, flores e frutos), as lavouras são perdidas. Portanto, as secas se caracterizam não apenas quando há escassez anual de chuvas, mas também quando estas ocorrem fora de época, reforçando o papel da irregularidade das chuvas no fenômeno das secas. Assim, a água no Bioma Caatinga é um mineral estratégico e sua gestão afigura-se como fator vital para a sobrevivência e o desenvolvimento das populações humanas. 
Não existe melhor termômetro para delinear o Bioma Caatinga do que os limites de sua própria vegetação. Até onde vão, de modo relativamente contínuo, as diferentes fácies da Caatinga estendem-se os ambientes desse bioma. Abrangendo o semiárido da Região Nordeste do País, o Bioma Caatinga é banhado pelo oceano desde a foz do Rio Parnaíba até as cercanias de Natal (RN). De Natal para o sul, até o norte de Minas Gerais, confina com o Bioma Mata Atlântica. Depois, limita-se com o Bioma Cerrado, ao longo das Bacias dos Rios São Francisco e Parnaíba, fechando-se o polígono na Cidade de Parnaíba (PI).

A tipologia vegetacional mais importante e onipresente é a Savana Estépica (caatingas florestada, arborizada, parque e gramíneo-lenhosa), que retrata, em sua fisionomia decidual e espinhosa, pontilhada de cactáceas e bromeliáceas, os rigores da secura, do calor e da luminosidade tropicais. A Caatinga, que constitui o mais antigo representante da aridez do último período glacial no Brasil, sofreu drástica redução de área desde então.

As variações fisionômicas desse bioma verificam-se não só de um lugar para outro como também em um mesmo local, conforme a estação do ano. Os contrastes fisionômicos são muito acentuados entre as estações das chuvas e da seca. Numa época, a Caatinga está despida, cinzenta e espinhosa, noutra, coberta de imenso e novo verde que emana da enorme quantidade de pequenas folhas, um verde que se espalha por toda parte, nas ervas e na abundante ramificação dos arbustos e das árvores (Figura 28). Esta paisagem é interrompida somente em poucas situações e, principalmente, pela presença de florestas (deciduais e semideciduais) e de cerrados, ambos associados a ambientes especiais, como áreas serranas, brejos e outros tipos de bolsões climáticos mais úmidos.

(a)

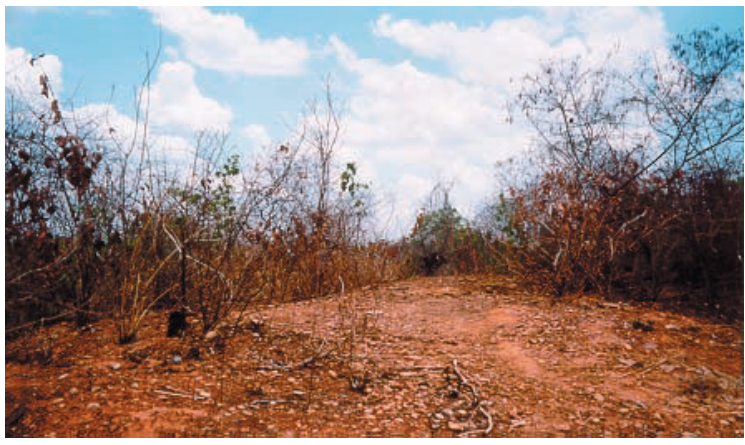

(b)

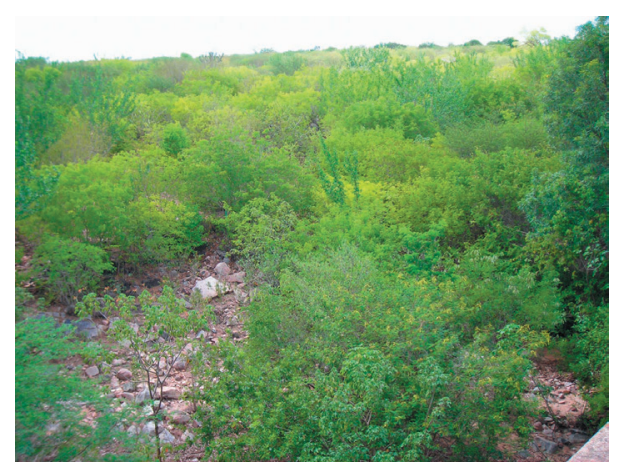

Figura 28 - Aspecto da Caatinga em época de estiagem (a) e em época de chuvas (b).

Fotos: Rosangela Garrido Machado Botelho. 
O Bioma Caatinga abrange as seguintes tipologias, com as respectivas formações remanescentes: Savana Estépica (Caatinga), predominante e definidora do bioma; Savana (Cerrado), com ocorrências isoladas no Piauí, Ceará, Rio Grande do Norte e Bahia; Floresta Ombrófila Aberta, também em ocorrências isoladas no Ceará, Paraíba, Pernambuco e Alagoas; Floresta Ombrófila Densa, com uma pequena ocorrência na Chapada Diamantina (BA); Floresta Estacional Semidecidual, com sua formação montana em pequenas ocorrências no Ceará, Paraíba e Pernambuco e áreas mais representativas na Bahia; Floresta Estacional Decidual, com remanescentes das formações vegetacionais submontana e montana e pequena área de ocorrência no sul do Piauí e outras mais expressivas no centro-sul da Bahia e norte de Minas Gerais; Formações Pioneiras, representadas pelas restingas e mangues da costa do Piauí, Ceará e Rio Grande do Norte; Refúgio Vegetacional, na região central da Bahia; e mais as Áreas de Tensão Ecológica (contatos entre tipos de vegetação) (Tabela 3).

Tabela 3 - Áreas remanescentes e áreas antropizadas, no Bioma Caatinga, segundo os tipos de vegetação

\begin{tabular}{|c|c|c|c|c|c|c|}
\hline \multirow{3}{*}{ Tipos de vegetação } & \multicolumn{6}{|c|}{ Bioma Caatinga } \\
\hline & \multicolumn{2}{|c|}{ Total no Bioma } & \multicolumn{2}{|c|}{ Área remanescente } & \multicolumn{2}{|c|}{ Área antropizada } \\
\hline & $\begin{array}{c}\mathrm{Em} \\
\mathrm{km}^{2}\end{array}$ & $\begin{array}{c}\text { Percentual } \\
(\%)\end{array}$ & $\begin{array}{c}\mathrm{Em} \\
\mathrm{km}^{2}\end{array}$ & $\begin{array}{c}\text { Percentual } \\
(\%)\end{array}$ & $\begin{array}{c}\mathrm{Em} \\
\mathrm{km}^{2}\end{array}$ & $\begin{array}{c}\text { Percentual } \\
(\%)\end{array}$ \\
\hline Área Total do Bioma & 844.453 & 100,0 & 507.951 & 60,0 & 328.501 & 39,0 \\
\hline Floresta Ombrófila Densa & 321 & 0,0 & - & - & 321 & 100,0 \\
\hline Floresta Ombrófila Aberta & 4.203 & 0,5 & - & - & 4.203 & 100,0 \\
\hline Floresta Estacional Semidecidual & 15.920 & 2,0 & 1.230 & 8,0 & 14.690 & 92,0 \\
\hline Floresta Estacional Decidual & 18.399 & 2,0 & 2.915 & 16,0 & 15.483 & 84,0 \\
\hline Savana & 17.135 & 2,0 & 14.287 & 83,0 & 2.848 & 17,0 \\
\hline Savana Estépica & 558.491 & 66,0 & 3.528 .232 & 63,0 & 205.668 & 37,0 \\
\hline Formações Pioneiras & 4.182 & 0,5 & 2.606 & 62,0 & 1.576 & 38,0 \\
\hline Contatos entre Tipos de Vegetação & 212.685 & 25,0 & 128.972 & 61,0 & 83.713 & 39,0 \\
\hline Refúgios Vegetacionais & 5.118 & 0,6 & 5.118 & 100,0 & - & - \\
\hline Superfície com Água & 8.002 & 1,0 & - & - & - & - \\
\hline
\end{tabular}

Fonte: Mapa de biomas do Brasil: primeira aproximação. Rio de Janeiro: IBGE, 2004. 1 mapa. Escala 1:5 000 000. Disponível em: <ftp://geoftp.ibge.gov.br/informacoes_ambientais/vegetacao/mapas/brasil/biomas.pdf>. Acesso em: jul. 2016.

Notas: 1 . Corresponde a $10,0 \%$ da área total do País.

2. Datas médias de referência: Região Nordeste - 1996 e Região Sudeste - 1982.

O Bioma Caatinga recobre três grandes províncias estruturais da classificação de Almeida e outros (1977): a Província Borborema, aqui referida como Nordeste Oriental; a Província ou Cráton São Francisco; e a Província Parnaíba.

O compartimento do Nordeste Oriental ou Província Estrutural da Borborema representa uma associação complexa de unidades geológicas, retrabalhadas e segmentadas no Ciclo Orogênico Brasiliano. Como nas demais áreas cratônicas, registra uma longa história geológica de aglutinações e fragmentações, com rifteamento, abertura e fechamento de oceanos, acreção/colisão entre fragmentos litosféricos, formação de orógenos, que caracterizam os Ciclos de Wilson (WILSON, 1966), e que atingiu a conformação atual com a grande aglutinação/colisão continental conhecida como Ciclo Orogênico Brasiliano-Pan-africano. 
Nesse contexto, terrenos granitíticos muito antigos (arqueanos) e domos ocorrem na região central do Ceará, formando a Serra de Baturité, imponente bloco de relevo pertencente aos Planaltos Residuais Sertanejos, limitado a sudeste por falhas do Lineamento Senador Pompeu. Além da Serra de Baturité, outros planaltos residuais incluem os maciços graníticos de Meruoca, Uruburetama e Mocambo, da região de Sobral (CE), e as sequências metavulcanossedimentares da Faixa Jaguaribeana (Grupo Orós-Jaguaribe) na divisa do Ceará com o Rio Grande do Norte. Estes grandes maciços residuais elevam-se a mais 1000 metros de altitude e apresentam vertentes úmidas voltadas para o litoral, além de contrafortes muitos secos a sotavento: a vegetação de Floresta Estacional reveste densamente as encostas úmidas (brejos ou "ilhas" de Mata Atlântica), enquanto a Caatinga ocupa os espigões ressecados voltados para sul.

Na base destes planaltos, encontra-se a Depressão Sertaneja, que ocupa grande parte dos Estados do Ceará e do Rio Grande do Norte, entre os Tabuleiros Costeiros, a norte e nordeste, e os Planaltos Sertanejos e da Borborema, ao sul (Figura 29). Talvez seja este o ambiente mais característico da Caatinga, juntamente com aquele das depressões dos Rios Paraguaçu/Itapicuru e Rio das Contas, na Bahia, nos domínios do Cráton São Francisco.

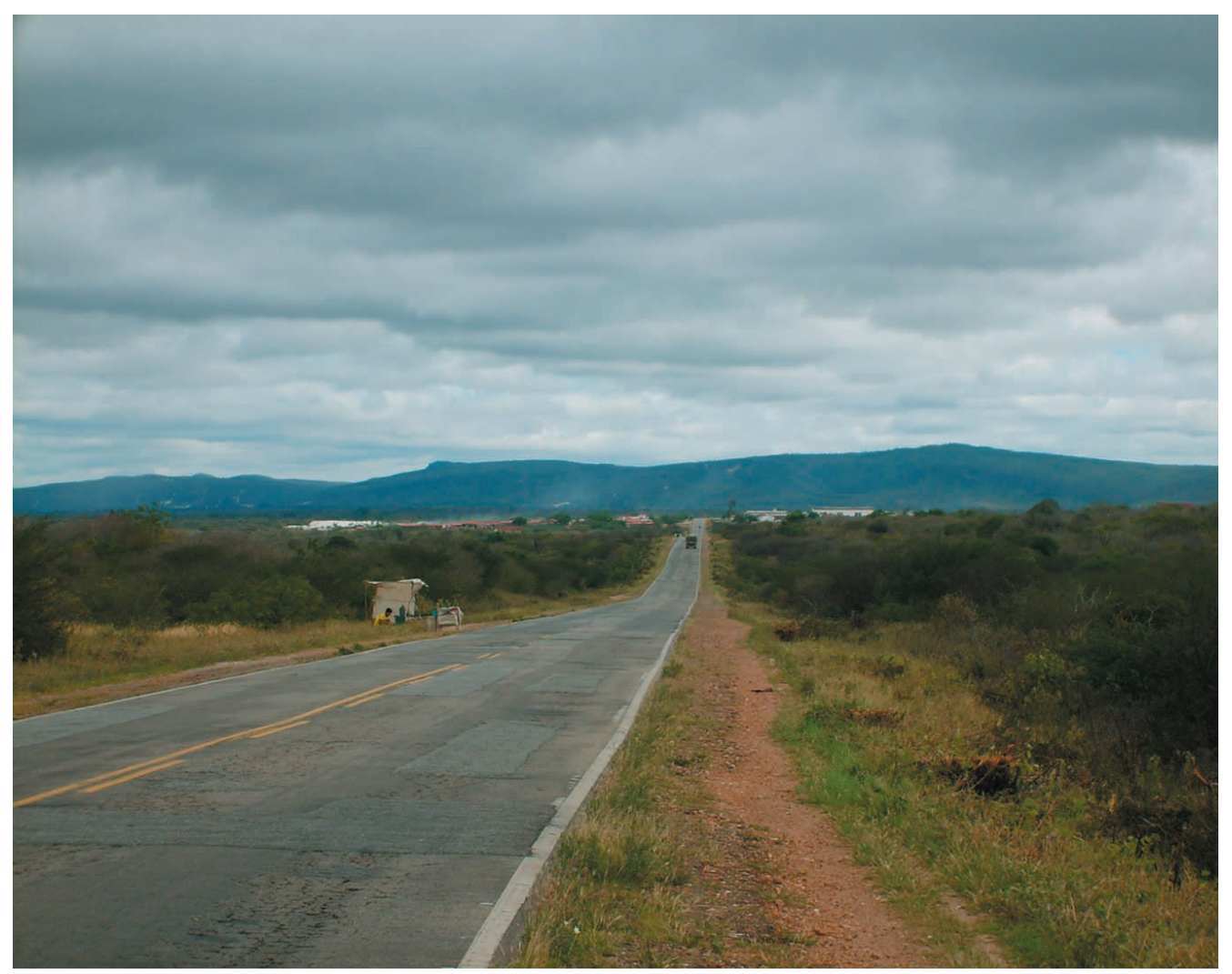

Figura 29 - Serra dos Cariris Velhos, Planalto da Borborema (PB).

Foto: Maria Amélia Vilanova Neta. 
Trata-se das amplas depressões periféricas e interplanálticas modeladas nas rochas granito-gnáissicas remobilizadas do interior nordestino. Inselbergues, pontas rochosas e os muitos lajedos são elementos caracterizadores do relevo (Figura 30) em certas áreas das depressões de Irauçuba, no Ceará, de Patos e Sousa, na Paraíba, e do Seridó, no Rio Grande do Norte. Em outros setores, ocorre verdadeira paisagem de "caos de blocos", como na região central do Rio Grande do Norte, nas proximidades do neck vulcânico (antiga chaminé vulcânica) que constitui o Pico do Cabugi, onde grandes blocos rochosos resultaram do desmantelamento de diques e são entremeados por áspera vegetação da Caatinga, rica em cactáceas.

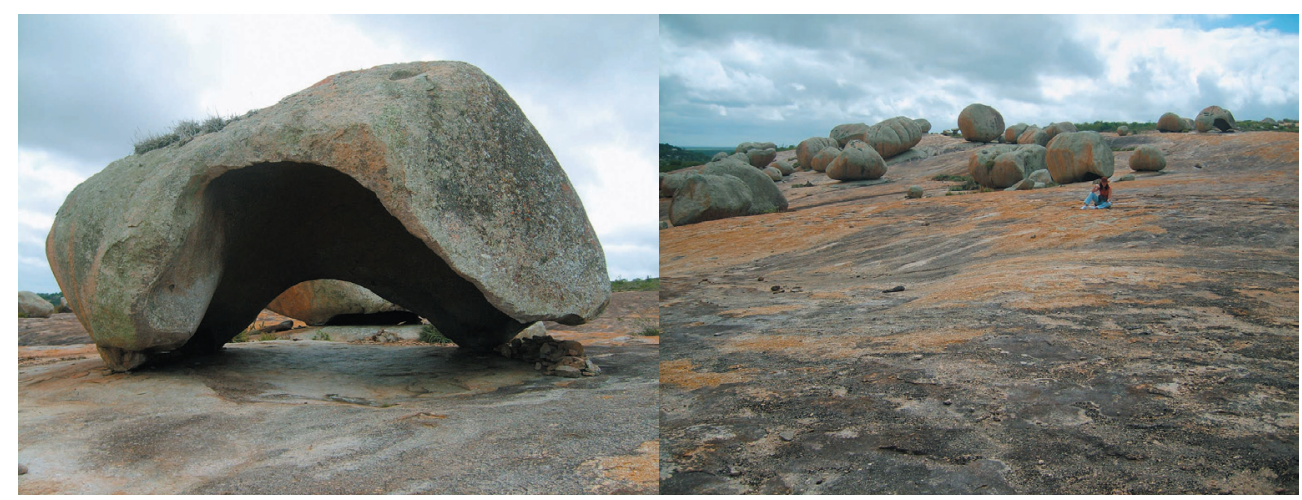

Figura 30 - Pedra do Capacete (a) e Lajedo do Pai Mateus (b), município de Cabaceiras (PB).

Fotos: Maria Amélia Vilanova Neta.

A superfície da Depressão Sertaneja, nivelada em altitudes que variam 100 a 400 metros, foi aplainada por sucessivas fases de erosão e reesculpida em épocas pré-atuais. Os solos são, geralmente, revestidos por pavimentação detrítica, constituída de fragmentos de rochas arestados e de calibres variados. A maioria dos solos possui pequena e mediana profundidade, alta fertilidade natural e apresenta em sua constituição teores consideráveis de minerais primários de fácil alteração, além de, quase sempre, argilominerais jovens (do tipo 2:1) na sua fração fina. Tais características, comuns nos solos desse bioma, são determinadas principalmente pelo baixo índice pluviométrico. Neossolos Regolíticos, Neossolos Litólicos, Neossolos Quartzarênicos, Luvissolos, Planossolos Nátricos, Argissolos e Cambissolos são os solos mais expressivos em termos de área.

As condições climáticas prevalecentes variam de semiáridas a áridas, com precipitações médias anuais variando de 800 a menos de 400 milímetros, e as chuvas concentrando-se numa única e curta estação. Os pesados aguaceiros alimentam uma drenagem temporária de natureza torrencial que lava a superfície topográfica, desnudando-a do material mais fino, ressaltando o "esqueleto" de detritos e expondo os afloramentos.

A extrema irregularidade anual e interanual das precipitações pluviométricas, aliada à natureza impermeável das rochas, é responsável por uma acentuada deficiência hídrica, não só superficial como subterrânea, revelada na paisagem de rios e riachos intermitentes e da comum ocorrência de poços com fracas vazões e águas salinas. A alimentação do lençol freático e a circulação hídrica subterrânea deficientes, no âmbito dos terrenos cristalinos, 
explicam por que a maior parte dos rios e riachos do semiárido seca durante os meses mais secos. A despeito disso, ao longo dos Rios Açu e Jaguaribe, há planícies fluviais expressivas, nas quais se pratica agricultura irrigada, especialmente no Vale do Açu.

Aspectos associados à condição de aridez, como solos com horizontes superficiais de muito pequena espessura e com baixos teores de matéria orgânica ( $\mathrm{A}$ fraco), presença significativa de cascalhos e matacões em superfície (pavimento desértico), são características bastante comuns e podem ser verificadas nas extensas áreas de ocorrência de Luvissolos Crômicos (antigos Brunos Não Cálcicos) e de alguns Argissolos, Cambissolos e Neossolos Litólicos (Figura 31). Este é o ambiente típico onde se instalou uma Caatinga das mais densas, de porte arbustivo-arbóreo, com espécies densamente entrelaçadas e a presença constante de cactáceas e bromeliáceas. Na maior parte do ano, a vegetação calcinada e cinza tem aspecto desolador. Com as primeiras chuvas, subitamente toda ela rebrota e se revigora.

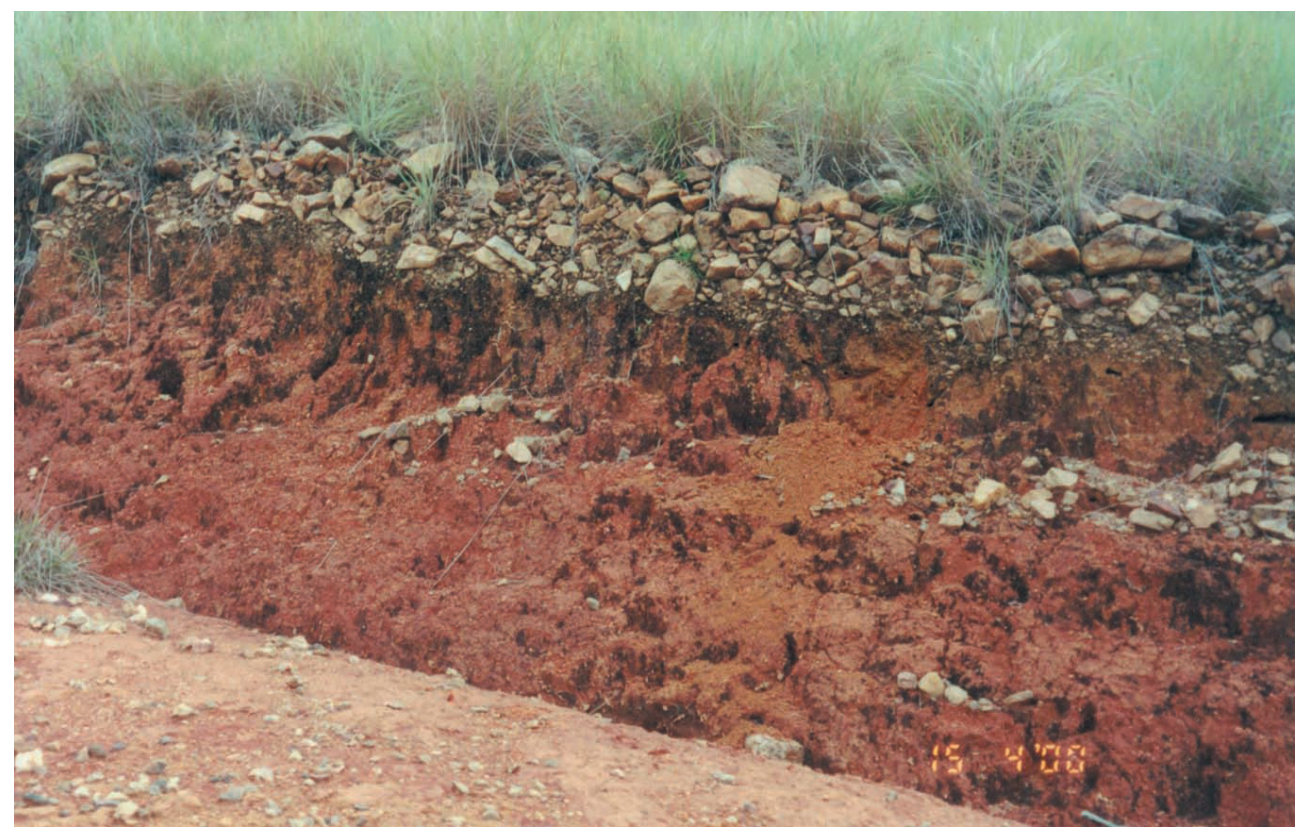

Figura 31 - Pedregosidade na superfície do solo (pavimento desértico).

Foto: Virlei Álvaro de Oliveira.

Solos dotados de argilas predominantemente expansivas (esmectíticas) na fração coloidal, anteriormente referidos como solos retrácteis (BRASIL, 1972), são hoje classificados, de acordo com o Sistema Brasileiro de Classificação de Solos (SISTEMA..., 2006), como Vertissolos e foram registrados em significativas ocorrências próximas aos Municípios de Souza e Campina Grande, na Paraíba, e ao Município de Mossoró, no Rio Grande do Norte (MAPA..., 2001). O termo retráctil foi usado para especificar a grande capacidade de expansão/contração da massa destes solos, frente a alternâncias do regime de umidade, causando fendilhamento expressivo no período seco. 
É importante destacar que, associadas a baixas taxas e à má distribuição da precipitação pluviométrica, se verificam também elevadas temperaturas, que determinam elevadas taxas de evaporação, tornando os solos potencialmente vulneráveis aos processos de salinização (halomorfismo). Tal fato pode ser constatado pelas extensas áreas de ocorrência de Planossolos Nátricos (MAPA..., 2001), que são solos cuja salinidade é determinada principalmente por sais de sódio, que ocorrem em proporção superior a $15,0 \%$ do complexo de troca, chegando a valores próximos a $50,0 \%$ em algumas situações, conforme determinações feitas em amostras de solos coletadas no Estado do Ceará (BRASIL, 1973b). A presença de eflorescências (crostas de sais cristalizados) é comum em leitos secos de córregos (Figura 32).

Contrariando o que por muito tempo se pensou como verdadeiro, o

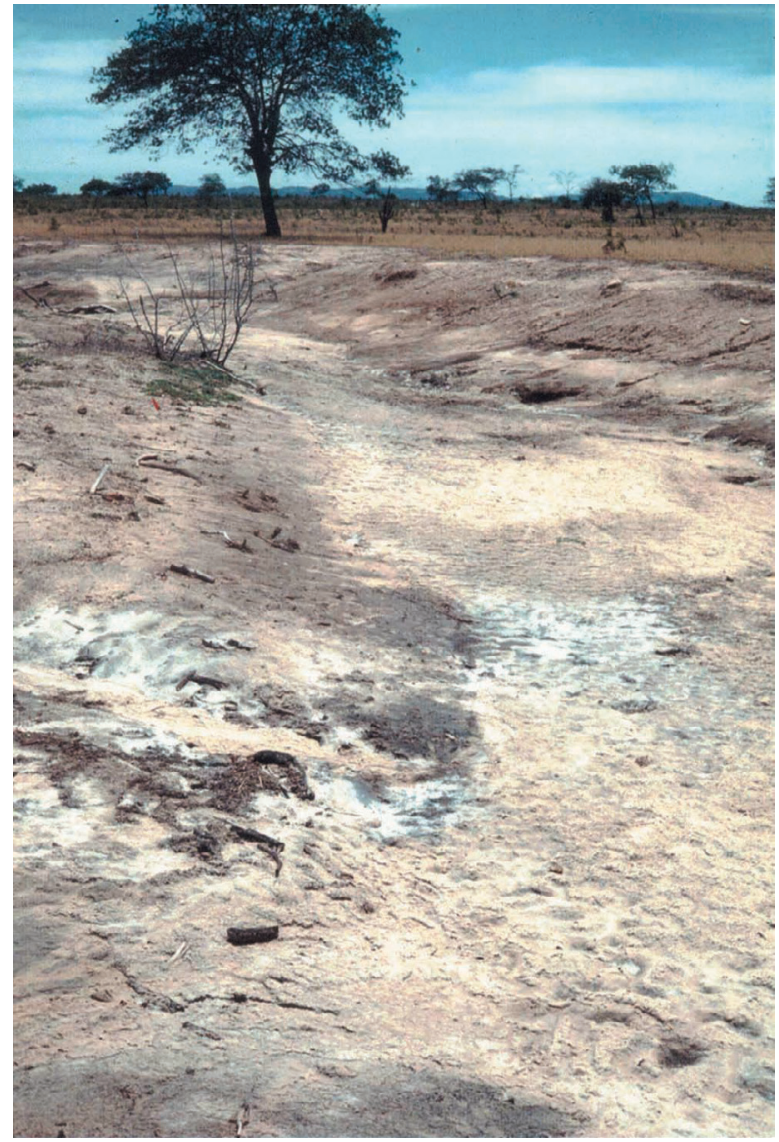
Figura 32 - Eflorescência na superfície do terreno, Sertão de Alagoas. Foto: Virlei Álvaro de Oliveira.

Bioma Caatinga, formado por diferen-

tes ambientes, que lhe conferem alta heterogeneidade paisagística, apresenta singularidade e elevada riqueza florística e faunística, além de consideráveis taxas de endemismo. Por ser o único bioma exclusivamente compreendido em Território Nacional, todo o patrimônio biológico que abriga não se encontra em nenhum outro país do mundo. Trata-se do semiárido com maior biodiversidade no planeta, muito embora ainda pouco conhecido do ponto de vista científico, haja vista o baixo número de inventários realizados em relação aos demais biomas (BRASIL, 2002; SIQUEIRA FILHO, 2012). Apesar disso, a Caatinga é um dos biomas brasileiros mais alterados e degradados por ação antrópica, havendo inclusive a formação de grandes núcleos de desertificação em alguns pontos. Contudo, as políticas públicas para conservação, estudos e uso dos recursos biológicos têm colocado o bioma em segundo plano. Sua conservação é um grande desafio e carece da superação de alguns obstáculos, entre eles a criação de mais Unidades de Conservação. Segundo dados do Cadastro Nacional de Unidades de Conservação - CNUC, o Bioma Caatinga possuía apenas 7,33\% de sua área protegida não alcançando a meta nacional para 2010 (10,0\% para o bioma). Todavia, 
obtiveram-se avanços consideráveis, sobretudo no incremento das áreas com proteção integral, de 1,10\%, em 2000, para 4,86\%, em 2010 (BRASIL, 2011). Também visando à formulação de políticas públicas para a conservação da biodiversidade do Bioma Caatinga, o Ministério do Meio Ambiente (BRASIL, 2007) identificou 292 áreas prioritárias para implementação de ações, classificadas segundo graus e categorias de importância biológica, representando um aumento de 210 áreas em relação as 82 áreas prioritárias identificadas no ano de 2000.

A rica vegetação da Caatinga, dominada por espécies de características xerofíticas, é ainda uma das principais fontes de energia para as populações locais, sob a forma de lenha. A lenha é usada tanto para fins domésticos, no preparo de alimentos, quanto para fins industriais, em padarias e olarias. A exploração de lenha, juntamente com a produção de carvão vegetal, é uma das maiores ameaças à vegetação da Caatinga. Nas áreas mais secas, como nas encostas a oeste do Planalto da Borborema, a exploração predatória da vegetação para a produção de lenha e de carvão é apontada como uma das causas da formação de núcleos de desertificação (MAPA..., 2008).

O desmatamento da Caatinga contribui ainda para o agravamento do efeito estufa, ao transferir, para a atmosfera, o carbono antes armazenado pela vegetação. No Bioma Caatinga, as áreas desmatadas ficam expostas à ação das chuvas torrenciais, que desencadeiam, de um lado, processos erosivos severos e, de outro, o alagamento de muitas áreas.

As plantas se agrupam em formações de aspecto seco e agreste, que são, na verdade, adaptações ao período de secas. Estão distribuídas em três estratos: herbáceo (formado, em grande parte, por gramíneas); arbustivo e arbóreo, com árvores caducifólias; e espinhosas, de baixo a médio porte. Nos curtos períodos da estação chuvosa, as partes vegetativas rebrotam, o que confere aspecto verde à paisagem, com o colorido diversificado das flores que emergem. Outra característica dos ecossistemas que integram o bioma é a presença de diversas espécies de cactos (Figura 33), como o mandacaru, o facheiro, o xique-xique, a coroa-de-frade e o quipá, além de muitas bromélias, a exemplo da macambira e da caroá. A flora da Caatinga caracteriza-se, igualmente, pela abundância de espécies arbóreas da família Leguminosae (ou Fabaceae), tais como as catingueiras, as juremas, o angico, o mulungu, e de espécies da família Euphorbiaceae, como a faveleira (Figura 34), o marmeleiro e as maniçobas. Além dessas, outras árvores típicas estão presentes na paisagem, como o juazeiro, o umbuzeiro, a aroeira-do-sertão e espécies de palmeiras que ocorrem de maneira esparsa, a exemplo da licuri, ou agrupada, como a carnaubeira. Algumas espécies fazem parte das listas oficiais de plantas ameaçadas de extinção, como a aroeira e as leguminosas, como o sabiá. Segundo dados cadastrados na Lista de Espécies da Flora do Brasil, a biodiversidade florística da Caatinga pode ser estimada em 5311 espécies (4 345 Angiospermas; 842 fungos; 96 Briófitas; 26 Samambaias e Licófitas e 2 Gimnospermas), com um total de 1547 espécies endêmicas (LISTA..., 2010). A última revisão regional coordenada pelo Ministério do Meio Ambiente indicou 53 áreas para proteção e conservação da diversidade florística da Caatinga. Desse total, 35,0\% foram classificadas como áreas insuficientemente conhecidas, mas provavelmente importantes do ponto de vista biológico (GIULIETTI, 2004). 


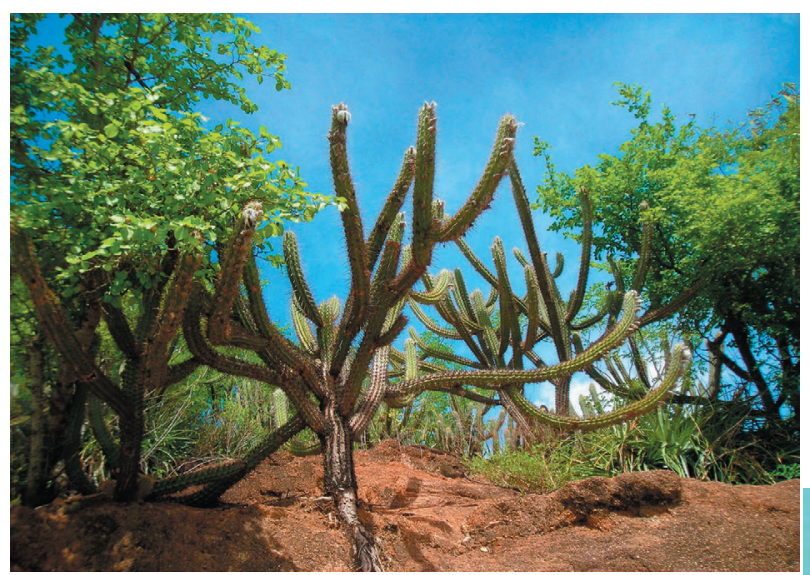

(a)

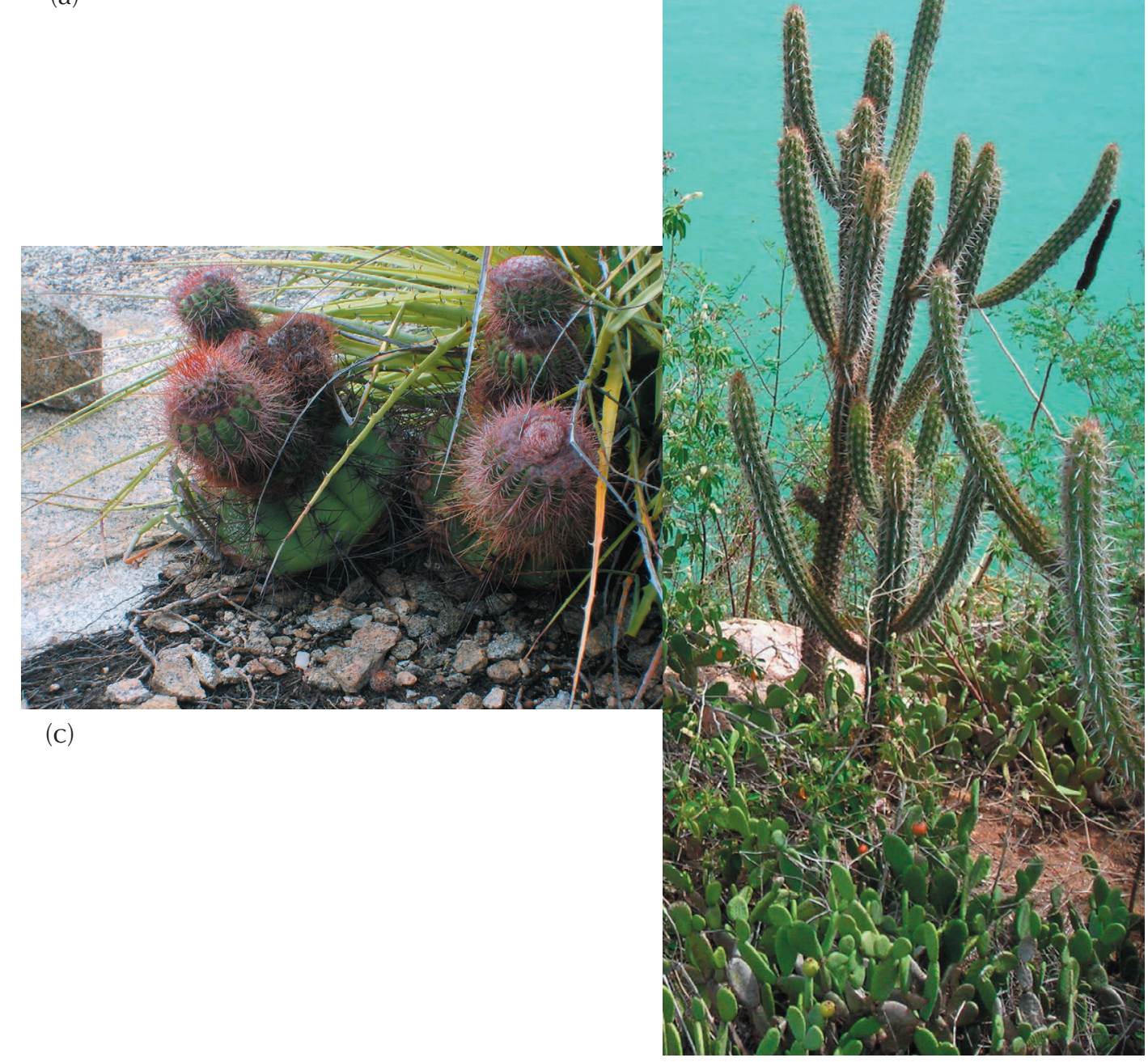

(b)

Figura 33 - Cactos típicos da caatinga: xique-xique (a), mandacaru e quipá (b), sendo este uma espécie rasteira, e coroa-de-frade (c). Fotos: Rosangela Garrido Machado Botelho (a) e (b) e Maria Amélia Vilanova Neta (c). 


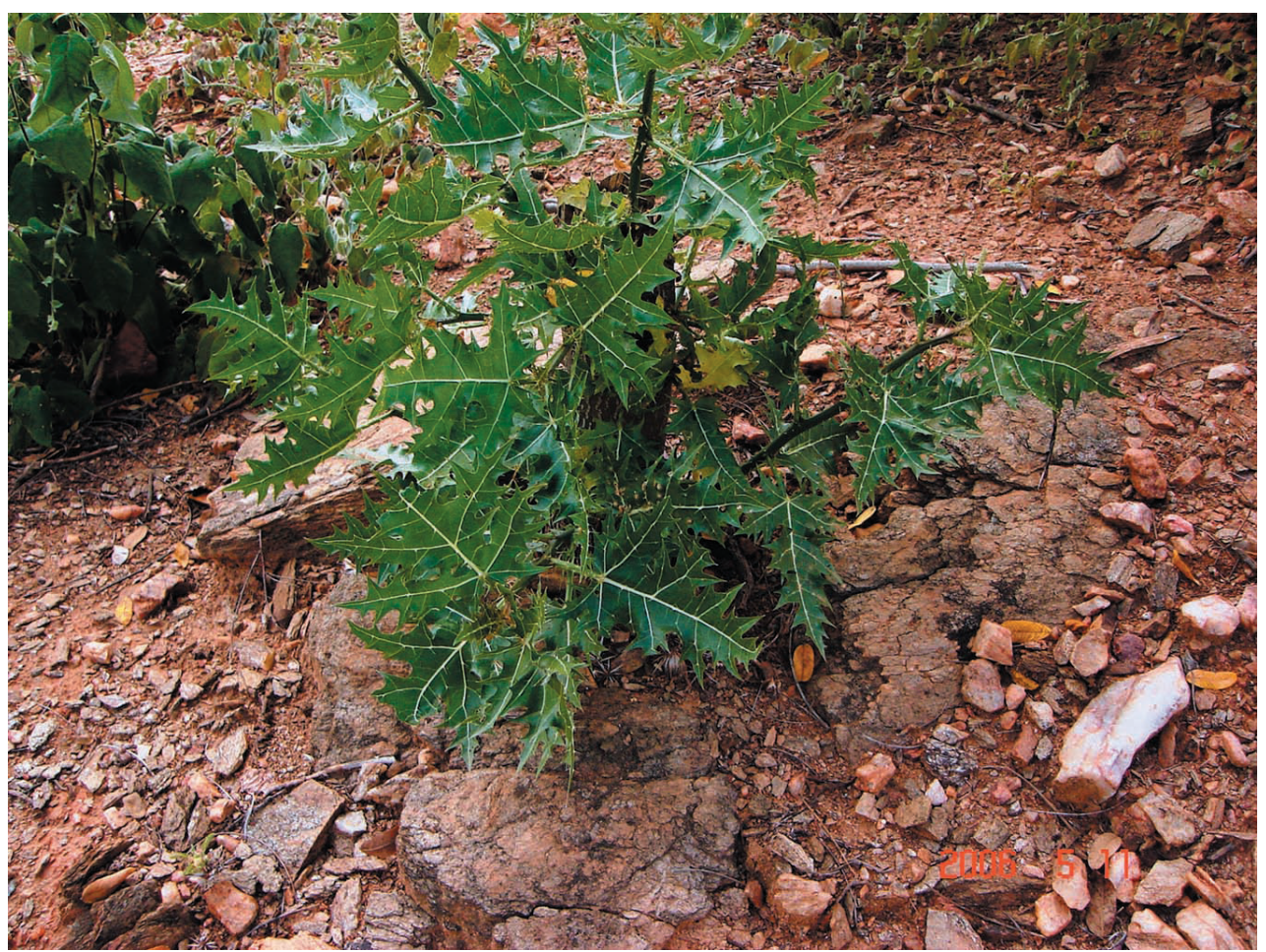

Figura 34 - Faveleira jovem.

Foto: Rosangela Garrido Machado Botelho.

Embora a fauna de aves seja uma das mais estudadas, ainda há falta de informações a respeito desse grupo animal. Silva e outros (2003) registram para o bioma um total de 510 espécies de aves, das quais cerca de 92,0\% (469) se reproduzem na região. Entre as ameaçadas de extinção, destacam-se duas: a ararinha-azul, considerada extinta na natureza, e a arara-azul-de-lear. Outras aves igualmente ameaçadas são: a maracanã, o pica-pau-anão-do-nordeste, o arapaçu-do-nordeste, o joão-xique-xique, o bico-virado-da-caatinga e o pintassilgo-do-nordeste. A última revisão regional coordenada pelo Ministério do Meio Ambiente selecionou 35 áreas prioritárias para a conservação da biodiversidade da avifauna, das quais 22 apresentam considerável importância biológica (PACHECO, 2004).

Até mais ou menos a metade do século passado, imaginava-se que a fauna de mamíferos do Bioma Caatinga era pobre, reduzida a um subconjunto da fauna do Bioma Cerrado. Estudos e revisões científicas mais recentes mostram o contrário. Trata-se de uma fauna rica e diferenciada, com pelo menos 148 espécies conhecidas, das quais 10 são endêmicas do Bioma Caatinga (OLIVEIRA, 2004a). Desse total, 10 espécies constam da lista oficial da fauna em extinção. Uma das principais ameaças é a caça generalizada, bastante comum no bioma. À medida que os estudos se intensificarem, o número de espécies conhecidas de mamíferos deverá aumentar, pois há falta de comprovação, no nível específico, de muitas espécies de roedores e de quirópteros, por exemplo. Entre as espécies amplamente distribuídas no bioma, e com evidências de serem endêmicas, destacam-se o rato-de-fava e o mocó (Figura 35), ambas observadas apenas em formações abertas. Entre os mamíferos ameaça- 
dos estão a onça-pintada, a onça-parda, a jaguatirica, o gato-maracajá, o gato-do-mato, o tamanduá-bandeira e o tatu-bola. A última revisão regional coordenada pelo Ministério do Meio Ambiente destacou 27 áreas para a implementação de ações prioritárias para a conservação das espécies da mastofauna ${ }^{15}$, das quais 14 foram consideradas como de extrema importância biológica (OLIVEIRA, 2004b).

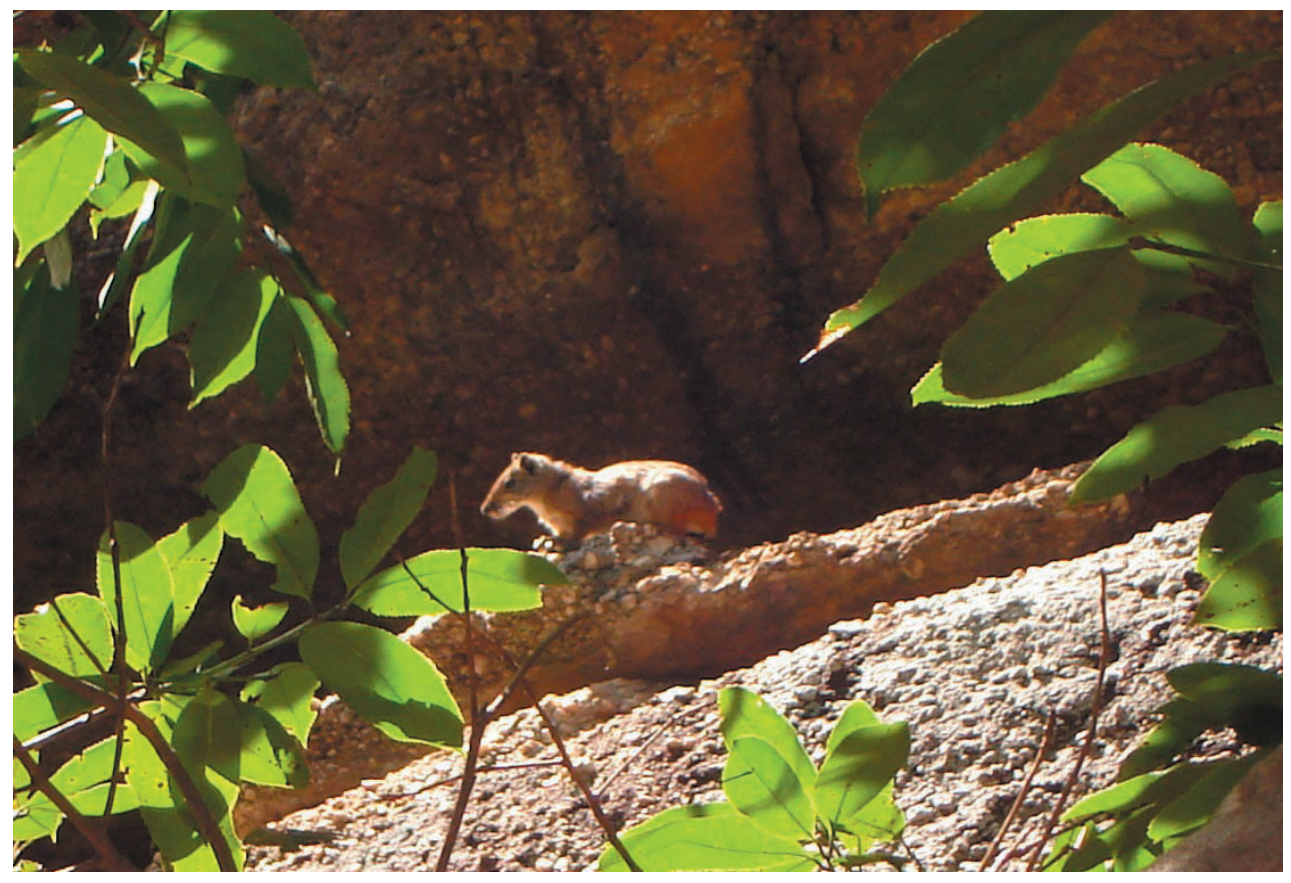

Figura 35 - Mocó, roedor característico do Bioma Caatinga.

Foto: Rosangela Garrido Machado Botelho.

No Planalto da Borborema, onde as cotas superam 1000 metros, a Caatinga povoa as escarpas ocidentais (voltadas para o interior do continente), que são extremamente secas, com precipitações médias anuais inferiores a 400 milímetros, e escala o planalto, difundindo-se pelos topos planos e vales mais elevados, onde as precipitações podem variar de $800 \mathrm{a}$ 1000 milímetros, já sob influência da umidade oceânica procedente do leste. Este é o limite entre os Biomas Caatinga e Mata Atlântica, a leste.

A região sudoeste da Borborema é ocupada pelo Planalto Sertanejo e pelo Patamar Sertanejo, que caracterizam relevos controlados pelas movimentações de falhas dos lineamentos Patos e Pernambuco, onde, entre outras estruturas, encontra-se embutida a Chapada do Araripe.

Dentre os planaltos residuais ou contínuos que se destacam do piso das depressões, parte foi modelada a partir de antigas bacias sedimentares, de idade mesozoica, posteriormente soerguidas. Entre elas, destacam-se as Bacias de Tucano e Tonã-Jatobá (Pernambuco e Bahia) e a Bacia do Araripe (Pernambuco e Ceará).

15 Conjunto de mamíferos de uma região ou ambiente. 
As Bacias de Tucano e Tonã-Jatobá são rifts (fossas tectônicas) que se prolongam desde o Recôncavo Baiano, preenchidas por arenitos, folhelhos e siltitos cretácicos. O relevo elaborado nesses sedimentos é dissecado, com tabuleiros seccionados por vales profundos, entalhando a superfície de erosão que nivelou os topos e truncou as rochas dos orógenos arqueanos e Paleoproterozoicos que enquadram rifts. Os Rios Vaza-Barris, Itapicuru e São Francisco atravessam a área onde a Caatinga apresenta feições características, mas se encontra, geralmente, muito degradada pela extração de lenha e a produção de carvão.

Uma paisagem de exceção é a denominada "Raso da Catarina", que se localiza no extremo nordeste da Bahia e faz parte da vasta unidade Tabuleiros de Tonã-Jatobá, representando uma continuidade da Depressão do Baixo São Francisco sobre os sedimentos da Bacia de Tucano-Jatobá. Com altimetria variando de 400 a menos de 300 metros, localiza-se a noroeste da Cidade de Jeremoabo e a oeste das localidades de Chorrochó e Macururé, aproximando-se das margens do Rio São Francisco. Trata-se de uma das áreas da Caatinga mais bem-preservadas. Praticamente despovoado, o Raso da Catarina é cortado por trilhas precárias, percorridas por caçadores e ocasionais viajantes. Nele predominam os Neossolos Quartzarênicos, que recobrem os topos conservados e descem pelas rampas suaves dos vales das poucas torrentes intermitentes. Manchas de Planossolos ocorrem nas bordas voltadas para o Rio São Francisco, mas eventuais afloramentos rochosos acentuam a desolação da paisagem. Esses solos aliam-se ao clima tropical quente com dois períodos secos (9 a 11 meses), de caráter acentuado e marcado por chuvas torrenciais irregulares (com precipitações médias anuais de menos de 500 milímetros), permitindo a instalação da exuberante vegetação do Bioma Caatinga, que estabelece ecótonos com o Cerrado e a Floresta Estacional Decidual nas bordas da área. Por causa destas características, foi criada pelo governo federal, em 1984, a Estação Ecológica Raso da Catarina, Unidade de Conservação com aproximadamente 100000 hectares.

Localizada entre os Planaltos da Borborema, a leste, e da Ibiapaba, a oeste, a Chapada do Araripe estende-se na direção leste-oeste entre os Estados do Ceará, de Pernambuco e do Piauí, com uma área de 6230 quilômetros quadrados. Trata-se de um relevo estrutural tabular nivelado por processos erosivos, atuando sobre arenitos e siltitos cretácicos (Figura 36). A superfície de topo, bastante homogênea e conservada, situa-se num nível altimétrico de cerca de 800 metros. Indícios de dissecação incipiente registram-se no setor oriental, onde o Riacho Jardim e seus afluentes entalham fracamente a topografia. No restante da superfície, a drenagem é inexpressiva, atestando porosidade e permeabilidade elevadas das rochas que capeiam a Chapada. O setor ocidental é revestido por densa cobertura de Caatinga, que transiciona a leste para vegetação de Cerrado. A Caatinga se mantém até o nível altimétrico de 700 metros. Os Latossolos que se desenvolveram apresentam baixa fertilidade, dificultando as atividades agrícolas, restritas a culturas de subsistência. Isso justifica a baixa densidade demográfica da Chapada e contribui para a preservação da vegetação natural. A Chapada enquadra-se no regime climático semiárido, mas com diferenças marcantes de pluviosidade de acordo com a geometria do relevo. As escarpas e esporões voltados para o Estado de Pernambuco, ao sul, conservam restos de mata seca, que cedem lugar à Caatinga nos sopés, onde chove menos de 600 milímitros ao ano. Os sedimentos mergulham suavemente para norte e leste, possibilitando o surgimento de inúmeras nascentes responsáveis pelos denominados 
"brejos" de pé de serra na região do Cariri cearense, onde se situam as Cidades de Juazeiro do Norte, Crato e Barbalha. As precipitações chegam a mais de 1200 milímitros. A maior umidade implica o predomínio de Floresta Estacional. A Caatinga voltará a ocorrer bem mais a norte, na Depressão Sertaneja.

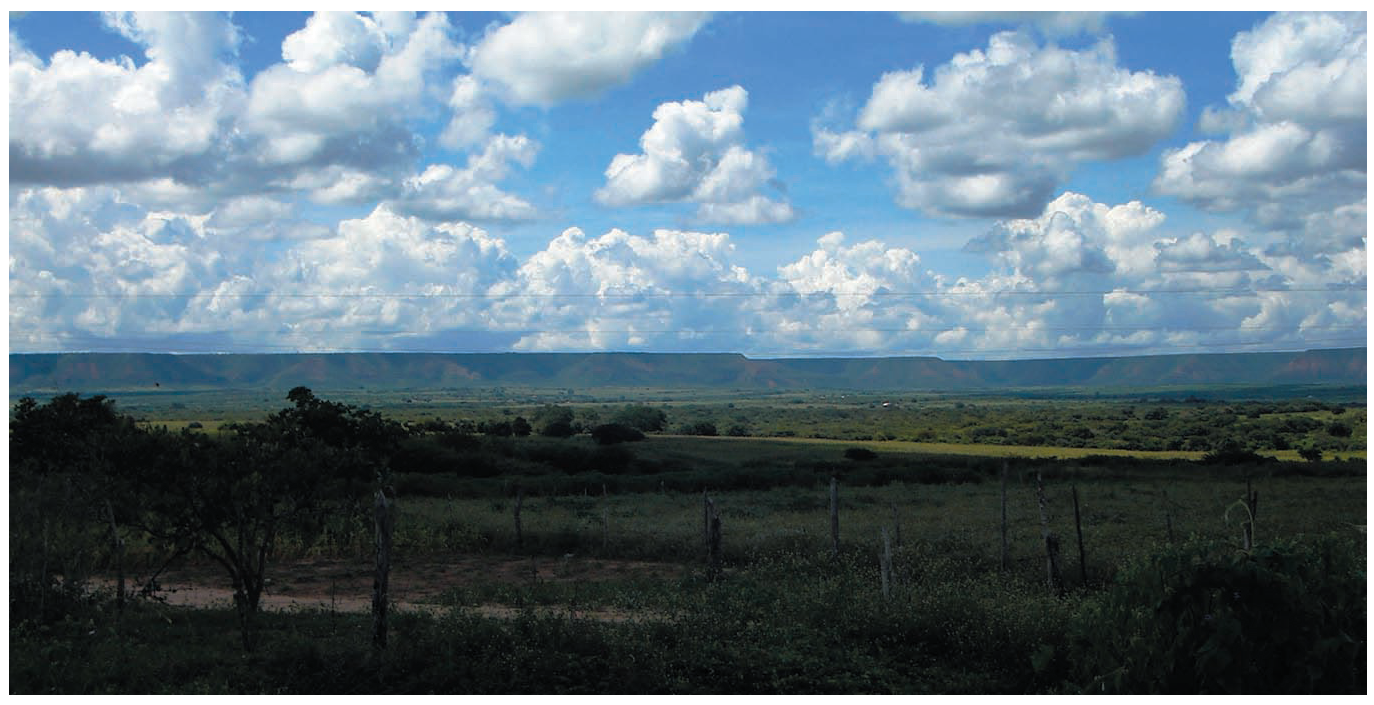

Figura 36 - Chapada do Araripe, vista ao longo da Rodovia BR-316, entre os Municípios de Ouricuri e Araripina (PE). Foto: Rosangela Garrido Machado Botelho.

As áreas mais úmidas, os brejos e os vales dos rios, são dedicadas à agricultura de subsistência, inclusive os leitos secos dos rios intermitentes. Plantam-se, principalmente, miIho, feijão e mandioca, culturas muito suscetíveis aos efeitos da seca. Nas partes mais secas, recobertas pela Caatinga, pratica-se a pecuária extensiva com gado bovino, caprino e ovino.

Em decorrência dos desmatamentos, do uso intensivo dos recursos naturais, do sobrepastoreio e do uso inadequado do solo, crescem vertiginosamente os problemas ambientais no Bioma Caatinga. Dados da Fundação Grupo Esquel Brasil, organização não governamental que desenvolve programas no semiárido nordestino, com ênfase na convivência sustentável e no combate à desertificação (SANTANA, 2003), sinalizam que a vazão de algumas fontes de água do semiárido está diminuindo ao longo dos anos. Entre 1850 e 1950, a vazão das fontes do Cariri, na Chapada do Araripe, sofreu uma redução anual de 0,2\%. De 1950 a 1970, essa taxa aumentou para 3,0\% e, de 1970 em diante, para algo em torno de 6,0\%. O estudo constata ainda que já secaram cerca de 200 fontes da parte cearense da Chapada e cerca de 70 do lado pernambucano.

Entre as maiores ameaças que pairam sobre o Bioma Caatinga está a desertificação. No Brasil, uma área de mais de 570000 quilômetros quadrados, onde vivem 13 milhões de pessoas, tem algum grau de suscetibilidade climática ao processo de desertificação (MAPA..., 2004a), estando a maior parte desta área inserida nesse bioma, inclusive aquelas 
com maior vulnerabilidade ao processo (Figura 37). Quatro núcleos de desertificação já foram identificados no Brasil, três deles no Bioma Caatinga (Irauçuba, Cabrobó e Seridó). O quarto núcleo, Gilbués (Figura 38), localiza-se no sudoeste do Estado do Piauí, em área do Bioma Cerrado, próximo ao limite com o Bioma Caatinga. Em todos os casos, o processo de desertificação é causado pelo uso inadequado da terra, com o sobrepastoreio, o desmatamento, as queimadas, a mineração e o garimpo como principais causas do processo. Isto significa que, embora condicionada por fatores climáticos e edafológicos, a desertificação é essencialmente causada pela ação antrópica.

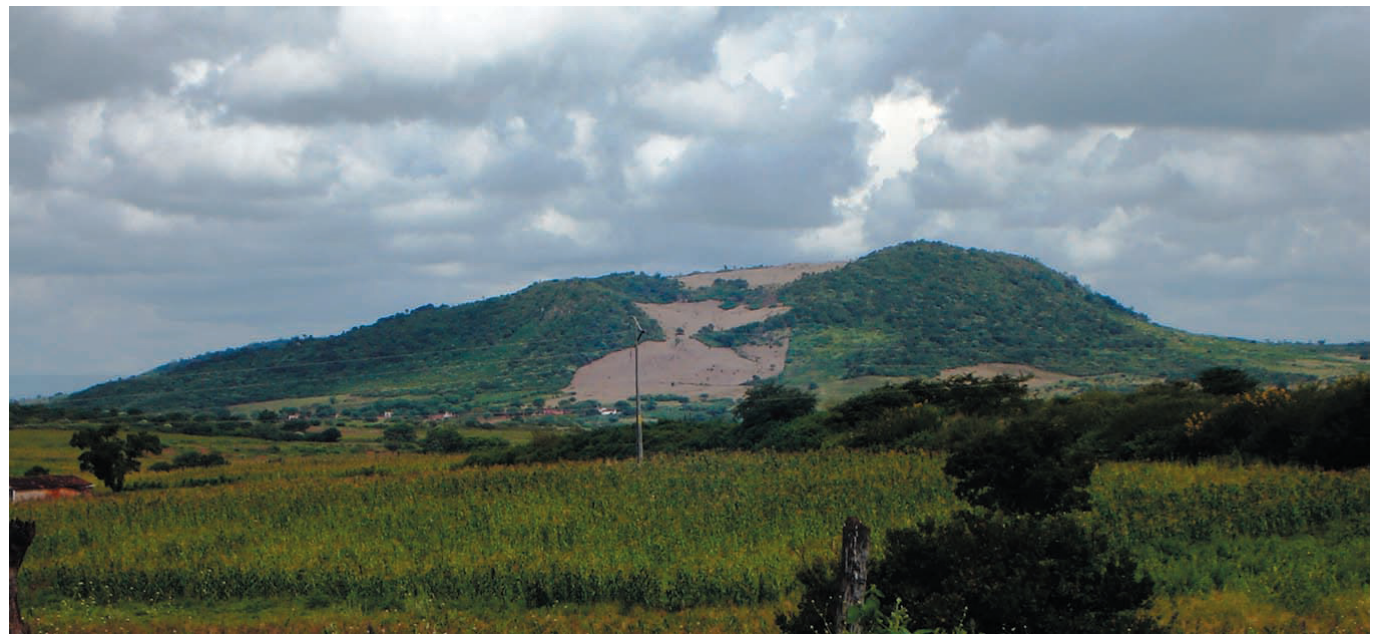

Figura 37 - Processo de "desertificação" no Município de Ouricuri (PE). Foto: Rosangela Garrido Machado Botelho.

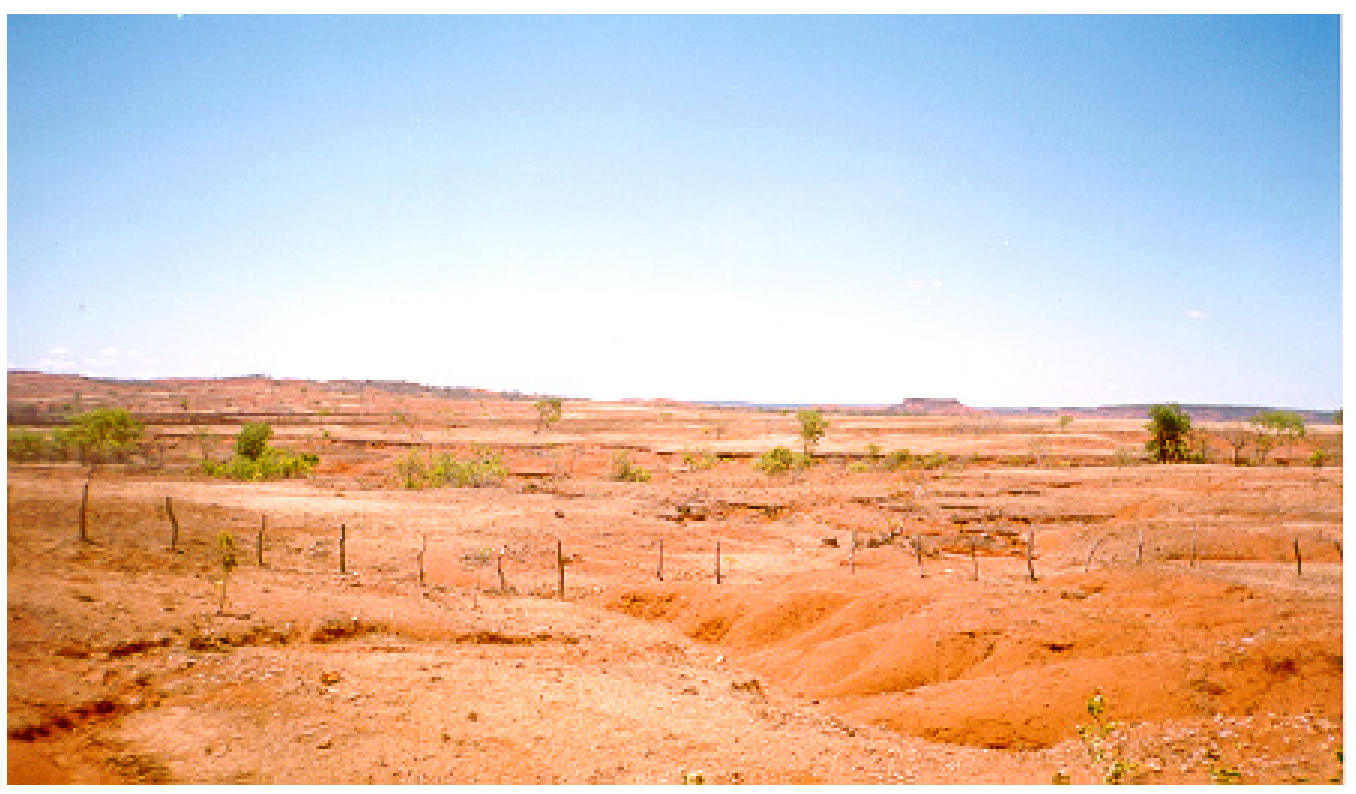

Figura 38 - "Desertificação" no Município de Gilbués (PI). Foto: Rosangela Garrido Machado Botelho. 


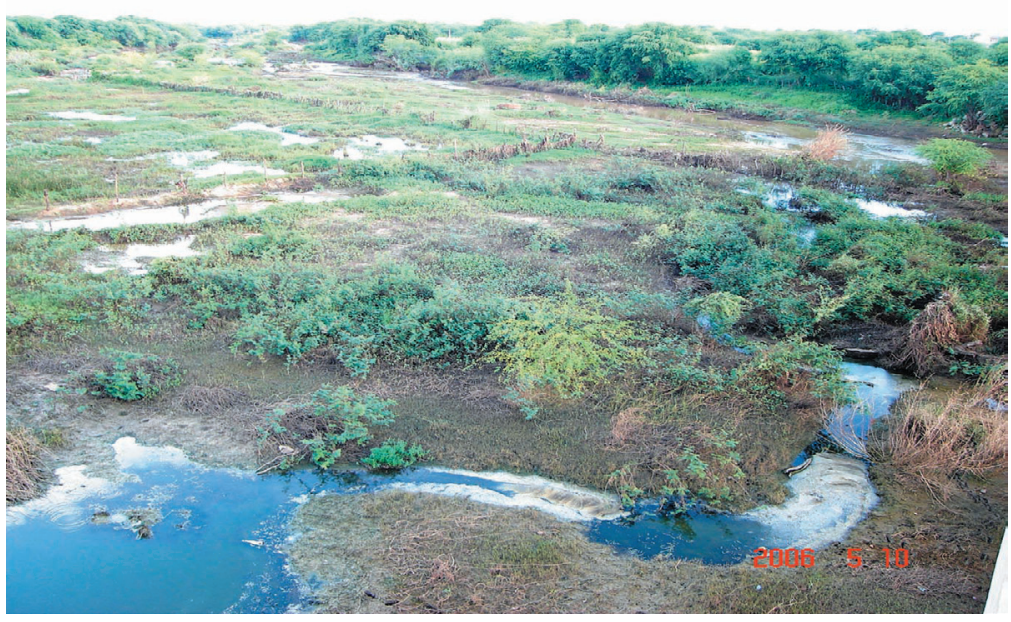

Figura 39 - Rio contaminado com esgoto, Bacia do Rio Pajeu, Município de Serra Talhada (PE) Foto: Rosangela Garrido Machado Botelho.
A maior parte dos rios do Bioma Caatinga vem apresentando redução de fluxo e/ou está contaminada, ameaçando a saúde das pessoas. Em algumas cidades, esses parcos recursos têm sido transformados em verdadeiros esgotos a céu aberto (Figura 39) - casos típicos dos Rios Ipojuca, Capibaribe e Una, no sertão pernambucano -, exemplos do cruel embate que ocorre entre a preservação do meio ambiente e a urbanização mal planejada. As consequências dessa ocupação desorganizada já são bastante evidentes: enchentes, assoreamento dos rios devido ao desmatamento e ocupação das margens, desaparecimento de áreas verdes, desmoronamento de encostas, redução da infiltração das águas pluviais e a consequente diminuição da alimentação subterrânea, além de comprometimento da qualidade das águas de alguns cursos de água, que viraram depósitos de lixo e canais de esgoto. Esses fatores são ainda agravados pela manifestação das doenças de veiculação hídrica, que se propagam mais facilmente onde são mais deficientes as condições sanitárias. Nos açudes, é comum a ocorrência da bionfalária, caramujo hospedeiro do parasita que causa a esquistossomose ("barriga d'água"), doença de veiculação hídrica endêmica no Bioma Caatinga.

A crescente degradação dos cursos de água, principalmente por efluentes domésticos, a destruição das matas ciliares, o assoreamento, a contaminação e o barramento de cursos de água, a sobrepesca, além da introdução de espécies exóticas, como a tilápia (de origem africana) e o tucunaré (originário da Bacia Amazônica), têm provocado o desaparecimento de várias espécies de peixes e outros organismos aquáticos. Estudos apontam um total de 240 espécies de peixes na Caatinga, das quais cerca de 57,0\% endêmicas, o que refuta a ideia de baixa diversidade da ictiofauna do Bioma Caatinga (ROSA, 2004b). Apesar disso, a ictiofauna da região é menos diversificada que a de outros biomas brasileiros, exceção feita aos peixes anuais, endêmicos, pertencentes à família Rivulidae. Estes têm distribuição exclusiva em lagoas sazonais, que se tornam completamente secas durante a estiagem e nas quais são depositados ovos resistentes, que eclodem nos períodos úmidos. Durante o último trabalho de identificação de áreas e ações para a conservação da biodiversidade, coordenado pelo Ministério do Meio Ambiente, 29 áreas prioritárias foram apontadas para a biota aquática, sendo que 16 foram classificadas como insuficientemente conhecidas, porém de provável importância biológica (ROSA, 2004a).

Na porção centro-sul do Bioma Caatinga, encontra-se o Cráton São Francisco, domínio morfoestrutural de evolução geológica complexa e onde estão localizadas as rochas mais antigas já registradas em território brasileiro. O Cráton São Francisco engloba um mosaico de terrenos arqueanos, extremamente arrasados, onde foram modeladas as depressões do Médio e Baixo Rio São Francisco, do Rio das Contas e dos Rios Paraguaçu/Itapicuru, distribuídas no entorno da Chapada Diamantina (Figura 40). 


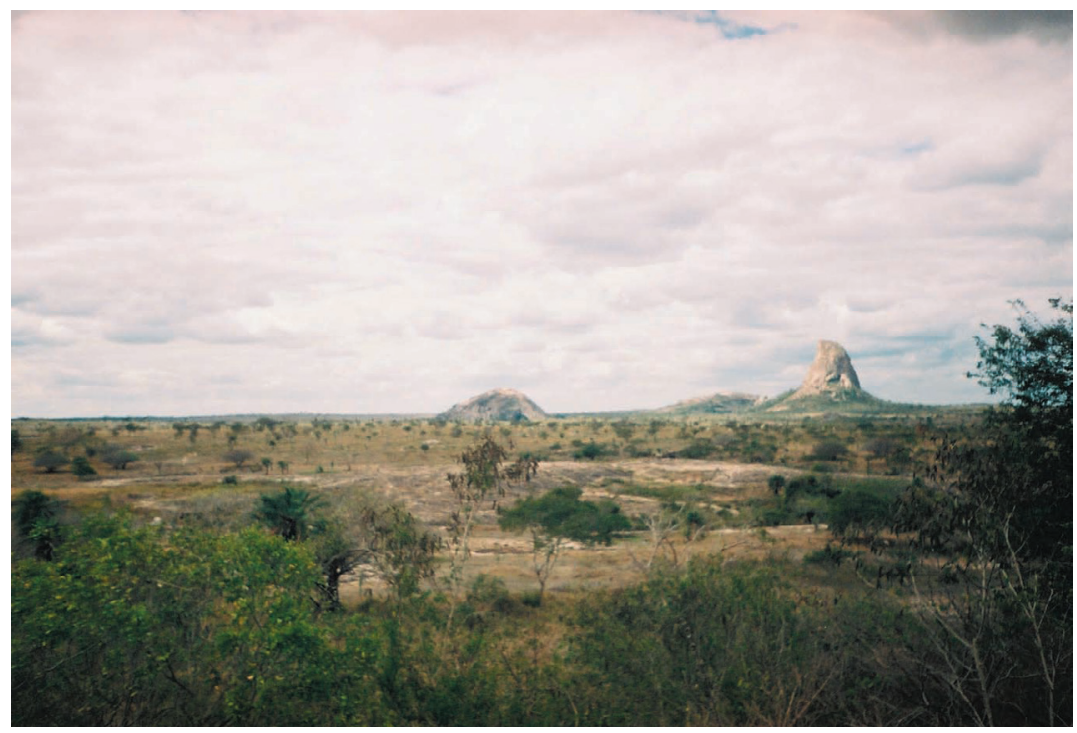

Figura 40 - Depressão dos Rios Paraguaçu/ltapicuru (BA), onde se observam inselbergues destacados na paisagem

Foto: Marco Antonio de Carvalho Oliveira.

Penetrando pelo Vale do Rio Paramirim, entre as Serras do Espinhaço e a Chapada Diamantina, essas depressões expandem-se por superfícies embutidas nos planaltos e tabuleiros sublitorâneos, ao longo dos Rios das Contas, Paraguaçu, Verde, Curaçá e outros. Nelas, os cinturões granito-greenstone constituem blocos crustais ou microcontinentes de variadas dimensões formados no Mesoarqueano (3 200 a 2800 milhões de anos), representando as primeiras placas tectônicas continentais no processo de formação do Cráton São Francisco.

Esses cinturões apresentam um enorme potencial para acumulação de bens minerais, especialmente metálicos, e são denominados de Cinturões de Brumado, Guajeru, Ibitira, Ubiraçaba, Umburanas, Riacho de Santana, Contendas-Mirante, entre outros, todos localizados no Estado da Bahia, expostos, de forma descontínua, na Depressão dos Rios Paraguaçu/Itapicuru e nas Baixadas do Rios Jacaré e Salitre. No Cinturão de Brumado (Bloco Gavião), registram-se os depósitos de magnesita e de talco da Serra das Éguas, e, no Vale do Rio Paramirim (Bloco Paramirim), encontram-se concentrações de chumbo e zinco na Formação Boquira, onde existe a mina de Boquira, que, entre 1959 e 1992, teria produzido cerca de 650000 toneladas de chumbo e zinco (DARDENNE; SCHOBBENHAUS, 2003). No Bloco Serrinha, encontra-se o distrito de ouro do Rio Itapicuru, com destaque para os depósitos de Fazenda Maria Preta, com reservas estimadas de 12,5 toneladas de ouro, e os da faixa Weber ${ }^{16}$, com os depósitos da mina Fazenda Brasileiro (até 150 toneladas de ouro).

16 Esta faixa corresponde a uma zona de cisalhamento com mais de 8 quilômetros de extensão, orientação E-W e mergulho de cerca de $45^{\circ}$ para sul. Trata-se de um dos mais importantes depósitos de ouro orogênico do Brasil. Situa-se entre as rochas das sequências Fazenda Canto e Fazenda Brasileiro (DARDENNE; SCHOBBENHAUS, 2003; COSTA, 2008). 
Parte dessas depressões, como nas Baixadas dos Rios Jacaré e Salitre, encontra-se modelada em rochas granito-gnássicas formadas durante a orogenia Jequié, ocorrida entre 2800 e 2700 milhões de anos atrás, devido à colisão dos fragmentos crustais do Mesoarqueano, originando várias associações granito-gnáissicas (complexos Tanque Novo, Ipirá, Almandina, Caraíba e Itabuna). A oeste da depressão ocorre o Bloco Jequié, constituído pelo Complexo Jequié, com rochas metamórficas de alto grau. De acordo com Delgado e outros (2003), os complexos Caraíba, Itabuna e Jequié representam sucessivos arcos magmáticos coalescidos entre 2810 e 2690 milhões de anos.

Uma outra parte dessas depressões trunca rochas metassedimentares e metaígneas desenvolvidas no início do Paleoproterozoico, bem como rochas do Cinturão Móvel Bahia Oriental. Os eventos geológicos ocorridos no final do Paleoproterozoico são caracterizados por magmatismo máfico-ultramáfico, alcalino e carbonatítico, cujos representantes apresentam importantes concentrações de bens minerais de interesse econômico, com várias jazidas detectadas e minas implantadas. Relacionam-se a estes eventos as jazidas de cromita (Campo Formoso e Jacurici), esmeralda (Carnaíba e Campo Formoso), cobre (Curaçá) e uma das maiores reservas mundiais de ferro-titânio-vanádio (em Campo Alegre de Lourdes), todas no Estado da Bahia. Formaram-se, ainda, complexos carbonatíticos ricos em fósforo (apatita) em Angico Dias (BA) e intrusões sieníticas encaixadas no Cinturão Móvel Bahia Oriental (Cara Suja, Ceraíma, Guanambi, Anuri, São Félix e Santanópolis).

Em meio às depressões, emergem imponentes conjuntos de relevo, formando planaltos contínuos e residuais, como as Serras de Jacobina e do Orobó, o Espinhaço Setentrional e a Chapada Diamantina (Figura 41). As Serras de Jacobina e do Orobó formam uma cadeia de montanhas de direção norte-sul, com dimensões de 300 quilômetros por 10 quilômetros. De acordo com Delgado e outros (2003), este conjunto montanhoso constitui-se de remanescentes de bacias do Orógeno Jacobina. Trata-se, segundo os autores, de uma rica província mineral polimetálica, com depósitos econômicos de ouro, cromo, esmeralda, manganês, bário e quartzo industrial, objeto de sistemáticas investigações geológicas.

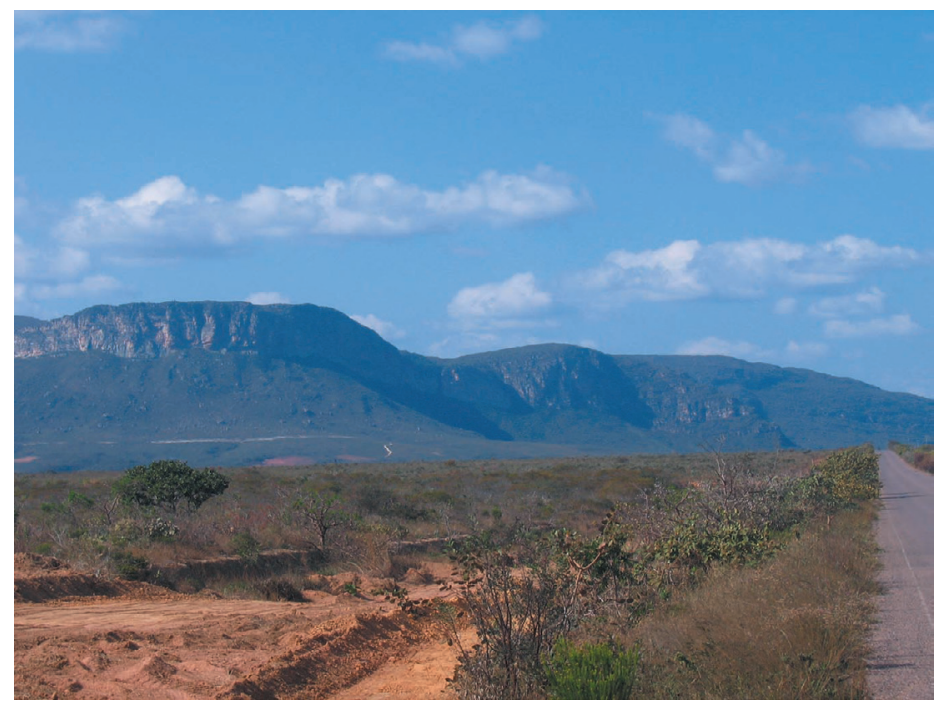

Figura 41 - Chapada Diamantina (BA). Foto: Marco Antonio de Carvalho Oliveira. 
A Serra do Espinhaço e a Chapada Diamantina, sob vários aspectos (cultural, econômico, paisagístico, turístico e ecológico), são elementos de grande destaque na fisiografia do Cráton São Francisco. Como feições geológicas, resultam de eventos em escala global ocorridos no final do Paleoproterozoico, caracterizados pela formação de sistemas de falhas intracontinentais, palco de magmatismo plutônico e vulcânico, cujo representante mais imponente no Bioma Caatinga é o sistema de grandes falhas (rifts) do Espinhaço, formador das Serras do Espinhaço Setentrional e de parte da Chapada Diamantina, na Bahia.

As rochas componentes da Chapada Diamantina também incluem os Grupos Rio dos Remédios (rochas sedimentares e vulcânicas) e Paraguaçu (conglomerados). A região das Cidades de Lençóis, Andaraí, Mucugê e Xique-Xique, na Chapada Diamantina, foi grande produtora de diamantes, que, desde o Século XIX, foram garimpados nos conglomerados das formações Tombador, principalmente, e Morro do Chapéu, bem como nos aluviões das Bacias dos Rios Paraguaçu, Santo Antônio e São José. Muitas dessas cidades devem sua origem à atividade garimpeira.

Bordejando o Chapadão Ocidental Baiano (as Chapadas do Rio São Francisco), o piso da depressão eleva-se para os patamares dissecados, em altimetrias de até 600 metros, sobre litologias do Grupo Bambuí, onde a presença de relevos cársticos impõe ao Bioma Caatinga características peculiares: as feições ruiniformes, com torres, paredões rochosos e lapas, que podem se apresentar recobertas de facheiros e bromélias, transicionando para uma densa mata seca nos recessos mais úmidos. Nada se compara à sinistra aparência dos escuros e fraturados maciços calcários, recobertos de cactos, das Serras do luiú e do Ramalho. Nas áreas calcárias, é comum a presença das barrigudas, árvores de grande porte e aparência peculiar (tronco alargado na parte central), da família das bombacáceas, que perdem as folhas na estação seca.

As rochas do Grupo Bambuí, e seus cronocorrelatos Bebedouro, Salitre, Jequitaí, bem como as Formações Palmares e Salobro, constituem o substrato das Baixadas de Irecê e dos Rios Jacaré e Salitre e formam patamares (Utinga e Ituaçu) nas bordas da Chapada Diamantina, em altimetrias que variam de 800 a mais de 1000 metros. Também aqui ocorrem dolinas e uvalas (feições típicas de áreas cársticas, relacionadas com a ocorrência de rochas carbonáticas), pontilhando as rampas elúvio-coluviais. Os rios principais adaptam-se a vales cársticos de bordas íngremes e de fundos chatos, demonstrando controle estrutural. A Caatinga desce dos tabuleiros vizinhos e adentra por essas depressões.

A vegetação da Chapada Diamantina é bastante complexa, variando desde Campo de Altitude (cotas mais altas) até Caatingas, nas partes mais baixas e secas, com a presença de Cerrados e Florestas Estacionais nas áreas mais úmidas. O clima mais ameno (devido à altitude), a beleza e a diversidade de paisagens, bem como o passado histórico, fazem da Chapada Diamantina um importante destino turístico da Bahia, especialmente o turismo de aventura e ecológico.

O Vale do Médio São Francisco já foi definido como um "vale de afundamento", denotando controle tectônico e abatimento em grande escala. Calcários, dolomitos, siltitos, folhelhos, argilitos e ardósias compõem o variado substrato litológico do Grupo Bambuí, que ali predomina. O relevo da depressão foi submetido a vários ciclos de arrasamento do relevo, 
resultando na superfície plana ou ondulada de hoje, nivelada em altimetrias que variam de 450 a mais de 500 metros. Os grandes interflúvios apresentam coberturas detrito-lateríticas cenozoicas, onde Latossolos e Argissolos espessos puderam se desenvolver. Flutuações do lençol freático e alternâncias climáticas agressivas permitiram a formação de bancadas de couraças ferruginosas (lateritas ou cangas), que preservam da erosão os desníveis do relevo na borda de chapadas e platôs. Nos setores topograficamente mais baixos, na confluência das rampas, ocorrem depressões fechadas do tipo dolinas, preenchidas por argilas de descalcificação. Sumidouros e ressurgências assinalam vales cársticos com rios de percursos subterrâneos. O clima semiárido, com duas estações bem-definidas, apresenta precipitações médias de 800 a 900 milímetros ao ano.

No Médio São Francisco, entre os Municípios de Petrolina e Paulo Afonso, as planícies fluviais apresentam alguma expressividade, constituindo a unidade de relevo denominada Planície do Rio São Francisco. Parte dessa área é usada para cultivos irrigados, especialmente no entorno de Petrolina e Juazeiro (Figura 42). A construção de barragens ao longo do Rio São Francisco para geração de energia (Figura 43) foi responsável pela inundação de grande parte dessas planícies, que eram utilizadas por pequenos agricultores, que foram obrigados a abandonar suas terras.

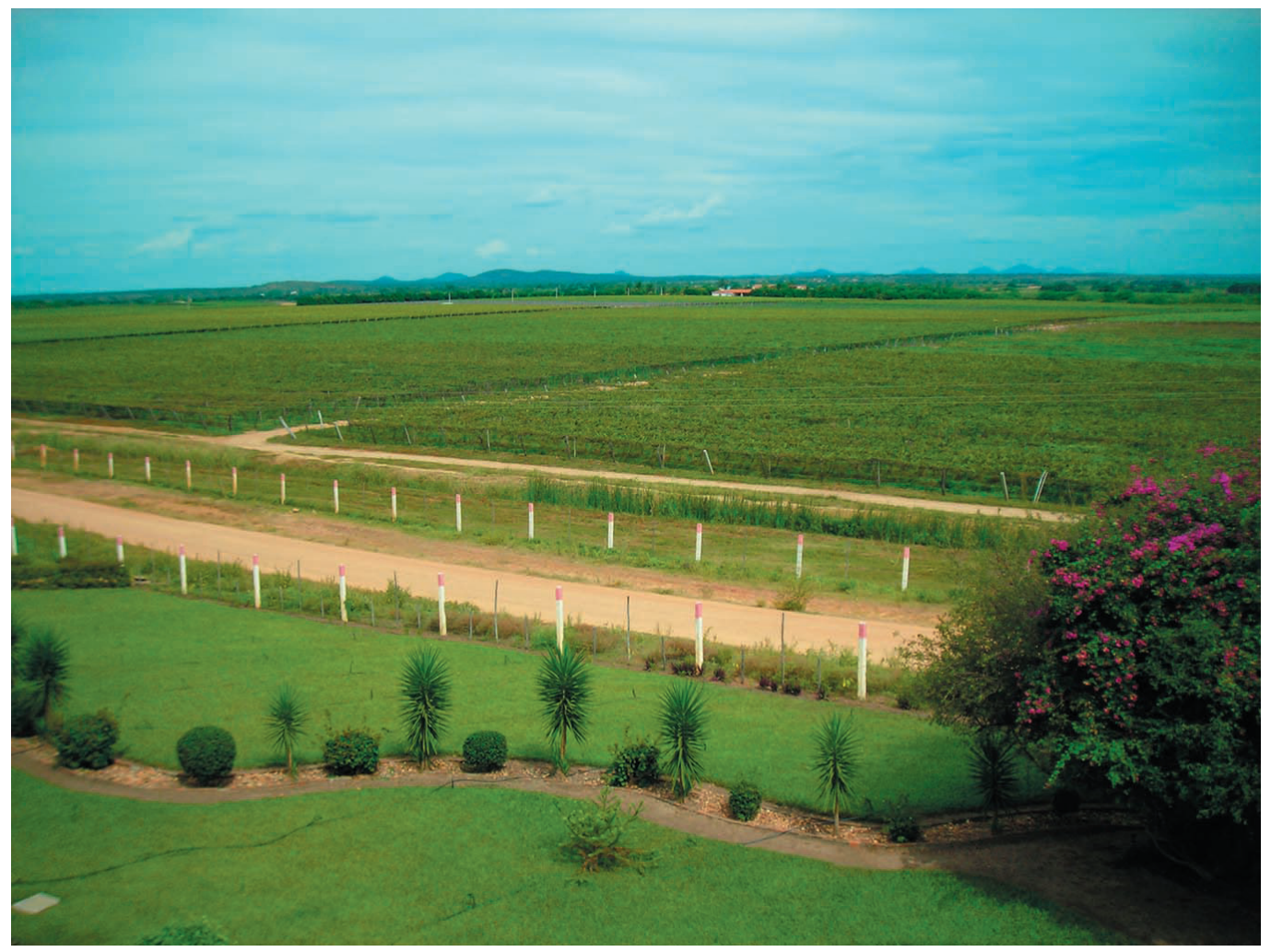

Figura 42 - Cultivo irrigado de uvas para produção de vinho no entorno do Município de Petrolina (PE). Foto: Rosangela Garrido Machado Botelho. 

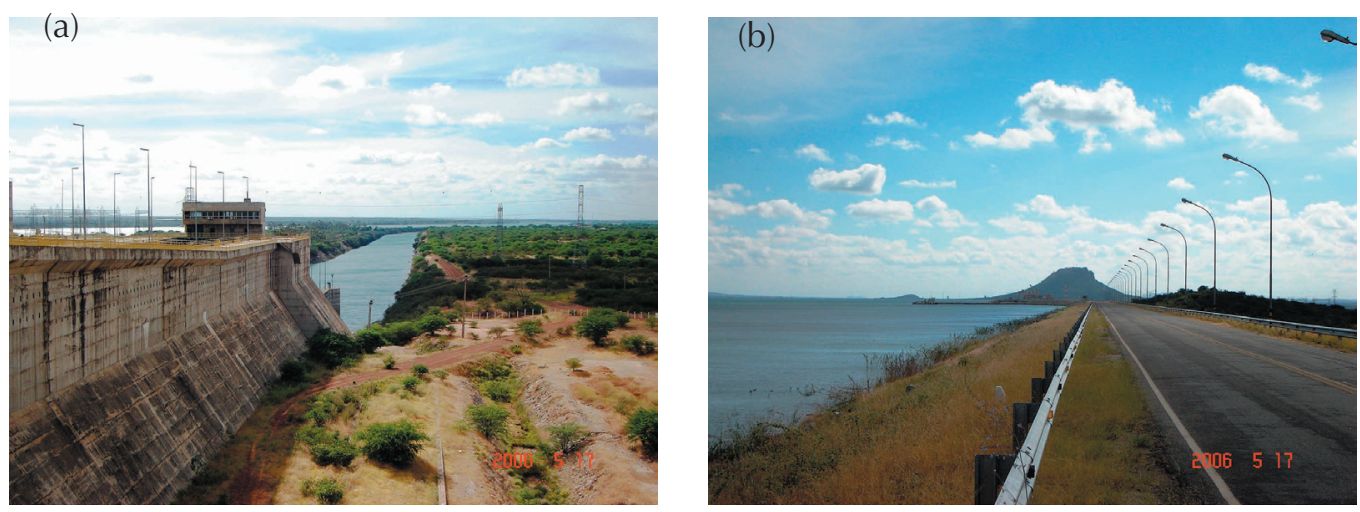

Figura 43 - Represa de Sobradinho na Bahia, próximo à divisa com Pernambuco (a) e reservatório de Sobradinho, um dos maiores lagos artificiais do mundo (b).

Fotos: Rosangela Garrido Machado Botelho.

Em Minas Gerais, a Caatinga acompanha a calha do Rio São Francisco e penetra pelo Vale do Rio Verde Grande. Mais a leste, entra em contato com o Bioma Cerrado nos "Gerais" dos chapadões periféricos.

Na região norte de Minas Gerais, cerca de 17,6 bilhões de metros cúbicos de água deixam de infiltrar-se naturalmente nos solos em decorrência da diminuição da cobertura vegetal (GEA, 1991 apud BRASIL, 1999; SIQUEIRA FILHO, 2012). Este fato provoca a redução na recarga do lençol freático - em muitos casos, ocasionando interrupção no deflúvio de algumas artérias fluviais - e compromete o abastecimento de água regionalmente. Em várias bacias hidrográficas do Bioma Caatinga, constatam-se reduções de deflúvio de vários cursos de água nos últimos anos. Rios outrora perenes tornaram-se intermitentes, e outros tantos dilataram seus períodos secos em função da diminuição na recarga do lençol freático, ocasionada, principalmente, pelos desmatamentos, sobretudo pela retirada das matas ciliares.

Ao longo do Vale do Rio São Francisco, especialmente no médio curso, foi implantada uma série de projetos de irrigação (Jaíba, no norte de Minas; Nilo Coelho e Bebedouro, em Petrolina; Salitre, em Juazeiro; Baixio do Irecê, em Xique-Xique; etc.), voltados principalmente para a produção de frutas, inclusive para exportação. Parte significativa da produção de frutas da maioria dos municípios da bacia está apoiada nos cultivos de banana, uva, manga, melancia, melão e maracujá. Destacam-se como os maiores produtores os Municípios de Petrolina (PE), Juazeiro (BA), Curaçá (BA), Santa Maria da Boa Vista (PE) e Bom Jesus da Lapa (BA), apresentando os dois primeiros uma produção total, em 2003, acima de 200000 toneladas, e os demais municípios, valores em torno de 60000 toneladas (VETORES..., 2009).

Esses projetos de irrigação geram "ilhas" de prosperidade econômica em meio à pobreza generalizada das regiões de Caatinga. Essa riqueza, no entanto, está ainda concentrada nas mãos de poucos. Um dos maiores impactos associados à irrigação é a salinização dos solos, que depende tanto do tipo de solo quanto da qualidade da água de irrigação e das técnicas utilizadas. Parte dos perímetros irrigados do Vale do Rio São Francisco e do Vale do Rio Açu (RN) é alvo deste processo. Também é comum o acúmulo de sais nas águas dos açudes, especialmente nas áreas mais ricas da Caatinga, tornando-as salobras. Estes processos alertam para a necessidade de um manejo cuidadoso e tecnicamente fundamentado dos recursos hídricos no Bioma Caatinga. 
Na Bacia do Rio Verde Grande, onde se localiza a Cidade de Montes Claros, a presença subjacente de litologias carbonáticas do Grupo Bambuí define as características principais do ambiente que se amplia para o norte no Vale do Rio São Francisco, no Estado da Bahia.

Ao longo dos cursos médio e baixo do Rio São Francisco, sempre sob condições climáticas semiáridas, a Caatinga envolve o lago da Barragem de Sobradinho. Na região da Cidade de Barra, campos de dunas e planos arenosos resultaram em uma paisagem única, os Campos de Dunas do Médio São Francisco, onde a Caatinga faz tríplice ecótono com o Cerrado e a vegetação Pioneira das áreas alagadas interdunares.

Dentre as 19 áreas indicadas pelo Ministério do Meio Ambiente como prioritárias para a conservação das espécies de répteis e anfíbios no Bioma Caatinga, duas delas, consideradas de extrema importância biológica, estão localizadas na região de dunas do Médio São Francisco, que concentram conjuntos únicos de espécies endêmicas (RODRIGUES, 2004). A herpetofauna (répteis e anfíbios) da Caatinga é composta por 156 espécies: 44 de lagartos; nove de anfisbenídeos; 47 de serpentes; quatro de quelônios; três de crocodilianos; e 49 de anfíbios, todas presentes nas áreas mais típicas da Caatinga Semiárida. Desse total, aproximadamente 15,0\% são espécies endêmicas, e uma única, o jacaré-de-papo-amarelo, figura na lista oficial de espécies ameaçadas de extinção (RODRIGUES, 2004)

Na grande Província Sedimentar do Meio-Norte ou Parnaíba, o Bioma Caatinga reveste tanto o domínio da Bacia Paleozoica do Parnaíba quanto da Bacia Mesozoica do Grajaú. Na Bacia Paleozoica, a Caatinga transpõe as bordas dos Patamares do Rio Parnaíba e atinge as chapadas do sul e do leste do Piauí, formando ecótonos com o Cerrado ao longo das Chapadas do Alto Parnaíba, em altimetrias de até 750 metros, instalando-se nos "vãos" nelas embutidos (300 a 450 metros). Para norte, ainda sobre a Bacia Paleozoica (Grupos Serra Grande e Canindé), recobre as cuestas e o reverso dos Planaltos da Ibiapaba, estendendo-se para norte e leste por sobre os Patamares do Rio Parnaíba, que ali são modelados sobre rochas do preenchimento da Bacia do Grajaú, representado pelas Formações Grajaú, Codó e Itapecuru.

Em boa parte desta província, composta por rochas inconsolidadas, porosas e permeáveis, com maiores espaços para acumular reservas hídricas subterrâneas, são encontrados rios perenes. As características do substrato asseguram a manutenção das descargas dos cursos de água nos meses de estiagem, como é o caso do Rio Parnaíba e de alguns de seus afluentes que drenam a Bacia Sedimentar Piauí-Maranhão (Figura 44). Esta é a parte do Bioma Caatinga com as maiores reservas subterrâneas de água.

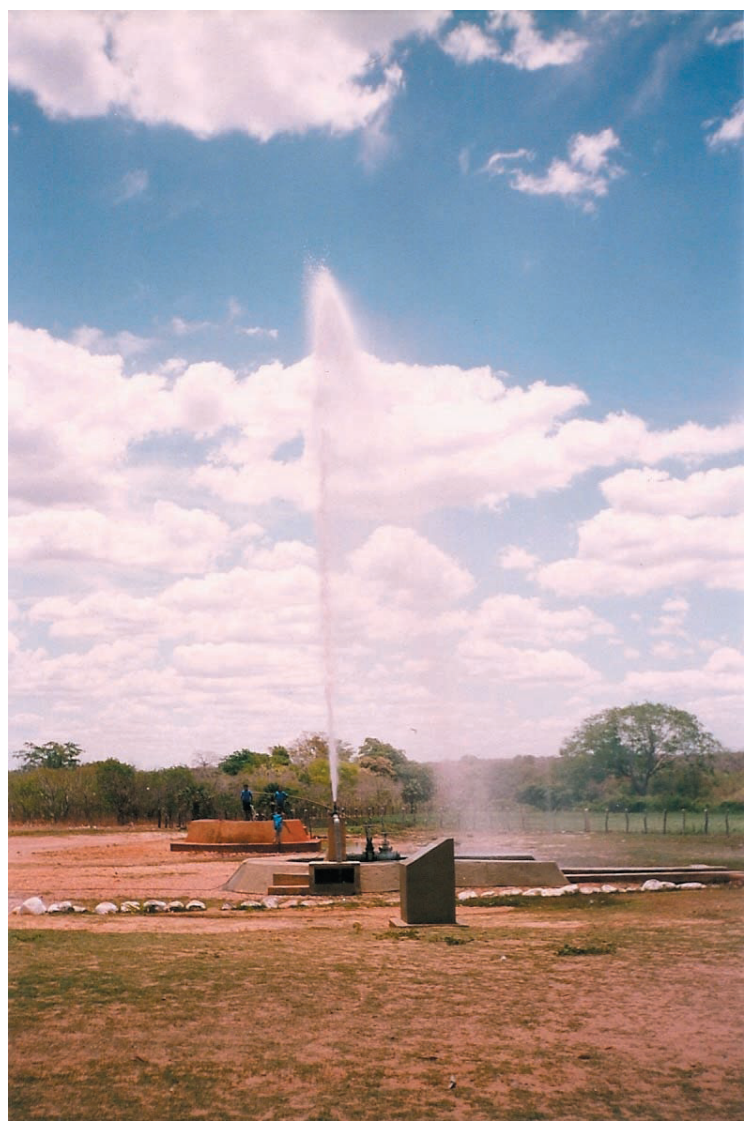

Figura 44 - Poço de extração de água subterrânea, que jorra até 60 metros de altura, nos limites entre os Municípios de Cristino Castro e Alvorada do Gurgueia (PI).

Foto: Rosangela Garrido Machado Botelho. 
Além de englobar estas três grandes províncias morfoestruturais, o Bioma Caatinga desce pelos cânions do Baixo Rio São Francisco (Figura 45), aproximando-se do litoral, chegando às praias no litoral setentrional nordestino (Piauí, Ceará e Rio Grande do Norte). Ecótonos com o Cerrado, com a Mata dos Cocais e com a vegetação Pioneira litorânea são estabelecidos no norte do Piauí e do Maranhão, onde a Caatinga, com características mistas mais brandas, pode ser identificada recobrindo e estabilizando setores de antigas dunas.

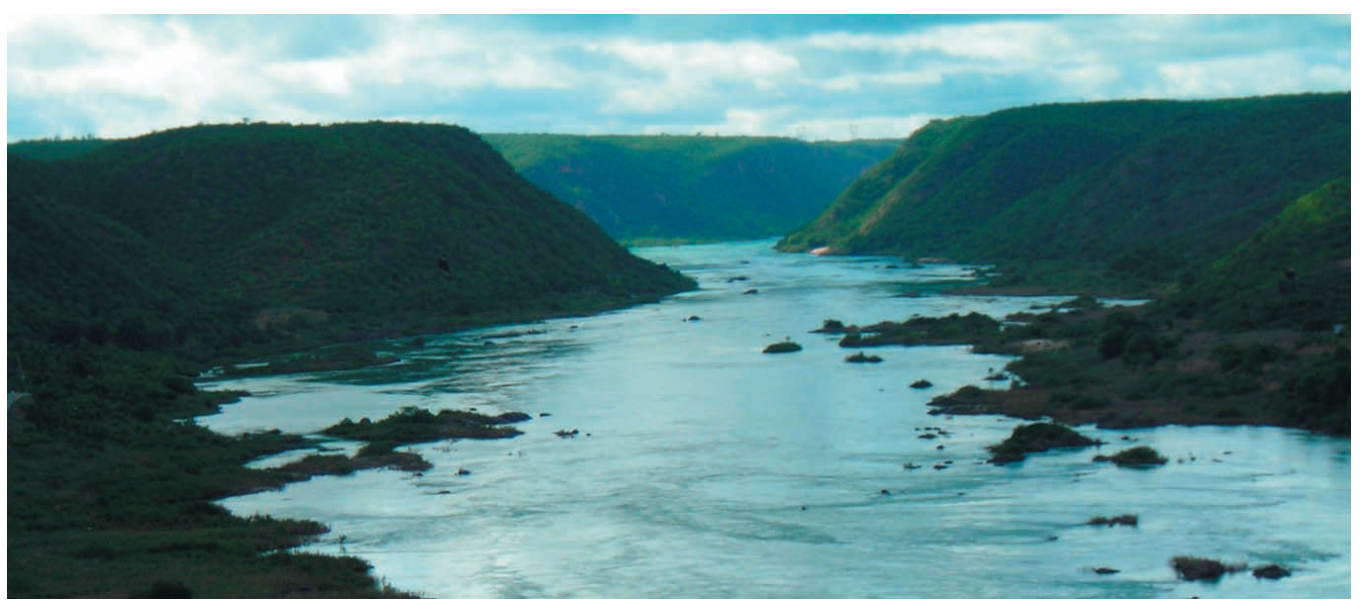

Figura 45 - Cânion do Baixo Rio São Francisco, Município de Piranhas (AL), parcialmente afogado pela Represa de Xingó. Foto: Rosangela Garrido Machado Botelho.

As planícies fluviomarinhas apresentam extensões significativas no trecho litorâneo entre a foz do Rio Parnaíba e a foz do Rio Acaraú, no Ceará. Daí para o litoral do Rio Grande do Norte, reduz-se a uma estreita planície de maré limitada por falésias ativas modeladas nos Tabuleiros Costeiros que, entre Fortaleza e Natal, são recobertos por campos de dunas eólicas, características deste trecho do litoral brasileiro e que mostram grande expressão entre Mossoró e Natal, no trecho conhecido como Saliente Oriental Nordestino.

Contudo, seja qual for a província morfoestrutural ou Caatinga da qual se fale, encontra-se sempre um estigma a ela associado: a seca. Além de constituir um fenômeno climático, natural e recorrente, a seca é também um fenômeno sociológico, quase um mito na Caatinga, usada para justificar todas as mazelas regionais, inclusive a pobreza crônica. A seca ainda é vista por boa parte da sociedade brasileira como uma excepcionalidade, quase um castigo divino.

A seca atua principalmente sobre o setor mais fraco da economia do semiárido, a agricultura de subsistência, da qual dependem quase $2 / 3$ da população. A desarmonia entre o ciclo vegetativo de algumas culturas tradicionais da região - como o milho, o feijão e a mandioca - e o irregular regime de chuvas desencadeiam, em certos períodos, a denominada "seca verde". A perda de lavouras inteiras esconde-se sob o falso pano de fundo da verdejante Caatinga - mais adaptada às condições climáticas. As chuvas que, de início, incentivaram o plantio, "falharam" no momento mais precioso - o da floração. Por outro lado, a baixa rentabilidade dos empreendimentos rurais - extremamente dependentes da ocorrência de 
chuvas - e o despreparo estrutural da agricultura - praticada ainda em condições rudimentares - agravam ainda mais o problema. As condições naturais desfavoráveis sedimentam a dependência do homem nordestino ao paternalismo das ações governamentais, que sempre atuam no sentido de, a cada seca, percorrer o mesmo caminho de mistificação, e poucas têm sido as medidas eficazes e definitivas tomadas para amenizar o flagelo das estiagens. Neste sentido, medidas simples para retenção de água, como cisternas e barragens subterrâneas, devem ser incentivadas.

A precariedade de recursos hídricos na Caatinga gerou o mito de que a solução estaria na ampliação da capacidade de armazenar água em superfície. Com esse objetivo, foram edificadas - desde a época do Império - obras de captação e represamento, muitas delas com resultados pouco satisfatórios, cujas causas vão desde a insuficiência e descontinuidade dos recursos financeiros até problemas de ordem econômico-cultural. O polêmico projeto de transposição das águas do Rio São Francisco para outros rios e açudes da Região Nordeste é mais uma tentativa, que visa a aumentar a disponibilidade dos recursos hídricos superficiais na região. Quanto às águas subterrâneas, observa-se que têm sido, em grande parte, exploradas onde são mais escassos os recursos superficiais - cerca de 70,0\% dos poços tubulares perfurados na região estão localizados no domínio dos terrenos cristalinos.

Desde que se começou a planejar o desenvolvimento do Brasil, a "meta" para a região de Caatingas sempre foi "lutar contra a seca", vencê-la. Este é um objetivo falacioso, inalcançável e equivocado. Como já proposto por Vasconcelos Sobrinho ${ }^{17}$, eminente estudioso pernambucano, o real objetivo deve ser conviver com a seca, procurando manejar os recursos hídricos da melhor forma possível, buscando tirar proveito das oportunidades que o ambiente semiárido oferece.

Elevar a qualidade de vida da população sertaneja não é tarefa fácil, óbvia ou imediata. Ela se inicia, entretanto, com a derrubada dos mitos que cercam o bioma: a Caatinga é pobre em recursos naturais (biodiversidade, bens minerais, recursos hídricos, solos etc.), e a seca é o grande vilão, responsável por todos os flagelos. A aceitação da seca como condição comum e natural do semiárido abre caminho para a criação de tecnologias e oportunidades de desenvolvimento voltadas às especificidades das caatingas. Este talvez seja o grande desafio do Século XXI para o Bioma Caatinga.

\footnotetext{
17 Professor, engenheiro agrônomo e ecólogo conservacionista, João Vasconcelos Sobrinho (1908-1989) introduziu as disciplinas Ecologia Conservacionista (primeira do gênero no Brasil) e Desertologia, na Universidade Federal Rural de Pernambuco (GARCIA, 2013) e na década de 1940 já alertava em seus vários trabalhos e palestras sobre a necessidade de ações de convivência com a seca.
} 


\section{Pantanal: no ritmo das cheias}

\section{Mapa 4 - Bioma Pantanal - Sistemas Pedoclimáticos}

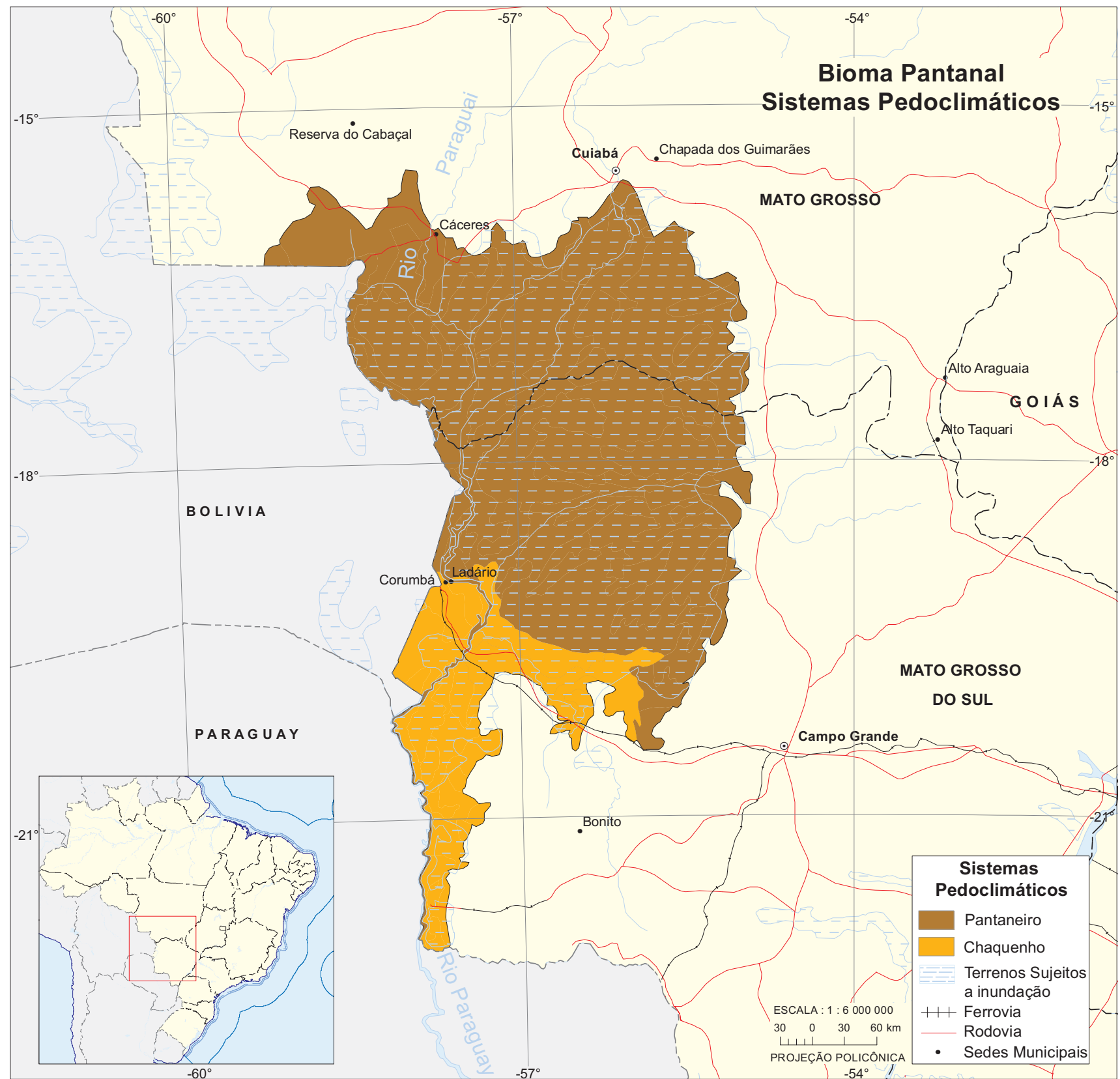

Fonte: IBGE, Diretoria de Geociências, Coordenação de Recursos Naturais e Estudos Ambientais. 
O Bioma Pantanal está localizado na Bacia do Alto Rio Paraguai e encontra-se praticamente restrito ao território brasileiro. Abrange parte dos Estados de Mato Grosso e Mato Grosso do Sul, prolonga-se pelas planícies pampianas centrais, e, a oeste, adentra o Paraguai e a Bolívia por uma pequena faixa. Compreende uma região dominantemente plana e deprimida (41,0\% da área daquela bacia), circundada por escarpas da borda da Bacia Sedimentar do Paraná e da Serra da Bodoquena, a leste (Figura 46), e pela Chapada dos Parecis e a Serra de Cuiabá, ao norte. Ao sul, o Bioma Pantanal é limitado pelo Rio Apa. Com relevo marcado por fortes contrastes e aspecto de anfiteatro, constitui a maior planície alagada contínua do planeta, cujas dinâmicas ecológica e socioeconômica estão fortemente associadas às influências diretas e indiretas advindas das regiões de planalto adjacentes, bem como ao regime hidrológico da Bacia do Alto Rio Paraguai.

As inundações que anualmente ocorrem nessa planície, por atingirem grande extensão (11 000 a 110000 quilômetros quadrados; área média inundável de 50000 quilômetros quadrados), por serem de longa duração (29 a 180 dias, dependendo da região) e por imprimirem modificações de vulto no meio físico, na vida silvestre e no cotidiano das populações locais, são consideradas um dos fenômenos naturais mais extraordinários da Terra e fator determinante da existência de um macroecossistema classificável como bioma. Neste sentido, difere dos demais biomas brasileiros, pois se trata do único que não foi definido com base na formação vegetal dominante, mas sim, e, principalmente, por seu sistema hidrológico peculiar.

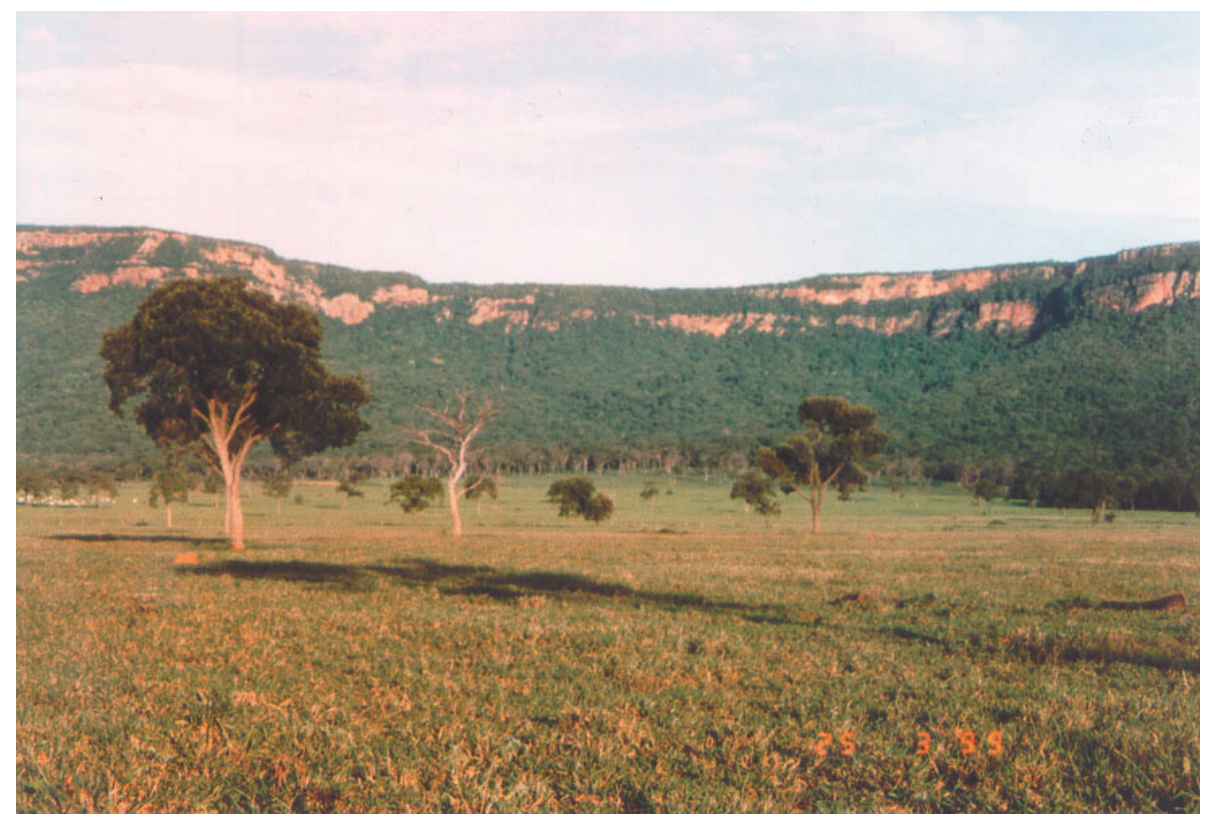

Figura 46 - Escarpas da Serra de Maracaju, trecho da borda oriental do Bioma Pantanal. Foto: Rosangela Garrido Machado Botelho.

A Planície do Pantanal está posicionada em altitudes que variam entre 80 e 150 metros com declividade quase nula, de 0,03 a 0,15 metro por quilômetro quadrado, no sentido norte-sul, e de 0,5 a 0,3 metro por quilômetro quadrado, no sentido leste-oeste (ALVARENGA et al., 1980). O Bioma Pantanal, no entanto, apresenta trechos com declividades maiores, 
como aqueles próximos às escarpas das serras circundantes, onde há registro de 23,7 metros por quilômetro quadrado, no sopé da Serra de Maracaju (BOTELHO, 2003). Possui apenas um vertedouro - a calha do Rio Paraguai - que, em seu prolongamento até a confluência com o Rio Paraná, drena com dificuldade pela garganta estreita e rasa do "Fecho dos Morros" da Serra do Amolar, que funciona quase como uma barragem natural. Essas características físicas fazem com que a cada ano, após alguns meses de chuvas, a Planície do Pantanal se transforme numa imensa área alagada, com grande parte dos ambientes terrestres passando para ambientes aquáticos, sujeitos a diferentes graus e períodos de inundação, lembrados nas lendas indígenas e nos primeiros mapas do Marechal Rondon como "Lagoa dos Xaraiés".

Toda a vida e a economia do Pantanal estão ligadas a esse regime de inundações periódicas. Nessas ocasiões, as águas dos Rios Paraguai, Cuiabá, São Lourenço, Taquari, Miranda e seus inúmeros afluentes saem de seus leitos e inundam enormes áreas. Somente os locais mais elevados escapam à inundação. A diferença de nível das águas entre as estações de seca e de cheias é em média de apenas 4 metros, mas, devido à pouca declividade, a maior parte do Pantanal fica alagada. O nível do Rio Paraguai, no Município de Ladário (MS), constitui o principal referencial do regime hidrológico da Bacia do Alto Paraguai. Quando o nível máximo do rio neste ponto supera o nível de alerta de enchente (4 metros), o ano é considerado como ano de cheia no Pantanal. Quando o nível máximo fica abaixo deste valor, o ano é considerado como ano de seca. Nos anos de pequenas cheias, o nível varia entre 4 e 5 metros. Quando o nível do rio atinge de 5 a 6 metros, a cheia é considerada normal. Nos anos de grandes cheias, as águas ultrapassam o nível de 6 metros, como aconteceu em 1988 (6,64 metros - maior marca histórica) e 1995 (6,56 metros - terceira marca do século), e o Rio Paraguai, no Pantanal, expande seu leito por cerca de 20 quilômetros de largura. A profundidade da submersão de terras no Pantanal varia em média de 0,5 a 1,5 metro. A duração da submersão é bastante variável e, em algumas áreas, pode alcançar até seis meses (AGÊNCIA NACIONAL DE ÁGUAS, 2004).

Dentro do ciclo de cheia e seca dos rios, no recuar das águas (período de vazante), a vegetação aquática morre, dando lugar à vegetação terrestre. Durante a enchente, parte da vegetação terrestre morre e se decompõe, e os produtos da decomposição são levados para os lagos (baías), córregos (corixos) e rios. Este fenômeno natural é chamado de "dequada" e é caracterizado pela alteração das características da água, como cor, odor, oxigênio dissolvido, gás carbônico dissolvido, $\mathrm{pH}$, condutividade elétrica, nutrientes dissolvidos (nitrogênio, fósforo, carbono), demanda bioquímica de oxigênio, dentre outras. Este fenômeno ocorre na subida das águas, normalmente de fevereiro a abril, quando o nível do Rio Paraguai passa de 3,5 metros (medido na régua de Ladário - MS). O fenômeno da "dequada" ocorre em toda a área de inundação dos Rios do Pantanal Sul, principalmente na área de inundação do Rio Paraguai.

O nível do Rio Paraguai, em Ladário (MS), constitui o principal referencial do regime hidrológico da Bacia do Alto Paraguai. Quando o nível máximo do rio neste ponto supera o nível de alerta de enchente (4 metros), o ano é considerado como ano de cheia no Pantanal. Quando o nível máximo fica abaixo deste valor, o ano é considerado como ano de seca. A alternância de ciclos de cheia e de seca, tanto anuais quanto plurianuais, ou seja, o regime hidrológico do Pantanal, constitui importante fator interveniente na socioeconomia e na biodiversidade da região. 
Em relação aos demais biomas brasileiros, o Pantanal é o único totalmente inserido num só domínio morfoestrutural, a Bacia Cenozoica do Pantanal. A origem desta bacia também é bastante peculiar, posto que não faz parte do conjunto de bacias pericratônicas subandinas (Beni, Chaco, Oriente, entre outras), conforme considerado por muitos autores, a despeito de se enquadrar num mesmo contexto tectônico. As bacias subandinas têm por origem um rebaixamento (ou subsidência) periférico à cadeia de montanhas devido à sobrecarga exercida pela mesma sobre a litosfera, fenômeno a que se dá o nome de isostasia flexural da litosfera (WALCOTT, 1970). Neste processo, a porção imediatamente adjacente à cadeia de montanhas é rebaixada, desenvolvendo bacias que, no caso, são limitadas a oeste pelos Andes orientais e a leste por um soerguimento litosférico desenvolvido nas bordas da depressão, como consequência do rebaixamento, e que migra para leste na medida do aumento da sobrecarga decorrente da própria evolução do cinturão andino. A peculiaridade da Bacia Cenozoica do Pantanal reside no fato de seu posicionamento ser coincidente com a área soerguida, também chamada de intumescência, da borda oriental da Bacia do Chaco, na Bolívia. Sua formação deve ter se iniciado quando a intumescência, em sua migração para leste, atingiu uma zona de maior fraqueza geológica correspondente ao Domínio das Estruturas Dobradas do Brasil Central, ou, mais precisamente, à Faixa de Dobramentos Paraguai. $\mathrm{O}$ fenômeno propiciou a reativação dessa zona de fraqueza e a consequente formação da bacia do Pantanal (USSAMI; SHIRAIWA; DOMINGUEZ, 1999) por abatimento de blocos por falhas de gravidade com planos de deslizamento voltados para leste.

A multiplicidade de planos de movimentação, em geral paralelos e orientados submeridianamente, explica as irregularidades do substrato da bacia e a variável espessura de seu preenchimento sedimentar que, conforme demonstrado em perfurações da Petrobras, atingem o assoalho rochoso desde 36 metros de profundidade, nas proximidades de Porto Murtinho, até algumas centenas de metros, como na fazenda São Bento $\left(18^{\circ} 10^{\prime} \mathrm{S}\right.$ e $\left.56^{\circ} 18^{\prime} \mathrm{W}\right)$, onde a perfuração atingiu 420 metros, e o embasamento não foi encontrado (FRANCO; PINHEIRO, 1982). O material sedimentar constitui-se, basicamente, de areias com fragmentos de calcários e arenitos ferruginosos e de conglomerados, quando próximos da borda da cuesta formada na Bacia Sedimentar do Paraná. A julgar pela idade deste preenchimento, a reativação das falhas começou na passagem do período Plioceno para o Pleistoceno, intervalo que marca o início da evolução da bacia e que se estende até os dias atuais.

A superfície do Pantanal, apesar da pouca amplitude altimétrica, apresenta irregularidades, expressas por segmentos recortados e separados das depressões por interflúvios rebaixados. Em meio à superfície plana, sedimentar, emergem os relevos residuais do conjunto Urucum, marcando a posição de blocos soerguidos das falhas de gravidade que controlam a evolução tectônica da bacia, que, por estarem ativas, desempenham um importante papel na sua dinâmica interna.

Os aportes aluviais provenientes dos planaltos sedimentares transpõem as percées ${ }^{18}$ abertas nos fronts das cuestas das bordas ocidentais e se espraiam a jusante, formando, na área pantaneira, um sistema de canais divergentes e feições peculiares, como: leques, baías, cordilheiras, capões, vazantes e corixos, como são regionalmente conhecidos (Figura 47). As baías configuram áreas deprimidas, geralmente circulares, com água salobra ou não, alcançando

\footnotetext{
18 Abertura feita por um curso d'água ao transpor uma frente de cuesta.
} 
centenas de metros de diâmetro (Figura 48). As cordilheiras (Figura 49) e os capões constituem elevações com 1 a 5 metros acima do relevo adjacente, entre as baías, ocupadas por florestas ou por vegetação de Savana (Cerrado), em forma de cordões ou ilhas, respectivamente. As vazantes referem-se às superfícies rebaixadas, entre as cordilheiras, com quilômetros de extensão, que servem de escoadouro das águas das baías e rios. E os corixos são cursos de água de fluxo estacional, com calha definida, geralmente com Floresta-de-Galeria e conectando baías.

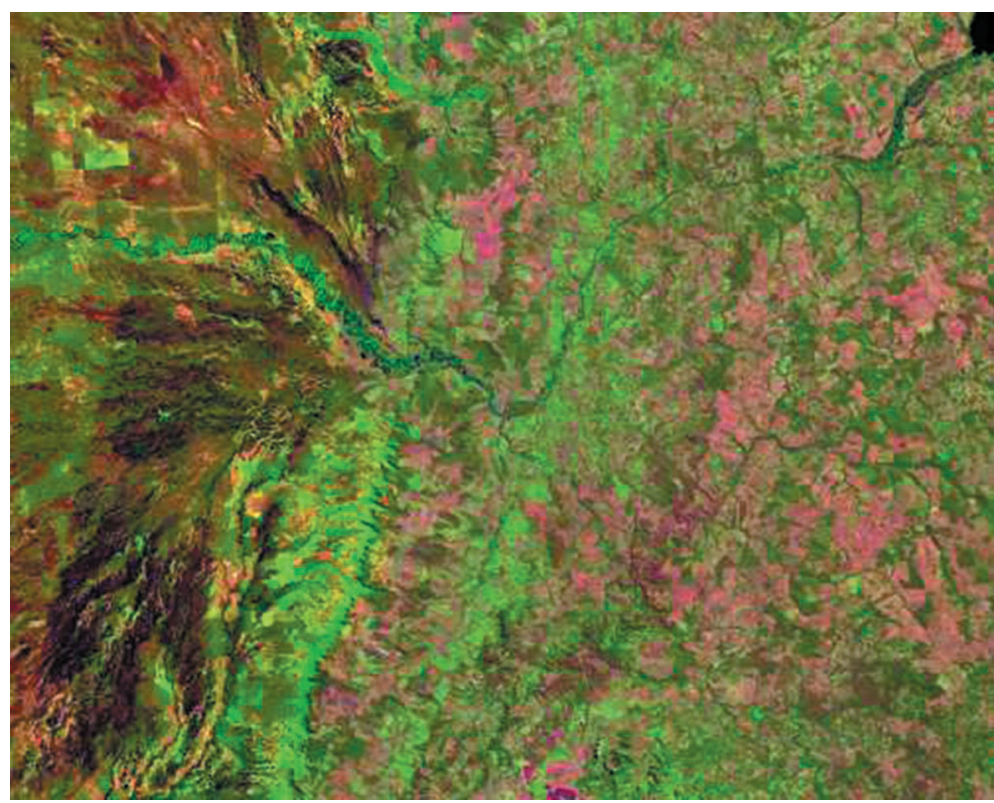

Figura 47 - Leque aluvial do Rio Taquari e percée aberta no front de cuesta da borda ocidental do Planalto de Maracaju (MS). Miranda e Coutinho (2004)

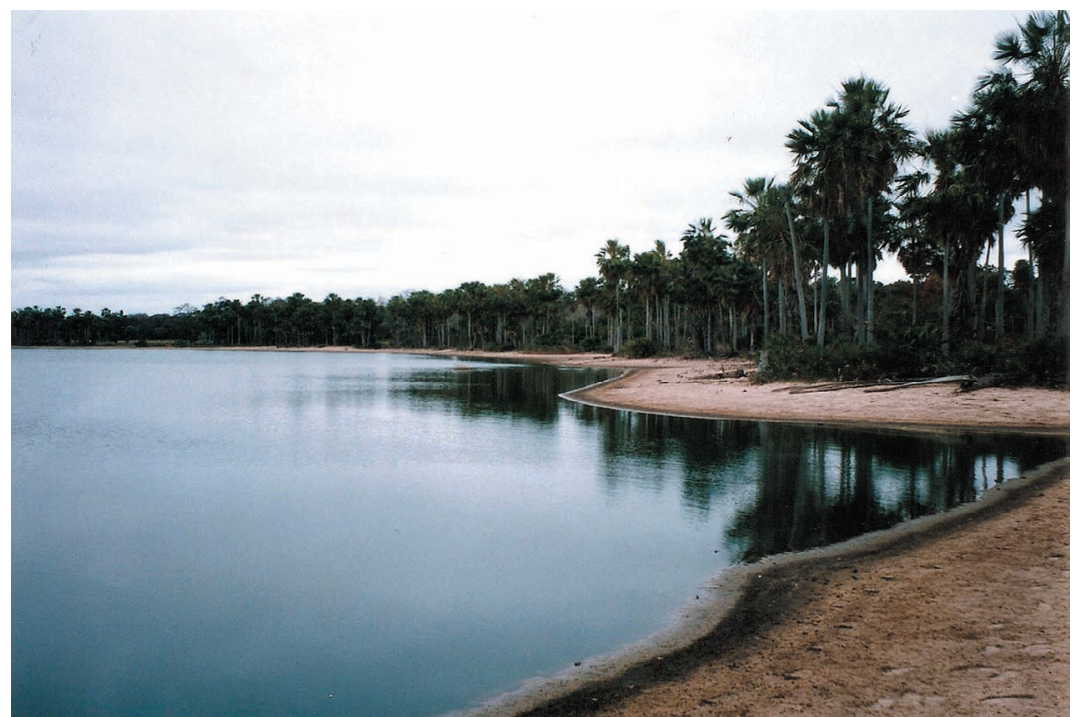

Figura 48 - Margem de lagoa salina permanente, de formato semicircular e totalmente fechada. Nota-se a típica faixa de areia e os carandás no seu entorno. Porção sudoeste do leque do Rio Taquari. Foto: Rosangela Garrido Machado Botelho. 


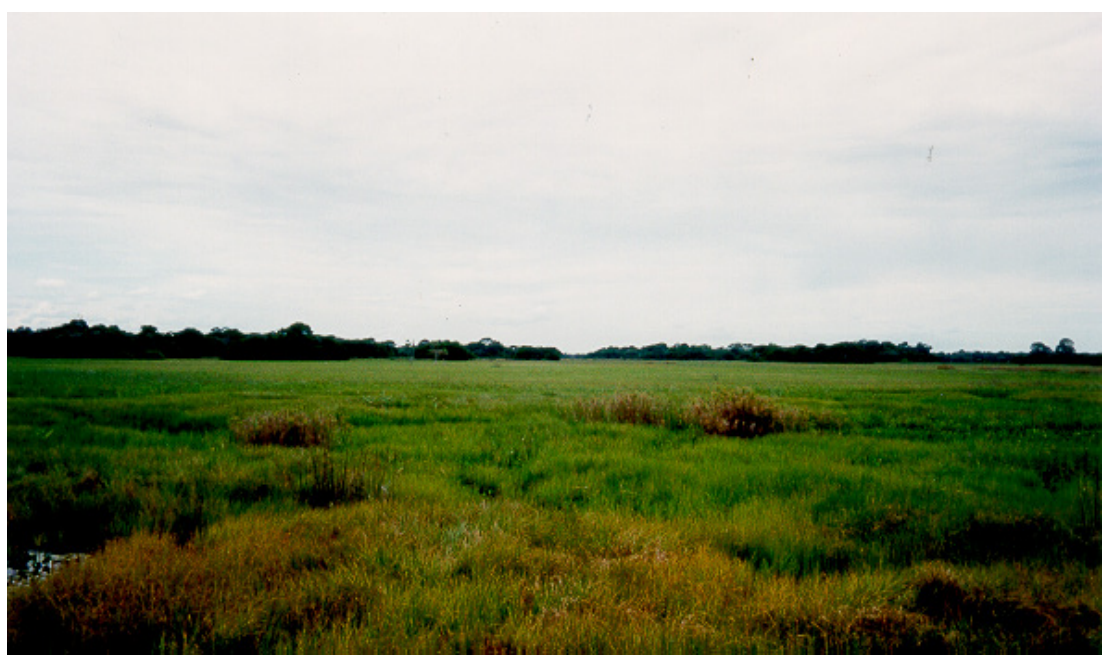

Figura 49 - Ao fundo, vê-se a vegetação de floresta recobrindo as cordilheiras e, em primeiro plano, a vegetação rasteira das áreas alagadiças, Pantanal do Abobral (MS).

Foto: Rosangela Garrido Machado Botelho.

Durante o período de inundação, as particularidades do relevo são ressaltadas, fazendo com que a Planície do Pantanal não se apresente totalmente uniforme, mas como um verdadeiro mosaico de paisagens. Nesse período, as cordilheiras se destacam como feições não submersas que servem de refúgio da fauna terrestre e da própria vida socioeconômica das populações. Abrigam vegetação de mata e várias formas de vida associadas. Pacas, onças, tatus, aves e insetos, entre outros animais, encontram ali abrigo, alimento e local para sua reprodução e para construção de ninhos. Para as cordilheiras é conduzido o gado durante as cheias. Ali os fazendeiros erguem suas casas, currais, estábulos e todo tipo de instalação que queiram deixar a salvo das inundações. Essa relação do homem com o meio é facilmente percebida no Pantanal e é mais antiga do que se possa imaginar. Estudos arqueológicos têm demostrado que, em tempos pré-históricos (até 8000 anos atrás aproximadamente), as populações indígenas acampavam nas cordilheiras em busca dos recursos alimentares dos rios menores, das lagoas e dos campos alagados (SCHMITZ, 1997). O estudo minucioso dos sítios arqueológicos encontrados nestas feições tem revelado que os primeiros habitantes do Pantanal, que viviam da pesca, da coleta e da caça, se deslocavam conforme a estação e ocupavam as áreas de cordilheiras, principalmente durante as cheias.

Além da heterogeneidade dessas feições, a Planície do Pantanal apresenta uma heterogeneidade em escala regional, possibilitando a identificação de diversos "pantanais" no seu interior, relacionados com a frequência, a altura e a duração das inundações nos diferentes setores da sua área de abrangência. Assim, somente no Brasil, já foram identificados de oito a 12 diferentes "pantanais" (FOLHA..., 1982; ANÁLISE..., 1997; SILVA; ABDON, 1998), que levam nomes locais e têm sido agrupados segundo o percentual da área ocupada por formações vegetais de Savana (Cerrado). Esta constitui a fitofisionomia predominante do Bioma Pantanal, que abriga também formações vegetacionais da Savana Estépica (a sudoeste), além de pequenas áreas de Floresta Estacional Semidecidual e Decidual (a norte), que se interpenetram e se misturam com a vegetação da Savana e com comunidades de espécies Pioneiras de distribuição generalizada (Tabela 4). 
Tabela 4 - Áreas remanescentes e áreas antropizadas, no Bioma Pantanal, segundo os tipos de vegetação

\begin{tabular}{|c|c|c|c|c|c|c|}
\hline \multirow{3}{*}{ Tipos de vegetação } & \multicolumn{6}{|c|}{ Bioma Pantanal } \\
\hline & \multicolumn{2}{|c|}{ Total no Bioma } & \multicolumn{2}{|c|}{ Área remanescente } & \multicolumn{2}{|c|}{ Área antropizada } \\
\hline & $\begin{array}{c}\mathrm{Em} \\
\mathrm{km}^{2}\end{array}$ & $\begin{array}{c}\text { Percentual } \\
(\%)\end{array}$ & $\begin{array}{c}\mathrm{Em} \\
\mathrm{km}^{2}\end{array}$ & $\begin{array}{c}\text { Percentual } \\
(\%)\end{array}$ & $\begin{array}{c}\mathrm{Em} \\
\mathrm{km}^{2}\end{array}$ & $\begin{array}{c}\text { Percentual } \\
(\%)\end{array}$ \\
\hline Área total do bioma & 150355 & 100,0 & 134375 & 90,0 & 14111 & 9,0 \\
\hline Floresta Estacional Semidecidual & 404 & $<0,5$ & 404 & 100,0 & - & - \\
\hline Floresta Estacional Decidual & 3127 & 2,0 & 1656 & 53,0 & 1471 & 47,0 \\
\hline Savana & 104038 & 69,0 & 93367 & 90,0 & 10670 & 10,0 \\
\hline Savana Estépica & 11805 & 8,0 & 9835 & 83,0 & 1970 & 17,0 \\
\hline Contatos entre tipos de vegetação & 29112 & 19,0 & 29112 & 100,0 & - & - \\
\hline Superfície com água & 1869 & 1,0 & - & - & - & - \\
\hline
\end{tabular}

Fonte: Mapa de biomas do Brasil: primeira aproximação. Rio de Janeiro: IBGE, 2004. 1 mapa. Escala 1:5 000 000. Disponível em: <ftp://geoftp.ibge.gov.br/informacoes_ambientais/vegetacao/mapas/brasil/biomas.pdf>. Acesso em: jul. 2016.

Notas: 1. Corresponde a 2,0\% da área total do País.

2. Data média de referência: 2000.

Dentre as feições geomorfológicas de leques, o do Rio Taquari é o mais representativo. O seu formato triangular indica grandes concentrações de descargas a partir do front, ligadas à torrencialidade das chuvas em um passado recente, cujo clima era mais seco e com chuvas fortes e concentradas (FRANCO; PINHEIRO, 1982). Nesta porção do Pantanal, os solos são arenosos, senão em todo o perfil, pelo menos em sua parte mais superficial. Ausência de pedogênese e uma podzolização incipiente, com migração quase que exclusivamente de ferro, resultam na formação de Neossolos Quartzarênicos e Espodossolos (Figura 50) em parte da área, enquanto, no restante, pequenas translocações de argila em áreas de sedimentações ligeiramente mais argilosas parecem ser responsáveis pela formação de Planossolos.

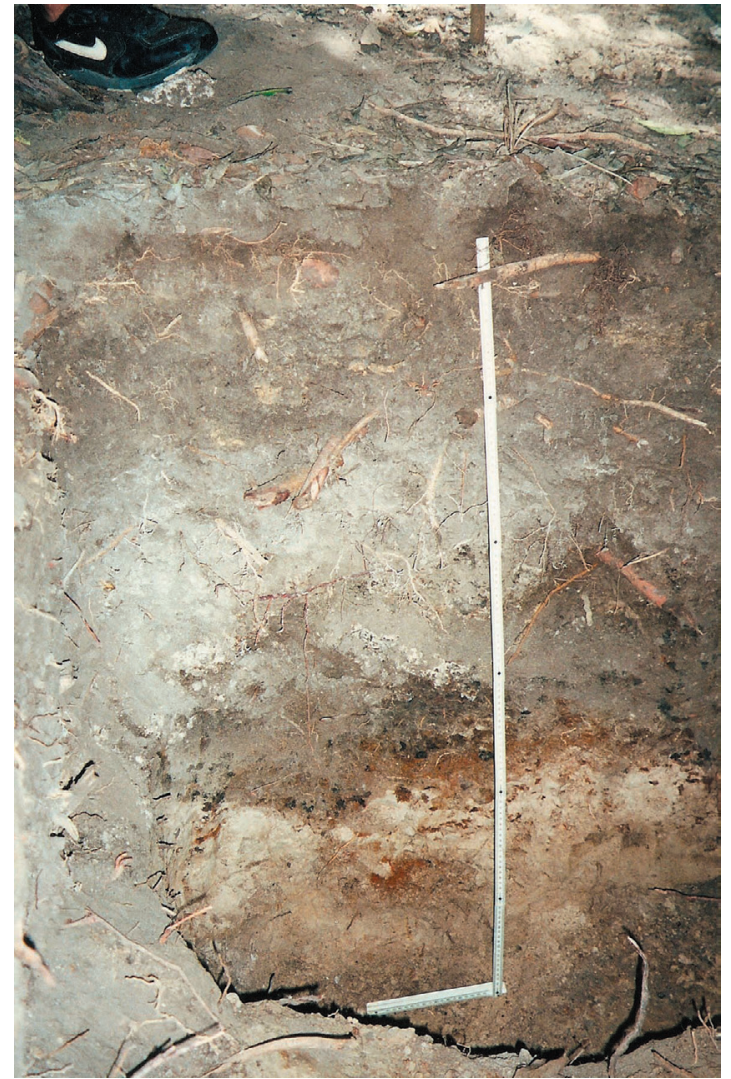

Figura 50 - Espodossolo em área de cordilheira. Nota-se a concentração de ferro em subsuperfície.

Foto: Rosangela Garrido Machado Botelho. 
Os solos "pantaneiros", de um modo geral, guardam estreita relação com a natureza dos sedimentos depositados, ou seja, a natureza do "material fonte" e dos processos ou formas de deposição/sedimentação. Climas mais úmidos foram responsáveis por sedimentações em condições de águas mais lentas, o que levou à deposição de sedimentos finos (pelíticos) e à formação de solos argilosos ou argilo-siltosos, enquanto períodos mais secos marcados por chuvas mais concentradas e, portanto, capazes de transportar sedimentos mais grosseiros, no caso desta planície, foram responsáveis pela formação de diversos leques aluviais, caracterizados pela deposição de sedimentos arenosos e pela formação de solos também arenosos, como no caso do Rio Taquari (FOLHA..., 1982).

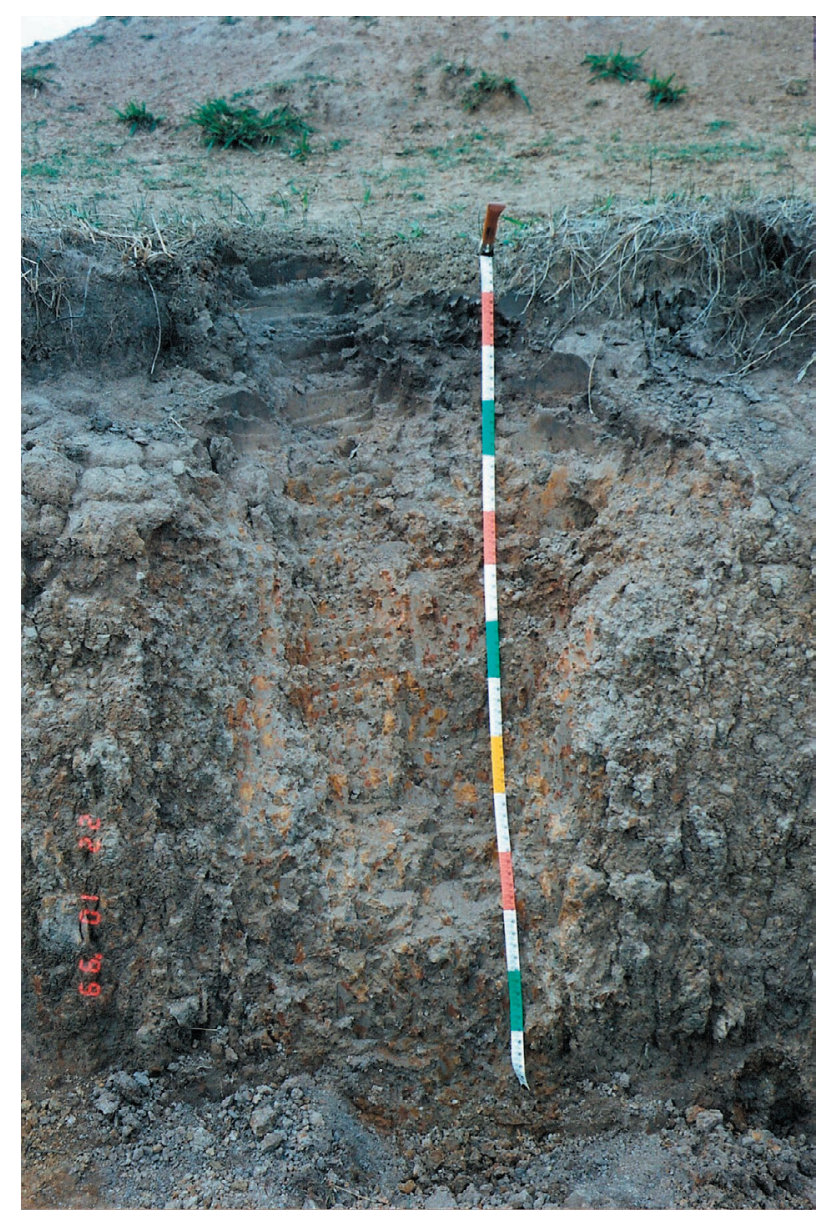

Figura 51 - Plintossolo Háplico Eutrófico.

Foto: Rosangela Garrido Machado Botelho.
A distribuição das diferentes classes de solos também pode ser compreendida à luz das pequenas variações de relevo, observadas na paisagem. Somente nas formas de relevo discretamente mais elevadas, representadas pelas cordilheiras, desenvolvem-se solos onde o hidromorfismo não é o processo determinante. Via de regra, são todos solos hidromórficos ou semi-hidromórficos, caracterizados morfologicamente por predomínio de cores acinzentadas e pela presença constante de mosqueados de redução, apresentando baixa potencialidade agrícola (COUTO, 2005). Com a persistência das condições anaeróbicas, impostas pelo longo período em que a maioria dos solos permanece sob uma espessa lâmina d'água, cria-se a condição para que o ferro na forma férrica (Fe+++), presente nos óxidos, seja reduzido para ferro na forma ferrosa (Fe++), que é bastante solúvel, o que possibilita sua translocação na fase aquosa. Como consequência, o solo torna-se acinzentado pela ausência de ferro férrico (de coloração avermelhada ou amarelada) e quase sempre surgem pontos de cores vivas (mosqueados) devido à concentração de ferro e à sua reoxidação (Figura 51).

A flutuação do lençol freático, associada à variação sazonal do regime de cheias e vazantes, propicia a alternância nas condições de redução e oxidação dos óxidos de ferro. Tal mecanismo é responsável pela formação, nos solos, de seções ou horizontes com ocorrência de plintita, que são características diagnósticas dos Plintossolos (ver Quadro 1) e de solos intermediários para estes, segundo o Sistema Brasileiro de Classificações de Solo (2013). O processo de plintização está presente não somente nos solos da planície, mas também nos solos do compartimento das rampas (BOTELHO, 2003). 
A distribuição da pluviosidade não é uniforme para o Pantanal, nem no tempo, nem no espaço. O clima da região apresenta caráter nitidamente estacional, devido às alternâncias de estações chuvosas e secas, com período úmido, em geral, de outubro a março, sendo janeiro, fevereiro e março os meses mais chuvosos. Além desta variabilidade anual, o Pantanal apresenta também uma variabilidade plurianual, com alternância de ciclos de anos mais chuvosos e outros relativamente secos. Espacialmente, há uma diminuição progressiva das chuvas das bordas dos planaltos circundantes em direção à calha principal do Paraguai, assim como das áreas mais elevadas (topo dos planaltos e escarpas) para as terras baixas da planície, apontando elevada correlação positiva entre altitude e intensidade das precipitações (TARIFA, 1986). A pluviosidade na área da planície pantaneira, em geral, não ultrapassa 1100 milímetros, sendo 200 a 300 milímetros mais elevada nos planaltos (ALFONSI; CAMARGO, 1986), onde o período úmido vai de outubro a março, com três a quatro meses secos, enquanto, na planície, pantaneira o período úmido é mais curto, de novembro a fevereiro, com cinco meses secos.

Há ainda uma nítida diferenciação nas precipitações entre o norte e o sul do Pantanal. O norte apresenta totais mais elevados, haja vista que a precipitação média de janeiro, mês com maior índice pluviométrico em todo o Pantanal, é de 250 milímetros a norte e 150 milímetros a sul. A porção sul do Pantanal, por suas características climáticas, especialmente a pluviosidade, encontra-se nos limites do clima semiárido. Esta área do Pantanal brasileiro pode ser considerada uma extensão do Chaco, região de clima semiárido que abrange territórios da Argentina, Paraguai e Bolívia.

As temperaturas no Pantanal também variam, estando a média anual entre $23^{\circ}$ e $25^{\circ}$ Celsius, sendo as mais baixas registradas nos planaltos circundantes (FOLHA..., 1982). As temperaturas sobem cerca de $4^{\circ}$ Celsius, das áreas elevadas das bordas ao centro do Pantanal, sendo a média de janeiro (mês de temperaturas mais altas) em torno de $28^{\circ}$ Celsius, nas porções centro e oeste, e de $24^{\circ}$ Celsius, nas áreas elevadas circundantes, e a média de julho (mês de temperaturas mais baixas), em torno de $23^{\circ} \mathrm{e} 19^{\circ} \mathrm{Celsius}$, respectivamente (ANTUNES, 1986).

Os condicionantes geomorfológicos constituem fatores determinantes na dinâmica atmosférica do Pantanal. A depressão, caracterizada por níveis altimétricos baixos, recebe intensa radiação solar, refletida nas altas temperaturas (que podem exceder $40^{\circ}$ Celsius), caracterizando-a como área ciclonal (centro de baixa pressão).

O Pantanal apresenta evapotranspiração real relativamente alta por ter lençol freático elevado em boa parte do ano. Como consequência, há grande perda de água por evaporação (superfícies de água livre) e transpiração, gerando um considerável déficit hídrico. A lixiviação é mínima, pela baixa drenabilidade de boa parte dos solos, e as perdas laterais de sais são relativamente reduzidas. Logo, os sais tendem a se acumular, particularmente nos solos argilosos da parte sul do Pantanal (Figura 52). 


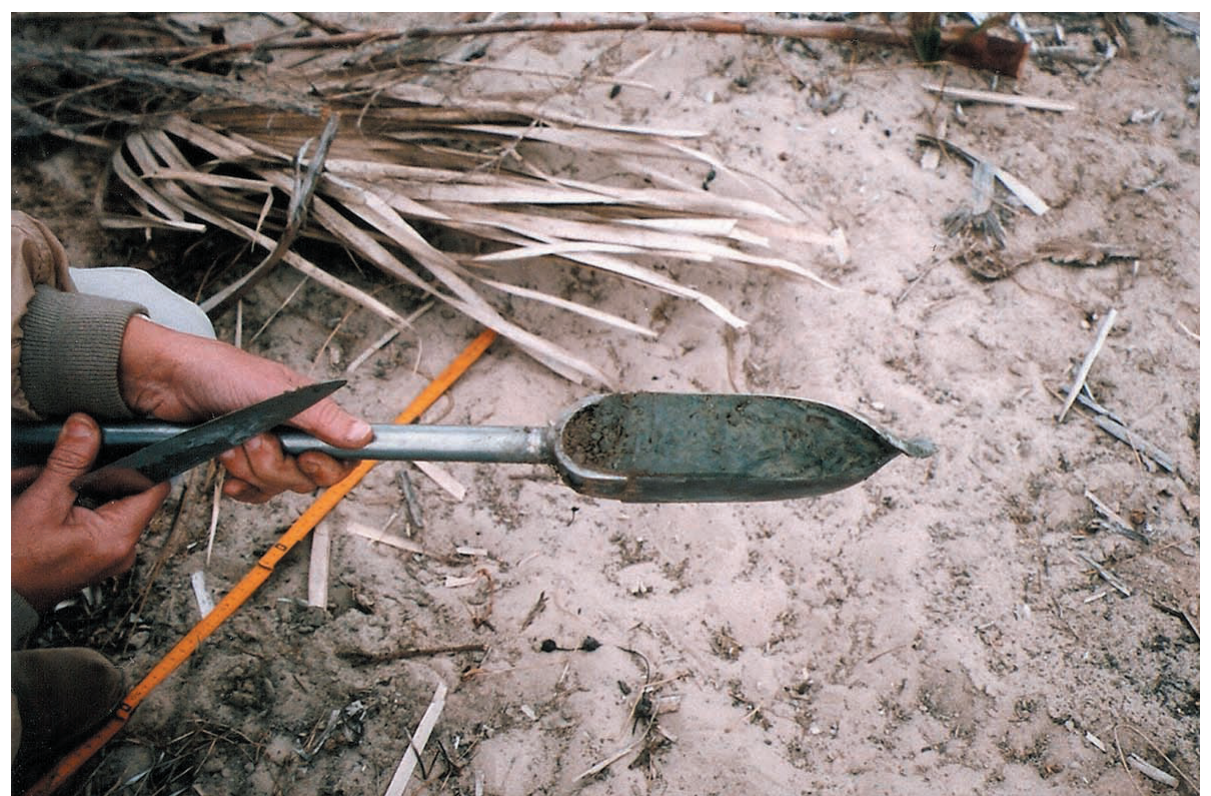

Figura 52 - Amostra de solo coletada no entorno de uma lagoa salina. A coloração esverdeada deve-se à concentração de sais em subsuperfície.

Foto: Rosangela Garrido Machado Botelho.

No interior da depressão, o sistema de drenagem ainda se encontra em estágio inicial de desenvolvimento. Há certa "desorganização" da rede de drenagem, que se apresenta não hierarquizada e com padrões amorfos, refletindo sua formação geologicamente recente e uma contínua história de pequenos soerguimentos e rebaixamentos, com desenvolvimento de anomalias de drenagem características, como inversões de drenagem, retilinearidade de canais, estreitamento de meandros, curvas em ângulo reto e mudanças no padrão do canal. Além disso, como o sistema funciona precariamente, há uma defasagem de até cinco meses entre as vazões de entrada e de saída, fazendo com que ocorram enchentes alternadas entre a região norte, que permanece inundada entre novembro e março, e a região sul, cujas enchentes se verificam entre maio e agosto. Portanto, as enchentes na porção sul do Pantanal brasileiro ocorrem no auge da estação seca, o que favorece as perdas de água por evapotranspiração e a retenção de sais no sistema.

Uma importante ocorrência mineral e que cuja exploração pode transformar-se em ameaça a este frágil ecossistema são os ambientes geológicos com jazimentos de ouro e diamantes na baixada Cuiabana, associados às faixas de dobramentos do Brasil Central, e nas nascentes dos Rios Paraguai e São Lourenço, encravados nos complexos de rochas cristalinas da Amazônia Meridional (setor sul do Cráton Amazônico). Estas ocorrências vêm atraindo o interesse de garimpeiros e mineradoras, cuja atividade é altamente prejudicial à produtividade biológica dos rios e corixos, em face do assoreamento provocado pelo rejeito do minério e da contaminação por mercúrio, metal usado intensivamente na recuperação do ouro. A atividade de extração de ouro nos Municípios de Poconé e Nossa Senhora do Livramento constitui grave ameaça à região. Considerando que o Pantanal é uma grande planície, susceptível à inundação periódica, a situação de contaminação por mercúrio dos corpos de água e/ou do sedimento de fundo dos rios é agravada na medida em que qualquer poluente lançado nos rios poderá se propagar em diferentes direções e atingir toda a área da planície. 
Além das feições morfológicas citadas, tem-se a área de acumulação que acompanha as calhas fluviais do Rio Paraguai, cujo curso e planície obedecem às orientações das falhas do substrato, e as de seus principais afluentes, que constituem os terraços e as planícies aluviais. Estas feições estão relacionadas com as condições hidrodinâmicas atuais e subatuais. O jogo de erosão e deposição reflete-se na instabilidade dos leitos.

Não fosse a proximidade do lençol freático com a superfície na região, associada aos aluviões decorrentes das cheias, a vegetação terrestre de boa parte do Bioma Pantanal seria semelhante à do Cerrado brasileiro (POR; FONSECA; LENCIONI NETO, 2007). Nas partes mais altas encontra-se a Savana Estépica; a Floresta Estacional Decidual, constituída por árvores dos gêneros Piptadenia, Bombax, Magonia etc.; e os contatos da Savana com a Savana Estépica, bem como destas com a Floresta Estacional (MAPA..., 2004b). Também nas margens elevadas dos rios, é comum a ocorrência da palmeira acuri, integrando matas ciliares juntamente com outras espécies, como a embaúba, o jenipapo, o pau-de-novato e diferentes tipos de figueiras. Importantes fitofisionomias das áreas inundáveis são os "paratudais", formados por árvores de grande porte como o ipê-roxo, e os "carandazais", aglomerações da palmeira carandá que, nos meses de junho a agosto, se tornam secos. Quanto à vegetação aquática, as plantas flutuantes, que são os principais produtores dos cursos de água, formam imensas massas verdes (Figura 53), verdadeiras "ilhas", conhecidas regionalmente por "batume" ou "camalotes" e constituídas, basicamente, por aguapés e Salvinia sp.

O Bioma Pantanal possui a flora menos diversificada entre todos os biomas brasileiros, com 1197 espécies, sendo 963 Angiospermas, 179 Briófitas, 30 fungos e 25 Samambaias e Licófitas; e o menor número de plantas endêmicas, totalizando 146 espécies, com 136 Angiospermas, oito Briófitas e duas Samambaias e Licófitas (LISTA..., 2010).

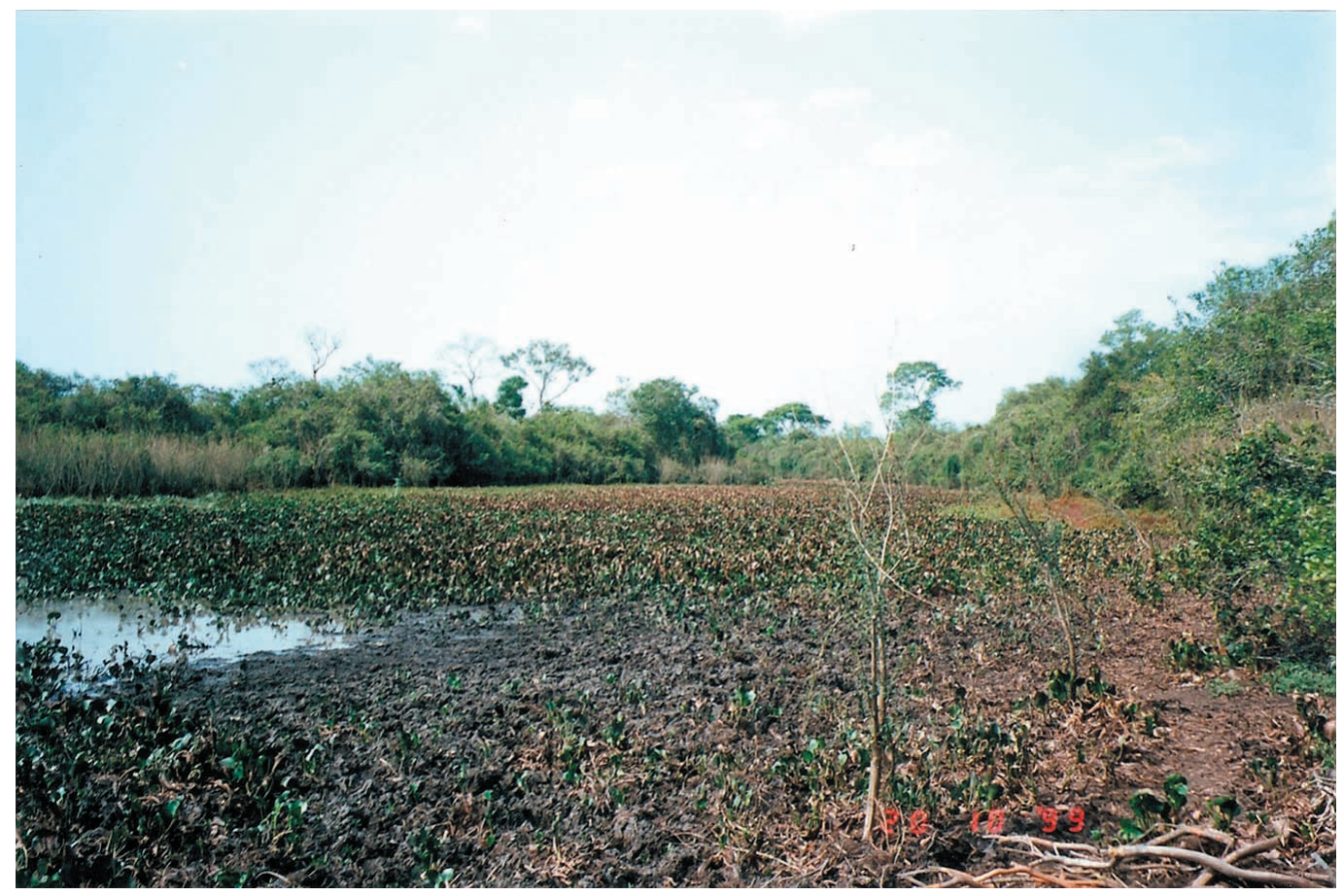

Figura 53 - Plantas aquáticas recobrindo corpos de água no Pantanal.

Foto: Rosangela Garrido Machado Botelho. 
Do ponto de vista morfoclimático, o Pantanal constitui uma forma relictual em desacordo com o clima úmido atual. Klammer (1982) registrou cones aluviais áridos, depressões salinas e campos arenosos de dunas. Após a fase de extrema aridez, a umidificação do clima descaracterizou as formas relacionadas com a fase árida, influenciando na perenidade dos rios e na formação de largas planícies. A própria sedimentação proveniente das áreas topograficamente elevadas do entorno contribuiu para mascarar estes registros.

A variedade fitofisionômica deste bioma está também associada à diversidade de tipos de solos, que podem ser relacionados com dois grandes sistemas pedoclimáticos: o chaquenho, parcialmente sobreposto pelas feições ligadas à umidificação atual do clima, na porção meridional, e o pantaneiro, situado na porção centro-norte do Bioma Pantanal. Este pode ser considerado como área de predomínio dos Plintossolos. Além destes, ocorrem, menos expressivamente, nas partes mais rebaixadas que corrrespondem às extensas planícies de inundação dos grandes rios (Cuiabá, Paraguai e São Lourenço), Planossolos, Vertissolos Hidromórficos, Gleissolos e Neossolos Flúvicos (MATO GROSSO, 2001). Nestes casos, a vegetação natural ou é arbórea, caracterizada como florestas higrófilas ou hidrófilas, ou é de campo hidrófilo ou higrófilo. No caso dos Plintossolos, sedimentos mais leves e mais antigos condicionam a formação de solos geralmente muito pobres quimicamente, de textura média/ argilosa ou arenosa/argilosa, sob vegetação de Savana (Cerrado).

A parte conhecida como Pantanal chaquenho congrega os Pantanais ao sul do leque do Rio Taquari e pode, grosso modo, ser considerada o domínio dos solos halomórficos (carbonáticos, salinos e/ou salino-sódicos), que ocorrem sob vegetação do tipo Savana Estépica (MAPA..., 2004b). Planossolos Háplicos solódicos, Planossolos Nátricos, Vertissolos Hidromórficos sódicos ou carbonáticos, Gleissolos Háplicos e Neossolos Flúvicos carbonáticos, vérticos e solódicos, são os principais solos encontrados.

A presença dos caracteres sódico, solódico, sálico, salino, carbonático e com carbonato é comum à maior parte dos solos do Pantanal chaquenho, ocorrendo de maneira isolada ou em combinação de dois ou mais no mesmo solo. Por esta razão, é comum a presença de sais cristalizados à superfície ou em fendas (eflorescências), bem como de concreções de CaCO3 (BRASIL, 1971).

Os solos desta porção do Pantanal são predominantemente eutróficos e têm o caráter vértico como ocorrência quase comum. Nos terrenos mais úmidos (depressões e planícies de inundação), evidencia-se a acumulação de sais de solubilidade mediana, como os carbonatos de cálcio (Figura 54). Perfis de Vertissolos apresentam resultados de $\mathrm{CaCO} 3$ equivalentes, entre $15,0 \%$ e 50,0\%, e presença de concreções de CaCO3 na fração cascalho que chega a 100,0\% (BRASIL, 1971). A presença de vegetação com concentração da palmeira carandá (Figura 55) é uma constante e constitui uma característica indicativa da presença de salinidade nos solos (MANUAL..., 2007). 


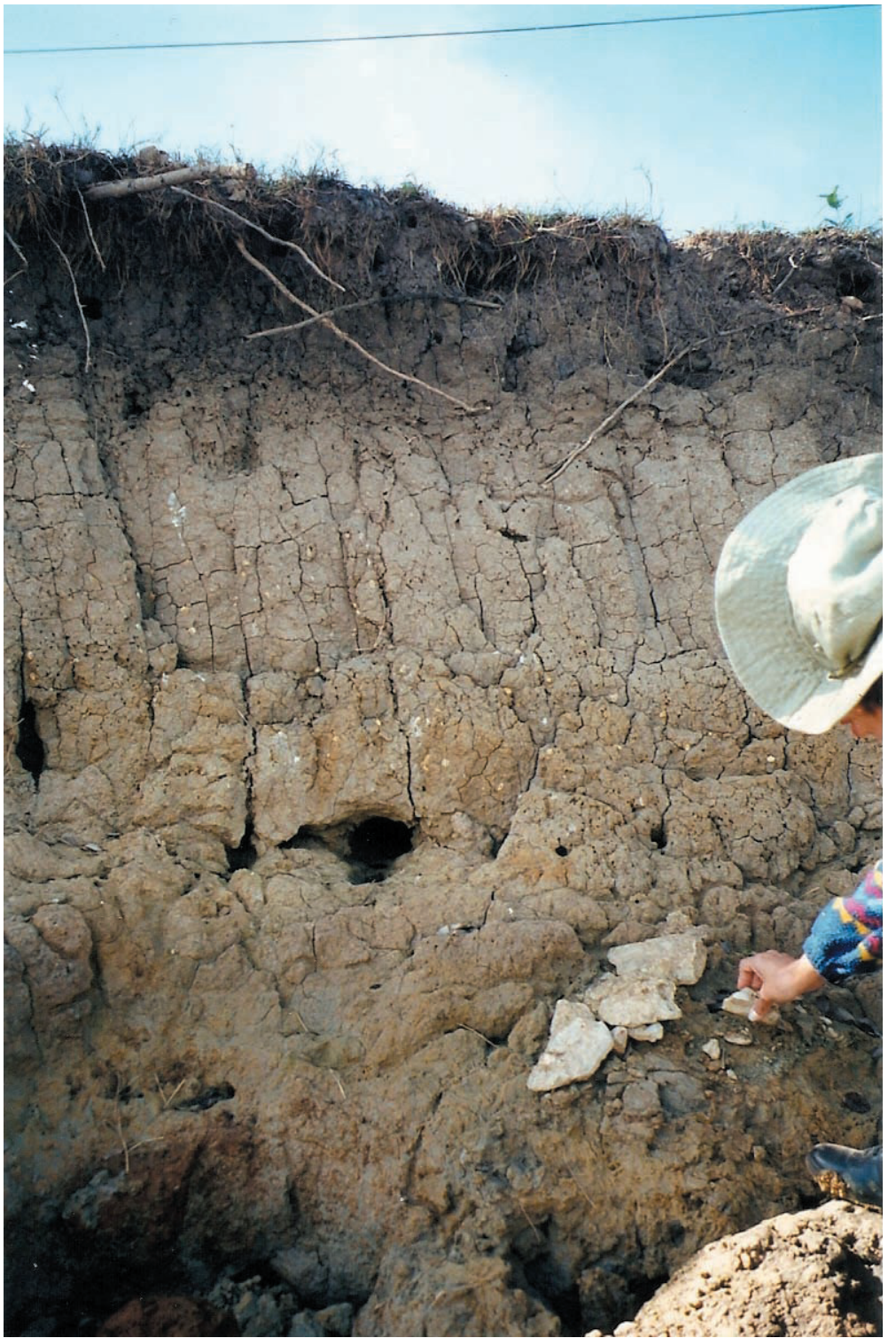

(a)

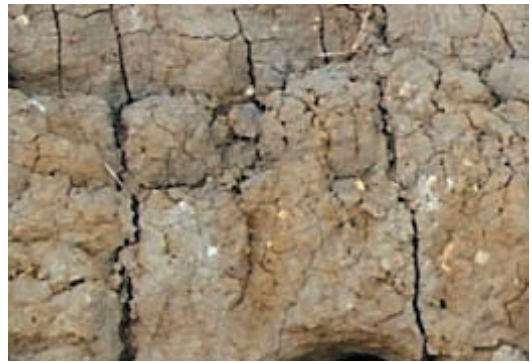

Figura 54. Concentração de sais e caráter vértico em solo às margens do rio Miranda, no Pantanal Chaquenho (a) e detalhe do fendilhamento e dos pontos de concentração de sais (b).

Foto: Rosangela Garrido Machado Botelho. 


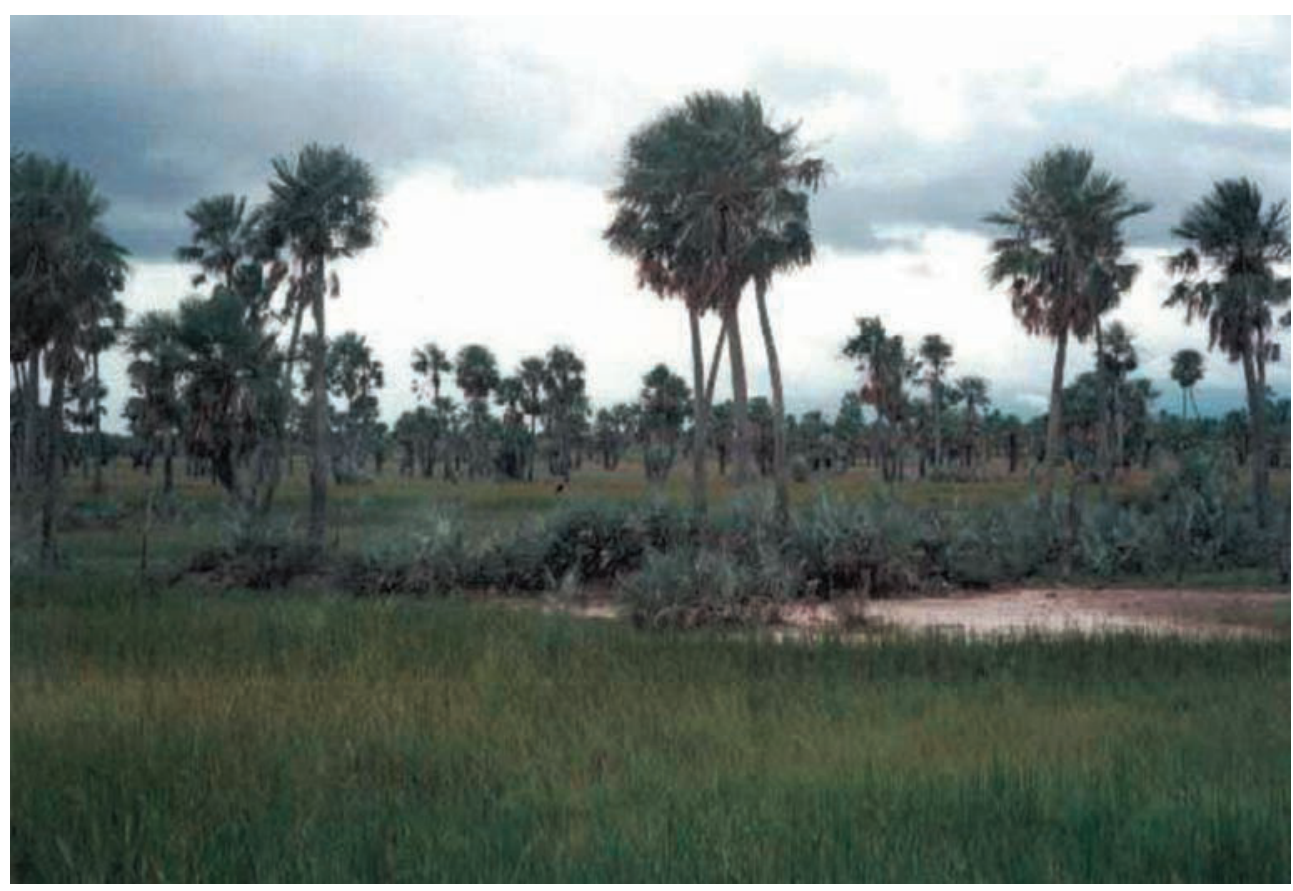

Figura 55 - Carandás em área de Planossolo Nátrico. Foto: Virlei Álvaro de Oliveira.

Os problemas ambientais mais visíveis estão relacionados com o desmatamento das áreas planaltinas. Até 2004, cerca de 26000 quilômetros quadrados da vegetação do Pantanal haviam sido transformados em áreas de pastagem e cultivo, enquanto, na Bacia do Alto Rio Paraguai, cerca de $44,0 \%$ da área teve sua vegetação natural descaracterizada totalmente (AVANÇO..., 2006). O desmatamento é responsável pelo entulhamento da planície com material sedimentar e, consequentemente, favorece povoamento com espécies invasoras da Savana, ocorrendo, portanto, a eliminação e/ou degradação da cobertura campestre natural. O aumento da carga sedimentar, devido às ações das áreas circunvizinhas, também provoca o assoreamento dos vales e a colmatagem das "baías", restringindo o reservatório de água e rompendo o equilíbrio faunístico.

No sistema chaquenho, distinguem-se dois ambientes: as áreas mais elevadas, alagadas de quatro a seis meses por ano, ocupadas por fisionomias do Contato de Floresta Estacional com Savana Estépica sobre Planossolo Nátrico e Planossolo Háplico solódico, ambos com textura arenosa/média e média/argilosa; e as depressões, cortadas por vários canais de drenagem que engrossam o volume de água dos drenos, alagadas por um longo período, de seis a nove meses, recobertas por Savana Estépica, desenvolvida sobre Vertissolo solódico e Gleissolo Háplico, além dos solos encontrados no ambiente anterior. 
Os problemas ambientais deste sistema estão relacionados com os desmatamentos. Estas ações poderão acelerar a estepização, devido ao aumento da evaporação e, consequentemente, à concentração de sódio na superfície do solo.

Nas planícies, em função de sua fragilidade, a instabilidade ambiental é observada, principalmente, no período das cheias, quando ocorrem inundações e desbarrancamentos locais de margens dos canais fluviais.

O fenômeno dos "arrombados" refere-se ao rompimento das margens dos rios nas partes onde a água apresenta maior energia ou nas áreas mais baixas do barranco, formando a cada ano novos canais. O fenômeno, que ocorre principalmente ao longo do baixo curso do Taquari, na sub-região de Paiaguás, é fruto da instabilidade do rio, mas parece estar sendo agravado pela atividade antrópica, responsável pela erosão a montante da planície pantaneira, no Planalto Central Brasileiro, com consequente assoreamento das calhas fluviais na área da planície.

A rápida expansão da agropecuária, a partir de meados da década de 1970, acelerou os processos erosivos no planalto e o assoreamento do Rio Taquari, que apresenta papel de destaque na socioeconomia da Nhecolândia e do Paiaguás, sub-regiões criatórias com maior número de bovinos de corte do Pantanal.

Juntamente com o material erodido e carreado, há também a migração de substâncias químicas para as planícies inundáveis, provenientes do uso de agroquímicos nas lavouras das áreas dos planaltos. Nessas áreas, é intenso o uso de agrotóxicos, de diferentes classes de toxidade, principalmente nas monoculturas da soja, da cana-de-açúcar e do milho, provocando a contaminação de rios e baías com os resíduos de insumos agrícolas e de pesticidas (herbicidas, inseticidas e fungicidas), constituindo importante questão ambiental no Pantanal.

Ao observarmos os dados de fluviometria da estação de Ladário, no Rio Paraguai, para o período de 1900 a 2005 (Figura 56), é possível perceber variações importantes nos valores e frequências das cheias e vazantes. Dividindo-se o período em duas partes, correspondentes à primeira e à segunda metade do Século $\mathrm{XX}$, nota-se que tanto os valores máximos quanto os mínimos e os do nível médio aumentaram na segunda metade do século, atestando uma elevação do nível das cheias no Pantanal, notadamente a partir do ano de 1974, quando os picos de cheia e vazante estão em cotas comparativamente mais elevadas. Tal fato pode decorrer do próprio ciclo climático e hidrológico que caracteriza o Pantanal, mas pode também representar uma resposta às interferências antrópicas no ambiente, como o crescimento da atividade agropecuária nas áreas de entorno da planície pantaneira, que resultou em assoreamento dos rios da planície e consequente elevação do nível das águas das inundações. 

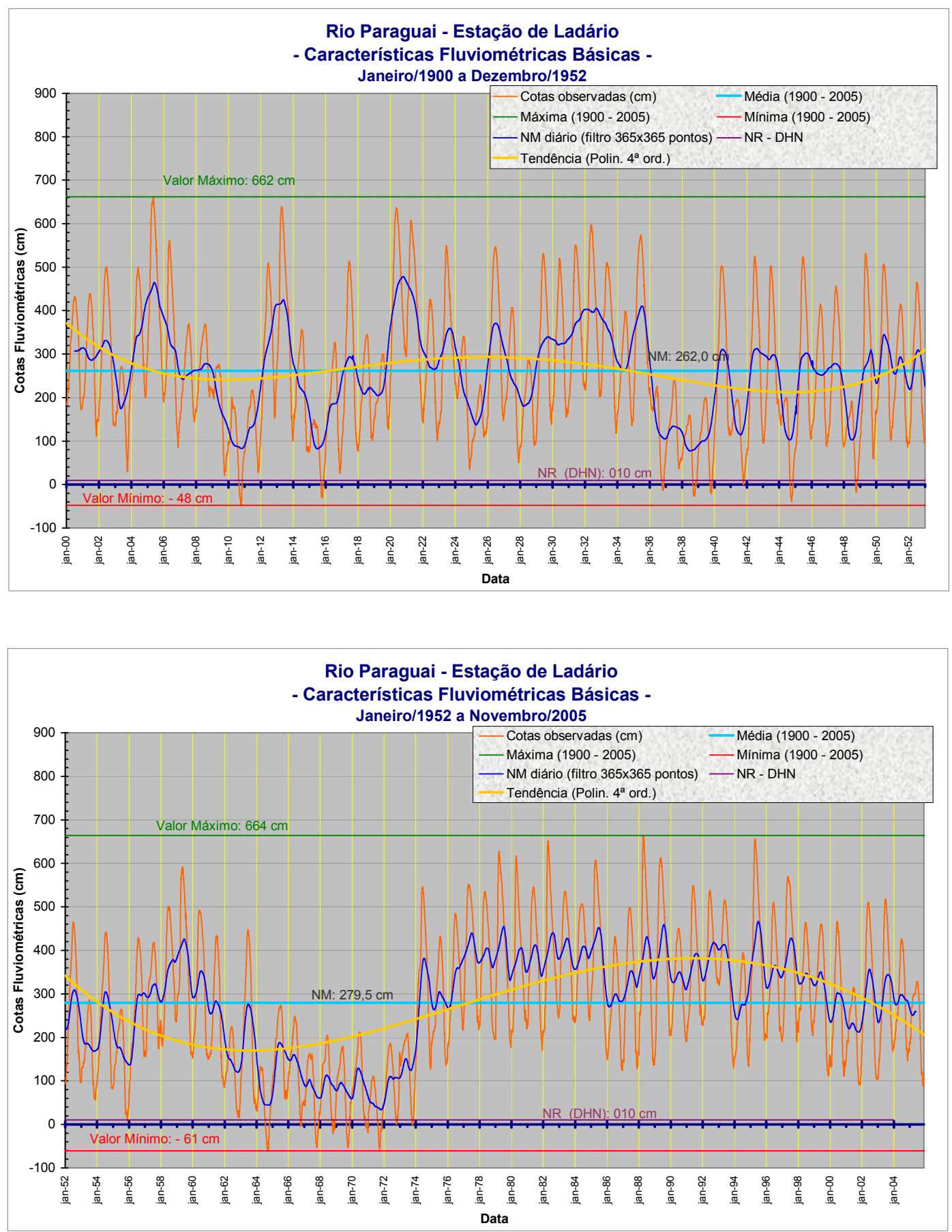

Figura 56 - Dados de fluviometria da estação de Ladário, no Rio Paraguai, para o período de 1900 a 2005. Boletim de Monitoramento da Bacia do Alto Paraguai (2006) 
O fenômeno dos "arrombados" assume maior importância quando se considera que as mudanças do leito do rio, de forma imprevisível, provocam inundações em algumas áreas e "seca" em outras, com consequências socioambientais.

As inundações têm reduzido a área de pasto disponível, causando inclusive a morte do gado. Em várias fazendas, houve considerável redução do rebanho bovino, afetando profundamente a pecuária de corte desenvolvida historicamente nestes locais. Vários produtores familiares perderam suas terras e se dirigiram para as Cidades de Corumbá e Ladário ou para os assentamentos rurais localizados nos municípios atingidos. Nas áreas que passaram a ficar mais secas, o efeito tem sido positivo, permitindo a expansão da criação de gado.

Por outro lado, os produtores que permaneceram nas partes não mais afetadas pelas inundações também encontram dificuldades de sobrevivência, tendo em vista as repercussões sobre as atividades de pesca e navegação. Os bancos de areia formados no leito do rio, em função do assoreamento, dificultam a navegação, aumentam o isolamento físico, as dificuldades para o escoamento da produção e para o deslocamento entre as moradias, o que contribui sensivelmente para a conformação de um quadro de profunda carência da população residente nestes locais.

Em relação aos efeitos destas transformações sobre a pesca, houve redução considerável da produção no Rio Taquari nas últimas duas décadas. Essa redução foi atribuída principalmente à evolução no assoreamento do rio nos últimos anos e, efetivamente, após a formação do "arrombado" do Caronal na fazenda que leva o mesmo nome (AGÊNCIA NACIONAL DE ÁGUAS, 2004).

Os peixes e as diferentes modalidades de pesca constituem recursos de grande importância ecológica e socioeconômica para o bioma. São determinantes na oferta de alimentos para muitas espécies de vertebrados do Pantanal (répteis, aves e mamíferos), mantêm populações humanas tradicionais que vivem desse recurso (pesca de subsistência), abastecem mercados locais ou nacionais (pesca comercial artesanal), servem de atrativo para o turismo (pesca esportiva e de iscas) e ainda despertam interesse estético (pesca ornamental), científico (pesca para pesquisa) e tecnológico (aquicultura). Há aproximadamente 400 espécies de peixes na Bacia do Alto Paraguai (BAP), das quais 263 foram catalogadas para o Pantanal (BRITSKI; SILIMON; LOPES, 1999; REIS; KULLANDER; FERRARIS JUNIOR, 2003). Muitas espécies são migratórias, como a curimatã, a piraputanga, o pintado, a cachara, o dourado, o jaú e o pacu. Durante a inundação da planície (outubro a abril), cardumes dessas e de outras espécies sobem os rios (piracema) e, logo após a desova, retornam rio abaixo (rodada) para alcançarem os campos inundados e baías, onde se alimentam. Na vazante (abril e maio), retornam aos leitos dos rios (lufada), por meio das vazantes e corixos, onde permanecem durante a seca (junho a outubro). Espécies que realizam movimentos locais ou mesmo sedentárias são frequentes em todos esses ambientes, com destaque para os predadores, como as piranhas. Nas áreas expostas a flutuações sazonais marcantes do ciclo hidrológico, as comunidades de peixes apresentam diferenças sazonais acentuadas entre os vários ambientes (FLORENTINO, 2012), mas nas áreas submetidas à alta inundação (com mais de oito meses de cheias), essas diferenças são pouco perceptíveis (POLAZ, 2013). 
Atraídos pela fartura de peixes e invertebrados, como caramujos e moluscos, que também têm relevância na cadeia trófica, predadores aquáticos, bem como alguns animais habitantes do Bioma Cerrado concentram-se em grande número no Pantanal, chamando a atenção de turistas e caçadores. Diversos peixes são importantes presas de répteis, como as sucuris e os jacarés; as aves paludícolas também se agregam nas vazantes e baías, para se alimentarem, sobretudo de peixes, ou em ninhais, para a reprodução, para onde os pais trazem alimentos, geralmente peixes, para os filhotes, enquanto estes atraem a predação de répteis e mamíferos oportunistas, como a anta, o caitetu, a paca, o tamanduá-bandeira, lobinhos, mão-pelada e primatas, como o macaco-prego e o bugio.

A pesca comercial e a esportiva são atividades tradicionais no Pantanal. Nas últimas décadas, tornaram-se muito intensas e têm gerado conflitos. O crescimento da demanda por espécies preferenciais aumenta o risco de sobrepesca desses estoques. Muito embora as estatísticas pesqueiras sejam falhas, as capturas no Mato Grosso do Sul, entre 1989 e 2000, mostraram um pico de produção comercial, em 1991-1992, e um pico da pesca esportiva, em 1992-1993, seguidos por redução de cerca de 50,0\% até o ano de 2000, para as duas atividades, com declínios correspondentes nos números de pescadores registrados. $\mathrm{O}$ aumento da pressão pesqueira exercida por turistas e por empresas que praticam pesca semi-industrial tem favorecido também o aparecimento de atravessadores que exploram a mão de obra artesanal sem cumprirem suas responsabilidades socioambientais. Além disso, estudos demostram que cerca de metade do pescado capturado no Pantanal é ilegal e provém de pescarias comerciais e esportivas clandestinas. Há também documentação mostrando que grande parte dos estabelecimentos da pesca esportiva (pousadas e pesqueiros) não são licenciados, agravando a pesca ilegal, os desmatamentos ciliares, a circulação intensa de embarcações motorizadas e a poluição no Pantanal (ALHO; GONÇALVES, 2005).

Outra grave ameaça aos ecossistemas pantaneiros pode estar representada pelas ações de engenharia circunscritas aos planos de melhoria da navegabilidade do Rio Paraguai, de interesse do Brasil e da Bolívia. Entre as obras em estudo, estão a retificação do curso do rio e o seu aprofundamento em alguns pontos, que podem modificar a duração e a extensão das inundações, com graves repercussões sobre os ambientes, a biodiversidade e a economia do Pantanal.

No Pantanal, foram registradas 35 espécies de anfíbios, todas com ampla distribuição geográfica e presença também no Bioma Cerrado, não se registrando, até então, endemismos na região. Embora essa riqueza de espécies seja inferior à do Cerrado vizinho, a abundância de anfíbios é bem maior, devido à ocorrência de habitats favoráveis, sobretudo na cheia, quando o coro da vocalização de sapos, rãs e pererecas celebra a estação no Pantanal. O canto dos anfíbios é uma expressão de territorialidade e comunicação dos machos para atrair as fêmeas para a reprodução, com cantos próprios de cada espécie. Muitas espécies de anfíbios do Pantanal têm hábitos arborícolas ou vivem em arbustos ao longo de rios, corixos e vazantes. Algumas espécies preferem habitats de águas permanentes dos rios, corixos e baías, onde vocalizam e se reproduzem durante todo o ano. Outras espécies acompanham a linha d'água na enchente e na vazante, mas há também as que, durante a seca, se refugiam em ambientes úmidos e permanecem em dormência, ou se enterram, até a chegada da próxima cheia. Existem também espécies que preferem habitats terrestres de floresta, vivendo 
em plantas das matas ciliares e cordilheiras. Algumas espécies também são encontradas nas cercanias das sedes de fazendas e pousadas no Pantanal, como o sapo-cururu, a rã-do-chaco, as pererecas-de-banheiro, a rã rapa-cuia e a rã-quarenta-e-três. Em geral, os anfíbios do Pantanal não são venenosos como algumas espécies amazônicas e, embora pelo menos três espécies tenham potencial como alimento humano, não há tradição desse consumo na região (ALHO; GONÇALVES, 2005).

Ocorrem, no Pantanal, 85 espécies de répteis, com a incorporação de elementos oriundos dos biomas vizinhos e baixo endemismo. Entre os répteis, destacam-se alguns abundantes predadores semiaquáticos: o jacaré, que se alimenta sobretudo de peixes, caranguejos, caramujos e insetos, e pode alcançar até 3 metros (Figura 57); e a sucuri-amarela, que alcança grande porte e domina as paisagens aquáticas da sub-região de Poconé (MT). Muito comuns também são as jiboias (Figura 58) e outras serpentes associadas às áreas sazonalmente inundadas do Pantanal. Somente quatro espécies de serpentes do Pantanal são peçonhentas, quase todas raras e associadas aos terrenos secos mais elevados, como as cordilheiras e os capões do Cerrado. Nesses ambientes, ocorrem também as únicas quatro espécies de répteis fossoriais ${ }^{19}$ ou semifossoriais do Pantanal, com destaque para as anfisbenas. Dentre os quelônios, ocorrem dois jabutis terrestres e a espécie aquática cágado-cabeçudo. Cerca de 20 espécies de lagartos vivem no Pantanal, a maioria com hábitos terrestres, embora alguns estejam também associados com os ambientes alagados. Os maiores e mais notáveis são, entre os primeiros, os teiús, e, entre os aquáticos, as iguanas e a dracena, que pode ser confundida com um pequeno jacaré (ALHO; GONÇALVES, 2005).

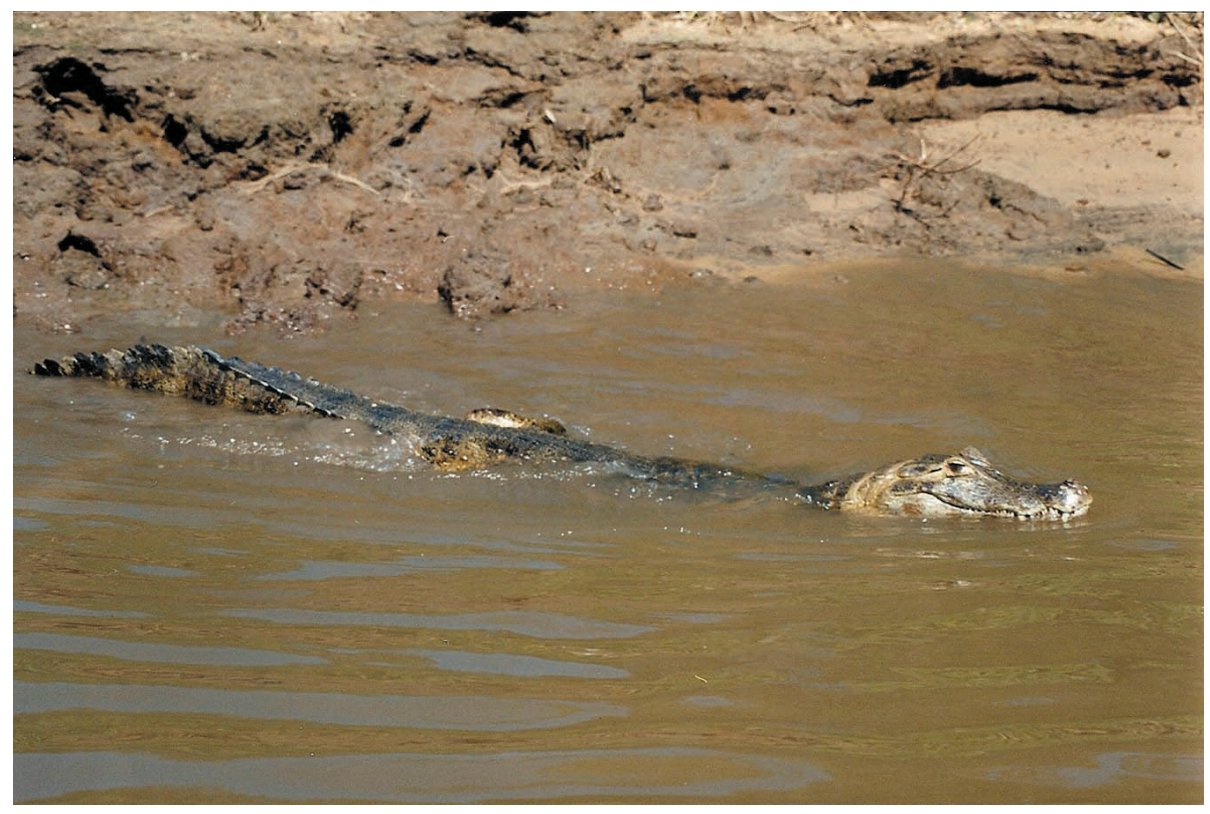

Figura 57 - Jacaré-do-pantanal, facilmente encontrado nas margens dos cursos de água. Foto: Rosangela Garrido Machado Botelho.

\footnotetext{
19 Animais que escavam o solo, normalmente possuindo pernas específicas para este trabalho. Os semifossoriais passam apenas parte do tempo abaixo do solo.
} 


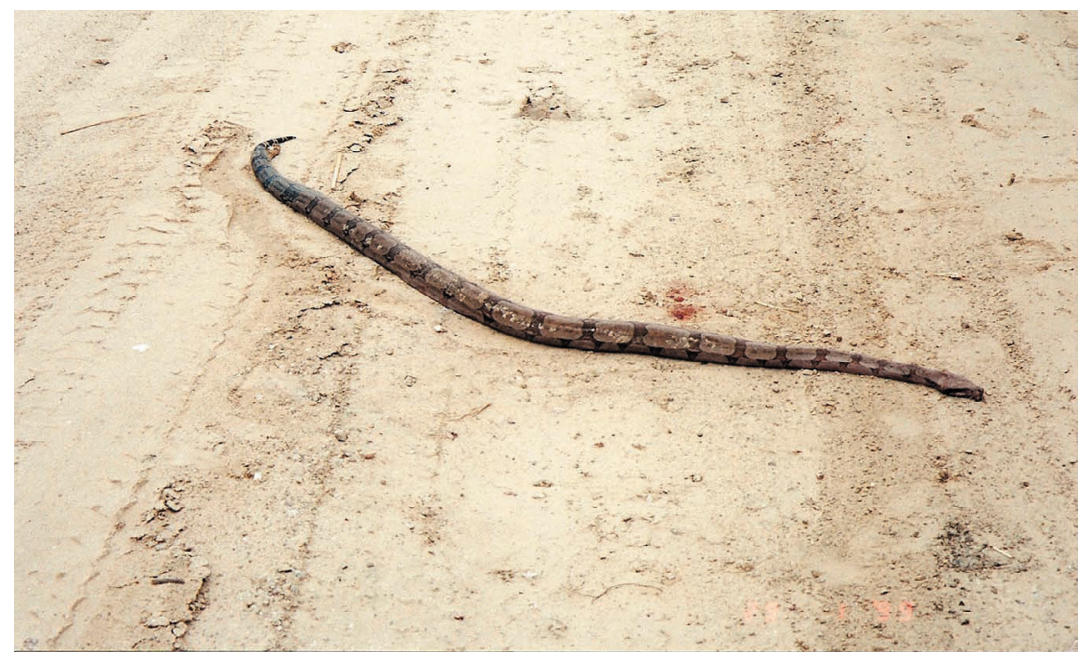

Figura 58 - Jiboia atropelada em estrada pantaneira.

Foto: Rosangela Garrido Machado Botelho.

O Pantanal é a planície de inundação com maior riqueza de espécies de aves em todo o mundo, com 463 espécies já registradas e amplo reconhecimento de que sua avifauna se encontra ainda insuficientemente amostrada. Nenhuma dessas espécies, contudo, é endêmica do Pantanal, pois também podem ser encontradas em biomas vizinhos. Além da alta diversidade de espécies, a extraordinária abundância de aves aquáticas e paludículas, e a formação de colônias (associações de espécies diferentes) concentradas em um mesmo ponto para reprodução, os chamados ninhais, são peculiaridades que contribuíram para tornar o Pantanal uma das regiões mais atrativas do mundo para observação e estudos de aves, desde meados do Século XIX (TUBELIS; TOMAS, 2000). Sucedem-se, nos ninhais, dois eventos reprodutivos: inicialmente, esses sítios de nidificação são ocupados por aves de plumagem branca (onda branca), tais como o cabeça-seca, a garça branca pequena, a garça branca grande, a garça-real e o colheireiro, entre outras, seguidas por espécies de plumagem negra (onda negra), tais como os biguás, anhingas e a garça. Essas colônias se concentram em árvores durante a estação seca (julho a outubro), para se beneficiarem da grande oferta de alimento disponível (presença maciça de peixes e invertebrados presos nas águas rasas das baías). Por outro lado, filhotes dessas aves que acidentalmente caem nas águas, atraem predadores como jacarés e sucuris, além de aves como o gavião-caracará (Figura 59) e o gavião-preto. Na estação seca, aves típicas como a marreca-cabocla, o irerê e o pato-do-mato são também observadas em altas densidades. A nidificação e o sucesso repro-

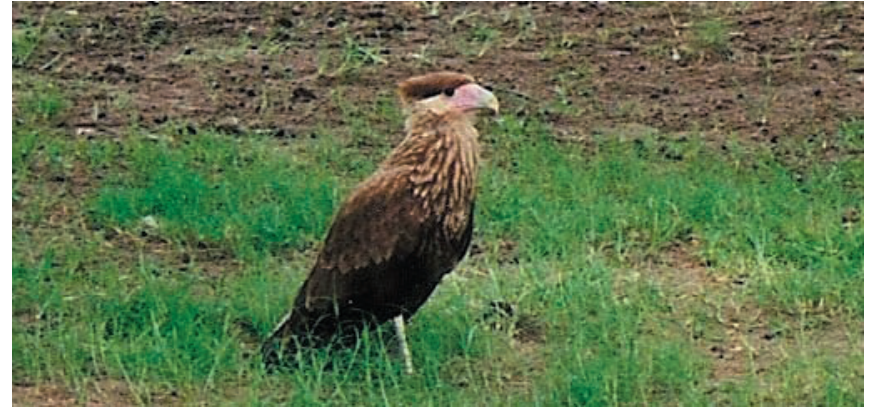

Figura 59 - Carcará, ave de rapina muito comum no Bioma Pantanal. Foto: Rosangela Garrido Machado Botelho. dutivo do tuiuiú, ave símbolo do Pantanal, tem sincronia com o regime de seca da região, quando há disponibilidade de alimentos para os filhotes (sobretudo do peixe muçum e moluscos). Normalmente, os filhotes estão prontos para voar ao final da seca, mas modificações hidrológicas durante as águas baixas podem ocasionar a interrupção reprodutiva e o abandono dos ninhos. 
Durante a estação cheia, os tuiuiús migram para lugares mais altos ainda pouco conhecidos e raramente são avistados no Pantanal. A abundância das araras, incluindo a arara-azul, também está relacionada com o ciclo hidrológico do Pantanal, bem como a oferta de nichos reprodutivos (sobretudo os ocos das árvores velhas de manduvi), também disputados por araras-vermelhas e o gavião-falcão-relógio, entre outros. O Pantanal é ainda usado por aves migratórias vindas da América do Norte, especialmente o maçarico, o falcão-peregrino e a triste-pia, que alcançam a região por meio das rotas do Brasil Central, Rio Negro e Cisandina (ALHO; GONÇALVES, 2005).

Um total de 132 espécies de mamíferos já foram catalogadas no Pantanal (ALHO; GONÇALVES, 2005), das quais duas são endêmicas, 11 estão ameaçadas de extinção e oito são consideradas deficientes em dados (MACHADO; DRUMMOND; PAGLIA, 2008). Embora bem representados na região, é a grande abundância de certas espécies que torna a fauna de mamíferos do Pantanal exuberante. São bastante comuns grandes populações de capivaras, espécie emblemática da região, que na época da seca espalha-se em grande grupos sociais nos campos de pastagens, onde as forrageiras são abundantes e diversificadas, e, na cheia, as populações se fragmentam e mudam de dieta para vegetação flutuante e outras plantas existentes nos capões de mata e de cerrados, onde se refugiam durante as noites. O lobinho, ou cachorro-do-mato, também é avistado com frequência no Pantanal, sobretudo na época da seca, quando deixa as tocas no final do dia para se alimentar de insetos, crustáceos, anfíbios, pequenos lagartos, filhotes de aves e pequenos mamíferos. O cervo-do-pantanal, maior veado da América do Sul, de ampla distribuição, mas raro em outros biomas, ainda é abundante no Pantanal, sobretudo nas áreas inundáveis durante a estação cheia, onde encontra farto suprimento alimentar de plantas aquáticas. O veado-campeiro (Figura 60), também bastante comum no Pantanal, foi retirado da última lista de fauna ameaçada de extinção (MACHADO; DRUMMOND; PAGLIA, 2008), em função do melhor conhecimento sobre estimativas de tamanho populacional. O bugiu também é comum no dossel das matas que margeiam os rios do Pantanal, onde se alimentam de brotos novos, flores, frutos e sementes. A onça-pintada, predador-topo da cadeia trófica, que exige enorme espaço de vida, ainda pode ser observada com certa frequência, embora venha sofrendo perseguição por atacar eventualmente animais de criação das fazendas (ALHO; GONÇALVES, 2005).

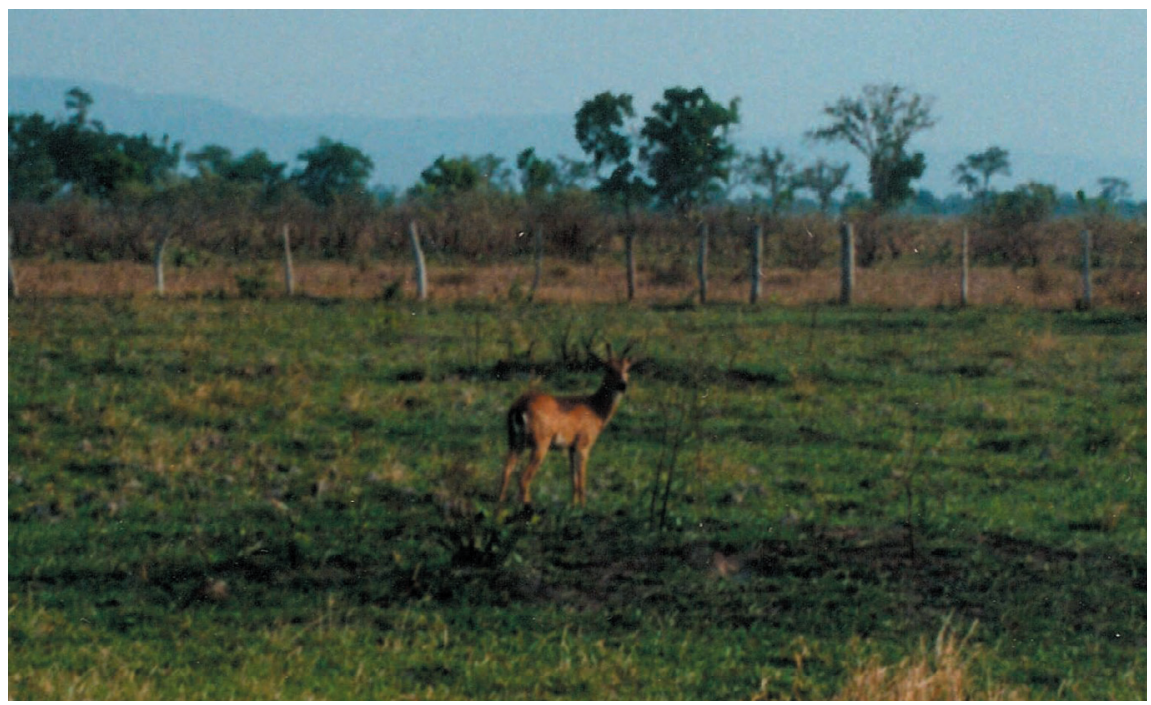

Figura 60 - Veado-campeiro, mamífero comum na planície pantaneira.

Foto: Rosangela Garrido Machado Botelho. 
A rica fauna do Pantanal depende, em larga escala, da alimentação aquática e tem seus ciclos vitais regulados pelo ciclo hidrológico, o que acentua a importância de não se interferir nos ciclos naturais de cheia e vazante na região, e de se preservar as cabeceiras dos rios.

O Pantanal é considerado a maior área úmida do mundo e foi declarado patrimônio nacional pela Constituição Federal do Brasil, de 1988, além de abrigar sítios de relevante importância como a Convenção sobre Zonas Úmidas de Importância Internacional ou Convensão de RAMSAR ${ }^{20}$. Contempla ainda áreas da Reserva da Biosfera, declaradas pela Organização das Nações Unidas para a Educação, a Ciência e a Cultura (United Nations Educational, Scientific and Cultural Organization - UNESCO), em 2000. Apesar do conhecimento sobre a relevância do Pantanal e do seu entorno para a manutenção dos recursos hídricos e para a conservação da biodiversidade, há poucas áreas que garantam a proteção da Bacia do Alto Paraguai e da planície pantaneira.

A partir de dados oficiais obtidos junto à Secretaria de Estado do Meio Ambiente SEMA, do Mato Grosso do Sul, e ao IBAmA, apenas 2,9\% da Bacia do Alto Paraguai e 4,5\% da área da planície pantaneira estão protegidos por algum tipo de Unidade de Conservação de Proteção Integral - UCPI e reservas particulares do patrimônio natural. Em toda a área dessa bacia, apenas 10596 quilômetros quadrados encontram-se protegidos em 19 UCPIs públicas e em 34 Reservas Particulares do Patrimônio Natural - RPPN. Na área de planície, são somente cinco UCPIs públicas e 16 RPPNs, totalizando 6758 quilômetros quadrados. Em Mato Grosso do Sul, existe apenas uma Unidade de Conservação pública na planície pantaneira, o Parque Estadual do Pantanal do Rio Negro, que protege 0,5\% do Pantanal naquele estado (LIVRO..., 2008).

Áreas com potencial para conservação foram identificadas: 19, em 1998, e 50, em 2006, totalizando, respectivamente, 59866 e 83562 quilômetros quadrados de áreas consideradas como prioritárias para conservação. Muitas delas são reconhecidas pelo alto grau de importância biológica, não encontrando substitutos ao longo da região, mas já sob pressão antrópica, apresentando em média 36,0\% de desmatamentos (ÁREAS..., 2015).

Outra avaliação das pressões sobre as áreas protegidas e as áreas prioritárias para conservação no Pantanal apresentou resultados semelhantes: em ordem decrescente de importância, as principais fontes de pressão aos sistemas naturais da Bacia do Alto Paraguai (nível máximo de pressão) são a pecuária, a agricultura e os aproveitamentos hidrelétricos, no planalto, e a pecuária, hidrovia e navegação, na planície. As áreas urbanas também pressionam os ecossistemas tanto no planalto como na planície, mas seus efeitos são menos abrangentes (nível alto de pressão). Apesar de muito localizados na bacia, os efeitos dos empreendimentos mineradores já dispararam o sinal de alerta (níveis moderados de pressão), assim como as atividades de irrigação, no planalto, e piscicultura e pesca, na planície pantaneira (AGÊNCIA NACIONAL DE ÁGUAS, 2004).

\footnotetext{
20 A Convenção sobre Zonas Úmidas de Importância Internacional, conhecida como Convenção de RAMSAR, é um tratado firmado por governos de diversos países que estabelece uma ação nacional e uma cooperação internacional para a conservação e o uso racional das zonas úmidas e de seus recursos naturais. A convenção recebeu o nome da cidade iraniana onde o acordo foi criado em 1971.
} 
O principal efeito das alterações antrópicas é a perda e fragmentação de habitats nos dois compartimentos ambientais da Bacia do Alto Paraguai (nível máximo de estresse). Outros efeitos extremos no planalto, como degradação dos solos, regime de fogo alterado, sedimentação nos córregos e introdução de espécies exóticas, apresentam níveis de estresse um pouco mais baixos, mas não menos preocupantes, na planície pantaneira. Por outro lado, alterações no regime hidrológico parecem mais pronunciadas na planície do que no planalto, embora a perda acelerada de matas ciliares acarrete danos irreversíveis ao regime hidrológico dos córregos nas cabeceiras e altere o ritmo e a magnitude dos efeitos que se dispersam e se acumulam na planície. A poluição por agrotóxicos também é um problema grave no planalto e seus efeitos cumulativos sobre os ecossistemas da planície parecem estar em curso, muito embora os dados sejam muito pontuais. Os efeitos da poluição por esgotos domésticos ainda parecem circunscritos aos centros urbanos, onde merecem forte atenção, mas podem potencialmente se dispersar pela bacia. Os impactos potenciais sobre a biodiversidade da planície provenientes da introdução de espécies exóticas ou da "sobrepesca de alguns estoques preferenciais" ainda não estão muito bem documentados, mas podem preocupar (LIVRO..., 2008).

Muitos dos impactos ambientais ocorridos no Pantanal são agravados pela dificuldade de implantação de políticas ambientais efetivas que garantam o uso sustentável dos seus recursos naturais e seu equilíbrio ecológico. Diante dos impactos identificados e riscos futuros sobre o Pantanal, planeja-se a criação efetiva de Unidades de Conservação de Proteção Integral (51,0\% das áreas prioritárias para conservação) e de Unidades de Conservação de Uso Sustentável. Busca-se também a implantação de práticas de recuperação de áreas degradadas, cadastro ambiental rural, boas práticas agrícolas, fomento ao uso sustentável, implantação de corredores ecológicos e mosaicos de áreas protegidas, bem como ações de compensação ambiental (ÁREAS..., 2015).

Em suma, é preciso reconhecer o Bioma Pantanal como um sistema altamente dinâmico e com acentuada fragilidade natural. A manutenção de seu equilíbrio extrapola os limites da área por ele abrangida e obriga o observador, preocupado com o uso racional dos recursos naturais e com a sobrevivência e a qualidade de vida das populações, sejam elas humanas ou não, a estender seu olhar para as áreas elevadas do entorno, cujo uso e ocupação se refletem, em menor ou maior prazo, sobre a planície pantaneira e toda a vida a ela associada. Para preservar o Pantanal é, portanto, fundamental a preservação do seu entorno, notadamente das áreas de cabeceiras dos rios que compõem a Bacia Hidrográfica do Alto Paraguai. 


\section{Pampa: paisagem e identidade gaúchas}

Mapa 5 - Bioma Pampa - Unidades de Relevo

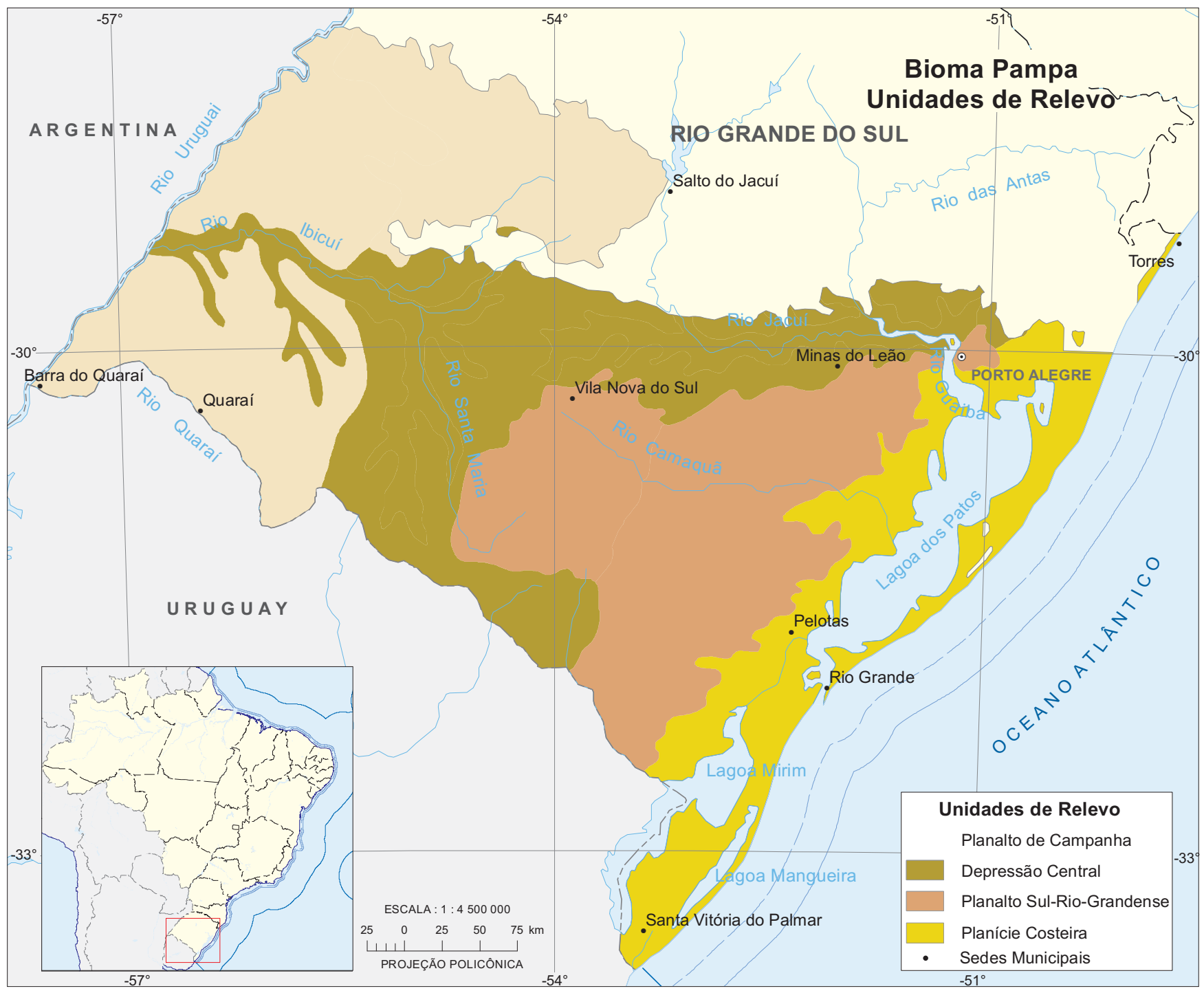

Fonte: IBGE, Diretoria de Geociências, Coordenação de Recursos Naturais e Estudos Ambientais. 
O Bioma Pampa constitui a porção brasileira dos pampas sul-americanos, que se estendem pelos territórios do Uruguai e da Argentina, sendo classificados como estepe no sistema fitogeográfico internacional. No Brasil, o Bioma Pampa delimita-se apenas com a Mata Atlântica e abrange o conjunto das diferentes formações fitogeográficas da porção meridional do Rio Grande do Sul (cerca de 63,0\% da área do estado), unificadas pelas fitofisionomias campestres predominantes (formações vegetais gramíneo-lenhosas e herbáceas), ainda observáveis em diferentes ambientes semipreservados dessa porção do território, e que recobrem superfícies com relevo aplainado ou suavemente ondulado a forte ondulado na Serra do Sudeste, sobre uma gama variada de litologias e solos (Figura 61).

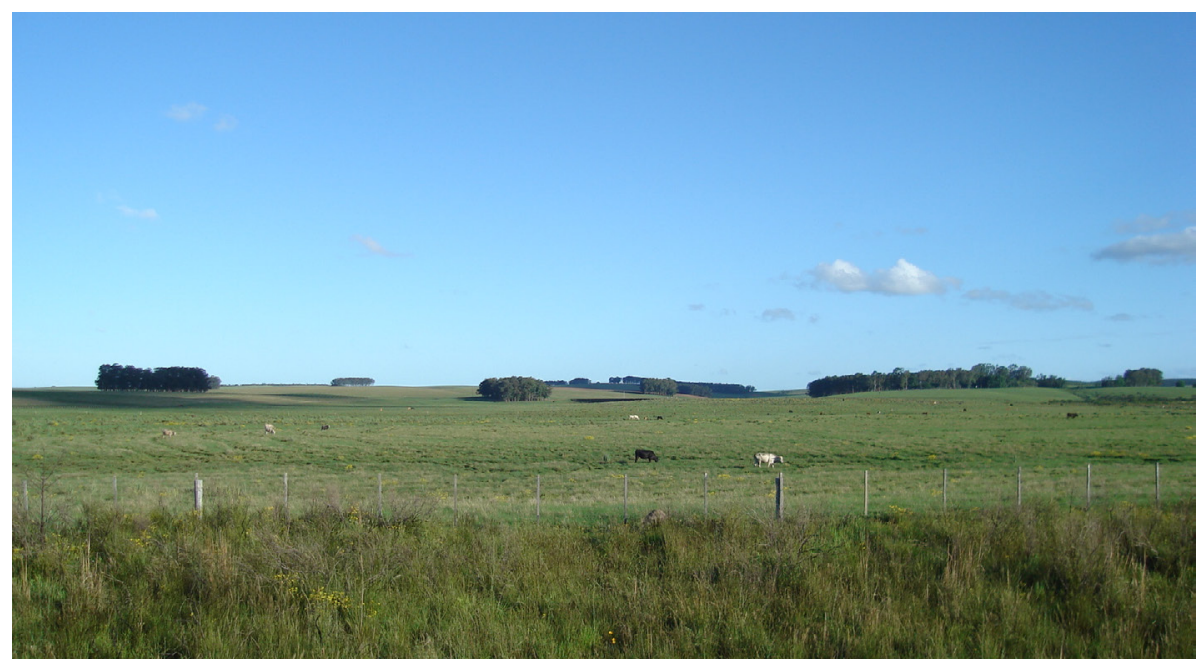

Figura 61 - Fitofisionomia campestre em relevo suave ondulado, norte do Município de Pelotas (RS).

Foto: Fernando Peres Dias.

No Bioma Pampa, as formações florestais típicas presentes são pouco expressivas e restringem-se, fundamentalmente, à vertente oriental do Planalto Sul-Rio-Grandense e às margens dos principais rios e de seus afluentes (MAPA..., 2004a).

O clima é chuvoso, sem período seco definido, marcado pela frequência de frentes polares e temperaturas negativas no inverno. Essas condições climáticas imprimem à boa parte dos solos pampianos algumas características peculiares, tais como a presença sistemática de cores brunadas e amareladas (Latossolos, Nitossolos e Argissolos), bem como solos com o caráter ebânico (SISTEMA..., 2013), que é determinado por cores escurecidas na maior parte do perfil (Chernossolos). Essas condições climáticas atuais produzem também uma estacionalidade fisiológica vegetal típica de clima frio e seco, com intenso processo de evapotranspiração, principalmente no Planalto da Campanha. A porção oriental do Bioma Pampa apresenta clima fortemente influenciado pela presença oceânica, com maior umidade, favorecendo a invasão das paisagens campestres por contingentes arbóreos representantes das florestas estacional decidual e ombrófila densa, notadamente nas partes norte e leste, caracterizando um processo de substituição natural das estepes por formações florestais, em função da mudança climática de frio e seco para quente e úmido, no atual período pós-glacial. Essas paisagens campestres, assim como as do Planalto das Araucárias (inseridas no Bioma Mata Atlântica), estão em desarmonia com o clima florestal atual e representam um espaço de imigração de pontas de fluxos florísticos arbóreos tropicais (pluviais e estacionais) interiores e costeiros. 
A flora do Bioma Pampa tem vínculos com troncos florísticos antigos, migrados em diferentes fases da geo-história regional, com fluxos insulares, ligados ao centro florístico austral-antártico, e com fluxos andinos, por meio das planícies ocidentais emergidas do mar no Quaternário (MAPA..., 2004a). O Pampa constitui também um dos grandes centros de formação de Cactaceae, de Bromeliaceae, além de Orchidaceae (LUTZENBERGER, 1997). Apesar da escassez de indivíduos arbóreos no bioma, algumas espécies de cactos regionais são epífitas. Outras estão adaptadas a ambientes de afloramentos rochosos de pequenas extensões, desenvolvendo-se nos lageados ou sobre matacões (Figura 62). Dentre as espécies vegetais importantes, estão o butiá-yataí, o espinilho (Figura 63), o inhanduvai e o capim santa-fé. Além da alta diversidade vegetal que aí se verifica, a flora do Pampa existente nos campos, banhados, capões e matas ciliares é bastante peculiar, rara e muito ameaçada. A Flora do Brasil registra para o bioma um total de 1623 espécies, entre as quais 1495 Angiospermas, dois Gimnospermas, 115 Briófitas, seis fungos e cinco Samambaias e Licófitas. No contexto das espécies endêmicas, o Pampa totaliza 279, em sua maioria Angiospermas (263), um Gimnosperma e 15 Briófitas (LISTA..., 2010). Boldrini (2009) destaca, no contexto da Lista de Espécies Ameaçadas de Extinção no Rio Grande do Sul, a ocorrência de 146 táxons no Bioma Pampa (dos quais 28 comuns com a Mata Atlântica, que totaliza 85 táxons). Nesse grupo, as famílias mais encontradas são: Cactaceae, com 50 espécies; Asteraceae, com 40; Poaceae, 25; Bromeliaceae, 20; e Amaranthaceae e Fabaceae, com 15 espécies.

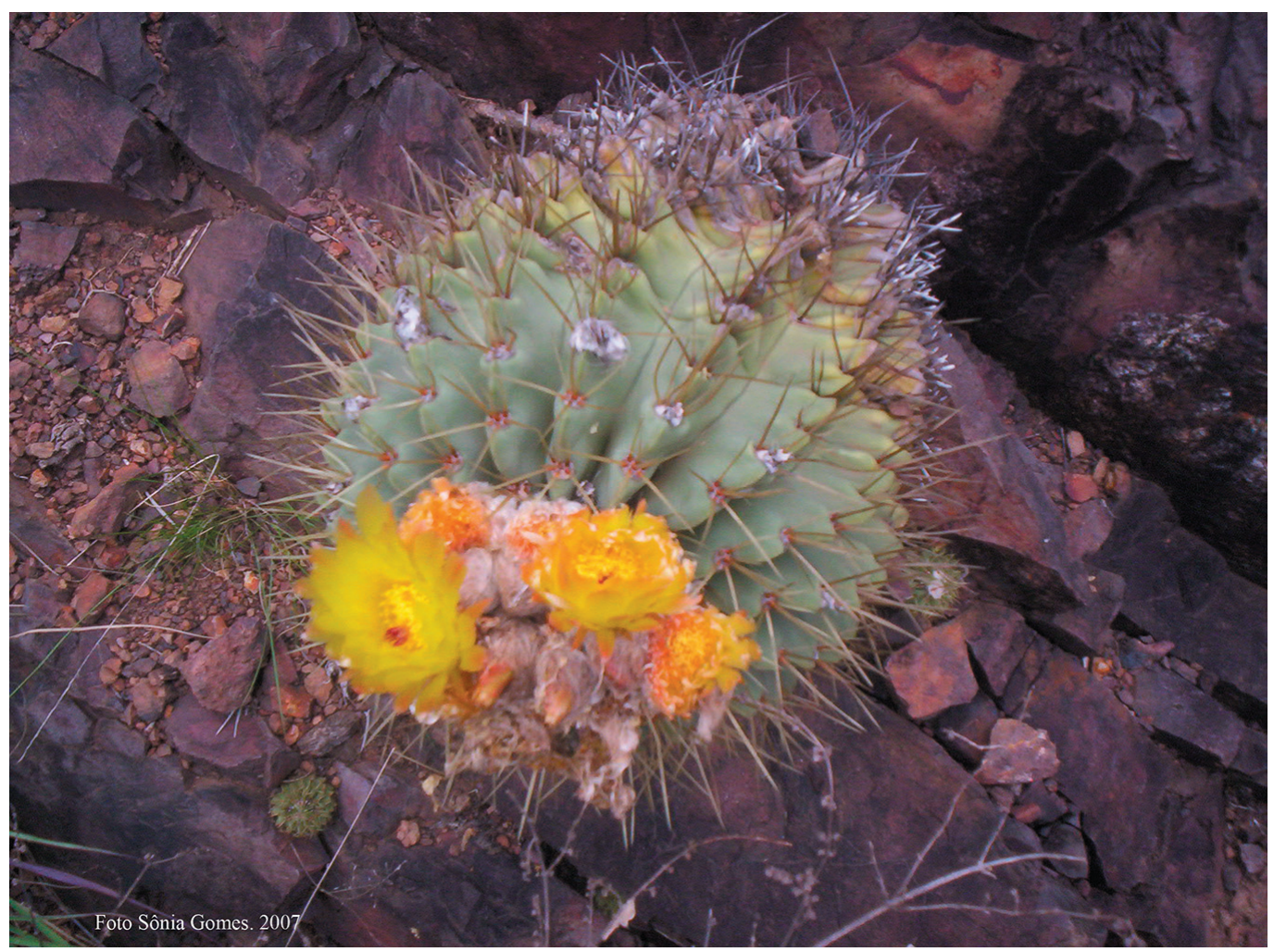

Figura 62 - Cactos desenvolvidos nos lageados do Planalto da Campanha. Foto: Sônia Gomes. 


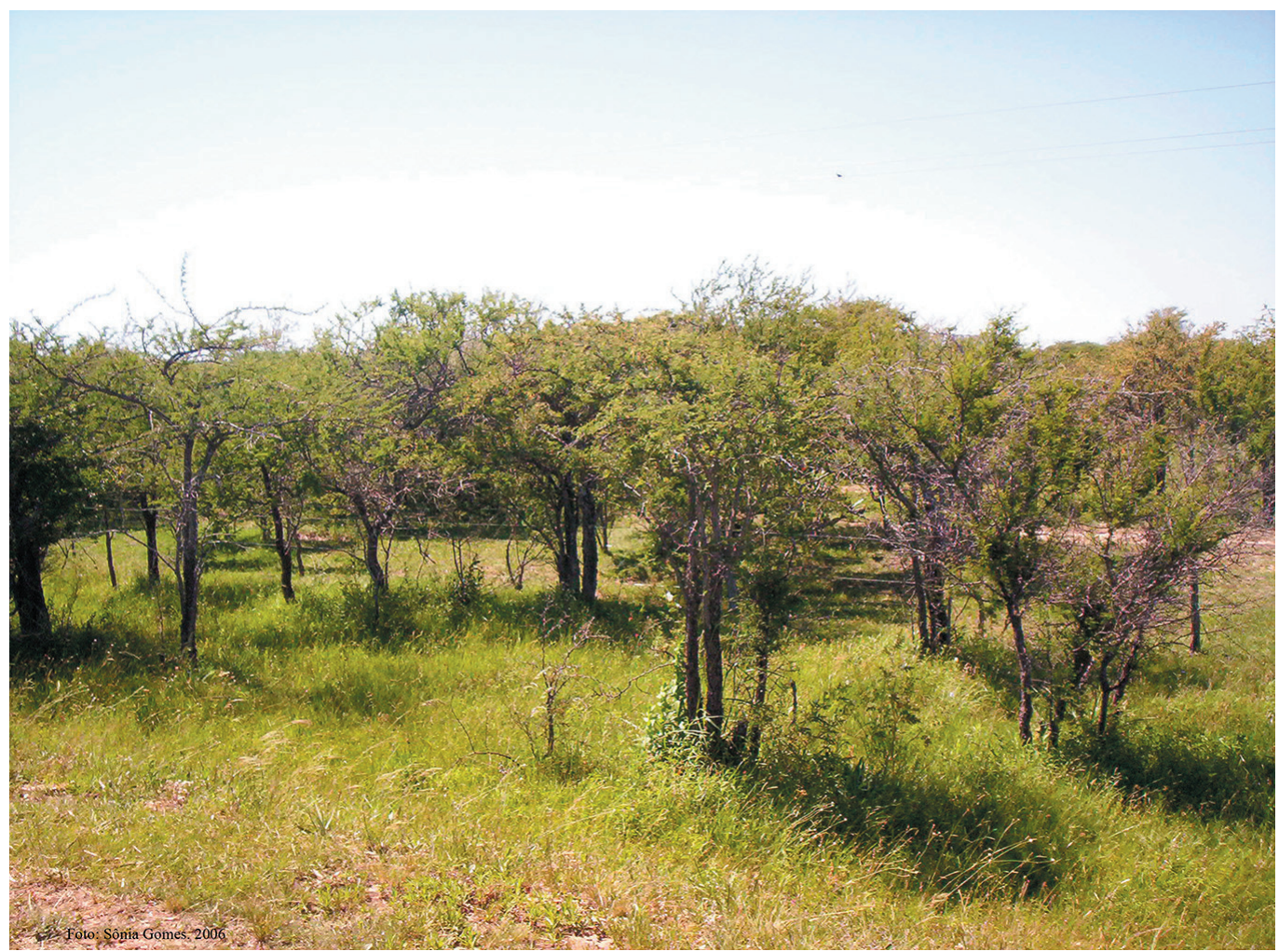

Figura 63 - Espinilhos, espécie arbóreo-arbustiva que forma ecossistema único no Parque Estadual do Espinilho, Município do Barra do Quaraí (RS).

Foto: Sônia Gomes.

Os ecossistemas naturais que compõem o Bioma Pampa, notadamente as formações campestres, apresentam também alta diversidade de espécies animais e reúnem algumas das espécies mais abundantes e emblemáticas da fauna gaúcha, tais como a ema, a perdiz, o quero-quero, a caturrita, o joão-de-barro, o zorrilho e o graxaim-do-campo ou "sorro", entre outros (BENCKE, 2009).

Muito embora as informações disponíveis não permitam estimativas muito precisas sobre a riqueza de espécies dos diferentes grupos da fauna para o bioma, a partir de compilações diversas, pode-se indicar que cerca de $1 / 4$ das espécies de mamíferos não voadores do Rio Grande Sul (25 espécies) habitam os ambientes campestres dos Pampas e da Mata Atlântica, das quais 14, de forma exclusiva, e 11, de forma facultativa ou em combinação com outros habitats. De forma análoga, esses ambientes campestres abrigam cerca de 120 espécies de aves nativas continentais, 97 espécies de répteis e 50 espécies de anfíbios. Cumpre destacar que várias dessas espécies de aves, répteis e anfíbios dos campos pampianos são compartilhadas com os encraves de campos planálticos da Mata Atlântica, um padrão biogeográfico que evidencia que essas áreas campestres estiveram unidas em uma época não muito remota, provavelmente isolando-se a partir da recente expansão das Florestas Ombrófilas (BENCKE, 2009). Cumpre observar que essas estimativas não incluem as espécies que ocupam habitats exclusivamente não campestres do Bioma Pampa. 
Também bastante característicos da fauna do Bioma Pampa são os peixes anuais, que habitam charcos rasos temporários das várzeas e planícies inundáveis inseridas em zonas campestres ou costeiras do sul do Brasil, Uruguai e Argentina, além do Chaco. Peixes anuais são encontrados apenas na forma adulta, durante um período relativamente curto do ano, sobrevivendo durante a seca na forma de ovos enterrados no lodo, que eclodem no ciclo seguinte de inundação anual. No Pampa brasileiro, são conhecidas 18 espécies de peixes anuais do gênero Austrolebias.

O conhecimento sobre a fauna de invertebrados do Bioma Pampa é bastante rudimentar, mas inventários recentes de lepidópteros diurnos, realizados com metodologia padronizada, no Pampa e nos Campos de Cima da Serra, têm evidenciado a estrita associação de borboletas da subfamília Satyrinae - sobretudo as do gênero Pampasatyrus - com ambientes campestres preservados, sugerindo que esses lepidópteros possam servir como indicadores da qualidade ambiental dos campos. Outro grupo a destacar é o das abelhas solitárias nativas das famílias Andrenidae e Colletidae, que mantêm uma estreita relação de dependência mútua com algumas espécies de plantas encontradas no Pampa, com alguns exemplos notáveis de coevolução (BENCKE, 2009).

Pelo menos sete espécies de vertebrados podem ser consideradas endêmicas das formações campestres do Bioma Pampa (cinco espécies de peixes do gênero Austrolebias; a cobra-coral Micrurus silviae; e o mamífero tuco-tuco). O macuquinho-da-várzea é compartilhado entre os Campos do Pampa e os Campos Planálticos da Mata Atlântica. Outras 13 espécies de vertebrados (duas aves, três répteis e oito anfíbios) ocorrem exclusivamente nos Campos Planálticos, Campos de Cima da Serra e Campos Gerais do Bioma Mata Atlântica. Outros endemismos importantes são compartilhados pelos campos pampianos do Rio Grande do Sul, Argentina e Uruguai, enquanto outros ocorrem associados aos ambientes florestais ou aos ambientes costeiros do Bioma Pampa brasileiro.

No contexto das espécies ameaçadas de extinção no Rio Grande do Sul, 21 espécies são usuárias obrigatórias de campos e dependem diretamente desses ecossistemas para sua sobrevivência. Outras 11 utilizam formações campestres de forma facultativa, a maioria das quais ocorre em mosaicos formados pelo contato entre formações vegetais abertas e Florestas Estacionais ou com araucária. Um terceiro conjunto de espécies ameaçadas ocupa as Matas-de-Galeria, corpos d'água sazonais e turfeiras. Nesse grupo, também se incluem algumas espécies aquáticas restritas ao domínio dos Campos Sulinos (ao menos no Rio Grande do Sul), principalmente moluscos bivalves. Pelo menos em parte, as 17 espécies desse grupo parecem depender da dominância fisionômica dos campos na paisagem (BENCKE, 2009).

O Bioma Pampa engloba quatro unidades de relevo: Planalto da Campanha, Depressão

\section{Central, Planalto Sul-Rio-Grandense e Planície Costeira.}

No Planalto da Campanha Gaúcha, predomina o relevo suave ondulado originário do derrame basáltico com cobertura vegetal gramíneo-lenhosa, podendo ser considerada como a área core do Bioma Pampa no Brasil. Essa unidade de relevo foi modelada predominantemente em rochas basálticas da Formação Serra Geral; apenas uma pequena parte foi esculpida em arenitos interderrames dessa formação, bem como em arenitos eólicos das sequências sedimentares gondwânicas (Formação Botucatu). 
A morfologia dessa unidade de paisagem é generalizadamente plana, sub-horizontalizada, com as áreas interfluviais com a forma de "coxilhas", das quais se destacam algumas, como as "coxilhas" de Santana, da Cruz, Maçambará, do Espinilho e do Caverá. Ressaltam, também, na paisagem dessa unidade, o "cerro do Jarau" (Figura 64) e certas áreas restritas, caracterizadas por topografias ruiniformes chamadas "guaritas". O "cerro do Jarau", localizado cerca de 20 quilômetros a noroeste da Cidade de Itaqui, corresponde, em superfície, a uma estrutura circular, marcada nas efusivas básicas da Formação Serra Geral. Resultado da atuação dos processos erosivos num "domo estrutural", essa estrutura expõe, no seu interior, arenitos e siltitos da Formação Rosário do Sul e, nas suas bordas elevadas, arenito da Formação Botucatu. Os arenitos interderrames ocorrem principalmente nas vizinhanças da Cidade de Alegrete e entre esta localidade e Itaqui, sempre sob a forma de pequenas manchas de até cerca de 20 quilômetros quadrados de área. Os arenitos eólicos (Formação Botucatu) ocorrem em pequena extensão, junto ao limite leste dessa unidade de relevo com a Depressão Central Gaúcha.

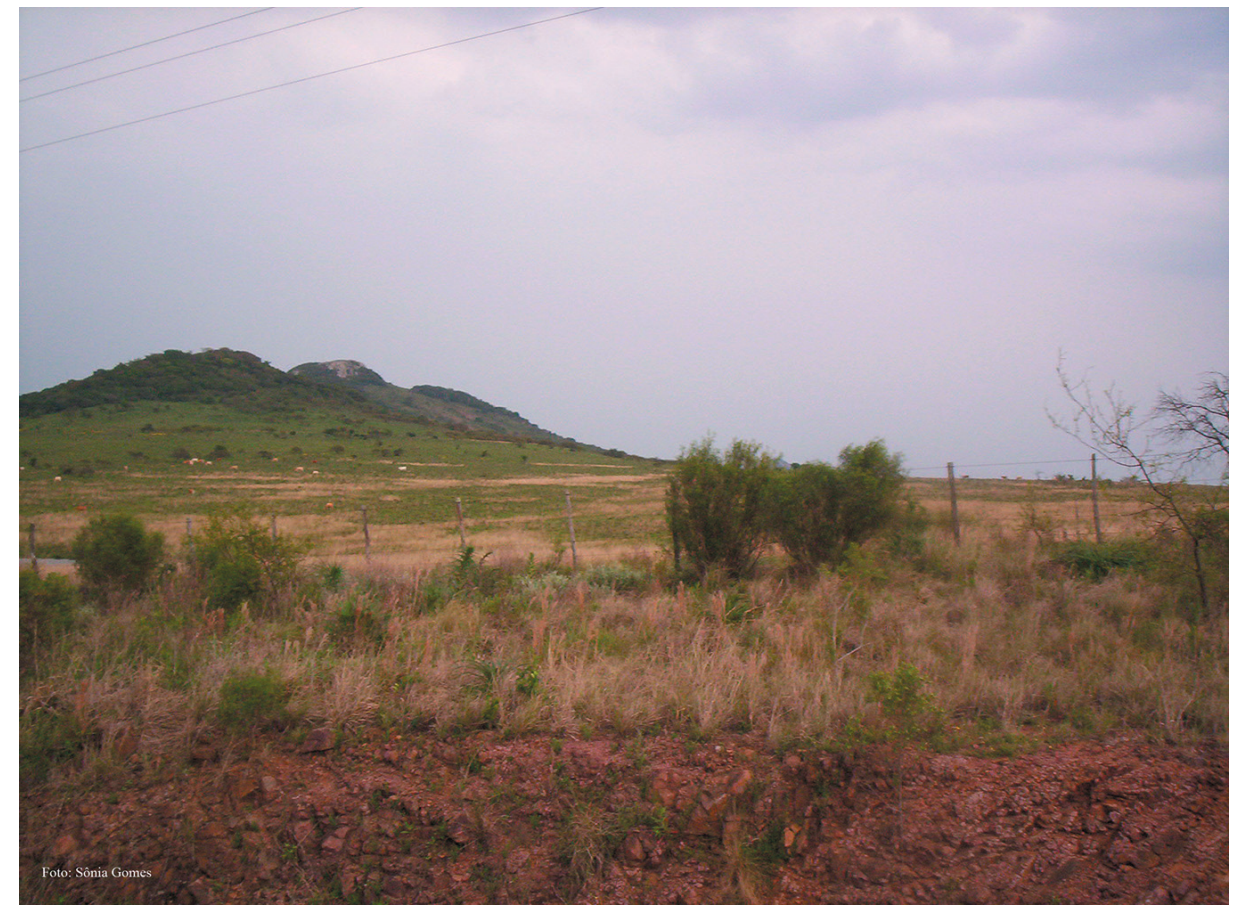

Figura 64 - Cerro do Jarau, Município de Jarau (RS). Foto: Sônia Gomes.

O único bem mineral conhecido no Planalto da Campanha Gaúcha é a ametista. Pequenas ocorrências dessa pedra semipreciosa localizam-se na metade sul desse planalto, sobretudo nas vizinhanças do Município de Quaraí (RS). Ela atapeta geodos ou forma massas esferoidais dentro de derrames vulcânicos da Formação Serra Geral.

Na porção mais ao norte, onde se encontra o chamado Planalto das Missões (Figura 65), os solos, mormente derivados das rochas do derrame basáltico, como os Latossolos Distroférricos e Nitossolos Eutróficos, são de boa potencialidade agrícola e suportam agricultura intensiva. 
Nessa região, ainda resta uma pequena área de Campos de barba-de-bode, situada a noroeste, ainda não convertida pela agricultura. A vegetação deste campo é relictual, de um período geológico mais seco, com muitos representantes da flora procedentes do Brasil Central, em meio as quais destacam-se as Rubiaceae, Fabaceae e Malvaceae (como a douradinha-do-campo, que está na lista de espécies ameaçadas de extinção no Rio Grande do Sul (BOLDRINI, 2009).

(b)

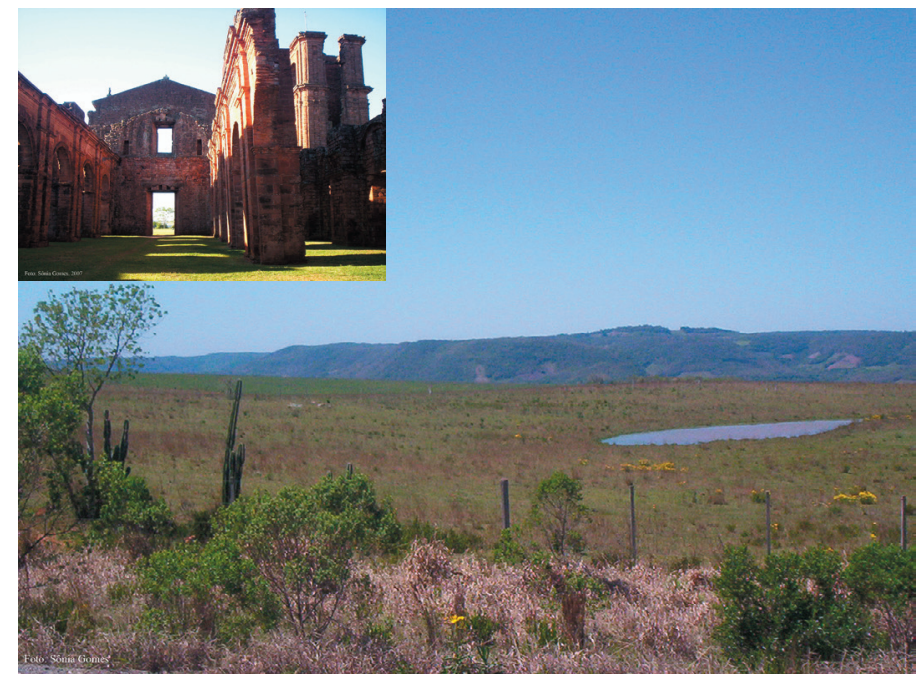

Figura 65 - Ruínas de São Miguel das Missões (a) e Planalto das Missões (b), que deve seu nome às missões jesuítas ali instaladas nos séculos XVII e XVIII. Foto: Sônia Gomes.

Na porção mais ao sul, na região da Campanha propriamente dita, as condições de frio bastante intenso e chuvas não muito abundantes contribuíram muito para a formação de solos de pequeno desenvolvimento e, quase sempre, com teores de matéria orgânica elevados, conferindo à boa parte dos mesmos coloração escura em quase todo o perfil, o que motivou a denominação desta região como "província dos ebânicos" no meio pedológico. A porção localizada no extremo sudoeste tem o predomínio absoluto de Chernossolos Ebânicos, conforme consta no trabalho de Cunha e outros (2001) sobre os solos do Município de Barra do Quaraí (RS), e no Mapa de solos do Brasil (2001), do IBGE. Além desses solos, Cunha e outros (2001) apontaram a ocorrência, em menor proporção, de Planossolos Háplicos, Nátricos e Gleissolos. Na porção leste deste compartimento (área de drenagem dos Rios Santa Maria e Ibicuí), predominam Planossolos, seguidos de Gleissolos (MAPA..., 2001), ambos eutróficos, que depois de submetidos à drenagem se prestam bem à exploração com lavouras. Nessa região, encontram-se os "Campos de solos profundos da Campanha", com presença marcante das gramíneas estivais, como as de hábito cespitoso ${ }^{21}$ (capim-caninha) e as rizmatosas, como o capim-forquilha, além das hibernais, como a flechilha e o cabelo-de-porco, em meio as quais desenvolvem-se ciperáceas, em locais muito úmidos. Nesses campos, são também registradas espécies procedentes dos Pampas argentino e uruguaio.

21 Diz-se das plantas que crescem lançando novos brotos ou caules de maneira aglomerada, geralmente formando uma touceira ou espesso tapete. 
A parte central da Campanha é constituída principalmente por solos rasos do tipo Neossolos Litólicos desenvolvidos sobre o substrato basáltico (MAPA..., 2001). Tais solos apresentam muitas limitações naturais à agricultura e normalmente são usados com pastagens (Figura 66). Nessa região, ocorrem os "Campos sobre solos rasos", com baixa retenção de umidade e associados ao déficit hídrico do verão, com predominância de gramíneas cespitosas de baixo porte. Nos locais onde os solos se apresentam um pouco mais profundos, registra-se um estrato contínuo de gramíneas rizomatosas ${ }^{22}$ e estoloníferas ${ }^{23}$, como a grama tapete, entremado por leguminosas, como o amendoim-nativo e ababosa-do-campo.

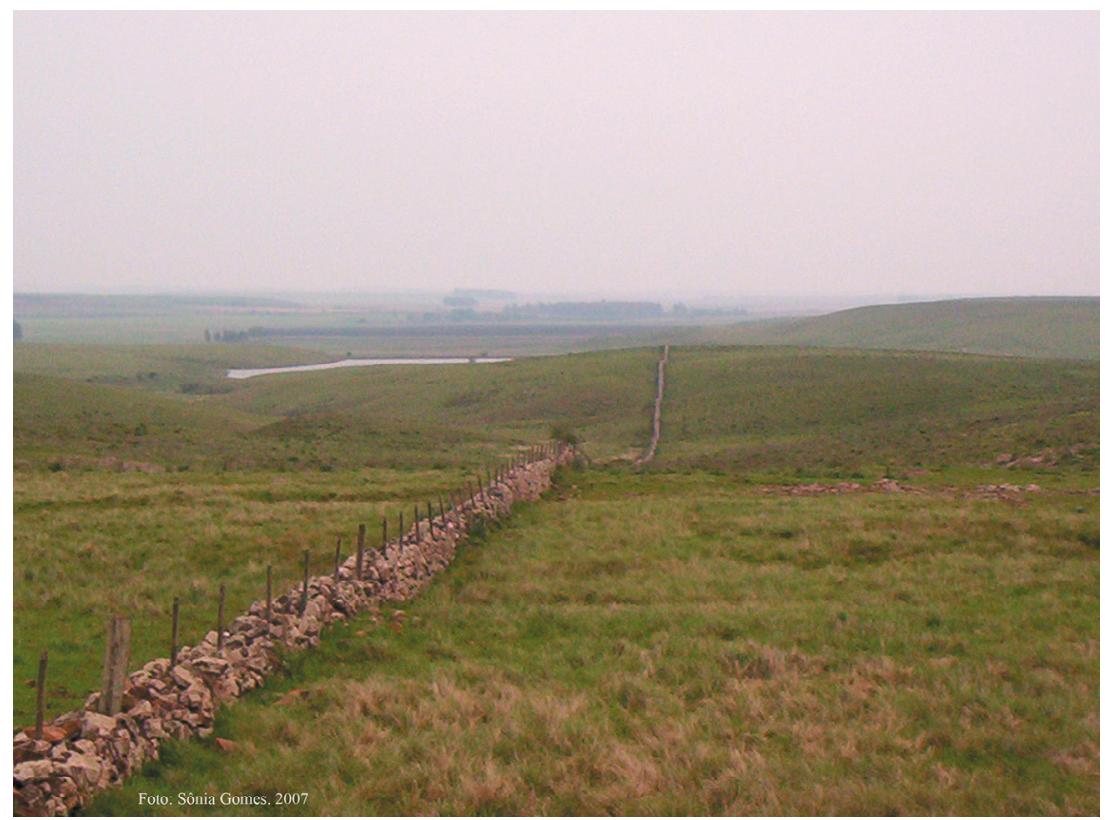

Figura 66 - Pastagem em área de ocorrência de Neossolos Litólicos, desenvolvidos sobre basaltos, Município de Quaraí (RS). Foto: Sônia Gomes.

Os processos erosivos atuantes no Planalto da Campanha Gaúcha têm levado ao surgimento de áreas onde o risco de "arenização" é constante. Equivocadamente, este fenômeno foi chamado inicialmente de "desertificação". Com efeito, não existe verdadeiramente um deserto sob o ponto de vista climático no sul do Brasil. A existência dos areais está ligada ao domínio de um paleoclima Quaternário predominantemente árido, que formou os depósitos semelhantes ao loess e que são constituídos por siltes de origem eólica, incoerentes, compostos também por seixos de quartzo, feldspato, calcita e dolomita. Os areais se restringem quase que exclusivamente à área de ocorrência do arenito da Formação Botucatu, desenvolvendo-se, inicialmente, associados à base dos cerros pela ação das águas de escoamento superficial, em áreas onde as formações superficiais são de textura francamente arenosa e, por isso mesmo, extremamente friáveis. O processo de desagregação é contínuo, cabendo aos ventos de forte

\footnotetext{
22 Plantas com caule que cresce horizontalmente, geralmente subterrâneo.

23 Plantas com crescimento de caule na horizontal, emitindo raízes e folhas na vertical.
} 
intensidade que ocorrem no bioma, especialmente os provenientes do quadrante sul, em função de sua elevada capacidade de transporte, promoverem uma intensa ação eólica de deflação que retrabalha os depósitos arenosos pouco consolidados. As áreas com declividade inferior a 10,0\% são aquelas preferencialmente invadidas pelos areais, muito embora eles também ocorram em declividades maiores.

A região de ocorrência de areais (Figura 67) está localizada no sudoeste do Rio Grande do Sul, a partir do meridiano de $54^{\circ}$ em direção oeste até a fronteira com a Argentina e o Uruguai (SUERTEGARAY; GUASSELLI; VERDUM, 2001). Nesta porção do território gaúcho, onde o Pampa avança para a Argentina e o Uruguai, a arenização dos solos tem afetado cerca de 10 municípios, como Alegrete, Uruguaiana, Quaraí, Itaqui e, principalmente, São Francisco de Assis. O solo arenoso descoberto gerou a área conhecida como "Deserto do Alegrete", onde se encontra a mais expressiva extensão desse processo na zona rural. Alegrete apresenta uma área total de 7669 quilômetros quadrados, dos quais, aproximadamente, 0,14\% são ocupados por areais. Nessa região, são encontrados os "Campos dos areais", onde o capim-limão e Elionurus sp. determinam sua fisionomia. Muitas plantas que se desenvolvem sobre este substrato frágil possuem estruturas especiais para lidar com as condições ambientais severas, especialmente no verão, tais como: a) estruturas subterrâneas, como rizomas e xilopódios, desenvolvidas provavelmente para suportar o estresse hídrico; e b) partes aéreas com muita pilosidade ou ainda com folhas coriáceas ou cerosas e glandulares, para suportar altas temperaturas, falta de água e ventos fortes, reduzindo a evapotranspiração. Habitam este ambiente, espécies latescentes, como as euforbiáceas e as apocináceas, e com óleo, como o capim-limão, substâncias que servem possivelmente para evitar a predação por animais (BOLDRINI, 2009).

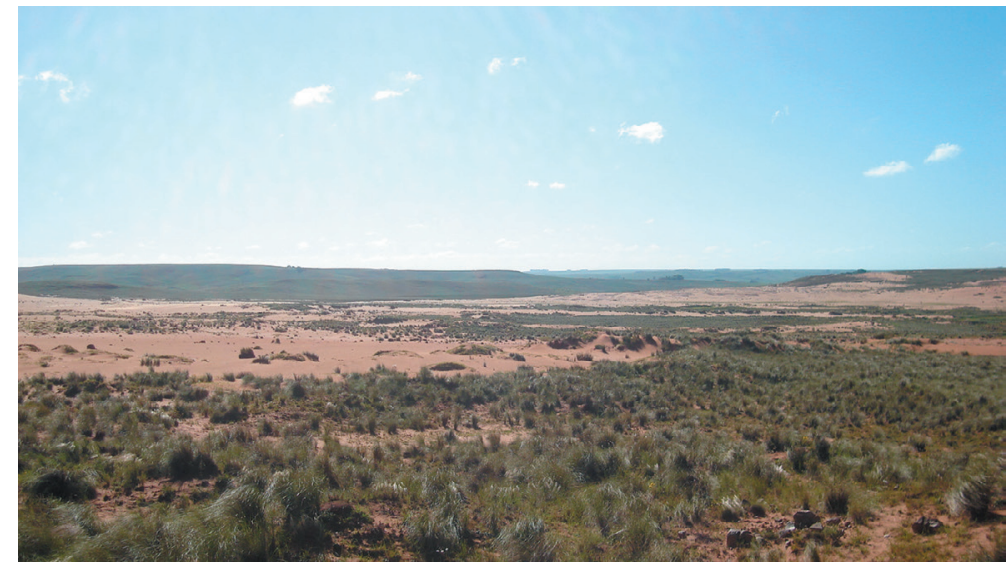

Figura 67 - Areais entre os Municípios de Santana do Livramento e Quaraí (RS).

Foto: Fernando Peres Dias.

A "arenização" deve ser entendida como um processo de retrabalhamento das formações superficiais e dos solos arenosos a partir de uma certa inconstância no regime pluviométrico associada a uma discreta deficiência hídrica, muito embora não se possa tipificar a ocorrência de uma estação seca bem-definida no Brasil Meridional. Mesmo em se tratando de um fenômeno natural, sobre o qual existem registros desde o Século XIX, sabe-se, com certeza, que a ocupação agrícola, em função da intensa mecanização utilizada nas culturas do trigo, soja e, principalmente, do arroz, tem acelerado significativamente o desenvolvimento desse processo, sobretudo a partir de meados do século passado. 
Conforme ressaltado por Suertegaray, Guasselli, Verdum (2001), o processo de arenização decorre, inicialmente, da evolução da dinâmica geomorfológica, onde se associaram processos hídricos e eólicos, subjugados aos condicionantes topográficos. O contato litológico abrupto que ocorre entre os depósitos arenosos inconsolidados e os sedimentos da Formação Botucatu facilitou a aceleração do avanço dos processos de ravinamento e voçorocamento, que rapidamente alcançaram os depósitos pelo carreamento do material erodido pela água e pelo vento. Assim, gradativamente, o material foi transportado para áreas mais baixas topograficamente, formando os areais.

A fragilidade ambiental dessas áreas tende a aumentar significativamente quando incorporadas ao processo produtivo agrícola de forma mais intensiva. Tanto o superpastoreio pela pecuária extensiva, desenvolvida sem o manejo de pastos e adoção de técnicas de manutenção e conservação do solo para reduzir o impacto do pisoteio, como as lavouras intensivas de capital, caracterizadas pelo grande aporte de maquinário pesado e pela rotação das lavouras de inverno e verão, podem ter contribuído para a aceleração do processo de formação desses grandes areais. Paula e Robaina (2003) comentam que, "nas últimas décadas, o homem tem participado como um agente acelerador dos processos modificadores e de desequilíbrio da paisagem", em razão da adoção de práticas agrícolas não compatíveis com a fragilidade do Bioma Pampa.

Embora a área plantada com soja tenha sido bastante reduzida na década de 1990, os impactos por ela gerados evoluíram, em especial no que se refere ao favorecimento dos processos erosivos, e demandam ações de controle rigoroso para conter o avanço do processo de arenização no sudoeste do estado.

A Depressão Central Gaúcha compreende, sobretudo, terrenos da Cobertura Sedimentar Gondwânica (Bacia do Paraná), formando uma faixa semicircular sinuosa entre Porto Alegre (a leste); Santiago e Alegrete (a oeste); e Santana do Livramento, Dom Pedrito e Bagé (no centro-sul), isolando o Planalto Sul-Rio-Grandense, na porção sudeste do estado. Corresponde a uma área sem grandes variações altimétricas (maiores cotas ao redor de 200 metros), onde dominam as formas de relevo denominadas coxilhas - formas amplas e alongadas, de topos convexos ou planos, com encostas caindo suavemente em direção aos vales. O contato dessa depressão, a noroeste, com o Planalto das Araucárias, e, a oeste, com o Planalto da Campanha Gaúcha, é brusco e escarpado. Nas proximidades desse contato, na superfície da depressão, destacam-se inúmeros residuais de topo tabular (morros-testemunho), constituídos por rochas básicas dos derrames vulcânicos da Formação Serra Geral e/ou arenitos eólicos resistentes da Formação Botucatu. As formações sedimentares se estruturaram no espaço de tempo situado entre o Permiano e o Jurássico, tendo como ambiente mais frequente de deposição o ambiente marinho de águas rasas. Tais formações são constituídas por litologias de granulação geralmente fina - na maior parte, argilitos, siltitos e folhelhos - com intercalações de calcário e raríssimos conglomerados.

Os bens minerais das formações sedimentares gondwânicas consistem em combustíveis fósseis e rochas carbonáticas. Os combustíveis fósseis compreendem camadas de carvão mineral (14 jazidas e sete ocorrências), integrantes da Formação Rio Bonito, bem como camadas de folhelho pirobetuminoso (algumas ocorrências) pertencentes à Formação Irati. Desses bens, o mais importante é o carvão mineral (Figuras 68 e 69), cujas reservas totais (somatório das reservas: medida, indicada e inferida) somavam aproximadamente 23,9 bilhões de toneladas 
no ano de 2004, de acordo com o Anuário Mineral Brasileiro 2005, do Departamento Nacional de Produção Mineral - DNPM. Com relação à extração desse bem mineral, observa-se que doenças respiratórias, por longo tempo, têm acometido mineiros envolvidos com essa atividade. A implantação de equipamentos que reduzem a quantidade de poeira inalada durante a atividade laboral, como máscaras especiais e sistemas de exaustão, tem contribuído para a redução dos casos de enfermidades pulmonares, muitas vezes fatais, registradas historicamente.

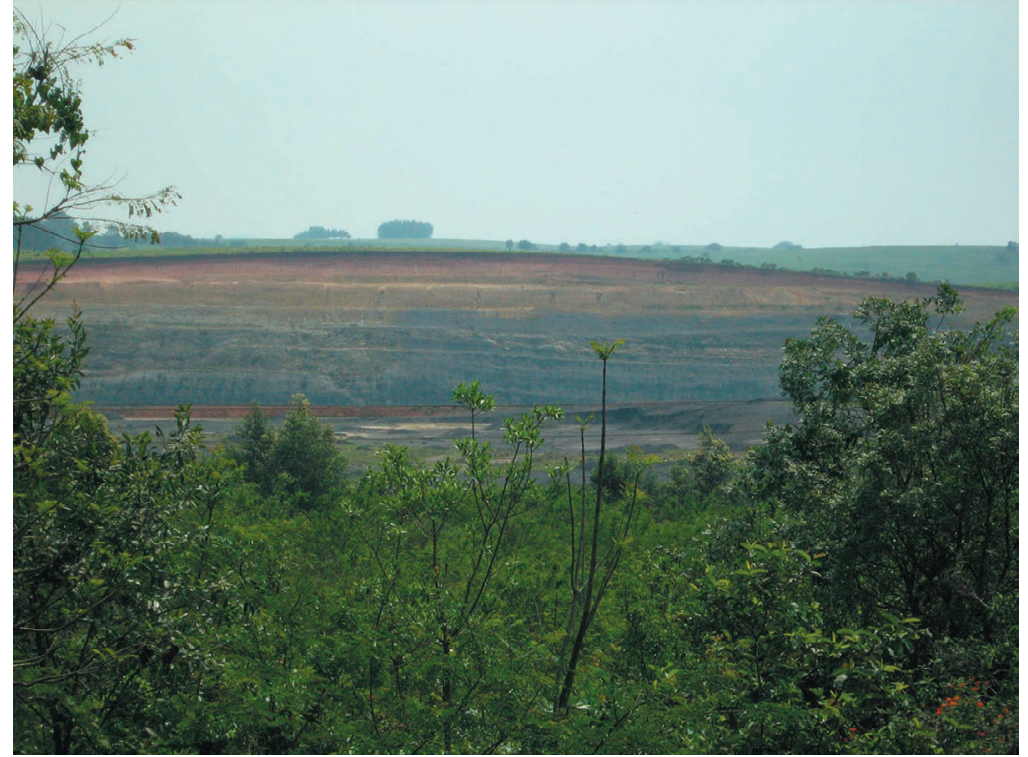

Figura 68 - Extração de carvão em Minas do Leão (RS). Foto: Eloisa Domingues.

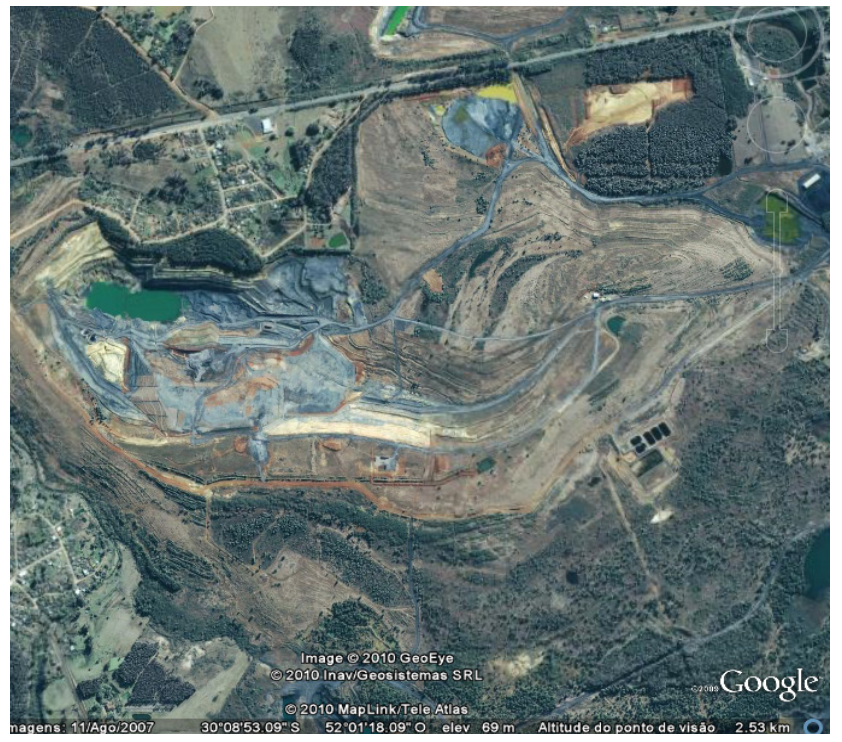

Figura 69 - Mineração de carvão no Município do Leão (RS). Imagem capturada no Google Earth em 2010. 
Os carvões do sul do Brasil são essencialmente usados na geração de energia elétrica (usinas térmicas a carvão). Além das questões associadas à saúde dos trabalhadores, outros fatores restringem o potencial de utilização destes carvões, tais como o baixo potencial energético, o alto teor de cinzas e a elevada produção de gases de efeito estufa $\left(\mathrm{CO}_{2}\right)$, por unidade de energia produzida com a queima dos mesmos.

As rochas carbonáticas, importante bem mineral utilizado em várias indústrias, ocorrem na mesma formação em que se localizam as camadas de folhelho pirobetuminoso - a Formação Irati - e sob a forma de lentes e camadas. Têm sido utilizadas na produção de cimento, cal, corretivo de acidez de solos e mármore comercial, entre outros produtos.

A Depressão Gaúcha é caracterizada por fisionomia campestre (gramíneo-lenhosa e herbácea), classificada como "Campos do centro do estado", com predominância de compostas entremeadas às gramíneas e composição de famílias botânicas mais semelhantes aos campos da Serra do Sudeste (BOLDRINI, 2009). Associada a esses campos, ocorrem Florestas-de-Galeria degradadas que, em geral, são compostas por espécies arbóreas deciduais. Quando comparada ao ambiente do Planalto da Campanha, ela apresenta maior disponibilidade de umidade, motivada pela maior regularidade pluviométrica e/ou pela maior concentração de drenagem e de depressões do terreno. Associadas à densa rede de drenagem, formaram-se extensas planícies sedimentares aluviais (Planícies e Terraços de Sistemas Fluviais), como ao longo das Bacias do Jacuí, Vacacaí e Santa Maria, onde predominam Planossolos Háplicos Eutróficos e outros solos hidromórficos como os Gleissolos. O uso agrícola nessas áreas é possível a partir de práticas de drenagem artificial. Nestas áreas é comum o cultivo de arroz (Figura 70).

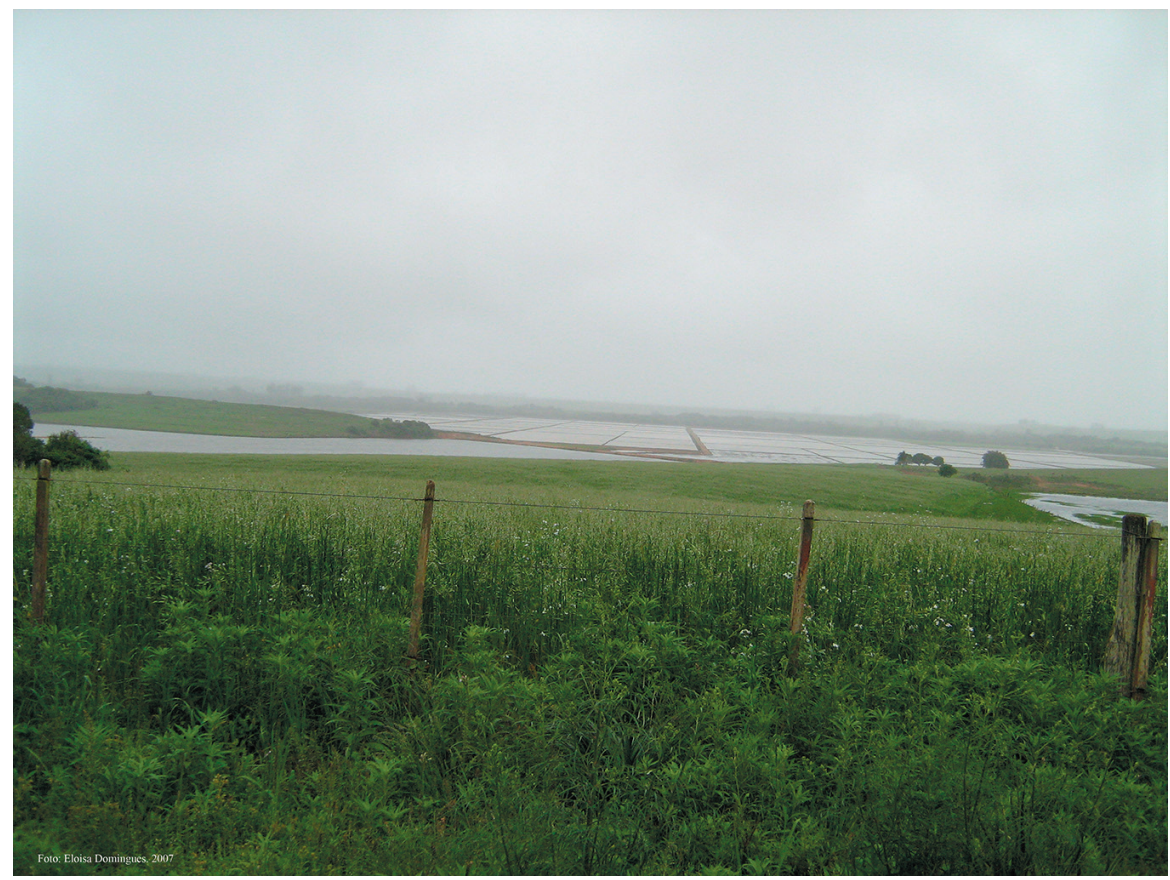

Figura 70 - Cultivo de arroz nas várzeas dos Rios Jacuí e Pardo. Foto: Eloisa Domingues. 
De modo geral, os rios do Bioma Pampa têm pouco volume de água em grande parte do ano, fato relacionado diretamente o caráter intermitente das nascentes. $O$ ressecamento das áreas onde se localizam muitas nascentes deve ser atribuído ao desmatamento generalizado ocorrente em todo o bioma, que não poupa nem estas áreas, e à inconstância do regime pluviométrico contemporâneo. Além desse fato, deve-se registrar que a rizicultura irrigada consome consideráveis volumes de água dos rios, alterando significativamente as condições hidrodinâmicas e contribuindo em muito para os decrescentes débitos fluviais registrados no Bioma Pampa. As Formações Pioneiras e as Florestas-de-Galeria foram, quase em sua totalidade, substituídas por culturas e pastagens (Tabela 5).

Tabela 5 - Áreas remanescentes e áreas antropizadas, no Bioma Pampa, segundo os tipos de vegetação

\begin{tabular}{|c|c|c|c|c|c|c|}
\hline \multirow{3}{*}{ Tipos de vegetação } & \multicolumn{6}{|c|}{ Bioma Pampa } \\
\hline & \multicolumn{2}{|c|}{ Total no Bioma } & \multicolumn{2}{|c|}{ Área Remanescente } & \multicolumn{2}{|c|}{ Área Antropizada } \\
\hline & $\begin{array}{c}\mathrm{Em} \\
\mathrm{km}^{2}\end{array}$ & $\begin{array}{c}\text { Percentual } \\
(\%)\end{array}$ & $\begin{array}{c}\mathrm{Em} \\
\mathrm{km}^{2}\end{array}$ & $\begin{array}{c}\text { Percentual } \\
(\%)\end{array}$ & $\begin{array}{c}\mathrm{Em} \\
\mathrm{km}^{2}\end{array}$ & $\begin{array}{c}\text { Percentual } \\
(\%)\end{array}$ \\
\hline Área total do bioma & 176496 & 100,0 & 103835 & 59,0 & 58636 & 33,0 \\
\hline Floresta Estacional Semidecidual & 6210 & 3,0 & - & - & 6210 & 100,0 \\
\hline Floresta Estacional Decidual & 3340 & 2,0 & - & - & 3340 & 100,0 \\
\hline Savana Estépica & 1607 & 1,0 & 428 & 27,0 & 1179 & 73,0 \\
\hline Estepe & 122682 & 70,0 & 100980 & 82,0 & 21702 & 18,0 \\
\hline Formações pioneiras & 20974 & 12,0 & 2033 & 10,0 & 18940 & 90,0 \\
\hline Contatos entre tipos de vegetação & 7658 & 4,0 & 394 & 5,0 & 7264 & 95,0 \\
\hline Superfície com água & 14025 & 8,0 & - & - & - & - \\
\hline
\end{tabular}

Fonte: Mapa de biomas do Brasil: primeira aproximação. Rio de Janeiro: IBGE, 2004. 1 mapa. Escala 1:5 000 000. Disponível em: <ftp://geoftp.ibge.gov.br/informacoes_ambientais/vegetacao/mapas/brasil/biomas.pdf>. Acesso em: jul. 2016.

Notas: 1. Corresponde a 2,0\% da área total do País.

2. Data média de referência: 1996.

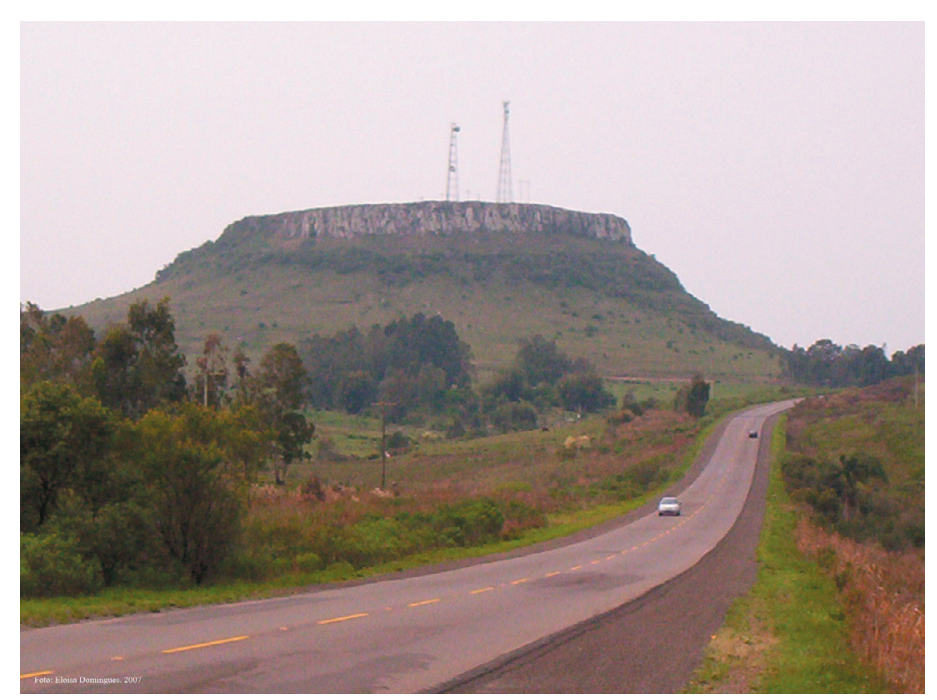

Figura 71 - Cerro de Palomas, Município de Santana do Livramento (RS). Foto: Eloisa Domingues.
Igualmente contemporâneo é o desenvolvimento e a recorrência de processos erosivos de forte intensidade ligados ao escoamento fluvial, fato este que, em alguns casos, provoca fortes retomadas erosivas a montante. A exacerbação destes processos tem levado a degradação ambiental, em algumas áreas, a extremos, com a abertura de muitos sulcos, ravinas e até mesmo voçorocas, estas últimas especialmente junto à base dos cerros mesetiformes (Figura 71).

O Planalto Sul-Rio-Grandense compreende o denominado Escudo Cristalino ou Escudo Sul-Rio-Grandense (CARVALHO, 1932), ou, conforme registra seguidamente a bibliografia geológica, simplesmente "terrenos pré-cambrianos" do Rio Grande do Sul. 
Estes são compostos pelas rochas do Cráton Rio de La Plata (terrenos granito-gnáissicos de evolução pré-brasiliana) e do Cinturão Móvel Dom Feliciano (remanescente dos orógenos brasilianos), as mais antigas do Bioma Pampa, do Neoarqueano (2,8 a 2,5 bilhões de anos atrás). As outras unidades geológicas do Bioma Pampa formaram-se no Fanerozoico, de 570 milhões de anos aos tempos atuais.

O Planalto encontra-se isolado entre a Planície Marino-Lagunar (a leste) e a Depressão Central (a norte, oeste e sul), alcançando altitudes superiores a 300/400 metros. Seus terrenos são mais altos, no contexto regional, e regados com maior intensidade pelas chuvas devido à influência marinha. Em razão disso, a cobertura vegetal natural é mais complexa, compondo-se das Estepes Arbórea Aberta, Parque e Gramíneo-Lenhosa, com marcante presença de Formações Florestais Estacionais Semideciduais, especialmente na face oriental próxima à Lagoa dos Patos. Muitas dessas áreas, originalmente ocupadas por subarbustos, arbustos e árvores de baixo porte, em decorrência da ampliação das áreas para pastagens, corte e queimadas, agora vem se apresentando como vegetação campestre, com o maior equilíbrio entre gramíneas e compostas, e presença de leguminosas, ciperáceas e rubiáceas. Associada a esses campos, ocorre uma vegetação rupestre com muitas cactáceas endêmicas (BOLDRINI, 2009).

Os solos dominantes são da ordem dos Argissolos e dos Neossolos Litólicos (MAPA..., 2001). Trabalhos de maior detalhe elaborados em alguns municípios da região (CUNHA; SILVEIRA; SEVERO, 1996; CUNHA et al., 1997, 2000) revelaram a presença de solos diversos. Dentre os mais expressivos estão os Argissolos (Bruno-Acinzentados, Amarelos e Vermelho-Amarelos) e Chernossolos, além de Neossolos Litólicos (Figura 72), todos, invariavelmente, com limitações ao uso agrícola determinadas principalmente por relevo acidentado, o que aumenta a susceptibilidade desses solos à erosão. De modo geral, predominam pastagens naturais ou manejadas.

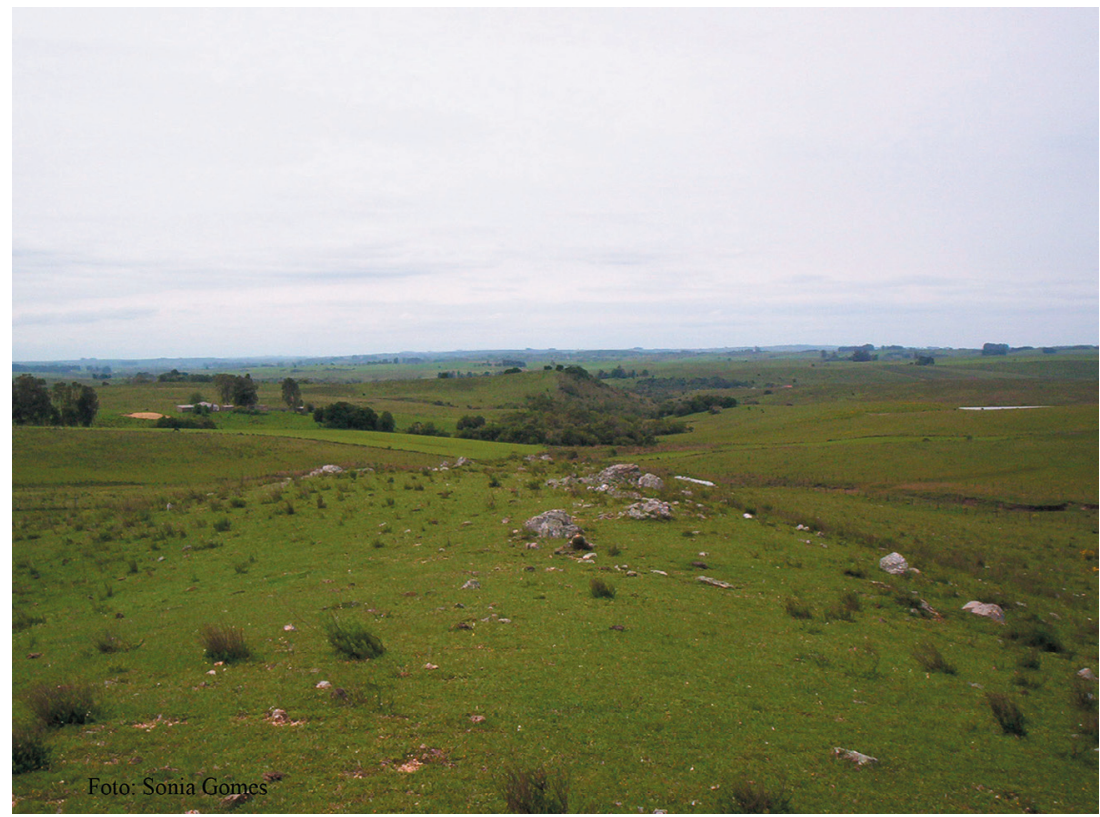

Figura 72 - Área de ocorrência de Neossolos Litólicos e afloramentos de rocha, arredores de Vila Nova do Sul (RS).

Foto: Sônia Gomes. 
Como bens minerais no Cráton Rio de La Plata destacam-se o ouro e o cobre. O ouro, que se localiza principalmente na região de Lavras do Sul, aparece sob a forma de mineralizações primárias e secundárias. As primárias consistem em filões de quartzo aurífero encaixados em intrusões graníticas ou em vulcânicas de sequências vulcanossedimentares; as secundárias estão em coluviões, bem como em aluviões dos cursos de água que percorrem as regiões das mineralizações primárias. Os teores desse metal são geralmente bastante baixos, com suas quantificações indicando que suas reservas são bem pequenas. O cobre ocorre nos Municípios de Caçapava do Sul e Lavras do Sul, onde há inúmeras ocorrências e algumas minas desse metal. As principais minas são as do Camaquã, no Município de Caçapava do Sul, responsáveis por 30000000 toneladas de minério em 1985, segundo o Anuário Mineral Brasileiro 1986. Contudo, posteriormente, em 1996, ocorreu o esgotamento total das reservas economicamente viáveis conhecidas (PAIM, 2002). Para o ano de 2004, o Anuário Mineral Brasileiro 2005 aponta o volume de cobre existente como sendo de 25134 toneladas.

$\mathrm{Na}$ área do Cinturão Móvel Dom Feliciano, os bens minerais existentes compreendem o cobre, o estanho, o tungstênio e as rochas carbonáticas. O cobre aparece em filões quartzosos (várias ocorrências) e em algumas intrusões graníticas. O estanho e o tungstênio, seguidamente associados e sob a forma, respectivamente, de cassiterita e wolframita, ocorrem em pegmatitos, em filões e como disseminações, tendo como encaixantes rochas graníticas ou xistosas. As rochas carbonáticas (mármores, calcários, dolomitos), formando simples ocorrências e também jazidas, se apresentam como camadas ou lentes encaixadas em diferentes litologias ao longo do cinturão.

A Planície Costeira compreende Terrenos Sedimentares de origem tanto fluvial quanto marinha, ocupando a faixa oriental do Estado do Rio Grande do Sul desde a fronteira com o Uruguai até a divisa com o Estado de Santa Catarina.

Evidenciando diferentes tipos de ambientes deposicionais de seus sedimentos, a Planície Gaúcha pode ser dividida em três partes: planície marinha, planície lagunar e planície alúvio-coluvionar (JUSTUS; MACHADO; FRANCO, 1986). A planície marinha abrange a região mais oriental da costa gaúcha, onde são marcantes as ações marinha e eólica, e onde predomina um litoral retilíneo, com praias que se estendem por centenas de quilômetros. Constata-se, nessa região, formações de dunas ativas ou semiestabilizadas pela vegetação, bem como terraços marinhos, alguns com sucessivos cordões de restingas. Entre os Municípios de Capão da Canoa e Mostardas ocorrem várias pequenas lagoas, que se comunicam com o oceano por meio de sangradouros, na época das chuvas.

A monotonia desse relevo essencialmente plano, de origem marinha, é interrompida, na costa gaúcha, bem próximo à divisa entre os Estados do Rio Grande do Sul e de Santa Catarina, pelo promontório de Torres (Figura 73). Constituído, na sua parte superior, por rochas efusivas básicas da Formação Serra Geral e, na inferior, por arenito da Formação Botucatu, esse relevo residual forma uma falésia na sua face voltada para o mar, as efusivas exibindo marcante disjunção colunar, além de entalhes relacionados com a abrasão marinha. Paleofalésias, bem como grutas de abrasão marinha, também podem ser observadas na região próxima a esse promontório, junto às lagoas dos Quadros, Itapeva e Sombrio (DELANEY, 1965), o que evidencia um nível de mar alto no último período interglacial. 


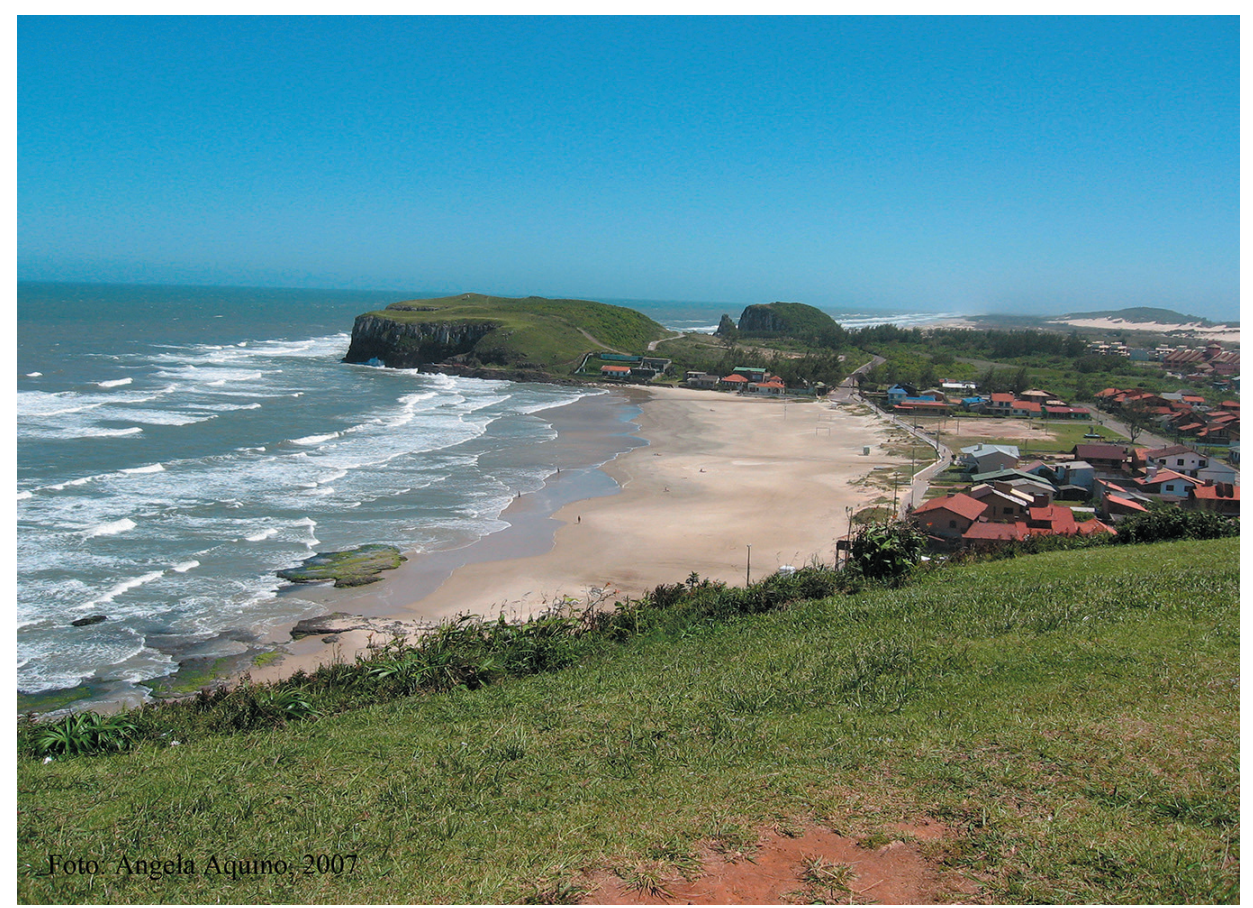

Figura 73 - Promontório de Torres, litoral gaúcho. Foto: Ângela Aquino.

A planície lagunar é a parte mais interna da Planície Gaúcha, que está mais diretamente associada às lagunas dos Patos e Mirim. Ela se caracteriza por ser uma área plana, homogênea, sem dissecação, na qual predominam modelados de acumulação, tais como planícies, cordões e terraços lacustres, entre outros. O estuário da Lagoa dos Patos e as praias oceânicas adjacentes assumem uma função crítica de interface entre ambientes marinhos/ límnicos e terrestres da planície costeira.

A Lagoa dos Patos destaca-se por ser a maior lagoa costeira do Atlântico Sul Ocidental (com cerca de 10000 quilômetros quadrados) e sua região estuarina compreende cerca de 10,0\% de sua área total. A única comunicação entre a região estuarina e o mar, que permite a entrada e a saída das diferentes espécies aquáticas que utilizam esta região, ocorre por meio de um estreito canal, localizado na extremidade sul da laguna, delimitado pelos molhes da Barra de Rio Grande, que possui apenas 4 quilômetros de comprimento e 0,5 a 3 quilômetros de largura (CHAO; PEREIRA; VIEIRA, 1985).

O estuário da Lagoa dos Patos é uma das áreas mais importantes de criação, reprodução e alimentação de organismos marinhos do sul do Brasil. A porção estuarina da Lagoa dos Patos e ambientes adjacentes possuem características propícias para o desenvolvimento de atividades de maricultura, como o cultivo de camarões marinhos. Espécies comuns da ictiofauna, ainda pouco conhecida no Bioma Pampa, são a traíra, o acará, o lambari, o jundiá e outros bagres, além do peixe-rei, espécie típica das lagoas costeiras. Contudo, os trabalhos da Secretaria de Biodiversidade e Florestas, do Ministério do Meio Ambiente, apontam apenas a área do alto Rio Quaraí como de muito alta importância para a conservação da ictiofauna do Pampa (BRASIL, 2002). 
A laguna recebe aporte de água doce de uma área de drenagem com aproximadamente 170000 quilômetros quadrados, na maior parte águas do sistema do Rio Guaíba, formado pelos Rios Jacuí, Sinos e Gravataí, que constroem o Delta do Rio Jacuí em frente à Cidade de Porto Alegre, na extremidade noroeste da laguna. Outro contribuinte menor de água doce é o Rio Camaquã, que constrói um sistema deltaico na porção central da margem oeste da laguna. As redes de drenagens combinadas dos Sistemas Fluviais Jacuí e Camaquã compõem a denominada Bacia de Drenagem do Sudeste e correspondem à metade da área do Estado do Rio Grande do Sul.

A porção alúvio-coluvionar da Planície Gaúcha é a borda oeste desta unidade de relevo, que faz contato com o Planalto Rebaixado de Canguçu (Zona Central do Cinturão Móvel

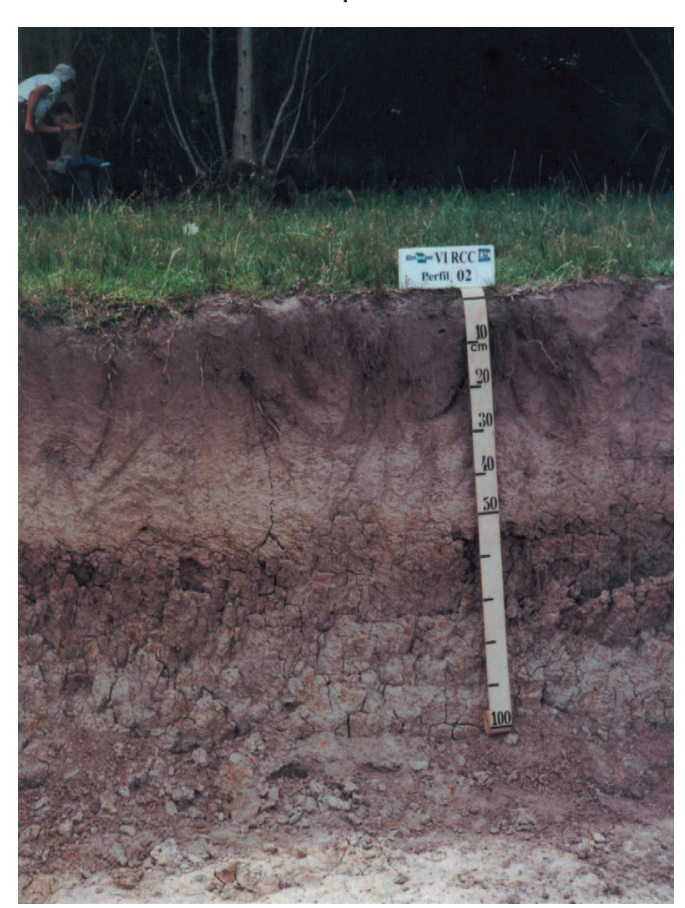

Figura 74 - Área de Planossolo Háplico Ta Distrófico, Município de Pelotas (RS).

Foto: Virlei Álvaro de Oliveira.
Dom Feliciano), limitando-se a leste com a planície lagunar por meio de rampas pouco acentuadas. Drenada pelos baixos cursos de inúmeros rios, que deságuam, em sua maioria, nas lagunas, essa área alúvio-coluvionar é constituída por depósitos oriundos da atuação de diferentes processos morfogenéticos: marinhos, eólicos, fluviais e torrenciais.

A Planície como um todo caracteriza-se pela presença de áreas aplainadas ou deprimidas, com solos, em geral, arenosos (distróficos ou álicos) ou hidromórficos, estes predominantemente da ordem dos Planossolos, Gleissolos, Neossolos Flúvicos e, em menor proporção, Organossolos (ver quadro sobre classes de solos). Na porção mais oriental, lado leste das grandes lagoas, ocorrem, junto às áreas de dunas, Neossolos Quartzarênicos em grandes proporções, enquanto nas porções mais internas predominam solos de textura mais argilosa, do tipo Planossolos (BRASIL, 1973a) (Figuras 74 e 75). Ao longo de toda a Planície Gaúcha, conhecem-se bens minerais, cuja real potencialidade não está bem-definida, destacando-se: acumulações de minerais pesados, nas praias e nos campos de dunas (concentrações principalmente de ilmenita, rutilo, magnetita e zircão), depósitos de areias, argilas, diatomitos, conchas calcárias e turfa.

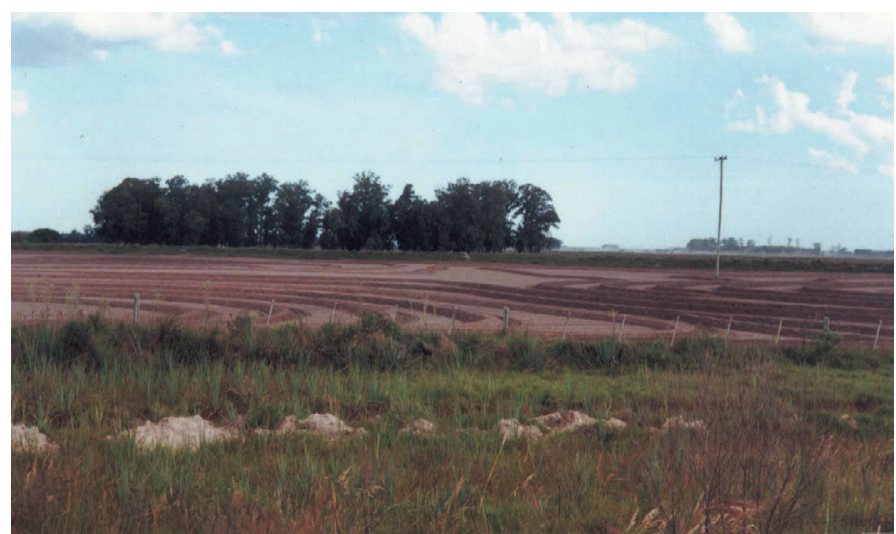

Figura 75 - Área de Planossolo Háplico drenada e preparada para plantio. Município de Pelotas (RS)

Foto: Virlei Álvaro de Oliveira. 
A cobertura vegetal natural está representada, principalmente, por Formações Pioneiras Arbustivo-Herbáceas, típicas do complexo lagunar, onde se destacam as Lagoas dos Patos, Mirim e Mangueira. As formações desses "Campos litorâneos" estão, em geral, associadas a bosques e capões de mata. Neles predominam espécies de Poaceae ("gramíneas"), em solos medianamente drenados e Cyperaceae, em solos pouco drenados. Nas matas costeiras de restinga, em geral de médio porte, são comuns algumas espécies da família Myrtaceae, como a pitangueira, espécies arbóreas da família Moraceae, entre elas a figueira, palmeiras como o butiá e, com boa frequência, espécies de bromélias e cactáceas. Nas áreas alagadas da Planície Costeira, nos chamados banhados, dependendo do grau de salinidade e nível de elevação das águas, aparece densa biomassa de vegetação constituída por espécies de gravatás, juncos e outras macrófitas aquáticas. Cabe ressaltar que entre esses banhados destaca-se o do Taim, localizado bem ao sul do estado, onde foi criada, em 1986, a Estação Ecológica do Taim (Figura 76), cuja área abrange, aproximadamente, 33000 hectares. Entre as massas de vegetais flutuantes, citam-se os aguapés. Os estudos de Irgand, Pedralli e Waechter (1984), no Banhado do Taim, exemplificam como flutuantes, entre outras, as espécies Salvinia herzogii, Lemna valdiviana e Pistia stratiotes. Entre as plantas emergentes, são comuns as espécies de junco e a espadana. Esses mesmos estudos apontam a ocorrência de 128 espécies de macrófitas aquáticas naquele banhado.

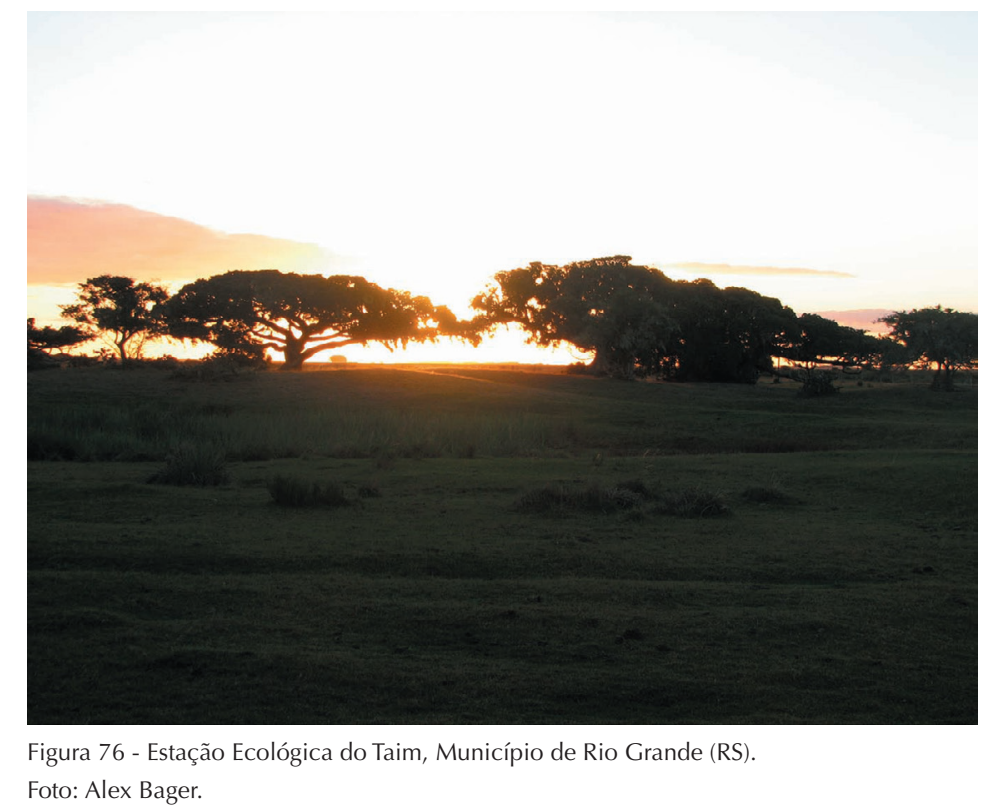

A diversidade da fauna na região dos banhados é significativamente elevada. Uma lista preliminar indica a ocorrência de 18 espécies de anfíbios na região do Banhado do Taim (GAYER; KRAUSE; GOMES, 1988). Muito frequentes são as rãs e as pererecas. São encontradas 21 espécies de répteis, com predominância de tartarugas de água doce (GOMES; KRAUSE, 1982), além da tartaruga verde-e-amarela, do jacaré-de-papo-amarelo, e, entre as serpentes, da urutu-cruzeiro. Quanto às aves, destacam-se o macuquinho-do-brejo, em perigo de extinção, e o pedreiro ou "terezinha", duas espécies endêmicas. Nos campos e bordas de alagados, é muito comum se avistar exemplares de quero-quero, ave considerada típica da região, além de grandes bandos de marrecos, entre eles a marreca-piadeira, e as tradicionais e representativas aves dos campos sul-rio-grandenses: as perdizes, a ema e o sabiá-do-banhado. 
Vale ressaltar que esta região é parte integrante das rotas de espécies migratórias que se deslocam dos Hemisférios Norte e Sul, inclusive daquelas que não se reproduzem nas latitudes de origem. Sete espécies de aves migram do norte, permanecendo nas áreas alagadas costeiras, nos meses de verão, com destaque para o batuiruçu, o maçarico-acanelado

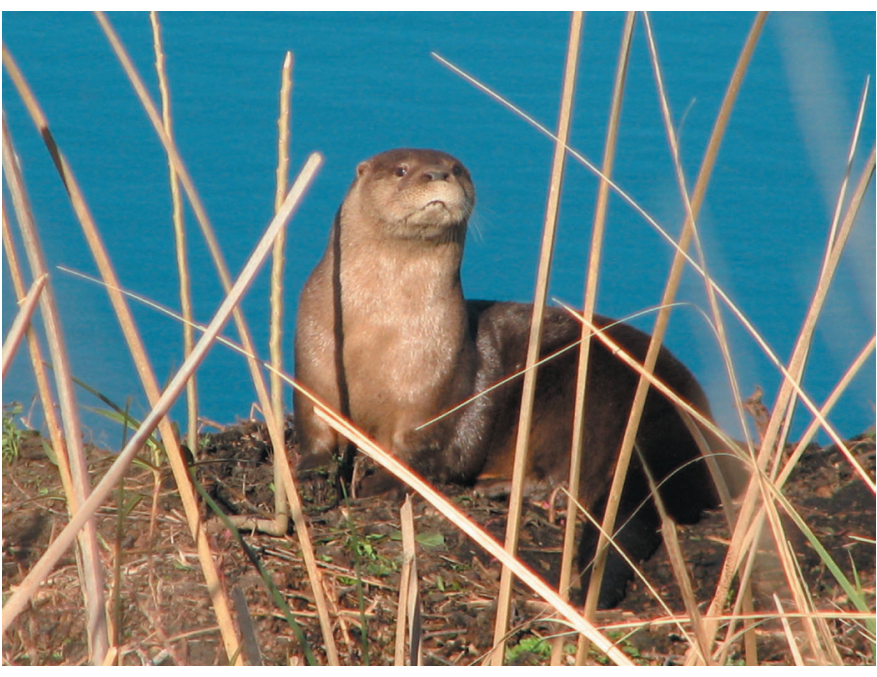

Figura 77 - Lontra, habitante comum na Estação Ecológica do Taim, Município de Rio Grande (RS).

Foto: Alex Bager.

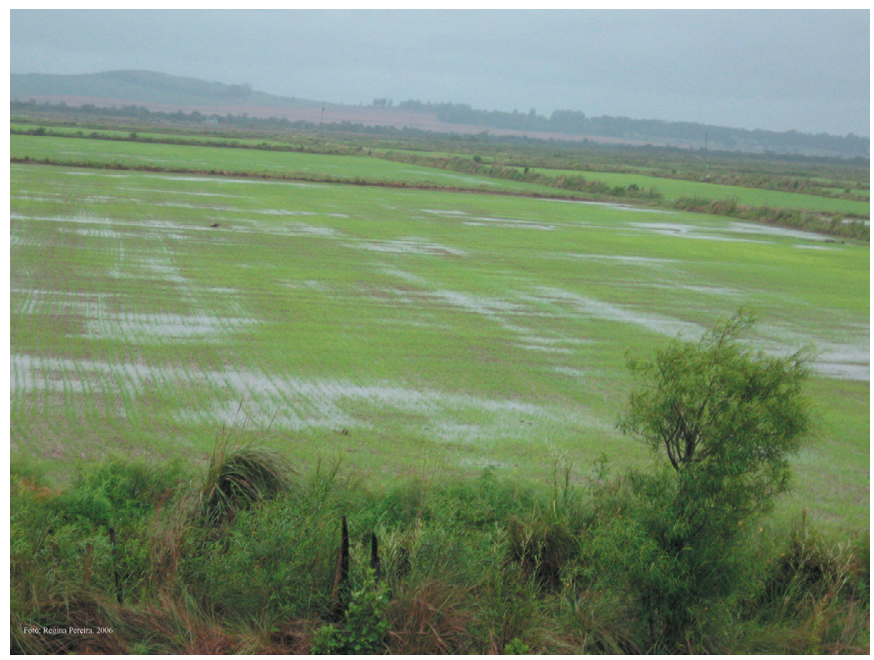

Figura 78 - Cultivo de arroz na planície lagunar, Município de Santa Vitória do Palmar (RS).

Foto. Regina Pereira. e a andorinha-de-bando, muito abundantes nos campos arenosos da planície costeira sul-rio-grandense (BENCKE, 2009). Outras cinco espécies, como os flamingos, por exemplo, vindos da Patagônia, aparecem apenas nos meses mais frios. Outras espécies meridionais, como o cisne-de-pescoço-negro e a capororoca, também chegam aos extensos banhados do Bioma Pampa, inclusive os salobres, para se reproduzirem (SICK, 1985). Também merecem destaque os pequenos papa-capins do gênero Sporophila, os caboclinhos, que se alimentam das sementes de gramíneas nativas e tendem a concentrar-se em margens capinzentas de banhados e nos campos úmidos ao longo das drenagens de regiões campestres (BENCKE, 2009). Cerca de nove espécies reproduzem-se nos campos do sul do Brasil. Após a reprodução, os indivíduos de várias espécies se juntam ao longo de suas rotas migratórias e deslocam-se até os campos tropicais do Brasil Central, onde passam o inverno e parte da primavera (BENCKE, 2009). Quanto aos mamíferos, destacam-se as capivaras e as lontras (Figura 77), muito frequentes, além do ratão-do-banhado, espécie endêmica dessa região.

De modo mais esparso, em meio à Planície Costeira, observam-se formações florestais, especialmente aquelas das terras baixas e aluviais, típicas da Floresta Ombrófila Densa. O relevo aplainado e os tipos de solo dominantes (sujeitos em maior ou menor grau a inundação ou encharcamento) favoreceram o uso da terra com pastagem natural associada ao cultivo do arroz (Figura 78). O uso do solo para o cultivo do arroz irrigado alterou o regime hidrológico da região, incluindo as Lagoas Mirim e Mangueira e o Banhado do Taim. Estes sistemas são interligados, de modo que a retirada de água para irrigação e as obras de construção de sistemas de irrigação afetam todo o sistema, principalmente em anos com déficit hídrico. 
A atividade humana pós-colonização no Bioma Pampa propiciou uma significativa homogeneização da cobertura vegetal, tanto nas áreas de Estepe quanto nas áreas de Formações Pioneiras (fluviais e lacustres), com uma acentuada diminuição das espécies lenhosas arbustivas (hemicriptófitas) em benefício daquelas dotadas de rizomas (geófitas). Atualmente, um novo processo vem se desenvolvendo e concorrendo para a modificação da paisagem campeira do Bioma Pampa. O gaúcho, descrito por Diegues (2005) como um "grupo pastoral, de cavaleiros e trabalhadores rurais vinculados à pecuária extensiva da região do pampa, vivendo no local nas grandes estâncias voltadas para a produção de gado de corte e de lã," tem presenciado a substituição dessas atividades tradicionais, que se estabeleceram desde o Século XVII, por reflorestamento (florestas comerciais) para atender à indústria de celulose no Rio Grande do Sul (Figura 79). O secular padrão de uso da terra pela pecuária em grande parte do estado encontra-se ameaçado.

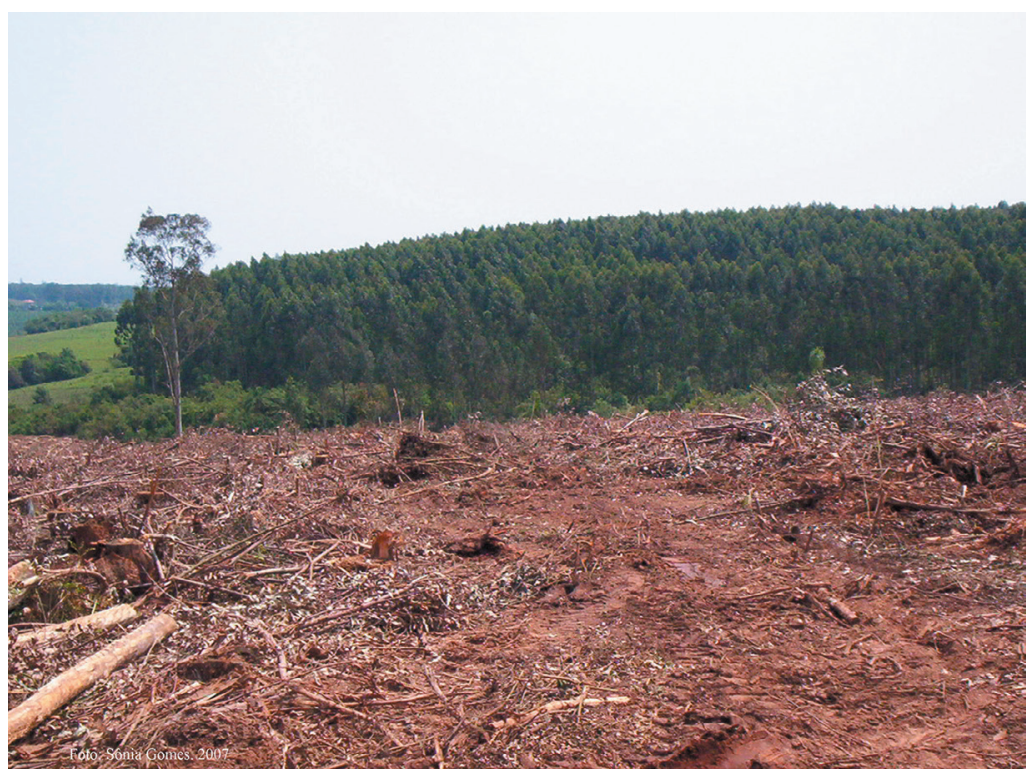

Figura 79 - Reflorestamento, Município de Caçapava do Sul (RS).

Foto. Sônia Gomes.

No debate estadual existe, atualmente, uma nítida divisão entre os que afirmam que as florestas exóticas podem ser uma alternativa para a economia de muitos municípios, e que veem na atividade a possível implantação de um novo polo madeireiro e moveleiro, e aqueles que sugerem que o Rio Grande do Sul se tornará um deserto verde. Empresas do setor de papel e celulose adquiriram grandes extensões de terra no sul do estado para a implantação da monocultura de árvores exóticas, principalmente eucalipto, acácia-negra e pinus, e já contabilizam mais de 200000 hectares plantados (AMBIENTALISTAS..., 2007). Em sua maioria são empresas de grande porte, verticalizadas, que integram todas as etapas do processo produtivo, desde a base florestal, industrialização e comercialização de papel e produtos derivados.

Com a implantação do processo produtivo voltado para a exportação, as áreas de florestas plantadas têm aumentado significativamente ano a ano. O domínio tecnológico para o manejo dos plantios, a disponibilidade de terras, a facilidade de acesso ao Porto do 
Rio Grande, aliados às características do clima e do solo, são os principais atrativos para as grandes empresas se inserirem com vantagens competitivas no mercado internacional, em especial frente aos países nórdicos. O processo produtivo no Rio Grande do Sul apresenta vantagens especiais em relação ao tempo de rotação, que chega a ser até 10 vezes menor que nos países europeus. Em sete anos, a árvore pode ser "colhida" (BELMONTE, 2005).

Enquanto isso, a Fundação Estadual de Proteção Ambiental - FEPAM - instituição reguladora de meio ambiente do Rio Grande do Sul - apresenta o Zoneamento Ambiental da Silvicultura para disciplinar os plantios de pinus, eucalipto e acácia no Pampa (ZONEAMENTO..., 2010). Segundo a Fundação, a estimativa é de que essas empresas juntas plantem 160000 hectares de árvores exóticas nos próximos 10 anos (BELMONTE, 2005). Esses dados, no entanto, diferem daqueles divulgados pela Agência de Fomento do Estado do Rio Grande do Sul (2005), segundo os quais a área plantada com pinus, eucalipto e acácia-negra deve alcançar um milhão de hectares nos próximos 10 anos, pois, nesse total, também estão incluídas as terras pretendidas por empresas de porte menor com financiamentos do ProFlora - Programa de Financiamento Florestal Gaúcho. Isso sem mencionar os financiamentos próprios de todas essas empresas. Segundo a Agência de Fomento do Estado do Rio Grande do Sul, os cálculos de outras instituições estimam que entre 3,0\% e 6,0\% dos 15,0 milhões de hectares da metade sul do estado poderiam ser ocupados pelas árvores exóticas (BELMONTE, 2005). Isso explica a enorme pressão que o estado vem sofrendo para licenciar áreas para essa atividade.

Dessa forma, a paisagem dos campos sulinos, com seus capões de árvores, os arbustos e as múltiplas pastagens com o gado solto, a fauna representativa (aves e animais terrestres), que, há tempos, é pouco vista na região, será rapidamente modificada de forma irreversível. A preocupação de ambientalistas e da população local é a da transformação dessa paisagem em "desertos verdes", como ocorreu no Estado do Espírito Santo, no Uruguai e no sul do Chile, como menciona Belmonte (2005), ao comentar as formas de descaracterização oriundas desse processo. Embora a FEPAM determine que as empresas desenvolvam projetos para reduzir os impactos negativos da exploração, e a imprensa apresente o lado positivo dessas monoculturas, a população em geral está bastante preocupada com o fato de que a paisagem possa ser totalmente alterada, transformando não apenas a paisagem física, mas também as relações sociais da produção e a cultura popular, que teve o Pampa como importante fator de construção da identidade gaúcha.

A discussão no estado avança e aponta para vários problemas, dentre eles: a redução da água disponível, em função do alto consumo de água pelas monoculturas; a intoxicação de organismos vivos e de seres humanos, devido à aplicação de dessecante químico; a perda da diversidade biológica do Pampa, com a extinção de espécies animais e vegetais dos ecossistemas primários (aproximadamente 100 tipos de árvores e arbustos e cerca de 200 espécies de gramíneas); a degradação do solo, que permanece descoberto cerca de dois anos após o plantio e nos dois anos depois da colheita, facilitando os processos de erosão e de compactação, em razão do uso de máquinas pesadas; a redução do número de empregos, uma vez que a mecanização de grande parte das etapas de trabalho reduz a demanda por mão de obra; a implantação de monoculturas de árvores para exportação em terras que iriam para reforma agrária; e o acirramento das disputas entre as empresas de celulose e as populações locais, especialmente indígenas e quilombolas. 
Dentre os impactos listados acima, vale destacar o uso do recurso água, não só em função dos "reflorestamentos" (plantio de florestas comerciais), mas também das lavouras irrigadas e das áreas urbanas. Embora o Rio Grande do Sul detenha grande parcela do Aquífero Guarani em seu subsolo, as preocupações com a perda da quantidade e da qualidade dos recursos hídricos nesse estado têm sido justificadas. A lavoura do arroz, ao contrário da soja, tem tido sua área ampliada, e sua grande demanda de água induz ao armazenamento por meio do barramento de rios, arroios e sangas ${ }^{24}$. Seu cultivo ocorre muitas vezes nas cabeceiras de drenagens, em especial nos banhados, áreas legalmente protegidas, que são também áreas importantes para a reprodução e a alimentação de várias espécies, como visto anteriormente.

Devido à significativa degradação no entorno dos cursos de água na região e à crescente preocupação com a conservação dos recursos hídricos no estado, a Secretaria do Meio Ambiente lançou, em 2003, o Programa de Restauração de Mata Ciliar, no Rio Grande do Sul, que se destina a recuperar a vegetação às margens e no entorno dos corpos hídricos das bacias hidrográficas do estado. O Programa teve como meta o plantio de aproximadamente 100000 mudas de espécies nativas por ano, visando à recuperação de 5000 hectares/ano nas Bacias dos Rios Santa Maria e Uruguai, por um período de cinco anos.

Tanto a lavoura do arroz como a da soja fazem uso intenso de agrotóxicos que, além de eliminarem uma série de espécies da fauna e da flora do Bioma Pampa ainda pouco conhecidas, são carreados pelas águas e infiltrados, contaminando rios e lençóis subterrâneos. No que se refere ao consumo de água em áreas urbanas, na maioria das bacias hidrográficas do Bioma Pampa, há forte degradação do recurso, ocasionada tanto pelo despejo de esgoto doméstico, resultado da precariedade dos serviços de saneamento básico, quanto pelo despejo de efluentes industriais.

Além dessas ameaças e da tendência à expansão das lavouras de soja - convencional e transgênica - o Bioma Pampa sofre outras ameaças, dentre as quais pode ser citada a invasão por capins exóticos, como o annoni, espécie africana invasora de extrema agressividade e de difícil controle (MEDEIROS; SAIBRO, FOCHT, 2009). Segundo os autores, a espécie já ocupa áreas expressivas de pastagens nativas também no Uruguai e na Argentina, além dos mais de um milhão de hectares registrados no Rio Grande do Sul. O enfrentamento desse problema exige um esforço amplo e profundo, integrando ferramentas de manejo de prevenção e controle, e aprimoramento dos projetos de pesquisa, que devem ser alicerçados em princípios ecológicos, multidisciplinares, integrados entre universidades e instituições de pesquisa regionais, nacionais e internacionais, empresas privadas e produtores rurais (MEDEIROS; SAIBRO, FOCHT, 2009).

De outro modo, a favor da manutenção da atividade pecuária extensiva do Pampa está sua condição de ser uma das poucas regiões no mundo onde ainda se produz carne em pastagens naturais. Do ponto de vista ecológico, o resultado é um "boi verde" com carne de alta qualidade, afirma o agrônomo Marco Antônio Hoffman (BOURSCHEIT, 2005). O especialista discorda do debate que tem sido promovido sobre o uso de índices de lotação de pasto (animal/hectare), para apoiar as propostas de parcelamento desses campos para assentamentos da reforma agrária, em vez da adoção de critério por índices de produtividade das propriedades rurais.

\footnotetext{
24 Termo gaúcho. Sanga é usado para designar pequeno curso de água, menor que um arroio.
} 
A produção de carne, tradicional na região, pode ser ampliada. Segundo Nabinger e outros (2009), estudos realizados em pastagens naturais demonstram a possibilidade de aumentar essa produção em pelo menos três vezes a média do estado e praticamente sem nenhum custo, apenas ajustando corretamente a carga animal e utilizando práticas simples de manejo de pastagens. Nabinger e outros (2009) evidenciam esse papel central da intensidade de pastagem na maioria de seus parâmetros, a começar pela sua diversidade florística e o uso da radiação solar que determina maior fixação (maior sequestro) de carbono atmosférico, o que deve, em futuro próximo, servir também como moeda de troca (crédito de carbono), valorizando ainda mais a atividade pecuária desenvolvida com base nas características naturais do bioma. Ainda, conforme os autores, o futuro promissor da pecuária de corte e também da ovinocultura de corte, dentre outros, deve unir eficientes programas de gestão e orientações técnicas, a exemplo de programas como a Rede de Referências e o Arranjos Produtivos Locais, promovendo, ao mesmo tempo, o produtor rural, o desenvolvimento regional e a proteção do Pampa.

A reflexão sobre as implicações dessa dinâmica de diferentes usos da terra e impactos ambientais somadas à discussão sobre a utilização das queimadas nos campos sul-rio-grandenses - prática vedada pela Constituição Estadual do Rio Grande do Sul, de 1989, - e ao reconhecimento do Pampa, pelo IBGE, em 2004, como um dos seis biomas brasileiros, lembram Vélez e outros (2009), vem gerando, no decorrer dos anos, a definição de projetos, políticas e ações de proteção e conservação do Bioma Pampa.

O processo de atualização das Áreas e Ações Prioritárias para a Conservação, Uso Sustentável e Repartição de Benefícios da Biodiversidade do Pampa, desenvolvido pela Secretaria de Biodiversidade e Florestas, do Ministério do Meio Ambiente, resultou em 105 áreas prioritárias, sendo 17 já protegidas e 88 novas áreas (BRASIL, 2007). No que diz respeito à importância biológica dessa flora, a mesma Secretaria (BRASIL, 2002) indica três grandes áreas para a conservação da biodiversidade, a saber: campos e matas da região central, campanha oeste e Rio Camaquã. Esse resultado traduz a atual situação do Bioma Pampa e o anseio da sociedade gaúcha, uma vez que mostra a necessidade de ampliar as áreas de proteção dos habitats e da sua biodiversidade por meio da indicação de criação de Unidades de Conservação (BRASIL, 2007).

Nesse contexto, Vélez e outros (2009) destacam várias outras ações exitosas da conservação, dentre as quais: Iniciativa de Conservación de los Pastizales del Cono Sur de Sudamérica ou Alianza del Pastiza ${ }^{25}$, com estudos e monitoramento das aves ameaçadas de extinção e migratórias, e experiências-piloto com produtores rurais visando integrar a biodiversidade no processo produtivo e difundir práticas de manejo que agreguem valor aos resultados da produção; e Iniciativa para Conservação dos Campos Temperados (TGCl), criada no âmbito do grupo de trabalho da União Internacional para Conservação da Natureza (International Union for Conservation of Natures - IUCN), com objetivo de

reverter a tendência de perda de biodiversidade e degradação nos campos temperados, por meio (i) da definição e manejo sustentável de áreas protegidas representativas, (ii) do amplo uso de práticas de manejo sustentável fora das unidades de conservação, e (iii) da duplicação do nível de proteção atual (5,5\%) até o ano de 2014 (VÉLEZ et al., 2009, p. 365).

\footnotetext{
${ }^{25}$ Que resulta da ação conjunta de quatro instituições fundadoras que participam da Federação BirdLife International, a saber: Aves Argentinas, Aves Uruguay, SAVE Brasil e Guyra Paraguay (VÉLEZ et al., 2009).
} 
Vélez e outros (2009) documentam ainda: o projeto Aglomerados Urbanos em Área Protegida, que visa promover métodos para o desenvolvimento socioeconômico da população com a tutela da natureza, mediante geração de novas rendas e fortalecimento das existentes (com instalação de unidades demonstrativas, formação profissional e promoção comercial das atividades econômicas que protegem o meio ambiente), promovendo também integração regional entre as Unidades de Conservação entre países vizinhos ${ }^{26}$; e a experiência da Associação dos Produtos de Carne do Pampa Gaúcho da Campanha Meridional - APROPAMPA, formada por produtores rurais, indústria frigorífica, varejo e outros agentes ligados à cadeia produtiva, com o propósito de produzir carne sustentável, cuidando das questões sociais, científicas e culturais da bovinocultura de corte ${ }^{27}$.

Várias outras iniciativas vêm se somando a essas, trazendo para o centro da reflexão além de todas as questões relativas à produção, desenvolvimento e conservação ambiental, também à preservação da cultura e da história gaúchas. A importância do Pampa para o Brasil transcende sua extensão, relativamente pequena, e sua localização situada no extremo sul do Território Nacional. Tanto em termos de ambiente natural (é o único bioma essencialmente campestre do País), quanto em termos históricos e culturais, o Pampa desempenha papel decisivo na construção das identidades paisagística e humana do Rio Grande do Sul e do Brasil. O Pampa é o lugar de nascimento (de "invenção") do gaúcho, personagem marcante para a história e a configuração do Território Nacional. O gaúcho foi moldado na paisagem campestre do Pampa e está tão intrinsecamente ligado a ela quanto o cavalo, o gado, as disputas de fronteira com os países vizinhos e o vento minuano. O gaúcho, nascido no Pampa, sobe o Planalto Meridional, reconfigura a identidade de imigrantes europeus ("agauchados" com o tempo), e se expande por todo o Brasil no rastro das migrações de agricultores (haja vista os Centros de Tradições Gaúchas). Mesmo hoje, com todas as mudanças de paisagem do Pampa brasileiro, este ainda é o elemento que une, reúne e individualiza os gaúchos, distinguindo-os e, ao mesmo tempo, integrando-os à diversidade do povo brasileiro.

O Pampa, único bioma brasileiro restrito a um único estado, marcou, e ainda marca, a cultura do povo gaúcho. Origem das vestimentas típicas e hábitos gastronômicos, palco de lutas históricas e célebres combatentes, o Pampa construiu, ao longo dos séculos, a identidade do gaúcho. Preservar o Pampa, além de um compromisso com a qualidade ambiental, a manutenção dos recursos naturais e o equilíbrio ecológico, é preservar essa identidade, ambos patrimônios nacionais.

\footnotetext{
${ }^{26}$ Na América Latina, Brasil (Municípios de Alegrete, Santana do Livramento, Rosário do Sul e Quaraí) e Uruguai (Rivera), além de projetos em municípios de Portugal e Itália, uma vez que o projeto se insere no âmbito do Programa URB-AL, que promove o intercâmbio entre cidades da União Europeia e da América Latina para o desenvolvimento de parcerias entre agentes locais, intercâmbios e transferência de conhecimentos e experiências sobre temas de interesse mútuo (VÉLEZ et al., 2009).

27 Em dezembro de 2006, a APROPAMA obteve, de forma inédita, junto ao Instituto Nacional da Propriedade Industrial - INPI o reconhecimento da Indicação de Procedência (IP), certificação concedida à carne originada de uma região geográfica específica, produzida dentro de regramentos específicos de produção (abate até os 36 meses, criação em pastagem nativa, ausência de suplementação e confinamento na alimentação, animais puros das raças 'Angus' ou 'Hereford' ou resultantes do cruzamento entre elas, com rastreabilidade desde o nascimento etc.) (VÉLEZ et al., 2009).
} 


\section{Mata Atlântica: espinha dorsal do País}

\section{Mapa 6 - - Bioma Mata Atlântica - Domínios Morfoestruturais}

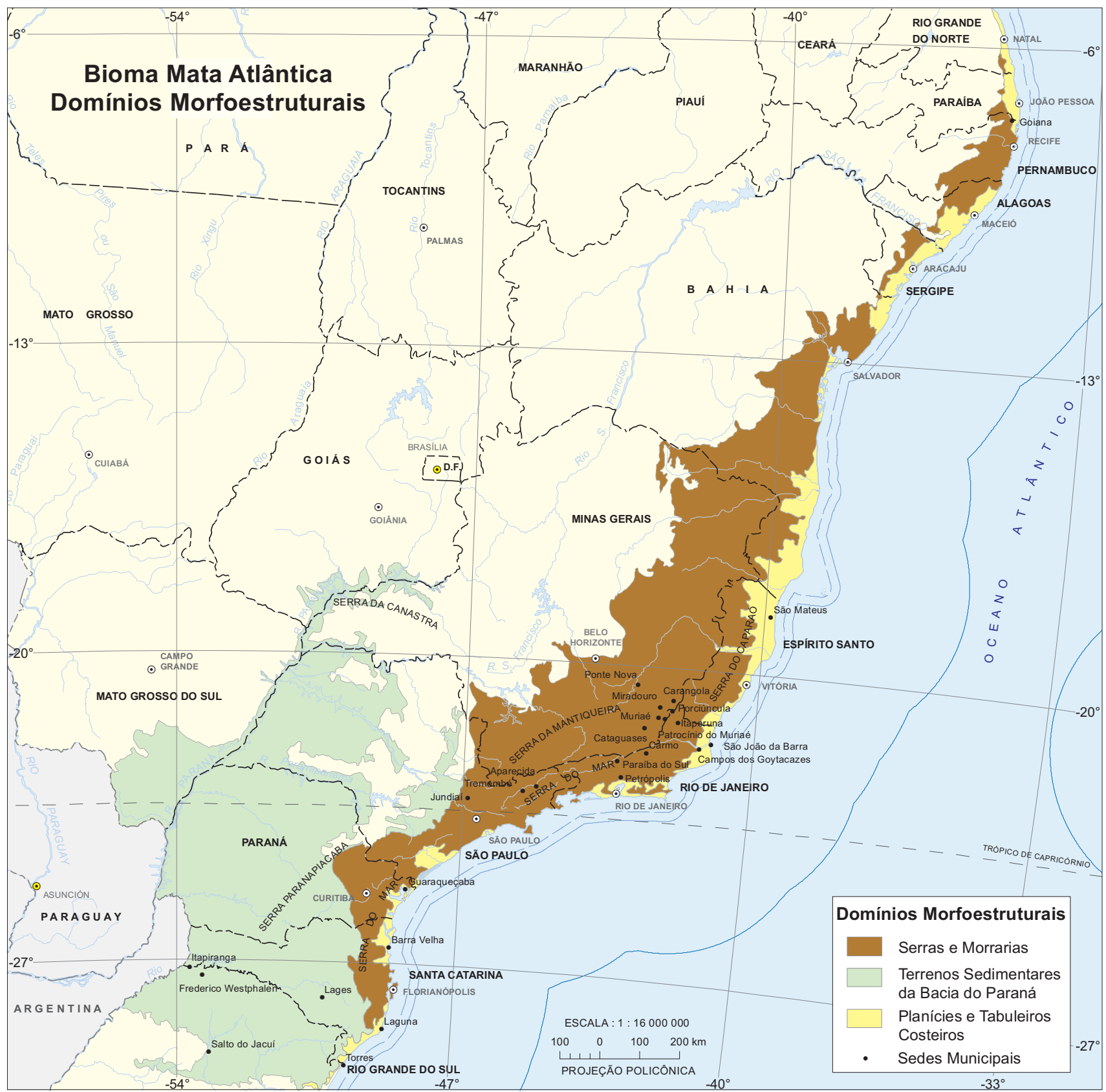

Fonte: IBGE, Diretoria de Geociências, Coordenação de Recursos Naturais e Estudos Ambientais. 
Considerando sua área de ocorrência original, o Bioma Mata Atlântica se estendia, integral ou parcialmente, por atuais 17 estados brasileiros (aproximadamente 13,0\% do Território Nacional) e avançava em porções da Argentina e do Paraguai, ocupando aproximadamente 1110182 quilômetros quadrados. O desenho formado pelos limites do desse bioma permite construir uma curiosa analogia com a espinha dorsal ou a coluna vertebral do corpo humano. Seu formato alongado e estreito, notadamente na parte superior (ao norte), e mais largo na base (ao sul), assim como as duas curvaturas - a maior, no litoral fluminense, estendendo-se até o norte catarinense, e a menor, no litoral baiano - podem ser facilmente associados às curvaturas lombar e cervical, respectivamente, da coluna vertebral humana. Contudo, não é apenas no formato ou distribuição territorial que o Bioma Mata Atlântica se assemelha à coluna vertebral, mas também na sua funcionalidade. A espinha dorsal é uma das partes mais importantes do corpo humano, pois ela é responsável pela sustentação e movimentos do corpo. Além disso, abriga a medula espinhal, que é um condutor de impulsos nervosos, importantes na produção e coordenação dos movimentos musculares e reflexos, pois exercem controle direto sobre os músculos (Figura 80).

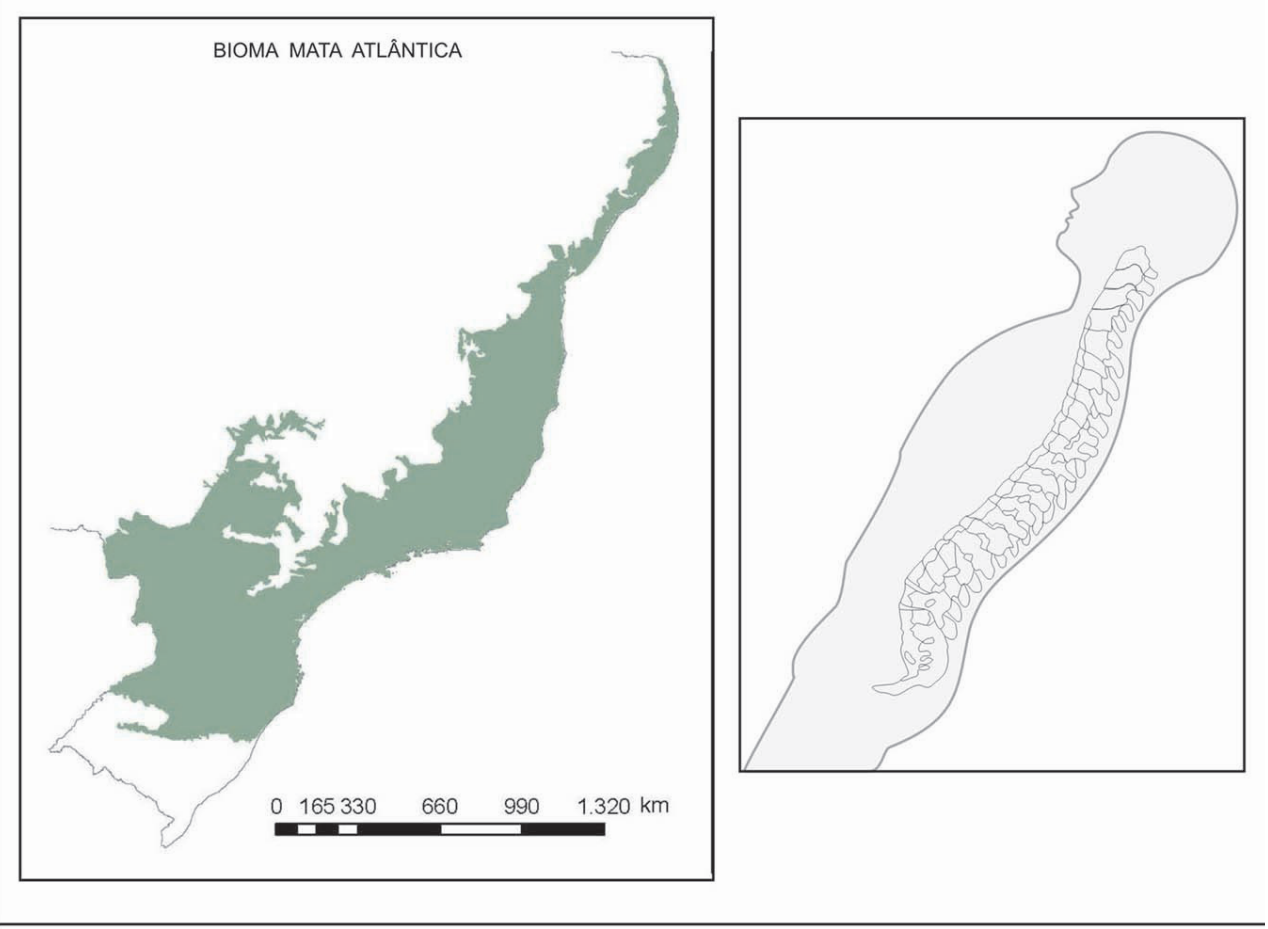

Figura 80 - Disposição do Bioma Mata Atlântica no Brasil e a coluna vertebral humana.

Ilustração: Glória Vanicore Ribeiro (arte gráfica) e Rosangela Garrido Machado Botelho (idealização).

Analogamente, pode-se dizer que a área ocupada pelo Bioma Mata Atlântica é responsável pela estruturação do Território Nacional, desde a época da colonização, quando surgiram os primeiros povoados e as primeiras cidades, abrigando, posteriormente, os principais ciclos econômicos brasileiros (pau-brasil, cana-de-açúcar e café), até os dias atuais, quando ainda comporta parcela significativa da população e dos centros urbanos que comandam a vida econômica, política e cultural do Brasil. Desta parte do País, partiram os bandeirantes, que 
desbravaram o interior e iniciaram sua colonização e exploração econômica. Dela partem grandes eixos rodoviários que interligam as diferentes regiões do Brasil, e nela estão presentes os principais portos e aeroportos, que fazem fluir mercadorias, pessoas e recursos financeiros que movimentam e sustentam o País. Nesta porção do território estão as principais cidades, cuja rede de influência se irradia, em diferentes graus de intensidade, por todo o território brasileiro, além dos principais complexos industriais, polos tecnológicos e centros de ensino e pesquisa. Sua área de abrangência tem hoje a maior densidade de população e as maiores taxas de urbanização do País.

Como resultado da intensa ocupação e do dinamismo econômico ao longo do tempo, este é o bioma brasileiro com menor área de cobertura vegetal original, ou seja, a Mata Atlântica se encontra largamente devastada, alterada e fragmentada, restando algumas áreas preservadas em Unidades de Conservação e outras em porções mais elevadas e íngremes do terreno. Ainda assim, suas reduzidas formações vegetais remanescentes abrigam uma biodiversidade ímpar, assumindo importância primordial pelos inúmeros serviços ambientais oferecidos a quase 120 milhões de pessoas que vivem nessa porção do território (CUNHA et al., 2013a).

O Bioma Mata Atlântica, dependente de maior volume e uniformidade de chuvas do que os biomas confinantes, constitui o grande conjunto florestal extra-amazônico, formado por Florestas Ombrófilas (Densa, Aberta e Mista) e Estacionais (Semideciduais e Deciduais). Cerca de $85,0 \%$ da superfície do Bioma Mata Atlântica era recoberta originalmente por formações do tipo florestal. Além dessas formações florestais, a Mata Atlântica abarca um complexo de ecossistemas associados (Tabela 6).

Tabela 6 - Áreas remanescentes e áreas antropizadas, no Bioma Mata Atlântica, segundo os tipos de vegetação

\begin{tabular}{|c|c|c|c|c|c|c|}
\hline \multirow{3}{*}{ Tipos de vegetação } & \multicolumn{6}{|c|}{ Bioma Mata Atlântica } \\
\hline & \multicolumn{2}{|c|}{ Total no Bioma } & \multicolumn{2}{|c|}{ Área Remanescente } & \multicolumn{2}{|c|}{ Área Antropizada } \\
\hline & $\begin{array}{l}\mathrm{Em} \\
\mathrm{km}^{2}\end{array}$ & $\begin{array}{l}\text { Percentual } \\
(\%)\end{array}$ & $\begin{array}{l}\mathrm{Em} \\
\mathrm{km}^{2}\end{array}$ & $\begin{array}{l}\text { Percentual } \\
(\%)\end{array}$ & $\begin{array}{l}\mathrm{Em} \\
\mathrm{km}^{2}\end{array}$ & $\begin{array}{l}\text { Percentual } \\
(\%)\end{array}$ \\
\hline Área total do bioma & 1110182 & 100,0 & 124782 & 11,0 & 964360 & 87,0 \\
\hline Floresta Ombrófila Densa & 210260 & 19,0 & 34447 & 16,0 & 175812 & 84,0 \\
\hline Floresta Ombrófila Aberta & 16696 & 2,0 & - & - & 16696 & 100,0 \\
\hline Floresta Ombrófila Mista & 167654 & 15,0 & 14504 & 9,0 & 153150 & 91,0 \\
\hline Floresta Estacional Semidecidual & 450083 & 41,0 & 4391 & 1,0 & 445691 & 99,0 \\
\hline Floresta Estacional Decidual & 91722 & 8,0 & 544 & 1,0 & 91178 & 99,0 \\
\hline Savana & 23658 & 2,0 & 14600 & 62,0 & 9058 & 38,0 \\
\hline Savana Estépica & 684 & $<0,5$ & 684 & 100,0 & - & - \\
\hline Estepe & 49669 & 4,0 & 34961 & 70,0 & 14707 & 30,0 \\
\hline Formações Pioneiras & 14117 & 1,0 & 9984 & 71,0 & 4133 & 29,0 \\
\hline Contatos entre tipos de vegetação & 64476 & 6,0 & 10543 & 16,0 & 53933 & 84,0 \\
\hline Refúgios vegetacionais & 123 & $<0,5$ & 123 & 100,0 & - & - \\
\hline Superfície com água & 21041 & 2,0 & - & - & - & - \\
\hline
\end{tabular}

Fonte: Mapa de biomas do Brasil: primeira aproximação. Rio de Janeiro: IBGE, 2004. 1 mapa. Escala 1:5 000 000. Disponível em: <ftp://geoftp.ibge.gov.br/informacoes_ambientais/vegetacao/mapas/brasil/biomas.pdf>. Acesso em: jul. 2016.

Notas: 1 . Corresponde a 13,0\% da área total do País.

2. Datas médias de referência: Região Centro-Oeste - 2000; Regiões Nordeste e Sul - 1996; Região Sudeste - 1982. 
O Bioma Mata Atlântica guarda um dos mais ricos e variados conjuntos florestais pluviais sul-americanos, somente suplantado em extensão pela Floresta Amazônica. Este quadro traduz um processo histórico de expansão de formações florestais sobre as campestres, partindo da costa para o interior, em consonância com o aumento do calor e da umidade no continente, no atual período interglacial. Neste processo, as formações ombrófilas substituem as estacionais, enquanto estas avançam sobre a Savana (Cerrado), a Estepe (campos do sul do Brasil) e a Savana Estépica (Caatinga).

A Floresta Ombrófila Densa está associada ao clima quente e úmido costeiro das Regiões Sul e Sudeste, do Brasil, sem período seco sistemático e com amplitudes térmicas amenizadas por influência marítima. Estas condições são espelhadas na grande riqueza estrutural e florística da vegetação, que, em geral, é desprovida de proteção gemular contra os rigores da seca e do frio.

Originalmente, a Floresta Ombrófila Aberta ocorria principalmente próximo ao litoral dos Estados de Alagoas, Pernambuco e Paraíba, associada a bolsões de umidade da costa nordestina, intercalando-se com outros tipos de vegetação, sobretudo a Floresta Ombrófila Densa e a Estacional Semidecidual.

Da Floresta Ombrófila Mista, restaram poucas e dispersas formações remanescentes nas Serras do Mar e da Mantiqueira e no Planalto Meridional. Neste último, em desacordo com o clima florestal de altitude reinante, ocorrem junto à Floresta Ombrófila Mista áreas disjuntas de Estepe (campos do planalto). Em relação à Floresta Estacional Semidecidual e à Decidual, suas formações primárias remanescentes ocupam situações geográficas mais interiorizadas, afastadas ou mais abrigadas da influência estabilizadora marítima, apresentando inserções disjuntas da Estepe e da Savana.

O Bioma Mata Atlântica compreende um complexo ambiental que incorpora cadeias de montanhas, platôs, vales e planícies de toda a faixa continental atlântica oriental brasileira. Nas Regiões Sudeste e Sul do País, expande-se para o oeste, alcançando as fronteiras com o Paraguai e a Argentina, avançando também sobre o Planalto Meridional até o Rio Grande do Sul. Abrange, assim, litologias do embasamento Pré-Cambriano, sedimentos da Bacia do Paraná e sedimentos cenozoicos.

Essas litologias e seus relevos associados formam três grandes domínios morfoestruturais, aqui denominados: Planícies e Tabuleiros Costeiros; Serras e Morrarias; e Terrenos Sedimentares da Bacia do Paraná, que serão discutidos a seguir:

\section{Planícies e Tabuleiros Costeiros}

As coberturas sedimentares fanerozoicas da costa, no Bioma Mata Atlântica, correspondem a formas de relevo aplainado, em diferentes estágios de dissecação, que muito bem caracterizam, do ponto de vista geomorfológico, longos trechos do litoral brasileiro: são os Tabuleiros Costeiros

Os Tabuleiros Costeiros abrangem uma faixa estreita e extensa, aplanada por processos que truncaram rochas sedimentares pliocênicas pertencentes ao Grupo Barreiras e, mais restritamente, rochas do Proterozoico. Tais formas de relevo estão modeladas sobre duas unidades litoestratigráficas do Terciário, compostas por rochas sedimentares pouco consolidadas, com estratificação, quando presente, apenas incipiente: o Grupo Barreiras e a Formação Pariquera-Açu. 
O Grupo Barreiras é formado por litologias de cores geralmente variegadas: conglomerados, arenitos, raros siltitos e argilitos. Estende-se por trechos da costa dos estados nordestinos, bem como do Espírito Santo e do Rio de Janeiro, constituindo, além de tabuleiros propriamente ditos, interflúvios tabulares e colinas semiarredondadas. Os tabuleiros, em geral, se apresentam, frente ao mar, cortados por falésias (Figura 81). É frequente a presença de níveis intermediários de crostas lateríticas bem-marcantes na morfologia típica dos tabuleiros, cuja altitude média é de 30 metros.

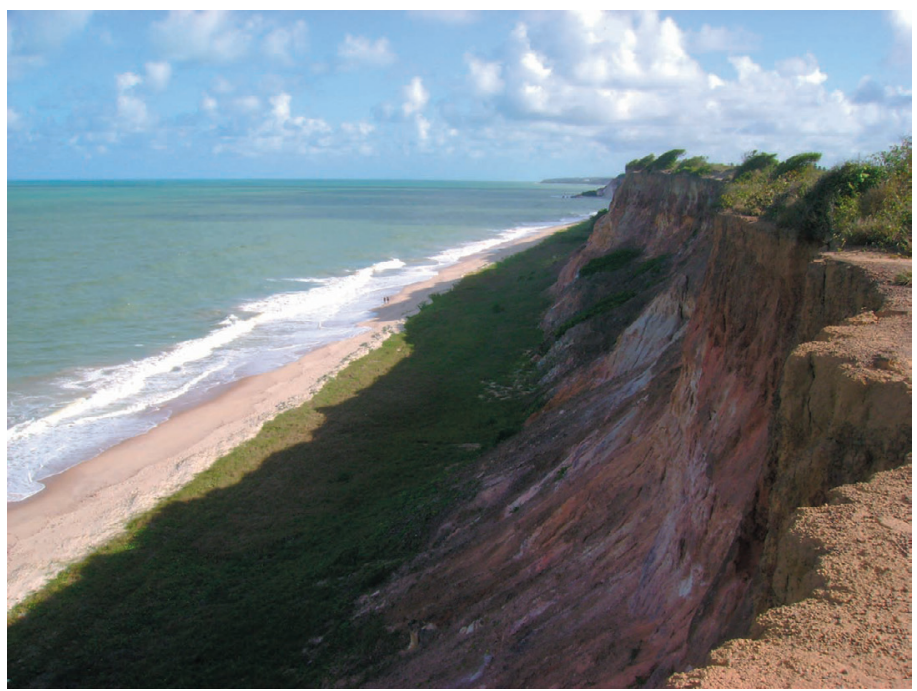

Figura 81 - Falésias desenvolvidas no Grupo Barreiras, litoral sul do Estado da Paraíba. Foto: Rosangela Garrido Machado Botelho.

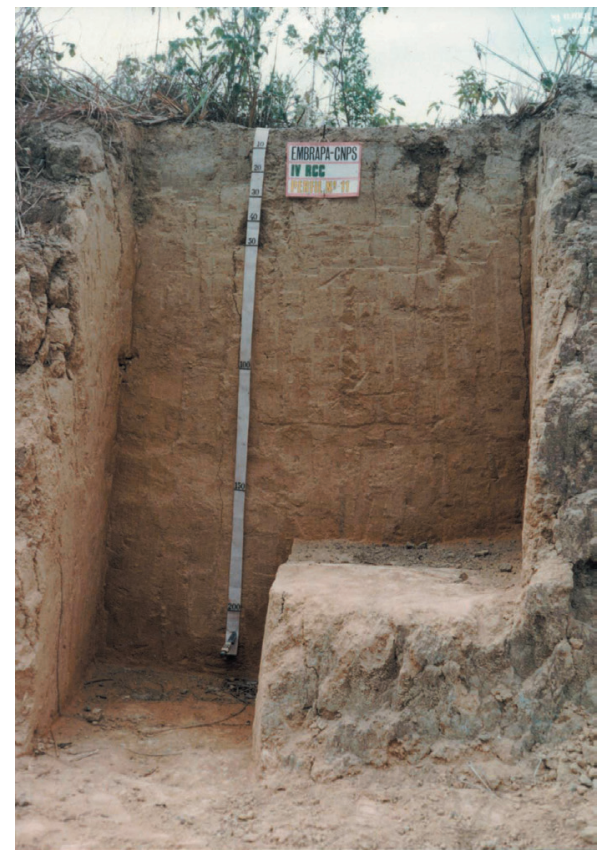

Figura 82 - Perfil de Latossolo Amarelo, Município deCampos dos Goytacazes (RJ).

Foto: Virlei Álvaro de Oliveira.
Considerado de origem continental por muitos autores, o Grupo Barreiras tem sido interpretado, mais recentemente, como tendo se depositado em mar raso, epicontinental (ARAI, 2005). Os bens minerais que ocorrem nesse grupo são materiais geralmente destinados à construção civil: areias, argilas e caulim.

A alteração dos sedimentos do Grupo Barreiras promoveu a formação de vários tipos de solos, com predomínio de Latossolos (Figura 82) e Argissolos (MAPA..., 2001). São, de modo geral, solos profundos, quimicamente pobres, mas com razoáveis condições físicas, o que, junto aos relevos aplanados, possibilita a motomecanização e faz com que sejam muito utilizados para diversas lavouras e reflorestamentos. 
Alguns solos podem apresentar horizontes coesos internamente (JACOMINE, 1969; RIBEIRO, 1998). Nestes casos, os solos apresentam-se duros ou muito duros quando secos, tornando-se rapidamente macios quando umedecidos. De acordo com Rezende (2000), a diminuição da aeração e o impedimento físico (resistência à penetração) são as principais causas de inibição do crescimento radicular em solos compactos e/ou densos dos tabuleiros.

A Formação Pariquera-Açu é constituída por rochas sedimentares arenosas, sílticas e areno-argilosas, com intercalações de conglomerados. Ocorre no extremo sul do Estado de São Paulo, em pequena extensão, balizada pela localidade homônima, e as Cidades de Registro e lguape. Forma colinas semiarredondadas, além de outras formas dissecadas de relevo.

Acompanhando os tabuleiros, encontram-se as formas de acumulação constituídas por depósitos sedimentares quaternários costeiros: são as Planícies Costeiras, pequenas planícies marinhas, cognominadas por certos autores de "planícies descontínuas". Grosso modo alongadas, as Planícies Costeiras acompanham a linha de costa, intercaladas por serras, montanhas, morros, grandes costões rochosos e falésias, além de outros elementos geográficos. São planícies comumente arenosas, de extensão bastante variável, que abrigam, no seu conjunto, muitas praias, conformando baías, enseadas, restingas e pontais. Entre as maiores, estão, por exemplo, as que se estendem de Torres (RS) a Laguna (SC) (Figura 83); de Barra Velha (SC) à região de Guaraqueçaba (PR); e a do delta do Rio Paraíba do Sul (RJ).

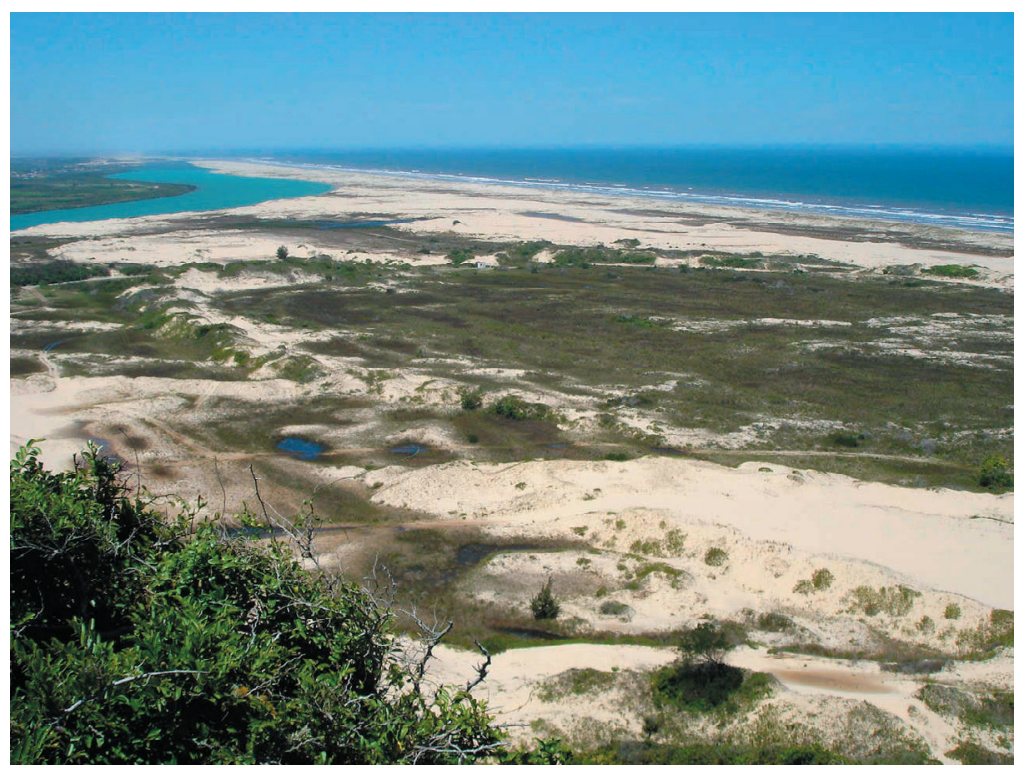

Figura 83 - Planície marinha com formação de restinga na foz do Rio Araranguá conjugada às dunas em Morro dos Conventos (SC).

Foto: Marcia de Melo Faria. 
O relevo, nessas planícies, modelado em depósitos sedimentares de diferentes origens - marinha, fluviomarinha, fluvial, lacustre, fluviolacustre ou mista - inclui praias, terraços marinhos, cordões litorâneos (Figura 84), sistemas simples ou múltiplos de laguna-barreira, campos de dunas fixas ou móveis e recifes de franja, além de maguezais - estes, em geral, se estendendo nas margens estuarinas e lagunares. Os sedimentos praiais, bem como os das dunas e dos terraços, são essencialmente quartzosos, de coloração branca a creme-clara, com bom selecionamento, de granulometria fina a média, com teor muito variável de restos de carapaças de animais marinhos. Sobretudo nos manguezais, os sedimentos se apresentam bastante argilosos e com coloração mais ou menos escura, devido à acumulação de matéria orgânica.

Os solos mais encontrados nas Planícies Costeiras são Espodossolos, Gleissolos e Neossolos Quartzarênicos Órticos e Hidromórficos. Sobre as áreas de solo arenoso, desenvolve-se a vegetação de restinga, cuja fisionomia varia desde formações herbáceo-arbustivas até florestas baixas, de aspecto xerofítico, com a presença marcante de cactos e bromélias. Entre os cordões arenosos, há a presença de brejos ricos em macrófitas aquáticas (Figura 85).

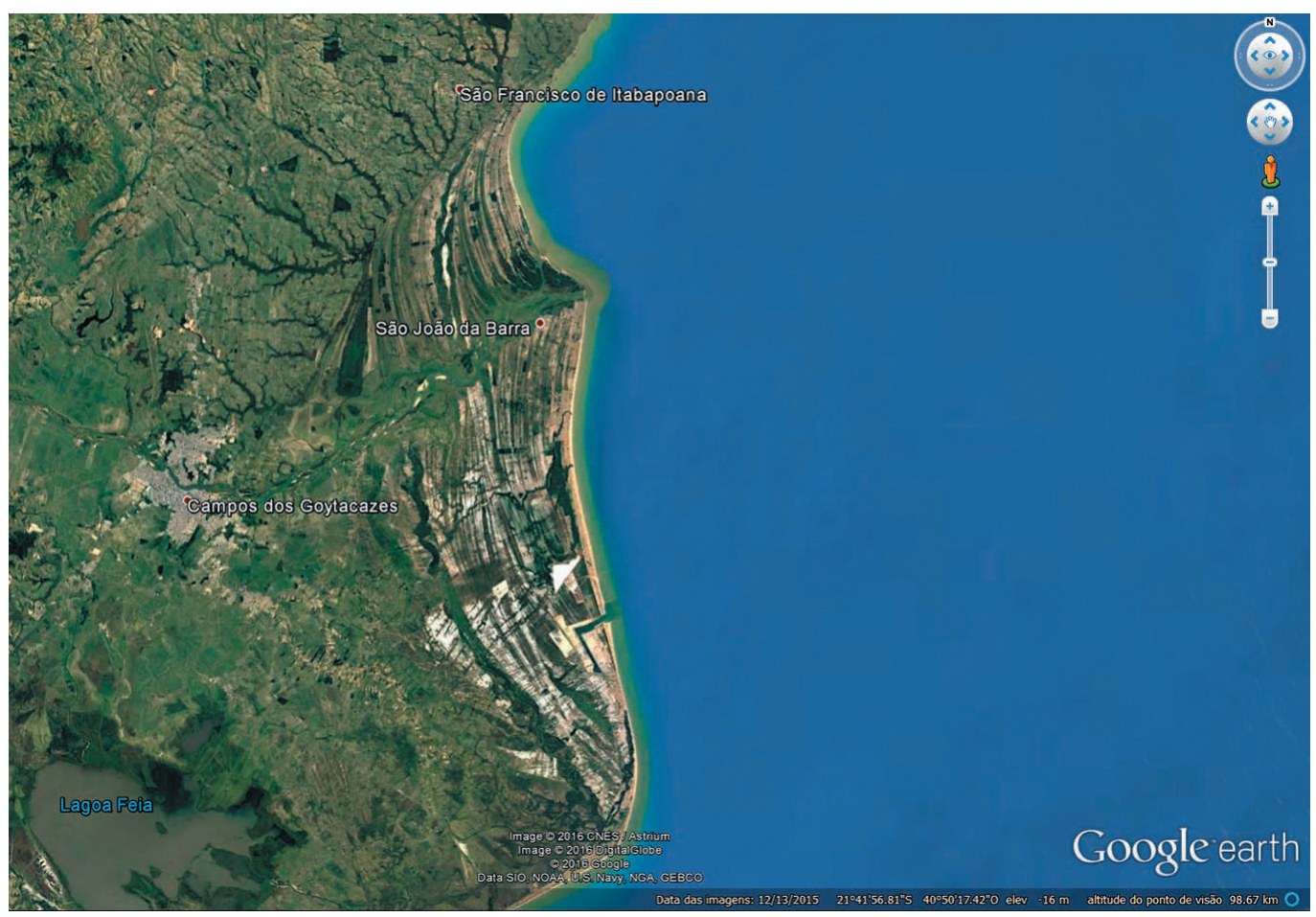

Figura 84 - Cordões litorâneos do complexo deltaico do Rio Paraíba do Sul (RJ). Imagem capturada no Google Earth em 2016. 


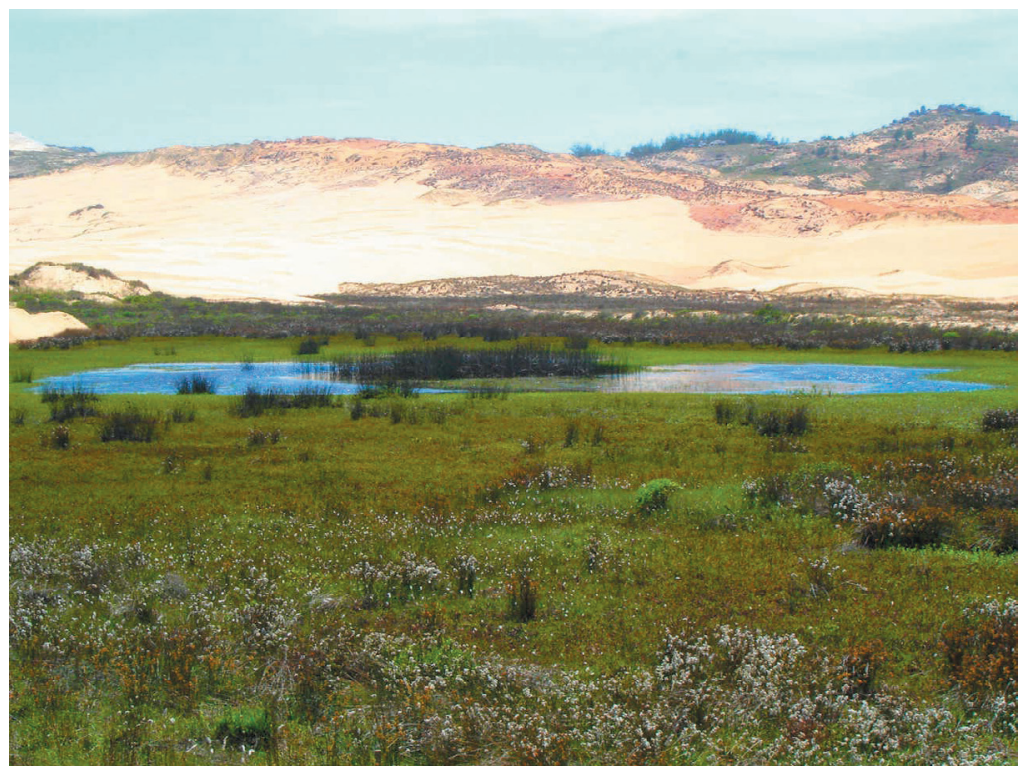

Figura 85 - Planície eólica (interduna) recoberta pela Formação Pioneira Marinha Herbácea, parcialmente alagada devido à elevação do lençol freático, e, em segundo plano, as dunas móveis no Cabo de Santa Marta (SC).

Foto: Marcia de Melo Faria.

O compartimento de Planícies e Tabuleiros Costeiros circunscreve mais de uma dezena de pequenas bacias costeiras, caracterizadas pela pouca extensão e vazão de seus corpos de água. De acordo com o panorama da qualidade das águas superficiais desenvolvida pela Agência Nacional de Águas - ANA (2005), a zona litorânea é a mais comprometida em termos de qualidade das águas de superfície, devido à expansão urbana e às atividades turísticas, apresentando poluição hídrica por esgotos, retirada da vegetação, aterros de manguezais e deposição de resíduos sólidos em rios e mangues.

Nas Bacias dos Rios Potengi e Pirangi, onde está localizada a Região Metropolitana de Natal (RN), o setor têxtil vem assumindo posição de destaque, com a multiplicação de unidades fabris. Tal atividade produz efluentes químicos oriundos de processos de lavagem e fixação de cores, que geram resíduos orgânicos e metais pesados, como o acetato de chumbo.

Em Sergipe, destacam-se as usinas açucareiras e alcooleiras que lançam vinhaça nos Rios Cotinguiba e Sergipe. Destacam-se, ainda, como fontes poluidoras no estado, as indústrias alimentícias, matadouros, indústrias de beneficiamento de couro, entre outras (BRASIL,1998).

Nas grandes cidades litorâneas, a principal fonte poluidora dos cursos de água é o lançamento de esgotos domésticos. Estes, ao atingirem o oceano, apesar da dispersão, comprometem a balneabilidade das praias, afetando as atividades turísticas e econômicas, além de aumentar o risco de doenças de veiculação hídrica. Neste caso, encontram-se, por exemplo, as Cidades do Recife e Salvador.

Na Região Metropolitana de Salvador, onde está localizado o Polo Petroquímico de Camaçari, a exploração petrolífera destaca-se como atividade altamente impactante, sendo comum o transporte de substâncias tóxicas e acidentes que comprometem a qualidade das águas. Nas margens do Rio Subaé, no Município de Santo Amaro da Purificação, no Recôncavo Baiano, a metalurgia de chumbo, no período de 1960 a 1993, contaminou e 
vem contaminando o local, devido à deposição de 490000 toneladas de rejeitos contendo metais pesados, sobretudo chumbo e cádmio (ANJOS, 1998 apud SERVIÇO GEOLÓGICO DO BRASIL, 2002).

Na zona costeira do Estado do Rio de Janeiro, a Baía da Guanabara destaca-se como um grande corpo de água receptor. Ela recebe diversos rios que atravessam regiões densamente povoadas e recebem grandes contribuições de lixo e de despejos industriais, os principais responsáveis pela presença de metais pesados nos sedimentos, principalmente na parte interna oeste, próximo às desembocaduras dos Rios São João de Meriti, Sarapuí e Iguaçu. Os rios da costa oeste apresentam os maiores picos de concentração de mercúrio, cromo, cobre e níquel. As maiores concentrações de mercúrio estão nos Rios Acari e São João de Meriti. A presença de metais pesados decresce em direção ao canal central e à entrada da Baía (FUNDAÇÃO ESTADUAL DE ENGENHARIA DO MEIO AMBIENTE, 2000).

Na década de 1990, foi criado o Programa de Despoluição da Baía de Guanabara, que engloba um conjunto de ações, entre as quais a coleta, o transporte e o tratamento adequados dos esgotos das bacias hidrográficas contribuintes da Baía, tendo em vista a recuperação da qualidade das suas águas.

A Baía de Sepetiba e sua bacia hidrográfica também têm como principal fonte poluidora a atividade industrial, responsável pela contaminação das águas com metais pesados. Esta contaminação decorre do lançamento dos metais em vários pontos do sistema hídrico da bacia e tem como principal foco os sedimentos de fundo da Baía de Sepetiba, em especial na sua porção leste (RIO DE JANEIRO, 1998).

O sistema das Lagoas de Jacarepaguá, no Município do Rio de Janeiro, apresenta-se fragilizado pela poluição dos esgotos domésticos da Barra da Tijuca e Jacarepaguá. No ano de 2000, cerca de 700 mil habitantes de 20 bairros da Bacia Hidrográfica da Barra da Tijuca, Recreio dos Bandeirantes e Jacarepaguá contribuíram com cerca de 40 mil quilogramas $\mathrm{DBO}^{28} /$ dia de esgotos, comprometendo a qualidade das águas e o equilíbrio ambiental na região (AGÊNCIA NACIONAL DE ÁGUAS, 2005). A partir do ano de 2007, com a inauguração do emissário submarino da Barra da Tijuca, parte dos esgotos passou a ser lançado em alto mar (a 5 quilômetros da costa), após tratamento primário.

Além da poluição industrial e do lançamento de esgotos, ocorre a extração indiscriminada de areia do leito e, principalmente, das planícies de inundação dos Rios Paraíba do Sul, Muriaé, Guandu e Jucu, o que altera significativamente a qualidade das suas águas.

Como bens minerais nas Planícies Costeiras, formando depósitos aparentemente de reduzidas dimensões, registram-se: minerais pesados (detríticos) - ilmenita, zirconita, monazita e rutilo - concentrados em níveis ou camadas dos sedimentos, constituindo as "areias negras", que ocorrem em diversos locais, desde o Estado de Alagoas até o Paraná, estendendo-se inclusive a regiões submersas; turfa e sapropelito, em vários locais, sobretudo na Bahia, Espírito Santo e Rio de Janeiro; e concheiros (sambaquis), principalmente nos Estados de Santa Catarina, São Paulo e Rio de Janeiro (Figura 86).

\footnotetext{
${ }^{28}$ Demanda Bioquímica de Oxigênio.
} 


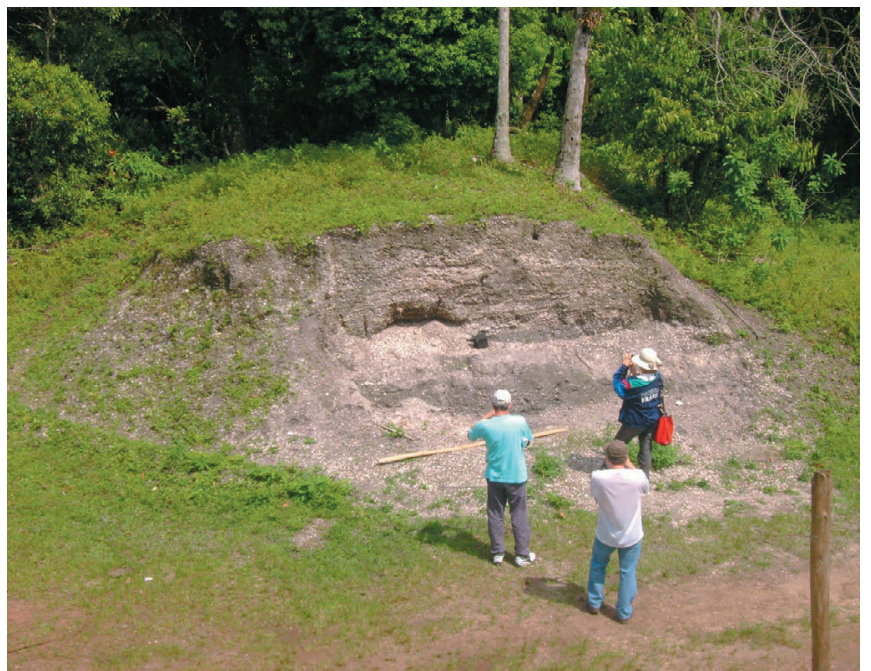

Figura 86 - Sambaqui, Ilha de São Francisco, litoral norte de Santa Catarina. Foto: Rosangela Garrido Machado Botelho.

No Estado de São Paulo, os Sistemas Estuarinos de Santos e São Vicente, inseridos na Região Metropolitana da Baixada Santista, representam os mais importantes exemplos brasileiros de degradação ambiental por poluição hídrica de origem industrial em ambientes costeiros. A região abriga o maior porto da América Latina (Santos) e o maior polo industrial do País, em Cubatão (COMPANHIA AMBIENTAL DO ESTADO DE SÃO PAULO, 2001). A partir de meados da década de 1980, o governo do estado, por meio da Companhia Ambiental do Estado de São Paulo - CEтESB, iniciou um programa de recuperação ambiental em Cubatão, que não só minimizou os problemas de poluição atmosférica e hídrica, como colocou a cidade no panorama internacional como exemplo de busca pelo desenvolvimento com base na sustentabilidade.

Na porção sul, destaca-se a Bacia do Rio Itajaí, em Santa Catarina, que recebe os esgotos urbanos de uma população de aproximadamente 900000 pessoas, com destaque para a Cidade de Blumenau. No verão, os serviços de disposição de lixo e de tratamento de esgotos na orla marítima tornam-se ainda mais deficitários em função da sobrecarga do turismo. A bacia apresenta ainda unidades industriais têxteis (Blumenau e Brusque), metal-mecânicas (Timbó e Pomerode), de pescado (Itajaí), resíduos de frigoríficos, beneficiadoras de óleo de soja, papeleiras e fecularias (Médio e Alto Vale do Itajaí) e, por esta razão, recebe também a descarga de grande parte dos efluentes e resíduos industriais produzidos.

Ressalta-se, ainda, os problemas de assoreamento da calha dos rios, aliados à instabilidade da sua foz e de erosão da faixa de areia na praia, como ocorre na Cidade de Conceição da Barra, na Bacia do Rio São Mateus (ES), em decorrência da remoção da mata ciliar e do mau uso do solo (ESPÍRITO SANTO, 2004). Outro problema refere-se à invasão de água salina nas áreas próximas à foz de alguns rios.

Alguns dos problemas existentes no domínio das Planícies e Tabuleiros Costeiros são função de atividades e intervenções exercidas nas áreas adjacentes das Serras e Morrarias, onde nascem e correm muitos dos rios que deságuam no litoral atlântico. A exemplo disso, tem-se a construção de diversas barragens ao longo da calha do Rio Paraíba do Sul, com a consequente interrupção do transporte de sedimentos, o que tem contribuído, a longo prazo, para a redução da linha de costa nas imediações de sua foz, em São João da Barra (RJ). 


\section{Serras e Morrarias}

Desde a extremidade norte do Bioma Mata Atlântica até quase sua extremidade sul, praticamente sem interrupções, encontram-se as feições geomorfológicas das Serras e Morrarias, que têm sua área mais expressiva na porção sudeste do Território Nacional, no âmbito dos domínios dos Cinturões Móveis Neoproterozoicos e das áreas cratônicas.

A área ocupada pelas Morrarias ou pelos chamados "mares de morros" (AB'SÁBER, 2003) caracteriza-se pela morfologia mamelonizada das colinas semelhantes a uma meia laranja e, sobretudo, pela profunda e extensa decomposição das rochas submetidas à ação dos processos morfogenéticos ligados ao clima tropical úmido (Figura 87).

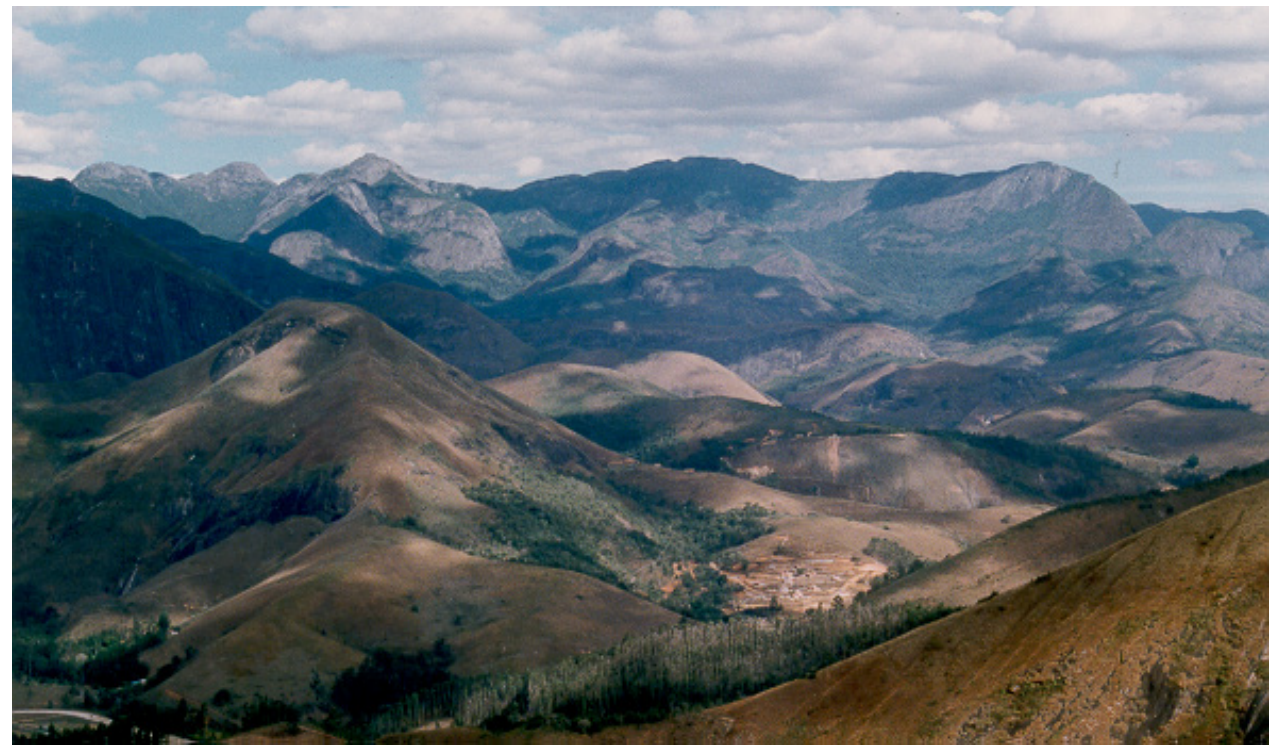

Figura 87 - Paisagem das Serras e Morrarias do Bioma Mata Atlântica, Município de Petrópolis (RJ). Foto: Rosangela Garrido Machado Botelho.

Chama a atenção, nos principais solos deste ambiente, a ocorrência de horizontes C ou $\mathrm{Cr}$ muito profundos, o que denota a grande eficiência do clima regional para a alteração das rochas, o que se deve provavelmente à abundância de chuvas. Por suas características, constitui uma área de fundamental importância para o conhecimento dos sistemas morfogenéticos das regiões intertropicais.

Argissolos Vermelho-Amarelos são os solos mais expressivos, seguidos de Latossolos Vermelho-Amarelos e Cambissolos, segundo o Mapa de solos do Brasil (2001), do IBGE. Os primeiros ocupam todas as situações de relevo, desde os fundos planos de vales, onde muitas vezes se originam de materiais transportados, até as encostas mais íngremes dos relevos montanhosos. Os Cambissolos, quase sempre associados a Neossolos Litólicos e Afloramentos de Rocha em pequenas proporções, ocupam as posições de relevo mais acidentado (forte ondulado, escarpado e montanhoso). Os Latossolos, salvo pouquíssimas exceções, ocorrem nas situações menos íngremes, como topos suavizados de morros ou pendentes longas.

Em razão das limitações do relevo acidentado e, em menor proporção, da baixa fertilidade natural dos solos, a maior parte da área é utilizada com pastagens. Entretanto, lavouras 
permanentes (principalmente café) e reflorestamentos também ocupam áreas relevantes. $\mathrm{O}$ plantio de cana-de-açúcar é expressivo nas porções do Bioma Mata Atlântica inseridas nas Regiões Nordeste e Sudeste, enquanto as pequenas lavouras desenvolvidas nos vales férteis junto às sedes de fazenda estão disseminadas por toda a região (Figura 88).

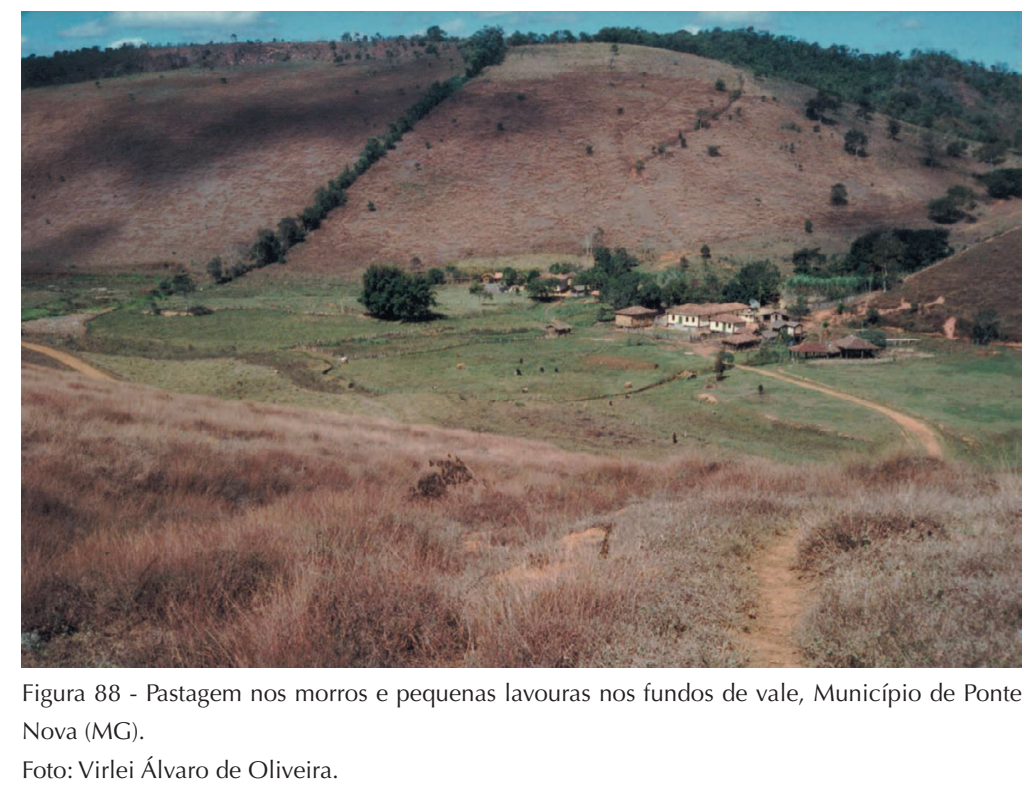

Este tipo de ambiente impõe, pelas suas características geomorfológicas, severas restrições à ocupação, tanto no que diz respeito à construção de estradas, como no que tange à localização de sítios urbanos. A paisagem típica dos "mares de morros" contrasta fortemente com as feições reconhecidas como penedos ou "pães-de-açúcar", de ocorrência muito generalizada, sobretudo entre os Estados do Rio de Janeiro e do Espírito Santo. Esses conjuntos têm constituição granito-gnáissica e se destacam pela posição topográfica, emergindo vigorosamente acima e à frente das escarpas das serras litorâneas.

As Serras ocorrem, assim como os planaltos, de maneira generalizada em quase toda a extensão do Bioma Mata Atlântica. No conjunto das grandes elevações montanhosas, merecem referência especial pelas suas magnitudes as Serras do Mar e da Mantiqueira. Ao longo de suas imponentes vertentes, são registradas algumas das maiores altitudes encontradas no Brasil. Especialmente na Serra da Mantiqueira, são comuns cotas altimétricas acima de 2000 metros, tendo como destaque o Pico da Bandeira, com 2892 metros, terceiro em altitude no território brasileiro.

A Serra do Mar está posicionada junto à costa, apresentando contorno irregular e formato alongado na direção nordeste-sudoeste, com área total de cerca de 35000 quilômetros quadrados. Vales estreitos, segmentos de drenagem retilíneos, linhas de cristas e de cumeadas paralelas, topografias com grandes desníveis e escarpas íngremes são as feições principais dessa unidade de relevo, relacionadas grandemente com fatores geológicos. Destes, se destacam: rochas com resistências bastante diferenciadas à erosão; foliações e eixos de dobramentos das rochas; falhas de diferentes tipos etc. Entre as rochas com predominam granitoides, gnaisses bandados e migmatitos. Inseridas nesses gnaisses e migmatitos, há raras 
camadas e lentes de mármores e de rochas calcossilicáticas, bem como de quartzitos e rochas metabásicas. Os granitoides pertencem, na sua maior parte, à série cálcio-alcalina, com altos teores de potássio, e à série alcalina; eles formam diversos maciços graníticos - pequenos batólitos e corpos ígneos menores, alojados em embasamentos gnáissicos e migmatíticos. Tais maciços têm altitudes geralmente superiores a 1000 metros. Destaca-se a sequência de maciços graníticos alinhados e também alongados na direção geral nordeste-sudoeste, que se sucedem do Estado do Rio de Janeiro ao nordeste do Estado de Santa Catarina, correspondendo a um conjunto de picos e cristas separados por vales não raramente profundos, em forma de "V", ladeados por vertentes de alta declividade. Essas cristas, descritas geralmente como serras, e esses picos recebem, localmente, denominações diversas, tais como: Serras dos Órgãos, da Bocaina, do Capivari, da Graciosa, do Marumbi, da Igreja, da Papanduva, do Imbira, do Quiriri, Queimada, do Boi etc.; e Picos Médio de Friburgo, Pedra do Sino, Pedra Alta, Paraná, Caratuva, do Marumbi etc.

Acompanhando os maciços graníticos, há sequências vulcanossedimentares, nas quais o aspecto geral do relevo é dado por formas colinosas. Depositadas no Neoproterozoico, em pequenas bacias tectônicas, essas sequências cobrem extensões muito restritas. Elas correspondem ao Grupo Campo Alegre, depositado em bacia justo a leste do Município de São Bento do Sul (SC), e ao Grupo Guaratubinha, depositado em bacia em torno de 40 quilômetros a sudeste de Curitiba.

Em tempos do Cenozoico, movimentos epirogênicos levaram, por outro lado, ao surgimento de poucas áreas deprimidas nessa unidade de relevo, que foram preenchidas por sedimentos fluviolacustres. O melhor exemplo de tais áreas, cujo modelado atual do relevo é de colinas esbatidas, é a da Bacia de Curitiba, localizada na cidade homônima e em seus arredores.

Do leste do Estado de São Paulo ao sul do Estado de Minas Gerais, estendem-se as Serras da Mantiqueira/Itatiaia, com área de cerca de 25000 quilômetros quadrados. Seu relevo comporta modelados de dissecação tanto homogênea quanto diferencial, predominando este último tipo nas áreas mais orientais da unidade. A dissecação diferencial está relacionada, sobretudo, com o forte tectonismo, que afetou as litologias dessas serras, originando falhas, fraturas e outras feições da tectônica rúptil, cujos traços seguem duas direções gerais principais: NE-SW e $\mathrm{N} 20^{\circ} \mathrm{E}$, sendo mais marcante a primeira. Vales de escarpas de falhas, linhas de crista e de cumeada, bem como outros elementos do relevo, se encontram adaptados às referidas feições geológicas, seguindo as mesmas direções gerais. As litologias, que consistem em gnaisses migmatizados ou não, gnaisses facoidais, gnaisses aluminosos, granitoides, blastomilonitos, rochas charnockíticas, xistos, filitos, eventuais metassiltitos, metarenitos, anfibolitos e rochas calcossilicáticas, foram geradas ou retrabalhadas no Neoproterozoico. Apenas alguns gnaisses, que constituem o Complexo Amparo e ocorrem em áreas restritas, notadamente no noroeste da unidade, são de idades mais antigas, integrando remanescentes de um embasamento arqueano-proterozoico. Os recursos minerais dessa unidade ocorrem sobretudo na porção meridional da mesma, justo a sul do Município de Jundiaí (SP), consistindo em pequenas jazidas de pegmatito e cobre, além de ocorrências de calcário, pegmatito, pirita, ouro, manganês e ferro. Nos corpos pegmatíticos, há mineralizações de "minerais industriais", tais como feldspato, berilo e quartzo, e de pedras semipreciosas, notadamente turmalina e topázio. 
Estendendo-se a norte, encontram-se as Serras da Mantiqueira e do Caparaó. Nestas, as estruturas geológicas, que obedecem a uma direção geral NE-SW (nordeste-sudoeste), se infletem para norte, onde passam a ter uma direção geral em torno de $\mathrm{N} 20^{\circ} \mathrm{E}$, o que condiciona a maior parte dos vales, das linhas de cristas e de cumeadas, das escarpas de falha, entre outras feições dessa unidade de relevo.

As rochas das Serras da Mantiqueira e do Caparaó originaram-se, em grande parte, no Orógeno Araçuaí-Rio Doce, cujo clímax foi há 590/560 milhões de anos. São rochas metamórficas de médio grau de metamorfismo, que compõem o Complexo Paraíba do Sul (MACHADO FILHO et al., 1983; KAUL et al., 2005): gnaisses bandados e de outros tipos, granitoides, migmatitos em geral estromáticos, não raro com ampla cataclase e recristalização. As rochas restantes da unidade ocorrem na metade oeste da mesma e correspondem a remanescentes de embasamentos mais antigos, que se enquadram em dois complexos, denominados Juiz de Fora e Pocrane.

O Complexo Juiz de Fora, de idade paleoproterozoica, com retrabalhamento no Neoproterozoico, é constituído por gnaisses de alto grau metamórfico, com migmatização em diferentes graus de intensidade. Inclui, muito raramente, outros tipos de rochas, entre os quais se destacam quartzitos. O Complexo Pocrane, de idade arqueana, imune de retrabalhamentos em eras geológicas posteriores (Paleo e Neoproterozoico), é formado por metamorfitos de médio grau metamórfico, sobretudo biotita-gnaisses foliados a bandados, de granulação fina e composição granodiorítica. Os bens minerais das Serras da Mantiqueira e do Caparaó consistem principalmente em jazimentos e ocorrências de mármores.

Em face de suas características orográficas, onde despontam vertentes com altas declividades e escarpas de difícil acesso, ambas as serras (do Mar e da Mantiqueira) têm sido, ao longo do tempo, um eficiente fator de proteção contra a exploração econômica a que foi submetido o Bioma Mata Atlântica. Os relevos montanhosos que as constituem são um importante testemunho do tectonismo cenozoico que afetou as Regiões Sul e Sudeste do Brasil. É nos maciços montanhosos das Serras do Mar e da Mantiqueira que se encontra boa parte das áreas remanescentes de floresta do Bioma Mata Atlântica, a maioria delas em Unidades de Conservação.

Durante o Eoceno, antigas zonas de cisalhamento foram reativadas por falhamentos normais. Este tectonismo originou blocos elevados por basculamento, que constituem verdadeiros horsts, como a Serra do Mar, e semi-horsts, como a Serra da Mantiqueira. As depressões tectônicas comportam-se como hemigrabens, a exemplo do Vale do Rio Paraíba do Sul e as Baixadas Santista e Fluminense. A complexidade tectônica e o condicionamento estrutural criaram vários compartimentos que funcionam como divisores de drenagem entre a vertente atlântica e a do interior. As amplitudes altimétricas entre os diversos compartimentos de relevo foram acentuadas por soerguimentos pleistocênicos. Grande parte do modelado alcantilado é decorrente da atuação de rios com forte gradiente, submetendo todo o conjunto a uma intensa erosão fluvial.

A Depressão do Rio Paraíba do Sul estende-se desde as proximidades da Cidade de São Paulo até Campos dos Goytacazes, no Estado do Rio de Janeiro. Deprimida em relação às serras circundantes - do Mar e da Mantiqueira -, nela se instalou a drenagem atual do Rio Paraíba do Sul, que juntamente com o Rio Doce constituem os maiores rios totalmente incluídos no Bioma Mata Atlântica. O quadro morfológico reflete fortemente os condicionantes geológicos. Cristas de serranias, linhas de cumeadas, sulcos estruturais, escarpas erosivas e vales (adaptados a falhas) dispõem-se segundo a direção geral das estruturas geológicas. 
Afora os terrenos rochosos do Pré-Cambriano, a Depressão do Rio Paraíba do Sul, na região do médio-superior curso desse rio, apresenta coberturas sedimentares que foram depositadas em três bacias tafrogênicas (riftes abortados): Bacias de Taubaté, Resende e Volta Redonda, formadas durante a fase inicial de deriva continental, da ruptura do supercontinente Gondwana, por reativações tectônicas tardias. A maior delas é a de Taubaté, situada entre as cidades paulistas de Jacareí e Cruzeiro, com 170 quilômetros de extensão, largura máxima de 20 quilômetros e alongada (eixo maior) segundo a direção nordeste-sudoeste. Cenário de sedimentação em ambientes lacustre e fluvial, do Eoceno aos tempos holocênicos, essa bacia foi então preenchida por sedimentos predominantemente finos, que originaram argilitos, siltitos, arenitos e conglomerados, litologias em que foram esculpidas colinas tabuliformes, terraços em vários níveis, amplas várzeas etc. A Bacia de Resende, junto à cidade homônima, no Estado do Rio de Janeiro, tem cerca de 40 quilômetros de comprimento e largura média de aproximadamente 6 quilômetros. Está posicionada na continuação, a nordeste, da Bacia de Taubaté, da qual se separa por um alto estrutural. Seu preenchimento ocorreu do Plioceno ao Pleistoceno (MACHADO FILHO et al., 1983), com formação de arenitos, conglomerados e materiais areno-argilosos, litologias sobre as quais se desenvolveram feições tabuliformes, planícies e terraços fluviais. A Bacia de Volta Redonda, restrita à área da cidade de mesmo nome, e supostamente homóloga à Bacia de Resende, tem extensão muito restrita. Os bens minerais da Depressão do Rio Paraíba do Sul são, sobretudo, jazimentos e ocorrências de mármores e calcários nos terrenos do Pré-Cambriano, bem como jazimentos de argila e ocorrências de turfa nas coberturas sedimentares das bacias tafrogênicas.

Embora apresente sua foz no domínio das Planícies e Tabuleiros Costeiros, o Rio Paraíba do Sul, assim como os Rios Doce, Mucuri, Jequitinhonha e Pardo constituem importantes corpos de água cujos cursos atravessam predominantemente terrenos do domínio das Serras e Morrarias.

No diagnóstico de qualidade dos trechos mineiro e parte final fluminense da Bacia do Rio Paraíba do Sul (UNIVERSIDADE FEDERAL DO RIO DE JANEIRO, 1999), uma das mais importantes do ponto de vista econômico para o País, os parâmetros que apresentaram maior nível de comprometimento foram os compostos fosfatados, a demanda bioquímica de oxigênio e os coliformes, evidenciando um processo contínuo de poluição por material orgânico.

Os municípios que mais contribuem com as ocorrências de matéria orgânica nos cursos de água monitorados na porção mineira da Bacia do Rio Paraíba do Sul são Ubá e Cataguases. Os rios que drenam a área urbana destes municípios apresentam uma vazão que não permite a depuração da matéria orgânica proveniente dos esgotos sanitários municipais. Os Ribeirões Ubá e Meia Pataca apresentaram DBO5,2029 acima do limite legal para cursos de água de Classe 2 (ZONEAMENTO ECOLÓGICO-ECONÔMICO, 2005). O fosfato total e o oxigênio dissolvido também apresentaram grande número de violações nestes cursos de água (INSTITUTO MINEIRO DE GESTÃO DAS ÁGUAS, 2003).

O Rio Paraibuna, afluente da margem esquerda do Rio Paraíba do Sul, pode ser considerado, segundo dados da Fundação Centro Tecnológico de Minas Gerais - CEтEC, com-

${ }^{29}$ Demanda Bioquímica de Oxigênio 5,20: quantidade de oxigênio necessária para oxidar a matéria orgânica por decomposição microbiana aeróbica para uma forma inorgânica estável, em um período de cinco dias, a $20^{\circ}$ Celsius (COMPANHIA DE TECNOLOGIA DE SANEAMENTO AMBIENTAL, 2009). 
prometido quanto aos níveis de poluentes industriais, a jusante da Cidade de Juiz de Fora (MG), pois recebe despejos de várias indústrias, predominantemente as de papéis, têxteis e alimentícias (AGÊNCIA NACIONAL DE ÁGUAS, 2005). Próximo à sua foz, entretanto, o Rio Paraibuna não apresenta fontes potenciais de poluição industrial, o que, associado a sua significativa vazão média de 170 metros cúbicos por segundo, favorece a manutenção de níveis aceitáveis de metais pesados e de outros resíduos de origem industrial (AGÊNCIA NACIONAL DE ÁGUAS, 2005).

No Rio Pomba, a jusante da Cidade de Cataguases (MG), os despejos domésticos de origem urbana e com alto nível de material fecal reduzem os índices de qualidade da água (aumento de DBO5,20 e de coliformes). O Rio Muriaé, último dos grandes afluentes do Paraíba do Sul, a jusante das Cidades de Muriaé, Patrocínio do Muriaé e Itaperuna (RJ), também apresenta-se bastante comprometido devido aos despejos orgânicos, com taxas elevadas de material fecal. O mesmo acontece com os Rios Carangola, a jusante das Cidades de Carangola e Porciúncula; e Glória, a jusante da Cidade de Miradouro (RJ).

No trecho do Rio Paraíba do Sul, compreendido entre a Barragem de Funil e a Elevatória de Santa Cecília (RJ), a qualidade da água vai decrescendo no sentido do fluxo do rio, à medida que a poluição orgânica, a poluição fecal e o nível de nutrientes aumentam em decorrência principalmente das atividades urbanas. No trecho compreendido entre a Elevatória de Santa Cecília e a Ilha dos Pombos, no Município de Carmo (RJ), a baixa vazão do rio exige uma estratégia de controle de modo a não permitir o lançamento indiscriminado de cargas poluentes. As fontes poluidoras são, basicamente, despejos domésticos de cidades como Barra do Piraí, Vassouras, Andrade Pinto, Valença e Paraíba do Sul. Nos períodos de estiagem, a retirada de água para abastecimento da Região Metropolitana do Rio de Janeiro e a geração de energia têm contribuído para piorar a qualidade da água do rio nos trechos a jusante, devido à diminuição da capacidade de diluição de efluentes.

A jusante da Cidade de Três Rios (RJ), após a confluência com os Rios Piabanha e Paraibuna, o Paraíba do Sul apresenta um aumento acentuado de vazão. O Rio Piabanha e seus afluentes Preto e Paquequer são os principais corpos receptores de todos os despejos domésticos e industriais dos Municípios de Petrópolis e Teresópolis, respectivamente. Já o Rio Paraibuna apresenta boa qualidade de água.

No trecho paulista do Rio Paraíba do Sul, o lançamento de esgotos domésticos constitui o principal fator para a má qualidade dos recursos hídricos. A má qualidade da água (excesso de nutrientes e de matéria orgânica) favorece o crescimento de plantas aquáticas, que, ao morrerem e se depositarem no fundo, provocam carência de oxigênio dissolvido. Este é um problema especialmente grave nos reservatórios/represas ao longo do Rio Paraíba do Sul. Em função da má qualidade das águas captadas pelos Municípios de Aparecida e Tremembé (SP), as empresas de saneamento locais necessitam de atenção especial no processo de tratamento de água bruta e na proteção dos mananciais (COMPANHIA DE TECNOLOGIA DE SANEAMENTO AMBIENTAL, 2003).

Considerando toda a Bacia do Paraíba do Sul, as áreas mais críticas em relação a despejos industriais brutos e líquidos, localizam-se nos Municípios de Resende, Barra Mansa e Volta Redonda (Médio Paraíba) (RJ), causadas por indústrias de grande porte e com poluentes importantes, como fenóis, cianetos, sulfetos, metais pesados (cromo, zinco, cobre, chumbo, cádmio, mercúrio) e solventes orgânicos. 
Na Bacia do Rio Doce (MG/ES), o despejo de efluentes industriais (além dos domésticos) agrava o problema de captação de água de boa qualidade para consumo humano, tornando cada vez mais difícil o seu tratamento. Nessa bacia, há concentrações de grandes indústrias: siderurgia e celulose, no Vale do Aço; beneficiadoras de cana-de-açúcar, em Ponte Nova; e metalurgia e mineração, com contaminação por metais pesados, principalmente no Rio Piracicaba, afluente do Rio Doce. A contaminação das águas com mercúrio, devido à mineração do ouro na bacia é expressiva (AGÊNCIA NACIONAL DE ÁGUAS, 2005).

$\mathrm{Na}$ Bacia do Rio Itapemirim (ES), indústrias de aguardente, frigoríficos e cooperativas de derivados do leite lançam seus efluentes e resíduos sólidos na rede de esgoto ou diretamente nos corpos de água, o que, aliado aos rejeitos das indústrias de mármore e granito da região (Municípios de Cachoeiro de Itapemirim e Castelo) e à poluição difusa advinda de práticas agrícolas inadequadas, causa assoreamento e turbidez nas épocas de chuva. Similarmente, na Bacia do Rio Itabapoana, marmorarias, cooperativas de leite e fábricas de linguiça lançam seus efluentes líquidos e resíduos sólidos diretamente nos cursos de água.

No Vale do Rio Jequitinhonha, a atividade de mineração no seu alto curso (desde o início de sua ocupação) é a principal responsável pela transformação do rio em um manancial extremamente raso e assoreado (BRASIL, 1996). Segundo o Instituto Mineiro de Gestão das Águas (2003), garimpos de ouro, diamante, pedras preciosas e metais ferrosos espalhados por toda bacia, principalmente nos Municípios de Diamantina, Bocaiúva, Coronel Murta, Jequitinhonha, Carbonita, Virgem da Lapa e Itinga, têm alterado a qualidade das águas da bacia, que, muitas vezes, têm sua turbidez e quantidade de sólidos em suspensão consideravelmente aumentadas em função da passagem de dragas.

O trecho do Rio Tietê, inserido no domínio das Serras e Morrarias, possui como importantes afluentes os Rios Aricanduva, Tamanduateí, Pinheiros e Juqueri. O Rio Tamanduateí recebe cerca de 40,0\% da carga poluidora gerada na Região Metropolitana de São Paulo, sendo, por esse motivo, um dos rios de mais baixa qualidade das águas no Estado de São Paulo. Os valores médios de oxigênio dissolvido, nitrogênio amoniacal, fósforo total, DBO5,20, e coliformes termotolerantes desses rios confirmam o total comprometimento da qualidade das águas dos corpos hídricos da Região Metropolitana de São Paulo (COMPANHIA DE TECNOLOGIA DE SANEAMENTO AMBIENTAL, 2003).

Na Grande São Paulo, destaca-se, ainda, a poluição dos Reservatórios Billings e Guarapiranga. Apesar de abrigar um dos mais importantes mananciais de abastecimento da Região Metropolitana de São Paulo, a Bacia do Rio Guarapiranga (afluente do Rio Pinheiros) vem sofrendo um contínuo e crescente processo de degradação ambiental, observado desde o final da década de 1960, fruto da intensa urbanização da metrópole paulista. Com a ocupação crescente, houve um acréscimo significativo da carga orgânica para o reservatório, causando um processo de eutrofização, que vem se acentuando nos últimos anos. 
A preservação do Rio Tietê começou efetivamente em uma ação iniciada em 1992, o Projeto Tietê. O programa, de responsabilidade da Companhia de Saneamento Básico do Estado de São Paulo - SABESP, tem como meta a despoluição do Tietê, recuperando o rio ao longo da Cidade de São Paulo, evitando que o esgoto de indústrias e residências chegue até seu leito sem tratamento.

As serras e os planaltos dissecados das Regiões Sul e Sudeste têm sido frequentemente palco de movimentos de massa do tipo fluxos detríticos e avalanches de detritos de magnitude catastrófica (Figura 89). Muito embora seja um fenômeno natural e recorrente nestas formas de relevo, responsável inclusive pelo recuo e evolução das vertentes, algumas variáveis relativas às vertentes, como a geometria e o forte gradiente associados à cobertura vegetal, têm grande influência na intensidade e distribuição espacial destes movimentos de massa. A investigação sistemática destes fenômenos, que acarretam grandes perdas ambientais e materiais, teve um largo impulso no Brasil da década de 1960, com a recuperação de laudos, documentos históricos e registros fotográficos. Atualmente, o emprego de Modelos Digitais de Terreno (MDT), alocados num Sistema de Informações Geográficas - SIG, tem-se mostrado extremamente útil na caracterização e na distribuição espacial dos deslizamentos, em muito contribuindo para o pleno conhecimento dos mecanismos geomorfogênicos que os desencadeiam.

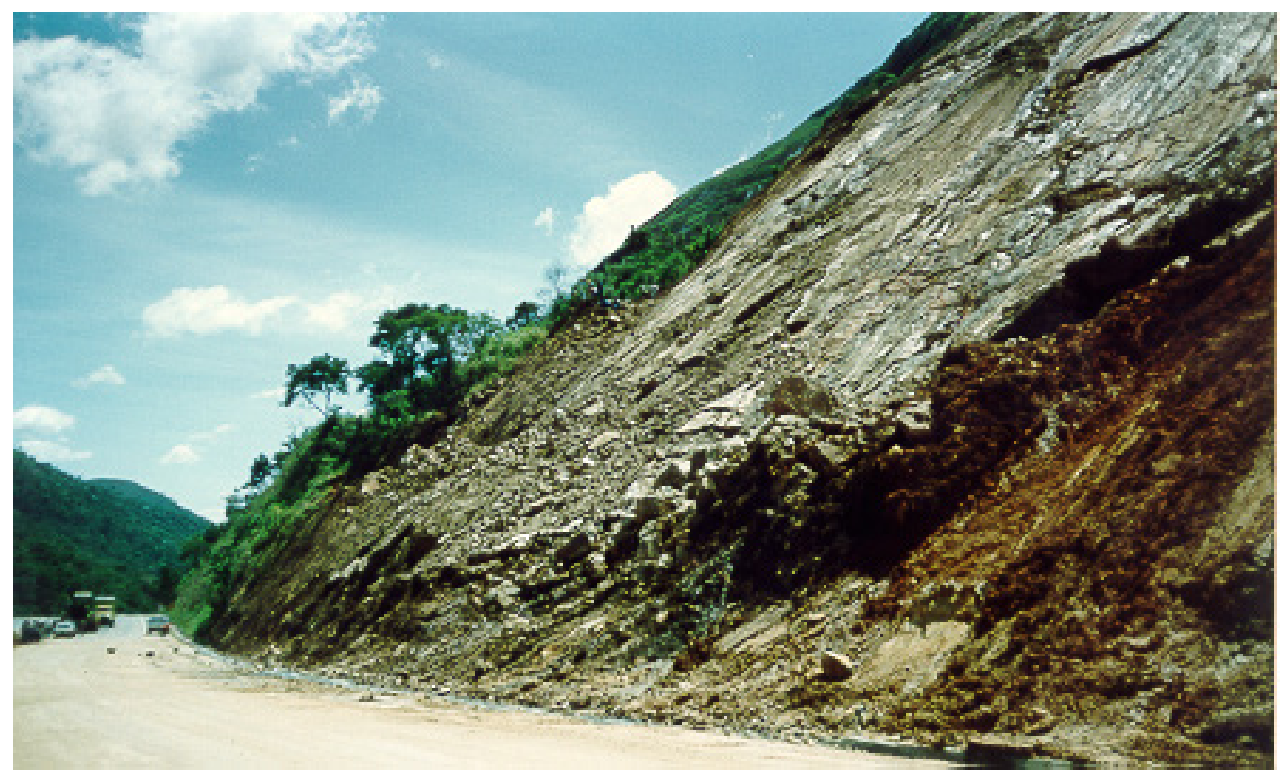

Figura 89 - Movimento de massa às margens da Rodovia BR-040, no Município de Petrópolis (RJ). Foto: Rosangela Garrido Machado Botelho. 


\section{Terrenos Sedimentares da Bacia do Paraná}

A Bacia Sedimentar do Rio Paraná constitui um grande domínio morfoestrutural que se estende do norte do Estado do Rio Grande do Sul ao Estado de Mato Grosso. Nos limites do Bioma Mata Atlântica, compreende os Planaltos das Araucárias e do Rio Paraná, os Patamares da Borda Oriental da Bacia do Paraná e a Depressão Periférica Paulista.

O Planalto das Araucárias prolonga-se do norte do Estado Rio Grande do Sul ao sudoeste do Estado do Paraná. Está esculpido, quase inteiramente, sobre as rochas vulcânicas da Formação Serra Geral, do Jurocretáceo, comportando duas unidades: o Planalto dos Campos Gerais, correspondente, grosso modo, às suas porções oriental e sul, modelado frequentemente sobre rochas vulcânicas de composição ácida (riolitos felsíticos, riodacitos, dacitos e outras litologias associadas); e o Planalto Dissecado do Rio Uruguai, correspondente aproximadamente a sua metade oeste, entalhado, por grande extensão, sobre rochas vulcânicas básicas (diferentes tipos de basalto).

A partir de rochas eruptivas ácidas, em elevadas altitudes, formaram-se Latossolos e Nitossolos Brunos, de baixa fertilidade natural e muitas vezes com teores de alumínio trocável muito elevados (alíticos e alumínicos). Apesar disso, sua utilização agrícola é muito intensa, verificando-se desde cultivo de grãos diversos até fruticultura de clima temperado (maçã principalmente). Sobre as rochas básicas, originaram-se Nitossolos Vermelhos (antigas Terras Roxas Estruturadas) (Figura 90) no oeste dos Estados do Paraná, Santa Catarina e Rio Grande do Sul (OLIVEIRA et al., 1999; MAPA..., 2001), que apresentam alta fertilidade química. Contudo, as condições de relevo na área de ocorrência destes solos são quase sempre impeditivas à sua exploração plena com lavouras. Entretanto, ainda assim, se verifica uma utilização quase intensiva, empregando-se sistema de manejo adaptado (semidesenvolvido com tração animal), com a incidência de erosão alcançando níveis alarmantes.

Associadas às rochas vulcânicas de composição ácida do Planalto dos Campos Gerais, existem, no Município de Salto do Jacuí (RS) e arredores, mineralizações de ametista e ágata, ao passo que, ligadas às vulcânicas de composição básica do Planalto Dissecado do Rio Uruguai, são conhecidas, nos Municípios de Itapiranga (SC), Frederico Westphalen (RS) e outros próximos, mineralizações de cobre e ametista, tratando-se, na grande maioria dos casos, de ocorrências minerais de pequena expressão.

O Planalto dos Campos Gerais, a par de um relevo plano, inclui formas de relevo mais acidentado, tais como

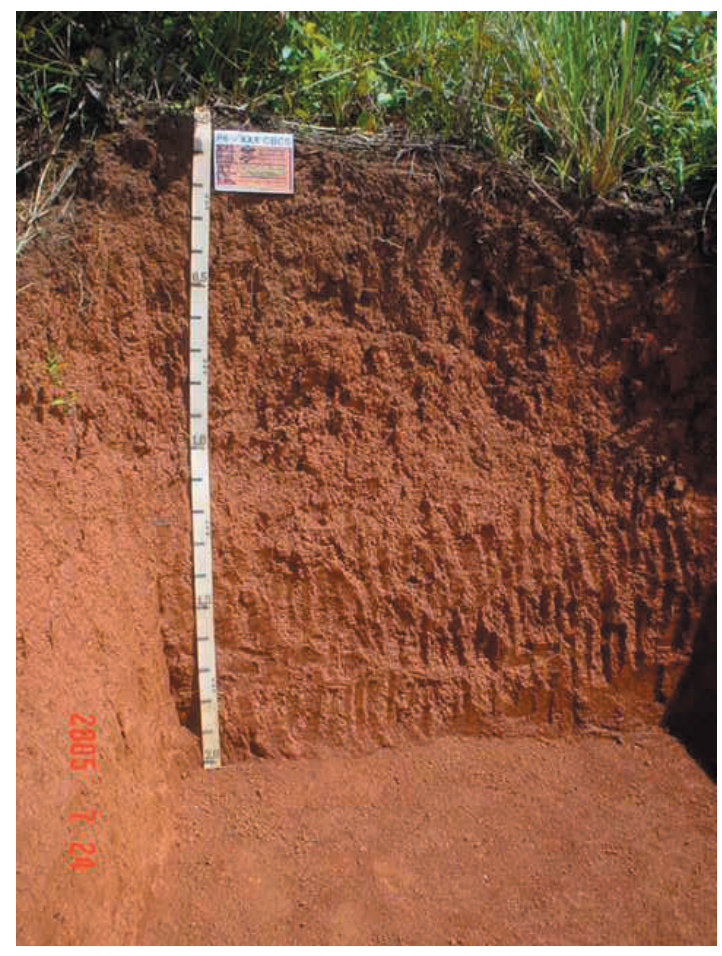

Figura 90 - Nitossolo Vermelho (antiga Terra Roxa), Município de Goiana (PE)

Foto: Virlei Álvaro de Oliveira. vales com profundo entalhamento fluvial, com encostas relativamente íngremes. O Planalto Dissecado do Rio Uruguai se caracteriza por apresentar vales, em geral, poucos profundos, com expressivo controle estrutural, colinas muitas vezes alongadas e, em certas áreas, muitos relevos residuais (morros-testemunhos). 
O Planalto do Rio Paraná ocupa o oeste do Estado de São Paulo, adentrando, em pequenas extensões, o norte do Estado do Paraná, o extremo sul do Estado do Mato Grosso do Sul e o oeste mineiro. Está esculpido, em grande parte, sobre litologias sedimentares pós-vulcânicas da Formação Serra Geral, pertencentes ao Grupo Bauru (arenitos quartzosos vermelhos ou arroxeados, de granulometria fina ou média), do Cretáceo; e, em menor extensão, sobre basaltos da Formação Serra Geral e arenitos da Formação Botucatu. Na maior parte de sua extensão, predomina um relevo homogêneo, com interflúvios alongados possuindo topos tabulares e vertentes convexas com baixa declividade. Os arenitos, principalmente do Grupo Bauru, forneceram material para a formação de solos de textura leve (média e arenosa/ média), do tipo Latossolo Vermelho-Amarelo, no extremo sul do Mato Grosso do Sul e norte do Paraná, e do tipo Argissolos Vermelho-Amarelos Eutróficos, no oeste paulista (OLIVEIRA et al., 1999; MAPA..., 2001). Aqui, o cultivo de café é ainda bastante relevante, embora, com a degradação dos solos, esteja havendo uma substituição paulatina por pastagens. Por outro lado, os derrames basálticos forneceram material para a formação de Latossolos Vermelhos Distro e Eutroférricos (antigos Latossolos Roxos) em amplas extensões de terras ao sul do Estado de Goiás, bem como ao norte (Vale dos Rios Grande/Mogi-Guaçu) e sul (Vale do Paranapanema) do Estado de São Paulo.

Os Patamares da Borda Oriental da Bacia do Paraná contornam os Planaltos das Araucárias e do Rio Paraná e se estendem do nordeste do Estado do Rio Grande do Sul ao nordeste do Estado de São Paulo. O contato com os referidos planaltos ocorre por meio de uma escarpa, correspondente à Serra Geral que, no Paraná e em Santa Catarina, se apresenta como uma verdadeira "cuesta". A diversidade de litologias das formações sedimentares em que estão esculpidos resultou no desenvolvimento de um relevo com características muito heterogêneas. Grande parte deste relevo, entretanto, se caracteriza por uma extensa superfície colinosa, em que as colinas estão separadas, conforme destacam Herrmann e Rosa (1990), "por amplas várzeas sem que exista, em muitas delas, uma drenagem organizada ou um talvegue definido". Na parte norte dessa unidade de patamares, e como consequência da ascensão e consolidação, na crosta, de um magma básico, existem inúmeros diques de diabásio paralelos, de direção geral nordeste-sudoeste, que correspondem a elevações lineares do terreno, com extensão não raro de algumas dezenas de quilômetros, com topos aguçados. O relevo da região do alto curso do Rio Itajaí-Açu e de seus formadores, em Santa Catarina, se acha marcado por extensos patamares e relevos residuais de topo plano, estes mantidos por litologias mais resistentes aos processos de alteração e erosão (arenitos). Na região de Lages (SC) e vizinhanças - Planalto de Lages, de acordo com Almeida (1952) -, há formas colinosas entremeadas por relevos residuais mais elevados, correspondentes a intrusões de rochas alcalinas. Mais para o sul, adentrando o Rio Grande do Sul, como uma faixa geralmente estreita e irregular que contorna a borda sudeste e sul do Planalto dos Campos Gerais, o relevo se caracteriza, sobretudo, por um sucessivo escalonamento de patamares estruturais esculpidos, neste caso, em basaltos da Formação Serra Geral.

Nesses três compartimentos da Bacia Sedimentar do Paraná, principalmente no Planalto das Araucárias, como sugere seu próprio nome, encontra-se a Floresta Ombrófila Mista, conhecida como Mata de Araucária, que ocupa terrenos acima de 500/600 metros de altitude (Figura 91). Caracteriza-se por uma rica mistura florística, na qual se destacam as duas únicas coníferas brasileiras, em especial o pinheiro-do-paraná. 


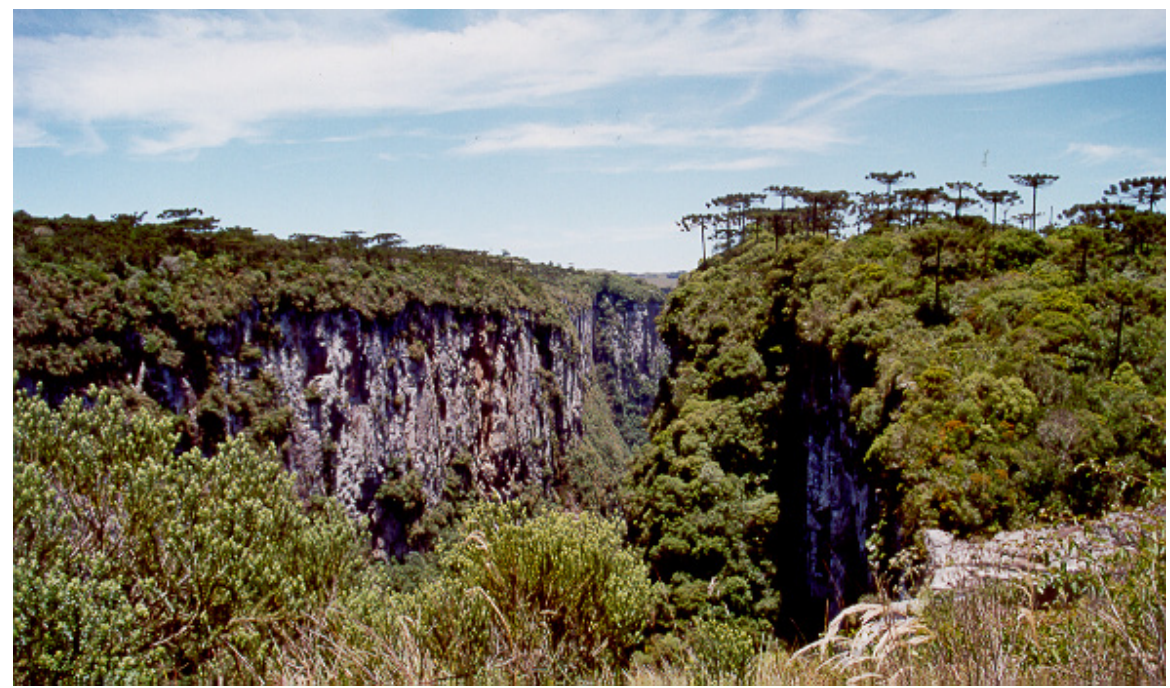

Figura 91 - Área de ocorrência da Floresta Ombrófila Mista, Planalto das Araucárias (RS).

Foto: Rosangela Garrido Machado Botelho.

A Depressão Periférica Paulista é um compartimento do relevo alongado, aproximadamente na direção norte-sul, formando um grande arco, que se estende na porção leste do Estado de São Paulo, limitado a leste por unidades litoestratigráficas do Pré-Cambriano e a oeste por grande escarpa arenito-basáltica da Bacia do Paraná. A depressão foi esculpida em terrenos essencialmente constituídos por litologias do Grupo Itararé (arenitos, diamectitos, ritmitos, siltitos e folhelhos) do Permocarbonífero, formando relevos predominantemente tabulares com bordas convexas (GATTO et al., 1983), com a presença de colinas com vertentes de baixa declividade. Em tais terrenos, os bens minerais de mais destaque são os depósitos de argilas.

Os Terrenos Sedimentares da Bacia do Paraná foram recobertos essencialmente por Florestas Estacionais, que se encontram atualmente bastante reduzidas e fragmentadas. Essas florestas são provavelmente as formações vegetais mais atingidas pela expansão das atividades agropastoris e urbanas no Bioma Mata Atlântica.

Um aspecto relevante desta porção do Bioma Mata Atlântica é que algumas das maiores Regiões Metropolitanas do País - São Paulo, Curitiba, Goiânia, Campo Grande e Brasília - localizam-se próximas às cabeceiras de rios que drenam para os Terrenos Sedimentares da Bacia do Paraná, que são, respectivamente, Tietê, Iguaçu, Meia Ponte, Anhanduí e São Bartolomeu, todos desaguando direta ou indiretamente no Rio Paraná.

A poluição de origem doméstica e industrial é o principal impacto sobre os recursos hídricos, estando a carga orgânica urbana concentrada principalmente na Sub-bacia do Tietê, onde se localiza a Região Metropolitana de São Paulo. Contudo, o Rio Tietê, ao se encaminhar para o interior do estado, passa por um processo de autodepuração e, ao atingir o Reservatório de Barra Bonita, apresenta níveis de poluição mais baixos. Como este reservatório possui uma grande capacidade assimilativa, característica de ambientes lênticos, ele representa um importante papel na recuperação da qualidade das águas do Tietê, mas, devido ao aporte de nutrientes, apresenta eutrofização de suas águas (COMPANHIA DE TECNOLOGIA DE SANEAMENTO AMBIENTAL, 2003). 
A Bacia do Rio Paraná juntamente com a Bacia do Rio Uruguai abrangem quase a totalidade dos Terrenos Sedimentares da Bacia do Paraná, possuindo grande importância para o País em função das atividades agroindustriais nelas desenvolvidas e pelo seu potencial hidrelétrico.

No Estado de Santa Catarina, algumas áreas das Bacias dos Rios Peperi-Guaçu, das Antas, Chapecó, Irani, Jacutinga, do Peixe e Canoas, pertencentes à Bacia do Rio Uruguai, apresentam conflitos entre lançamento de efluentes urbanos, rurais e industriais e o abastecimento da população.

Uma importante fonte de contaminação dos rios destas sub-bacias são os efluentes da criação de suínos no oeste catarinense. Esta região apresenta a maior concentração de suínos por quilômetro quadrado do País. Este fato, aliado ao alto grau de confinamento, gera um grande volume e uma alta concentração de dejetos líquidos. Estes dejetos vêm poluindo contínua e crescentemente as águas da região, notadamente os pequenos mananciais (AGÊNCIA NACIONAL DE ÁGUAS, 2005).

Na Bacia do Rio Uruguai, as maiores fontes de poluição industrial estão nos Rios do Peixe (região de Videira e Caçador) e Canoas (Município de Lages), localizados na parte superior da bacia, representadas principalmente por fábricas de papel e celulose. Destacam-se também as indústrias de couro, curtumes, matadouros, cervejarias e agroindústrias (AGÊNCIA NACIONAL DE ÁGUAS, 2001).

Nas Bacias dos Rios Tubarão e Araranguá, em Santa Catarina, merece destaque a exploração de carvão, que representa uma fonte importante de poluição das águas superficiais, com destaque para a região de Criciúma e Tubarão.

A poluição hídrica, causada pela drenagem ácida, é provavelmente o impacto mais significativo da mineração e beneficiamento do carvão mineral. Essa poluição decorre da percolação da água de chuva sobre os rejeitos das atividades de lavra e beneficiamento. Essas águas adquirem baixos valores de $\mathrm{pH}(<3)$, altos valores de ferro total, sulfato total e vários outros elementos tóxicos que impedem a sua utilização em qualquer atividade e destroem a flora e a fauna aquática (ALEXANDRE; KREBS, 1995 apud SERVIÇO GEOLÓGICO DO BRASIL, 2002).

Apesar de a extração do carvão ter sido bastante reduzida, o desenvolvimento desta atividade por mais de 80 anos no Município de Tubarão e arredores causou grande impacto no rio homônimo, já que o carvão retirado do solo era lavado no local e os dejetos lançados no rio. Em alguns trechos o Rio Tubarão está totalmente morto (AGÊNCIA NACIONAL DE ÁGUAS, 2005).

Os diferentes domínios morfoestruturais aqui apresentados expressam a grande heterogeneidade de condições abióticas do Bioma Mata Atlântica, também marcado pela diversidade de comunidades biológicas, que refletem sua complexa história biogeográfica ao longo do Quaternário. Como resultado da sobreposição da distribuição de espécies com diferentes atributos ecológicos e histórias evolutivas diversas, a biota atual da Mata Atlântica apresenta grande riqueza de espécies (diversidade pontual ou Alfa), elevado número de endemismos e expressiva heterogeneidade espacial (diversidade de diferenciação ou Beta). Mesmo com uma compreensão apenas parcial dessa complexa história evolutiva, em decorrência do 
alto grau de fragmentação da vegetação original, Olson e outros (2001) mapearam a ocorrência de 12 ecorregiões na Mata Atlântica. Posteriormente, com base em endemismos de vertebrados, Silva e Casteleti (2003) propuseram agregar essas áreas em oito biorregiões. Por sua extraordinária riqueza de espécies, alto grau de endemismos e acentuada devastação e fragmentação florestal, a Mata Atlântica apresenta também os mais elevados números de espécies ameaçadas de extinção no Brasil (PAGLIA; FONSECA; SILVA, 2008).

A despeito da intensa conversão de suas florestas e ecossistemas associados em paisagens antrópicas, a Mata Atlântica ainda apresenta uma concentração extraordinária de espécies. Dados do Instituto de Pesquisa da Mata Atlântica - IPEMA e da Conservação Internacional Brasil mostram que a riqueza florística pontual é acentuada e que os dois maiores recordes de diversidade de árvores foram registrados na Mata Atlântica: 454 espécies em um único hectare no sul da Bahia e 476 espécies em amostra de mesmo tamanho na região serrana do Espírito Santo (CONSERVAÇÃO..., 2005). Ainda segundo a Conservação Internacional Brasil, a Mata Atlântica ocupa o quarto lugar entre os 25 hotspots mundiais para a diversidade de plantas vasculares. A diversidade vegetal traduz-se pela presença de muitas espécies de bromélias (Figura 92), de samambaias (epífitas e arborescentes), lianas, aráceas, além de orquídeas e muitas palmeiras, destacando-se o palmito-doce, que se encontra em processo de extinção. Nas matas secundárias de baixa altitude, são frequentes as quaresmeiras, o fedegoso ou aleluia e as embaúbas. Em trechos mais primitivos, citam-se, do estrato arbóreo superior, espécies de grande porte, como o cedro, o alecrim, o angico, o açoita-cavalo, o ipê-amarelo, entre tantas. Outras grandes árvores da Mata Atlântica são os jequitibás, a canela-santa, a maçaranduba, os jacarandás, a peroba-rosa e outras perobas do mesmo gênero, sem deixar de mencionar o pau-brasil. Algumas dessas árvores podem alcançar mais de 30 metros de altura.

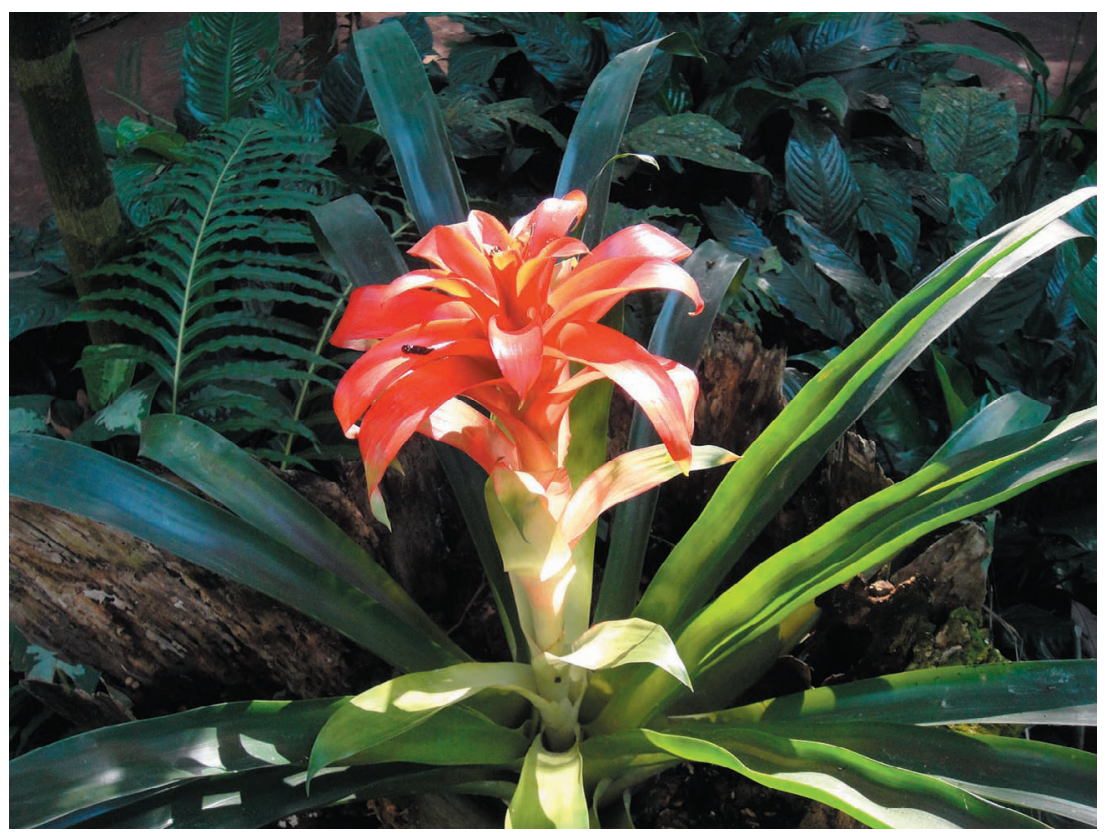

Figura 92 - Bromélia, planta típica da Mata Atlântica. Foto: Rosangela Garrido Machado Botelho. 
A Flora do Brasil registra para a Mata Atlântica um total de 18713 espécies, entre as quais 14382 Angiospermas, 10 Gimnospermas, 810 Samambaias e Licófitas, 1347 Briófitas, e 2164 fungos. A Mata Atlântica apresenta também o maior número de espécies de plantas endêmicas entre todos os biomas do País, totalizando 10211 espécies, em sua maioria Angiospermas (9 545 espécies), além de um Gimnosperma, 346 Samambaias e Licófitas, 234 Briófitas e 85 fungos (LISTA..., 2010). Constam da lista oficial de espécies ameaçadas no Brasil 276 espécies de plantas da Mata Atlântica, entre as quais, o pau-brasil, espécie cujo nome batizou o País, o palmito juçara, a araucária, além de várias orquídeas e bromélias (MAPA..., 2008).

A biota aquática apresenta uma rica fauna de peixes, com aproximadamente 350 espécies (CUNHA et al., 2013a). Diferentes espécies habitam poços, corredeiras, corredores e remansos dos pequenos riachos que permeiam as áreas de floresta e desenvolveram adaptações às condições de vida em cabeceiras de cursos de água com regimes de alta pluviosidade, estando em associação íntima com a mata, que lhes garante, fundamentalmente, nutrição e proteção. Outras espécies habitam as calhas dos grandes rios, com destaque para as espécies migradoras. De modo geral, da nascente à foz, esses riachos curtos e íngremes apresentam comunidades com números crescentes de espécies, com diminuição da riqueza nos estuários, onde o filtro seletivo da salinidade exclui diversas espécies. Os inventários sobre essa fauna são incompletos, o que dificulta avaliá-la com precisão, mas uma compilação preliminar (MENEZES et al., 2007) registrou elevados índices de endemismo (267/309; 85,0\% das espécies). Também é reconhecido que as bacias do leste brasileiro, compreendidas entre a Foz do Rio São Francisco e o norte do Estado de Santa Catarina, representam a região de endemismo com o maior número de espécies ameaçadas (59/309; 19,0\% das espécies), devido à acentuada degradação ambiental da região (ROSA; LIMA, 2008). Os peixes-anuais, que habitam brejos de florestas costeiras, que estão sendo convertidos pela ocupação acelerada das regiões litorâneas, representam o grupo mais ameaçado, com 16 espécies incluídas no Livro vermelho da fauna brasileira ameaçada de extinção (MACHADO; DRUMMOND; PAGLIA, 2008). Outras 26 espécies de peixes de pequeno porte que habitam os riachos e ribeirões da Mata Atlântica, tais como os lambaris, o canivete, a corredora, o bagrinho e as cambevas, estão ameaçados pela remoção da cobertura florestal e poluição. Além disso, espécies de médio a grande porte que habitam as calhas dos principais rios da região (Paraíba do Sul, Doce, Jequitinhonha e Paraguaçu), incluindo o piau, as piabanhas, a vermelha, o andirá, os cascudos, o peracuca e o surubim, estão ameaçados pelo desmatamento, assoreamento dos canais, poluição e construção de hidrelétricas (ROSA; LIMA, 2008).

Quanto à herpetofauna, os números evidenciam, igualmente, alta diversidade biológica. Segundo a Conservation International, a fauna de anfíbios do Bioma Mata Atlântica ocupa, assim como as plantas vasculares, a quarta posição mundial em diversidade biológica, com registro de 456 espécies de anfíbios (CUNHA et al., 2013a), com destaque para as mais de 90 espécies de anuros endêmicos. A intensa destruição da Mata Atlântica faz com que todas as 16 espécies ameaçadas de extinção e a única espécie já considerada extinta pertençam ao domínio da Mata Atlântica (HADDAD, 2008). Metade dessas espécies tem ocorrência nos ecossistemas campestres da Mata Atlântica (Campos de Cima da Serra - RS e SC; Campos Planálticos - RS, SC e PR e Campos Gerais - PR), com destaque para quatro espécies do gênero Melanophryniscus (BENCKE, 2009). No que se refere aos répteis, já foram registradas 
para a Mata Atlântica 311 espécies (CUNHA et al., 2013a), das quais aproximadamente 20,0\% são endêmicas. A grande maioria das espécies de lagartos e serpentes da Mata Atlântica não consegue sobreviver em ambientes alterados, como pastos, plantações, eucaliptais e pinheirais, enquanto outras, como a cascavel, estão aumentando sua área de distribuição, por serem capazes de invadir áreas abertas criadas pela derrubada da floresta. Entre as 20 espécies de répteis ameaçadas de extinção no Brasil, 13 ocorrem no Bioma Mata Atlântica, seis delas restritas às restingas litorâneas que sofrem grande pressão de ocupação humana (MARTINS; MOLINA, 2008). Entre as espécies de répteis presentes, destacam-se a tartaruga, a lagartixa-da-areia, o jacaré-de-papo-amarelo, ameaçados de extinção, os jabutis, o lagarto teiú e alguns ofídios peçonhentos, como a coral verdadeira, a surucucu e a jararaca, além de cobras inofensivas, como a jiboia.

Quanto às aves, a biodiversidade é ainda mais expressiva. Foram registradas 934 espécies (CUNHA et al., 2013a), o que torna a avifauna do Bioma Mata Atlântica uma das mais ricas do planeta, com números elevados de espécies endêmicas (188 espécies) e de espécies ameaçadas de extinção (98 espécies). As aves endêmicas da Mata Atlântica do "Centro Pernambuco de endemismo" sobrevivem em diminutos fragmentos isolados e ameaçados por desmatamento, caça e degradação difusa do ambiente (SILVEIRA; STRAUBE, 2008). O maior conhecimento que se tem a respeito desta classe está concentrado na porção sudeste-sul do bioma, que detém alta diversidade ornitológica submetida à forte pressão antrópica (BRASIL, 2002). São exemplos de espécies representativas dos diferentes ecossistemas que compõem o Bioma Mata Atlântica aves como a jacutinga (Figura 93), o mutum, o jaó, o macuco, o jacu, o gavião-real, o urubu-rei, vários psitacídeos, como o raro e ameaçado papagaio-de-peito-roxo, o gavião-pega-macaco, a gralha-azul (da Mata de Araucárias), a curicaca, o tucano-de-bico-preto e o araçaris, além de diferentes espécies pertencentes às ordens dos Apodiformes (beija-flores) e dos Passeriformes.

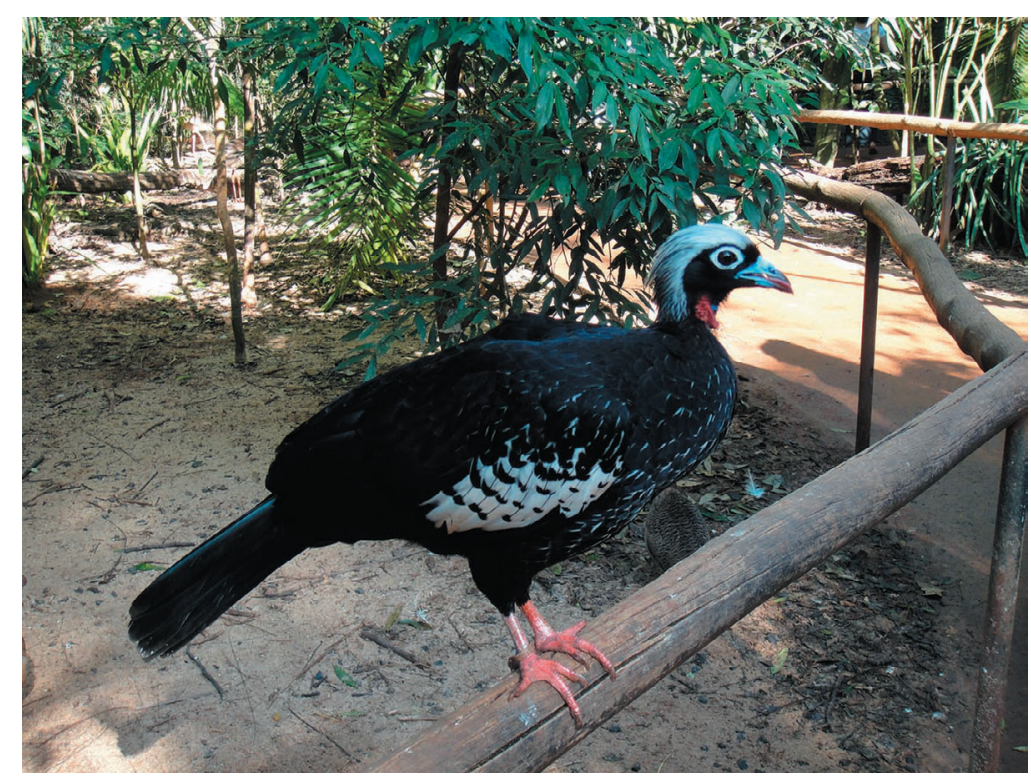

Figura 93 - Jacutinga, ave típica da Mata Atlântica, cujo principal alimento é o fruto do palmiteiro. Foto: Rosangela Garrido Machado Botelho. 
Para a mastofauna, as listas apontam 270 espécies conhecidas, com taxa de endemismo da ordem de 22,0\% (55 espécies). Mais de 40 espécies estão ameaçadas de extinção (CUNHA et al., 2013a), por estarem expostas a uma ou mais das 17 fontes de ameaças identificadas, com destaque para a destruição de habitat e o desmatamento (CHIARELLO et al., 2008). Apesar do conhecimento acerca desta classe zoológica, ainda há lacunas a serem preenchidas, havendo necessidade de se proceder a inventários mais detalhados, embora o nível de conhecimento sobre a mastofauna da Mata Atlântica seja bem melhor do que para os demais biomas. Entre os mamíferos, merecem destaque algumas espécies de primatas, como o mono-carvoeiro ou muriqui, o maior macaco americano, o guariba, o macaco-prego, o mico-leão, o mico-leão-de-cara-preta, o mico-leão-dourado, o sauá e outras variedades de saguis. Integram também a mastofauna as preguiças, o quati (Figura 94), o cachorro-do-mato, o queixada, o caxinguelê, a cutia, a paca etc. Mamíferos de grande porte, como a anta, e predadores, por exemplo, felinos como o puma ou suçuarana, a onça pintada e outros do gênero Leopardus também se destacam. Cabe, por fim, citar animais como a irara, o raro ouriço-preto, o ouriço-cacheiro, a lontra etc.

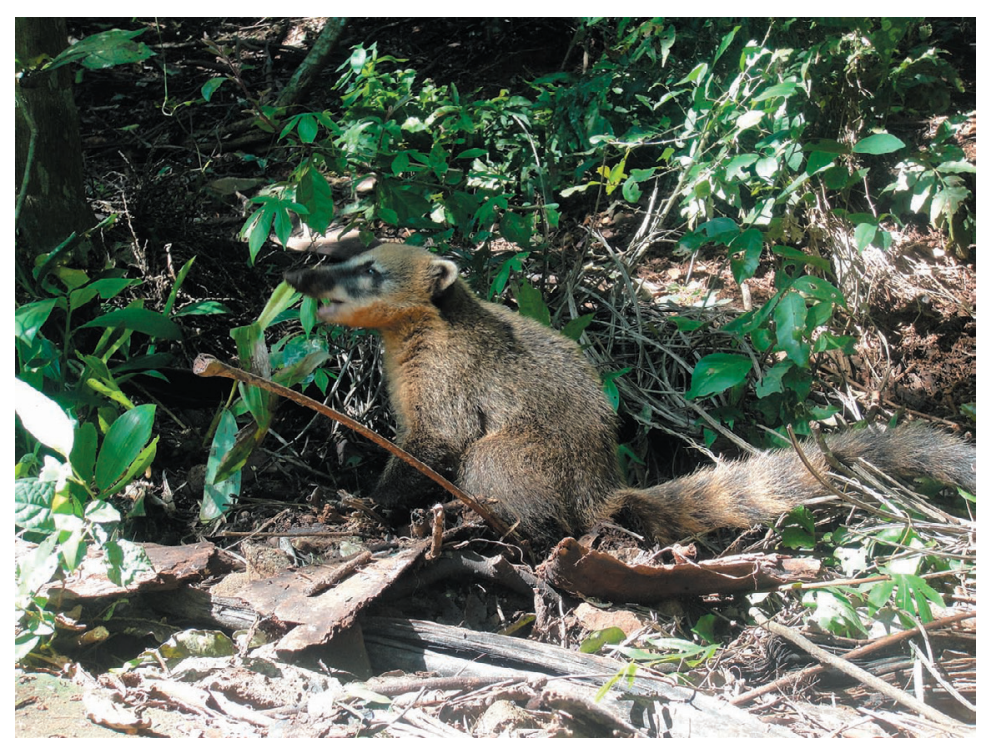

Figura 94 - Quati, mamífero comum na Mata Atlântica, facilmente reconhecível por seu focinho preto e alongado, e cauda geralmente com anéis claros e escuros. Foto: Rosangela Garrido Machado Botelho.

Em qualquer um dos grandes domínios morfoestruturais apresentados, o Bioma Mata Atlântica enfrenta graves ameaças à sua preservação. Suas florestas estão bastante fragmentadas, restando de $7,26 \%$ (incluindo apenas remanescentes de florestas bem-preservados, com área superior a 100 hectares) a 27,0\% (considerando os remanescentes dos vários estágios de recuperação, com menos de 3 hectares, em todas as fisionomias dentro dos limites do Bioma Mata Atlântica) da área originalmente ocupada (CUNHA et al., 2013a). Além de fragmentado, o habitat remanescente está bastante degradado, tornando crítica a sobrevivência de populações viáveis de muitas espécies, sobretudo aquelas mais exigentes em área, como 
os grandes vertebrados terrestres (onça, antas, porco-do-mato, aves de rapina) ou aquáticos (peixes migradores). Considerando o lapso de tempo entre a perda de habitat e a perda de espécies, muitas espécies da Mata Atlântica encontram-se no limiar da extinção (CUNHA et al., 2013a). Entre as plantas, 276 espécies da Mata Atlântica constam da lista oficial de espécies ameaçadas no Brasil (MAPA..., 2008). De acordo com o Livro vermelho da fauna brasileira ameaçada de extinção (MACHADO; DRUMMOND; PAGLIA, 2008), 380 espécies da lista oficial (60,6\%) têm distribuição conhecida na Mata Atlântica e, considerando apenas os vertebrados terrestres, pode-se afirmar que aproximadamente 8,5\% das espécies do bioma e 25,0\% das espécies endêmicas da Mata Atlântica estão ameaçadas de extinção (PAGLIA; FONSECA; SILVA, 2008). O desaparecimento de espécies da flora e da fauna está ligado à destruição de seu habitat e ao desmatamento. No caso da fauna, contribuem, ainda, para o processo de extinção de espécies, a caça, o tráfico de animais, o atropelamento em rodovias e a introdução de espécies exóticas, entre 17 fontes de ameaças identificadas (CHIARELLO et al., 2008).

Para Dean (1998), o processo exploratório das espécies nativas iniciado pelos colonizadores, e sua substituição por espécies exóticas, apoiou-se inicialmente no modelo da plantation-escravista, com a cultura da cana-de-açúcar, que durou mais de 300 anos, e outros que o sucederam, como o da pecuária, do café e do cacau, que comandaram o processo de derrubada e fragmentação da Mata Atlântica.

Nas áreas de pecuária, o sobrepastoreio rapidamente degradou as pastagens, reduzindo as espécies de maior palatabilidade, degradando os solos e deixando os campos com plantas raquíticas ou doentes. Desse modo, em busca de solos mais férteis, a pecuária avançou sobre novas áreas de mata. A abertura dessas novas terras se dava pelo desmatamento, que, progressiva e lentamente, destruiu parcela significativa do bioma. Com os desmatamentos, a erosão, especialmente nas áreas de maior declividade, se acentuou e desencadeou processos de assoreamento e inundação.

Os processos de urbanização, de expansão agrícola, de industrialização e o crescimento demográfico do litoral para o interior se intensificaram durante o Século XX, acelerando a degradação da Mata Atlântica. Dentre as principais atividades responsáveis por esta degradação estão: a exploração seletiva de madeiras e a extração ilegal de lenha; as queimadas; o uso irracional dos solos; a extração ilegal de palmito; o turismo predatório; a expansão urbana sobre manguezais; a caça ilegal de animais; a construção de barragens; a industrialização; e o lançamento de poluentes.

Por outro lado, o Bioma Mata Atlântica foi também o berço do movimento ambiental brasileiro (MITTERMEIER et al., 2005). Novas preocupações de cunho científico-social sobre o futuro da Mata Atlântica surgem no final do Século XX, já na década de 1980, com uma significativa participação da sociedade e com uma perspectiva mais moderna e realista das questões ambientais. Esses movimentos obtiveram conquistas importantes com o reconhecimento da Mata Atlântica como patrimônio nacional pela Constituição Federal do Brasil de 1988 e por ocasião da Conferência das Nações Unidas sobre o Meio Ambiente e Desenvolvimento (Rio 92), quando a Mata Atlântica é reconhecida como um dos biomas mais ameaçados do mundo, impulsionando novas conquistas. 
As poucas "ilhas" de floresta que restam da Mata Atlântica original representam valiosos repositórios de fauna e flora, isto é, constituem um banco genético significativo que precisa ser preservado. Os títulos conferidos - Reserva da Biosfera da Mata Atlântica (Declaração UnESCO s/n, 1991 - 1a fase); Sítio do Patrimônio Natural Mundial e Reservas de Mata Atlântica do Sudeste, nos Estados do Paraná e São Paulo (Declaração UNESCO s/n, 1999) - reconhecem a sua importância e a necessidade de sua preservação. A Reserva da Biosfera da Mata Atlântica, cuja área abrange cerca de 35 milhões de hectares, estende-se por mais de 5000 quilômetros do litoral brasileiro, do Ceará ao Rio Grande do Sul, e foi a primeira unidade da Rede de Reservas da Biosfera (Programa Homem e a Biosfera/Man and the Biosphere-MaB, da UNESCO) declarada no Brasil, tendo sido ampliada em cinco fases sucessivas entre 1991 e 2002 (RESERVA DA BIOSFERA DA MATA ATLÂNTICA, 2004a).

Após constar como um dos hotspots em território brasileiro, com base nas elevadas taxas de diversidade de espécies e alto grau de endemismo, sob forte pressão antrópica (MYERS, 1988), a Mata Atlântica ganha status internacional e passa a figurar entre os cinco primeiros biomas no ranking dos hotspots mundiais (MYERS et al., 2000; MITTERMEIER et al., 2005).

O Decreto n.750, de 10 de fevereiro de 1993, incorporou o conceito de Domínio da Mata Atlântica, estabeleceu seus limites e ensejou diversas resoluções do Conselho Nacional do Meio Ambiente - CONAMA, definindo conceitos e parâmetros de conservação para as diversas fitofisionomias que o compõem. Destaca-se que os limites do Domínio da Mata Atlântica (MAPA..., 2008) diferem daqueles do Bioma Mata Atlântica, apesar da grande superposição entre eles. A área do Domínio é maior do que a do Bioma, pois o primeiro incorpora as áreas de floresta não contíguas extra-amazônicas.

A mobilização social e o desenvolvimento científico culminaram na aprovação da Lei da Mata Atlântica, Lei n. 11.428, de 22 de dezembro de 2006, e do Decreto n. 6.660, de 21 de novembro de 2008. A Lei da Mata Atlântica regula a conservação, a proteção, a regeneração e a utilização do bioma, visando preservar os remanescentes da Mata Atlântica no País, a lém de criar meios para a sua recuperação em regiões onde hoje está praticamente extinta. O Decreto n. 6.660/2008 detalha os procedimentos necessários para promover a intervenção ou o uso sustentável nos remanescentes de vegetação nativa da Mata Atlântica, bem como discrimina os tipos de vegetação protegidos pela Lei da Mata Atlântica e apresenta sua delimitação no Mapa da área de aplicação da lei n. 11.428 de 2006, elaborado pelo IBGE (MAPA..., 2008).

O estabelecimento de áreas protegidas tem sido um dos mais importantes instrumentos para a conservação de amostras representativas das diversidades biológica e cultural da Mata Atlântica. Não obstante o crescimento substancial do número de áreas protegidas no bioma nos últimos 50 anos, a maioria delas é muito pequena, carecendo de plano de manejo, definição da situação fundiária, inventários da biodiversidade, monitoramento e fiscalização. Muitas delas foram criadas em função de uma oportunidade favorável, de modo que, além do tamanho, sua forma e zoneamento podem não ser os mais adequados para os fins conservacionistas (GALINDO-LEAL; CÂMARA, 2005). Atualmente apenas cerca de 3,3 milhões de hectares ( $2,5 \%$ da área do bioma) estão protegidos em Unidades de Conservação de proteção integral, principalmente em parques nacionais e estaduais, e outros 6,1 milhões 
de hectares em categorias de Unidades de Conservação de Uso Sustentável, o que representa $6,1 \%$ da área historicamente ocupada pelas florestas e ecossistemas associados, majoritariamente em Áreas de Proteção Ambiental (CUNHA et al., 2013a). Por outro lado, essas áreas não estão uniformemente distribuídas entre as diversas formações florestais e ecossistemas associados, fato que torna ainda mais urgentes as medidas para a criação e a implantação de novas Unidades de Conservação (BRASIL, 2007).

No esforço de ampliar essas áreas, a Deliberação da Il Conferência Nacional do Meio Ambiente, ocorrida em novembro de 2005, ressaltou que o Brasil deve aumentar o número das Unidades de Conservação, atingindo pelo menos 20,0\% da área original de cada bioma, garantindo o mínimo de 4,0\% de áreas de proteção integral, em cinco anos (BRASIL, 2007). Entre 1993 e 2011, 20 iniciativas de priorização de áreas para a conservação da biodiversidade na Mata Atlântica foram conduzidas, variando extremamente quanto aos métodos, escalas, resoluções das informações e graus de implementação dos resultados. Dessas 20 iniciativas, seis foram exercícios estaduais (PE, MG, ES, SP, PR e RJ), cinco abarcaram uma escala regional (ecorregião da Serra do Mar, Mata Atlântica do Nordeste etc...), e nove abrangeram todo o limite legal da Mata Atlântica (com destaque para a última revisão, que indicou 880 áreas prioritárias para o Bioma Mata Atlântica, sendo que desse total 522 representavam novas áreas, e 358 eram áreas sob algum tipo de proteção no ano de 2006). Cumpre destacar ainda que apenas metade dessas iniciativas foi reconhecida pelo poder público como instrumentos oficiais de políticas ambientais e, comparativamente com as demais, foram as que geraram mais ações práticas de conservação no bioma (PAGLIA, 2013).

Para atingir, entretanto, o objetivo de maximizar as chances de proteger elementos essenciais da biodiversidade, é de fundamental importância que tais iniciativas não apenas sejam incorporadas como políticas públicas às diferentes esferas de decisão governamental, mas também que sejam amplamente divulgadas e discutidas com a sociedade. A Mata Atlântica abriga um dos maiores contingentes de biodiversidade do planeta. Porém, o patrimônio representado pelo Bioma Mata Atlântica vai muito além da riqueza de sua biodiversidade ou de sua exuberância paisagística. Ele está intimamente ligado à proteção dos solos e de mananciais de água potável, que precisam sustentar uma população numerosa e atender a sua demanda por alimentos, matérias-primas para indústrias e serviços essenciais a sua sobrevivência e qualidade de vida. 


\section{Referências}

AB'SÁBER, A. N. Os domínios de natureza no Brasil: potencialidades paisagísticas. Cotia: Ateliê Editorial, 2003. 159 p. (Natureza: textos de apoio, 1).

AGÊNCIA DE FOMENTO DO ESTADO DO RIO GRANDE DO SUL. Desenvolvimento florestal estará em debate. Porto Alegre: Caixa-RS, [2005?]. Disponível em: <www.caixars. com.br>. Acesso em: nov. 2005.

AGÊNCIA NACIONAL DE ÁGUAS (Brasil). Bacias brasileiras do rio da Prata: avaliações e propostas. Brasília, DF: ANA, 2001. 102 p. Disponível em: <http://rhama.net/download/ artigos/artigo85.pdf>. Acesso em: jul. 2016.

Panorama da qualidade das águas superficiais no Brasil. Brasília, DF:ANA, 2005.175 p. (Cadernos de recursos hídricos, 1). Disponível em: $<$ http://arquivos.ana.gov.br/institucional/ sge/CEDOC/Catalogo/2005/PanoramaDaQualidadeDasAguasSuperficiaisNoBrasil/ANAIQA.swf>. Acesso em: jul. 2016.

Plano estratégico de recursos hídricos dos afluentes da margem direita do rio Amazonas: resumo executivo. Brasília, DF: ANA, 2012. 144 p. Disponível em: <http:// arquivos.ana.gov.br/institucional/sge/CEDOC/Catalogo/2013/planoEstrategicoDeRecursos. pdf>. Acesso em: jul. 2016.

Projeto implementação de práticas de gerenciamento integrado de bacia hidrográfica para o pantanal e bacia do Alto Paraguai (ANA/GEF/PNUMA/OEA): subprojeto 2.3 - planejamento ecorregional do pantanal - MS/MT: relatório final. Brasília, DF: Agência Nacional de Águas - ANA, 2004. 176 p.

AGUIAR, L. M. de S.; MACHADO, R. B. Áreas prioritárias para a pesquisa de morcegos no domínio do cerrado. In: DINIZ, I. R. et al. (Org.). Cerrado: conhecimento científico quantitativo como subsídio para ações de conservação. Brasília, DF: Universidade de Brasília - UnB: Thesaurus, 2010. cap. 14, p. 441-458.

ALFONSI, R. R.; CAMARGO, M. B. P. de. Condições climáticas para a região do pantanal mato-grossense. In: SIMPÓSIO SOBRE RECURSOS NATURAIS E SÓCIO-ECONÔMICOS DO PANTANAL, 1., 1984, Corumbá. Anais... Brasília, DF: Empresa Brasileira de Pesquisa Agropecuária - Embrapa, Departamento de Difusão de Tecnologia, Corumbá: Empresa Brasileira de Pesquisa Agropecuária - Embrapa, Centro de Pesquisa Agropecuária do Pantanal - CPAP, 1986. p. 29-42. Disponível em: <http://www.cpap.embrapa.br/publicacoes/online/ DOC05.pdf>. Acesso em: jul. 2016.

ALHO, C. J. R.; GONÇALVES, H. C. Biodiversidade do pantanal: ecologia e conservação. Campo Grande: Ed. Uniderp, 2005. 142 p.

ALHO, C. J. R.; STRÜSSMANN, C.; VASCONCELLOS, L. A. S. Indicadores da magnitude da diversidade e abundância de vertebrados silvestres do pantanal num mosaico de hábitats sazonais. In: SIMPÓSIO SOBRE RECURSOS NATURAIS E SÓCIO-ECONÔMICOS DO PANTANAL, 3., 2000, Corumbá. Anais... Corumbá: Empresa Brasileira de Pesquisa Agropecuária - Embrapa Pantanal: Universidade Federal de Mato Grosso do Sul - UFMS, 2000. 54 p. Disponível em: <http://www.cpap.embrapa.br/agencia/congresso/Bioticos/ ALHO-074.pdf>. Acesso em: jul. 2016. 
ALLEM, A. C.;VALLS, J. F. M. Recursos forrageiros nativos do pantanal mato-grossense. Brasília, DF: Empresa Brasileira de Pesquisa Agropecuária - Embrapa, Departamento de Difusão de Tecnologia, 1987. 339 p. (Embrapa-Cenargen. Documentos, 8).

ALMEIDA, F. F. M. de. Contribuição à geomorfologia da região oriental de Santa Catarina. Boletim Paulista de Geografia, São Paulo: Associação dos Geógrafos Brasileiros - AGB, n. 10, p. 3-32, mar. 1952.

ALMEIDA, F. F. M. et al. Províncias estruturais brasileiras. In: SIMPÓSIO DE GEOLOGIA DO NORDESTE, 8., 1977, Campina Grande. Atas... Recife: Sociedade Brasileira de Geologia SBG, Núcleo Nordeste, 1977. p. 363-391. (Boletim da Sociedade Brasileira de Geologia, Núcleo do Nordeste, 6).

ALVARENGA, S. M. et al. Levantamento preliminar de dados para o controle de enchentes da bacia do Alto Paraguai. Goiânia: Projeto Radambrasil, 1980. 44 p. (Relatório interno Radambrasil, 31-GM).

AMAZONAS. Secretaria de Estado do Meio Ambiente e Desenvolvimento Sustentável. Nota técnica sobre a seca no Amazonas. Manaus, 2005. Disponível em: <http://www.sds.am.gov. br/dsv/download/img_download/20051018153725NOTA_TECNICA_CLIMA.doc>. Acesso em: out. 2005.

AMBIENTALISTAS denunciam manobra em audiências que favorecem as papeleiras no RS. São Leopoldo: Instituto Humanista Unisinos, 2007. Notícia de 19 de jun. 2007. Disponível em: <http://www.ihu.unisinos.br/noticias/noticias-anteriores/7866-ambientalistas-denunciammanobra-em-audiencias-que-favorecem-as-papeleiras-no-rs >. Acesso em: jul. 2016.

AMORIM, M. A. et al. Caracterização granulométrica e mineralógica dos sedimentos na várzea do Lago Grande de Curuaí, Pará: compreensão da dinâmica sedimentar. In: CONGRESSO DA ASSOCIAÇÃO BRASILEIRA DE ESTUDOS DO QUATERNÁRIO, 10., 2005, Guarapari. Anais... São Paulo: Abequa, 2005. 6 p. Disponível em: <http://www. abequa.org.br/trabalhos/0130_resumo_abequa4.pdf>. Acesso em: jul. 2016.

ANÁLISE integrada e prognóstico da bacia do Alto Paraguai. In: BRASIL. Ministério do Meio Ambiente, dos Recursos Hídricos e da Amazônia Legal. Plano de conservação da bacia do Alto Paraguai (Pantanal) - PCBAP. Brasília, DF, 1997. v. 3. Programa Nacional do Meio Ambiente. Projeto Pantanal.

ANTUNES, M. P. Diagnóstico da área de estudo-resumo. In: SIMPÓSIO SOBRE RECURSOS NATURAIS E SÓCIO-ECONÔMICOS DO PANTANAL, 1., 1984, Corumbá. Anais ... Brasília, DF: Empresa Brasileira de Pesquisa Agropecuária - Embrapa, Departamento de Difusão de Tecnologia; Corumbá: Universidade Federal de Mato Grosso do Sul - UFMS, 1986. p. 207227. Disponível em: <http://www.cpap.embrapa.br/publicacoes/online/DOC05.pdf>. Acesso em: jul. 2016.

ANUÁRIO MINERAL BRASILEIRO 1986. Brasília, DF: Departamento Nacional de Produção Mineral - DNPM, v. 15, 1986.

ANUÁRIO MINERAL BRASILEIRO 2005. Brasília, DF: Departamento Nacional de Produção Mineral - DNPM, v. 34, 2005. Disponível em: <http://www.dnpm.gov.br/dnpm/paginas/ anuario-mineral/anuario-mineral-brasileiro-2005>. Acesso em: mar. 2016. 
AQUINO, S.; LATRUBESSE, E. M.; SOUZA FILHO, E. E. de. Relações entre o regime hidrológico e os ecossistemas aquáticos da planície aluvial do rio Araguaia. Acta Scientiarum. Biological Sciences, Maringá: Eduem, v. 30, n. 4, p. 361-369, 2008. Disponível em: <http://periodicos. uem.br/ojs/index.php/ActaSciBiolSci/article/view/5866/5866>. Acesso em: jul. 2016.

ARAI, M. A grande elevação eustática do mioceno: a verdadeira origem do grupo barreiras. In: CONGRESSO DA ASSOCIAÇÃO BRASILEIRA DE ESTUDOS DO QUATERNÁRIO, 10., 2005, Guarapari. Anais... São Paulo: Abequa, 2005. 6 p. Disponível em: <http://www. abequa.org.br/trabalhos/0310_arai_artigoabequa.pdf>. Acesso em: jul. 2016.

ÁREAS prioritárias para conservação da biodiversidade no cerrado e pantanal. Brasília, DF: Fundo Mundial para a Natureza - WWF- Brasil: Ministério do Meio Ambiente, 2015. 128 p. Disponível em: <http://www.wwf.org.br/?50322>. Acesso em: jul. 2016.

AVANÇO do desmatamento na bacia do Alto Paraguai e pantanal brasileiro. In: AMAIVOS. Rio de Janeiro, 2006. Notícia de 21 fev. 2006. Disponível em: <http://amaivos.uol.com.br/ amaivos2015/?pg=noticias\&cod_canal=49\&cod_noticia=6615>. Acesso em: jul. 2016.

BACIA do São Francisco. In: INSTITUTO BRASILEIRO DO MEIO AMBIENTE E DOS RECURSOS NATURAIS RENOVÁvEIS. Programa Nacional de Desenvolvimento da Pesca Amadora - PNDPA. Brasília, DF: Ibama, [2007?]. Disponível em: <http://www.ibama.gov.br/ pescaamadora/locais/b_dosaofrancisco.htm>. Acesso em: out. 2007.

BARRETO, P.; ARIMA, E.; BRITO, M. Pecuária e desafios para a conservação ambiental na Amazônia. Belém: Instituto do Homem e Meio Ambiente da Amazônia - Imazon, 2005. 4 p. (O Estado da Amazônia, n. 5). Disponível em: <http://imazon.org.br/publicacoes/pecuariae-desafios-para-a-conservacao-ambiental-na-amazonia/>. Acesso em: jul. 2016.

BARRETO, P. et al. Pressão humana no bioma Amazônia. Belém: Instituto do Homem e Meio Ambiente da Amazônia - Imazon, 2005. 6 p. (O estado da Amazônia, n. 3). Disponível em: $<$ http://imazon.org.br/publicacoes/pressao-humana-no-bioma-amazonia/>. Acesso em: jul. 2016.

BARTHEM, R. B.; GOULDING, M. Um ecossistema inesperado: a Amazônia revelada pela pesca. Lima: Amazon Conservation Association - ACA; Tefé: Sociedade Civil Mamirauá, 2007. 241 p.

BARTHEM, R. B.; RIBEIRO, M. C. L. de B.; PETRERE JUNIOR, M. Life strategies of some longdistance migratory catfish in relation to hydroeletric dams in the amazon basin. Biological Conservation, London: Elsevier, v. 55, n. 3, p. 339-345, 1991. Disponível em: <http://www. sciencedirect.com/science/article/pii/000632079190037A>. Acesso em: jul. 2016.

BAYLEY, P. B.; PETRERE JUNIOR, M. Amazon fisheries: assessment methods, current status and management options. In: DODGE, D. P. (Ed.). Proceedings of the international large river symposium (LARS). Ottawa: Department of Fisheries and Oceans, 1989. p. 385-398. (Canadian special publication of fisheries and aquatic sciences, 106). Disponível em: <http:// www.dfo-mpo.gc.ca/Library/111846.pdf>. Acesso em: jul. 2016.

BELMONTE, R. V. Plantio de florestas ou deserto verde. 2005. Disponível em: <http://www. rvb.jor.br/desertoverde.htm>. Acesso em: abr. 2007. 
BENCKE, G. A. Diversidade e conservação da fauna dos campos do sul do Brasil. In: PILLAR, V. de P. et al. (Ed.). Campos sulinos: conservação e uso sustentável da biodiversidade. Brasília, DF: Ministério do Meio Ambiente, 2009. cap. 7, p. 101-121. Disponível em: <http://www. mma.gov.br/publicacoes/biodiversidade/category/58-probio-i-serie-biodiversidade?downl oad=964: campos-sulinos-conservacao-e-uso-sustentavel-da-biodiversidade $>$. Acesso em: mar. 2016.

BERTRAN, P. História da terra e do homem no planalto central: eco-história do Distrito Federal: do indígena ao colonizador. Brasília, DF: Solo, c1994. 314 p.

BEZERRA, P. E. L. et al. Geologia regional da amazônia legal brasileira. Goiânia: Projeto Radambrasil, 1986. (Relatório interno Radambrasil, 1061-G).

BOLDRINI, I. I. A flora dos campos do Rio Grande do Sul. In: PILLAR, V. de P. et al. (Ed.). Campos sulinos: conservação e uso sustentável da biodiversidade. Brasília, DF: Ministério do Meio Ambiente, 2009. cap. 4, p. 63-77. Disponível em: <http://www.mma.gov.br/ publicacoes/biodiversidade/category/58-probio-i-serie-biodiversidade?download=964:cam pos-sulinos-conservacao-e-uso-sustentavel-da-biodiversidade>. Acesso em: mar. 2016.

BOLETIM DE MONITORAMENTO DA BACIA DO ALTO PARAGUAI. Brasília, DF: Agência Nacional de Águas - ANA, v. 1, n. 3, nov. 2006. Disponível em: <http://arquivos. ana.gov.br/saladesituacao/BoletinsMensais/AltoParaguai/Boletim_Monitoramento_Alto_ Paraguai_2006_11.pdf>. Acesso em: jul. 2016.

BOTELHO, R. G. M. Caracterização pedo-geomorfológica do alto rio Negro e borda leste do pantanal da Nhecolândia (MS). 2003. 143 p. Tese (Doutorado)-Programa de Pós-Graduação em Geografia Física, Universidade de São Paulo, São Paulo, 2003.

BOTELHO, R. G. M.; MACEDO, E. L. R. Textura superficial dos solos da Amazônia Legal: indicador de potencial de uso e manejo das terras. In: CONGRESSO BRASILEIRO DE CIÊNCIA DO SOLO, 32., 2009, Fortaleza. Anais... Viçosa: Sociedade Brasileira de Ciência do Solo - SBCS, 2009. 1 CD-ROM.

BOURSCHEIT, A. O rico, desconhecido e ameaçado Pampa. Revista do Ibama, Brasília, DF: Instituto Brasileiro de Meio Ambiente e dos Recursos Naturais Renováveis - Ibama, v. 1, n. 0, p. 21-23, dez. 2005. Disponível em: <http://www.ibama.gov.br/phocadownload/ sala_de_imprensa/revista-n0.pdf> Acesso em: jul. 2016.

BRASIL. Constituição (1988). Constituição da República Federativa do Brasil. Brasília, DF, [2016]. Disponível em: <http://www.presidencia.gov.br/legislacao>. Acesso em: jul. 2016.

BRASIL. Departamento Nacional da Produção Mineral. Projeto Goiânia II: relatório final. Brasília, DF: DNPM; Goiânia: Companhia de Pesquisa de Recursos Minerais - CPRM, Agência Goiânia, 1975. 5 v. Disponível em: <http://rigeo.cprm.gov.br/xmlui/handle/ doc/8904?show=full>. Acesso em: jul. 2016.

Divisão de Pesquisa Pedológica. Levantamento de reconhecimento dos solos do estado do Rio Grande do Sul. Rio de Janeiro, 1973a. 431 p. (Boletim técnico, n. 30). Disponível em: <http://library.wur.nl/isric/fulltext/isricu_i00003061_001.pdf>. Acesso em: mar. 2016. 
Divisão de Pesquisa Pedológica. Levantamento de reconhecimento dos solos do sul do estado de Mato Grosso. Rio de Janeiro, 1971. 839 p. (Boletim técnico, n. 18). Disponível em: <https://library.wur.nl/isric/fulltext/isricu_i00003049_001.pdf>. Acesso em: mar. 2016.

Divisão de Pesquisa Pedológica; SUPERINTENDÊNCIA DO DESENVOLVIMENTO DO NORDESTE. Levantamento exploratório [de] reconhecimento de solos do estado do Ceará. Recife: Sudene; Rio de Janeiro, 1973b. v. 1. (Boletim técnico, n. 28; Sudene. Pedologia, n. 16). Disponível em: <http://library.wur.nl/isric/fulltext/isricu_i00003058_001. pdf $>$. Acesso em: mar. 2016.

Equipe de Pedologia e Fertilidade do Solo; SUPERINTENDÊNCIA DO DESENVOLVIMENTO DO NORDESTE. I. Levantamento exploratório [de] reconhecimento de solos do estado da Paraíba; II. Interpretação para uso agrícola dos solos do estado da Paraíba. Rio de Janeiro: Ministério da Agricultura, Equipe de Pedologia e Fertilidade do Solo; Recife: Sudene, 1972. 683 p. (Boletim técnico, n. 15; Sudene. Pedologia, n. 8). Disponível em: <http://library.wur.nl/isric/fulltext/isricu_i00003046_001.pdf>. Acesso em: mar. 2016.

Ministério do Meio Ambiente. Agenda 21 brasileira: agricultura sustentável. Brasília, DF, 1999. 125 p. (Documento para seminário: produto 02).

Secretaria de Biodiversidade e Florestas. Áreas prioritárias para conservação, uso sustentável e repartição de benefícios da biodiversidade brasileira: atualização: portaria MMA n. 9, de 23 de janeiro de 2007. Brasília, DF, 2007. 300 p. (Biodiversidade, 31). Disponível em: <http://www.mma.gov.br/estruturas/chm/_arquivos/biodiversidade31.pdf>. Acesso em: jul. 2016.

Secretaria de Biodiversidade e Florestas. Biodiversidade brasileira: avaliação e identificação de áreas e ações prioritárias para conservação, utilização sustentável e repartição dos benefícios da biodiversidade nos biomas brasileiros. Brasília, DF, 2002. 404 p. Disponível em: <http://www.mma.gov.br/estruturas/chm/_arquivos/biodivbr.pdf >. Acesso em: jul. 2016.

Secretaria de Biodiversidade e Florestas. Quarto relatório nacional para a convenção sobre diversidade biológica. Brasília, DF, 2011. 247 p. (Biodiversidade, 38). Disponível em: <http://www.mma.gov.br/estruturas/sbf2008_dcbio/_arquivos/quarto_relatorio_147.pdf >. Acesso em: jul. 2016.

Secretaria de Recursos Hídricos. Caderno da região hidrográfica do TocantinsAraguaia. Brasília, DF, 2006. 132 p. Disponível em: <http://www.mma.gov.br/estruturas/161/_ publicacao/161_publicacao02032011035943.pdf>. Acesso em: jul. 2016.

Secretaria de Recursos Hídricos. Plano diretor de recursos hídricos para os Vales do Jequitinhonha e Pardo - Planvale. Brasília, DF, 1996. v. 1. 1998. $10 \mathrm{v}$

Secretaria de Recursos Hídricos. Plano nacional de recursos hídricos. Brasília, DF,

BRITSKI, H. A.; SILIMON, K. Z. de S. de; LOPES, B. S. Peixes do pantanal: manual de identificação. Brasília, DF: Empresa Brasileira de Pesquisa Agropecuária - Embrapa, Serviço de Produção de Informação - SPI; Corumbá: Embrapa, Centro de Pesquisa Agropecuária do Pantanal - CPAP, 1999. 184 p. 
CARACTERIZAÇÃO dos problemas relacionados aos "arrombados" na bacia do rio Taquari. In: AGÊNCIA NACIONAL DE ÁGUAS (Brasil). Projeto implantação de práticas de gerenciamento integrado de bacia hidrográfica para o pantanal e bacia do Alto Paraguai. Brasília, DF: ANA; Corumbá: Empresa Brasileira de Pesquisa Agropecuária - Embrapa Pantanal, 2004. 20 p. Relatório final do Subprojeto 1.7 - Solução dos problemas relacionados aos "arrombados" na bacia do rio Taquari. Elaborado em cooperação com o Fundo para o Meio Ambiente Mundial - GEF, o Programa das Nações Unidas para o Meio Ambiente - Pnuma e a Organização dos Estados Americanso - OEA. Disponível em: <http://www.ana.gov.br/gefap/arquivos/ Resumo\%20Executivo\%20Subprojeto\%201.7.pdf>. Acesso em: jul. 2016.

CARVALHO, P. F. de. Reconhecimento geológico no estado do Rio Grande do Sul. Boletim [do] Serviço Geológico e Mineralógico, Rio de Janeiro, v. 66, p. 1-73, 1932.

CHAO, L. H.; PEREIRA, L. E.; VIEIRA, J. P. Estuarine fish community of the dos Patos Lagoon, Brazil: a baseline study. In: YÁÑEZ-ARANCIBIA, A. (Ed.). Fish community ecology in estuaries and coastal lagoons: towards an ecosystem integration. México: Universidad Nacional Autónoma de México - UNAM, 1985. p. 429-450.

CENSO AGROPECUÁRIO 2006: Brasil, grandes regiões e unidades da federação: segunda apuração. Rio de Janeiro: IBGE, 2012. Disponível em: <http://www.ibge.gov.br/home/ estatistica/economia/agropecuaria/censoagro/2006_segunda_apuracao/default.shtm>. Acesso em: jul. 2016.

CHIARELlO, A. G. et al. Mamíferos ameaçados de extinção no Brasil. In: MACHADO, A. B. M.; DRUMMOND, G. M.; PAGLIA, A. P. (Ed.). Livro vermelho da fauna brasileira ameaçada de extinção. Brasília, DF: Ministério do Meio Ambiente; Belo Horizonte: Fundação Biodiversitas, 2008. v. 2, p. 681-874. (Biodiversidade, 19). Disponível em: <http:// www.icmbio.gov.br/portal/images/stories/biodiversidade/fauna-brasileira/livro-vermelho/ volumell/Mamiferos.pdf >. Acesso em: jul. 2016.

COCHRANE, T. T. et al. Land in tropical America: a guide to climate, landscapes, and soils for agronomists in Amazonian, the Andean Piedmont, Central Brazil and Orinoco. Cali: Centro Internacional de Agricultura Tropical - CIAT; Planaltina: Empresa Brasileira de Pesquisa Agropecuária - Embrapa, Centro de Pesquisa Agropecuária dos Cerrados - CPAC, 1985. 3 v. Disponível em: <http://bbeletronica.cpac.embrapa.br/versaomodelo/html/1985/ livros/cochrane_01.shtml>. Acesso em: jul. 2016.

COLLARES, J. E. R. Mapa de biomas do Brasil: uma síntese de mais de trinta anos de mapeamento da vegetação. In: DISPERATI, A. A.; SANTOS, J. R. dos (Ed.). Aplicações de geotecnologias na engenharia florestal. Curitiba: Copiadora Gabardo, 2004. p. 1-11.

COLLI, G. R. et al. Herpetofauna da Reserva Ecológica do IBGE e seu entorno. In: RIBEIRO, M. L. (Org.). Reserva Ecológica do IBGE: biodiversidade terrestre. Rio de Janeiro: IBGE, 2011. v. 1, t. 2, cap. 24, p. 132-145. Disponível em: <http://biblioteca.ibge.gov.br/index. php/biblioteca-catalogo?view=detalhes\&id=249522>. Acesso em: jul. 2016.

COMPANHIA DE TECNOLOGIA DE SANEAMENTO AMBIENTAL (SP). Relatório de qualidade das águas interiores do estado de São Paulo 2002. São Paulo: Cetesb, 2003. 269 p. Disponível em: <http://aguasinteriores.cetesb.sp.gov.br/publicacoes-e-relatorios/>. Acesso em: jul. 2016. 
Relatório de qualidade das águas interiores no estado de São Paulo 2008. São Paulo, 2009. 528 p. Disponível em: <http://aguasinteriores.cetesb.sp.gov.br/publicacoes-erelatorios/>. Acesso em: jul. 2016.

Sistema estuarino de Santos e São Vicente. São Paulo: Cetesb, 2001. 141 p. Disponível em: <http://www.acpo.org.br/biblioteca/06_areas_contaminadas_\%20saturadas/relatorio_ sistema_estuarino_santos_sv.pdf >. Acesso em: jul. 2016.

CONGRESSO AQUÍFERO GUARANI, 2., 2008, Ribeirão Preto. Conclusões e recomendações. São Paulo: Secretaria do Meio Ambiente, 2009. 36 p. Disponível em: <http://www.ambiente. sp.gov.br/institutogeologico/files/2012/03/IIConSAG_nov2008.pdf>. Acesso em: jul. 2016.

CONSERVAÇÃO da mata atlântica no estado do Espírito Santo: cobertura florestal e unidades de conservação. Vitória: Instituto de Pesquisa da Mata Alântica - Ipema; Rio de Janeiro: Conservação Internacional Brasil, 2005.

CONVENÇÃO de Ramsar 1971. Conservação e uso racional de zonas úmidas. In: RAMSAR. Gland, [2003?a]. Disponível em: <http://www.ramsar.org>. Acesso em: nov. 2005.

CONVENÇÃO de Ramsar sobre áreas úmidas. Limites fornecidos pelo MMA. In: RAMSAR. Gland, [2003?b]. Disponível em: <http://www.ramsar.org>. Acesso em: nov. 2003.

COOPERATIVA DE SERVIÇOS, PESQUISAS TECNOLÓGICAS E INDUSTRIAIS. Planos de bacia: UGRHI 1 - Serra da Mantiqueira e UGRHI 2 - Paraíba do Sul. São Paulo, 2001.

COSTA, L. L. C. Características petrográficas e aspectos metalogenéticos do corpo C-59, mina Fazenda Brasileiro, Bahia. 2008. 84 p. Trabalho de Conclusão de Curso (Graduação)Instituto de Geociências, Universidade Federal da Bahia - UFBA, Salvador, 2008.

COUTO, E. G. A diversidade dos solos no pantanal mato-grossense no âmbito do PELD. In: MOURÃO, G.; SOUZA JUNIOR, P. T. de; COUTO, E. G. (Ed.). Resultados de pesquisa do programa ecológico de longa duração (PELD) no pantanal mato-grossense. Corumbá: Empresa Brasileira de Pesquisa Agropecuária - Embrapa Pantanal, 2005. Trabalho não publicado.

COWLING, S. A.; MASLIN, M. A.; SYKES, M. T. Paleovegetation simulations of lowland Amazonia and implications for neotropical allopatry and speciation. Quaternary Research, Amsterdam: Elsevier; Seattle: Quartenary Research Center, v. 55, n. 2, p. 140-149, 2001. Disponível em: <http://www.sciencedirect.com/science/article/pii/S0033589400921975>. Acesso em: jul. 2016.

CUNHA, A. A. et al. Espécies, ecossistemas, paisagens e serviços ambientais: uma estratégia espacial integradora para orientar os esforços de conservação e recuperação da biodiversidade na mata atlântica. In: MAPEAMENTOS para a conservação e recuperação da biodiversidade na mata atlântica: em busca de uma estratégia espacial integradora para orientar ações aplicadas. Brasília, DF: Ministério do Meio Ambiente, Secretaria de Biodiversidade e Florestas, 2013a. cap. 1, p. 11-32. (Biodiversidade, 49). Disponível em: $<$ http://www.mma.gov.br/publicacoes/biodiversidade/category/142-serie-biodiversidade>. Acesso em: jul. 2016.

CUNHA, A. A. et al. Perspectivas para a integração de dados e uso de sistemas de informação geográfica e da ecologia de paisagens para a tomada de decisão para a conservação e 
recuperação da biodiversidade da mata atlântica brasileira. In: MAPEAMENTOS para a conservação e recuperação da biodiversidade na mata atlântica: em busca de uma estratégia espacial integradora para orientar ações aplicadas. Brasília, DF: Ministério do Meio Ambiente, Secretaria de Biodiversidade e Florestas, 2013b. cap. 7, p. 201-213. (Biodiversidade, 49). Disponível em: <http://www.mma.gov.br/publicacoes/biodiversidade/ category/142-serie-biodiversidade>. Acesso em: jul. 2016.

CUNHA, N. G. da; SILVEIRA, R. J. da C.; SEVERO, C. R. S. Estudo dos solos do município de Herval. Pelotas: Empresa Brasileira de Pesquisa Agropecuária - Embrapa, Centro de Pesquisa Agropecuária de Clima Temperado - CPACT: Universidade Federal de Pelotas - UFPel, 1996. 45 p. (Embrapa-CPACT. Documentos, 13). Disponível em: <http://ainfo.cnptia.embrapa.br/ digital/bitstream/item/41396/1/Herval.pdf>. Acesso em: jul. 2016.

CUNHA, N. G. da et al. Estudo de solos do município de Barra do Quaraí-RS. Pelotas: Empresa Brasileira de Pesquisa Agropecuária - Embrapa Clima Temperado: Universidade Federal de Pelotas - UFPel, 2001. 84 p. (Embrapa Clima Temperado. Circular técnica, 30). Disponível em: <http://ainfo.cnptia.embrapa.br/digital/bitstream/item/41456/1/MUNICIPIO-DE-BARRADO-QUARAI.pdf>. Acesso em: jul. 2016.

CUNHA, N. G. da et al. Estudo dos solos do município de Camaquã-RS. Pelotas: Empresa Brasileira de Pesquisa Agropecuária - Embrapa Clima Temperado: Universidade Federal de Pelotas - UFPel, 2000. 98 p. (Embrapa Clima Temperado. Circular técnica, 20). Disponível em: <http://ainfo.cnptia.embrapa.br/digital/bitstream/item/41437/1/camaqua.pdf>. Acesso em: jul. 2016.

CUNHA, N. G. da et al. Estudo dos solos do município de Piratini. Pelotas: Empresa Brasileira de Pesquisa Agropecuária - Embrapa, Centro de Pesquisa Agropecuária de Clima Temperado - CPACT: Universidade Federal de Pelotas - UFPel, 1997. 91 p. (EmbrapaCPACT. Documentos, 26). Disponível em: <http://ainfo.cnptia.embrapa.br/digital/bitstream/ item/41337/1/Piratini.pdf>. Acesso em: jul. 2016.

DARDENNE, M. A.; SCHOBBENHAUS, C. Depósitos minerais no tempo geológico e épocas metalogenéticas. In: BIZZI, L. A. et al. (Ed.). Geologia, tectônica e recursos minerais do Brasil: texto, mapas \& SIG. Brasília, DF: Serviço Geológico do Brasil - CPRM, 2003. parte 3, p. 362-448. Disponível em: <http://www.cprm.gov.br/didote/pdf/geologia_tectonica.pdf>. Acesso em: jul. 2016.

DEAN, W. A ferro e fogo: a história e a devastação da mata atlântica brasileira. São Paulo: Companhia das Letras, 1998. 484 p.

DELANEY, P. J. V. Fisiografia e geologia de superfície da planície costeira do Rio Grande do Sul. Porto Alegre: Universidade Federal do Rio Grande do Sul - UFRGS, Escola de Geologia, 1965. 195 p. (Publicação especial da Escola de Geologia, 6).

DELGADO, I. de M. et al. Geotectônica do escudo atlântico. In: BIZZI, L. A. et al. (Ed.). Geologia, tectônica e recursos minerais do Brasil: texto, mapas \& SIG. Brasília, DF: Serviço Geológico do Brasil - CPRM, 2003. parte 2, p. 227-334. Disponível em: <http://www.cprm. gov.br/didote/pdf/geologia_tectonica.pdf>. Acesso em: jul. 2016.

DIAS, B. F. de S. Cerrados, uma caracterização. In: (Coord.). Alternativas de desenvolvimento dos cerrados: manejo e conservação dos recursos naturais renováveis. 2 . 
ed. Brasília, DF: Fundação Pro-Natureza - Funatura: Instituto Brasileiro do Meio Ambiente e dos Recursos Naturais - Ibama, 1996. p. 11-25.

Prefácio. In: RIBEIRO, M. L. (Org.). Reserva Ecológica do IBGE: biodiversidade terrestre. Rio de Janeiro: IBGE, 2011. v. 1, t. 1, p. 4-7. Disponível em: <http://biblioteca.ibge. gov.br/index.php/biblioteca-catalogo?view=detalhes\&id=249522>. Acesso em: jul. 2016.

DIAS, M. A. F. S.; COHEN, J. C. P.; GANDU, A.W. Interações entre nuvens, chuvas e a biosfera na Amazônia. Acta Amazonica, Manaus: Instituto Nacional de Pesquisas da Amazônia INPA, v. 35, n. 2, p. 215-222, abr./jun. 2005. Disponível em: <http://www.scielo.br/scielo. php?pid=S0044-59672005000200011\&script=sci_arttext>. Acesso em: jul. 2016.

DIEGUES, A. C. Aspectos sócio-culturais e políticos do uso da água. São Paulo: Universidade de São Paulo - USP, Núcleo de Apoio à Pesquisa sobre Populações Humanas e Áreas Úmidas Brasileiras - Nupaub, 2005. 15 p. Texto publicado no Plano Nacional de Recursos Hídricos, do Ministério do Meio Ambiente, 2005. Disponível em: <http://nupaub.fflch.usp.br/sites/ nupaub.fflch.usp.br/files/color/agua.pdf>. Acesso em: jul. 2016.

DINIZ, I. R. et al. (Org.) Cerrado: conhecimento científico quantitativo como subsídio para ações de conservação. Brasília, DF: Universidade de Brasília - UnB: Thesaurus, 2010. 496 p.

DINIZ-FILHO, J. A. F. et al. Anuran species richness, complementarity and conservation conflicts in brazilian cerrado. Acta Oecologica, Amsterdam: Elsevier, v. 29, n. 1, p. 9-15, Jan./Feb. 2006. Disponível em: <http://www.sciencedirect.com/science/article/pii/ S1146609X05000846>. Acesso em: jul. 2016.

DOREA, J. G.; BARBOSA, A. C.; SILVA, G. S. Fish mercury bioaccumulation as a function of feeding behavior and hydrological cycles of the rio Negro, Amazon. Comparative Biochemistry and Physiology. Part C: Toxicology \& Pharmacology, Amsterdam: Elsevier, v. 142, n. 3-4, p. 275-283, Mar./Apr. 2006. Disponível em: <http://www.sciencedirect.com/ science/article/pii/S1532045605002280>. Acesso em: jul. 2016.

EMPRESA DE PESQUISA ENERGÉTICA. Plano nacional de energia 2030. Rio de Janeiro: EPE, 2007. 407 p. Disponível em: <http://www.epe.gov.br/PNE/20080111_1.pdf>. Acesso em: mar. 2016.

ESPÍRITO SANTO (Estado). Secretaria de Meio Ambiente e de Recursos Hídricos. Rede de monitoramento da qualidade da água. Cariacica: Seama, [2004?]. Disponível em: <http:// www.seama.es.gov.br/scripts/ sea1004.asp>. Acesso em: nov. 2004.

ESTEVES, F. de A. Fundamentos de limnologia. Rio de Janeiro: Interciência, 1988. 575 p.

ESTUDO das espécies ícticas e opções de manejo piscícola no Parque Estadual do Cantão estado do Tocantins: sumário executivo. Manaus: Fundação Djalma Batista - FDB: Instituto Nacional de Pesquisas da Amazônia - INPA, 2001. 209 p. Disponível em: <http://www. gesto.to.gov.br/site_media/upload/gestao/documentos/Ictiofauna_do_Parque_Estadual_do_ Cantao.pdf>. Acesso em: jul. 2016.

FATOS e números do Brasil florestal. São Paulo: Sociedade Brasileira de Silvicultura - SBS, 2006. 105 p. Disponível em: <http://www.ipef.br/estatisticas/relatorios/SBS-2005.pdf>. Acesso em: jul. 2016. 
FELFILI, J. M.; SILVA JÚNIOR, M. C. da (Org.). Biogeografia do bioma cerrado: estudo fitofisionômico da Chapada do Espigão Mestre do São Francisco. Brasília, DF: Universidade de Brasília - UnB, Dep. de Engenharia Florestal, 2001. 152 p.

FERREIRA, M. N. A importância do Jalapão na conservação do cerrado brasileiro. 2007. Trabalho apresentado no I Simpósio sobre Conservação e Desenvolvimento Sustentável do Jalapão, realizado em Palmas, 2007. Disponível em: <http://www.pequi.org.br/Ferreira. pdf $>$. Acesso em: nov. 2007.

FLORENTINO, A. C. A estrutura das comunidades de peixes das bacias dos rios Cuiabá e Negro, pantanal, Brasil. 2012. 187 p. Tese (Doutorado em Biologia de Água Doce e Pesca Interior)-Instituto Nacional de Pesquisas da Amazônia, Manaus, 2012.

FOLHA SA.21 Santarém: geologia, geomorfologia, pedologia, vegetação, uso potencial da terra. Rio de Janeiro: Projeto Radambrasil, 1976. 510 p. (Levantamento de recursos naturais, v. 10). Disponível em: <http://biblioteca.ibge.gov.br/index.php/biblioteca-catalogo?view=d etalhes\&id=224027 $>$. Acesso em: mar. 2016.

FOLHA SE.21 Corumbá e parte da folha SE.20: geologia, geomorfologia, pedologia, vegetação, uso potencial da terra. Rio de Janeiro: Projeto Radambrasil, 1982. 448 p. (Levantamento de recursos naturais, v. 27). Disponível em: <http://biblioteca.ibge.gov.br/ index.php/biblioteca-catalogo?view=detalhes\&id=213270>. Acesso em: jul. 2016.

FRANCO, M. do S. M.; PINHEIRO, R. Geomorfologia. In: FOLHA SE.21 Corumbá e parte da folha SE.20: geologia, geomorfologia, pedologia, vegetação, uso potencial da terra. Rio de Janeiro: Projeto Radambrasil, 1982. p. 161-224. (Levantamento de recursos naturais, v. 27). Disponível em: <http://biblioteca.ibge.gov.br/index.php/biblioteca-catalogo?view=detalhes $\& i d=213270>$. Acesso em: jul. 2016.

FUNDAÇÃO CENTRO TECNOLÓGICO DE MINAS GERAIS. Levantamento de reconhecimento de solos e aptidão agrícola em áreas abrangidas pelo PDRI-AM, município de Parintins: relatório técnico final. Belo Horizonte: Cetec, 1986. 169 p.

FUNDAÇÃO ESTADUAL DE ENGENHARIA DO MEIO AMBIENTE (RJ). Bacia da baía da Guanabara: programas e projetos: qualidade das águas. Rio de Janeiro: Feema, 2000. Disponível em: <http://www.feema.rj.gov.br/bacia_baia_guanabara.htm>. Acesso em: fev. 2004.

GALDINO, S. Pantanal registra o mais longo e intenso ciclo de cheia. Curitiba: Agronline, [2002?]. Notícia de 05 maio 2002. Disponível em: <http://www.agronline.com.br/artigos/ artigo.php?id=68>. Acesso em: jul. 2016.

GALDINO, S.; SILVA, D. J. da. Cheia e seca no pantanal. Corumbá: Empresa Brasileira de Pesquisa Agropecuária -Embrapa Pantanal, [2005?]. Disponível em: <http://www.cpap. embrapa.br/destaques/cheia.htm>. Acesso em: dez. 2005.

GALDINO, S.; VIEIRA, L. M.; PELLEGRIN, L. A. (Ed.). Impactos ambientais e socioeconômicos na bacia do rio Taquari - Pantanal. Corumbá: Empresa Brasileira de Pesquisa Agropecuária -Embrapa Pantanal, 2006. 356 p. Disponível em: <http://www.cpap.embrapa.br/publicacoes/ online/Livro025.pdf>. Acesso em: jul. 2016. 
GALINDO-LEAL, C.; CÂMARA. I. de G. Status do hotspot mata atlântica: uma síntese. In: (Ed.). Mata atlântica: biodiversidade, ameaças e perspectivas. São Paulo: Fundação SOS Mata Atlântica; Belo Horizonte: Conservação Internacional, 2005. p. 3-11.

GASPAR, L. Vasconcelos Sobrinho. In: FUNDAÇÃO JOAQUIM NABUCO. Pesquisa Escolar. Recife, 2009. Disponível em: <http://basilio.fundaj.gov.br/pesquisaescolar/ index.php?option $=$ com_content $\&$ view $=$ article $\& i d=126 \% 3$ Avasconcelos sobrinho\&catid $=56 \% 3$ Aletra-v\&ltemid=1 >. Acesso em: jul. 2016.

GATTO, L. C. S. et al. Geomorfologia. In: FOLHAS SF.23/24 Rio de Janeiro/Vitória: geologia, geomorfologia, pedologia, vegetação, uso potencial da terra. Rio de Janeiro: Projeto Radambrasil, 1983. p. 305-384. (Levantamento de recursos naturais, v. 32). Disponível em: $<$ http://biblioteca.ibge.gov.br/index.php/biblioteca-catalogo?view=detalhes\&id=217129>. Acesso em: jul. 2016.

GAYER, S. M. P.; KRAUSE, L.; GOMES, N. Lista preliminar dos anfíbios da Estação Ecológica do Taim, Rio Grande do Sul, Brasil. Revista Brasileira de Zoologia, Curitiba: Sociedade Brasileira de Zoologia - SBZ, v. 5, n. 3, p. 419-425, 1988. Disponível em: <http://www. scielo.br/scielo.php?script=sci_arttext\&pid=S0101-81751988000300007\&lng=en\&nrm=is o\&tlng=pt>. Acesso em: jul. 2016.

GENTRY, A. H. Patterns of neotropical plant species diversity. In: HECHT, M. K.; WALLACE, B.; PRANCE, E. T. (Ed.). Evolutionary biology: volume 15. New York: Plenum Press, 1982. p. 1-84.

GENTRY, A. H. Tropical forest biodiversity: distributional patterns and their conservational significance. Oikos, Lund: Nordic Society Oikos, v. 63, n. 1, p. 19-28, Feb. 1992.

GIULIETTI, A. M. (Coord.). Vegetação: áreas e ações prioritárias para a conservação da caatinga. In: SILVA, J. M. C. da (Org.). Biodiversidade da caatinga: áreas e ações prioritárias para a conservação. Brasília, DF: Ministério do Meio Ambiente; Recife: Universidade Federal de Pernambuco - UFPE, 2004. parte 2, p. 114-131. Disponível em: <http://ainfo. cnptia.embrapa.br/digital/bitstream/item/18265/1/Caatingaaa.pdf>. Acesso em: jul. 2016.

GOMES, N.; KRAUSE, L. Lista preliminar de répteis da Estação Ecológica do Taim, Rio Grande do Sul. Revista Brasileira de Zoologia, Curitiba: Sociedade Brasileira de Zoologia SBZ, v. 1, n. 1, p. 71-77, 1982. Disponível em: <http://www.scielo.br/scielo.php?script=sci_ arttext\&pid=S0101-81751982000100011\&lng=en\&nrm=iso\&tlng=pt>. Acesso em: jul. 2016.

GOULDING, M. Ecologia da pesca do rio Madeira. Manaus: Instituto Nacional de Pesquisas da Amazônia - INPA, 1979. 172 p.

HACON, S. et al. Mercury exposure through fish consumption in the urban area of Alta Floresta in the Amazon basin. Journal of Geochemical Exploration, Amsterdam: Elsevier, v. 58, n. 2-3, p. 209-216, Apr. 1997. Disponível em: <http://www.sciencedirect.com/ science/article/pii/S0375674296000660>. Acesso em: jul. 2016.

HADDAD, C. F. B. Uma análise da lista brasileira de anfíbios ameaçados de extinção. In:

MACHADO, A. B. M.; DRUMMOND, G. M.; PAGLIA, A. P. (Ed.). Livro vermelho da fauna brasileira ameaçada de extinção. Brasília, DF: Ministério do Meio Ambiente; Belo Horizonte: 
Fundação Biodiversitas, 2008. v. 2, p. 287-320. (Biodiversidade, 19). Disponível em: <http:// www.icmbio.gov.br/portal/images/stories/biodiversidade/fauna-brasileira/livro-vermelho/ volumell/Anfibios.pdf>. Acesso em: jul. 2016.

HADFIELD, M. G. Introduction to the symposium: the crisis in invertebrate conservation. American Zoologist, Oxford: Oxford Journals; Thousand Oaks: American Society of Zoologists, v. 33, n. 6, p. 497-498, Dec. 1993. Disponível em: <http://az.oxfordjournals. org/content/33/6/497>. Acesso em: jul. 2016.

HAFFER, J. Speciation in Amazonian forest birds. Science, Washington: American Association for the Advancement of Science - AAAS, v. 165, n. 3889, p. 131-137, July 111969.

HAFFER, J.; PRANCE, G. T. Impulsos climáticos da evolução na Amazônia durante o cenozóico: sobre a teoria dos refúgios da diferenciação biótica. Estudos avançados, São Paulo: Universidade de São Paulo - USP, Instituto de Estudos Avançados - IEA, v. 16, n. 46, p. 175-206, set./dez. 2002. Disponível em: <http://www.scielo.br/scielo.php?script=sci_ arttext\&pid=S0103-40142002000300014\&lng=en\&nrm=iso/\&tlng=pt $>$. Acesso em: jul. 2016.

HERRMANN, M. L. de P.; ROSA, R. de O. Relevo. In: MESQUITA, O. V. et al. (Coord.). Geografia do Brasil. Rio de Janeiro: IBGE, 1990. v. 2: Região Sul, p. 55-84. Disponível em: $<$ http://biblioteca.ibge.gov.br/index.php/biblioteca-catalogo?view=detalhes\&id=220702>. Acesso em: jul. 2016.

HOTSPOTS. Arlington: Conservation Internacional, [2009?]. Disponível em: <http://www. conservation.org.br/como/index.php?id=8>. Acesso em: dez. 2009.

INSTITUTO DO PARQUE DO PANTANAL. A biodiversidade do pantanal. Campo Grande: IPP, [2005?]. Disponível em: <http://www.parqueregionaldopantanal.org.br>. Acesso em: nov. 2005.

INSTITUTO MINEIRO DE GESTÃO DAS ÁGUAS. Projeto águas de Minas: qualidade das águas superficiais em 2002. Belo Horizonte: IGAM em convênio com a Fundação Estadual do Meio Ambiente - FEAM e a Fundação Centro Tecnológico de Minas Gerais - Cetec, 2003. 230 p.

INSTITUTO NACIONAL DE PESQUISAS ESPACIAIS (Brasil). Taxas anuais do desmatamento: 1988 até 2013. São José dos Campos: INPE, [2014?]. Disponível em: <http://www.obt.inpe. br/prodes/prodes_1988_2013.htm>. Acesso em: jul. 2016.

INTERNATIONAL UNION FOR THE CONSERVATION OF NATURE. IUCN red list of threatened species. Cambridge, [2005?]. Disponível em: <http://www.iucnredlist.org/ search>. Acesso em: nov. 2005.

IRGAND B. E.; PEDRALLI, G.; WAECHTER, J. L. Macrófitos aquáticos da Estação Ecológica do Taim, Rio Grande do Sul, Brasil. Roessleria, Porto Alegre: Instituto de Pesquisas de Recursos Naturais Renováveis Ataliba Paz - IPRNR-AP, v. 6, n. 1, p. 395-404, 1984.

JACOMINE, P. K. T. Descrição das características morfológicas, físicas, químicas e mineralógicas de alguns perfis de solos sob vegetação de cerrado. Rio de Janeiro: Ministério da Agricultura, Escritório de Pesquisas e Experimentação, 1969. 126 p. (Boletim técnico, n. 11). 
JUNK, W. J.; BAYLEY, P. B.; SPARKS, R. E. The flood pulse concept in river-floodplain systems. In: DODGE, D. P. (Ed.). Proceedings of the international large river symposium (LARS). Ottawa: Department of Fisheries and Oceans, 1989. p. 110-127. (Canadian special publication of fisheries and aquatic sciences, 106). Disponível em: <http://www.dfo-mpo. gc.ca/Library/111846.pdf>. Acesso em: jul. 2016.

JUSTUS, J. de O.; MACHADO, M. L. de A.; FRANCO, M. do S. M. Geomorfologia. In: FOLHA SH.22 Porto Alegre e parte das folhas SH.21 Uruguaiana e SI.22 Lagoa Mirim: geologia, geomorfologia, pedologia, vegetação, uso potencial da terra. Rio de Janeiro: Projeto Radambrasil, 1986. p. 313-404. (Levantamento de recursos naturais, v. 33). Disponível em: $\quad<$ http://biblioteca.ibge.gov.br/biblioteca-catalogo.html?view=detalhes\&id=219048>. Acesso em: jul. 2016.

KASPER, D. et al. Mercúrio em peixes: fontes e contaminação. Oecologia Brasiliensis, Rio de Janeiro: Universidade Federal do Rio de Janeiro - UFRJ, Programa de Pós-Graduação em Ecologia - PPGE, v. 11, n. 2, p. 228-239, 2007. Disponível em: <https://dialnet.unirioja.es/ servlet/articulo?codigo=2685303 >. Acesso em: jul. 2016.

KAUL, P. F. T. et al. Geologia. In: FOLHA SG.22 Curitiba, parte da folha SG.21 Asunción e folha SG.23 Iguape: geologia, geomorfologia, pedologia, vegetação, uso potencial da terra. Rio de Janeiro: Projeto Radambrasil, 2005. (Levantamento de recursos naturais, v. 35). Trabalho não publicado.

KLAMMER, G. Die Paläowüste des Pantanal von Mato Grosso und die pleistozäne klimageschichte der brasilianischen randtropen. Zeitschrift fur Geomorphologie, Stuttgart: Schweizerbart Science Publishers, v. 26, n. 4, p. 393-416, 1982.

LEAL, I. R.; TABARELLI, M.; SILVA, J. M. C. da (Ed.). Ecologia e conservação da caatinga. Recife: Universidade Federal de Pernambuco - UFPE, 2003. 822 p. Disponível em: <http://www. mma.gov.br/estruturas/203/_arquivos/5_livro_ecologia_e_conservao_da_caatinga_203. pdf>. Acesso em: jul. 2016.

LENTINI, M.; VERÍSSIMO, A.; PEREIRA, D. A expansão madeireira na Amazônia. Belém: Instituto do Homem e Meio Ambiente da Amazônia - Imazon, 2005. Disponível em: <http:// imazon.org.br/a-expansao-madeireira-na-amazonia/>. Acesso em: jul. 2016.

LIMA, F. C. T.; CAIRES, R. A. Peixes da estação ecológica serra geral do Tocantins, bacias dos rios Tocantins e São Francisco, com observações sobre as implicações biogeográficas das "águas emendadas" dos rios Sapão e Galheiros. Biota Neotropica, São Paulo: Fundação de Amparo à Pesquisa do Estado de São Paulo - Fapesp, Programa Pesquisas em Caracterização, Conservação, Restauração e Uso Sustentável da Biodiversidade - Biota, v. 11, n. 1, p. 231250, 2011. Disponível em: <http://www.biotaneotropica.org.br/v11n1/pt/download?article +bn03411012011+item>. Acesso em: jul. 2016.

LINO, C. F.; DIAS, H. (Org.). Águas e florestas da mata atlântica: por uma gestão integrada. São Paulo: Conselho Nacional da Reserva da Biosfera da Mata Atlântica, 2004. 132 p. (Políticas públicas. Cadermo, n. 27). Disponível em: <http://www.rbma.org.br/rbma/pdf/ caderno_27.pdf>. Acesso em: jul. 2016.

LISTA de espécies da flora do Brasil. Rio de Janeiro: Jardim Botânico do Rio de Janeiro - JBRJ, 2010. Disponível em: <http://www.floradobrasil.jbrj.gov.br> Acesso em: jul. 2016. 
LIVRO verde da avaliação ambiental estratégica do pantanal. Brasília, DF: Ministério do Meio Ambiente em convênio com a Universidade de Brasília - UnB e a Universidade Estadual de Mato Grosso do Sul - UEMS, 2008. 241 p. Disponível em: <http://www.unemat. br/prppg/docs/publicacoes/Livro_Verde_da_AAE_do_Pantanal.pdf>. Acesso em: jul. 2016.

LOPES, A. S. Solos sob "cerrado": características, propriedades e manejo. Piracicaba: Associação Brasileira para Pesquisa da Potassa e do Fosfato, 1983. 162 p.

LUTZENBERGER, J. Prefácio para "Índices de lotação pecuária para o Rio Grande do Sul". Porto Alegre: Federação da Agricultura do Rio Grande do Sul - Farsul, 1997. Disponível em: $<$ http://www.fgaia.org.br/texts/t-pref.html>. Acesso em: jul. 2016.

MACEDO, L. Manaus e leste do Amazonas sofrem a seca mais severa dos últimos 103 anos, diz pesquisador do INPE. [S.I.]: Rota Brasil Oeste, 2005. Notícia de 19 out. 2005. Disponível em: <http://www.brasiloeste.com.br/noticia/1651/seca-amazonas>. Acesso em: jul. 2016.

MACHADO, A. B. M.; DRUMMOND, G. M.; PAGLIA, A. P. (Ed.). Livro vermelho da fauna brasileira ameaçada de extinção. Brasília, DF: Ministério do Meio Ambiente; Belo Horizonte: Fundação Biodiversitas, 2008. 2 v. (Biodiversidade, 19). Disponível em: <http:// www.biodiversitas.org.br/livrovermelho2008/>. Acesso em: jul. 2016.

MACHADO FILHO, L. et al. Geologia. In: FOLHAS SF.23/24 Rio de Janeiro/Vitória: geologia, geomorfologia, pedologia, vegetação, uso potencial da terra. Rio de Janeiro: Projeto Radambrasil, 1983. p. 27-304. (Levantamento de recursos naturais, v. 32). Disponível em: $<$ http://biblioteca.ibge.gov.br/index.php/biblioteca-catalogo?view=detalhes\&id=217129>. Acesso em: jul. 2016.

MAGALHÃES, M. P. Evolução e seleção cultural na Amazônia neotropical. Amazônia: Ciência \& Desenvolvimento, Belém: Banco da Amazônia, v. 3, n. 5, p. 93-112, jul./dez. 2007. Disponível em: <http://www.bancoamazonia.com.br/images/arquivos/institucional/ biblioteca/revista_amazonia/edicao05/CD_Vol_V_Evolucao_Selecao_Cult.pdf $>$. Acesso em: jul. 2016.

MANUAL técnico da vegetação brasileira. Rio de Janeiro: IBGE, 1992. 92 p. (Manuais técnicos em geociências, n. 1). Disponível em: <http://biblioteca.ibge.gov.br/index.php/ biblioteca-catalogo?view=detalhes\&id=223267> . Acesso em: jul. 2016.

MANUAL técnico da vegetação brasileira. 2. ed. rev. e ampl. Rio de Janeiro: IBGE, 2012. 272 p. (Manuais técnicos em geociências, n. 1). Disponível em: <http://www.ibge.gov.br/home/ geociencias/recursosnaturais/vegetacao/manual_vegetacao.shtm>. Acesso em: jul. 2016.

MANUAL técnico de pedologia. 2. ed. Rio de Janeiro: IBGE, 2007. 320 p. (Manuais técnicos em geociências, n. 4). Acompanha 1 CD-ROM. Disponível em: <http://biblioteca.ibge.gov. br/index.php/biblioteca-catalogo?view=detalhes\&id=237318 . Acesso em: jul. 2016.

MAPA da área de aplicação da lei n. 11.428 de 2006. Rio de Janeiro: IBGE, 2008. 1 mapa, color. Escala 1:5 000 000; proj. policônica. Disponível em: <http://www.mma.gov.br/ estruturas/sbf_chm_rbbio/_arquivos/mapa_de_aplicao_da_lei_11428_mata_atlantica.pdf >. Acesso em: jul. 2016. 
MAPA de biomas do Brasil: primeira aproximação. Rio de Janeiro: IBGE, 2004a. 1 mapa, color. Escala 1:5 000 000; proj. policônica. Disponível em: <ftp://geoftp.ibge.gov.br/ informacoes_ambientais/vegetacao/mapas/brasil/biomas.pdf>. Acesso em: jul. 2016.

MAPA de solos do Brasil. Rio de Janeiro: IBGE: Empresa Brasileira de Pesquisa Agropecuária - Embrapa Solos, 2001. 1 mapa, color. Escala 1: 5.000.000; proj. policônica. Elaborado a partir de compilações, atualizações e conversão para o meio digital de levantamentos de solos produzidos pelo Projeto Radambrasil, pela Diretoria de Geociências do IBGE, e pelo Serviço Nacional de Levantamento e Conservação de Solos da Embrapa. Disponível em: <ftp://geoftp.ibge.gov.br/informacoes_ambientais/pedologia/mapas/brasil/solos.pdf>. Acesso em: jul. 2016.

MAPA de unidades de relevo do Brasil. 2. ed. Rio de Janeiro: IBGE, 2006. 1 mapa, color. Escala 1:5 000 000; proj. policônica. Disponível em: <ftp://geoftp.ibge.gov.br/informacoes_ ambientais/geomorfologia/mapas/brasil/relevo_2006.pdf>. Acesso em: jul. 2016.

MAPA de vegetação do Brasil. 3. ed. Rio de Janeiro: IBGE, 2004b. 1 mapa, color. Escala 1:5 000 000; proj. policônica. Disponível em: <ftp://geoftp.ibge.gov.br/informacoes_ambientais/ vegetacao/mapas/brasil/vegetacao.pdf>. Acesso em: jul. 2016.

MARGULIS, S. Causas do desmatamento da Amazônia brasileira. Brasília, DF: Banco Mundial, 2003. 100 p. Disponível em: <http://siteresources.worldbank.org/BRAZILINPOREXTN/ Resources/3817166-1185895645304/4044168-1185895685298/010CausasDesmatament oAmazoniaBrasileira.pdf>. Acesso em: jul. 2016.

MARINHO-FILHO, J.; MACHADO, R. B.; HENRIQUES, R. P. B. Evolução do conhecimento e da conservação do cerrado brasileiro. In: DINIZ, I. R. et al. (Org.). Cerrado: conhecimento científico quantitativo como subsídio para ações de conservação. Brasília, DF: Universidade de Brasília - UnB: Thesaurus, 2010. cap. 1, p. 13-31.

MARTINS, M.; MOLINA, F. de B. Panorama geral dos répteis ameaçados do Brasil. In: MACHADO, A. B. M.; DRUMMOND, G. M.; PAGLIA, A. P. (Ed.). Livro vermelho da fauna brasileira ameaçada de extinção. Brasília, DF: Ministério do Meio Ambiente; Belo Horizonte: Fundação Biodiversitas, 2008. v. 2, p. 327-373. (Biodiversidade, 19). Disponível em: <http:// www.icmbio.gov.br/portal/images/stories/biodiversidade/fauna-brasileira/livro-vermelho/ volumell/Repteis.pdf>. Acesso em: jul. 2016.

MATO GROSSO. Secretaria de Planejamento e Coordenação Geral. Diagnóstico sócioeconômico-ecológico do estado de Mato Grosso e assistência técnica na formulação da segunda aproximação do zoneamento sócio-econômico-ecológico. Cuiabá: Seplan, 2001. 1 CD-ROM.

MEDEIROS, R. B. de; SAIBRO, J. C.; FOCHT, T. Invasão de capim-annoni (Eragrostis plana Nees) no bioma pampa no Rio Grande do Sul. In: PILLAR, V. de P. et al. (Ed.). Campos sulinos: conservação e uso sustentável da biodiversidade. Brasília, DF: Ministério do Meio Ambiente, 2009. cap. 25, p. 317-330. Disponível em: <http://www.mma.gov.br/publicacoes/ biodiversidade/category/58-probio-i-serie-biodiversidade?download=964:campos-sulinosconservacao-e-uso-sustentavel-da-biodiversidade>. Acesso em: jul. 2016. 
MELO, M. R. S.; LIMA, F. C. T.; RIBEIRO, M. C. L. B. The rectangle of fish biodiversity in central Brazil: insights from the genus Characidium (Crenuchidae: Characiformes). In: JOINT MEETING OF ICHTHYOLOGISTS AND HERPETOLOGISTS, 2014, Chattanooga. Abstracts... Lawrence: American Society of Ichthyologists and Herpetologists - ASIH, 2014. p. 337. Disponível em: <https://conferences.k-state.edu/joint-meeting/files/2015/09/2014JMIH-Abstract-Book-1w7651p.pdf>. Acesso em: jul. 2016.

MENEZES, N. A. et al. Peixes de água doce da mata atlântica: lista preliminar das espécies e comentários sobre conservação de peixes de água doce neotropicais. São Paulo: Museu de Zoologia da Universidade de São Paulo - MZUSP, 2007. 407 p.

MIRANDA, E. E. de; COUTINHO, A. C. (Coord.). Brasil visto do espaço. Campinas: Empresa Brasileira de Pesquisa Agropecuária - Embrapa Monitoramento por Satélite, 2004. Disponível em: <http://www.cdbrasil.cnpm.embrapa.br>. Acesso em: dez. 2009.

MITTERMEIER, R. A. et al. Hotspots revisited: earth's biologically richest and most endangered terrestrial ecoregions. Arlington: Conservation Internacional; Monterrey: Cemex, 2005. $392 \mathrm{p}$.

MORAIS, H. C.; DINIZ, I. R. Invertebrados terrestres na APA Gama e Cabeça de Veado. In: RIBEIRO, M. L. (Org.). Reserva Ecológica do IBGE: biodiversidade terrestre. Rio de Janeiro: IBGE, 2011. v. 1, t. 2, cap. 22, p. 100-117. Disponível em: <http://biblioteca.ibge.gov.br/ index.php/biblioteca-catalogo?view=detalhes\&id=249522>. Acesso em: jul. 2016.

MYERS, N. Threatened biotas: hotspots in tropical forests. Environmentalist, v. 8, n. 3, p. 187208, 1988.

MYERS, N. et al. Biodiversity hotspots for conservation priorities. Nature, London: Macmillian Magazines, v. 403, p. 853-858, Feb. 24 2000. Disponível em: <http://www.nature.com/ nature/journal/v403/n6772/full/403853a0.html>. Acesso em: jul. 2016.

NABINGER, C. et al. Produção animal com base em campo nativo: aplicações de resultados de pesquisa. In: PILLAR, V. de P. et al. (Ed.). Campos sulinos: conservação e uso sustentável da biodiversidade. Brasília, DF: Ministério do Meio Ambiente, 2009. cap. 13, p. 175-198. Disponível em: <http://www.mma.gov.br/publicacoes/biodiversidade/category/58-probioi-serie-biodiversidade?download=964:campos-sulinos-conservacao-e-uso-sustentavel-dabiodiversidade>. Acesso em: jul. 2016.

NEGRET, A. Fluxos migratórios na avifauna da Reserva Ecológica do IBGE, Brasília, DF, Brasil. Revista Brasileira de Zoologia, Curitiba: Sociedade Brasileira de Zoologia - SBZ, v. 5, n. 2, p. 209214, 1988. Disponível em: <http://www.scielo.br/scielo.php?script=sci_arttext\&pid=S010181751988000200005\&lng=en\&nrm=iso\&tlng=pt $>$. Acesso em: jul. 2016.

NOGUEIRA, C. et al. Diversidade de répteis Squamata e evolução do conhecimento faunístico no cerrado. In: DINIZ, I. R. et al. (Org.). Cerrado: conhecimento científico quantitativo como subsídio para ações de conservação. Brasília, DF: Universidade de Brasília - UnB: Thesaurus, 2010. cap. 11, p. 333-376.

NORES, M. An alternative hypothesis for the origin of amazonian bird diversity. Journal of Biogeography, Hoboken: Wiley, v. 26, n. 3, p. 475-485, May 1999. Disponível em: <http:// onlinelibrary.wiley.com/doi/10.1046/j.1365-2699.1999.t01-1-00311.x/full>. Acesso em: jul. 2016. 
OLIVEIRA, J. A. de. Diversidade de mamíferos e o estabelecimento de áreas prioritárias para a conservação do bioma caatinga. In: SILVA, J. M. C. da et al. (Org.). Biodiversidade da caatinga: áreas e ações prioritárias para a conservação. Brasília, DF: Ministério do Meio Ambiente; Recife: Universidade Federal de Pernambuco, 2004a. parte 3, p. 264-282. Disponível em: $<$ http://ainfo.cnptia.embrapa.br/digital/bitstream/item/18270/1/Biodiversidade_Caatinga_ parte3.1.pdf>. Acesso em: jul. 2016.

(Coord.). Mamíferos: áreas e ações prioritárias para a conservação da caatinga. In: SILVA, J. M. C. da et al. (Org.). Biodiversidade da caatinga: áreas e ações prioritárias para a conservação. Brasília, DF: Ministério do Meio Ambiente; Recife: Universidade Federal de Pernambuco, 2004b. parte 3, p. 284-292. Disponível em: <http://ainfo.cnptia.embrapa.br/ digital/bitstream/item/18271/1/Caatinga1.pdf>. Acesso em: jul. 2016.

OLIVEIRA, J. B. de et al. Mapa pedológico do estado de São Paulo: legenda expandida. Campinas: Instituto Agronômico - IAC; Rio de Janeiro: Empresa Brasileira de Pesquisa Agropecuária -Embrapa Solos, 1999. 64 p.

OLIVEIRA, V. A. de; COSTA, J. R. S. Levantamento detalhado dos solos. In: ZONEAMENTO ambiental da bacia do córrego Taquara - Distrito Federal. Rio de Janeiro: IBGE, 1995. p. 73162.

OLIVEIRA, V. A. de et al. Pedologia, aptidão agrícola e uso atual das terras. In: DIAGNÓSTICO agroambiental do entorno do Parque Nacional das Emas: primeira fase: pedologia, aptidão agrícola e uso atual das terras. Goiânia: Agência Goiana de Desenvolvimento Rural e Fundiário - Agenciarural, 2003. v. 1, 227 p. (Documentos, n. 2).

OLIVEIRA FILHO, A. T.; RATTER, J. A. A study of the origin of the central Brazilian forests by the analysis of plant species distribution patterns. Edinburgh Journal of Botany, Edinburgh: Royal Botanic Garden Edinburgh; Cambridge: Cambridge University Press, v. 52, n. 2, p. 141-194, July 1995.

OLSON, D. M. et al. Terrestrial ecoregions of the world: a new map of life on Earth. BioScience, Oxford: Oxford Journals; Reston: American Institute of Biological Sciencies AIBS, v. 51, n. 11, p. 933-938, Nov. 2001. Disponível em: <http://bioscience.oxfordjournals. org/content/51/11/933.full>. Acesso em: jul. 2016.

PAGLIA, A. P. Avaliação das abordagens e iniciativas de priorização de ações para a conservação da biodiversidade na mata atlântica. In: MAPEAMENTOS para a conservação e recuperação da biodiversidade na mata atlântica: em busca de uma estratégia espacial integradora para orientar ações aplicadas. Brasília, DF: Ministério do Meio Ambiente, Secretaria de Biodiversidade e Florestas, 2013. cap. 3, p. 85-134. (Biodiversidade, 49). Disponível em: <http://www.mma.gov.br/publicacoes/biodiversidade/category/142-seriebiodiversidade>. Acesso em: jul. 2016.

PAGLIA, A. P.; FONSECA, G. A. B. da; SILVA, J. M. C. da. A Fauna brasileira ameaçada de extinção: síntese taxonômica e geográfica. In: MACHADO, A. B. M.; DRUMMOND, G. M.; PAGLIA, A. P. (Ed.). Livro vermelho da fauna brasileira ameaçada de extinção. Brasília, DF: Ministério do Meio Ambiente; Belo Horizonte: Fundação Biodiversitas, 2008. v. 1, p. 6370. (Biodiversidade, 19). Disponível em: <http://www.icmbio.gov.br/portal/images/stories/ biodiversidade/fauna-brasileira/livro-vermelho/volumel/vol_I_parte2.pdf $>$. Acesso em: jul. 2016. 
PACHECO, J. F. (Coord.). Aves: áreas e ações prioritárias para a conservação da caatinga. In: SILVA, J. M. C. da et al. (Org.). Biodiversidade da caatinga: áreas e ações prioritárias para a conservação. Brasília, DF: Ministério do Meio Ambiente; Recife: Universidade Federal de Pernambuco, 2004. parte 3, p. 251-262. Disponível em: <http://ainfo.cnptia.embrapa.br/ digital/bitstream/item/18269/1/Caatinga_.pdf>. Acesso em: jul. 2016.

PAIM, P. S. G. Minas do Camaquã, RS: marco da história da mineração de cobre no Brasil. In: SCHOBBENHAUS C. et al. (Ed.). Sítios geológicos e paleontológicos do Brasil. Brasília, DF: Departamento Nacional de Produção Mineral - DNPM em convênio com o Serviço Geológico do Brasil - CPRM e a Comissão Brasileira de Sítios Geológicos e Paleobiológicos - Sigep, 2002. p. 501-510. Disponível em: <http://sigep.cprm.gov.br/sitios.htm\#Vol1>. Acesso em: jul. 2016.

PAULA, P. M. de; ROBAINA, L. E. de S. Estudo das bacias hidrográficas com desenvolvimento de areais no município de Alegrete-RS. In: SIMPÓSIO BRASILEIRO DE GEOGRAFIA FÍSICA APLICADA, 10., 2003, Rio de Janeiro. Trabalhos apresentados... Rio de Janeiro: Universidade do Estado do Rio de Janeiro - UERJ, 2003, p. 766-772. Disponível em: <http://www.cibergeo. org/XSBGFA/eixo3/3.3/016/016.htm>. Acesso em: jul. 2016.

PENTEADO, M. M. Fundamentos de geomorfologia. 3. ed. Rio de Janeiro: IBGE, 1980. 185 p. Disponível em: <http://biblioteca.ibge.gov.br/index.php/biblioteca-catalogo?view=detalh es\&id=281427>. Acesso em: jul. 2016.

PERZ, S. G. et al. O dilema das estradas não-oficiais na Amazônia. Ciência Hoje, Rio de Janeiro: Instituto Ciência Hoje - ICH, v. 37, n. 222, p. 56-58, dez. 2005.

PLANO de ação para prevenção e controle do desmatamento na Amazônia Legal (PPCDAm): $3^{\text {a }}$ fase (2012-2015) pelo uso sustentável e conservação da floresta. Brasília, DF, 2013. 171 p. Disponível em: <http://www.mma.gov.br/images/arquivo/80120/PPCDAm/_FINAL_ PPCDAM.PDF>. Acesso em: jul. 2016.

POLAZ, C. N. M. Caracterização da Ictiofauna e aplicação do índice de integridade biótica no Parque Nacional do Pantanal Mato-Grossense, Poconé, MT. 2013. 175 p. Tese (Doutorado)-Programa de Pós-Graduação em Ciências da Engenharia Ambiental, Universidade de São Paulo, São Carlos, 2013. Disponível em: <http://www.teses.usp.br/teses/ disponiveis/18/18139/tde-26082013-091018/publico/TeseCarlaNatachaMarcolinoPolaz. pdf>. Acesso em: jul. 2016.

POMPÊO, M. L. M.; MOSCHINI-CARLOS, V.; SILVA-FILHO, C. G. Transporte de nitrogênio, fósforo e seston em três rios pré-amazônicos (estado do Maranhão, Brasil). Bioikos, Campinas: Pontifícia Universidade Católica de Campinas - PUC-Campinas, Centro de Ciências da Vida, v. 16, n. 1-2, p. 29-39, 2002. Disponível em: <http://periodicos.puc-campinas.edu.br/seer/ index.php/bioikos/article/view/903>. Acesso em: jul. 2016.

POR, F. D.; FONSECA, V. L. I.; LENCIONI NETO, F. Pantanal. [2007?]. Disponível em: <http:// www.mre.gov.br/cdbrasil/itamaraty/web/port/meioamb/ecossit/pantanal>. Acesso em: jun. 2007.

POTT, A.; POTT, V. J. Plantas do pantanal. Brasília, DF: Empresa Brasileira de Pesquisa Agropecuária - Embrapa, Serviço de Produção de Informação - SPI; Corumbá: Embrapa, Centro de Pesquisa Agropecuária do Pantanal - CPAP, 1994. 320 p. 
PRANCE, G. T. Phytogeographic support for the theory of Pleistocene forest refuges in the Amazon basin, based on evidence from distribution patterns in Caryocaraceae, Chrysobalanaceae, Dichapetalaceae and Lecythidaceae. Acta Amazônica, Manaus: Instituto Nacional de Pesquisas da Amazônica - INPA, v. 3, n. 3, p. 5-28, 1973. Disponível em: $<$ https://acta.inpa.gov.br/fasciculos/3-3/PDF/v3n3a02.pdf>. Acesso em: jul. 2016.

PROENÇA, C. E. B. et al. Regionalização, centros de endemismos e conservação com base em espécies de angiospermas indicadoras da biodiversidade do cerrado brasileiro. In: DINIZ, I. R. et al. (Org.). Cerrado: conhecimento científico quantitativo como subsídio para ações de conservação. Brasília, DF: Universidade de Brasília - UnB: Thesaurus, 2010. cap. 3, p. 33-88.

PROJETO Prodes: monitoramento da floresta amazônica brasileira por satélite. São José dos Campos: Instituto Nacional de Pesquisas Espaciais - INPE, Coordenação-Geral de Observação da Terra - OBT, [2015]. Disponível em: <http://www.obt.inpe.br/prodes/index. php>. Acesso em: mar. 2016.

PROJETO zoneamento das potencialidades dos recursos naturais da Amazônia Legal. Rio de Janeiro: IBGE, 1990. 212 p. Disponível em: <http://biblioteca.ibge.gov.br/index.php/ biblioteca-catalogo?view=detalhes\&id=222382>. Acesso em: jul. 2016.

O QUE SÃO áreas úmidas? Brasília, DF: Fundo Mundial para a Natureza - WWF-Brasil, 2009. Disponível em: <http://www.wwf.org.br/natureza_brasileira/questoes_ambientais/ areas_umidas/>. Acesso em: jul. 2016.

QUEIROZ, L. J. de et al. (Org.). Peixes do rio Madeira. São Paulo: Dialeto Latin American Documentary, 2013. 3 v. Disponível em: <http://www.santoantonioenergia.com.br/ peixesdoriomadeira >. Acesso em: jul. 2016.

RAMOS, V. L. S.; NUNES, B. T. A.; NATALI FILHO, T. Geomorfologia. In: FOLHA SE. 23 Belo Horizonte: geologia, geomorfologia, pedologia, vegetação, uso potencial da terra. Rio de Janeiro: Projeto Radambrasil, 1984. (Levantamento de recursos naturais, v. 38). Trabalho não publicado.

RATTER, J. A.; BRIDGEWATER, S.; RIBEIRO, J. F. Analysis of the floristic composition of the Brazilian cerrado vegetation, III: comparison of the woody vegetation of 376 areas. Edinburgh Journal of Botany, Edinburgh: Royal Botanic Garden Edinburgh; Cambridge: Cambridge University Press, v. 60, n. 1, p. 57-109, Mar. 2003.

REGIÃO centro-oeste. In: GEOGRAFIA do Brasil. Rio de Janeiro: IBGE, 1989.v. 1. Disponível em: <http://biblioteca.ibge.gov.br/index.php/biblioteca-catalogo?view=detalhes \&id=220702 $>$. Acesso em: jul. 2016.

REIS, R. E.; KULLANDER, S. O.; FERRARIS JUNIOR, C. J. (Org.). Check list of the freshwater fishes of South and Central America. Porto Alegre: EDIPUCRS, 2003. 729 p.

RESENDE, E. K. de. Os pulsos de inundação e o rio Taquari. Curitiba: Agronline, [2004?]. Notícia de 14 abr. 2004. Disponível em: <http://www.agronline.com.br/artigos/os-pulsosinundacao-rio-taquari>. Acesso em: jul. 2016.

RESERVA DA BIOSFERA DA MATA ATLÂNTICA (Brasil). Texto síntese. São Paulo, 2004a. Disponível em: <http://www.rbma.org.br/rbma/rbma_1_textosintese.asp>. Acesso: jul. 2016. 
Espécies ameaçadas. São Paulo, 2004b. Disponível em: <http://www.rbma.org.br/ anuario/mata_04_esp_ecies.asp >. Acesso em: jul. 2016.

REUNIÃO de correlação, classificação e aplicação de levantamentos de solos da região centro-oeste RCC - GO/MT. Rio de Janeiro: Empresa Brasileira de Pesquisa Agropecuária Embrapa Solos, 2004. 106 p. (Boletim de pesquisa e desenvolvimento, 55). Disponível em: $<$ http://ainfo.cnptia.embrapa.br/digital/bitstream/item/89279/1/bpd-55-rcc-go.pdf>. Acesso em: jul. 2016.

REZENDE, J. O. de. Solos coesos dos tabuleiros costeiros: limitações agrícolas e manejo. Salvador: Secretaria da Agricultura, Irrigação e Reforma Agrária - Seagri, 2000. 117 p. (Estudos agrícolas, v. 1).

RIBEIRO, L. P. Os latossolos amarelos do recôncavo baiano: gênese, evolução e degradação. Salvador: Secretaria do Planejamento, Ciência e Tecnologia - Seplantec, 1998. 99 p.

RIBEIRO, M. C. L. de B. (Coord.). Biota aquática. In: CERRADO e pantanal: áreas e ações prioritárias para conservação da biodiversidade. Brasília, DF: Ministério do Meio Ambiente, Secretaria de Biodiversidade e Florestas, 2007. p. 193-256. (Biodiversidade, 17). Disponível em: <http://www.mma.gov.br/estruturas/chm/_arquivos/cerrado_pantanal.pdf>. Acesso em: jul. 2016.

RIBEIRO, M. C. L. de B.; PRETERE JUNIOR, M. Fisheries ecology and management of the Jaraqui (Semaprochilodus Taeniurus, S. Insignis) in central Amazonia. Regulated Rivers: Research and Management, Hoboken: Wiley, v. 5, n. 3, p. 195-215, June/July 1990.

RIBEIRO, M. C. L. de B.; PRETERE JUNIOR, M.; JURAS, A. A. Ecological integrity and fisheries ecology of the Araguaia-Tocantins river basin, Brazil. Regulated Rivers: Research and Management, Hoboken: Wiley, v. 11, n. 3-4, p. 325-350, Nov. 1995.

RIBEIRO, M. C. L. de B. et al. A singularidade do fenômeno de águas emendadas: uma explicação biogeográfica. In: FONSECA, F. O. (Org.). Águas emendadas. Brasília, DF: Secretaria de Desenvolvimento Urbano e Meio Ambiente - Seduma. 2008, p. 294-310. Disponível em: <http://www.recursoshidricos.df.gov.br/aguas_emendadas/documentos/ Aguas_Emendadas.pdf $>$. Acesso em: jul. 2016.

RIBEIRO, R.; BEZERRA, A.; MARINHO-FILHO, J. Coleções científicas e a conservação de mamíferos do cerrado. In: DINIZ, I. R. et al. (Org.). Cerrado: conhecimento científico quantitativo como subsídio para ações de conservação. Brasília, DF: Universidade de Brasília - UnB: Thesaurus, 2010. cap. 13, p. 415-440.

RIO DE JANEIRO (Estado). Secretaria de Meio Ambiente e Desenvolvimento Sustentável. Macroplano de gestão e saneamento ambiental da bacia da Baía de Sepetiba. Rio de Janeiro: Semads; Brasília, DF: Programa Nacional do Meio Ambiente - PNMA, 1998. 36 p. Relatório R8, t. 1: estudos de base.

RIO GRANDE DO SUL. Secretaria do Meio Ambiente. Programa de restauração da mata ciliar. Porto Alegre: Sema, [2007?]. Disponível em: <http://www.sema.rs.gov.br/sema/html/ mataciliar.htm>. Acesso em: out. 2007. 
RODRIGUES, M. T. (Coord.). Anfíbios e répteis: áreas e ações prioritárias para a conservação da caatinga. In: SILVA, J. M. C. da et al. (Org.). Biodiversidade da caatinga: áreas e ações prioritárias para a conservação. Brasília, DF: Ministério do Meio Ambiente; Recife: Universidade Federal de Pernambuco, 2004. parte 3, p. 182-188. Disponível em: <http:// ainfo.cnptia.embrapa.br/digital/bitstream/item/18281/1/Caatinga.pdf>. Acesso em: jul. 2016.

ROSA, R. (Coord.). Biota aquática: áreas e ações prioritárias para a conservação da caatinga. In: SILVA, J. M. C. da et al. (Org.). Biodiversidade da caatinga: áreas e ações prioritárias para a conservação. Brasília, DF: Ministério do Meio Ambiente; Recife: Universidade Federal de Pernambuco, 2004a. parte 3, p. 164-171. Disponível em: <http://ainfo.cnptia.embrapa.br/ digital/bitstream/item/18279/1/Caatinga4.pdf>. Acesso em: jul. 2016.

ROSA, R. Diversidade e conservação dos peixes da caatinga. In: SILVA, J. M. C. da et al. (Org.). Biodiversidade da caatinga: áreas e ações prioritárias para a conservação. Brasília, DF: Ministério do Meio Ambiente; Recife: Universidade Federal de Pernambuco, 2004b. parte 3, p. 150-156. Disponível em: <http://ainfo.cnptia.embrapa.br/digital/bitstream/ item/18278/1/Caatinga3.pdf>. Acesso em: jul. 2016.

ROSA, R. S.; LIMA, F. C. T. Os peixes brasileiros ameaçados de extinção. In: MACHADO, A. B. M.; DRUMMOND, G. M.; PAGLIA, A. P. (Ed.). Livro vermelho da fauna brasileira ameaçada de extinção. Brasília, DF: Ministério do Meio Ambiente; Belo Horizonte: Fundação Biodiversitas, 2008. v. 2, p. 9-19. Disponível em: <http://www.icmbio.gov.br/ portal/images/stories/biodiversidade/fauna-brasileira/livro-vermelho/volumell/Peixes.pdf $>$. Acesso em: jul. 2016.

RUFFINO, M. L. (Ed.). A pesca e os recursos pesqueiros na Amazônia brasileira. Manaus: Instituto Brasileiro do Meio Ambiente e dos Recursos Naturais Renováveis - Ibama, Projeto Manejo dos Recursos Naturais da Várzea - ProVárzea, 2004. 268 p. Disponível em: <http:// petpesca-ufam.webnode.com.br/news/livro-pdf-a-pesca-e-os-recursos-pesqueiros-naamazonia-/>. Acesso em: jul. 2016.

SALATI, E.; MARQUES, J.; MOLION, L. C. B. Origem e distribuição das chuvas na Amazônia. Interciencia, Caracas: Asociación Interciencia, v. 3, n. 4, p. 200-206, 1978.

SANTANA, S. R. Custo social da desertificação. Brasília, DF: Fundação Grupo Esquel Brasil, 2003. 3 p. Disponível em: <http://www.esquel.org.br/index.php?option=com_content\&vie $\mathrm{w}=$ article\&id=73\&ltemid=77>. Acesso em: jul. 2016.

SCHMITZ, P. I. Pantanal: os primeiros passos da pré-história. Ciência Hoje, Rio de Janeiro: Instituto Ciência Hoje - ICH, v. 22, n. 129, p. 36-45, jul. 1997.

SERVIÇO GEOLÓGICO DO BRASIL. Monitoramento hidrológico. Brasília, DF: CPRM: Agência Nacional de Águas - ANA, dez. 2013. [13] p. (Boletim, n. 44). Disponível em: $<$ http://arquivos.ana.gov.br/infohidrologicas/monitoramento/AmazoniaOcidental/BoletimM onitoramentoAO_n_044-2013.pdf>. Acesso em: jul. 2016.

Monitoramento hidrológico. Brasília, DF: CPRM: Agência Nacional de Águas - ANA, jan. 2014. [13] p. (Boletim, n. 3). Disponível em: $<$ http://arquivos.ana.gov.br/infohidrologicas/ monitoramento/AmazoniaOcidental/BoletimMonitoramentoAO_n_003-2014.pdf >. Acesso em: jul. 2016. 
. Relatório perspectivas do meio ambiente do Brasil: Geo-Brasil 2002: uso do subsolo. Brasília, DF: CPRM, 2002. 27 p. Disponível em: <http://rigeo.cprm.gov.br/xmlui/handle/ doc/2445?show=full $>$. Acesso em: jul. 2016.

SICK, H. Ornitologia brasileira: uma introdução. Brasília, DF: Ed. Universidade de Brasília - UnB, c1985. 2 v.

SILVA, D. J. da. Enchente atípica do rio Paraguai chama a atenção dos pesquisadores no pantanal. Corumbá: Empresa Brasileira de Pesquisa Agropecuária - Embrapa Pantanal, [2005a]. Disponível em: <http://www.cpap.embrapa.br/destaques/noticias/enchente.htm> Acesso em: jul. 2016.

Nível do rio Paraguai volta a subir no pantanal. Corumbá: Empresa Brasileira de Pesquisa Agropecuária - Embrapa Pantanal, [2005b]. Disponível em: <http://www.cpap. embrapa.br/destaques/noticias/cheia2.htm>. Acesso em: jul. 2016.

SILVA, D. S. et al. Influence of ecological factors and of land use on mercury levels in fish in the Tapajós river basin, Amazon. Environmental Research, Amsterdam: Elsevier, v. 109, n. 4, p. 432-446, May 2009. Disponível em: <http://www.sciencedirect.com/science/article/pii/ S0013935109000309>. Acesso em: jul. 2016.

SILVA, J. M. C.; CASTELETI, C. H. Status of biodiversity of the atlantic forest of Brazil. In: GALINDO-LEAL, C.; CÂMARA, I. de G. (Ed.). The atlantic forest of South America: biodiversity status, threats, and outlook. Washington: Island Press, 2003. p. 43-59.

SILVA, J. M. C. ; SANTOS, M. P. D. A importância relativa dos processos biogeográficos na formação da avifauna do cerrado e de outros biomas brasileiros. In: SCARIOT, A.; SOUSASILVA, J. C.; FELFILI, J. M. (Org.). Cerrado: ecologia, biodiversidade e conservação. Brasília, DF: Ministério do Meio Ambiente, 2005. cap. 12, p. 220-233.

SILVA, J. M. C. da et al. Aves da caatinga: status, uso do habitat e sensitividade. In: LEAL, I. R.; TABARELLI, M.; SILVA, J. M. C. da (Ed.). Ecologia e conservação da caatinga. Recife: Universidade Federal de Pernambuco - UFPE, 2003. p. 237-273. Disponível em: <http://www. mma.gov.br/estruturas/203/_arquivos/5_livro_ecologia_e_conservao_da_caatinga_203. pdf>. Acesso em: jul. 2016.

SILVA, J. S. V.; ABDON, M. M. Delimitação do pantanal brasileiro e suas sub-regiões. Pesquisa Agropecuária Brasileira, Brasília, DF: Empresa Brasileira de Pesquisa Agropecuária - Embrapa Informação Tecnológica, v. 33, n. especial, p. 1703-1711, out. 1998. Disponível em: <http://seer.sct.embrapa.br/index.php/pab/article/view/5050>. Acesso em: jul. 2016.

SILVEIRA, L. F.; STRAUBE, F. C. Aves ameaçadas de extinção no Brasil. In: MACHADO, A. B. M.; DRUMMOND, G. M.; PAGLIA, A. P. (Ed.). Livro vermelho da fauna brasileira ameaçada de extinção. Brasília, DF: Ministério do Meio Ambiente; Belo Horizonte: Fundação Biodiversitas, 2008. v. 2, p. 379-383. Disponível em: <http://www.icmbio.gov. br/portal/images/stories/biodiversidade/fauna-brasileira/livro-vermelho/volumell/Aves.pdf>. Acesso em: jul. 2016.

SIOLI, H. The Amazon and its main affluents: hydrography, morphology of the river courses and rivers types. In: (Ed.). The Amazon: limnology and landscape ecology of a mighty tropical river and its basin. Dordrecht: W. Junk Publishers, 1984. p. 127-165. (Monographiae biologicae, v. 56). 
SIQUEIRA FILHO, J. A. de (Org.). Flora das caatingas do rio São Francisco: história natural e conservação. Rio de Janeiro: Andrea Jakobsson; Petrolina: Universidade Federal do Vale do São Francisco - Univasf, 2012. 552 p.

SISTEMA brasileiro de classificação de solos. 2. ed. Brasília, DF: Empresa Brasileira de Pesquisa Agropecuária - Embrapa Informação Tecnológica; Rio de Janeiro: Embrapa Solos, 2006. 306 p. Disponível em: <http://ainfo.cnptia.embrapa.br/digital/bitstream/item/93143/1/ sistema-brasileiro-de-classificacao-dos-solos2006.pdf>. Acesso em: jul. 2016.

SISTEMA brasileiro de classificação de solos. 3. ed. rev. e ampl. Brasília, DF: Empresa Brasileira de Pesquisa Agropecuária - Embrapa Informação Tecnológica; Rio de Janeiro: Embrapa Solos, 2013. 353 p.

SOMBROEK, W. G. Reconnaissance soil survey of the area Guamá-Imperatriz (area along the upper part of the Brazilian highway BR-14. Belém: Superintendência do Plano de Valorização Econômica da Amazônia - SPVEA; Rome: Food and Agriculture Organization of the United Nations - FAO, 1962. 146 p.

SOUZA, O. B.; ZANCHETTA, I. Seca na Amazônia: alguma coisa está fora da ordem. [S.I.]: Rota Brasil Oeste, 2005. Notícia de 27 out. 2005. Disponível em: <http://www.brasiloeste. com.br/noticia/1654/seca-amazonia>. Acesso em: jul. 2016.

STEEGE, H. T. et al. An analysis of the floristic composition and diversity of Amazonian forests including those of the Guiana shield. Journal of Tropical Ecology, Cambridge: Cambridge University Press, v. 16, n. 6, p. 801-828, Nov. 2000.

SUERTEGARAY, D. M. A.; GUASSELLI, L. A.; VERDUM, R. (Org.). Atlas da arenização: sudoeste do Rio Grande do Sul. Porto Alegre: Secretaria da Coordenação e Planejamento, 2001. 84 p.

TARIFA, J. R. O sistema climático do pantanal: da compreensão do sistema à definição de prioridades de pesquisa climatológica. In: SIMPÓSIO SOBRE RECURSOS NATURAIS E SÓCIO-ECONÔMICOS DO PANTANAL, 1., Corumbá, 1984. Anais ... Brasília, DF: Empresa Brasileira de Pesquisa Agropecuária - Embrapa, Departamento de Difusão de Tecnologia; Corumbá: Embrapa, Centro de Pesquisa Agropecuária do Pantanal - CPAP, 1986. p. 9-27. Disponível em: <https://www.embrapa.br/busca-de-publicacoes/-/publicacao/787689/ anais>. Acesso em: jul. 2016.

TRANCOSO, R. et al. Sistemas de informação geográfica como ferramenta para o diagnóstico e gestão de macrobacias no arco do desmatamento na Amazônia. In: SIMPÓSIO BRASILEIRO DE SENSORIAMENTO REMOTO, 12., Goiânia, 2005. Anais... São José dos Campos: Instituto Nacional de Pesquisas Espaciais - INPE, 2005. p. 2405-2412. Disponível em: <http://marte.sid.inpe.br/col/ltid.inpe.br/sbsr/2004/11.20.13.29/doc/2405.pdf>. Acesso em: jul. 2016.

TUBELIS, D. P.; COWLING, A.; DONNELLY, C. Role of mixed-species flocks in the use of adjacent savannas by forest birds in the central cerrado, Brazil. Austral Ecology, Hoboken: Wiley; Windsor: Ecological Society of Australia - ESA, v. 31, n. 1, p. 38-45, Feb. 2006. 
TUBELIS, D. P.; TOMAS, W. M. Lista atualizada das espécies do pantanal. Brasília, DF: Fundação Pró-Natureza - Funatura em convênio com a Conservation International do Brasil, a Fundação Biodiversitas e a Universidade de Brasília - UnB, 2001. Trabalho apresentado no Workshop Ações Prioritárias para a Conservação da Biodiversidade do Cerrado e do Pantanal, realizado em Brasília, 2001. Disponível em: <http://www.bdt.fat.org.br/workshop/ cerrado/br/contribuicao/avespantanal>. Acesso em: nov. 2005.

TUBELIS, D. P.; TOMAS, W. M. Revisão e atualização da listagem de espécies de aves registradas na planície do pantanal. In: SIMPÓSIO SOBRE RECURSOS NATURAIS E SÓCIO-ECONÔMICOS DO PANTANAL, 3., Corumbá, 2000. Os desafios do novo milênio. Corumbá: Empresa Brasileira de Pesquisa Agropecuária - Embrapa Pantanal, 2000. 46 p. Disponível em: <http://www.cpap.embrapa.br/agencia/congresso/Bioticos/TUBELIS-077. pdf> Acesso em: jul. 2016.

UNIVERSIDADE FEDERAL DO RIO DE JANEIRO. Laboratório de Hidrologia e Estudos do Meio Ambiente. Programa de investimentos de Minas Gerais: modelagem de qualidade da água. Rio de Janeiro, 1999. 331 p. PPG-RE-013-R0. Projeto preparatório para o gerenciamento dos recursos hídricos do Paraíba do Sul, elaborado em convênio com a Secretaria de Recursos Hídricos e o Comitê para Integração da Bacia Hidrográfica do Rio Paraíba do Sul - Ceivap. Disponível em: <www.hidro.ufrj.br/ppg/layout.html>. Acesso em: jul. 2016.

USSAMI, N.; SHIRAIWA, S.; DOMINGUEZ, J. M. L. Basement reactivation in a sub-Andean foreland flexural bulge: the pantanal wetland, SW, Brazil. Tectonics, Washington, DC: American Geophysical Union - AGU, v. 18, n. 1, p. 25-39, Feb. 1999. Disponível em: <http://onlinelibrary.wiley.com/doi/10.1029/1998TC900004/epdf> Acesso em: jul. 2016.

VANZOLINI, P. E. Paleoclimas e especiação em animais da América do Sul tropical. Estudos Avançados. São Paulo: Universidade de São Paulo - USP, Instituto de Estudos Avançados - IEA, v. 6, n. 15, p. 41-65, 1992. Disponível em: <http://www.revistas.usp.br/eav/article/ view/9580>. Acesso em: jul. 2016.

VÉLEZ, E. et al. Um panorama sobre as iniciativas de conservação dos campos sulinos. In: PILLAR, V. de P. et al. (Ed.). Campos sulinos: conservação e uso sustentável da biodiversidade. Brasília, DF: Ministério do Meio Ambiente, 2009. cap. 28, p. 356-379. Disponível em: $<$ http://www.mma.gov.br/publicacoes/biodiversidade/category/58-probio-i-serie-biodivers idade?download=964:campos-sulinos-conservacao-e-uso-sustentavel-da-biodiversidade $>$. Acesso em: jul. 2016.

VETORES estruturantes da dimensão socioeconômica da bacia hidrográfica do rio São Francisco 2009. Rio de Janeiro: IBGE, 2009. 179 p. (Estudos e pesquisas. Informação geográfica, n. 6). Acompanha 1 CD-ROM. Disponível em: <http://biblioteca.ibge.gov.br/ index.php/biblioteca-catalogo?view=detalhes\&id=242291 >. Acesso em: jul. 2016.

VIEIRA, L. M. Pantanal: um bioma ameaçado. Curitiba: Agronline, [2002?]. Notícia de 14 mar. 2002. Disponível em: <http://www.agronline.com.br/artigos/artigo.php?id=61>. Acesso em: jul. 2016. 
O pantanal e a contaminação por mercúrio. Curitiba: Agronline, [2005?]. Notícia de 21 fev. 2005. Disponível em: <http://www.agronline.com.br/artigos/artigo.php?id=205>. Acesso em: jul. 2016.

A problemática socieconômica e ambiental da bacia do rio Taquari e perspectivas. Curitiba: Agronline, [2004?]. Notícia de 14 abr. 2004. Disponível em: <http://www. agronline.com.br/artigos/artigo.php?id=158>. Acesso em: jul. 2016.

WALCOTT, R. I. Isostatic response to loading of the crust in Canada. Canadian Journal of Earth Sciences, Ottawa: NRC Research Press, v. 7, n. 2, p. 716-727, 1970.

WASSERMAN, J. C.; HACON, S. S.; WASSERMAN, M. A. O ciclo do mercúrio no ambiente amazônico. Mundo \& Vida, Niterói: Universidade Federl Fluminense - UFF, Programa de Pós-Graduação em Ciência Ambiental - PGCA, v. 2, n. 1/2, p. 46-53, 2001. Disponível em: $<$ http://www.uff.br/cienciaambiental/mv/mv2/MV2(1-2)46-53.pdf>. Acesso em: jul. 2016.

WILSON, J. T. Did the Atlantic close and then re-open? Nature, London: Macmillian Magazines, v. 211, n. 5050, p. 676-681, Aug. 13 1966. Disponível em: <http://fossilhub. org/wp-content/uploads/2012/10/Wilson1966_did_Atlantic_reopen.pdf>. Acesso em: jul. 2016.

WINGE, M. et al. Glossário geológico ilustrado. Brasília, DF: Universidade de Brasília - UnB, Instituto de Geociências, 2001. Disponível em <http://sigep.cprm.gov.br/glossario>. Acesso em: fev. 2010.

ZONEAMENTO ambiental da silvicultura: estrutura, metodologia e resultados. Porto Alegre: Secretaria Estadual do Meio Ambiente - SEMA, 2010. v. 1. Disponível em <http://www. fepam.rs.gov.br/biblioteca/silvicultura/v1_ZAS\%20APROVADO\%20CONSOLIDADO\%20 CORRIGIDO\%20V-18-05-2010.pdf>. Acesso em: fev. 2010.

ZONEAMENTO ECOLÓGICO-ECONÔMICO (Programa : Brasil). Zoneamento ecológicoeconômico da bacia do rio Parnaíba: um foco nos cerrados do sul do Piauí e Maranhão: subsídios para o diagnóstico. Brasília, DF: Consórcio ZEE Brasil, 2005. 80 p. 


\title{
Uma contribuição à geografia dos recursos hídricos
}

\author{
Eugênio Antônio de Lima \\ Hellen Cano \\ José Antônio Sena do Nascimento
}

\begin{abstract}
A água constitui elemento essencial à vida, enquanto componente biológico dos seres vivos e meio de vida de várias espécies vegetais e animais, assim como fator fundamental de localização dos assentamentos humanos e, portanto, de entendimento das formas de organização socioeconômica do Território Nacional.
\end{abstract}

A divisão do território brasileiro segundo a distribuição espacial dos recursos hídricos longe de constituir uma simples e tradicional delimitação geográfica do País adquire, na atualidade, uma importância central para a gestão do Território Nacional notadamente quando se considera o sentido estratégico que vem adquirindo a regulação do uso dos recursos hídricos.

Com efeito, nenhum outro recurso natural oferece tantos usos socioeconômicos quanto a água, incluindo seu aproveitamento para o abastecimento doméstico e industrial e como matéria-prima nas atividades industriais e agrícolas, para geração de energia e irrigação, entre outros. Este capítulo tem, assim, como objetivo delinear algumas diferenças geográficas relacionadas com uso e a disponibilidade dos recursos hídricos no Brasil.

A água é vista aqui, contudo, não somente como um recurso, mas como um serviço' prestado pelos ecossistemas ao bem-estar humano, bem como ela é considerada um sistema em si constituído de águas interiores.

\footnotetext{
1 Serviços ecossistêmicos são os benefícios que as pessoas adquirem dos ecossistemas saudáveis, os quais são descritos pela Avaliação Ecossistêmica do Milênio como serviços de produção, de regulação, de suporte, e culturais (ECOSYSTEMS..., 2003). Os serviços de produção ou aprovisionamento são os bens que se obtém dos ecossistemas tais como alimento, combustível, fibras, água potável, e recursos genéticos. Os serviços de regulação são os benefícios que se obtém da regulação de processos dos ecossistemas, inclusive a manutenção da qualidade do ar, regulação do clima, controle da erosão, regulação de doenças humanas e purificação da água. Os serviços culturais são os benefícios não materiais que as pessoas obtêm dos ecossistemas através de enriquecimento espiritual, desenvolvimento cognitivo, e experiências de reflexão, de recreação e estéticas. Serviços de suporte são aqueles que são necessários para a produção de todos os outros serviços de ecossistemas, como a produção primária, a produção de oxigênio, e a formação de solo. Mudanças na integridade dos ecossistemas e na biodiversidade afetam esses serviços e podem impactar o bem-estar humano de várias formas.
} 
Como o ciclo da água desempenha muitos papéis no clima, na química e na biologia da Terra, é difícil defini-lo distintamente como um serviço de suporte, de regulação ou de provisionamento. A precipitação, que cai como chuva ou neve, é a melhor fonte de água para os ecossistemas. Os ecossistemas, por sua vez, controlam o caráter de renovação do recurso água doce para o bem-estar humano [...] Juntamente com a energia e os nutrientes, a água é, sem dúvida, a peça central para a prestação de serviços ecossistêmicos para a humanidade. (FALKENMARK; FOLKE, 2003 apud ECOSYSTEMS..., 2005, p. 168, tradução nossa)

Embora o papel de todos os serviços ecossistêmicos da água sejam importantes, o mais bem documentado é o serviço de provisionamento, em parte porque os recursos hídricos são o bem mais tangível, mais facilmente mensurável, diferentemente da mensuração dos demais, como o serviço de regulação das vazões dos rios, do papel da água no ciclo hidrológico e na manutenção de florestas, dentre outros.

O presente capítulo concentra-se na análise de um tema central ao avanço do conhecimento dos recursos hídricos no Brasil que é aquele relativo a sua distribuição geográfica no Território Nacional.

Para tanto, ele reúne informações demográficas, econômicas e ambientais que caracterizam não só a geografia das águas superficiais - as regiões hidrográficas - como a das águas subterrâneas - as províncias hidrogeológicas - possibilitando, portanto, uma visão inicial de duas vertentes fundamentais e complementares que envolvem a problemática em torno da distribuição desigual dos recursos hídricos no imenso território brasileiro.

Esse capítulo constitui, portanto, uma contribuição inicial na elaboração, em escala nacional, de um grande quadro de referência sobre questões conceituais, metodológicas e operacionais recorrentes na discussão em torno da inserção dos recursos hídricos no planejamento territorial do Brasil.

Nesse sentido, na parte referente às águas superficiais, ele reúne um conjunto de informações que permitem fazer uma leitura regionalizada dos recursos hídricos no País, com destaque para o cruzamento de informações básicas derivadas da dimensão socioeconômica, tais como o tamanho e densidade da população e o Produto Interno Bruto - PIB municipal, além daquelas oriundas do quadro natural, associadas aos biomas brasileiros.

Na parte referente às águas subterrâneas, o capítulo descreve a conjugação de fatores geológicos, geomorfológicos e climáticos que servem como parâmetro para definir as regiões denominadas de províncias hidrogeológicas, nos quais os sistemas aquíferos apresentam condições hidrogeológicas semelhantes no que se refere ao armazenamento, circulação, descarga e qualidade química das águas.

Um foco especial é dado à Região Nordeste, possibilitando um conhecimento mais detalhado da geografia das águas subterrâneas dessa imensa e importante região do País, cuja deficiência hídrica constitui histórico condicionante e renovado desafio no que diz respeito às formas social e ambientalmente sustentáveis de apropriação e uso de seu território.

Finalmente, o tema da vulnerabilidade social e ambiental conclui o presente capítulo apontando para questões centrais que envolvem a importância estratégica que a informação sobre o acesso e a qualidade dos recursos hídricos possui no avanço da quantificação estatística e da análise geográfica acerca da qualidade de vida da população em um momento histórico que passa por um acelerado processo de alterações climáticas. 


\section{Regiões hidrográficas: fundamentação e operacionalização de um recorte espacial}

Dada as dimensões continentais do Brasil e a grande diversidade de condições de disponibilidade de água, bem como de atendimento das necessidades básicas da população relacionadas com os recursos hídricos, como é o caso do saneamento, a escolha de recortes espaciais relevantes para o estudo de realidades específicas ao tema representou um marco inicial para a caracterização pretendida dos recursos hídricos em escala nacional.

Nesse contexto, pode-se afirmar que a divisão de bacias hidrográficas de um determinado país representa um desafio e sua compartimentação depende dos objetivos que se pretende atingir, da concepção metodológica adotada e, sobretudo, da escala de apresentação.

Desta forma, concluiu-se que a região hidrográfica, unidade geográfica reconhecidamente utilizada para o planejamento dos recursos hídricos, seria o recorte espacial de nível de agregação compatível com as dimensões dos biomas, contextos econômicos regionais e macro vetores da expansão populacional do País.

O Sistema Nacional de Gerenciamento de Recursos Hídricos pode ser considerado a representação concreta da Política Nacional de Recursos Hídricos instituída pela Lei n. 9.433 de 08.01.1997, com o objetivo principal de prevenção e uso racional das águas, além da proposição de criação dos comitês de bacias hidrográficas. Desde esta data reconhece-se a bacia hidrográfica ${ }^{2}$ como a unidade de planejamento para as questões relacionadas com a água.

Havia, entretanto, a necessidade de um novo conceito para operacionalizar a Política Nacional dos Recursos Hídricos e o Sistema Nacional de Gerenciamento de Recursos Hídricos. Assim, em 2003, o Conselho Nacional de Recursos Hídricos - CNRH regulamentou e institucionalizou a região hidrográfica como unidade do gerenciamento de recursos hídricos com o objetivo de orientar, fundamentar e implementar o Plano Nacional de Recursos Hídricos.

Nesse contexto, a Resolução n. 32, de 15.10.2003 do CNRH, considerou como região hidrográfica "o espaço territorial brasileiro compreendido por uma bacia, grupo de bacias ou subbacias hidrográficas contíguas com características naturais, sociais e econômicas homogêneas ou similares, com vistas a orientar o planejamento e gerenciamento dos recursos hídricos".

No que se refere especificamente ao tema dos recursos hídricos, a utilização de uma base de informações atualizada e disponível sobre as características da população, fatores de pressão referentes às condições de vida e às atividades econômicas permite uma análise abrangente e mais completa para avaliação da disponibilidade hídrica e questões relacionadas com o recorte espacial escolhido, no caso, as regiões hidrográficas (Mapa 1), cuja caracterização a seguir é baseada nos dados do relatório Conjuntura dos recursos hídricos no Brasil 2013, publicado pela Agência Nacional de Águas - ANA.

\footnotetext{
2 De modo geral, os limites das bacias são definidos de acordo com critérios técnicos que incluem a separação dos divisores de água a partir da identificação das cabeceiras dos canais de primeira ordem, chegando-se à delimitação dos rios que formam a rede de drenagem principal. Assim, dependendo da escala do mapa a divisão hidrográfica pode ser cada vez mais detalhada e, portanto, comportar inúmeras subdivisões. Segundo a classificação de Otto Pfasfstetter, o Brasil possui seis bacias de ordem 1; 39 bacias de ordem 2; 351 bacias de ordem 3; 2541 bacias de ordem 4; 14921 bacias de ordem 5; e 60001 bacias de ordem 6 (CONJUNTURA..., 2013).
} 
Mapa 1 - Regiões hidrográficas

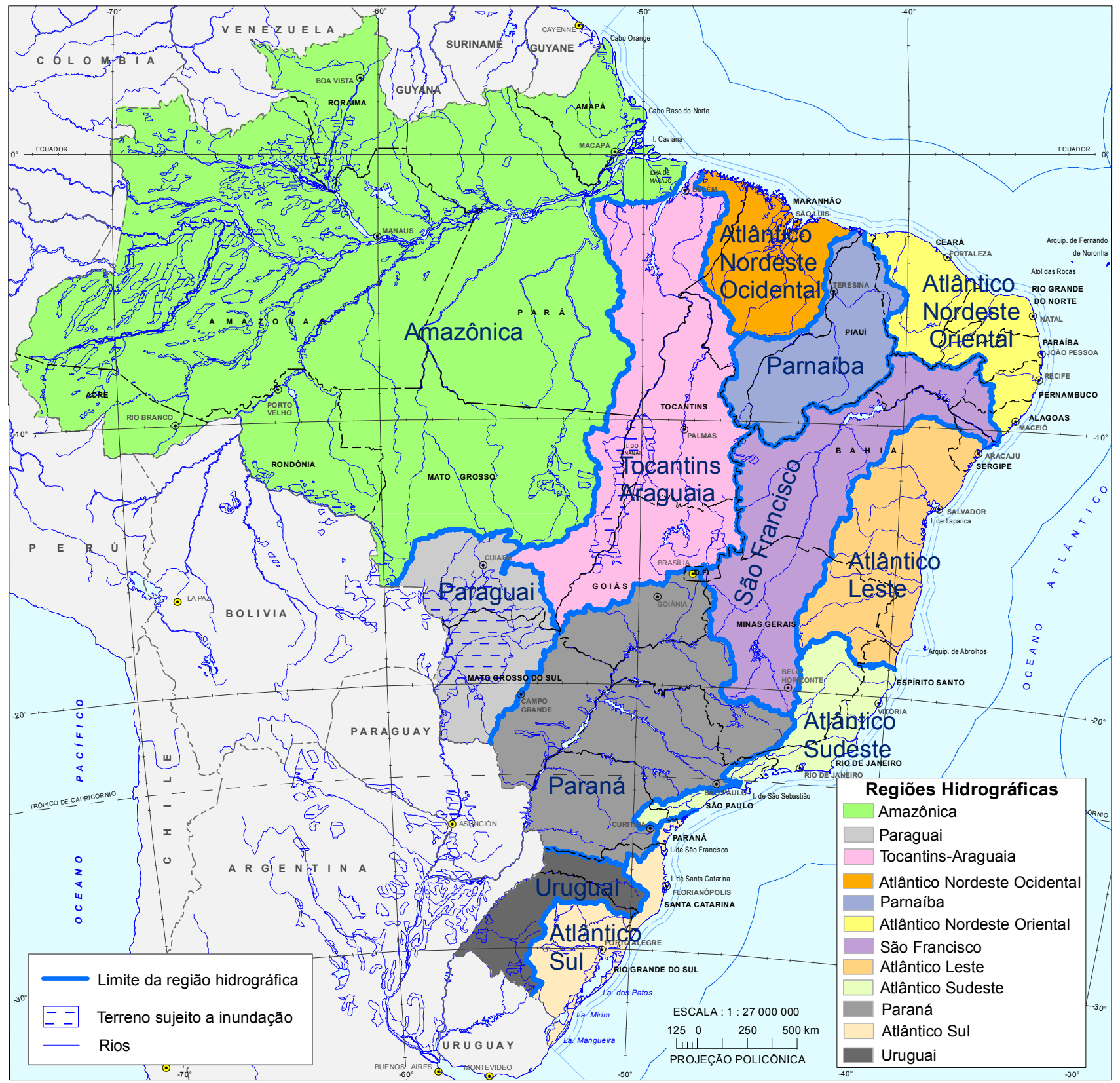

Fonte: Conselho Nacional de Recursos Hídricos (Brasil). Resolução n. 32, de 15 de outubro de 2003. Brasília, DF, 2003. Extraído de: Atlas Nacional do Brasil Milton Santos. Rio de Janeiro: IBGE, 2010. Disponível em: <http://biblioteca.ibge.gov.br/index.php/biblioteca-catalogo?view=detalhes\&id=247603>. Acesso em jun. 2016. 


\section{Distribuição da população nas regiões hidrográficas}

Nos aspectos populacionais, a distribuição da população pelas regiões hidrográficas revela um padrão concentrado onde se destaca a Região Hidrográfica do Paraná como a mais populosa, em contraste com a Região Hidrográfica Paraguai, a menos populosa. O Mapa 2 e a Tabela 1 apresentam a distribuição populacional segundo as 12 regiões hidrográficas do Brasil.

O exame da distribuição populacional por região hidrográfica da forma mais agregada, como apresentada no Mapa 2, é útil no sentido de explicar parte da pressão que a população exerce sobre os recursos hídricos, principalmente no que se refere ao consumo das famílias (abastecimento de água e saneamento). Outros tipos de uso da água, como irrigação e consumo industrial não estão diretamente ligados ao consumo da população local, pois, muitas vezes, cultivos agrícolas para exportação e produtos da indústria são enviados para fora da região hidrográfica.

Situações de escassez de água, como a vivenciada de forma generalizada em várias regiões hidrográficas do Brasil em 2014, demonstram a necessidade de revisão de políticas públicas que regulam o uso intensivo da água na produção econômica sem levar em conta os limites dos recursos hídricos, bem como revelam a urgência de programas e campanhas de conscientização do uso racional da água pela população e pelos demais setores usuários.

A geografia da densidade populacional por setores censitários (Mapa 3) revela que a distribuição populacional interna a cada região hidrográfica possui aspectos distintos, com áreas de alta concentração demográfica, em geral referentes às capitais estaduais e grandes cidades, em oposição a índices baixíssimos em extensas áreas do País.

No Mapa 3 ficam evidenciadas as marcadas diferenças que coexistem no interior das regiões hidrográficas. Nesse sentido, individualmente, elas podem possuir adensamentos populacionais distribuídos distintamente no território, variando de menos de 1 habitante por quilômetro quadrado $\left(\mathrm{hab} / \mathrm{km}^{2}\right)$ até mais de $500 \mathrm{hab} / \mathrm{km}^{2}$. Observam-se também adensamentos de até $100 \mathrm{hab} / \mathrm{km}^{2}$ em regiões hidrográficas esparsamente habitadas, como é o caso da Amazônia (2,7 hab/km²-por região hidrográfica), e vazios demográficos nas Regiões Hidrográficas do Paraná e do Atlântico Sudeste, por exemplo, pertencentes a classes de altas densidades demográficas (Mapa 2 e Tabela 1).

As desigualdades observadas na distribuição das densidades demográficas entre as regiões hidrográficas (Tabela 1) e no interior das regiões hidrográficas (Mapa 3) reafirmam a necessidade de se caminhar no sentido da visão integrada e multiescalar que permita interligar as formas de uso dos recursos hídricos às igualmente diferenciadas formas de povoamento engendradas pela sociedade ao longo do tempo, aí incluídos, os processos de urbanização e de formação de manchas crescentes de alta concentração da população no espaço geográfico. 
Mapa 2 - Densidade demográfica e população total nas regiões hidrográficas - 2013

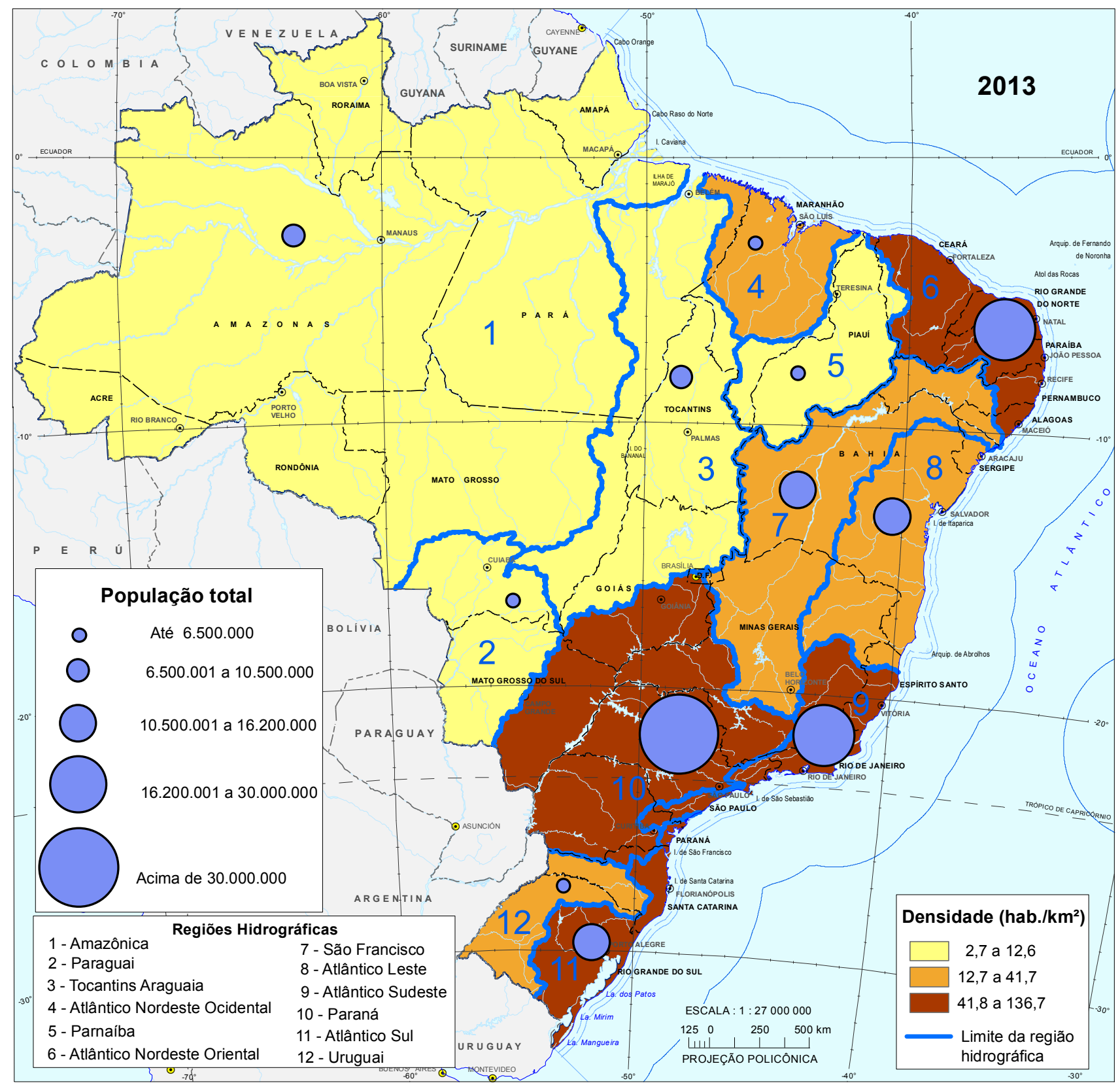

Fontes: 1. Estimativas da população residente nos municípios brasileiros com data de referência em 1o de julho de 2013. Rio de Janeiro: IBGE, 2013. Disponível em: <ftp://ftp.ibge.gov.br/Estimativas_de_Populacao>. Acesso em: maio 2016. 2. Conselho Nacional de Recursos Hídricos (Brasil). Resolução n. 32 , de 15 de outubro de 2003. Brasília, DF, 2003. Disponível em: <http://www.cnrh.gov.br/index.php?option=com_content\&view=article\&id=14>. Acesso em: maio 2016. 
Mapa 3 - Regiões hidrográficas e distribuição da população - 2013

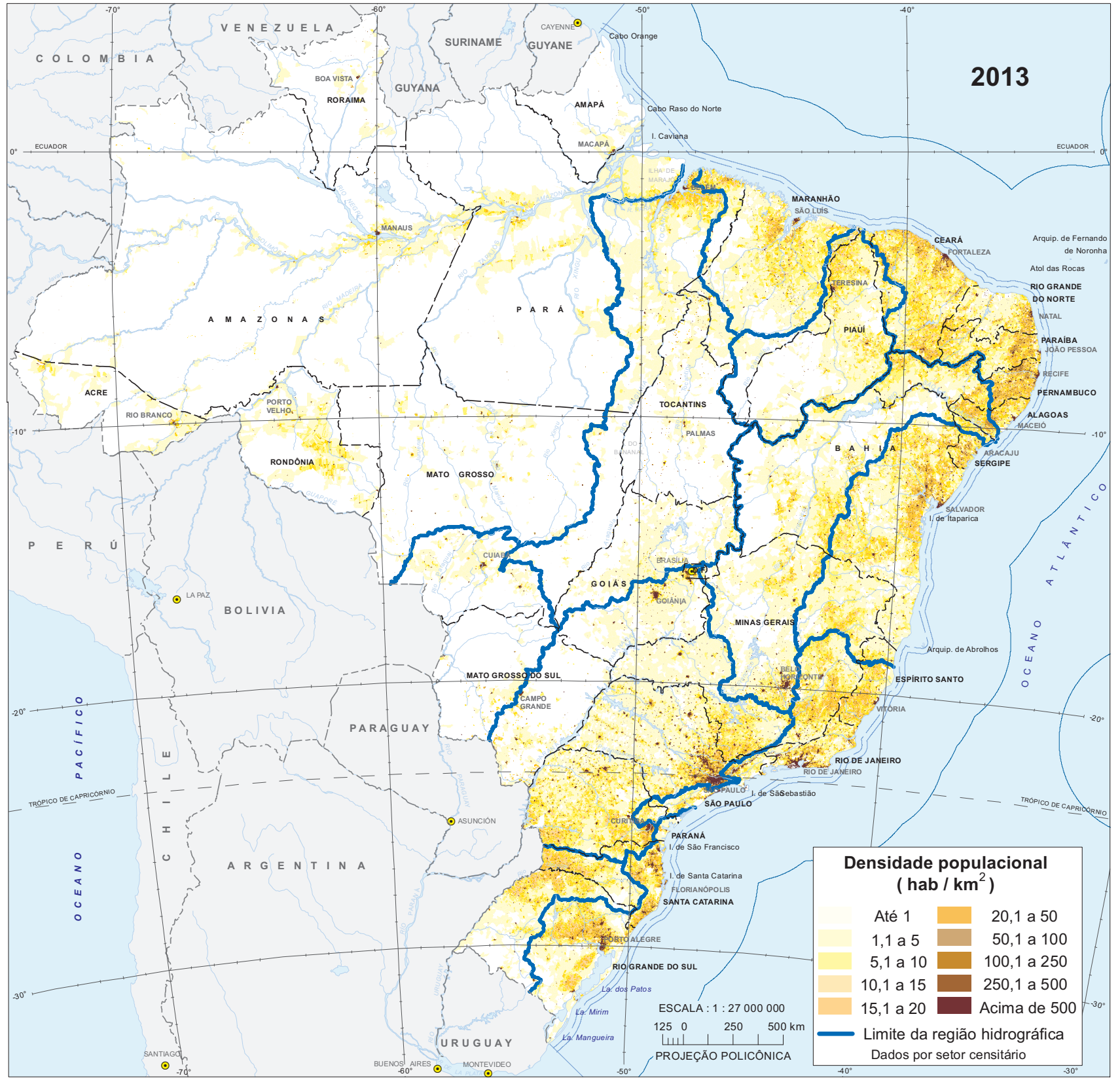

Fontes: 1. Estimativas da população residente nos municípios brasileiros com data de referência em 1o de julho de 2013. Rio de Janeiro: IBGE, 2013. Disponível em: <ftp://ftp.ibge.gov.br/Estimativas_de_Populacao >. Acesso em: maio 2016. 2. Conselho Nacional de Recursos Hídricos (Brasil). Resolução n. 32, de 15 de outubro de 2003. Brasília, DF, 2003. Disponível em: <http://www.cnrh.gov.br/index.php?option=com_content\&view=article\&id=14>. Acesso em: maio 2016 
Tabela 1 - Área, distribuição da população e densidade nas regiões hidrográficas - 2013

\begin{tabular}{rlr|r|r}
\hline \multicolumn{1}{c|}{ Região hidrográfica } & Área $\left(\mathrm{km}^{2}\right)$ & População & Densidade $\left(\mathrm{hab} / \mathrm{km}^{2}\right)$ \\
\hline 1 Amazônia & 3869953 & 10458790 & 2,7 \\
2 Paraguai & 363446 & 3111356 & 8,6 \\
3 & Tocantins-Araguaia & 918822 & 8992847 & 9,8 \\
4 & Atlântico Nordeste Ocidental & 274301 & 6393828 & 23,3 \\
5 & Parnaíba & 333056 & 4209040 & 12,6 \\
6 & Atlântico Nordeste Oriental & 286802 & 25278051 & 88,1 \\
7 & São Francisco & 638576 & 15015855 & 23,5 \\
8 & Atlântico Leste & 388160 & 16174377 & 41,7 \\
9 & Atlântico Sudeste & 214629 & 29339937 & 136,7 \\
10 & Paraná & 879873 & 64322182 & 73,1 \\
11 & Atlântico Sul & 187522 & 13574899 & 72,4 \\
12 & Uruguai & 174533 & 4136331 & 23,7 \\
\hline
\end{tabular}

Fontes: 1. Estimativas da população residente nos municípios brasileiros com data de referência em 1ำ de julho de 2013 . Rio de Janeiro: IBGE, 2013. Disponível em: <ftp://ftp.ibge.gov.br/Estimativas_de_Populacao>. Acesso em: maio 2016. 2. Conjuntura dos recursos hídricos no Brasil 2013. Brasília, DF: Agência Nacional de Águas - ANA, 2013. Disponível em: <http:// arquivos.ana.gov.br/institucional/spr/conjuntura/webSite_relatorioConjuntura/projeto/index.html>. Acesso em: maio 2016.

\section{Distribuição das atividades econômicas e regiões hidrográficas}

Ao lado dos fatores de pressão diretamente relacionados ao consumo de água pela população, a pressão exercida pelas atividades econômicas deve ser analisada no contexto da gestão dos recursos hídricos. Como destacado anteriormente, muitas vezes a utilização da água em determinadas bacias e regiões hidrográficas pode estar diretamente relacionada ao tipo de uso da terra e fatores de produção do que ao consumo direto da população que nela vive.

O PIB dos Municípios, calculado pelo IBGE para todos os municípios brasileiros, é reflexo e produto, de certa forma, da grande diversidade do capital natural, assim como das variações climáticas e contextos econômicos, sociais e políticos diferenciados que interagem nas 5565 unidades administrativas municipais no ano de 2011.

A Tabela 2 e o Mapa 4 apresentam os totais aproximados do PIB dos Municípios por região hidrográfica. Nestes, observa-se as diferenças espaciais na concentração do PIB e, por conseguinte, na distribuição das atividades econômicas entre as regiões hidrográficas. 
Tabela 2 - Produto Interno Bruto aproximado, total e per capita, segundo as regiões hidrográficas - 2011

\begin{tabular}{rl|r|r}
\hline \multirow{2}{*}{ Região hidrográfica } & \multicolumn{2}{c}{ PIB aproximado } \\
\cline { 3 - 4 } & & Total (1 000 R\$) & Per capita (R\$) \\
\hline 1 & Amazônia & 139400000 & 13329 \\
2 & Paraguai & 50200000 & 16134 \\
3 & Tocantins-Araguaia & 288300000 & 32059 \\
4 & Atlântico Nordeste Ocidental & 36000000 & 5630 \\
5 & Parnaíba & 28100000 & 6676 \\
6 & Atlântico Nordeste Oriental & 250700000 & 9918 \\
7 & São Francisco & 202000000 & 13452 \\
8 & Atlântico Leste & 178700000 & 11048 \\
9 & Atlântico Sudeste & 593200000 & 20218 \\
10 & Paraná & 1617000000 & 25139 \\
11 & Atlântico Sul & 323000000 & 23794 \\
12 & Uruguai & 62300000 & 15062 \\
\hline
\end{tabular}

Fontes: 1. IBGE, Produto Interno Bruto dos Municípios 2012. 2. Conjuntura dos recursos hídricos no Brasil 2013. Brasília, DF Agência Nacional de Águas - ANA, 2013. Disponível em <http://arquivos.ana.gov.br/institucional/spr/conjuntura/webSite_ relatorioConjuntura/projeto/index.html>. Acesso em: maio 2016.

Apesar de manter padrão similar ao da concentração populacional, o Mapa 4 revela aspectos diferenciados das formas de apropriação e uso do território brasileiro e, portanto, da distribuição das atividades econômicas no País. É o caso, por exemplo, da Região Hidrográfica do Tocantins-Araguaia que, em virtude de sua produção agropecuária e da presença da capital federal, situa-se, em termos de PIB total, em patamar semelhante a outras regiões hidrográficas bem mais populosas.

No campo das estatísticas ambientais existem na atualidade estratégias internacionais que visam quantificar, em termos físicos e monetários, a relação entre o uso da água nos setores econômicos (indústria, agropecuária e saneamento) ${ }^{3}$ e as reservas existentes, para aferir com maior precisão o real valor desse recurso natural.

Nesse sentido, o reconhecimento das diferenças regionais constitui um elemento central no caminho da incorporação das especificidades econômicas e ambientais, essenciais para relacionar o uso dos recursos hídricos e a capacidade das reservas de água em face dos múltiplos usos que as atividades humanas pressupõem.

\footnotetext{
3 Destacam-se os seguintes documentos: International recommendations for water statistics (2012); o System of environmental-economic accounting 2012: central framework (2014); e o System of environmental-economic accounting for water - SEEA-water (2012) elaborados pela mesma organização e adotados como padrão internacional pela Comissão de Estatísticas das Nações Unidas (United Nations Statistical Commission - UNSC).
} 
Mapa 4 - Produto Interno Bruto nas regiões hidrográficas - 2010

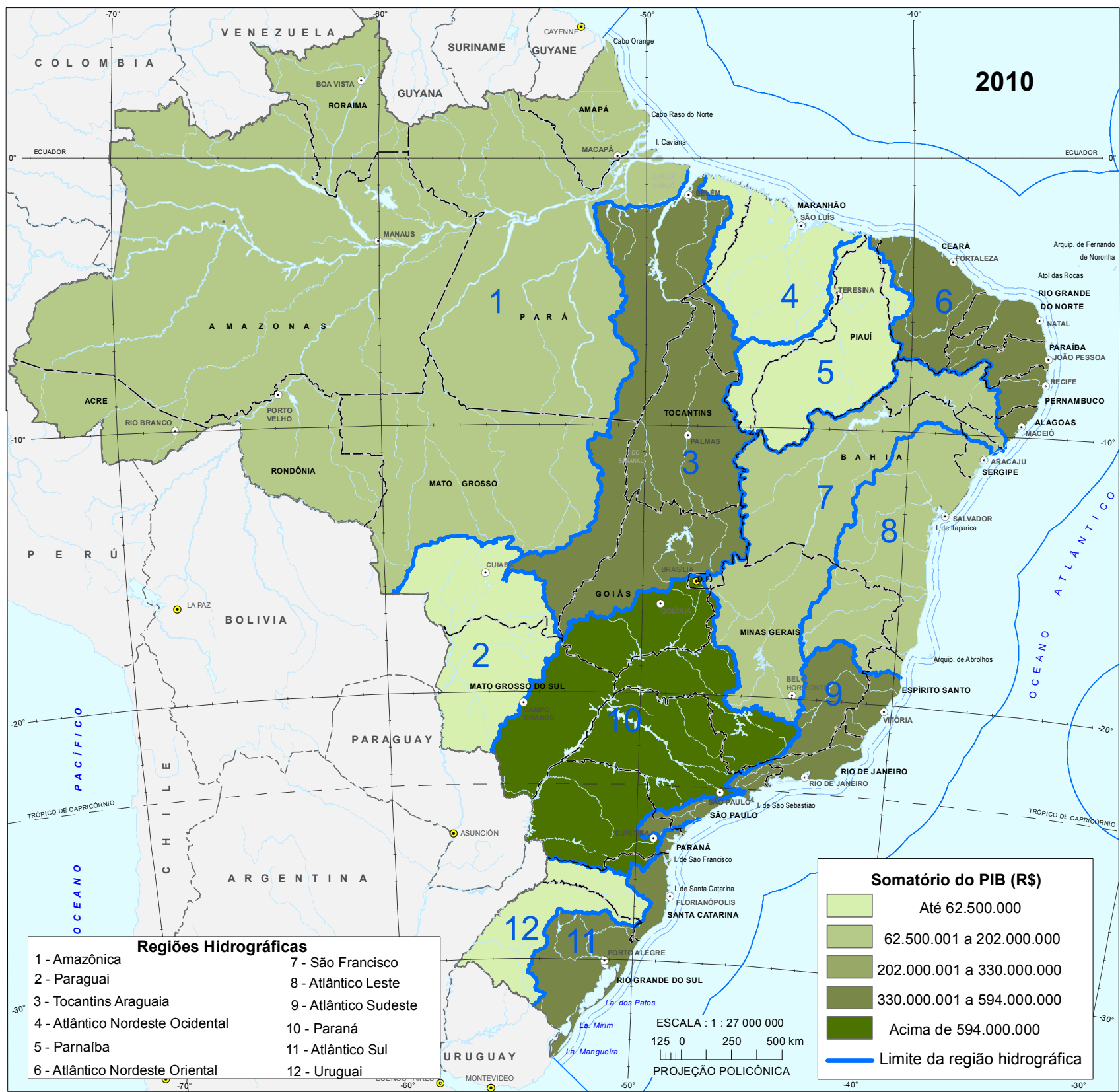

Fontes: 1. IBGE, Produto Interno Bruto dos Municípios 2012. 2. Conselho Nacional de Recursos Hídricos (Brasil). Resolução n. 32 , de 15 de outubro de 2003. Brasília, DF, 2003. Disponível em: <http://www.cnrh.gov.br/index.php?option=com_content\&view=article\&id=14>. Acesso em: maio 2016 


\section{Caracterização socioeconômica das regiões hidrográficas brasileiras}

Uma contextualização inicial das regiões hidrográficas brasileiras constitui etapa obrigatória para se avançar no processo de quantificação/valoração dos recursos hídricos em escala regional. Assim, reunimos aqui informações relevantes na caracterização das formas dominantes de uso dos recursos hídricos em cada uma das regiões.

\section{Região Hidrográfica Amazônica}

A Região Hidrográfica Amazônica é constituída pela Bacia Hidrográfica do Rio Amazonas em Território Nacional, pelas bacias hidrográficas dos rios existentes na Ilha de Marajó, além das bacias hidrográficas dos rios situados no Estado do Amapá que deságuam no Atlântico Norte, de acordo com a Resolução n. 32, de 15.10.2003 do CNRH, perfazendo um total de $3869953 \mathrm{~km}^{2}$.

A população na Região Hidrográfica Amazônica, em 2013, era de 10458790 habitantes (5,2\% da população do País) e a densidade demográfica de apenas 2,7 hab/km², enquanto sua área ocupa 42,0\% do Território Nacional.

As capitais estaduais de Manaus, Rio Branco, Porto Velho, Boa Vista e Macapá, bem como os Municípios de Santarém (PA) e Sinop (MT), são os centros urbanos que mais se destacam dentre os 304 municípios da Região Hidrográfica Amazônica.

Segundo a Agência Nacional de Águas - ANA, a Bacia Hidrográfica do Rio Amazonas é constituída pela mais extensa rede hidrográfica do globo terrestre, ocupando uma área total da ordem de $6110000 \mathrm{~km}^{2}$, desde suas nascentes na região dos Andes peruanos até sua foz no Oceano Atlântico (na Região Norte do Brasil) (CONJUNTURA..., 2013). Esta bacia continental se estende por vários países da América do Sul: Brasil (63,0\%), Peru (17,0\%), Bolívia (11,0\%), Colômbia (5,8\%), Equador (2,2\%), Venezuela (0,7\%) e Guiana $(0,2 \%)$.

Em termos de vazão, a contribuição média da Bacia Hidrográfica do Rio Amazonas, em território brasileiro, é da ordem de 132145 metros cúbicos por segundo (m³/s) (73,6\% do total do País). Adicionalmente, a contribuição de territórios estrangeiros para as vazões da região hidrográfica é da ordem de 76000 m³/s.

As maiores demandas pelo uso da água na região ocorrem nas sub-bacias dos Rios Tapajós, Madeira e Negro, e tem por finalidade o uso para abastecimento humano e dessedentação animal, representando, respectivamente, $33,0 \%$ e $32,0 \%$ da demanda total da região, que é de 78,8 m³/s. De modo geral, os consumos estimados são pouco significativos quando comparados com a disponibilidade hídrica por sub-bacia (CONJUNTURA..., 2013).

\section{Região Hidrográfica do Paraguai}

A Região Hidrográfica do Paraguai inclui uma das maiores extensões úmidas contínuas do planeta, o Pantanal, considerado patrimônio nacional, pela Constituição Federal do Brasil, de 1988, e Reserva da Biosfera, pela Organização das Nações Unidas para a Educação, a Ciência e a Cultura (United Nations Educational Scientific and Cultural Organization UNESCO), no ano 2000. 
As áreas úmidas são ecossistemas na interface entre ambientes aquáticos e terrestres; elas podem ser continentais ou litorâneas, naturais ou artificiais, permanentes ou periodicamente inundadas por águas rasas ou consistem em solo encharcado. Suas águas podem ser frescas, ou muito ou moderadamente salinas. As zonas úmidas são o lar de comunidades vegetais e animais específicos, adaptados às sua dinâmica hidrológica. (JUNK et al., 2014, p. 12, tradução nossa).

Essas áreas fornecem habitats que são de fundamental relevância para a manutenção da integridade funcional e da biodiversidade. A importância desta região hidrográfica deve-se, em parte, ao que assegura a Avaliação Ecossistêmica do Milênio:

Áreas úmidas oferecem diversos serviços para a sociedade, tais como o armazenamento de água, o tamponamento do rio e descarga de córregos, recarga de águas subterrâneas, retenção de sedimentos, purificação de água, a regulação do microclima, recreação e ecoturismo, armazenamento de carbono, a produção de madeira, e da provisão de produtos não-madeireiros, plantas medicinais, peixe, produtos agrícolas, água potável para seres humanos e animais, e terras para criação de animais. Além disso, contribuem para a preservação cultural, fornecendo abrigo e condições de vida para comunidades tradicionais (ECOSYSTEMS..., 2005 apud JUNK et al., 2014, p. 6, tradução nossa).

O principal rio dessa região hidrográfica é o Paraguai, que nasce em território brasileiro e drena uma área de $1095000 \mathrm{~km}^{2}:$ 33,0\% no Brasil $\left(363446 \mathrm{~km}^{2}\right)$ e o restante na Argentina, Bolívia e Paraguai.

Cerca de 3111356 pessoas residiam na região em 2013, o equivalente a 1,54\% da população do Brasil nesse ano, sendo $87,0 \%$ em áreas urbanas (ESTIMATIVAS..., 2013). Os Municípios de Cuiabá (MT) com 551 mil habitantes, Várzea Grande (MT) com 253 mil, Rondonópolis (MT) com 195 mil, Corumbá (MS) com 104 mil e Cáceres (MT) com 88 mil habitantes, representam os principais centros populacionais.

Na Região Hidrográfica do Paraguai estão presentes, além do Pantanal, o Bioma Cerrado e zonas de transição entre os dois biomas. Os tipos de vegetação predominantes são as Savanas Arborizada (Cerrado) e Florestada (Cerradão).

Com relação aos indicadores de saneamento básico do Censo Demográfico 2010, 93,0\% dos habitantes dessa região tinham acesso à rede de abastecimento de água, percentual semelhante ao valor médio nacional que é de $91,0 \%$. Por outro lado, a rede de esgoto alcançava apenas 29,0\% da população, muito abaixo, portanto, da média nacional. Quanto ao esgoto tratado, a região apresentava um percentual de 19,0\%, abaixo da média nacional de 30,0\% (CENSO DEMOGRÁFICO 2010, 2011).

Desde a década de 1970, a expansão da pecuária e da soja em áreas do Planalto tem aumentado o desmatamento e a erosão. Pelo fato de vários rios da região, como o Taquari e o São Lourenço, apresentarem elevada capacidade de transporte de sedimentos, vêm crescendo a deposição de sedimentos no Pantanal e o consequente assoreamento dos rios localizados nas regiões de menor altitude. 


\section{Região Hidrográfica do Tocantins-Araguaia}

A Região Hidrográfica do Tocantins-Araguaia apresenta grande potencialidade para a agricultura irrigada, especialmente para o cultivo de frutíferas, de arroz e outros grãos (milho e soja). Atualmente, a necessidade de uso de água para irrigação corresponde a 62,0\% da demanda total da região e se concentra na Sub-Bacia do Araguaia devido ao cultivo de arroz por inundação. A área irrigável (por inundação e outros métodos) é estimada em 230197 hectares (CONJUNTURA..., 2013).

A Região Hidrográfica do Tocantins-Araguaia corresponde a aproximadamente 11,0\% do Território Nacional e abrange os Estados de Goiás (21,0\%), Tocantins (30,0\%), Pará (30,0\%), Maranhão (4,0\%), Mato Grosso (15,0\%), além do Distrito Federal (0,1\%). Sua configuração é alongada, com sentido Sul-Norte, seguindo a direção predominante dos cursos d'água principais, os Rios Tocantins e Araguaia, que se unem na parte setentrional da região, a partir de onde é denominado Tocantins, e que segue até desaguar na Baía da Ilha de Marajó.

Em 2013, ela concentrava 4,5\% da população nacional, sendo 76,0\% em áreas urbanas. A densidade demográfica era de $9,8 \mathrm{hab} . / \mathrm{km}^{2}$, bem menor que a densidade demográfica do País, de 22,4 hab/km² (ESTIMATIVAS..., 2013).

Na Região Hidrográfica do Tocantins-Araguaia estão presentes os Biomas Amazônia, ao norte e noroeste, e Cerrado nas demais áreas. O desmatamento da região se intensificou a partir da década de 1970, com a construção da Rodovia Belém-Brasília, da Hidrelétrica de Tucuruí e da expansão das atividades agropecuárias e de mineração. Atualmente, o desmatamento se deve principalmente à atividade de indústrias madeireiras nos Estados do Pará e Maranhão (CONJUNTURA..., 2013).

Segundo a análise feita pela ANA sobre as informações de saneamento básico do Censo Demográfico 2010, o nível de abrangência da distribuição de água apresenta realidades bastante variadas, com valores entre 1,2\% em Floresta do Araguaia, no Estado do Pará e 100\% em Novo Alegre, no Tocantins; Divinópolis do Goiás; e Araguainha, no Estado de Mato Grosso. A média regional de atendimento da população por rede de esgoto é de apenas 18,0\% e, do percentual do esgoto coletado, apenas 6,0\% é tratado (CONJUNTURA..., 2013).

\section{Região Hidrográfica Atlântico Nordeste Ocidental}

A Região Hidrográfica Atlântico Nordeste Ocidental está situada, basicamente, no Estado do Maranhão e numa pequena porção oriental do Estado do Pará. Sua área é de $274301 \mathrm{~km}^{2}$ (aproximadamente 3,2\% da área do Brasil), dos quais, cerca de 9,0\% pertencem ao Estado do Pará e 91,0\% ao Estado do Maranhão. A população total na região, em 2013, era de 6393828 habitantes, equivalente a 3,18\% da população brasileira. De acordo com o Censo Demográfico 2010, 61,0\% dessa população vive em áreas urbanas.

A região apresenta uma vazão média de $2608 \mathrm{~m}^{3} / \mathrm{s}$, ou seja, 1,0\% do total do País. As Sub-Bacias dos Rios Mearim e Itapecuru são as maiores, com áreas de 101061 km² e $54908 \mathrm{~km}^{2}$, respectivamente, onde se concentra a maior demanda por $\mathrm{m}^{3} / \mathrm{s}$ de água. 
A principal necessidade da água na bacia é para consumo humano, correspondendo a $45,0 \%$ do total. Em seguida, vem a demanda animal, com $18,0 \%$ do uso total e a demanda para irrigação, com $15,0 \%$.

De acordo com o Mapa de biomas e de vegetação do Brasil (2004b), os mais importantes ecossistemas da região são as florestas ombrófilas e estacionais, restingas, savanas (cerrados) e áreas de contato entre os diferentes tipos de vegetação. Os impactos ambientais mais significativos em função da ocupação humana são observados, atualmente, na zona de transição ocidental das áreas de floresta. Segundo a ANA, em grande parte da bacia costeira do nordeste ocidental, são utilizadas práticas agrícolas inadequadas, acarretando processos erosivos, salinização e, em alguns casos, formação de áreas desertificadas (CONJUNTURA..., 2013).

A região não enfrenta grandes problemas em relação à qualidade das águas dos rios. Isso se deve, principalmente, às localidades urbanas de pequeno e médio portes e ao parque industrial de pouca expressão. Porém, na Região Metropolitana de São Luís e em alguns núcleos urbanos ribeirinhos, a contaminação das águas pelo lançamento de esgotos sem tratamento causa perdas e restringe outros usos. Estima-se que a carga orgânica doméstica remanescente na bacia hidrográfica seja de 154 toneladas de DBO5/dia (Demanda bioquímica de oxigênio), cerca de 2,8\% do total do País (CONJUNTURA..., 2013).

\section{Região Hidrográfica do Parnaíba}

Depois da Bacia do Rio São Francisco, a Região Hidrográfica do Parnaíba é hidrologicamente a segunda mais importante da Região Nordeste. Sua área, a mais extensa dentre as 25 bacias da vertente Nordeste, abrange o Estado do Piauí e parte dos Estados do Maranhão e do Ceará. A região, no entanto, apresenta grandes diferenças inter-regionais tanto em termos de desenvolvimento econômico e social quanto em relação à disponibilidade hídrica.

A escassez de água, aliás, tem sido historicamente apontada como um dos principais motivos para o baixo índice de desenvolvimento econômico e social. Entretanto, os aquíferos da região apresentam o maior potencial hídrico da Região Nordeste e podem ser explorados de maneira sustentável, representando um grande diferencial em relação às demais áreas dessa região no que se refere à possibilidade de promover o desenvolvimento econômico e social.

A região ocupa uma área de 333056 km², o equivalente a 3,9\% do Território Nacional, e drena a quase totalidade do Estado do Piauí (99,0\%) e parte dos Estados do Maranhão (19,0\%) e Ceará (10,0\%). O Rio Parnaíba possui 1400 quilômetros de extensão. A maioria dos afluentes localizados a jusante de Teresina são perenes e supridos por águas pluviais e subterrâneas.

Os principais afluentes do Rio Parnaíba são os seguintes: Balsas, situado no Maranhão; Poti, cuja nascente localiza-se no Estado do Ceará; e Canindé, Piauí, Uruçuí-Preto, Gurguéia e Longá, todos no Estado do Piauí.

A população total da região segundo estimativa de população do IBGE, em 2013, era de 4209040 habitantes (2,09\% da população nacional) com densidade demográfica de 12,6 hab $/ \mathrm{km}^{2}$, dos quais, segundo o Censo Demográfico 2010, 35,0\% encontram-se na área rural. Há destaque para a Unidade Hidrográfica de Poti, onde se situa a capital estadual, com índice de urbanização de 92,0\%. 
O percentual da população abastecida por água, em 2010, segundo o Censo Demográfico 2010, apresentava uma média de 91,0\%, equivalente à média nacional. No entanto, a situação é crítica em relação à rede de esgotamento sanitário que apresenta um valor médio de $10,0 \%$, muito abaixo da média nacional $(62,0 \%)$.

\section{Região Hidrográfica Atlântico Nordeste Oriental}

A Região Hidrográfica Atlântico Nordeste Oriental tem uma importância singular em relação à ocupação urbana, ao contemplar cinco importantes capitais da Região Nordeste, Regiões Metropolitanas, dezenas de grandes núcleos urbanos e um parque industrial significativo. Nesse cenário, destaca-se o fato de a região abranger mais de uma dezena de pequenas bacias costeiras, caracterizadas pelas pequenas extensão e vazão de seus corpos d'água.

A região apresenta uma área de $286802 \mathrm{~km}^{2}$, equivalente a 3,3\% do território brasileiro. Uma população de 25278051 pessoas reside nessas bacias, representando 12,57\% da população do País. Seguindo a tendência de urbanização do Brasil, 80,0\% (19 167761 de habitantes) desse contingente está nas capitais e Regiões Metropolitanas de Recife, Fortaleza, Maceió, Natal e João Pessoa, além de grandes Municípios como Caruaru (PE), Mossoró (RN) e Campina Grande (PB), entre outras (ESTIMATIVAS..., 2013).

A população rural era de 4,9 milhões de habitantes, em 2010, e em toda a região encontram-se 739 sedes municipais (16,0\% do País). A distribuição da área da bacia nas Unidades da Federação é a seguinte: Piauí (1,0\%), Ceará $(46,0 \%)$, Rio Grande do Norte (19,0\%), Paraíba (20,0\%), Pernambuco (10,0\%), Alagoas (5,0\%).

A região contempla fragmentos dos Biomas Mata Atlântica, Caatinga e dos Biomas Costeiros e Insulares. Da mesma forma que em outras regiões hidrográficas costeiras, na Região Hidrográfica Atlântico Nordeste Oriental observa-se um intenso processo de povoamento desde os primórdios da colonização do Brasil. Em muitas áreas originalmente de Caatinga, a vegetação foi substituída pela pecuária. De maneira análoga, a área ocupada pelo Bioma Mata Atlântica (Zona da Mata) passou por intenso movimento de desmatamento para a implantação da cultura canavieira. Ainda hoje, o extrativismo vegetal, principalmente para exploração do potencial madeireiro, representa uma das atividades de maior impacto sobre o meio ambiente.

Em algumas áreas das bacias costeiras limítrofes com a Região Hidrográfica do São Francisco, situa-se parte do Polígono das Secas, território reconhecido pela legislação como sujeito a períodos críticos de prolongadas estiagens e diferentes índices de aridez.

\section{Região Hidrográfica do São Francisco}

Fundamental pelo volume de água transportada para o Semiárido, a Região Hidrográfica do São Francisco abrange 521 municípios em seis Estados: Bahia, Minas Gerais, Pernambuco, Alagoas, Sergipe e Goiás, além do Distrito Federal. Com 2700 km, o Rio São Francisco nasce na Serra da Canastra, no Estado de Minas Gerais, e escoa no sentido sul-norte 
pelos Estados da Bahia e Pernambuco, quando altera seu curso para o sudeste, chegando ao Oceano Atlântico na divisa entre os Estados de Alagoas e Sergipe. Devido à sua extensão e aos diferentes ambientes que percorre, a região está dividida em Alto, Médio, Sub-médio e Baixo São Francisco.

A área de drenagem ocupa 8,0\% do Território Nacional e sua cobertura vegetal contempla fragmentos de Cerrado no Alto e Médio curso, Caatinga no Médio e Submédio curso e de Mata Atlântica no Alto São Francisco, principalmente nas cabeceiras. A bacia concentra a maior quantidade e diversidade de peixes de água doce da Região Nordeste. A vazão natural média anual do Rio São Francisco é de $2846 \mathrm{~m} 3 / \mathrm{s}$, mas ao longo do ano pode variar entre $1077 \mathrm{~m}^{3} / \mathrm{s}$ e $5290 \mathrm{~m}^{3} / \mathrm{s}$.

Em 2013, 15015855 pessoas habitavam a região, segundo a estimativa de população do IBGE, o equivalente a 7,5\% da população do País, sendo a maioria habitante da Região Metropolitana de Belo Horizonte. A agricultura é uma das mais importantes atividades econômicas, mas a região possui fortes contrastes socioeconômicos, com áreas de acentuada riqueza e alta densidade demográfica e áreas de pobreza crítica e população bastante dispersa. Dos 456 municípios com sede na bacia, somente 93 tratam seus esgotos.

Como reflexo das principais atividades econômicas na região hidrográfica, há necessidade de recuperação ambiental das áreas degradadas para mitigar os impactos sobre os recursos hídricos. A região vive extremos de secas e de cheias. O semiárido, que extrapola a área da Bacia do São Francisco, é vulnerável e sujeito a períodos críticos de prolongadas estiagens, que têm sido responsáveis por êxodo de parte de sua população. Por outro lado, os moradores da Região Metropolitana de Belo Horizonte enfrentam enchentes frequentes.

Ao mesmo tempo em que possui uma abundância em termos de recursos naturais, a Região Hidrográfica do São Francisco abriga uma diversidade de culturas, de locais históricos, de sítios arqueológicos e de importantes centros urbanos. Desta forma, a associação das dimensões do Rio às belezas naturais da região e ao patrimônio cultural acumulado no decorrer dos séculos consolida um grande potencial para o desenvolvimento do turismo, atividade ainda incipiente.

O potencial hidrelétrico aproveitado da Bacia é de 10473 megawatts (MW), distribuídos principalmente nas Usinas Três Marias, Queimado, Sobradinho, Itaparica, Complexo Paulo Afonso e Xingó. Os reservatórios Três Marias e Sobradinho têm papel fundamental na regularização das vazões do Rio São Francisco. Um dos maiores desafios é que a Bacia registra todos os tipos de usos dos recursos hídricos (irrigação, geração de energia, navegação, saneamento, pesca e aquicultura, atividades turísticas e de lazer), o que exige uma análise do conjunto para que se possa planejar adequadamente sua gestão.

Estudos realizados pela ANA apontam que o crescimento da agricultura, a pretendida revitalização da navegação, o aumento da demanda energética e a retirada de água da bacia por transposição são temas que podem gerar conflitos entre os setores usuários. Em 2005, a ANA concedeu outorga para o Projeto de Integração do Rio São Francisco, que prevê duas captações (eixo norte e eixo leste) no Rio São Francisco, para complementar a oferta de água local nos Estados do Ceará, Rio Grande do Norte, Paraíba e Pernambuco. 


\section{Região Hidrográfica Atlântico Leste}

A Região Hidrográfica Atlântico Leste contempla as capitais dos Estados de Sergipe e Bahia, alguns grandes núcleos urbanos e um parque industrial significativo, estando nela inseridos, parcial ou integralmente, 526 municípios.

A região tem uma área de $388160 \mathrm{~km}^{2}$, equivalente a 4,5\% do território brasileiro. A população da Região Hidrográfica Atlântico Leste era de 16174377 habitantes, representando 8,0\% da população do País em 2013. Seguindo a tendência da distribuição populacional brasileira, 75,0\% (aproximadamente 11,2 milhões de habitantes) desse contingente encontrava-se nas cidades, principalmente nas Regiões Metropolitanas de Salvador e Aracaju (ESTIMATIVAS..., 2013). A densidade demográfica é de $41,7 \mathrm{hab} / \mathrm{km}^{2}$, enquanto a média do Brasil é de 22,4 hab/km².

Em toda a região estão situadas 468 sedes municipais (8,0\% do País). A distribuição da área da bacia nas Unidades da Federação é: Sergipe (3,8\%), Bahia (66,8\%); Minas Gerais (26,2\%) e Espírito Santo (3,2\%).

A vazão média de longo período da região é estimada em 1484 m³/s, o que representa 0,9\% do total do País.

A Região Hidrográfica Atlântico Leste comporta fragmentos dos Biomas Mata Atlântica, Caatinga, pequena área de Cerrados e, evidentemente, Biomas Costeiros e Insulares. É nessa região hidrográfica que se observa uma das maiores evoluções da ação antrópica sobre a vegetação nativa: a Caatinga foi devastada pela pecuária que invadiu os sertões; o Recôncavo Baiano e a Zona da Mata foram desmatados para a implantação da cultura canavieira; e as matas úmidas do sul da Bahia foram substituídas pelas plantações de cacau. Ainda hoje, o extrativismo vegetal, principalmente para exploração do potencial madeireiro, representa uma das atividades de maior impacto sobre o meio ambiente.

\section{Região Hidrográfica Atlântico Sudeste}

A Região Hidrográfica Atlântico Sudeste é conhecida nacionalmente pelo elevado contingente populacional e pela importância econômica de sua indústria. O grande desenvolvimento da região, entretanto, é motivo de problemas em relação à disponibilidade de água. Isso ocorre porque, ao mesmo tempo em que apresenta uma das maiores demandas hídricas do País, ela possui também uma das menores disponibilidades relativas.

Promover o uso sustentável dos recursos hídricos na região, garantindo seu uso múltiplo, representa um grande desafio. O ideal para se garantir uma melhor preservação ambiental é colocar em prática formas de gestão que conciliem o crescimento econômico e populacional com a preservação dos recursos.

A Região Hidrográfica Atlântico Sudeste tem $214629 \mathrm{~km}^{2}$ de área, equivalente a 2,5\% do País. Os seus principais Rios são o Paraíba do Sul e o Doce, com respectivamente 1150 km e $853 \mathrm{~km}$ de extensão. Além desses, a região hidrográfica também é formada por diversos e pouco extensos rios que formam as seguintes Bacias: São Mateus, Santa Maria, Reis Magos, Benevente, Itabapoana, Itapemirim, Jacu, Ribeira e litorais do Rio de Janeiro e São Paulo. 
Cerca de 29339937 pessoas habitavam a região em 2013 (14,6\% da população do País), 92,0\% das quais em áreas urbanas (ESTIMATIVAS..., 2013). Outras características demográficas marcantes da região são os significativos adensamentos populacionais, onde se destacam a Região Metropolitana do Rio de Janeiro, com mais 3000 hab $/ \mathrm{km}^{2}$. Além dessa, destacam-se as Regiões Metropolitanas de Vitória (ES) e da Baixada Santista (SP) (Mapa 3).

Em relação ao uso e à ocupação do solo, um dos principais problemas se refere à ocupação irregular de encostas, áreas ribeirinhas e de mananciais, estimulada em grande parte pela especulação imobiliária. Devido ao intenso e desordenado processo de uso e ocupação, podem ser encontrados, ao longo dos rios, apenas pequenos trechos com vegetação ciliar e geralmente em mau estado de conservação.

\section{Região Hidrográfica do Paraná}

A Região Hidrográfica do Paraná, com 32,0\% da população nacional, apresenta aquela de maior desenvolvimento econômico do País. Com uma área de 879873 km², abrange os Estados de São Paulo (25,0\% da região), Paraná (21,0\%), Mato Grosso do Sul (20,0\%), Minas Gerais $(18,0 \%)$, Goiás $(14,0 \%)$, Santa Catarina (1,5\%) e o Distrito Federal $(0,5 \%)$.

Em 2013, segundo a estimativa de população do IBGE, 64322182 pessoas viviam na região, sendo 93,0\% em áreas urbanas (CENSO DEMOGRÁFICO 2010, 2011). A região abriga a cidade mais populosa da América do Sul, São Paulo, com cerca de 11,1 milhões de habitantes. Outros importantes centros populacionais são: Brasília, Curitiba, Goiânia, Campinas, Campo Grande e Uberlândia. A maior parte de população se concentra nas Unidades Hidrográficas dos Rios Tietê e Grande, que, juntas, correspondem a 61,0\% da população total.

O crescimento de grandes centros urbanos, como São Paulo, Curitiba e Campinas, em rios de cabeceira, tem gerado uma grande pressão sobre os recursos hídricos. Isso ocorre porque, ao mesmo tempo em que aumentam as demandas, diminui a disponibilidade de água devido à contaminação por efluentes domésticos, industriais e drenagem urbana.

Originalmente, a Região Hidrográfica do Paraná apresentava os Biomas Mata Atlântica e Cerrado e cinco tipos de fisionomias de vegetação: savana (ou cerrado), floresta ombrófila densa, floresta estacional semidecidual, floresta estacional decidual (conhecidas vulgarmente como Mata Atlântica) e floresta ombrófila mista (ou Mata de Araucária). O uso do solo na região passou por grandes transformações ao longo dos ciclos econômicos do País, o que ocasionou um grande desmatamento.

Essa região hidrográfica possui a maior demanda por recursos hídricos do País, equivalente a $736 \mathrm{~m}^{3} / \mathrm{s}$, que corresponde a $31,0 \%$ da demanda nacional. A irrigação é a maior usuária de recursos hídricos (42,0\% da demanda total), seguida do abastecimento industrial $(27,0 \%)$.

Com relação ao saneamento, de acordo com o Censo Demográfico 2010, os percentuais da população atendida com abastecimento de água variavam de 90,0\% (Paranaíba) a 98,0\% (Grande). A maioria das unidades hidrográficas está com um percentual acima da média do Brasil que era de $91,0 \%$. O percentual da população atendida com rede coletora de esgotos nas unidades hidrográficas variavam entre 38,0\% (Piriqui) e 96\% (Grande). Os percentuais de tratamento de esgotos variavam de 33,0\% (Piriqui) e 97,0\% (Paranapanema), enquanto a média nacional era de 30,0\%. 


\section{Região Hidrográfica Atlântico Sul}

A Região Hidrográfica Atlântico Sul destaca-se por abrigar um expressivo contingente populacional, pelo desenvolvimento econômico e por sua importância para o turismo. A região se inicia ao norte, próximo à divisa dos Estados de São Paulo e Paraná e se estende até o Arroio Chuí, ao sul. Possui uma área total de 187522 km², o equivalente a 2,2\% do País.

Abrangendo porções dos Estados do Paraná, Santa Catarina e Rio Grande do Sul, a região tinha, em 2013, 13574899 habitantes (6,75\% da população nacional), sendo que 88,0\% em área urbana (ESTIMATIVAS..., 2013). Ela abriga 451 municípios e 411 sedes municipais, entre os quais destacam-se, no contexto socioeconômico: Paranaguá, no Estado do Paraná; Joinville e Florianópolis, no Estado de Santa Catarina; e Caxias do Sul, Santa Maria, Pelotas e a Região Metropolitana de Porto Alegre, no Estado do Rio Grande do Sul. A população da região está concentrada, principalmente, nas Unidades Hidrográficas Litoral de Santa Catarina e Guaíba.

Em 2010, os dados de saneamento mostravam que 91,0\% da população era abastecida por água, valor equivalente à média nacional. As unidades hidrográficas da região apresentavam índices de atendimento da população por esgoto que variavam entre $37,0 \% \mathrm{e}$ $70,0 \%$. O nível de esgoto tratado era baixo, apresentando valores entre 10,0 e 19,0\% (CENSO DEMOGRÁFICO 2010, 2011).

Sob intensa e histórica ação antrópica, a Mata Atlântica, vegetação original predominante nesta região hidrográfica, estendia-se desde o Estado de São Paulo até o norte do Estado do Rio Grande do Sul.

\section{Região Hidrográfica do Uruguai}

A Região Hidrográfica do Uruguai tem importância para o País em função das atividades agroindustriais desenvolvidas e de seu potencial hidrelétrico. O Rio Uruguai possui 2200 km de extensão e se origina da confluência dos Rios Pelotas e Canoas. Nesse trecho, o rio assume a direção leste-oeste, dividindo os Estados do Rio Grande do Sul e Santa Catarina. A bacia hidrográfica totaliza, em território brasileiro, $174533 \mathrm{~km}^{2}$ de área, o equivalente a 2,0\% do Território Nacional.

Em função das suas características hidrológicas e dos principais rios formadores, a área foi dividida em 13 unidades hidrográficas, sendo quatro no Estado de Santa Catarina e nove no Estado do Rio Grande do Sul. Em 2013, 4136331 pessoas viviam na parte brasileira da Região Hidrográfica do Uruguai (2,1\% da população do País), com maior concentração nas Unidades Hidrográficas de Chapecó, Canoas, Ibicuí e Turvo.

Na região existem atualmente 384 municípios, dos quais merecem destaque Lages e Chapecó, no Estado de Santa Catarina; Erechim, ljuí, Uruguaiana, Santana do Livramento e Bagé, no Estado do Rio Grande do Sul.

Os números do saneamento básico (CENSO DEMOGRÁFICO 2010, 2011) são também importantes para a caracterização da Região. Em relação à parcela de população abastecida 
de água, com exceção das Unidades Hidrográficas Ijuí, Quaraí, Santa Maria e Negro, todas as demais apresentavam, em 2010, valores abaixo da média nacional (91,0\%). O valor médio de atendimento pela rede de esgoto na região é de 33,0\%. A porcentagem de esgoto tratado nas unidades hidrográficas era muito baixa, com média de 10,0\%, inferior, portanto, à média brasileira (30,0\%).

Em relação à vegetação, a bacia apresentava, originalmente, nas nascentes do rio Uruguai, estepes (ou campos) e floresta ombrófila mista (mata com Araucária) e, na direção sudoeste, as estepes e floresta estacional decidual (Mata do Alto Uruguai e Mata Atlântica). Segundo a ANA, atualmente, a região encontra-se intensamente desmatada e apenas regiões restritas conservam remanescentes da vegetação original (CONJUNTURA..., 2013).

\section{Regiões hidrográficas no contexto dos biomas brasileiros}

Outra forma de contextualizar os recursos hídricos no Território Nacional diz respeito à leitura conjugada de duas regiões naturais que, de modo muito particular, têm nos recursos hídricos um atributo essencial na definição/delimitação de suas fronteiras: a divisão regional do Brasil em biomas e em regiões hidrográficas.

Com efeito, por um lado, o bioma, de acordo com o IBGE, é um conjunto de vida (vegetal e animal) constituído pelo agrupamento de tipos de vegetação contíguos e identificáveis em escala regional (Tabela 3/Mapa5), com condições geoclimáticas similares e história compartilhada de mudanças, o que resulta em uma diversidade biológica própria (MAPA..., 2004b).

Por outro lado, a disponibilidade de água é uma das condições determinantes para o desenvolvimento e predominância de tipos específicos de vegetação e da biodiversidade como um todo, sendo, portanto, pertinente avaliar essa disponibilidade nos diversos biomas que ocorrem no Brasil (Mapa 5).

Tabela 3 - Área aproximada dos biomas, total e percentual em relação ao Território Nacional 2004

\begin{tabular}{|c|c|c|}
\hline \multirow{2}{*}{ Biomas continentais } & \multicolumn{2}{|c|}{ Área aproximada dos biomas } \\
\hline & Total $\left(\mathrm{km}^{2}\right)$ & Percentual (\%) \\
\hline Total & 8514877 & 100,00 \\
\hline Amazônia & 4196943 & 49,29 \\
\hline Cerrado & 2036448 & 23,92 \\
\hline Mata Atlântica & 1110182 & 13,04 \\
\hline Caatinga & 844453 & 9,92 \\
\hline Pampa & 176496 & 2,07 \\
\hline Pantanal & 150355 & 1,76 \\
\hline
\end{tabular}

Fonte: Mapa de biomas e de vegetação. Rio de Janeiro: IBGE, 2004. Disponível em: <http://www.ibge.gov.br/home/presidencia/ noticias/21052004biomashtml.shtm>. Acesso em: maio 2016. 
Mapa 5 - Biomas e regiões hidrográficas - 2004

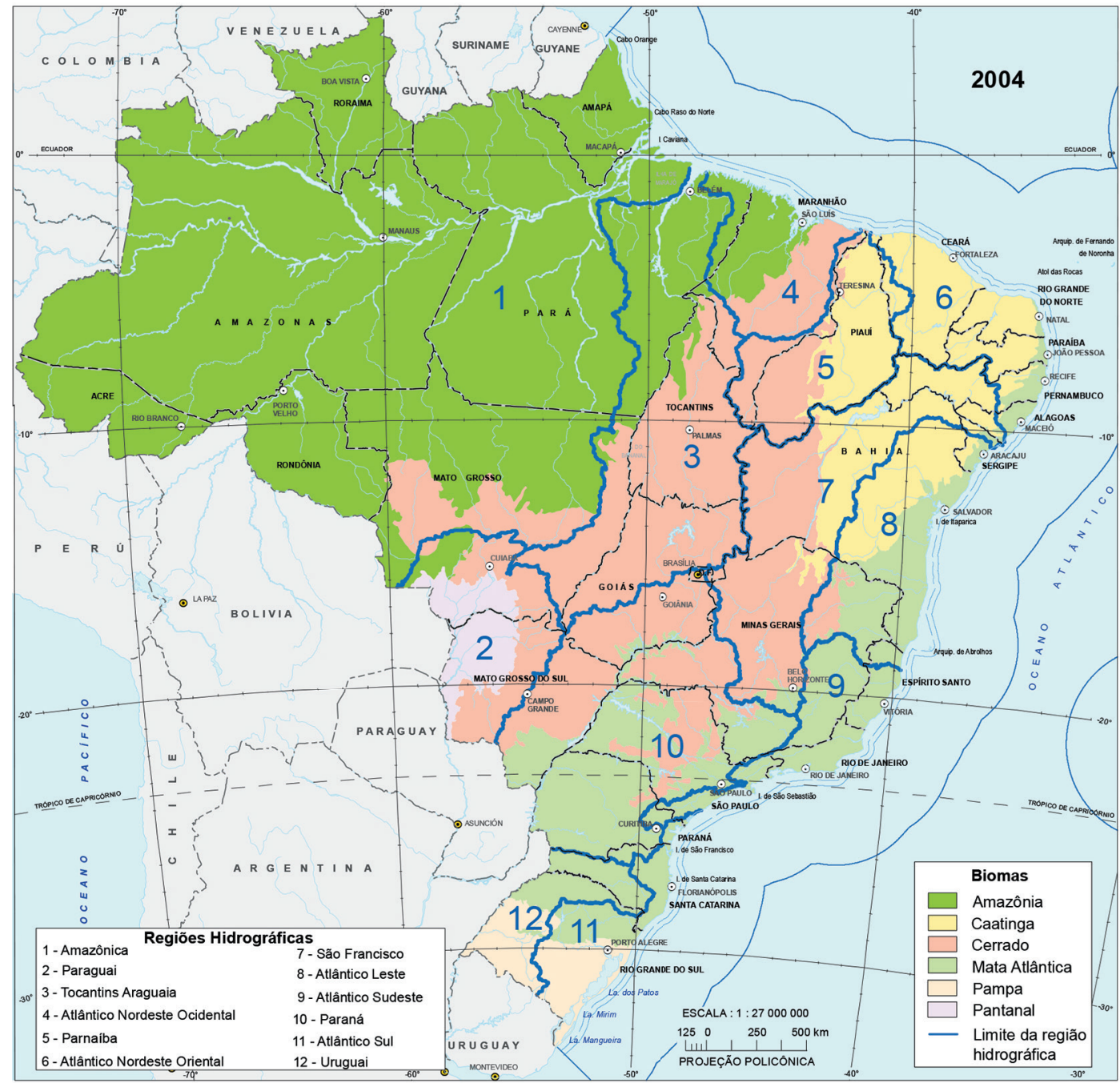

Fontes: 1. Mapa de biomas do Brasil: primeira aproximação. Rio de Janeiro: IBGE, 2004. Escala 1:5 000 000. 2. Conselho Nacional de Recursos Hídricos (Brasil). Resolução n. 32, de 15 de outubro de 2003. Brasília, DF, 2003. Disponível em: <http://www. cnrh.gov.br/index.php?option=com_content\&view=article\&id=14>. Acesso em: maio 2016. 


\section{Regiões hidrográficas e biomas brasileiros}

Amazônia: A Amazônia é o bioma brasileiro de maior extensão superficial, possuindo um território de 4196943 milhões de km² (MAPA..., 2004a) que corresponde a 1/3 das florestas tropicais do mundo. Esse bioma ocupa a porção norte do território brasileiro, abrangendo os Estados do Acre, Amapá, Amazonas, Pará, Rondônia, Roraima e ainda uma porção dos Estados do Maranhão, Tocantins e Mato Grosso.

A relação com a disponibilidade hídrica é evidente, uma vez que seus rios representam cerca de 20,0\% das reservas de água doce do planeta, estabelecendo-se, por conseguinte, uma dependência entre os seus diversos ecossistemas e a presença de um grande volume de água que compreende, além da floresta úmida de terra firme, diferentes tipos de matas, campos abertos e até espécies de cerrado.

A Bacia Amazônica é a maior bacia hidrográfica do mundo: cobre cerca de 6 milhões de km² e tem 1100 afluentes. Seu principal rio, o Amazonas, corta a região para desaguar no Oceano Atlântico, lançando ao mar cerca de 175 milhões de litros d'água a cada segundo (BIOMAS, 2015).

A função ecológica de uma floresta do porte da Floresta Amazônica está intimamente relacionada com o clima e ao ciclo hidrológico, tendo em vista a regulação climática de todo nosso planeta, seja por meio da retenção de carbono atmosférico, seja por meio da evapotranspiração e dispersão de chuvas para todo o continente sul-americano. A floresta acompanha em grande medida os principais rios da Bacia do Amazonas, desde o sopé dos Andes até o Atlântico.

Caatinga: A Caatinga é o bioma predominante na Região Nordeste do Brasil e o mais árido de todos. Com uma superfície de 844453 km², ele cobre cerca de 10,0\% do Território Nacional e ocorre no interior da Região Nordeste, desde o Estado da Bahia até o Estado do Maranhão. Sua vegetação típica é seca e espinhosa por causa da falta de chuvas durante grande parte do ano. Porém, quando chega o período de chuvas, as folhagens voltam a brotar e a paisagem fica mais verde.

No contexto da disponibilidade de água através da precipitação, destaca-se a questão do déficit hídrico na maior parte da área abrangida pelo bioma. O clima na região varia do superúmido (com pluviosidade em torno de 2000 mm/ano), num pequeno trecho, até o semiárido, em área maior, com pluviosidade entre 300-500 mm/ano e chuvas restritas a poucos meses durante o ano. As plantas desenvolveram adaptações únicas para enfrentar a aridez. Na estação seca, caem as folhas da maioria das árvores e os troncos aparecem esbranquiçados (PRADO, 2003 apud MONITORAMENTO..., 2011a). A paisagem reflete essa aridez, dominada por uma vegetação arbustiva, ramificada e espinhosa, com muitas bromeliáceas, euforbiáceas e cactáceas (COIMBRA FILHO; CÂMARA, 1996 apud MONITORAMENTO..., 2011a). As florestas mais úmidas, chamadas brejos de altitude, estendem-se sobre as encostas e topos das chapadas e serras com mais de $500 \mathrm{~m}$ de altitude, que recebem mais de $1200 \mathrm{~mm}$ de chuvas (ANDRADE LIMA, 1982; PRADO, 2003 apud MONITORAMENTO..., 2011a). 
O aumento da altitude é um dos fatores que controla a quantidade de chuva e modifica a paisagem geral do bioma: as serras variam de $1000 \mathrm{~mm}$ a $2000 \mathrm{~mm}$ e as chuvas chegam a 1500 mm/ano, o que é de suma importância para a vegetação e a fauna e para a exploração humana dos recursos naturais. Cortada por dois grandes rios caudalosos e perenes (os Rios Parnaíba e São Francisco) e por outros rios menores e em grande parte temporários, muito da água usada pelas pessoas que habitam a Caatinga vem de açudes. Isso é importante especialmente porque ali chove menos de 600 milímetros $(\mathrm{mm})$ anuais, em geral, nos meses iniciais do ano.

Pantanal: O Pantanal é a ligação entre o Cerrado (na Região Centro-Oeste), o Chaco (na Bolívia) e a Região Amazônica (na Região Norte do País). Segundo o Ministério do Meio Ambiente, o Bioma Pantanal é considerado uma das maiores extensões úmidas contínuas do planeta e sofre influência direta de três importantes biomas brasileiros: Amazônia, Cerrado e Mata Atlântica (BIOMAS, 2015). Como é uma área de transição, a região é formada por uma variedade de ecossistemas que são periodicamente inundados, apresentando, por isso, fauna bastante diversificada. Segundo Alho (2005 apud MONITORAMENTO..., 2011d), as influências dos outros biomas propiciam as diferenças climáticas, o que ocasiona diversas características dos rios e solos, formando diferentes sub-regiões ou tipos de pantanais.

O Bioma Pantanal constitui a maior área continental periodicamente alagável do planeta. Ele possui $150355 \mathrm{~km}^{2}$ e se entende não somente pelo Território Nacional, mas também pela Bolívia e Paraguai. O Pantanal é um imenso reservatório de água, constituindo passagem obrigatória de grande parte do fluxo que percorre a Bacia do Prata.

O lento ciclo das cheias e vazantes, conhecido como pulso de inundação, cria um variado mosaico de paisagens. As baías, denominadas as lagoas pantaneiras, são os elementos mais peculiares da região. Elas compõem a paisagem com rios tortuosos, campos alagáveis, matas ciliares, capões de matas, salinas e corixos (nome regional para os riachos da planície) formando os diferentes habitats pantaneiros. Toda essa variedade de ambientes dominada pela água sustenta uma diversa fauna de peixes de pequeno a grande porte, aves e mamíferos.

O clima do Pantanal é predominantemente tropical continental marcado pelas altas temperaturas e grande índice pluviométrico, um verão quente e chuvoso e um inverno frio e seco. Dessa maneira, na época das chuvas, ou seja, no verão, o Pantanal fica praticamente intransitável por terra; enquanto no período da seca, no inverno, os rios secam e sobra o barro, daí seu nome "Pantanal".

Todos os habitantes do Pantanal têm suas vidas marcadas pelo eterno ciclo das águas, desde o dourado, um peixe de escamas, até o ribeirinho. O início do período chuvoso ocorre, geralmente, de outubro a março com precipitação média de $1200 \mathrm{~mm}$ a $1400 \mathrm{~mm}$ e a estação de seca, entre abril e setembro. O ciclo hidrológico e a dinâmica hídrica do bioma são condicionantes importantes que garantem a alta biodiversidade e possibilitam o funcionamento ecológico de toda região (IMPLEMENTAÇÃO..., 2004 apud MONITORAMENTO..., 2011d). As planícies de inundação constituem terras planas que são inundadas quando o escoamento superficial excede a capacidade normal do canal (BARELLA et al., 2001 apud MONITORAMENTO..., 2011d). 
O Pantanal é cercado por uma série de serras. É isso que o torna um reservatório de água a temperaturas quentes, uma concentração de vida. No entanto, toda essa água chega ao Pantanal depois de transitar desde nascentes por toda a sua volta, ou seja, a inundação do Pantanal depende das águas que são trazidas das cabeceiras dos rios do planalto. $\mathrm{O}$ escoamento, ao deixar o planalto, é de largura estreita, portanto, o fluxo extravasa o leito, inundando a planície e preenchendo as depressões na qual formam baías e lagoas (ALHO, 2003 apud MONITORAMENTO..., 2011d).

A expansão desordenada das atividades agropecuárias na região do Pantanal tem contribuído para a degradação dos ambientes naturais (com perda de biodiversidade), para intensificação da erosão laminar e do assoreamento e para contaminação dos rios com biocidas (SANTOS, 2006 apud MONITORAMENTO...,, 2011d). Os desequilíbrios acarretam prejuízos para a exploração agropecuária, para setores socioeconômicos e principalmente para o meio ambiente (GALDINO; VIEIRA; SORIANO, 2003 apud MONITORAMENTO..., 2011d).

São também consideradas ameaças à conservação dos ecossistemas e processos ecológicos no Pantanal os projetos de infraestrutura (hidrelétricas, hidrovias, mineradoras), a caça, a invasão de espécies exóticas e a poluição resultante do uso de pesticidas nas áreas agrícolas localizadas nas cabeceiras dos principais rios que drenam a planície (ALHO et al., 1988 apud MONITORAMENTO..., 2011d), o que causa, dentre outras consequências, o assoreamento e a mudança da trajetória dos corpos d'água, descaracterização da paisagem e a contaminação das bacias.

Cerrado: O Cerrado é considerado o segundo maior bioma brasileiro em extensão, distribuindo-se por todo o Brasil Central, com uma área original de $2036448 \mathrm{~km}^{2}$, aproximadamente 20,0\% do território do País. Localizando-se principalmente no Planalto Central brasileiro, é um ecossistema similar às Savanas de outros continentes, abrangendo os seguintes Estados: Amapá, Maranhão, Piauí, Rondônia, Distrito Federal, Goiás, Mato Grosso, Mato Grosso do Sul, Minas Gerais, São Paulo, Tocantins e Bahia.

A relação entre a disponibilidade hídrica e o ciclo de vida de sua vegetação é bastante estreita, uma vez que, durante seis meses, o Cerrado torna-se verdejante devido às frequentes chuvas que vão de outubro a abril. Nos meses restantes, torna-se pronunciadamente seco e susceptível a queimadas, às vezes espontâneas.

Segundo a classificação climática adotada no Brasil, o clima do Bioma Cerrado é o tropical sazonal de inverno seco com temperatura média anual em torno de $22-23^{\circ} \mathrm{C}$. A precipitação medial anual varia entre $1200 \mathrm{~mm}$ a $1800 \mathrm{~mm}$. Entre maio e setembro, os índices pluviométricos reduzem-se e a umidade relativa do ar fica entre 10,0 a 30,0\%, podendo haver secas prolongadas (MONITORAMENTO...,, 2011b).

No Cerrado, encontram-se as nascentes das três maiores bacias hidrográficas da América do Sul (Amazônica/Tocantins, São Francisco e Prata), o que resulta em um elevado potencial aquífero e favorece a biodiversidade da região (BIOMAS, 2015).

Segundo o Ministério do Meio Ambiente, depois da Mata Atlântica, o Cerrado é o bioma brasileiro que mais sofreu alterações com a ocupação humana (MONITORAMENTO..., 2011b). A pressão sobre a biodiversidade e sobre os recursos hídricos estão ligadas à mudança 
de cobertura e uso da terra devido à crescente pressão para incrementar a produção de carne e grãos, voltados principalmente aos mercados externos, o que acarreta um progressivo esgotamento dos recursos naturais da região, entre eles a água. Nas três últimas, décadas esse processo tem caracterizado o Cerrado como palco da expansão da fronteira agrícola brasileira.

Mata Atlântica: Cerca de 70,0\% da população brasileira concentra-se na Mata Atlântica, que abrange 15 estados brasileiros das Regiões Sul, Sudeste, Centro-Oeste e Nordeste. (LEVANTAMENTO..., 2007 apud MONITORAMENTO..., 2012).

Segundo o Ministério do Meio Ambiente, a Mata Atlântica constitui o bioma brasileiro com menor porcentagem de cobertura vegetal natural, possuindo, no entanto, uma relevante parte da diversidade biológica do País com várias espécies endêmicas (MONITORAMENTO..., 2012). A porcentagem de $7,0 \%$ restante da cobertura florestal original $\left(1200000 \mathrm{~km}^{2}\right.$ de floresta de grande porte) é um fato agravado porque os recursos hídricos (rios) abastecem mais de 120 milhões de brasileiros, com remanescentes que regulam o fluxo dos mananciais hídricos, asseguram a fertilidade do solo, controlam o clima e protegem escarpas e encostas das serras (LEVANTAMENTO..., 2007 apud MONITORAMENTO..., 2012).

Sua ocupação histórica remonta aos principais ciclos econômicos que levaram a uma intensa perda desse bioma.

Seu relevo é acidentado e o solo raso, frequentemente ocorrendo o afloramento das rochas. Uma floresta tão exuberante é sustentada pela alta umidade trazida do oceano e deixada na Serra do Mar.

A disponibilidade hídrica varia também em função das grandes variações de altitude e latitude. A Mata Atlântica se expressa em diferentes formações vegetais e paisagens: floresta ombrófila densa, restingas, manguezais, campos de altitude naturais, refúgios vegetacionais, áreas de várzea e dunas. A floresta ombrófila densa, por exemplo, luxuriante e biodiversa formação florística existente próxima ao mar, se desenvolve em toda sua plenitude nas áreas mais úmidas. Mais para o interior do País, a floresta apresenta formações que perdem parcialmente as folhas no período de seca, a Mata Atlântica de planalto.

Pampas: De maneira genérica, os campos da Região Sul do País são chamados de "Pampas", denominação que corresponde somente aos tipos de campo encontrados num único Estado: o Rio Grande do Sul (63,0\%), estendendo-se também pelo Uruguai e Argentina. Em outras partes da região, encontram-se as matas de araucárias e, também, campos semelhantes à savana. Segundo o Ministério do Meio Ambiente, a vegetação torna-se mais densa próxima aos cursos d'água e nas encostas de planaltos (MONITORAMENTO..., 2011c). A precipitação anual fica em torno de 1200 mm, com pouca variação sazonal. A pecuária é a principal atividade econômica da região devido à fertilidade do solo (outras atividades impactantes são as lavouras de arroz em áreas de banhado e o plantio de eucalipto). No entanto, há também a ocorrência de solos arenosos na região do Município de Alegrete, o que inspira maiores cuidados em seu manejo para que não haja desertificação. 
A disponibilidade hídrica é alta, tendo em vista que a Região Sul do Brasil, onde este bioma se localiza, caracteriza-se pela abundância e boa distribuição das chuvas. Os processos de degradação das terras e desertificação que ocorrem estão assim muito mais ligados a fatores de manejo do que ao déficit hídrico.

No litoral, o Banhado do Taim e as lagoas costeiras (como a Lagoa dos Patos) formam ambientes salobros, únicos no País. Esses banhados e lagoas abrigam espécies endêmicas e populações expressivas de aves aquáticas.

O relevo apresenta topos mais planos, vegetação rala e pobre em espécies, que se torna mais densa e rica nas encostas, com predominância de gramíneas e leguminosas. Segundo o Ministério do Meio Ambiente, o bioma exibe um imenso patrimônio cultural associado à biodiversidade. Em sua paisagem predominam os campos, entremeados por capões de mata, matas ciliares e banhados (BIOMAS, 2015).

Os Pampas, ou campos sulinos, estão adaptados ao clima mais frio do Brasil, com temperaturas eventuais abaixo de zero, geadas e até neve. Estimam-se o número das espécies vegetais em 3 000, das quais nada menos que 400 de gramíneas.

A análise da geografia dos recursos hídricos no Brasil não se esgota, contudo, na leitura conjugada das 12 regiões hidrográficas e dos seis biomas coexistentes no território brasileiro. Ao contrário, ela se completa e se complexifica quando se leva em conta um novo recorte regional do País agora focado na distribuição espacial das águas subterrâneas.

\section{Recursos hídricos subterrâneos do Brasil}

Da mesma forma que os recursos hídricos superficiais, os recursos hídricos subterrâneos são imprescindíveis ao atendimento das necessidades do País. A Hidrogeologia é o ramo da Geologia que estuda as águas subterrâneas, ou seja, tem como foco a parcela do ciclo hidrológico que se infiltra no solo e percola em subsuperfície, formando os aquíferos (unidades geológicas capazes de armazenar e produzir águas subterrâneas).

Águas subterrâneas abastecem nascentes, rios, pântanos e lagoas. Por isso, mesmo na época seca, a maioria dos nossos rios é perene. Os aquíferos têm importância estratégica e suas funções são ainda pouco exploradas seja no campo da produção, armazenamento, circulação, regularização, filtragem e autodepuração, além daquelas no campo do abastecimento e manutenção dos ecossistemas aquáticos.

A conjugação de fatores geológicos (litologia, estratigrafia, estrutura e tectônica), geomorfológicos e climáticos serve como parâmetro para definir regiões onde os sistemas aquíferos apresentam condições hidrogeológicas semelhantes (armazenamento, circulação, descarga e qualidade química das águas). Essas grandes regiões são denominadas províncias hidrogeológicas (Mapa 6). 


\section{Mapa 6 - Águas subterrâneas nas províncias hidrogeológicas}

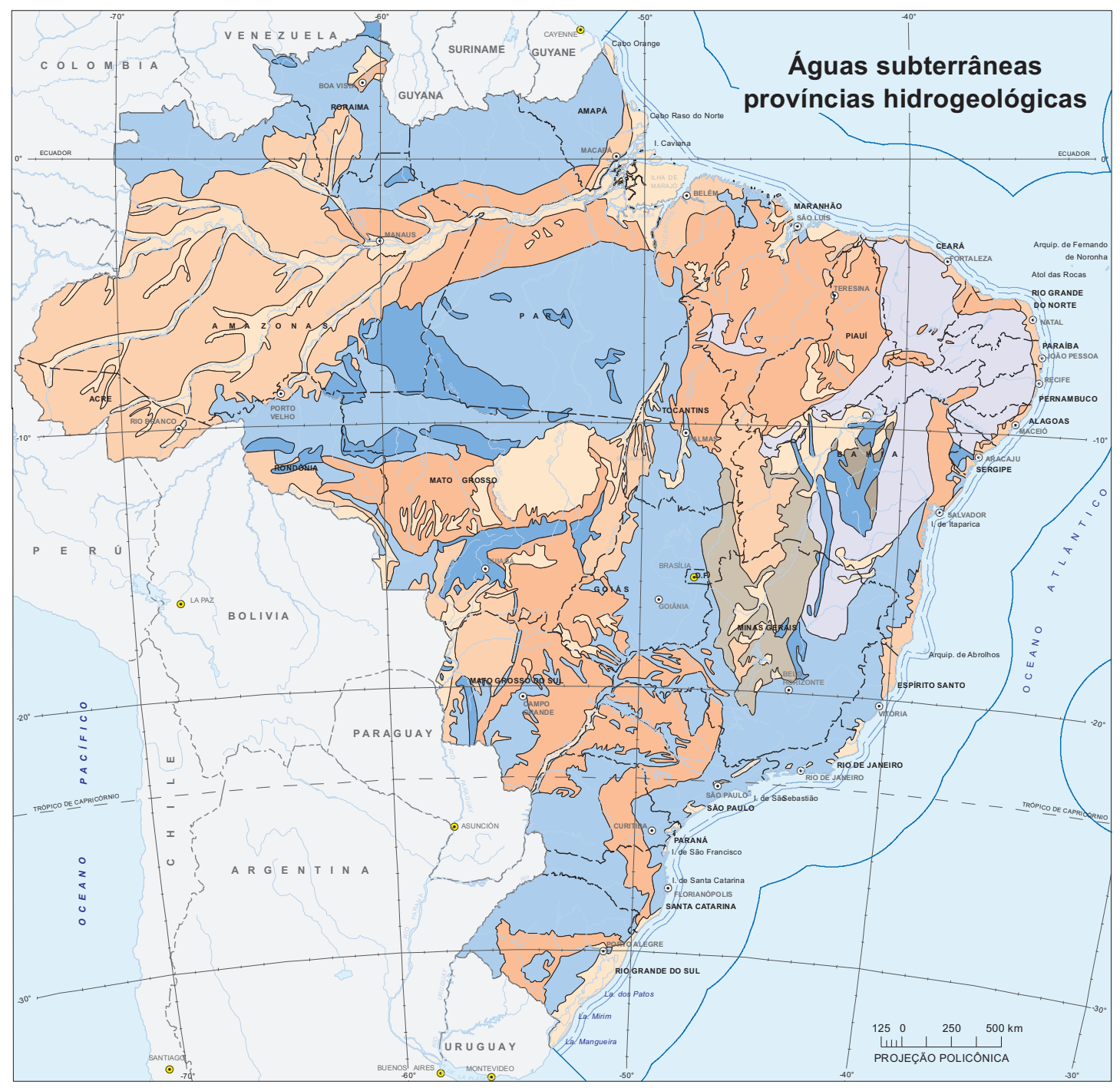

Província intergranular

Aquiferos contínuos, de extensão regional. constituídos por sedimentos clásticos. Reune litologias e estruturas altamente favoráveis à acumulação de abundantes recursos hídricos, em condiçōes livres e artesianas. Exploração por poços profundos. Qualidade química das águas geralmente boa. Importância hidrogeológica relativa, grande.

Aquíferos contínuos, de extensão variável. livres e/ou semi-confinados, constituídos por sedimentos clásticos pouco consolidados. Permeabilidade fraca a média. Qualidade química das águas geralmente boa. Importância hidrogeológica relativa, média.

Aquíferos livres, de extensão restrita e espessuras reduzidas, constituídos por sedimentos clásticos não consolidados. Permeabilidade média. Exploração por poços rasos. Qualidade química das águas geralmente boa. Importância hidrogeológica relativa, pequena.

\section{Província fissural}

Aquiferos locais, fraturados e/ou com certa porosidade intersticial. Formados por rochas metaclásticas (metarenitos, quartzitos, etc.). Permeabilidade média. Qualidade química das águas geralmente boa. Importância hidrogeológica relativa, média.

Aquíferos locais, em rochas cristalinas (ígneas e matamórficas),com circulação hídrica subterrânea restrita aos sistemas de fraturamento. Recarga (pluviometria) regular a elevada. Qualidade química das águas boa a ligeiramente salina. Importância hidrogeológica relativa pequena a média.

Aquiferos locais, livres, em rochas cristalinas (igneas e matamórficas), com circulação hídrica subterrânea restrita às zonas fraturadas. Recarga (pluviometria) irregular e reduzida. Águas em geral salinizadas. Poços com baixa produtividade. Importância hidrogeológica relativa pequena a muito pequena.

\section{Província cárstica}

Aquiferos locais, francamente carsticos, formados por rochas carbonáticas. As zonas fraturadas foram ampliadas pela dissolução cársticas, dando origem a cavernas, dolinas e rios subterrâneos. Aguas geralmente duras (alto teor de Caco3). Importancia hidrogeologica relaliva, média.

rais. Constituídos por rochas carbonáticas e metapelíticas. Permeabilidade baixa a mélia Águas ligeiramente salinas. Importância hidrogeológica relativa, pequena.

Fontes: 1. Ministério de Minas e Energia, Departamento Nacional de Produção Mineral - DNPM. 2. IBGE, Diretoria de Geociências, Coordenação de Recursos Naturais e Estudos Ambientais. Extraído de: Atlas nacional do Brasil Milton Santos. Rio de Janeiro: IBGE, 2010. Disponível em: <http://biblioteca.ibge.gov. br/index.php/biblioteca-catalogo?v iew $=$ detalhes\&id $=247603>$. Acesso em jun. 2016. 
No território brasileiro, as águas subterrâneas estão abrigadas em diferentes tipos de reservatórios, que vão desde as zonas fraturadas do embasamento cristalino até os depósitos sedimentares mais recentes. Esses sistemas aquíferos podem ser agrupados em três grandes províncias hidrogeológicas: intergranular (porosa), fissural e cárstica.

\section{Províncias hidrogeológicas do Brasil}

A Província Intergranular ou Porosa é formada por rochas sedimentares e ocupa cerca de 48,0\% da área total do País, compreendendo vários sistemas aquíferos, como: Amazonas (Alter do Chão, Solimões e Boa Vista), Parecis, Paraná (Guarani, Bauru, Tubarão, Ponta Grossa e Furnas), Parnaíba (Serra Grande, Cabeças, Poti-Piauí, Motuca, Corda e Itapecuru), Recôncavo-Tucano-Jatobá (Marizal, São Sebastião, Tacaratu e Sergi), Potiguar (Açu-Jandaíra), Paraíba-Pernambuco (Beberibe), Araripe (Missão Velha), Sergipe-Alagoas, (Marituba), São Francisco (Urucuia-Areado), São Luís-Barreirinhas, São Paulo e Taubaté, além do Grupo Barreiras e Coberturas Cenozóicas.

A Província Fissural ocupa pouco mais de 50,0\% do território brasileiro, sendo constituída por uma associação de rochas ígneas, metavulcanossedimentares e vulcânicas (granitos, gnaisses, granodioritos, migmatitos, anfibolitos, xistos, basaltos, diabásios, etc). Caracteriza-se pelo modo peculiar de circulação de suas águas - através de fraturas. Podem ser também incluídas, nessa província, as rochas metassedimentares (metarenitos, metassiltitos, quatzitos), que apesar de apresentarem características de aquífero misto (poroso-fissural), comportam-se muito mais como um aquífero do tipo fissural. São dignas de registro as ocorrências de rochas metassedimentares nos Estados de Minas Gerais, Bahia e Sergipe (Supergrupo Espinhaço e Faixa de Dobramentos Sergipana).

O fato de os aquíferos fissurais possuírem pontos de recarga e vias de circulação restritos às fraturas torna-os pouco produtivos, especialmente na Região Nordeste, onde a recarga é deficiente em função dos índices pluviométricos reduzidos. Este fato repercute na grande incidência de poços secos ou com vazões reduzidas, em geral produzindo águas salinas; influencia também o caráter intermitente de boa parte da rede de drenagem, devido à reduzida parcela destinada à restituição subterrânea. Já na Região Sul, por exemplo, os basaltos da formação Serra Geral constituem aquíferos importantes regionais e são largamente explorados.

A Província Cárstica compreende os depósitos desenvolvidos em rochas de natureza carbonática (calcários), onde os condutos aquíferos (fraturas) foram ampliados pela dissolução cárstica (fenômeno provocado pelas águas das chuvas e dos rios em regiões calcárias), dando origem a cavernas, sumidouros, dolinas e outras feições erosivas características. Aquíferos dessa natureza ocorrem com destaque nos Estados da Bahia, Minas Gerais, Goiás e Rio Grande do Norte.

A qualidade da água subterrânea em algumas regiões hidrográficas reveste-se de suma importância, particularmente em situações de clima semiárido onde a disponibilidade de águas superficiais é limitada e sujeita a grande variabilidade sazonal. 
O detalhamento de aspectos da hidrogeologia da Região Nordeste é apresentado em seguida por ser tal informação crucial nessa região do País, tanto para o abastecimento da população quanto para o desenvolvimento das atividades nos diversos setores de sua economia.

\section{Hidrogeologia da Região Nordeste}

Os nove estados que compõem a Região Nordeste do Brasil somam uma área de 1554257 km², dos quais cerca de 60\% correspondem ao Polígono das Secas - região onde predominam condições climáticas semiáridas, que se manifestam através da ocorrência de precipitações pluviométricas escassas e irregulares e extensos períodos anuais de forte insolação e evaporação, responsáveis por uma acentuada deficiência hídrica.

Nesta região é bastante comum a ocorrência de secas - muitas delas calamitosas -, cujas consequências determinam repetidos danos à agricultura e à pecuária, desencadeando problemas sociais e econômicos. Essas dificuldades naturais reforçam a importância de se conhecer as principais características dos reservatórios subterrâneos e a qualidade das águas da região.

Especificamente no que tange à abrangência do Polígono das Secas, temos grande parte da Região Hidrográfica do Parnaíba e parcelas significativas da Regiões Hidrográficas Atlântico Nordeste Oriental e São Francisco, estendendo-se também para algumas áreas da Atlântico Nordeste Ocidental e Atlântico Leste.

Considerando que boa parte da Região Nordeste está submetida ao clima semiárido, os recursos hídricos subterrâneos avultam em importância, sobretudo por representarem um manancial naturalmente protegido dos efeitos da estiagem e da poluição, que armazenam expressivos volumes de água. Podem ser citados, como exemplos, as Bacias Sedimentares do Parnaíba, Recôncavo-Tucano-Jatobá, Potiguar, Araripe, Sergipe-Alagoas, Pernambuco-Paraíba, além do Grupo Barreiras e outras ocorrências sedimentares de menor expressão.

Algumas capitais nordestinas como Natal, São Luís, Teresina, Recife, Aracaju e Maceió são abastecidas parcialmente por poços tubulares, que exploram aquíferos de natureza sedimentar (porosos); na zona rural, muitas vezes são a única fonte que subsiste aos rigores da seca. Em contrapartida, cerca de mais de $55,0 \%$ das rochas que formam o arcabouço geológico da Região Nordeste são de natureza cristalina (granitos, gnaisses, quartzitos, migmatitos). Nelas, a circulação das águas subterrâneas só é possível através das fraturas, o que resulta em reservatórios pouco promissores, com reservas limitadas e, sobretudo, com águas geralmente salinas, conforme demonstram os mapas apresentados.

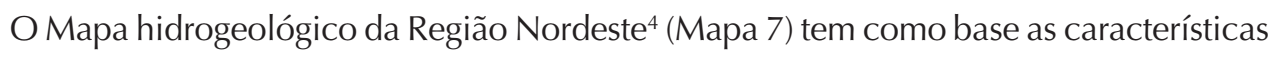
hidrogeológicas das diferentes rochas que ocorrem nessa região e representa um conjunto de unidades geológicas com características hidrogeológicas similares.

\footnotetext{
4 Os dados de vazão foram obtidos de um cadastro de 54864 poços tubulares oriundos do Sistema de Informações de Águas Subterrâneas - SIAGAS desenvolvido pelo Serviço Geológico do Brasil - CPRM; da Superintendência do Desenvolvimento do Nordeste - Sudene; do Departamento Nacional de Obras Contra as Secas - Dnocs; da Companhia de Engenharia Rural da Bahia CERB; da Companhia de Desenvolvimento do Piauí - Comdepl; da Companhia de Desenvolvimento de Recursos Minerais da Paraíba - CDRM; da Companhia de Desenvolvimento Econômico de Sergipe - CoDIsE; da Fundação Cearense de Meteorologia e Recursos Hídricos - Funceme; da Companhia de Saneamento Ambiental do Maranhão - Caema; da Companhia de Águas e Esgotos do Rio Grande do Norte - Caern; Companhia de Água e Esgotos da Paraíba - Cagepa; e da Companhia de Saneamento de Alagoas - CaSAl.
} 


\section{Mapa 7 - Mapa hidrogeológico da Região Nordeste}

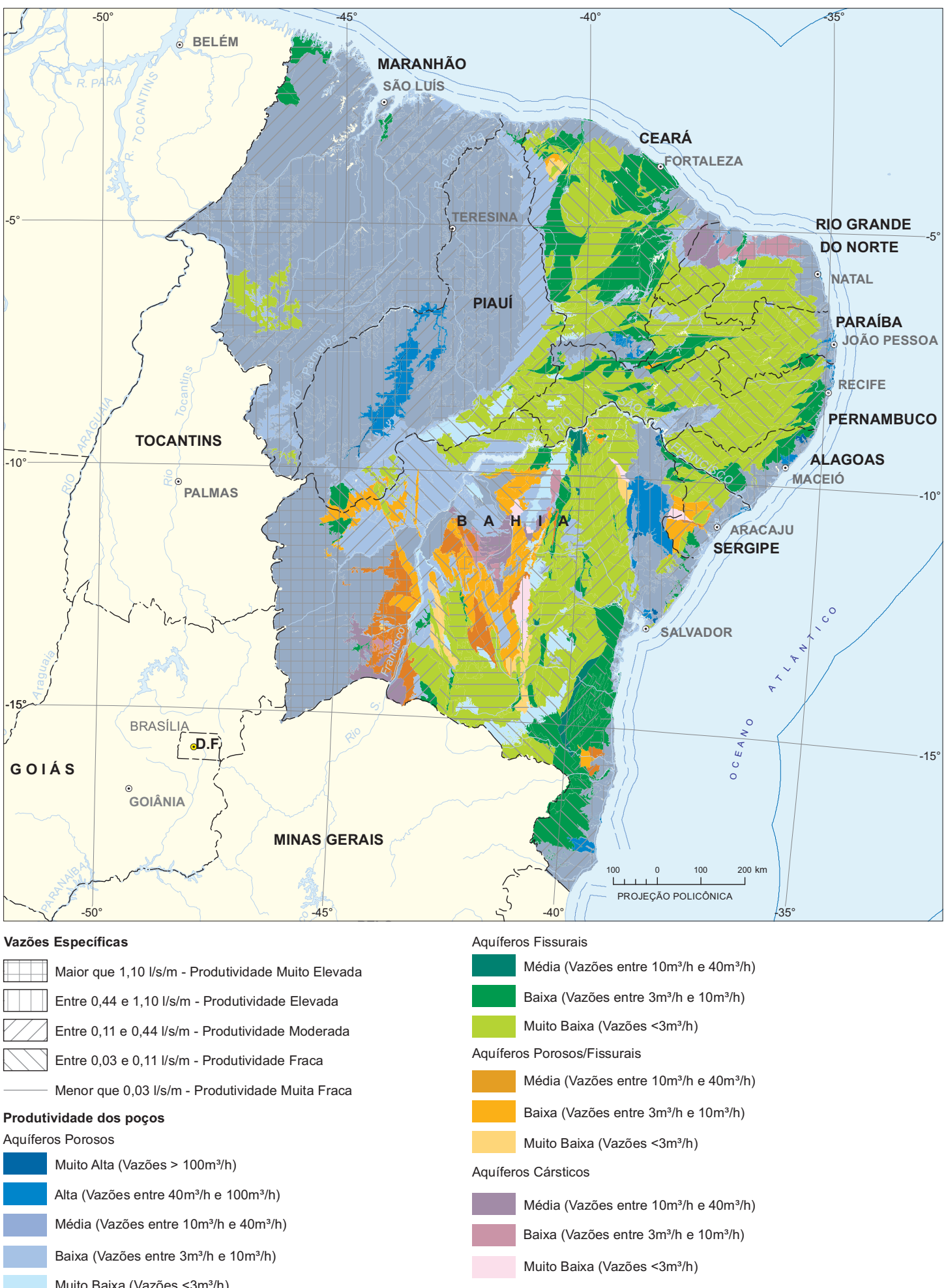

Fonte: Mapa hidrogeológico da região nordeste do Brasil. IBGE, 2013. Disponível em: <ftp://geoftp.ibge.gov.br/informacoes_ambientais/geologia/levantamento_hidrogeologico_e_hidroquimico/mapas/regionais/nordeste_hidrogeologico.pdf >. Acesso em jun. 2016. 
A vazão pode ser definida como a quantidade de litros d'água (ou de metros cúbicos) que pode ser extraída, por unidade de hora, de um determinado ponto de captação subterrânea (poço tubular). A média das vazões calculadas para um sistema aquífero serve como referência para estabelecer-se o potencial de exploração dos poços daquela unidade. Por exemplo, poços com vazões inferiores a $3 \mathrm{~m}^{3} / \mathrm{h}$ (considerada muito baixa) são bastante comuns entre os aquíferos fissurais e permitem atender apenas a pequenas demandas (fazendas e pequenos aglomerados), enquanto que poços com vazões superiores a $100 \mathrm{~m}^{3} / \mathrm{h}$ (encontrados com certa frequência em regiões onde ocorrem os aquíferos porosos) podem abastecer núcleos populacionais relativamente maiores. Enquanto que a vazão mede apenas o potencial médio dos pontos de captação (poço), a vazão específica vai um pouco mais além, permitindo uma avaliação regional e se refere, portanto, à produtividade do conjunto da unidade hidrogeológica.

A vazão específica é definida pela relação entre a vazão e o rebaixamento (que é a diferença que ocorre no nível da água do aquífero após o bombeamento), ou seja, para um mesmo valor de vazão, quanto menor for a variação sofrida pelo impacto do bombeamento, maior será a vazão e, portanto, maior a produtividade do aquífero. Isto significa dizer, que um aquífero cuja vazão específica é elevada (maior que 1,10 litro/segundo/metro) não sofre grandes perdas de volume durante o bombeamento, como é o caso, por exemplo, das grandes bacias sedimentares que ocorrem no Maranhão-Piauí (Bacia do Parnaíba), Bahia-Pernambuco (Bacia Recôncavo-Tucano-Jatobá) e Rio Grande do Norte (Bacia Potiguar), consideradas as maiores reservas de águas subterrâneas da Região Nordeste.

Os aquíferos porosos (geralmente desenvolvidos em rochas denominadas arenitos) detêm as maiores vazões da Região Nordeste. Isto se deve não só à estrutura desses depósitos - semelhantes a uma esponja -, como também devido às suas grandes extensões territoriais e ao grande espaço que dispõem para armazenar suas reservas em água subterrânea (em alguns casos, com mais de 3000 metros de espessura). Já os aquíferos fissurais apresentam espaços bastante limitados para armazenar suas reservas, haja vista que têm natureza impermeável (a exemplo dos granitos e gnaisses) e as fraturas, que são feições localizadas, constituem o único caminho para que as águas infiltradas a partir das chuvas (escassas e concentradas em poucos meses no ano) atinjam o manancial, de modo que a maior parte das precipitações pluviométricas tem como destino o escoamento superficial.

A deficiência na realimentação das reservas faz com que as vazões dos poços perfurados nos aquíferos fissurais da região sejam, em geral, reduzidas (menor que $3 \mathrm{~m}^{3} / \mathrm{h}$ ) e as águas geralmente salinizadas (salgadas e salobras), sendo bastante expressivo o número de poços secos e abandonados. Embora ocupando quase $60 \%$ do espaço nordestino, os aquíferos fissurais têm exploração limitada para fins de abastecimento humano, em função de tais características, e quase sempre utilizados para abastecimento animal.

Os aquíferos cársticos são pouco frequentes (Bahia e Rio Grande do Norte) e, em certa medida, se parecem com os aquíferos fissurais, diferenciando destes na forma dos condutos aquíferos, já que nestes as fraturas encontram-se ampliadas pela dissolução cárstica, dando origem a cavernas, depressões (dolinas) e rios subterrâneos. São importantes sobretudo na irrigação, com destaque para as regiões de Irecê, na Bahia e Mossoró, no Rio Grande do Norte, principalmente devido ao fato de que são escassos os recursos superficiais nessas áreas. 
Os aquíferos porosos-fissurais possuem, simultaneamente, porosidades de interstícios (poros) e de fraturas, sendo as melhores vazões $\left(10 \mathrm{~m}^{3} / \mathrm{h}\right.$ a $\left.40 \mathrm{~m}^{3} / \mathrm{h}\right)$ restritas a áreas submetidas a intenso fraturamento e situadas em regiões com bons índices pluviométricos e de relevo pouco acidentado.

O Mapa hidrogeológico da Região Nordeste e a descrição de suas diferentes nuances, representativos dos diversos potenciais de produção hídrica existentes nessa região, deixam evidenciado o complexo quadro de condicionantes naturais relativos ao acesso aos recursos hídricos superficiais e subterrâneos que são, sem dúvida, fundamentais para garantir à população da Região a disponibilidade e o acesso à água. Esta garantia se constitui, dentre outras metas, em um dos objetivos de desenvolvimento sustentável (Mapa 7).

\section{Vulnerabilidade social e ambiental}

Cientificamente, "está bem estabelecido que os serviços ecossistêmicos prestados por águas interiores são vitais para o bem-estar humano e redução da pobreza" (DUGAN, 1990; REVENGA; KURA, 2003; FINLAYSON et al., 1992; FINLAYSON; MOSER, 1991; WHIGHAM et al., 1993; MITSCH, 1994; MCCOMB; DAVIS, 1998; LUNDQVIST; GLEICK, 2000 apud ECOSYSTEMS..., 2005, p. 575, tradução nossa). Os benefícios desses serviçOs para o bem-estar humano e, portanto, a degradação dos mesmos afetam diretamente e, em particular, a disponibilidade de água doce, de alimentos, de ciclagem de nutrientes, o tratamento de resíduos e desintoxicação, a regulação das ameaças naturais (enchentes, secas, etc.) e vários serviços culturais e religiosos (ECOSYSTEMS..., 2005).

Os impactos sobre o bem-estar humano quando da degradação dos serviços de suporte e regulação de águas interiores, muitas vezes não são reconhecidos tão facilmente quanto aqueles serviços de provisionamento de água (vide o racionamento causado pela diminuição da quantidade de água disponível para abastecimento em diversos centros urbanos no Brasil). Mas ele pode ser muito significativo quando, por exemplo, reduz-se a capacidade de uma zona úmida de filtrar a água ou desintoxicar os resíduos, provocando consequências significativas para a saúde humana.

Na perspectiva da vulnerabilidade social, Freire (2011) afirma que, embora complexa e por vezes polêmica, esta questão implica conhecer e analisar o espaço geográfico em suas mais variadas dimensões, escalas e percepções. Esse mesmo autor, em 2008, ao realizar um trabalho de identificação das áreas da bacia hidrográfica do São Francisco com maior grau de vulnerabilidade social, construiu um indicador considerando quatro características fundamentais de municípios cujos domicílios encontram-se em situação de precariedade: em decorrência do baixo rendimento, da presença de crianças, do responsável com baixa escolaridade e da insuficiência dos serviços de saneamento básico (FREIRE et. al., 2008).

Sobre o acesso aos serviços de saneamento básico (CENSO DEMOGRÁFICO 2010, 2011) e condições de vida, ligadas direta ou indiretamente aos recursos hídricos, a construção de indicadores relacionados é bastante útil para contextualização das regiões hidrográficas brasileiras no que se refere ao atendimento de aspectos básicos. Em tese, tais indicadores refletem a correta apropriação dos recursos hídricos pela população para a satisfação das 
condições de vida consideradas no contexto do desenvolvimento sustentável. As condições de saneamento representam um dos requisitos básicos para a qualidade de vida da população. O acesso simultâneo à água potável, ao esgotamento sanitário e à coleta de lixo é o requisito mínimo para um ambiente saudável.

Tais situações repercutem diretamente sobre a saúde da população, em particular das crianças e idosos, ao impedirem que as condições de qualidade da água e de exposição ao lixo se tornem sérios vetores de doenças. Isso demonstra, novamente, a íntima relação entre o bem-estar da população com a saúde dos ecossistemas aquáticos e uso racional dos recursos hídricos. A Avaliação Ecossistêmica do Milênio afirma, com alto grau de certeza científica, que

\begin{abstract}
A manutenção de um fluxo adequado de água de boa qualidade é necessário para manter a saúde dos sistemas de águas interiores, bem como de estuários e deltas. O inverso também é verdadeiro: os sistemas de águas interiores saudáveis geram e mantém os fluxos adequados de água de boa qualidade. À medida que os serviços de apoio de águas interiores são o resultado de interações entre os componentes ecológicos dentro do sistema e as da bacia hidrográfica, o bemestar humano está inexoravelmente ligados à manutenção do caráter ecológico dos sistemas de águas interiores (ECOSYSTEMS..., 2005, p. 575, tradução nossa).
\end{abstract}

A vulnerabilidade social decorre, assim, de fenômenos diversos, com causas e consequências distintas, a partir de uma visão mais complexa das condições de vida e dos riscos sociais que atingem os vários segmentos populacionais, bem como das possibilidades de sua superação ou minimização.

"Como o bem-estar humano é fortemente afetado pela medida em que as pessoas são capazes de satisfazer as suas necessidades mais básicas (água, comida, abrigo e saúde) de uma maneira segura, o uso sustentável das águas, para garantir bem-estar humano, é vital" (ECOSYSTEMS..., 2005, p. 575, tradução nossa). Ou seja, para se abordar o tema da qualidade de vida, faz-se necessário incorporar à análise os outros elementos que permitem a um indivíduo viver com dignidade e segurança, dentre eles, os elementos do capital natural, conforme relatado nesse capítulo.

\title{
Referências
}

AGÊNCIA NACIONAL DE ÁGUAS (Brasil). Programa de ações estratégicas para o gerenciamento integrado do Pantanal e bacia do Alto Paraguai: relatório final. Brasília, DF: ANA, 2004.315 p. Acima do título: Implementação de práticas de gerenciamento integrado de bacia hidrográfica para o Pantanal e a Bacia do Alto Paraguai. Disponível em: <file://C:/ Users/1367242/Downloads/20091202140622_ALTO_PARAG_REL_FINAL.pdf >. Acesso em: maio 2016.

ALHO, C. J. R. et. al. Conservação da biodiversidade da bacia do Alto Paraguai. Campo Grande, MS: Ed.Uniderp, 2003. 466 p.

ALHO, C. J. R.; LACHER JÚNIOR, T. E.; GONÇALVES, H. C. Environmental degradation in the Pantanal ecosystem: in Brazil, the world's largest wetland is being threatened by human 
activities. BioScience, Oxford: Oxford University Press; Washington, DC: American Institute of Biological Sciences, v. 38, n. 3, p. 164 -171, mar. 1988. Disponível em: <http://www.jstor. org/stable/i256205>. Acesso em: maio 2016.

ANDRADE-LIMA, D. de. Present-day forest refuges in northeastern Brazil. In: INTERNATIONAL SYMPOSIUM FOR THE ASSOCIATION FOR TROPICAL BIOLOGY, 5., 1979, Caracas. Biological diversification in the tropics: proceedings.... Nova York: Columbia University Press, 1982. p. 245-251.

ATLAS nacional do Brasil Milton Santos. Rio de Janeiro: IBGE, 2010. Disponível em: <http:// biblioteca.ibge.gov.br/index.php/biblioteca-catalogo?view=detalhes\&id=247603>. Acesso em jun. 2016.

BARELLA, W. et.al. As relações entre as matas ciliares, os rios e os peixes. In: RODRIGUES, R. R.; LEITÃO FILHO, H. F. (Ed.). Matas ciliares: conservação e recuperação. São Paulo: Edusp; Fundação de Amparo à Pesquisa do Estado de São Paulo - Fapesp, 2001. p. 187-207.

BIOMAS. Brasília, DF: Ministério do Meio Ambiente, [2015]. Disponível em: <http://www. mma.gov.br/biomas> Acesso em: maio 2016.

BRASIL. Lei n. 9.433, de 8 de janeiro de 1997. Institui a Política Nacional de Recursos Hídricos, cria o Sistema Nacional de Gerenciamento de Recursos Hídricos, regulamenta o inciso XIX do art. 21 da Constituição Federal, e altera o art. $1^{\circ}$ da Lei n. 8.001, de 13 de março de 1990, que modificou a Lei n. 7.990, de 28 de dezembro de 1989. Diário Oficial [da] República Federativa do Brasil, Brasília, DF, ano 135, n. 6, 09 jan. 1997. Seção 1, p. 470-474. Disponível em: <http://www.presidencia.gov.br/legislacao >. Acesso em: maio 2016.

CENSO DEMOGRÁFICO 2010. Características da população e dos domicílios: resultados do universo. Rio de Janeiro: IBGE, 2011. Disponível em: <http://www.ibge.gov.br/home/ estatistica/populacao/censo2010/caracteristicas_da_populacao/default_caracteristicas_da_ populacao.shtm>. Acesso em: maio 2016.

COIMBRA FILHO, A. F.; CÂMARA, I. de G. Os limites originais do bioma Mata Atlântica na região nordeste do Brasil. Rio de Janeiro: Fundação Brasileira para Conservação da Natureza, 1996. 86 p.

CONJUNTURA dos recursos hídricos no Brasil 2013. Brasília, DF: Agência Nacional de Águas - ANA, 2013. 432 p. Disponível em: <http://arquivos.ana.gov.br/institucional/spr/ conjuntura/webSite_relatorioConjuntura/projeto/index.html>. Acesso em: maio 2016.

CONSELHO NACIONAL DE RECURSOS HÍDRICOS (Brasil). Resolução n. 32, de 15 de outubro de 2003. Institui a Divisão Hidrográfica Nacional. Brasília, DF: CNRH, 2003. Disponível em: <http:// www.cnrh.gov.br/index.php?option=com_content\&view=article\&id=14>.Acessoem: maio2016. ECOSYSTEMS and human well-being: a framework for assessment. Washington, DC: Island Press, 2003. 245 p. Relatório apresentado pelo Grupo de Trabalho Millennium Ecosystem Assessment. Disponível em: <http://pdf.wri.org/ecosystems_human_wellbeing.pdf>. Acesso em: maio 2016.

ECOSYSTEMS and human well-being: current state and trends: findings of the Condition and Trends Working Group of the Millennium Ecosystem Assessment. Washington, DC: Island 
Press, 2005. 901 p. (Millennium ecosystem assessment series, v. 1). Disponível em: <http:// millenniumassessment.org/en/Condition.html>. Acesso em: maio 2016.

ESTIMATIVAS da população residente nos municípios brasileiros com data de referência em 1 o de julho de 2013. Rio de Janeiro: IBGE, 2013. Disponível em: <ftp://ftp.ibge.gov.br/ Estimativas_de_Populacao>. Acesso em: maio 2016.

FREIRE, N. C. F. Diagnóstico jurídico-institucional. In: DIAGNÓSTICO do macrozoneamento ecológico-econômico da bacia hidrográfica do rio São Francisco. Brasília, DF: Ministério do Meio Ambiente, 2011. p. 415-445. Disponível em: <http://www.mma.gov.br/gestao-territorial/ zoneamento-territorial/macrozee-da-bacia-do-s\%C3\%A3o-francisco/item/10439>. Acesso em: maio 2016.

FREIRE, N. C. F. et. al. Tipologia da vulnerabilidade social na bacia de São Francisco. Trabalho apresentado no II Simpósio Brasileiro de Ciências Geodésicas e Tecnologias da Geoinformação, realizado em Recife, 2008. Disponível em: <https://www.ufpe.br/cgtg/ SIMGEOII_CD/Organizado/cart_sig/157.pdf>. Acesso em: maio 2016.

GALDINO, S.; VIEIRA, L. M.; SORIANO, B. M. A. Erosão na bacia do Alto Taquari. Corumbá: Empresa Brasileira de Pesquisa Agropecuária - Embrapa, 2003. 46 p. (Documentos, n. 52) Disponível em: <http://www.cpap.embrapa.br/publicacoes/online/DOC52.pdf>. Acesso em: maio 2016.

GALVÃO, A. L. C. de O.; GALVÃO, W. S. As relações espaciais entre os dados de localização de cavernas e as ottobacias: bacias hidrográfica geocodificada do Brasil. Revista Brasileira de Espeleologia, Brasília, DF: Centro Nacional de Pesquisa e Conservação de Cavernas, v. 2, n. 2, p. 38-56, 2012. Disponível em: <http://www.icmbio.gov.br/revistaeletronica/index. php/RBEsp/article/view/315/pdf>. Acesso em: maio 2016.

ÍNDICE paulista de vulnerabilidade social. São Paulo: Fundação Sistema Estadual de Análise de Dados - Seade, [2015]. Disponível em: <http://produtos.seade.gov.br/projetos/ipvs/>. Acesso em: maio 2016.

INTERNATIONAL recommendations for water statistics. New York: United Nations, Statistics Division, 2012. 197 p. (Statistical papers, Series M, n. 91). Disponível em: <http://unstats. un.org/unsd/envaccounting/pubs.asp>. Acesso em: maio 2016.

JUNK, W. J. et. al. Brazilian wetlands: their definition, delineation, and classification for research, sustainable management, and protection. Aquatic Conservation: marine and freshwater ecosystems, Chichester, GB: John Wiley \& Sons, v. 24, n. 1, p. 5-22, 2014. Disponível em: <http:// onlinelibrary.wiley.com/journal/10.1002/(ISSN)1099-0755/issues>. Aceso em: maio 2016.

LEVANTAMENTO da cobertura vegetal nativa do bioma mata atlântica: relatório final. Rio de Janeiro: Instituto de Estudos Socioambientais do Sul da Bahia - IESB, 2007. 84 p. Acima do título: Projeto de conservação e utilização sustentável da diversidade biológica brasileira - Probio. Disponível em: <http://mapas.mma.gov.br/geodados/brasil/vegetacao/ vegetacao2002/mata_atlantica/documentos/relatorio_final.pdf>. Acesso em: maio 2016.

MAPA de biomas do Brasil: primeira aproximação. Rio de Janeiro: IBGE, 2004a. 1 mapa. Escala 1:5 000 000. Projeção policônica. 
MAPA de biomas e de vegetação. Rio de Janeiro: IBGE, 2004b. Disponível em: <http://www. ibge.gov.br/home/presidencia/noticias/21052004biomashtml.shtm>. Acesso em: maio 2016.

MAPA de vegetação do Brasil. Rio de Janeiro: IBGE, 2004c. 1 mapa, color. Escala 1:5000 000. Projeção policônica. Disponível em: <ftp://geoftp.ibge.gov.br/informacoes_ambientais/ vegetacao/mapas/brasil/vegetacao.pdf>. Acesso em jun. 2016.

MAPA hidrogeológico da região nordeste do Brasil. IBGE, 2013. 1 mapa, color. Escala 1:2 500 000. Projeção policônica. Disponível em: <ftp://geoftp.ibge.gov.br/informacoes_ ambientais/geologia/levantamento_hidrogeologico_e_hidroquimico/mapas/regionais/ nordeste_hidrogeologico.pdf>. Acesso em: jun. 2016.

MONITORAMENTO do desmatamento nos biomas brasileiros por satélite: monitoramento do bioma caatinga 2008-2009. Brasília, DF: Ministério do Meio Ambiente: Instituto Brasileiro do Meio Ambiente e dos Recursos Naturais Renováveis - Ibama, 2011a. 46 p. Disponível em: <http://www.mma.gov.br/estruturas/sbf_chm_rbbio/_arquivos/relatorio_ tecnico_caatinga_2008_2009_72.pdf>. Acesso em: maio 2016.

MONITORAMENTO do desmatamento nos biomas brasileiros por satélite: monitoramento do bioma cerrado 2009-2010. Brasília, DF: Ministério do Meio Ambiente: Instituto Brasileiro do Meio Ambiente e dos Recursos Naturais Renováveis - Ibama, 2011b. [64] p. Disponível em: <http://www.mma.gov.br/estruturas/sbf_chm_rbbio/_arquivos/relatoriofinal_ cerrado_2010_final_72_1.pdf>. Acesso em: maio 2016.

MONITORAMENTO do desmatamento nos biomas brasileiros por satélite: monitoramento do bioma mata atlântica 2008-2009. Brasília, DF: Ministério do Meio Ambiente: Instituto Brasileiro do Meio Ambiente e dos Recursos Naturais Renováveis - Ibama, 2012. [100 p.]. Disponível em: <http:/www.mma.gov.br/estruturas/sbf_chm_rbbio/_arquivos/relatorio_ tcnico_mata_atlantica_2008_2009_72.pdf>. Acesso em: maio 2016.

MONITORAMENTO do desmatamento nos biomas brasileiros por satélite: monitoramento do bioma pampa 2008-2009. Brasília, DF: Ministério do Meio Ambiente: Instituto Brasileiro do Meio Ambiente e dos Recursos Naturais Renováveis - Ibama, 2011c. [34] p. Disponível em: <http://www.mma.gov.br/estruturas/sbf_chm_rbbio/_arquivos/relatrio_tcnico_ monitoramento_pampa_2008_2009_72.pdf>. Acesso em: maio 2016.

MONITORAMENTO do desmatamento nos biomas brasileiros por satélite: monitoramento do bioma pantanal 2008-2009. Brasília, DF: Ministério do Meio Ambiente: Instituto Brasileiro do Meio Ambiente e dos Recursos Naturais Renováveis - Ibama, 2011d. 30 p. Disponível em: <http://www.mma.gov.br/estruturas/sbf_chm_rbbio/_arquivos/relatrio_ tcnico_monitoramento_pantanal_2008_2009_72.pdf>. Acesso em: maio 2016.

PRADO, D. E. As caatingas da América do Sul. In: LEAL, I. R.; TABARELLI, M.; SILVA, J. M. C. (Ed.). Ecologia e conservação da Caatinga. Recife: Universidade Federal de Pernambuco UFPE, 2003. p. 3-73. Disponível em: <http://www.mma.gov.br/estruturas/203/_arquivos/5_ livro_ecologia_e_conservao_da_caatinga_203.pdf> Acesso em: maio 2016. 
SANTOS, J. R. Avanços das pesquisas e aplicações de sensoriamento remoto no monitoramento da paisagem: contribuições aos estudos do Pantanal. In: SIMPÓSIO DE GeOTECNOLOGIAS NO PANTANAL, 1., 2006, Campo Grande. Anais... Campo Grande: Empresa Brasileira de Pesquisa Agropecuária - Embrapa; Embrapa Informática Agropecuária; Instituto Nacional de Pesquisas Espaciais - INPE, 2006, p. 675-683. Disponível em: <https:// www.geopantanal.cnptia.embrapa.br/2010/publicacoes.html>. Acesso em: maio 2016.

SEN, A. Capability and well-being. In: NUSSBAUM, M.; SEN, A. (Ed.). The quality of life. Oxford: Clarendon Press; New York: Oxford University Press, 1993. p. 30-553.

SYSTEM of environmental-economic accounting 2012: central framework. New York: United Nations, 2014. 346 p. Preparado sob os auspícios da Organização das Nações Unidas ONU, Comissão das Comunidades Européias - Eurostat, Organização das Nações Unidas para a Alimentação e a Agricultura - FAO, Fundo Monetário Internacional - IMF, Organização para a Cooperação e o Desenvolvimento Econômico - OCDE, e Banco Mundial. Disponível em: <http://unstats.un.org/unsd/envaccounting/pubs.asp>. Acesso em: maio 2016.

SYSTEM of environmental-economic accounting for water - SEEA-water. New York: United Nations, Department of Economic and Social Affairs, 2012.197 p. Preparado em colaboração com o subgrupo de contas de água, do grupo de Londres sobre contas ambientais. Disponível em <http://unstats.un.org/unsd/envaccounting/pubs.asp>. Acesso em: maio 2016. 


\title{
Desenvolvimento local sustentável e governança ambiental
}

\author{
Denise Kronemberger \\ Valéria Grace Costa
}

\begin{abstract}
O desenvolvimento local foi impulsionado no Brasil em meados da década de 1990 e resultou de algumas mudanças importantes, como o processo de redemocratização nos anos 1980, com a descentralização do planejamento e gestão das políticas públicas e a ampliação da participação da sociedade na esfera pública.

Nos anos 1990 continua o processo de consolidação de um novo padrão de relação entre Estado e sociedade, baseado na participação social, na formação de parcerias, na busca de integração das ações, nas articulações inter e intragovernamentais. Verifica-se, desde então, a proliferação de iniciativas inovadoras governamentais, sobretudo de governos municipais e não governamentais, a ampliação das metodologias de apoio ao desenvolvimento local, e o surgimento de diversos arranjos institucionais, que se tornam espaços de interlocução, de governança, tais como: fóruns, agências, conselhos, comitês e consórcios.

Tal processo constitui, desde então, um elemento central para se conhecer a geografia do Brasil contemporâneo, uma vez que a ação pública sobre o território passa a refletir, de alguma forma e, crescentemente, a pressão política que os diversos segmentos da sociedade brasileira passam a exercer nas escalas local, regional e nacional.

Nesta primeira parte, apresentamos os conceitos mais importantes sobre desenvolvimento local e governança. Esta última diz respeito à dimensão político-institucional do desenvolvimento, que perpassa todas as demais dimensões. Na segunda parte contém uma breve análise da governança ambiental no Brasil, com ênfase nos municípios. A ênfase dada à governança ambiental é importante para introduzir o debate nas discussões acerca do desenvolvimento local e suscitar novos trabalhos e aprofundamentos.
\end{abstract}


Procuramos selecionar variáveis que se identificam com a ideia de desenvolvimento local, como diferentes formas de articulação e de arranjos institucionais. Os dados foram obtidos em pesquisas do Instituto Brasileiro de Geografia e Estatística - IBGE sobre o número de organizações da sociedade civil que atuam na área de meio ambiente e proteção animal, os municípios que realizam articulações interinstitucionais na área de meio ambiente, municípios que firmam parcerias dos governos municipais com o governo federal para implementação de programas de meio ambiente e algumas institucionalidades participativas, entre outras instâncias e formas de praticar a governança ambiental no País. Sempre que possível foi apresentada série histórica em nível nacional e os mapas foram elaborados com base no último ano do dado disponível.

\section{Desenvolvimento local sustentável}

Desenvolvimento local é o processo de aproveitamento das vantagens comparativas e competitivas de uma localidade para favorecer o seu crescimento econômico, melhorar a qualidade de vida da população, fortalecer o capital social ${ }^{1}$, promover uma boa governança e o uso sustentável dos recursos naturais (PAULA, 2008). Nota-se que para um desenvolvimento local convergem fatores ambientais, sociais, econômicos, políticos e institucionais, que se cruzam e se interpenetram.

É um processo endógeno de mudanças estruturais, conduzido a partir dos atores locais ('desenvolvimento endógeno'), ou seja, realizado de 'baixo para cima'² (bottom up), através da sua mobilização e articulação em torno de um projeto coletivo, aproveitando as potencialidades e capacidades locais e as oportunidades do contexto externo, e minimizando as restrições ou fatores que o dificultam (BUARQUE, 2002). É, portanto, "uma nova estratégia de desenvolvimento, em que a comunidade assume um novo papel: de comunidade demandante, ela emerge como agente, protagonista, empreendedora, com autonomia e independência" (ALCOFORADO, 2006, p. 86).

Para alcançar estes objetivos é necessário que a sociedade local tenha capacidade de "formular propósitos coletivos, de progresso material, equidade, justiça social e sustentabilidade e mobilizar os recursos necessários para sua obtenção" (SENRA, 2010, p. 5), que é o conceito de Desenvolvimento Econômico Territorial - DET, segundo a formulação do Instituto Latinoamericano y del Caribe de Planificación Econômica y Social - LLPES da Comisión Econômica para América latina y el Caribe - Cepal (SENRA, 2010, p. 5). O diferencial do desenvolvimento local em relação a outros paradigmas de desenvolvimento está na incorporação da dimensão territorial, pois é uma construção de atores mobilizados em um processo dinâmico de valorização de ativos locais na base de uma identificação coletiva com uma

\footnotetext{
1 Capital social é a "capacidade de uma sociedade de estabelecer laços de confiança interpessoal e redes de cooperação com vistas à produção de bens coletivos" (ARAÚJO, 2003, p. 10).

2 Não se quer dizer com isto que o desenvolvimento será buscado somente de baixo para cima, pois a participação cidadã não prescinde do papel fundamental do Estado.
} 
cultura e um território. Estes ativos são os recursos próprios de um território, que permitirão a este se diferenciar em relação aos demais territórios (PECQUEUR, 2005).

Desse modo, o desenvolvimento local é focado nas pessoas, no seu ambiente e na sua capacidade para inovar, efetuar transformações e empreender, baseado em valores como cooperação, solidariedade, partilha, complementaridade, confiança, corresponsabilidade. Tem como referência a formação de parcerias, as articulações em rede e os ativos locais (potenciais individuais e coletivos, oportunidades, vantagens comparativas e competitivas) (MELO NETO; FRÓES, 2002).

O desenvolvimento local pode ocorrer em diversos recortes territoriais, porque o local é produto do processo de desenvolvimento, da participação social, sendo um espaço que vai sendo construído pela sociedade, que vai originando configurações territoriais diversas. É o alvo socioterritorial das ações, portanto, não é dado, mas se define e redefine a partir destas ações, o que remete a um contexto de relações que ultrapassa o nível micro. Por isso, ele também é denominado desenvolvimento territorial (FRANCO, 1998, 2002; SPERANZA, 2006; SILVEIRA, 2010). Portanto, o local não é uma questão de escala, também "não se trata do mesmo desenvolvimento em miniatura", mas é uma questão de natureza, é um "outro desenvolvimento", conforme aponta Silveira (2010, p. 46). Local também tem relação com identidade, que pode ser construída politicamente, tem a ver com o sentido de pertencimento, com a conexão e um sentido compartilhado de uma história vivida de maneira conjunta (TENÓRIO, 2012).

Qual, então, é a relação entre desenvolvimento local e governança?

Governança é o conjunto das várias maneiras pelas quais os diversos atores sociais se articulam e cooperam, realizando ações, gerenciando seus problemas comuns e acomodando seus interesses. Abrange instituições públicas e privadas, regimes formais de coordenação e autoridade, como os aspectos gerenciais do Estado, mecanismos informais que atendam a determinadas necessidades e redes sociais informais (MILANI; SOLINÍS, 2002, apud ALBAGLI, 2007).

Implica, por exemplo, na formação de parcerias, constituição de arranjos institucionais com a participação conjunta de governos-empresas-sociedade, entre outras formas de articulação. Uma boa governança é, portanto, fundamental no processo de desenvolvimento local sustentável.

Particularmente a governança ambiental exerce um papel fundamental na viabilização de um uso sustentável dos recursos naturais, um dos principais objetivos do desenvolvimento local, porque estimula a inserção dos movimentos sociais e ambientais nos processos decisórios e a ação política com autonomia e independência, favorecendo o real exercício da cidadania e da democracia em busca do bem-estar. Refere-se a "que, na área do meio ambiente, estejam ampliando os espaços de participação dos diversos segmentos da sociedade civil organizada" (OLIVEIRA; BARCELLOS; GREEN, 2011, p. 17).

No Brasil, ocorre uma multiplicidade de ações públicas e privadas que visam apoiar ou induzir o desenvolvimento local, como a Agenda 21 Local, os Programas de Desenvol- 
vimento Regional, os empreendimentos de Economia Solidária ${ }^{3}$, os Arranjos Produtivos Locais - APL, iniciativas de empreendedorismo social ${ }^{4}$, tecnologias sociais ${ }^{5}$, inclusão digital e muitas outras. Essa diversidade de ações constitui, de certa forma, tentativas de implementar uma nova dinâmica territorial do desenvolvimento. Elas têm etapas de execução diferentes, porém, têm em comum a formação de redes sociais e o fomento às dinâmicas democrático-participativas. Visam tornar as comunidades protagonistas do seu desenvolvimento, ao participarem das tomadas de decisão.

Estas iniciativas compõem um processo onde emergem novos atores, que criam novas territorialidades, uma vez que alteram as suas relações com as localidades/regiões, ou seja, mudam o modo de agir em seu meio de referência, podendo, inclusive, contribuir para criar laços mais fortes de identidade territorial (sentido de pertencimento), quando expressam resistência aos mecanismos da globalização ou quando aproveitam as potencialidades para valorizar os territórios (ALBAGLI, 2004). As experiências da Associação de Desenvolvimento Sustentável e Solidário da Região Sisaleira - АРАEB, na Bahia, da Associação dos Agricultores Ecológicos das Encostas da Serra Geral - Agreco, em Santa Catarina, e as regiões com o registro de Indicação Geográfica - IG são alguns exemplos destas iniciativas.

Quando surgiu em 1980 no Município de Valente, na Bahia, a АРАEB tinha como principal objetivo valorizar a produção de sisal. Posteriormente, a iniciativa foi se ampliando, incorporando municípios vizinhos e contemplando outros temas, como a convivência com a seca, a educação, a comunicação, a cultura, o crédito, o meio ambiente e o desenvolvimento sustentável.

A AgreCo, no seu início, em 1996, visava produzir hortifrutigranjeiros com manejo ecológico, no Município de Santa Rosa de Lima, em Santa Catarina. A iniciativa ampliou-se, estendendo-se pela Região das Encostas da Serra Geral e incorporando outras atividades, como as agroindústrias organizadas de forma associativa (Rede AGRECO), projetos de ecovilas, comércio solidário, agroturismo, cooperativa de crédito, agricultura ecológica, e inserção dos agricultores de pequeno e médio porte em nichos de mercados nacionais e internacionais, através de produtos artesanais e orgânicos.

\footnotetext{
3 Para Singer (2003, p. 11-28): “A economia solidária surge como modo de produção e distribuição alternativo ao capitalismo [...]. Casa o princípio da unidade entre posse e uso dos meios de produção e distribuição [...] com o princípio da socialização destes meios". Como exemplos estão as cooperativas populares, as empresas de autogestão, os clubes de troca e os projetos de economia de comunhão, entre outros.

4 O empreendedorismo social produz bens e serviços para solucionar problemas sociais, não está voltado para os mercados, mas para atender as pessoas em situação de exclusão social, pobreza e risco de vida. Seu objetivo é capacitar para ações empreendedoras, para "empoderar" as comunidades (MELO NETO; FRÓES, 2002). Como exemplos podem ser mencionadas as ações da Pastoral da Criança, organismo de ação social da Confederação Nacional dos Bispos do Brasil - CNBB e do Comitê de Democratização da Informática - CDI, organização social que usa a tecnologia para transformação social, como as Escolas de Informática e Cidadania, entre outras.

5 Para Melo Neto e Fróes (2002, p. 34): "Arranjos institucionais definidos e implementados por associações, pelos governos em seus diversos níveis, universidades, sindicatos, equipes gestoras dos programas e projetos de desenvolvimento social em uma comunidade e pelos membros da comunidade".
} 
As IGs decorrem da valorização de ativos locais, produtos tradicionais com qualidade diferenciada, vinculados a determinados territórios, reconhecidos pelo Instituto Nacional de Propriedade Intelectual - INPI. Procuram contribuir para a conservação ambiental, para a economia local e para o dinamismo regional. São exemplos: em Goiabeiras Velha, bairro antigo na parte continental norte de Vitória, as panelas de barro; no Pampa gaúcho, da Campanha Meridional, a carne bovina e seus derivados; também no Rio Grande do Sul, no Município de Pelotas - os doces tradicionais de confeitaria e de frutas e no Vale dos Vinhedos - os vinhos e espumantes; em Paraty, no Estado do Rio de Janeiro, as aguardentes; na Região do Cerrado mineiro, o café; na Região do Jalapão, do Estado do Tocantins, o artesanato em capim dourado, entre outros (INDICAÇÕES..., 2014).

Em todos estes exemplos a dimensão ambiental do desenvolvimento local está presente, considerando que as condições ambientais exercem influência nas características dos produtos, como também a necessidade de conservar as regiões produtoras, garantindo sua sustentabilidade.

\section{Governança ambiental no Brasil}

\section{Organizações da sociedade civil}

As organizações da sociedade civil representam a capacidade de intervenção ativa das comunidades na realidade em que vivem. Contribuem para aumentar a capacidade da sociedade de exercer a sua cidadania e desenvolver-se de forma sustentável.

Em 2010, existiam no Brasil um total de 2242 Fundações Privadas e Associações sem Fins Lucrativos - FASFIL que desenvolviam ações de meio ambiente e proteção animal, representando apenas $0,8 \%$ do total das FASFIL do País. Vale ressaltar, contudo, que como o tema é transversal, meio ambiente também pode ser tratado por entidades com outras finalidades. A maioria das FASFIL (60,0\%) foi fundada entre 2001 e 2010. Em termos de pessoal ocupado assalariado, elas empregavam 10337 trabalhadores, representando 0,5\% do total de pessoal ocupado nas FASFIL. A maioria encontrava-se nas Regiões Sudeste (3 972) e Nordeste (3 963) (AS FUNDAÇÕES..., 2012). 
A maioria das FASFIL de meio ambiente localizava-se nas Regiões Sudeste (50,0\%) e Sul $(23,0 \%)$. Os Estados de São Paulo, Minas Gerais e Rio de Janeiro possuíam o maior número de unidades (574, 285 e 213, respectivamente) (Mapa 1). Por outro lado, quando analisadas segundo o tamanho de população das Unidades da Federação, Santa Catarina, Distrito Federal e Rio Grande do Sul possuíam o maior número de FAsflL por mil habitantes, conforme apresentado no Gráfico 1.

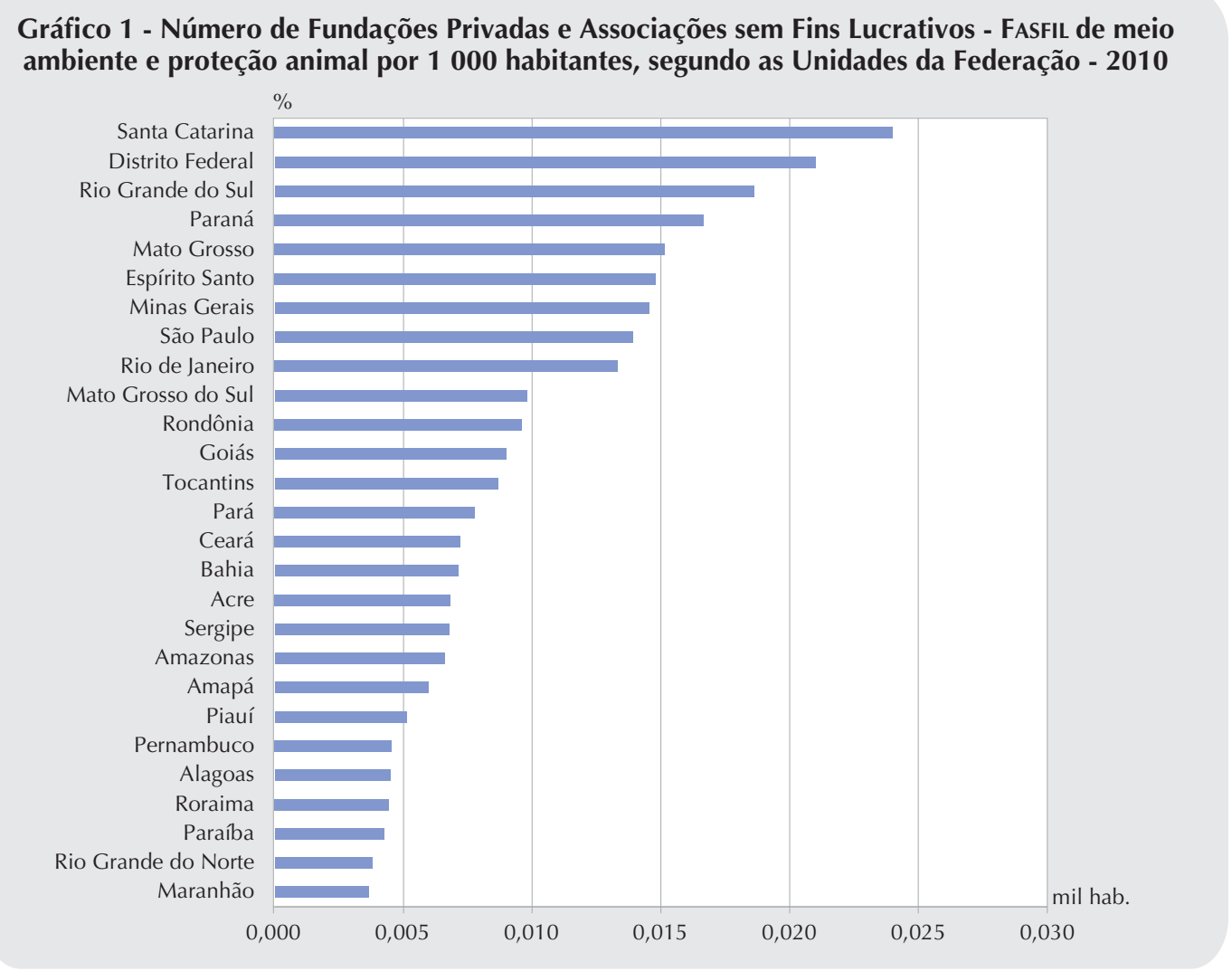

Fonte: As fundações privadas e associações sem fins lucrativos no Brasil 2010. Rio de Janeiro: IBGE, 2012. (Estudos e pesquisas. Informação econômica, n. 20). Estudo realizado pelo IBGE em parceria com o Instituto de Pesquisa Econômica Aplicada - IPEA, a Associação Brasileira de Organizações Não Governamentais - Abong e o Grupo de Institutos, Fundações e Empresas - GIFE. Disponível em: <ftp://ftp.ibge.gov.br/Fundacoes_Privadas_e_Associacoes/2010/fasfil.pdf>. Acesso em: maio 2016.

Entre os municípios, 42,0\% possuíam apenas uma FASFIL e 25,0\% tinham somente duas. Os dez municípios com os maiores números de unidades locais, em 2010, eram: São Paulo (162), Rio de Janeiro (95), Curitiba (64), Brasília (54), Porto Alegre (40), Belo Horizonte (34), Fortaleza (24), Salvador (24), Belém (23) e Campinas (23) (Mapa 1). 
Mapa 1 - Fundações Privadas e Associações sem Fins Lucrativos - Fasfil de meio ambiente e proteção animal nos municípios brasileiros com pelo menos 50000 habitantes - 2010

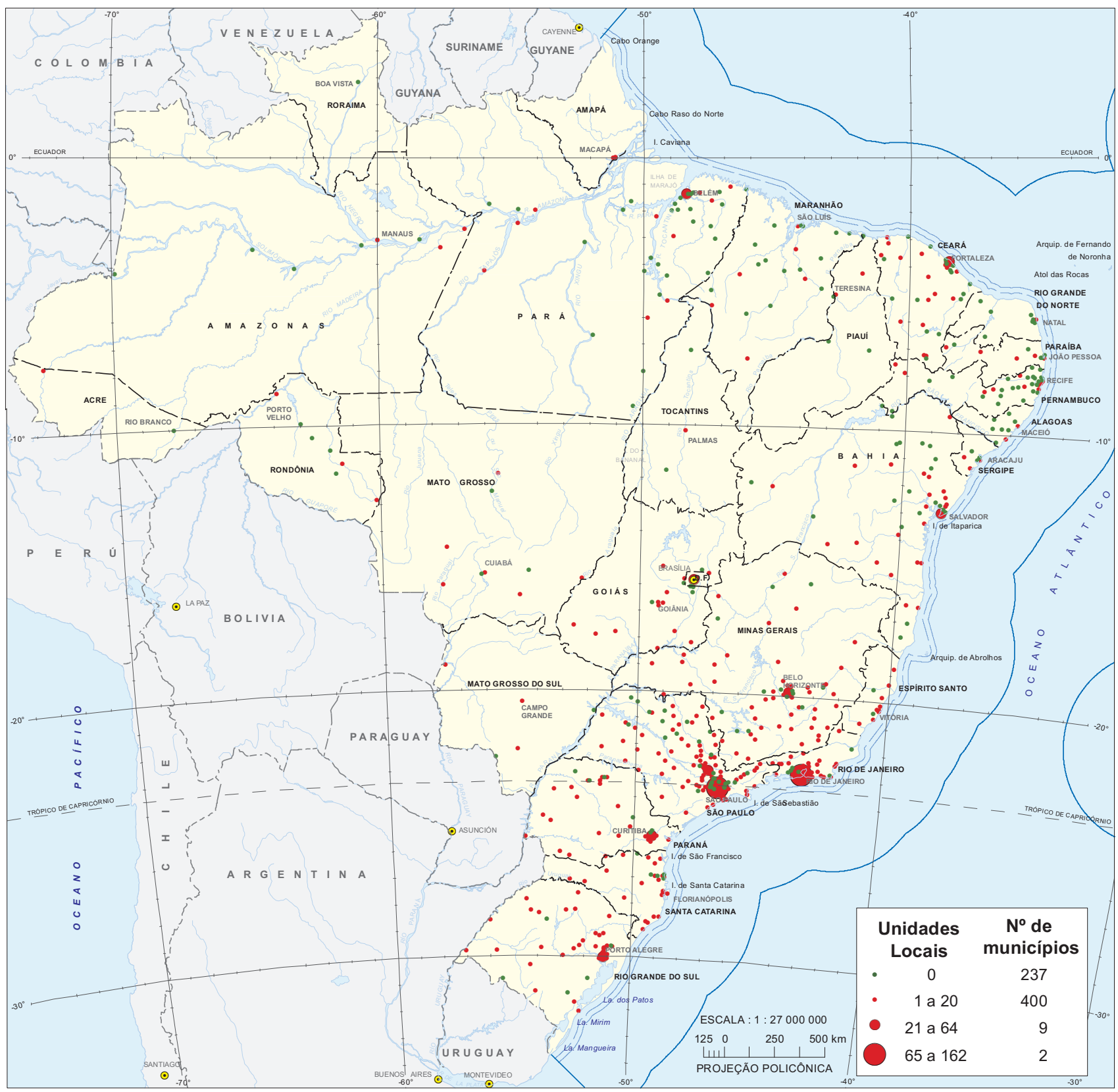

Fonte: As fundações privadas e associações sem fins lucrativos no Brasil 2010. Rio de Janeiro: IBGE, 2012. (Estudos e pesquisas. Informação econômica, n. 20). Estudo realizado pelo IBGE em parceria com o Instituto de Pesquisa Econômica Aplicada - IPEA, a Associação Brasileira de Organizações Não Governamentais - ABONG e o Grupo de Institutos, Fundações e Empresas - GIFE. Disponível em: <ftp://ftp.ibge.gov.br/Fundacoes_Privadas_e_ Associacoes/2010/fasfil.pdf>. Acesso em: maio 2016. 


\section{Institucionalidades participativas}

No processo de desenvolvimento local também são criadas 'novas institucionalidades', que são instâncias de governança, para apoiar esse processo ou parte dele. São os Fóruns, as Agências, os Comitês de Bacias Hidrográficas, os Conselhos Municipais, os Conselhos de Desenvolvimento, os Consórcios Intermunicipais, as Associações de Municípios e as Redes, que conferem maior representatividade política e social ao desenvolvimento local. Eles constituem espaços públicos de negociação e participação cidadã.

Nesse trabalho será analisada a distribuição espacial dos municípios com Conselhos de Meio Ambiente, com participação em Comitês de Bacias Hidrográficas - CBH e com Fóruns da Agenda 21 Local. Os CBH, por exemplo, são arranjos institucionais participativos que apoiam o desenvolvimento local, na medida em que procuram a interação entre os atores sociais (representantes do poder público, da sociedade civil e dos usuários da água) para ordenar a ocupação das bacias, buscando o uso criterioso da água, criando, utilizando e fortalecendo as instituições locais.

\section{Conselhos de Meio Ambiente}

Os Conselhos Municipais de Meio Ambiente são órgãos colegiados inseridos no poder executivo municipal, de natureza deliberativa ou consultiva, integrados por diferentes atores sociais (governo, empresariado, universidades, trabalhadores e sociedade civil) que lidam com temas relacionados com o meio ambiente e que integram a estrutura dos órgãos locais do Sistema Nacional do Meio Ambiente - Sisnama. Tais Conselhos têm como função acompanhar a implementação da política ambiental do município, negociar demandas e interesses e mediar conflitos (LEDO, 2013).

Embora não esteja prevista de forma direta nem obrigatória a criação de Conselhos pelos municípios na Constituição Federal do Brasil de 1988, ao contrário de outros instrumentos como o plano diretor, alguns preceitos constitucionais indicam a gestão participativa nas diversas esferas de poder. Além disso, o texto constitucional ressalta a importância do município para o desenvolvimento local sustentável. Tais pressupostos são respaldados pelo princípio de descentralização e da gestão democrática, claramente explícitos na Constituição do Brasil de 1988.

A criação e a implementação dos Conselhos de Meio Ambiente vão ao encontro do estabelecido no Art. 225 da Constituição do Brasil de 1988 que enuncia como "direito comum a todos o usufruto de um meio ambiente ecologicamente equilibrado, considerado bem de uso comum e essencial à sadia qualidade de vida" (BRASIL, 2016a). De forma mais direta a relação e a função dos Conselhos podem ser identificadas na continuidade do mesmo texto ao enunciar que "compete ao poder público e à coletividade o dever de defendê-lo e de preservá-lo para as gerações atuais e futuras" (BRASIL, 2016a).

A Resolução n. 237, de 19.12.1997, do Conselho Nacional do Meio Ambiente - Conama fundamenta juridicamente, de forma mais específica, a criação e a importância dos Conselhos de Meio Ambiente através do seu Art. 20 ao tratar das competências licenciatórias dos entes federados: "Os entes federados, para exercerem suas competências licenciatórias, deverão 
ter implementados os Conselhos de Meio Ambiente, com caráter deliberativo e participação social e, ainda, possuir em seus quadros ou a sua disposição profissionais legalmente habilitados (CONSELHO NACIONAL DO MEIO AMBIENTE, 2003).

Em nível federal o Conama atende esta função. Em nível estadual há os Conselhos Estaduais de Meio Ambiente e, em nível local, os Conselhos Municipais de Meio Ambiente. Embora existam algumas recomendações estabelecidas pelo Conama e pelo Instituto Brasileiro do Meio Ambiente e dos Recursos Naturais Renováveis - IBAMA em relação às atribuições dos Conselhos, os municípios possuem autonomia para a elaboração do projeto de lei de criação, bem como para o estabelecimento de sua competência e funções. Entretanto, a composição da representação dos diversos segmentos sociais, bem como a indicação nominal dos seus membros, é estabelecida pela prefeitura.

De acordo com a Resolução n. 237, de 19.12.1997, do ConAmA, entre as principais funções geralmente atribuídas aos conselhos municipais é possível destacar as relacionadas a seguir:

- propor a política ambiental do município e fiscalizar o seu cumprimento;

- promover a educação ambiental;

- propor a criação de normas legais, bem como a adequação e regulamentação de leis, padrões e normas municipais, estaduais e federais;

- opinar sobre aspectos ambientais de políticas estaduais ou federais que tenham impactos sobre o município; e

- receber e apurar denúncias feitas pela população sobre degradação ambiental, sugerindo à prefeitura as providências cabíveis (CONSELHO NACIONAL DO MEIO AMBIENTE, 2003) .

O IBAmA sugere que o Conselho Municipal de Meio Ambiente tenha uma composição paritária, ou seja, que considere, em igualdade numérica, representantes do poder público e da sociedade civil organizada. Essa composição pode ser bipartite - poder público (municipal, estadual e federal) e outros segmentos (empresarial, sindical, academia, entidades ambientalistas etc.) - ou tripartite - poder público, setor produtivo (empresarial e sindical) e entidades.

A prefeitura deve fornecer todas as condições para o funcionamento do Conselho Municipal de Meio Ambiente. Por isso, convém que antes da sua criação seja instalado o órgão ambiental municipal. Este órgão deverá ter capacidade técnica suficiente para dar apoio, inclusive administrativo, ao funcionamento do Conselho. Cabe ainda ao executivo municipal colocar em prática as decisões do Conselho para que este se torne um efetivo instrumento de promoção de qualidade ambiental no município (CONSELHO NACIONAL DO MEIO AMBIENTE, 2003).

Além da representatividade de diversos segmentos sociais, a importância e o nível de atuação dos conselhos também podem ser avaliados de acordo com sua atividade efetiva. Desta maneira, a frequência com que realizam as reuniões, embora não revele a qualidade da atuação, nos permite diferenciá-los de alguma forma. A Pesquisa de Informações Básicas Municipais - MUNIC, do IBGE levantou esta informação. 
Foram considerados ativos, os conselhos que realizaram reunião pelo menos uma vez nos 12 meses anteriores à data de referência da pesquisa. A existência de um Conselho ativo pode indicar que há alguma forma de participação comunitária na gestão municipal.

Em 2013, 3784 municípios possuíam Conselhos de Meio Ambiente, dentre os quais 2873 eram ativos, representando 74,7\% daqueles que possuíam Conselhos de Meio Ambiente e 50,7\% do total de municípios brasileiros. Considerando que em 2001, havia 22,3\% municípios brasileiros com Conselhos ativos, houve um aumento considerável nesta forma de participação, superior a 100\% no Brasil como um todo.

A distribuição desses Conselhos por Grandes Regiões também mostra estas diferenças, conforme apresentado no Gráfico 2. Com exceção do Nordeste, que apresenta um número relativamente menor do número de municípios com Conselhos, o comportamento das outras regiões é bem semelhante entre si e com o do Brasil.

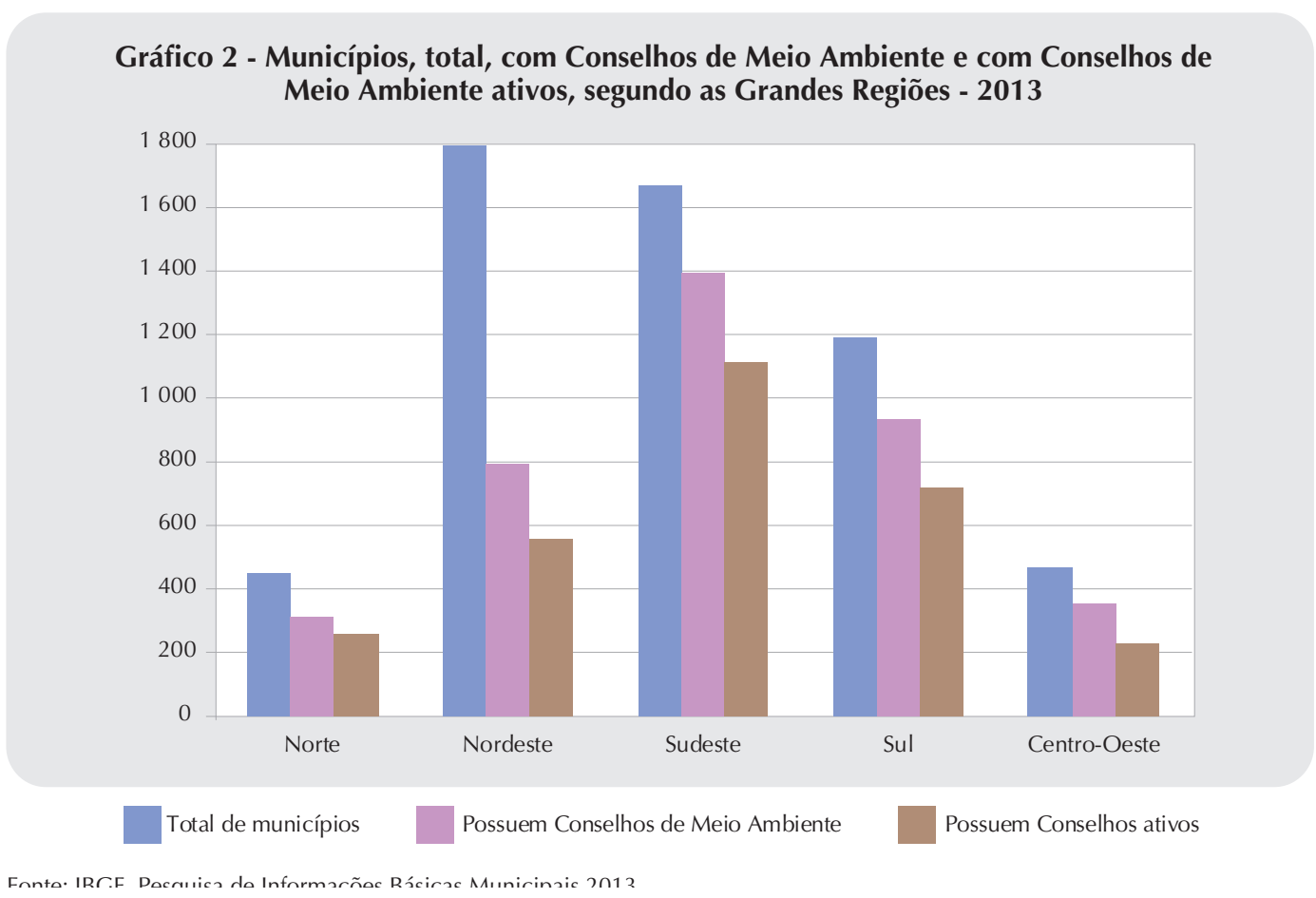

A quantidade de reuniões anuais, no entanto, varia bastante no total de municípios, desde aqueles que fizeram somente uma reunião durante o ano (381 municípios) até aquele que realizou 60 encontros (um município), conforme o Mapa 2. A média de reuniões foi em torno de seis por ano. 
As maiores frequências ocorreram nos 437 municípios que realizaram duas ou nos 402 municípios com 12 reuniões anuais. O Mapa 2 também revela que a região com maior número de municípios com Conselhos de Meio Ambiente ativos foi a Sudeste, seguida da Região Sul. Os valores percentuais também são maiores nestas duas regiões (Tabela 3). De todos os estados, Minas Gerais é o mais representado em relação ao número de Conselhos Municipais de Meio Ambiente, com 521 municípios. No entanto, se considerarmos os valores relativos, Rio de Janeiro e Rio Grande do Sul possuem posição de destaque no que se refere à atividade dos Conselhos (Tabelas 2 e 3 ).

Quando o enfoque é relacionado com o tamanho populacional dos municípios, fica evidenciada a maior participação, em termos absolutos, dos municípios menores, de até 50000 habitantes, tanto no Brasil como em cada uma das Grandes Regiões. Em termos relativos, no entanto, há uma crescente representação nas faixas de população, variando de 41,0\% (municípios com até 5000 habitantes) a 92,0\% (municípios com população superior a 500000 habitantes), conforme apresentado na Tabela 1.

Tabela 1- Municípios, total e com Conselhos Municipais de Meio Ambiente ativos, segundo as classes de tamanho da população dos municípios - Brasil - 2013

\begin{tabular}{|c|c|c|c|c|}
\hline \multirow{3}{*}{$\begin{array}{c}\text { Classes de tamanho da } \\
\text { população dos municípios }\end{array}$} & \multicolumn{4}{|c|}{ Municípios } \\
\hline & \multirow{2}{*}{\multicolumn{2}{|c|}{ Total }} & \multicolumn{2}{|c|}{ Com Conselhos de Meio Ambiente ativos } \\
\hline & & & Total & Percentual (\%) \\
\hline Brasil & & 5570 & & 51,58 \\
\hline Até 5000 hab. & & 1247 & & 41,46 \\
\hline De 5001 a 10000 hab. & & 1227 & & 42,54 \\
\hline De 10001 a 20000 hab. & & 1378 & & 46,37 \\
\hline De 20001 a 50000 hab. & & 1080 & & 61,57 \\
\hline De 50001 a 100000 hab. & & 339 & & 77,88 \\
\hline De 100001 a 500000 hab. & & 260 & & 88,46 \\
\hline Mais de 500000 hab. & & 39 & & 92,31 \\
\hline
\end{tabular}

Fonte: IBGE, Pesquisa de Informações Básicas Municipais 2013.

A Tabela 2 mostra que nas Regiões Norte e Nordeste houve o predomínio de Conselhos ativos nos municípios situados na faixa entre 10000 e 50000 habitantes, enquanto no Sudeste todos os estratos inferiores a 50000 habitantes foram bem representados. No Sul, houve destaque para o estrato das menores cidades em tamanho populacional: até 5000 habitantes. A Região Centro-Oeste é a que possui menor número de municípios com Conselhos de Meio Ambiente ativos com a participação predominante nos quatro primeiros estratos populacionais. 
Tabela 2 - Municípios com Conselhos de Meio Ambiente e com Conselhos de Meio Ambiente por Grandes Regiões, segundo as classes de tamanho da população dos municípios - 2013

\begin{tabular}{|c|c|c|c|c|c|c|c|c|c|c|}
\hline \multirow{3}{*}{$\begin{array}{c}\text { Classes de tamanho da } \\
\text { população dos municípios }\end{array}$} & \multicolumn{10}{|c|}{ Municípios com Conselhos de Meio Ambiente } \\
\hline & \multicolumn{2}{|c|}{ Norte } & \multicolumn{2}{|c|}{ Nordeste } & \multicolumn{2}{|c|}{ Sudeste } & \multicolumn{2}{|c|}{ Sul } & \multicolumn{2}{|c|}{ Centro-Oeste } \\
\hline & Total & Ativos & Total & Ativos & Total & Ativos & Total & Ativos & Total & Ativos \\
\hline Total & 450 & 258 & 1794 & 558 & 1668 & 1113 & 1191 & 717 & 467 & 227 \\
\hline Até 5000 hab. & 80 & 31 & 234 & 17 & 374 & 208 & 420 & 215 & 139 & 46 \\
\hline De 5001 a 10000 hab. & 81 & 36 & 360 & 58 & 397 & 228 & 280 & 149 & 109 & 51 \\
\hline De 10001 a 20000 hab. & 110 & 66 & 577 & 163 & 359 & 230 & 228 & 132 & 104 & 48 \\
\hline De 20001 a 50000 hab. & 111 & 68 & 443 & 197 & 290 & 226 & 159 & 122 & 77 & 52 \\
\hline De 50001 a 100000 hab. & 42 & 34 & 119 & 73 & 107 & 92 & 52 & 51 & 19 & 14 \\
\hline De 100001 a 500000 hab. & 24 & 21 & 50 & 40 & 124 & 113 & 48 & 44 & 14 & 12 \\
\hline Mais de 500000 hab. & 2 & 2 & 11 & 10 & 17 & 16 & 4 & 4 & 5 & 4 \\
\hline
\end{tabular}

Fonte: IBGE, Pesquisa de Informações Básicas Municipais 2013.

Em termos percentuais, os valores acompanham, em nível nacional, uma crescente variação, conforme o aumento do tamanho populacional dos municípios (Tabela 3).

Tabela 3 - Percentual de municípios com Conselhos de Meio Ambiente ativos em relação ao total de municípios com Conselhos de Meio Ambiente, por Grandes Regiões, segundo as classes de tamanho da população dos municípios - 2013

\begin{tabular}{|c|c|c|c|c|c|}
\hline \multirow{2}{*}{$\begin{array}{c}\text { Classes de tamanho da } \\
\text { população dos municípios }\end{array}$} & \multicolumn{5}{|c|}{ Percentual de municípios com Conselhos de Meio Ambiente ativos (\%) } \\
\hline & Norte & Nordeste & Sudeste & Sul & Centro-Oeste \\
\hline Total & 57,3 & 31,1 & 66,7 & 60,2 & 48,6 \\
\hline Até 5000 hab. & 38,8 & 7,3 & 55,6 & 51,2 & 33,1 \\
\hline De 5001 a 10000 hab. & 44,4 & 16,1 & 57,4 & 53,2 & 46,8 \\
\hline De 10001 a 20000 hab. & 60,0 & 28,2 & 64,1 & 57,9 & 46,2 \\
\hline De 20001 a 50000 hab. & 61,3 & 44,5 & 77,9 & 76,7 & 67,5 \\
\hline De 50001 a 100000 hab. & 81,0 & 61,3 & 86,0 & 98,1 & 73,7 \\
\hline De 100001 a 500000 hab. & 87,5 & 80,0 & 91,1 & 91,7 & 85,7 \\
\hline Mais de 500000 hab. & 100,0 & 90,9 & 94,1 & 100,0 & 80,0 \\
\hline
\end{tabular}

Fonte: IBGE, Pesquisa de Informações Básicas Municipais 2013.

A atuação dos Conselhos Municipais de Meio Ambiente pode contribuir para a melhoria da qualidade de vida da população municipal, visto suas atribuições de "definir, acompanhar, fiscalizar, promover e avaliar políticas, ações, projetos e programas referentes às questões relativas ao meio ambiente" (RIO DE JANEIRO, 2010, p. 62) dentre as quais os focos mais visíveis são os serviços relacionados com o saneamento ambiental (abastecimento de água, coleta e destinação do lixo, coleta e destinação dos esgotos sanitários e a drenagem pluvial). 
Mapa 2 - Municípios com Conselho de Meio Ambiente ativo - 2013

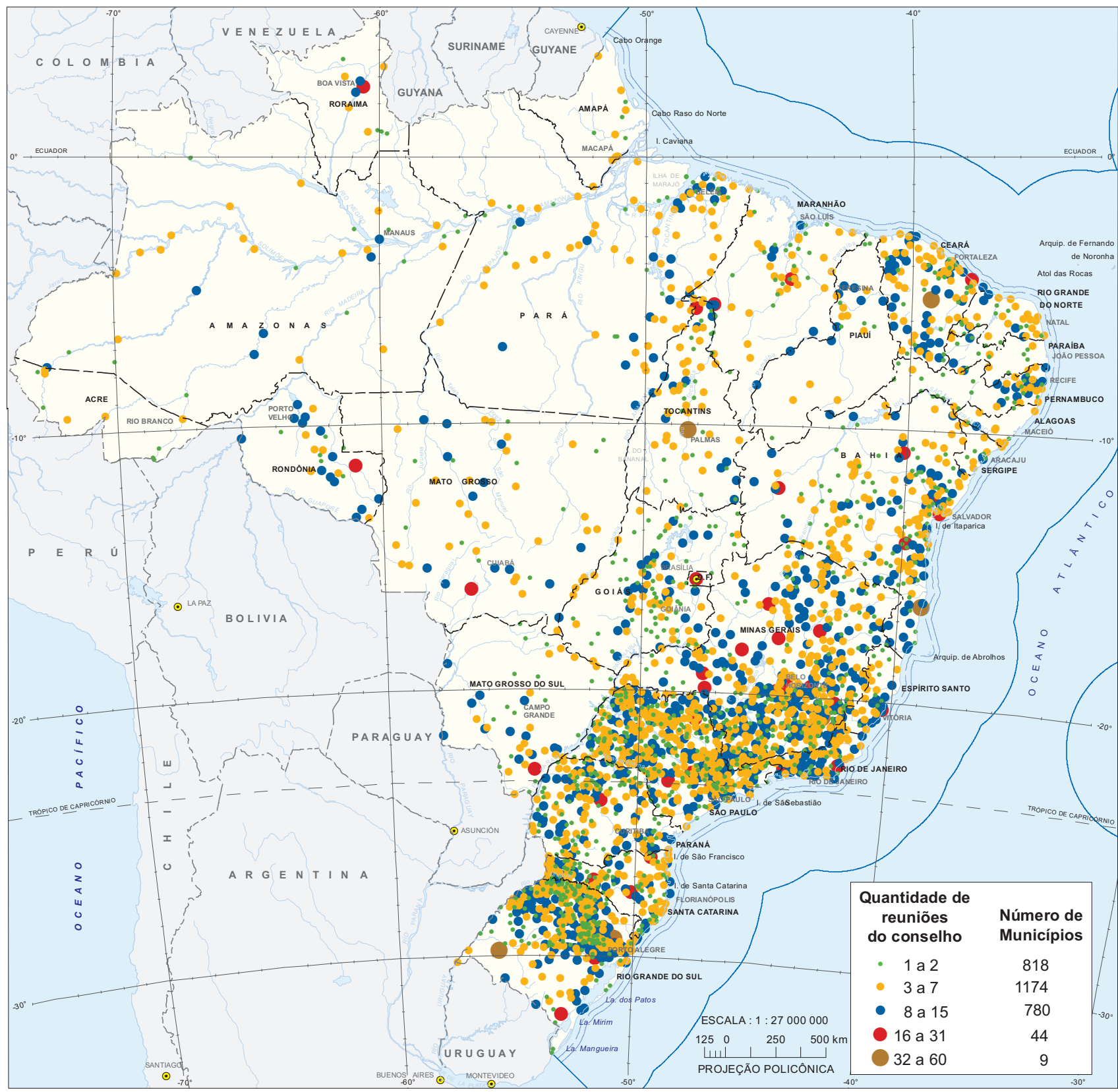

Fonte: IBGE, Pesquisa de Informações Básicas Municipais 2013. 


\section{Comitês de Bacias Hidrográficas}

Os Comitês de Bacias Hidrográficas - CBH integram o Sistema Nacional de Gerenciamento de Recursos Hídricos - SINGREH, criado pela Lei n. 9.433, de 08.12.1997, que estabelece a Política Nacional de Recursos Hídricos. Segundo essa Política, os comitês têm como competência: promover o debate entre as entidades intervenientes; articular sua atuação; arbitrar conflitos referentes ao uso da água; e aprovar o Plano de Recursos Hídricos, entre outras atribuições. Os comitês são arranjos institucionais compostos por representantes das esferas de governo federal, estadual e municipal, da sociedade civil, do setor privado e dos usuários das águas.

Com efeito, eles representam uma das formas de articulação intermunicipal ou entre a União e os Estados. Trata-se, portanto, de um modelo de gestão descentralizado e participativo para a tomada de decisões relativas ao uso, à recuperação e à conservação dos recursos hídricos. Os recursos hídricos podem contribuir para a segurança alimentar e nutricional, a saúde pública, a geração de hidroenergia, entre outros objetivos de desenvolvimento sustentável. Sua gestão, integrada e efetiva deve, portanto, considerar os aspectos ambientais, econômicos, sociais e político-institucionais das bacias hidrográficas.

De acordo com a MUNIC, do IBGE, em 2013, 73,1\% do total de municípios brasileiros participavam de CBH, enquanto em 2002 representavam 46,8\% (PERFIL..., 2014).

A distribuição destes municípios por classes de tamanho populacional, apresentada na Tabela 4, deixa evidenciada uma relevante participação em todos os estratos populacionais, considerando que tais valores relativos são superiores a $65,0 \%$ de participação em cada um destes estratos. Observamos também que há a mesma tendência em relação aos Conselhos de Meio Ambiente, caracterizada pela participação crescente, conforme o tamanho dos municípios, chegando à quase totalidade nos municípios com população superior a 500000 habitantes.

Tabela 4 - Municípios, total e que participam de Comitê de Bacia Hidrográfica segundo as classes de tamanho da população dos municípios - Brasil - 2013

\begin{tabular}{l|r|r|r}
\hline \multirow{2}{*}{$\begin{array}{c}\text { Classes de tamanho da } \\
\text { população dos municípios }\end{array}$} & \multirow{3}{|c}{ Municípios } \\
\cline { 3 - 5 } & Total & \multicolumn{2}{|c}{ Que participam de Comitê de Bacia Hidrográfica } \\
\cline { 3 - 5 } & & Total & Percentual (\%) \\
\hline \multirow{2}{*}{ Brasil } & $\mathbf{5 5 7 0}$ & $\mathbf{4 ~ 0 7 4}$ & $\mathbf{7 3 , 1}$ \\
Até 5000 hab. & 1247 & 826 & 66,2 \\
De 5001 a 10000 hab. & 1227 & 859 & 70,0 \\
De 10001 a 20000 hab. & 1378 & 1006 & 73,0 \\
De 20001 a 50000 hab. & 1080 & 826 & 76,5 \\
De 50001 a 100 000 hab. & 339 & 291 & 85,8 \\
De 100 001 a 500 000 hab. & 260 & 230 & 88,5 \\
Mais de 500000 hab. & 39 & 36 & 92,3 \\
\hline
\end{tabular}

Fonte: IBGE, Pesquisa de Informações Básicas Municipais 2013. 
No recorte das Grandes Regiões, o Norte é a única que se diferencia quanto à tendência apresentada no Brasil de participação crescente conforme o tamanho da população, como apresentado na Tabela 5. Nesta região, ao contrário das demais, as cidades de até 5000 habitantes possuem maior representação em $\mathrm{CBH}$.

A distribuição segundo as Grandes Regiões (Tabela 5) mostra que a Região Sudeste possui a maior participação de municípios com CBH (93,2\%) e do percentual correspondente às cidades com população acima de 500000 habitantes (94,1\%). A Região Sul também tem uma representação considerável, acompanhando o comportamento de primazia destas duas regiões em relação às institucionalidades participativas consideradas neste artigo. Por outro lado, a Região Norte é a que possui o menor número de municípios e a menor participação deles em CBH (34,9\%). Nesta região, Rondônia (32,7\%) possui maior percentual de participação municipal em Comitês, embora este ainda seja baixo se considerarmos a maioria dos estados do País.

Tabela 5 - Percentual de municípios com participação em Comitês de Bacias Hidrográficas, por Grandes Regiões, segundo as classes de tamanho da população dos municípios - 2013

\begin{tabular}{|c|c|c|c|c|c|}
\hline \multirow{2}{*}{$\begin{array}{l}\text { Classes de tamanho da } \\
\text { população dos municípios }\end{array}$} & \multicolumn{5}{|c|}{ Percentual de municípios com participação em Comitês de Bacias Hidrográficas (\%) } \\
\hline & Norte & Nordeste & Sudeste & Sul & Centro-Oeste \\
\hline Total & 34,9 & 65,2 & 93,2 & 77,1 & 58,7 \\
\hline Até 5000 hab. & 56,3 & 47,4 & 86,9 & 66,0 & 48,9 \\
\hline De 5001 a 10000 hab. & 33,3 & 52,5 & 91,9 & 75,7 & 60,6 \\
\hline De 10001 a 20000 hab. & 35,5 & 65,3 & 93,6 & 84,6 & 58,7 \\
\hline De 20001 a 50000 hab. & 16,2 & 76,5 & 97,9 & 85,5 & 63,6 \\
\hline De 50001 a 100000 hab. & 38,1 & 88,2 & 99,1 & 94,2 & 78,9 \\
\hline De 100001 a 500000 hab. & 41,7 & 80,0 & 99,2 & 97,9 & 71,4 \\
\hline Mais de 500000 hab. & 100,0 & 81,8 & 94,1 & 100,0 & 100,0 \\
\hline
\end{tabular}

Fonte: IBGE, Pesquisa de Informações Básicas Municipais 2013.

No Nordeste, Ceará $(94,6 \%)$ e Pernambuco $(77,3 \%)$ se destacam com valores acima do valor médio da região $(65,2 \%)$ e do Brasil $(73,0 \%)$. O estado menos representado nesta região é o Maranhão, com apenas 27,0 \% de municípios com participação em $\mathrm{CBH}$.

Na Região Sul há uma representação bem equilibrada entre os três estados que a compõe, com um pequeno predomínio de Santa Catarina $(84,7)$, enquanto no Centro-Oeste destaca-se o Estado de Mato Grosso do Sul (86,0\%).

Os extremos são representados pelo Estado do Amapá, que não possui municípios com participação em CBH, e o Estado de São Paulo, no qual apenas um de seus 645 municípios não faz parte desse tipo de organismo (PERFIL..., 2014). 
Através da representação no Mapa 3 é possível visualizarmos o comportamento apresentado anteriormente, relativo à distribuição da participação municipal nas Unidades da Federação do País e nas regiões hidrográficas.

As regiões hidrográficas correspondem à divisão que considera as grandes bacias hidrográficas do País, definidas segundo o Conselho Nacional de Recursos Hídricos - CNRH. De acordo com a Resolução n. 32, de 15.10.2003, do CNRH, o Brasil passou a ser dividido em 12 regiões hidrográficas, conforme apresentadas no Mapa 3.

As regiões hidrográficas, cujos municípios possuem maior participação em CBH são aquelas nas quais as suas áreas territoriais estão predominantemente nas Regiões Sul e Sudeste do País, reforçando o padrão apresentado anteriormente quando analisamos a distribuição por Unidades da Federação. O Mapa 3 e a Tabela 6 evidenciam a maior representação espacial e participação das Bacias do Atlântico Sudeste, do Rio Paraná, Rio São Francisco e Rio Uruguai.

Destaca-se, neste sentido, a Bacia do Atlântico Sudeste que contém as Bacias do Rio Paraíba do Sul e do Rio Doce. Nessas bacias, distinguem-se os CBH do Rio Doce, nos Estados de Minas Gerais e Espírito Santo; do Rio Paraíba do Sul, nos Estados de São Paulo, Rio de Janeiro e Minas Gerais; dos Rios Piracicaba, Capivari e Jundiaí - PCJ, e do Rio Grande, ambos nos Estados de Minas Gerais e São Paulo.

O Comitê da Bacia do Rio São Francisco, representando a bacia do mesmo nome, também merece destaque dada a participação de mais de 400 municípios, abrangendo os Estados da Bahia, Minas Gerais, Pernambuco, Alagoas, Sergipe e Goiás, além do Distrito Federal.

Por outro lado, as Bacias Amazônica e Atlântico Nordeste Ocidental possuem as menores representações de municípios participantes de $\mathrm{CBH}$ (23,4\% e 27,2\%, respectivamente) (Tabela 6).

Tabela 6 - Municípios, total e com participação em Comitês de Bacias Hidrográficas, segundo as Regiões Hidrográficas - Brasil - 2013

\begin{tabular}{|c|c|c|c|}
\hline \multirow{3}{*}{ Regiões Hidrográficas } & \multicolumn{3}{|c|}{ Municípios } \\
\hline & \multirow{2}{*}{ Total } & \multicolumn{2}{|c|}{ Com participação em Comitês de Bacias Hidrográficas } \\
\hline & & Total & Percentual (\%) \\
\hline Total & 5563 & 4074 & 73,2 \\
\hline Amazônica & 274 & 64 & 23,4 \\
\hline Tocantins- Araguaia & 383 & 168 & 43,9 \\
\hline Nordeste Ocidental & 195 & 53 & 27,2 \\
\hline Parnaíba & 262 & 111 & 42,4 \\
\hline Nordeste Oriental & 740 & 514 & 69,5 \\
\hline São Francisco & 453 & 397 & 87,6 \\
\hline Atlântico Leste & 490 & 407 & 83,1 \\
\hline Atlântico Sudeste & 509 & 459 & 90,2 \\
\hline Paraná & 1398 & 1233 & 88,2 \\
\hline Atlântico Sul & 427 & 323 & 75,6 \\
\hline Uruguai & 355 & 295 & 83,1 \\
\hline Paraguai & 77 & 50 & 64,9 \\
\hline
\end{tabular}

Fontes: 1. IBGE, Pesquisa de Informações Básicas Municipais 2013. 2. Agência Nacional de Águas - ANA. 
Mapa 3 - Municípios com participação em Comitê de Bacia Hidrográfica - 2013

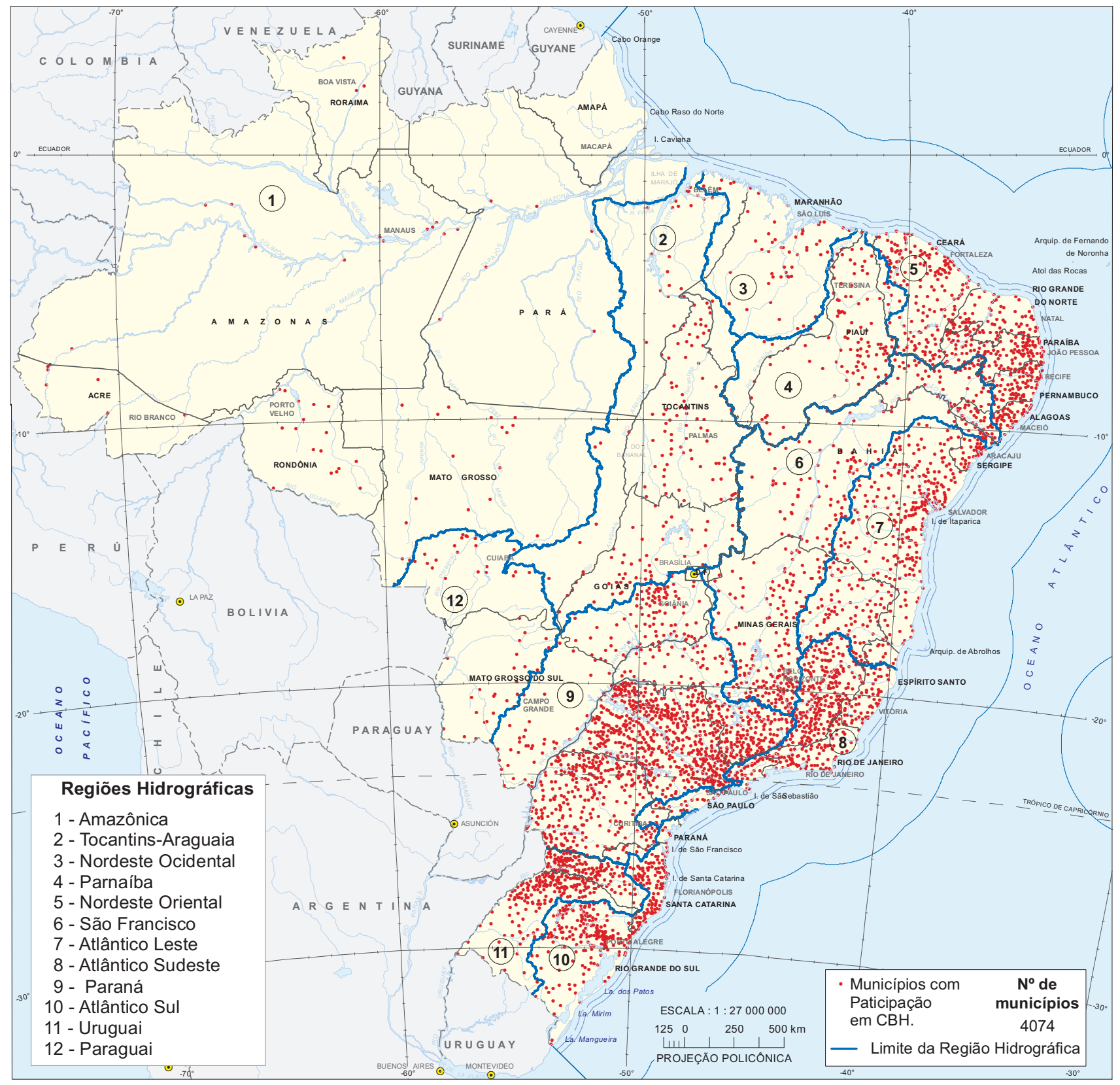

Fontes: 1. IBGE, Pesquisa de Informações Básicas Municipais 2013. 2. Agência Nacional de Águas - ANA. 


\section{Fórum da Agenda 21 Local}

A Agenda 21 Local constitui uma estratégia de apoio ao desenvolvimento contínuo participativo e multissetorial, que trata de questões ambientais, sociais, econômicas, políticas, institucionais e culturais, tendo como base alguns princípios básicos: formação de parcerias, participação social e responsabilidade compartilhada entre governo e sociedade. Portanto, acompanhar a sua expansão geográfica pelo País, o seu avanço ou retrocesso, se reveste de grande relevância enquanto medida do avanço de instrumentos da governança no território brasileiro.

Em 2002, 29,7\% dos municípios brasileiros haviam iniciado a construção da Agenda 21 Local que, em números absolutos, correspondia a 1652 municípios. A proporção era maior (cerca de 69,7\%) entre os mais populosos (acima de 500000 habitantes), fazendo com que metade da população brasileira residisse em municípios com Agenda 21 Local iniciada, segundo o Suplemento de Meio Ambiente da MUNIC 2002 (PERFIL..., 2005). Segundo a Munic 2009, esse percentual alcançou apenas 19,9\%, permanecendo a concentração (60,0\%) das Agendas em municípios mais populosos. Ocorreu uma queda do percentual na Região Nordeste (63,8\%, em 2002, para 25,8\%, em 2009) (PERFIL..., 2010). Isto revela a importância de se construir arranjos institucionais formando uma vasta rede de parcerias, com a participação de governos, organizações da sociedade civil e empresas, além do protagonismo local, para que as iniciativas sejam bem-sucedidas, assegurando a sustentabilidade do processo de desenvolvimento local.

Em 2012, a proporção de municípios com Agenda 21 iniciada alcançou 18,1\%, sendo que entre estes, 57,9\% possuíam mais de 500000 habitantes, proporção menor do que em 2002, conforme a MUNIC 2012 (PERFIL..., 2013). Em 2013, 21,5\% dos municípios (1 197, em números absolutos) haviam iniciado a elaboração das Agendas, sendo que destes, 25,9\% eram municípios entre 20001 e 50000 habitantes e 22,0\% tinham entre 10001 e 20000 habitantes (PERFIL..., 2014).

Os Fóruns da Agenda 21 Local são institucionalidades compostas por representantes do poder público e da sociedade civil, com a missão de elaborar, monitorar e avaliar o Plano Local de Desenvolvimento Sustentável. Uma das suas principais atribuições é representar os anseios dos participantes durante o processo de formulação de políticas e de elaboração e implementação do Plano, definindo uma visão de futuro desejado pela comunidade, que se traduza em ações a serem incluídas no planejamento municipal.

Em 2002, os Fóruns da Agenda 21 Local estavam presentes em 15,0\% dos municípios brasileiros, representando 47,0\% dos que possuíam Agenda 21. Em 2009, a proporção alcançou 11,0\%, representando 63,0\% dos que possuíam Agenda 21. Em 2013, cerca de 13,8\% dos municípios brasileiros possuíam Fórum da Agenda 21 Local, o que representava 64,2\% dos municípios com Agenda 21. Apenas 5,1\% do total dos municípios brasileiros possuíam Fórum ativo (282), ou seja, que se reuniu nos últimos 12 meses à data da pesquisa.

No seu conjunto representavam 23,6\% dos municípios com Agenda 21 iniciada. A distribuição segundo a etapa da Agenda 21 era a seguinte: 110 municípios estavam na etapa de sensibilização/mobilização (39,0\%); 35 estavam definindo o diagnóstico e metodologia (12,4\%); 56 estavam elaborando o Plano Local de Desenvolvimento Sustentável $(19,9 \%)$ e 81 estavam na fase de implementação das ações da Agenda em políticas públicas (28,7\%) (Mapa 4). 
Mapa 4 - Municípios com Fórum da Agenda 21 Local, segundo o estágio da Agenda - 2013

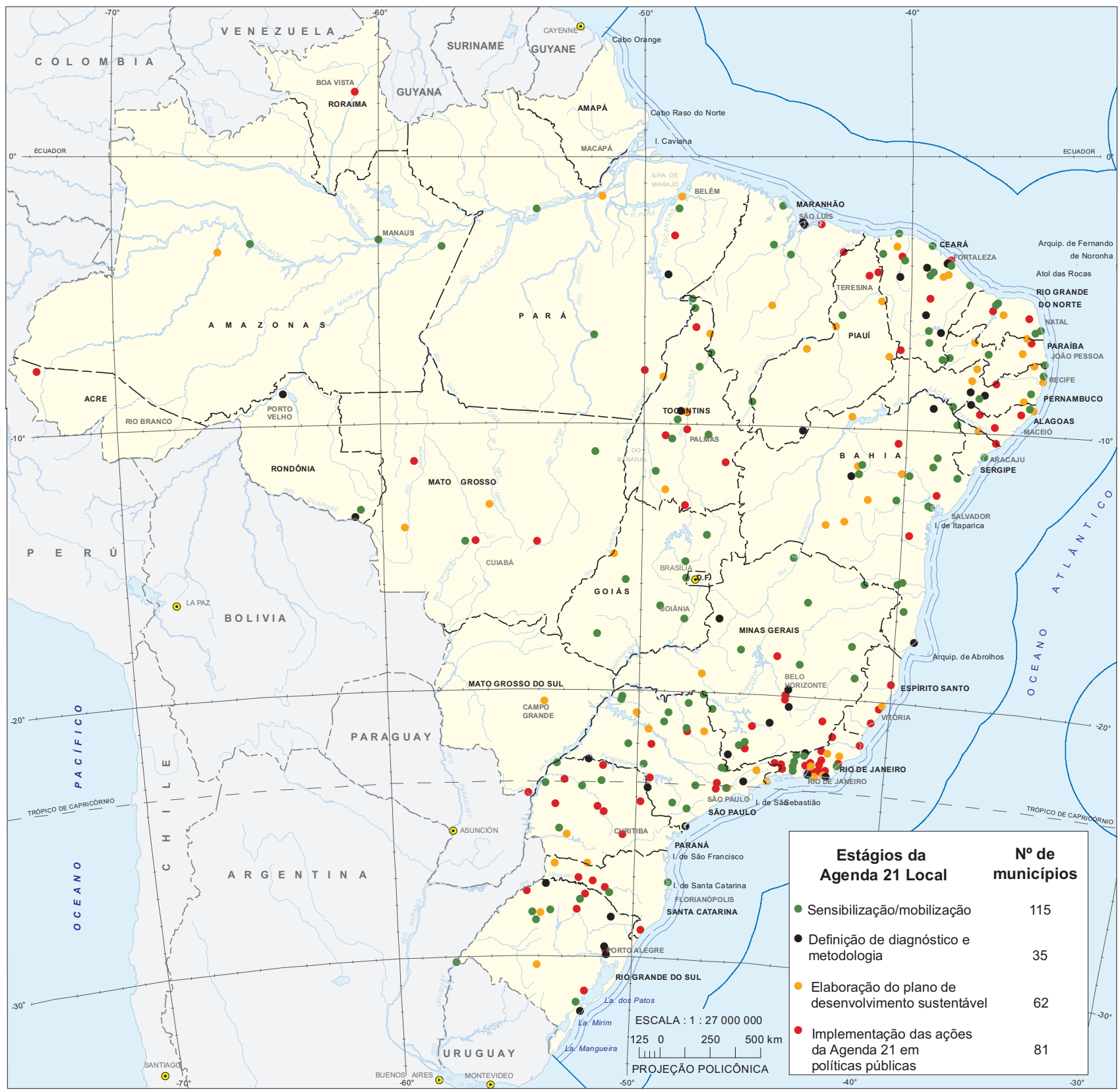

Fonte: IBGE, Pesquisa de Informações Básicas Municipais 2013. 


\section{Articulações interinstitucionais e parcerias na área de meio ambiente}

\section{Consórcios públicos e parcerias com o setor privado}

As dinâmicas locais não podem estar isoladas, sendo necessário articular estratégias municipais com as regionais, nacionais ou até internacionais, a médio e longo prazos, para que as experiências locais possam evoluir a partir das conexões externas virtuosas. A articulação entre os locais pode ser facilitada pela criação de novas formas de gestão, mais flexíveis, ou novas institucionalidades responsáveis por uma gestão intermunicipal voltada para o desenvolvimento regional, como os consórcios de municípios, os $\mathrm{CBH}$, os Conselhos Regionais, os pactos e agências regionais (DOWBOR, 2008). Elas representam "organizações intermediárias entre o Estado, o mercado e a sociedade, que vão instrumentalizar as estratégias de desenvolvimento local" (ALBUQUERQUE; ZAPATA, 2010, p. 224), facilitam a realização de projetos comuns e a resolução de problemas.

As formas de associação na área de meio ambiente, consideradas neste trabalho, foram: consórcios públicos e administrativos entre os entes federativos, convênios de parceria com o setor privado, apoio do setor privado ou de comunidades, programas na área ambiental desenvolvidos em parceria com o governo federal, participação do município na Comissão Interinstitucional de Educação Ambiental - CIEA, participação do município nos Governos Locais pela Sustentabilidade (Local Governments for Susteinability - ICLEI). ${ }^{6}$

Os consórcios públicos são definidos como:

parcerias formadas por dois ou mais entes da federação, para a realização de objetivos de interesse comum em qualquer área, voltados para o desenvolvimento regional. Os consórcios podem ser firmados entre todas as esferas de governo (municípios-municípios, municípios-estados, municípiosestado-União). Entretanto, a União somente participará de consórcios públicos em que também façam parte todos os estados em cujos territórios estejam situados os municípios consorciados. Todo consórcio público possui CNPJ (BRASIL, 2005 apud PESQUISA..., 2011, p. 14).

Sobre os consórcios públicos, Senra declara:

O consórcio público é um instrumento que visa fortalecer a cooperação federativa e dá consistência legal ao arranjo institucional de caráter público para as parcerias entre município, estado, Distrito Federal e União. Os consórcios públicos poderão apoiar a execução de políticas com conteúdos transversais e multidisciplinares. Esta importância se destaca especialmente nas regiões metropolitanas, aglomerações urbanas, bacias hidrográficas, Rides, mesorregiões e microrregiões geográficas onde os grandes problemas urbanos e regionais dependem de gestão compartilhada (SENRA, 2010, p. 62).

\footnotetext{
6 Fundada em 1990 como a International Council for Local Environmental Initiatives - ICLEl.
} 
Os consórcios administrativos são firmados visando interesses comuns nas esferas de governo:

são convênios formados por dois ou mais entes da federação, para a realização de objetivos de interesse comum em qualquer área, voltados para o desenvolvimento regional. Podem ser firmados entre todas as esferas de governo (municípios-municípios, municípios-estados, municípios-estado-União). Entretanto, a União somente participará de consórcios administrativos em que também façam parte todos os estados em cujos territórios estejam situados os municípios consorciados (BRASIL, 2005 apud PESQUISA..., 2011, p. 14).

Convênio de parceria com o setor privado é o "acordo firmado entre o município e o setor privado que assumem e pactuam responsabilidades de projetos e/ou serviços". Apoio do setor privado ou de comunidades "são as ações que contribuem para a realização de algum projeto ou manutenção de serviços em que não seja obrigatória a contrapartida da prefeitura" (BRASIL, 2005 apud PESQUISA..., 2011, p. 15).

Em 2009, era baixo o nível de articulação interinstitucional para tratar de questões ambientais com outros municípios e outras esferas de governo e/ou com o setor privado, conforme apresentado na Tabela 7. Apenas $17,5 \%$ dos municípios realizavam consórcio intermunicipal, proporção que reduziu em 2011 (14,9\%). Para os demais níveis de governo e o setor privado os percentuais eram inferiores a 10,0\% em 2009. Em 2011, as proporções de municípios que realizavam consórcios com o estado e com o governo federal aumentaram em relação a 2009, sendo que apenas 5,6\% dos municípios realizavam consórcio com o governo federal na área de meio ambiente enquanto em 2009 esta proporção era de 2,9\%.

Tabela 7 - Municípios com Articulação Interinstitucional na Política de Meio Ambiente, segundo o tipo de ariticulação interinstitucional - Brasil - 2009/2011

\begin{tabular}{|c|c|c|c|c|c|}
\hline \multirow{3}{*}{ Tipo de Articulação Interinstitucional } & \multicolumn{5}{|c|}{ Municípios com Articulação na Área de Meio-Ambiente } \\
\hline & \multicolumn{2}{|c|}{ Total } & \multicolumn{3}{|c|}{ Proporção (\%) (1) } \\
\hline & 2009 & 2011 & 2009 & & \\
\hline Consórcio Intermunicipal & \multicolumn{2}{|c|}{ (2) 974} & \multicolumn{2}{|c|}{17,5} & 14,9 \\
\hline Consórcio com o Estado & (2) 496 & (3) 693 & \multicolumn{2}{|r|}{8,9} & 12,5 \\
\hline Consórcio com o Governo Federal & (2) 160 & (3) 309 & \multicolumn{2}{|c|}{2,9} & 5,6 \\
\hline Convênio de Parceria com o Setor Privado & 360 & 328 & \multicolumn{2}{|r|}{6,5} & 5,9 \\
\hline Apoio do Setor Privado & 437 & 327 & \multicolumn{2}{|r|}{7,9} & 5,9 \\
\hline
\end{tabular}

Fonte: IBGE, Pesquisa de Informações Básicas Municipais 2009/2011.

(1) Proporção em relação ao número total de municípios brasileiros. (2) Consórcio público. (3) Para permitir a comparação com o ano de 2009 foram considerados conjuntamente os consórcios públicos e administrativos.

Em termos absolutos, o consórcio público intermunicipal era o tipo de articulação que predominava em 2011, praticado em 704 municípios, seguido do consórcio administrativo com o estado (431 municípios) e do convênio de parceria com o setor privado (328 municípios) (Mapas 5, 6 e 7). 
Mapa 5 - Municípios com articulações interinstitucionais: consórcio público - 2011

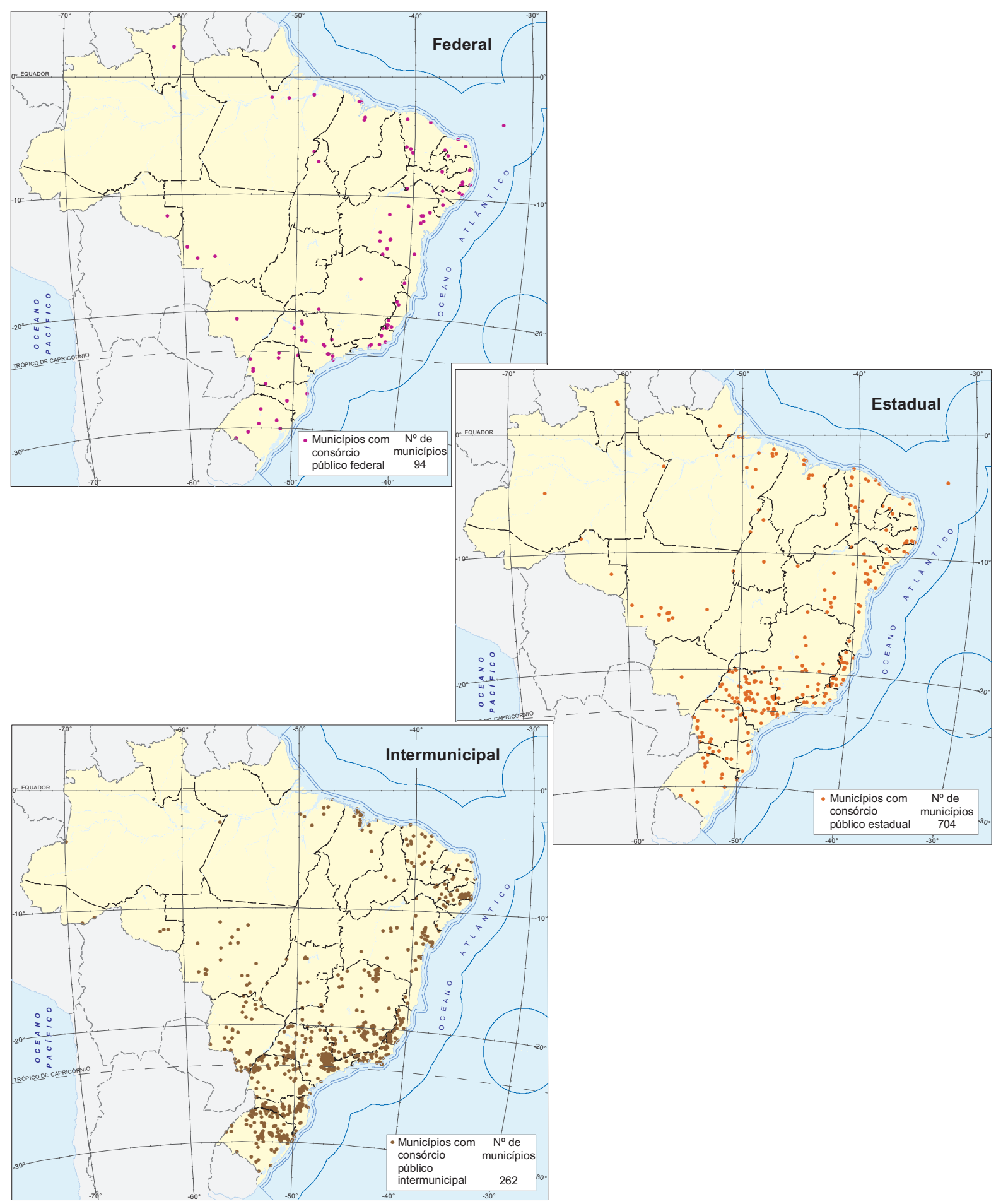

Fonte: IBGE, Pesquisa de Informações Básicas Municipais 2011. 
Mapa 6 - Municípios com articulações interinstitucionais: consórcio administrativo - 2011

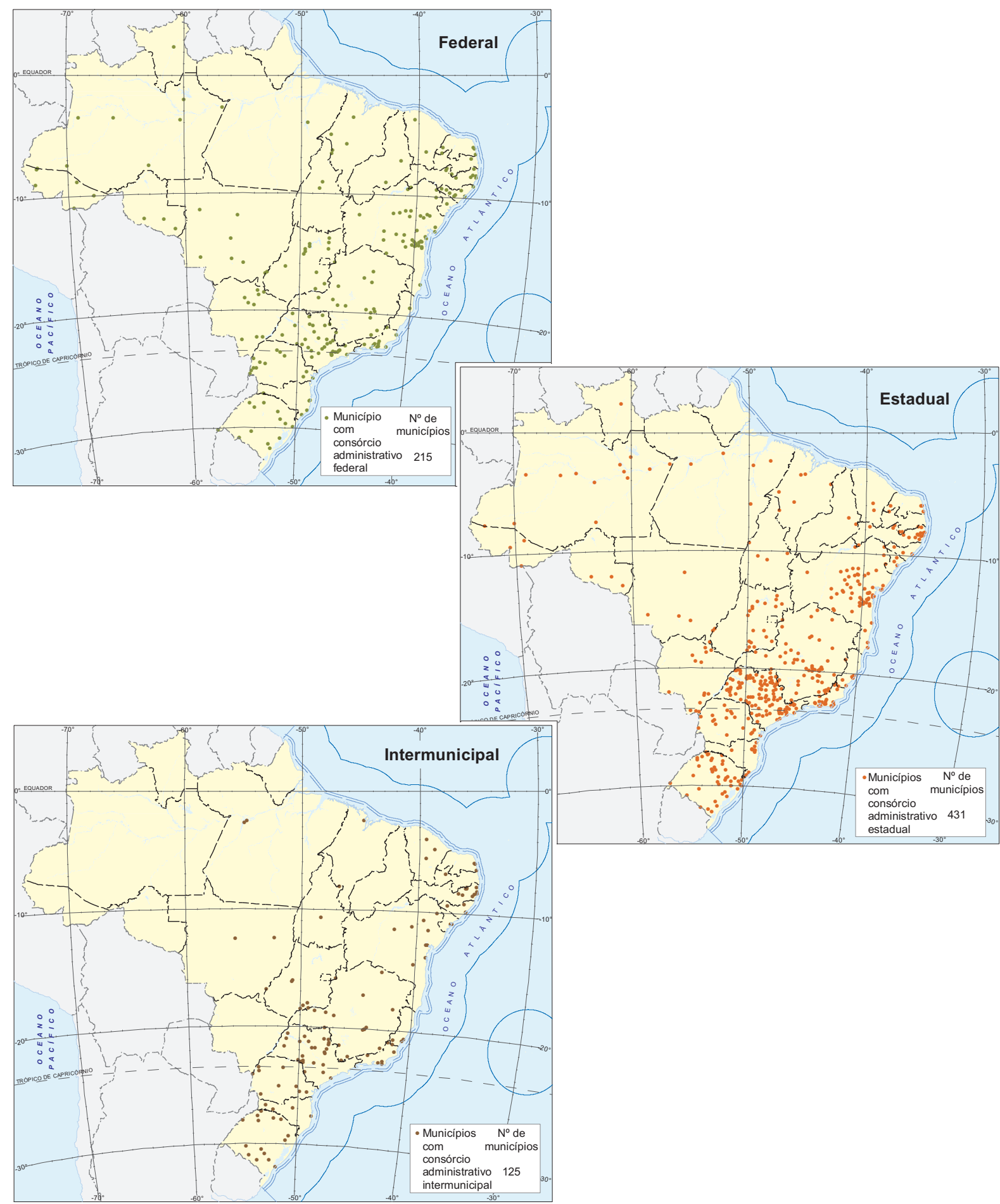

Fonte: IBGE, Pesquisa de Informações Básicas Municipais 2011. 
Mapa 7 - Municípios com articulações interinstitucionais - 2011
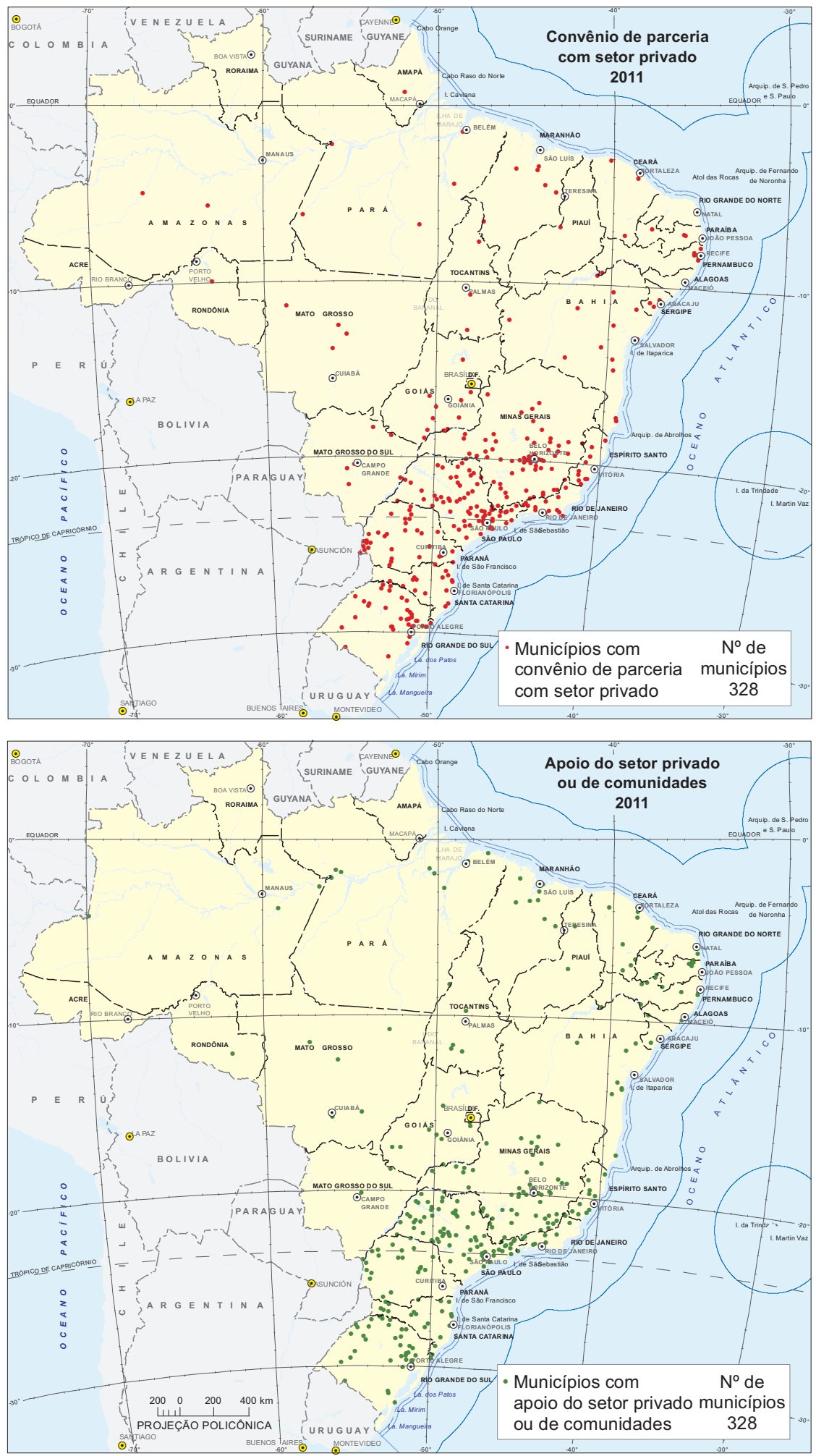

Fonte: IBGE, Pesquisa de Informações Básicas Municipais 2011. 


\section{Outros programas de parcerias}

A MUNIC, do IBGE investigou em 2013 a presença, nos municípios, de um conjunto de programas da área ambiental desenvolvidos em parceria com o governo federal, que estão descritos no Quadro 1.

Quadro 1 - Programas e ações ambientais do governo federal

\begin{tabular}{|c|c|c|}
\hline Programas ambientais & Descrição geral dos Programas & Órgãos responsáveis \\
\hline Coletivo Educador & $\begin{array}{l}\text { Conjuntos de instituições atuantes em processos } \\
\text { formativos permanentes, participativos, } \\
\text { continuados e voltados à totalidade e diversidade } \\
\text { de habitantes de um determinado território. É } \\
\text { resultado e realizador do Programa Nacional de } \\
\text { Educação Ambiental - ProNEA e do Programa } \\
\text { Nacional de Formação de Educadoras e } \\
\text { Educadores Ambientais - ProFEA. }\end{array}$ & Ministério do Meio Ambiente \\
\hline Sala Verde & $\begin{array}{l}\text { É um espaço definido, vinculado a uma } \\
\text { instituição pública ou privada, que poderá se } \\
\text { dedicar a projetos, ações e programas } \\
\text { educacionais voltados à questão ambiental. São } \\
\text { potenciais centros de informação e formação } \\
\text { ambiental. }\end{array}$ & $\begin{array}{l}\text { Departamento de Educação Ambiental do } \\
\text { Ministério do Meio Ambiente }\end{array}$ \\
\hline Circuito Tela Verde - CTV & $\begin{array}{l}\text { Tem o objetivo de atender à demanda por } \\
\text { material audiovisual para tratar a educação } \\
\text { ambiental nos espaços educadores; estimular a } \\
\text { produção audiovisual independente sobre a } \\
\text { temática socioambiental. }\end{array}$ & $\begin{array}{l}\text { Departamento de Educação Ambiental - } \\
\text { DEA e Secretaria de Articulação } \\
\text { Institucional e Cidadania Ambiental - } \\
\text { SAIC do Ministério do Meio Ambiente em } \\
\text { parceira com a Secretaria do Audiovisual - } \\
\text { SAv do Ministério da Cultura. }\end{array}$ \\
\hline $\begin{array}{l}\text { Conferência Nacional } \\
\text { Infantojuvenil pelo Meio } \\
\text { Ambiente - CNIJMA }\end{array}$ & $\begin{array}{l}\text { Campanha pedagógica que traz a dimensão da } \\
\text { política ambiental para a educação que mobiliza } \\
\text { jovens entre } 11 \text { e } 14 \text { anos em pesquisas e debates } \\
\text { com a comunidade escolar sobre os desafios } \\
\text { socioambientais contemporâneos. }\end{array}$ & $\begin{array}{l}\text { Diretoria de Educação Ambiental - DEA } \\
\text { do Ministério do Meio Ambiente } \\
\text { Coordenação Geral de Educação } \\
\text { Ambiental - CGEA do Ministério da } \\
\text { Educação }\end{array}$ \\
\hline $\begin{array}{l}\text { Educação Ambiental no Plano } \\
\text { de Gestão Integrada de Resíduos } \\
\text { Sólidos -PGIRS }\end{array}$ & $\begin{array}{l}\text { Programas e ações de educação ambiental devem } \\
\text { fazer parte do PGIRS conforme proposta } \\
\text { metodológica contida no manual de orientação } \\
\text { do plano. }\end{array}$ & Ministério do Meio Ambiente \\
\hline $\begin{array}{l}\text { Agenda Ambiental na } \\
\text { Administração Pública - A3P }\end{array}$ & $\begin{array}{l}\text { Tem o objetivo de implementar a gestão } \\
\text { socioambiental sustentável das atividades } \\
\text { administrativas e operacionais do governo. Seus } \\
\text { princípios vão desde uma mudança dos } \\
\text { investimentos, compras e contratação de serviços } \\
\text { pelo governo até uma gestão adequada dos } \\
\text { resíduos gerados e dos recursos naturais } \\
\text { utilizados visando a melhoria da qualidade de } \\
\text { vida no ambiente de trabalho. }\end{array}$ & Ministério do Meio Ambiente \\
\hline
\end{tabular}

Fontes: 1. IBGE, Pesquisa de Informações Básicas Municipais 2013. 2. Ministério do Meio Ambiente. Ver referências. 
No que se refere à participação dos municípios nestes programas da área ambiental, 34,1\% (1 902) dos municípios brasileiros implantaram pelo menos um dos programas investigados, segundo a MUNIC, realizada pelo IBGE em 2013 (PERFIL..., 2014). Ainda segundo a MUNIC 2013,

o programa de maior incidência (25,5\%) é o de Educação Ambiental no Plano de Gestão Integrada de Resíduos Sólidos, por ser este último uma exigência prevista na legislação da Política Nacional de Resíduos Sólidos. A elaboração desse plano é condição para o município ter acesso a recursos, incentivos e financiamentos do governo federal disponíveis para essa área (PERFIL..., 2014, p. 73).

Os demais programas têm a seguinte participação percentual, em relação ao total de municípios brasileiros: Conferência Infantojuvenil pelo Meio Ambiente $(9,0 \%)$, Sala Verde (6,5\%), Sustentabilidade ambiental das instituições públicas como a Agenda Ambiental na Administração Pública (5,2\%), Coletivo Educador (4,4\%) e Circuito Tela Verde (1,7\%) (Mapa 8).

Em 2013, somente 6,4\% dos municípios brasileiros participavam da Comissão Interinstitucional de Educação Ambiental - CIEA, com pelo menos uma reunião realizada nos últimos 12 meses (Mapa 9).

A CIEA tem como finalidade,

promover a discussão, a gestão, a coordenação, o acompanhamento e a avaliação, bem como a implementação das atividades em educação ambiental. A Comissão pode ser de âmbito estadual ou similar, podendo ser de caráter consultivo e/ou deliberativo (PERFIL..., 2014, p. 74).

A MuNIC pesquisou, em 2012, a participação do município em alguma rede internacional de cidades. Entre os temas tratados no questionário da pesquisa, selecionamos a rede ICLEl, que é uma "associação democrática e internacional de governos locais e organizações governamentais nacionais e regionais que assumiram um compromisso com o desenvolvimento sustentável" (PERFIL..., 2013, anexo). Cabe observar que apenas 19 municípios participavam desta rede no ano considerado: Aveiro, Fortaleza, Belo Horizonte, Contagem, Vitória, Rio de Janeiro, Campinas, Cananéia, Guarulhos, Mauá, Osasco, Santo André, São Carlos, São Paulo, Guaratuba, Toledo, Porto Alegre, Santa Maria e Goiânia. 
Mapa 8 - Parceria de governo municipal com o governo federal para implementação de programas de meio ambiente, por tipo de programa - 2013
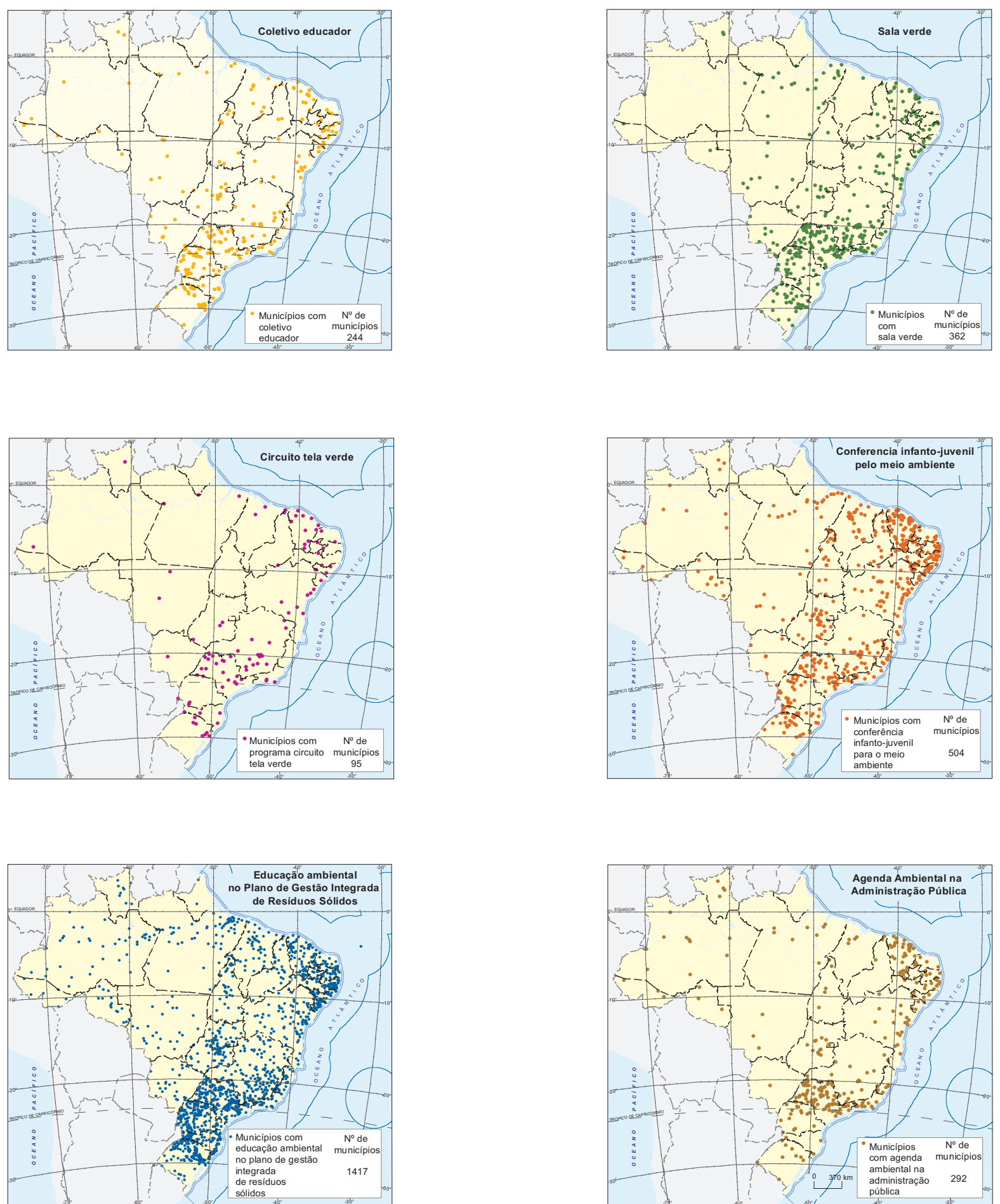

Fonte: IBGE, Pesquisa de Informações Básicas Municipais 2013. 
Mapa 9 - Comissão Interinstitucional de Educação Ambiental - CIEA de âmbito estadual ou similar - 2013

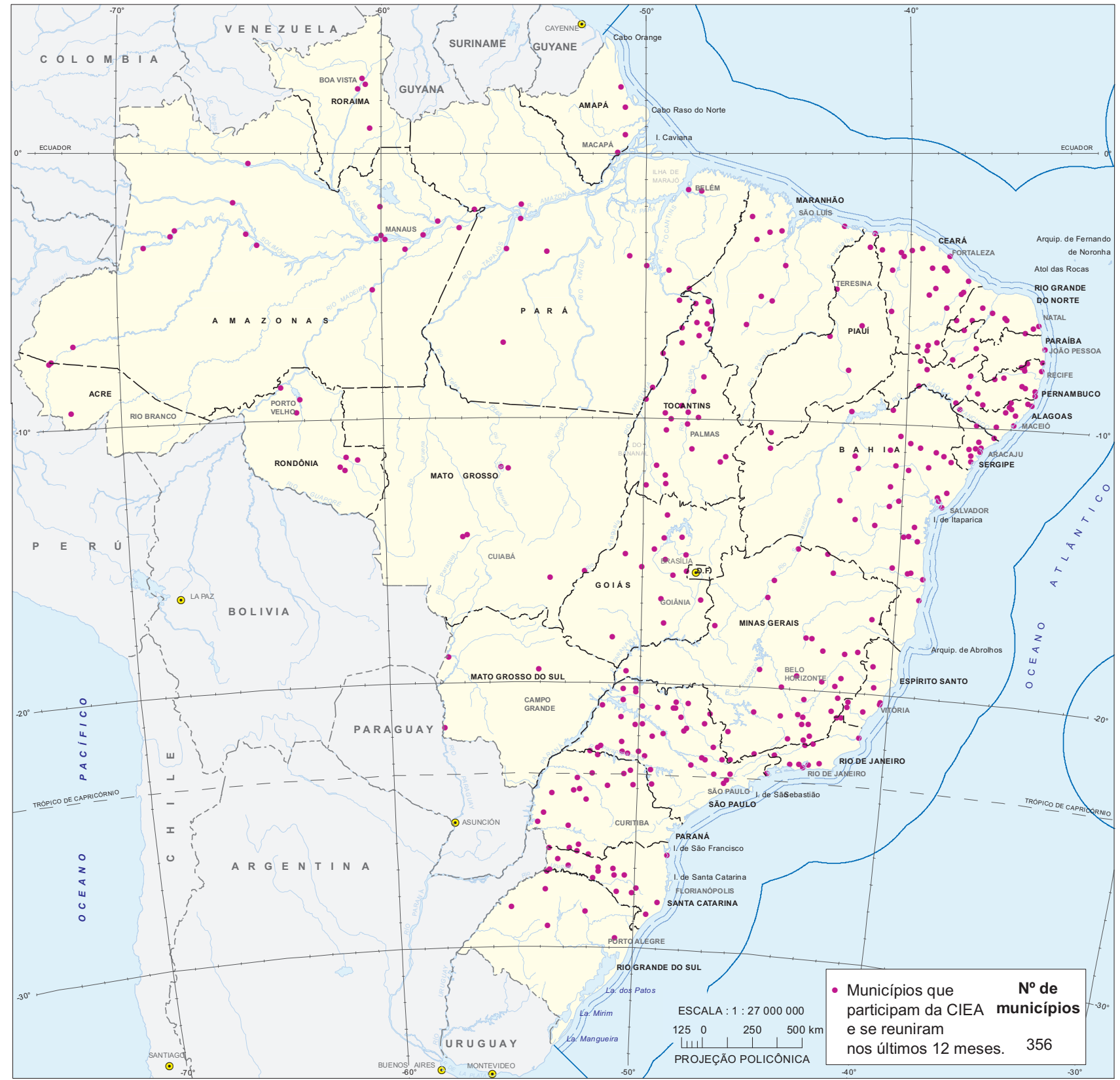

Fonte: IBGE, Pesquisa de Informações Básicas Municipais 2013. 


\section{Considerações finais}

As institucionalidades participativas correspondentes aos Conselhos de Meio Ambiente, Comitês de Bacias Hidrográficas e Fórum da Agenda 21 Local, consideradas neste capítulo, apresentaram algumas semelhanças quanto à frequência de ocorrência nos municípios e, portanto, em sua distribuição geográfica no território brasileiro.

Os Conselhos tiveram representação em 3784 municípios $(67,9)$, sendo ativos em 2873 (51,5). A participação em Comitês de bacias foi a mais representativa, ocorrendo em 4074 municípios brasileiros (73,0\%); enquanto a participação no Fórum da Agenda 21 Local foi a menos representativa, com a ocorrência em 1197 municípios brasileiros (21,5\%). Nos três casos houve maior participação nas Regiões Sudeste e Sul e em municípios com população superior a 500000 habitantes. No entanto, apenas 212 municípios possuem, simultaneamente, Conselho de Meio Ambiente ativo, Comitê de Bacia e Fórum ativo da Agenda 21 Local (Mapas 2, 3 e 4), revelando, a princípio, uma maior participação e poder de articulação e intervenção nas questões que envolvem a gestão ambiental e o desenvolvimento local. No entanto, conforme comentado anteriormente, a quantificação em si não nos permite garantir a qualidade e efetiva participação da sociedade civil nestes organismos e os resultados efetivos no espaço local. Outros elementos seriam necessários para mensuração de tais efeitos nos municípios brasileiros.

Em termos de articulações e parcerias, cerca de 29,1\% dos municípios brasileiros efetuam algum tipo de articulação interinstitucional, seja com outro ente federativo ou com o setor privado. Destes, 87,5\% realizam de 1 a 2 tipos de articulação (1 418 municípios); 10,4\% realizam de 3 a 4 tipos de articulação (168 municípios); e 2,1\% realizam de 5 a 7 tipos (34 municípios) (Mapa 10). Aproximadamente 108 municípios têm convênio de parceria com o setor privado e também recebem apoio do setor privado, 42 municípios têm os três tipos de consórcio público (intermunicipal, estadual e federal) e 19 municípios têm consórcio administrativo simultaneamente nos três níveis (intermunicipal, estadual e federal).

Aproximadamente 34,0\% dos municípios brasileiros tem algum programa de meio ambiente praticado em parceria com o governo federal, o que representa 1902 municípios. Destes, 87,1\% (1 657 municípios) têm 1 ou 2 programas implementados, 11,3\% (214) têm 3 ou 4 programas e somente 1,6\% (31) tem 5 ou 6 (Mapa 10). Os municípios que têm simultaneamente os seis programas mencionados neste trabalho são: Buriti dos Lopes, Fortaleza, Juazeiro do Norte, Quixeramobim, Severínia, Suzanópolis e Itaguajé.

As diferentes práticas de governança aqui consideradas cruzam-se, por diversas vias, na temática do desenvolvimento local. Múltiplas escalas estão presentes, no sentido de que foram consideradas formas de articulação entre diferentes níveis de governo (município-município, município-estado, município-União), entre governo municipal e iniciativa privada, nas diversas esferas públicas (Conselhos, Comitês, Fóruns) e nos vínculos internacionais, como o ICLEI. Vale ressaltar que a existência destas formas de governança, sobretudo quando ocorrem simultaneamente num mesmo território, pode indicar alterações no modo de perceber e construir o desenvolvimento. No entanto, é necessário avaliar se a participação da sociedade é efetiva, ou seja, se a gestão é de fato compartilhada e como estas formas nutrem as experiências de desenvolvimento local. 
Mapa 10 - Municípios com articulações interinstitucionais e parcerias na área de meio ambiente - 2011/2013
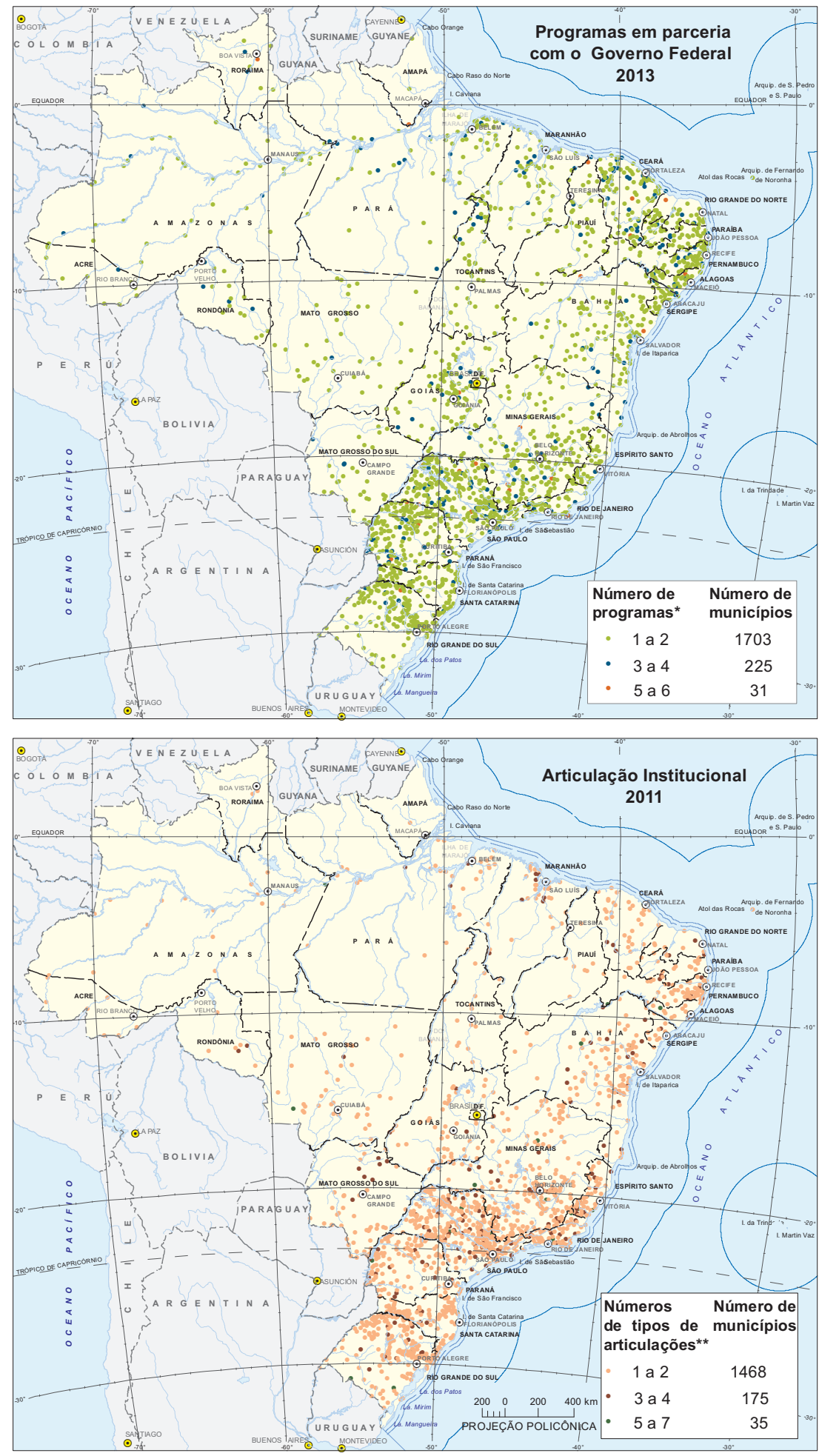

Fonte: IBGE, Pesquisa de Informações Básicas Municipais 2011/2013. 


\section{Referências}

ALBAGLI, S. Sociedade da informação e do conhecimento: novos desafios às políticas de informação em ciência, tecnologia e inovação. In: CONGRESSO BRASILEIRO DE SOCIOLOGIA, 13., 2007, Recife. Anais... Recife: Universidade Federal de Pernambuco - UFPE, 2007. Disponível em: <http://www.sbsociologia.com.br/portal/index. php?option=com_docman>. Acesso em: jun. 2016.

Território e territorialidade. In: BRAGA, C.; MORELLI, G.; LAGES, V. N. (Org.). Territórios em movimento: cultura e identidade como estratégia de inserção competitiva. Rio de Janeiro: Relume Dumará; Brasília, DF: Serviço de Apoio às Micro e Pequenas Empresas - Sebrae, 2004. Apresentação Ignacy Sachs. p. 25-69. Disponível em: <http://inspirebr.com. br/uploads/midiateca/d64c55dfd943251ede2b6330035a5994.pdf>. Acesso em: jun. 2016.

ALBAGLI, S.; BRITTO, J. (Org). Glossário de arranjos e sistemas produtivos e inovativos locais: relatório da fase piloto. Rio de Janeiro: Universidade Federal do Rio de Janeiro UFRJ, Instituto de Economia, 2002. Estudo da Rede de Pesquisa em Sistemas Produtivos e Inovativos Locais - RedSist. Disponível em: <http://www.ie.ufrj.br/redesist/Glossario/ Glossario\%20Sebrae.pdf>. Acesso em: jun. 2016.

ALBUQUERQUE, F.; ZAPATA, T. A importância da estratégia de desenvolvimento local/territorial no Brasil. In: DOWBOR, L., POCHMANN, M. (Org.). Políticas para o desenvolvimento local. São Paulo: Fundação Perseu Abramo - FPA, 2010. p. 215-229. Disponível em: <http://dowbor.org/blog/wp-content/uploads/2012/06/10PochmannLivroLo calPoliticas-1.pdf>. Acesso em: jun. 2016.

ALCOFORADO, F. Globalização e desenvolvimento. São Paulo: Nobel, 2006. 213 p.

BACIAS hidrográficas. Brasília, DF: Agência Nacional de Águas - ANA. Disponível em: $<$ http://www2.ana.gov.br/Paginas/portais/bacias/default.aspx>. Acesso em: jun. 2016.

BRASIL. Constituição (1988). Constituição da República Federativa do Brasil. Brasília, DF, [2016a]. Disponível em: <http://www.presidencia.gov.br/legislacao> Acesso em: jun. 2016.

Lei n. 11.107, de 6 de abril de 2005. Dispõe sobre normas gerais de contratação de consórcios públicos e dá outras providências. In: PESQUISA de informações básicas municipais: manual de coleta: 2011. [Rio de Janeiro]: IBGE, 2011. Disponível em: <http:// biblioteca.ibge.gov.br/index.php/biblioteca-catalogo?view=detalhes\&id=52632>. Acesso em: jun. 2016.

Ministério do Meio Ambiente. Agenda ambiental na administração pública: A3P. Brasília, DF, 2016b. Disponível em: <http://www.mma.gov.br/destaques/item/8852>. Acesso em: jun. 2016.

Ministério do Meio Ambiente. Circuito tela verde. Brasília, DF, 2016c. Disponível em: <http://www.mma.gov.br/educacao-ambiental/educomunicacao/circuito-tela-verde>. Acesso em: jun. 2016. 
Ministério do Meio Ambiente. Coletivos educadores. Brasília, DF, 2016d. Disponível em: $\quad<$ http://www.mma.gov.br/educacao-ambiental/formacao/pronatec/item/363forma\%C3\%A7\%C3\%A3o-de-educadores-coletivos-educadores>. Acesso em: jun. 2016.

- Ministério do Meio Ambiente. Conferência Nacional Infantojuvenil pelo Meio Ambiente. Brasília, DF, 2016e. Disponível em: <http://conferenciainfanto.mec.gov.br/>. Acesso em: jun. 2016.

Ministério do Meio Ambiente. Planos de gestão de resíduos sólidos: manual de orientação: apoiando a implementação da política nacional de resíduos sólidos: do nacional ao local. Brasília, DF, 2016f. Disponível em: <http://www.mma.gov.br/estruturas/182/_ arquivos/manual_de_residuos_solidos3003_182.pdf>. Acesso em: jun. 2016.

Ministério do Meio Ambiente. Salas verdes. Brasília, DF, 2016g. Disponível em: $<$ http://www.mma.gov.br/educacao-ambiental/educomunicacao/salas-verdes $>$. Acesso em: jun. 2016.

BUARQUE, S. C. Construindo o desenvolvimento local sustentável: metodologia de planejamento. Rio de Janeiro: Garamond, 2002. 177 p. (Terra mater).

COMITÊS de Bacias Hidrográficas. Brasília, DF, 2014. Disponível em: <http://www.cbh.gov. br/>. Acesso em: jun. 2016.

CONJUNTO de normas legais: recursos hídricos. 7 ed. Brasília, DF: Conselho Nacional de Recursos Hídricos - CNRH. 2011.

CONJUNTURA dos recursos hídricos no Brasil 2013. Brasília, DF: Agência Nacional de Águas - ANA, 2013. Disponível em: <http://arquivos.ana.gov.br/institucional/spr/conjuntura/ webSite_relatorioConjuntura/projeto/index.html>. Acesso em: jun. 2016.

CONSELHO NACIONAL DE RECURSOS HÍDRICOS (Brasil). Resolução n. 32, de 15 de outubro de 2003. Institui a Divisão Hidrográfica Nacional. Brasília, DF: CNRH, 2003. Disponível em: <http://www.cnrh.gov.br/>. Acesso em: jun. 2016.

CONSELHO NACIONAL DO MEIO AMBIENTE (Brasil). Resolução n. 237, de 19 de dezembro de 1997. Regulamenta os aspectos de licenciamento ambiental estabelecidos na Política Nacional do Meio Ambiente. Brasília, DF: Conama, 1997. Disponível em: <http:// www.mma.gov.br/port/conama/res/res97/res23797.html>. Acesso em: jun. 2016.

CONSELHOS de meio ambiente no Brasil: conselhos estaduais, conselhos municipais. Brasília, DF: Ministério do Meio Ambiente, 2014. Disponível em: <http://www.mma.gov.br/ port/conama/conselhos/conselhos.cfm>. Acesso em: jun. 2016.

D'ARAúJO, M. C. Capital social. Rio de Janeiro: Zahar, 2003. 65 p. (Passo a passo, 25).

DOWBOR, L. Democracia econômica: alternativas de gestão social. Petrópolis: Vozes, 2008. 214 p.

FRANCO. A. de. Desenvolvimento local integrado e sustentável: dez consensos. Proposta: experiências em educação popular. Rio de Janeiro: Federação de Órgãos para Assistência Social e Educacional - FASE, v. 27, n. 78, 1998. 
Pobreza e desenvolvimento local. Brasília, DF: Agência de Educação para o Desenvolvimento - AED, 2002. 294 p.

AS FUNDAÇÕES privadas e associações sem fins lucrativos no Brasil 2010. Rio de Janeiro: IBGE, 2012. 173 p. (Estudos e pesquisas. Informação econômica, n. 20). Acompanha 1 CD-ROM. Estudo realizado pelo IBGE em parceria com o Instituto de Pesquisa Econômica Aplicada - IPEA, a Associação Brasileira de Organizações Não Governamentais - Abong e o Grupo de Institutos, Fundações e Empresas - GIFE. Disponível em: <ftp://ftp.ibge.gov.br/ Fundacoes_Privadas_e_Associacoes/2010/fasfil.pdf>. Acesso em: jun. 2016.

INDICAÇÕES geográficas brasileiras. Brasília, DF: Serviço Brasileiro de Apoio às Micro e Pequenas Empresas - Sebrae; Instituto Nacional da Propriedade Industrial - INPI, 2014. 264 p. Disponível em: <http://www.sebrae.com.br/sites/PortalSebrae/bis/catalogo-indicacoesgeograficas-brasileiras,c1e390411e9e9410VgnVCM2000003c74010aRCRD>. Acesso em: jun. 2016.

INDICADORES de desenvolvimento sustentável: Brasil 2015. Rio de Janeiro: IBGE, 2015. 351 p. Disponível em: <http://biblioteca.ibge.gov.br/index.php/biblioteca-catalogo?view=d etalhes\&id=294255>. Acesso em: jun. 2016.

LEDO, S. O papel dos conselhos municipais de meio ambiente e de desenvolvimento sustentável. [S. I.: s. n.], [2013].

MELO NETO, F. P. de; FRÓES, C. Empreendedorismo social: a transição para a sociedade sustentável. Rio de Janeiro: Qualitymark, 2002. 208 p.

OLIVEIRA, S. M. C. de; BARCELLOS, F. C.; GREEN, A. P. L. Urbanização, impactos ambientais e governança no complexo regional centro-sul. Revista Iberoamericana de Economía Ecológica - Revibec, Morelia: Universidad Nacional Autônoma de México - UNAM, v. 16-17, p. 17-32, 2011. Disponível em: <http://www.redibec.org/revibec.html>. Acesso em: jun. 2016.

PERFIL dos municípios brasileiros 2009. Rio de Janeiro: IBGE, 2010. 477 p. Acompanha 1CD-ROM. Acima do título: Pesquisa de Informações Básicas Municipais. Disponível em: $<$ http://www.ibge.gov.br/home/estatistica/economia/perfilmunic/defaulttab1_perfil.shtm>. Acesso em: jun. 2016.

PERFIL dos municípios brasileiros 2012. Rio de Janeiro: IBGE, 2013. 271 p. Acompanha 1CD-ROM. Acima do título: Pesquisa de Informações Básicas Municipais. Disponível em: $<$ http://www.ibge.gov.br/home/estatistica/economia/perfilmunic/defaulttab1_perfil.shtm>. Acesso em: jun. 2016.

PERFIL dos municípios brasileiros 2013. Rio de Janeiro: IBGE, 2014. 284 p. Acompanha 1CD-ROM. Acima do título: Pesquisa de Informações Básicas Municipais. Disponível em: $<$ http://www.ibge.gov.br/home/estatistica/economia/perfilmunic/defaulttab1_perfil.shtm>. Acesso em: jun. 2016.

PERFIL dos municípios brasileiros: meio ambiente 2002. Rio de Janeiro: IBGE, 2005. Acompanha 1CD-ROM. Acima do título: Pesquisa de Informações Básicas Municipais. Disponível em: <http://www.ibge.gov.br/home/estatistica/economia/perfilmunic/meio_ ambiente_2002/default.shtm>. Acesso em: jun. 2016. 
PAIVA, F.; MONTEIRO, J. de P. Os 5 elementos: a essência da gestão compartilhada no pacto de cooperação do Ceará. Rio de Janeiro: Qualitymark, 2001. 119 p.

PAULA, J. de. Desenvolvimento local: textos selecionados. Brasília, DF: Serviço Brasileiro de Apoio às Micro e Pequenas Empresas - Sebrae, 2008. 79 p.

PECQUEUR, B. O desenvolvimento territorial: uma nova abordagem dos processos de desenvolvimento para as economias do Sul. Raízes, Campina Grande: Universidade Federal de Campina Grande - UFCG, Centro de Humanidades, v. 24, n. 1/2, p. 10-22, jan./dez. 2005. Disponível em: <http://www.ufcg.edu.br/ raizes/>. Acesso em: jun. 2016.

RIO DE JANEIRO (RJ). Rio Lei Orgânica do Município. 2. ed. rev. e ampl. Rio de Janeiro: Procuradoria-Geral do Município - PGM, 2010. 224 p. Texto atualizado até a Emenda n. 20/2009. Disponível em: <http://www.rio.rj.gov.br/web/pgm>. Acesso em: jun. 2016.

SANTOS, M. O espaço do cidadão. 7. ed. São Paulo: Editora da Universidade de São Paulo - Edusp, 2007. 176 p. (Coleção Milton Santos, 8).

SENRA, K. V. Políticas e instituições para desenvolvimento econômico territorial: o caso do Brasil. Santiago do Chile: Comissão Econômica para a América Latina e o Caribe Cepal, 2010. 109 p. (Desarrollo territorial, 8). Disponível em: <http://bibspi.planejamento. gov.br/bitstream/handle/iditem/499/05\%20Desenvolvimento\%20territorial_ILPES. pdf? sequence=1>. Acesso em: jun. 2016.

SILVEIRA, C. M. Desenvolvimento local e novos arranjos socioinstitucionais: algumas referências para a questão da governança. In: DOWBOR, L.; POCHMANN, M. (Org.). Políticas para o desenvo/vimento local. São Paulo: Fundação Perseu Abramo - FPA, 2010. 400 p. p. 41- 65. Disponível em: <http://dowbor.org/blog/wp-content/uploads/2012/06/10P ochmannLivroLocalPoliticas-1.pdf>. Acesso em: jun. 2016.

SINGER, P. Economia solidária: um modo de produção e distribuição. In: SINGER, P.; SOUZA, A. R. (Org.). Economia solidária no Brasil: a autogestão como resposta ao desemprego. 2. ed. São Paulo: Contexto, 2003, 360 p. p. 11-28. (Coleção Economia).

SPERANZA, J. S. Limites e possibilidades do desenvolvimento local. Sinais Sociais, Rio de Janeiro: Serviço Social do Comércio - Sesc, v. 1, n. 2, p. 142-187, set./dez. 2006. Disponível em: <http://www.sesc.com.br/wps/wcm/connect/9e034e9d-479e-4acbbe2f-a78653d3cd07/02.pdf?MOD=AJPERES\&CACHEID=9e034e9d-479e-4acb-be2fa78653d3cd07>. Acesso em: jun. 2006.

TENÓRIO, F. G. Cidadania e desenvolvimento local: critérios de análise. Rio de Janeiro: Fundação Getulio Vargas - FGV, 2012. 264 p. 


\title{
Diversidade e patrimônio cultural
}

\author{
Ana Maria Goulart Bustamante \\ Jorge Kleber Teixeira Silva \\ "A diversidade das culturas humanas está atrás de nós, \\ à nossa volta e à nossa frente" \\ (LÉVI-STRAUSS, 2000) \\ “[...] a diversidade cultural é, para o gênero humano, tão necessária \\ como a diversidade biológica para a natureza" \\ (Declaração Universal sobre a Diversidade Cultural)
}

Uma das chaves de entendimento da geografia do Brasil contemporâneo diz respeito ao tema das diversidades brasileiras e ao conjunto dos direitos a elas relacionados, de acordo com leis e instrumentos de governança internacionais, como a Convenção para a Proteção do Patrimônio Mundial, Cultural e Natural, instituída, em 1972, durante a Conferência Geral da Organização das Nações Unidas para a Educação, a Ciência e a Cultura - UNESCO, e a Convenção sobre Diversidade Biológica, estabelecida, em 1992, durante a Conferência das Nações Unidas sobre Meio Ambiente e Desenvolvimento, a Rio-92.

Com efeito, assim como existe uma diversidade sociocultural e natural no território brasileiro, forjada no decorrer do processo histórico de povoamento do País, existe igualmente uma complexidade normativa que regula, na atualidade, essa diversidade, por meio de uma variedade de fontes, como leis, decretos, tratados e convenções internacionais, que são absorvidos pela legislação nacional, conforme Quadro 1. 
Quadro 1 - Atos multilaterais promulgados pelo Brasil no campo da diversidade cultural

\begin{tabular}{|c|c|c|c|c|c|}
\hline \multirow{2}{*}{ Nome } & \multicolumn{2}{|c|}{ Promulgação } & \multicolumn{2}{|c|}{$\begin{array}{c}\text { Aprovação pelo Congresso } \\
\text { Nacional }\end{array}$} & \multirow[b]{2}{*}{ Observações } \\
\hline & Decreto $\mathrm{n}$. & Data & $\begin{array}{l}\text { Decreto } \\
\text { Legislativo } \\
\text { n. }\end{array}$ & Data & \\
\hline $\begin{array}{l}\text { Convenção Relativa à Proteção } \\
\text { do Patrimônio Mundial, } \\
\text { Cultural e Natural }\end{array}$ & 80978 & 12.12 .1977 & (1) 74 & 30.06 .1977 & $\begin{array}{l}\text { Adotada em Paris, } \\
\text { em novembro de 1972, } \\
\text { na XVII sessão da } \\
\text { Conferência Geral } \\
\text { da Organização das } \\
\text { Nações Unidas para } \\
\text { a Educação, a Ciência } \\
\text { e a Cultura (1) }\end{array}$ \\
\hline $\begin{array}{l}\text { Convenção sobre Diversidade } \\
\text { Biológica }\end{array}$ & 2519 & 16.03.1998 & (1) 2 & 03.02 .1994 & $\begin{array}{l}\text { Assinada no Rio de Janeiro em } \\
05.06 .1992 \text { (1) }\end{array}$ \\
\hline $\begin{array}{l}\text { Convenção n } 169 \text { da } \\
\text { Organização Internacional do } \\
\text { Trabalho - OIT sobre Povos } \\
\text { Indígenas e Tribais }\end{array}$ & 5051 & 19.04 .2004 & (1)143 & 20.06.2002 & $\begin{array}{l}\text { Adotada em Genebra, em } \\
27.06 .1989 \text { (1) }\end{array}$ \\
\hline $\begin{array}{l}\text { Convenção para a Salvaguarda } \\
\text { do Patrimônio Cultural } \\
\text { Imaterial }\end{array}$ & 5753 & 12.04 .2006 & (1) 22 & 01.02 .2006 & $\begin{array}{l}\text { Adotada em Paris, } \\
\text { em 17.10.2003 } \\
\text { e assinada em } \\
03.11 .2003 \text { (1) }\end{array}$ \\
\hline $\begin{array}{l}\text { Convenção sobre a Proteção e } \\
\text { Promoção da Diversidade das } \\
\text { Expressões Culturais }\end{array}$ & 6177 & 01.08 .2007 & 485 & 20.12 .2006 & $\begin{array}{l}\text { Assinada em Paris, } \\
\text { em 20.10.2005, } \\
\text { com Instrumento } \\
\text { de Ratificação } \\
\text { depositado pelo } \\
\text { Brasil em 16.01.2007. } \\
\text { Entrou em vigor } \\
\text { internacional em } \\
18.03 .2007\end{array}$ \\
\hline
\end{tabular}

Fonte: Shiraishi Neto, J. (Org.). Direito dos povos e das comunidades tradicionais no Brasil: declarações, convenções internacionais e dispositivos jurídicos definidores de uma política nacional. Manaus: Universidade Federal do Amazonas - UFAM, Programa de Pós-Graduação em Sociedade e Cultura na Amazônia - PPGSCA; Fundação Ford, 2007. (Coleção documentos de bolso, n. 1). Disponível em: <http://novacartografiasocial.com/?wpdmact=process\&did=MjEuaG90bGluaw==>. Acesso em: jan. 2016.

Desde a Convenção para a Proteção do Patrimônio Mundial, Cultural e Natural, de 1972, a UNESCO divulga regularmente uma lista na qual são elencados bens considerados de importância para toda a humanidade. No Brasil, a distribuição espacial desses bens, escolhidos como patrimônio da humanidade (Mapa 1), reflete a geografia traçada pelos processos históricos que construíram a sociodiversidade cultural brasileira. Isto é, eles se localizam principalmente na costa atlântica leste, nos muitos portos "naturais" associados ao povoamento inicial da colônia portuguesa e que hoje são as cidades históricas, desde São Luís, no Maranhão, e Olinda, em Pernambuco, esta última ligada ao porto de Recife, além de São Cristóvão, em Sergipe, Salvador, na Bahia (ou Baía de Todos os Santos) e Rio de Janeiro, na Baía de Guanabara. O patrimônio mundial ainda avança para o interior de Minas Gerais e Goiás, seguindo os caminhos da mineração de ouro e diamantes, e para o Rio Grande do Sul, onde se encontram as ruínas das missões dos jesuítas, que tentaram criar outra forma de convívio com e entre indígenas. 
Mapa 1 - Patrimônio Mundial - 2013

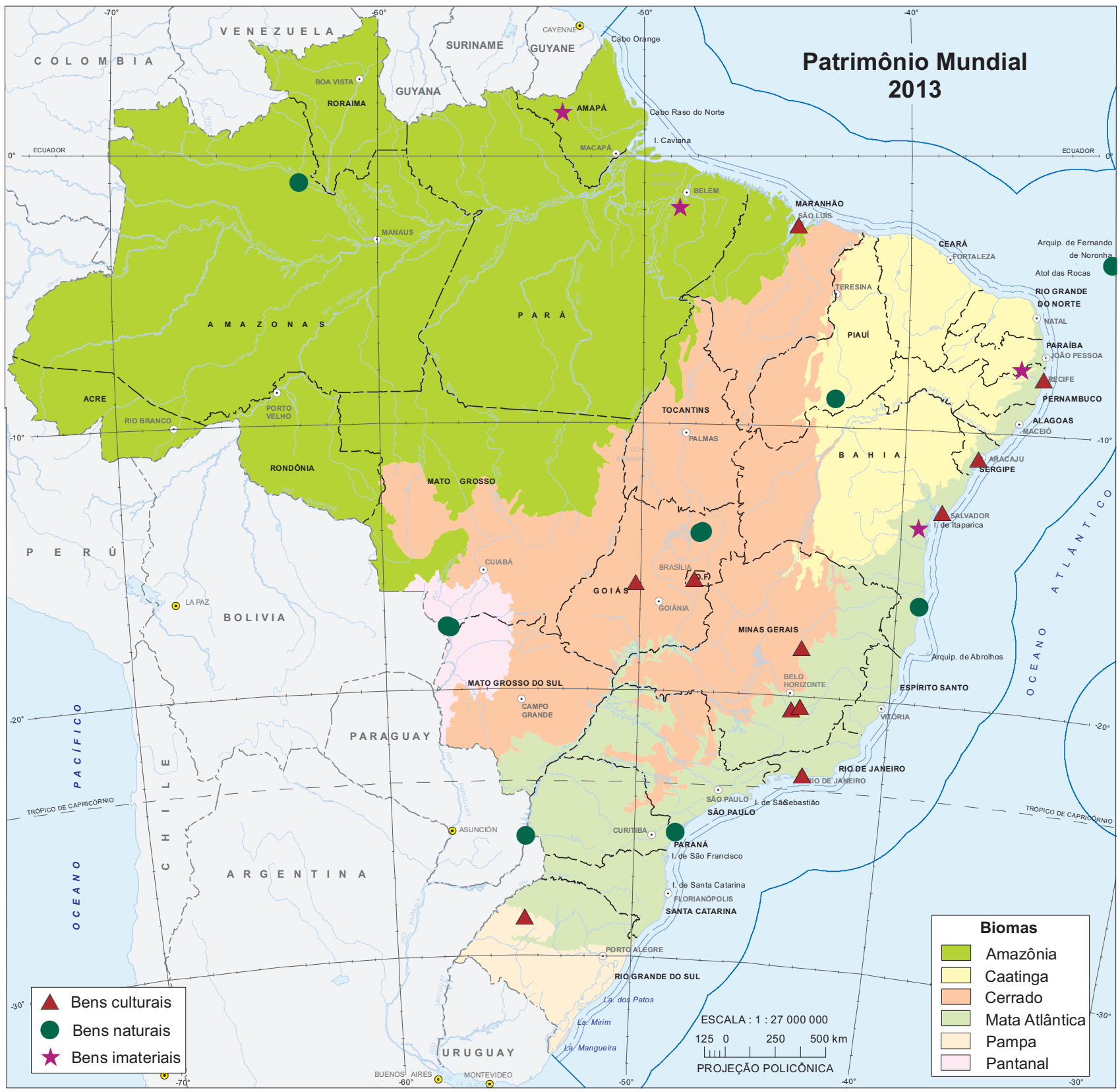

Fontes: 1. Lista do Patrimônio Mundial no Brasil. Brasília, DF: Organização das Nações Unidas para a Educação, a Ciência e a Cultura - Unesco, [2013]. Disponível em: <http://www.unesco.org/new/pt/brasilia/culture/world-heritage/list-of-world-heritage-in-brazil/\#c1048555>. Acesso: jan. 2016. 2. Indicadores de desenvolvimento sustentável: Brasil 2015. Rio de Janeiro: IBGE, 2015. Disponível em: <http://www.ibge.gov.br/home/geociencias/ recursosnaturais/ids/default_2015.shtm>. Acesso em: jan. 2016. 
Ainda de acordo com o Mapa 1, o patrimônio mundial natural do Brasil é também reconhecido e significativo, pois indica a apropriação da natureza e de sua biodiversidade, em razão de sua riqueza simbólica e cultural, ilustrada em bens como o Parque Nacional do Iguaçu, onde ficam as famosas Cataratas do Iguaçu, a Costa do Descobrimento, no litoral da Bahia, e as ilhas atlânticas, que abrangem o Parque Nacional de Fernando de Noronha e o Atol das Rocas. Outras áreas destacadas pelo patrimônio mundial representam os diferentes biomas do Brasil, como as áreas protegidas da Amazônia, da Mata Atlântica, do Pantanal e do Cerrado. O Bioma Caatinga está representado, no patrimônio mundial, pelo Parque Nacional da Serra da Capivara, que abriga grande riqueza arqueológica e natural.

A escolha dos bens do patrimônio mundial é feita por uma comissão formada por mais de 20 países, incumbida de avaliar as candidaturas propostas pelos órgãos de patrimônio dos países signatários da Convenção. No Brasil, o órgão responsável pelo Patrimônio Cultural Material e Imaterial é o Instituto do Patrimônio Histórico e Artístico Nacional - IPHAN, e as ações governamentais de preservação dos bens culturais são inscritas desde 1936 em quatro livros: Livro do Tombo Arqueológico, Etnográfico e Paisagístico; Livro do Tombo Histórico; Livro do Tombo das Belas Artes; e Livro do Tombo das Artes Aplicadas ${ }^{1}$. Nosso objetivo, neste capítulo, é mostrar como esses bens são representativos do processo de ocupação do território brasileiro em sua rica diversidade sociocultural e natural.

\section{As diversidades coexistentes no Brasil}

Diversidade é uma palavra-chave na abordagem dos temas nacionais e, portanto, elemento central da geografia do Brasil. Além de abrigar 30\% de todas as florestas tropicais da Terra e seu maior sistema fluvial, o Brasil possui a mais vasta biota e reúne um número de espécies estimado em 1,8 milhão, incluindo-se entre os cinco países do mundo com maior diversidade biológica terrestre. A "megadiversidade"2 biológica brasileira distribuída num território de 8,5 milhões de quilômetros quadrados, se associa à imensa diversidade sociocultural captada em parte pelas informações demográficas oficiais (CENSO DEMOGRÁFICO 2010, 2011), que indicam um total de 190,8 milhões de pessoas residentes no Brasil, em 2010 (Tabela 1).

A diversidade sociocultural e natural resultante dessas interações está representada nos bens de valor histórico, artístico, arqueológico, etnográfico e paisagístico, além de bens que, embora tenham expressão material, são essencialmente imateriais, como saberes tradicionais, formas de expressão, celebrações e lugares especialmente ligados à identidade cultural e à continuidade das tradições.

\footnotetext{
1 Para informações mais detalhadas consultar o portal do IPHAN, no endereço: <http://portal.iphan.gov.br/pagina/detalhes/608>.

2 Para informações mais detalhadas, consultar: MEGADIVERSIDADE. Belo Horizonte: Conservação Internacional - CI Brasil, v. 1-5, 2005-2009. Disponível em: <http://www.conservation.org/global/brasil/publicacoes/Pages/revista-megadiversidade.aspx>. Acesso em: jan. 2016.
} 
Ao longo de um tempo que recua bem mais do que os quinhentos anos contados a partir do "descobrimento do Brasil", diversos povos contribuíram, e contribuem, para a composição da identidade cultural brasileira, marcando sua presença nas áreas mais remotas do Território Nacional. O levantamento e o mapeamento da riqueza cultural resultante das interações das populações do Brasil com os recursos naturais de seu território são formas de conhecimento da realidade brasileira e de construção de cidadania. Desse modo, é sob o ângulo da diversidade sociocultural e natural que se organiza este capítulo da geografia do Brasil. Mais especificamente, será enfatizada a forma como o Estado brasileiro vem absorvendo, em seu arcabouço legal como também em indicadores e cadastramentos, a diversidade presente em seu imenso território.

Tabela 1 - População residente, por sexo, segundo a cor ou raça - Brasil - 2010

\begin{tabular}{|c|c|c|c|c|c|c|}
\hline \multirow{3}{*}{ Cor ou raça } & \multicolumn{6}{|c|}{ População residente } \\
\hline & \multicolumn{3}{|c|}{ Total } & \multicolumn{3}{|c|}{ Percentual (\%) } \\
\hline & Total & Homens & Mulheres & Total & Homens & Mulheres \\
\hline Total & 190755799 & 93406990 & 97348809 & 100,0 & 49,0 & 51,0 \\
\hline Branca & 91051646 & 43652488 & 47399158 & 47,7 & 22,9 & 24,9 \\
\hline Preta & 14517961 & 7526611 & 6991350 & 7,6 & 4,0 & 3,7 \\
\hline Amarela & 2084288 & 951404 & 1132884 & 1,1 & 0,5 & 0,6 \\
\hline Parda & 82277333 & 40861864 & 41415469 & 43,1 & 21,4 & 21,7 \\
\hline Indígena & 817963 & 409907 & 408056 & 0,4 & 0,2 & 0,2 \\
\hline Sem declaração & 6608 & 4716 & 1892 & 0,0 & 0,0 & 0,0 \\
\hline
\end{tabular}

Fonte: Censo Demográfico 2010. Características da população e dos domicílios: resultados do universo. Rio de Janeiro: IBGE, 2011. Disponível em: <http://www.ibge.gov.br/home/estatistica/populacao/censo2010/caracteristicas_da_populacao/default_ caracteristicas_da_populacao.shtm >. Acesso em: jan. 2016.

Com efeito, da população residente no Brasil, em 2010 (Tabela 1), chama atenção a presença de cerca de 100 milhões de pessoas que se autodeclararam pardas ou pretas; de pouco mais de 2 milhões declaradas amarelas; de mais de 800 mil que se declararam indígenas; além de pouco mais de 91 milhões que se identificaram como brancas. Esse conjunto diversificado de pessoas, de acordo com suas variadas culturas, interage num território com seis biomas continentais predominantes - Amazônia, Mata Atlântica, Cerrado, Caatinga, Pantanal e Pampa, além dos biomas costeiros, cada um extremamente diverso em si mesmo, como será visto mais adiante.

Conforme mostram os Mapas 2, 3, 4 e 5, em todos os biomas convivem, em várias composições, populações que se autodeclararam segundo a diferente cor ou raça, o que dá uma dimensão das adaptações culturais que identificam a sociedade brasileira, espacialmente distribuída entre os diversos biomas continentais. A distribuição por cor ou raça autodeclarada reflete, de certo modo, o processo de povoamento do Brasil, que, por sua vez, está representado em seu patrimônio cultural. 
Mapa 2 - População, por cor ou raça - Parda - 2010

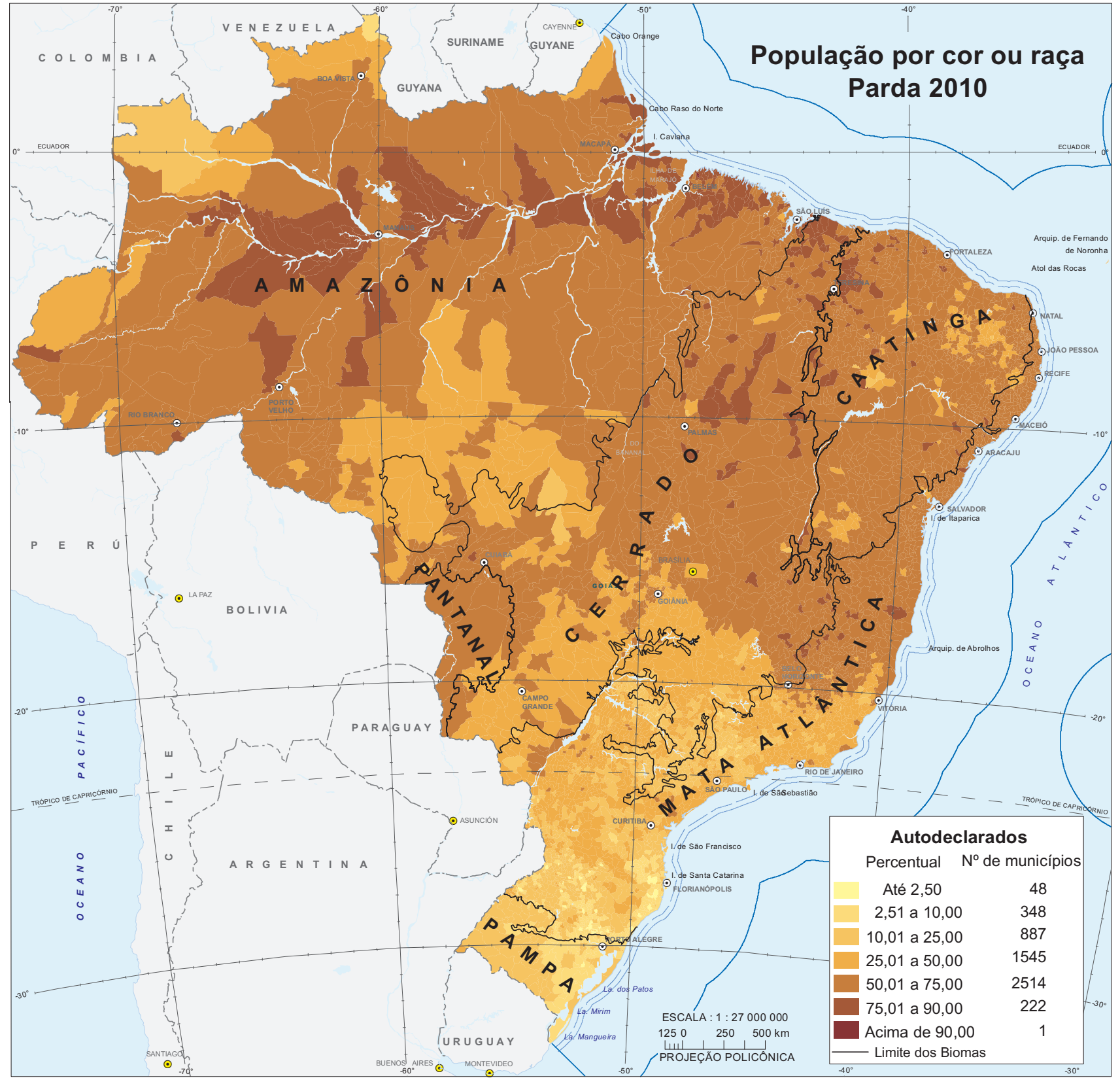

Fonte: Censo Demográfico 2010. Características da população e dos domicílios: resultados do universo. Rio de Janeiro: IBGE, 2011. Disponível em: <http:// www.ibge.gov.br/home/estatistica/populacao/censo2010/caracteristicas_da_populacao/default_caracteristicas_da_populacao.shtm>. Acesso em: jan. 2016. 
Mapa 3 - População, por cor ou raça - Branca - 2010

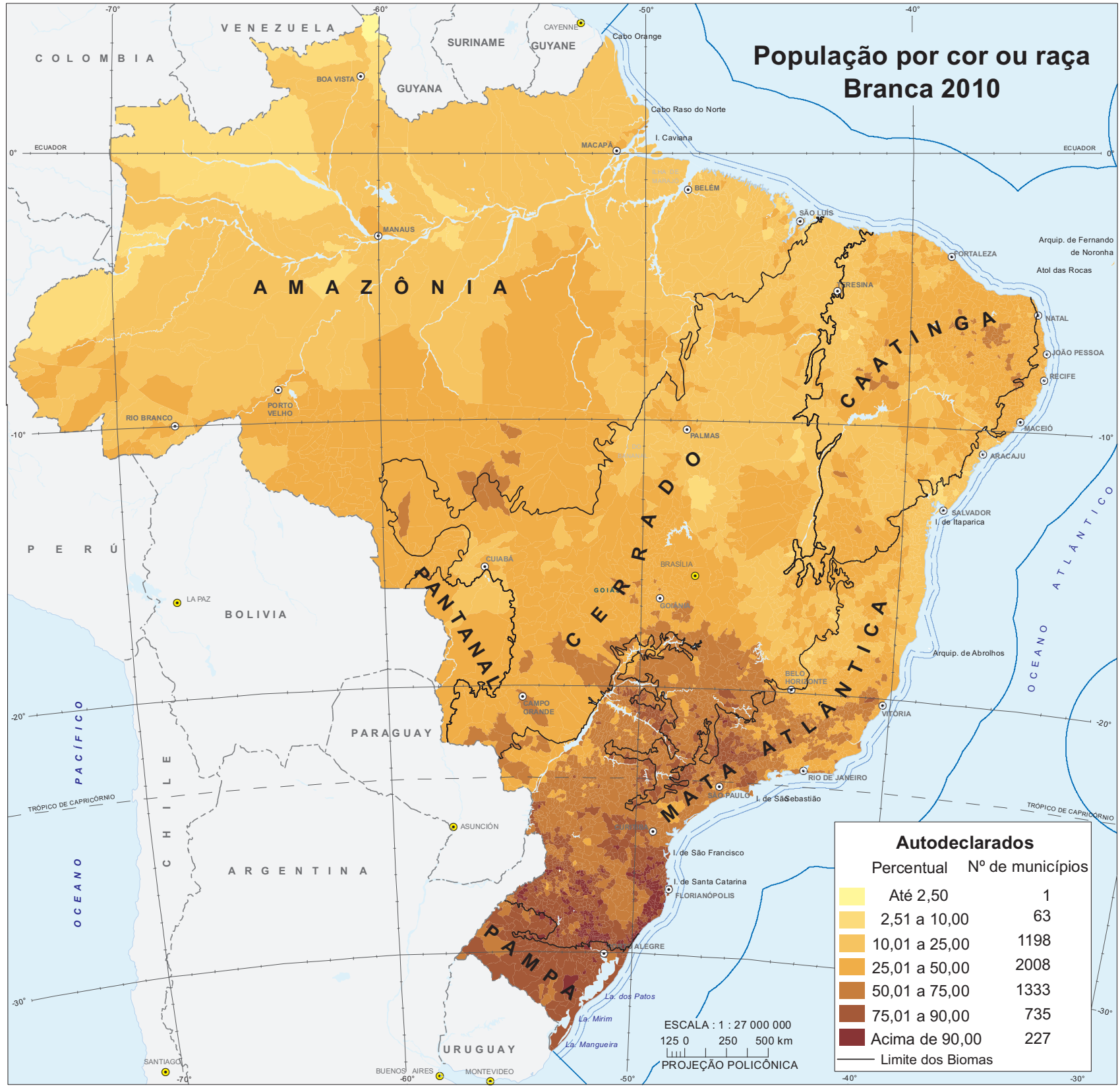

Fonte: Censo Demográfico 2010. Características da população e dos domicílios: resultados do universo. Rio de Janeiro: IBGE, 2011. Disponível em: <http:// www.ibge.gov.br/home/estatistica/populacao/censo2010/caracteristicas_da_populacao/default_caracteristicas_da_populacao.shtm>. Acesso em: jan. 2016. 
Mapa 4 - População, por cor ou raça - Preta - 2010

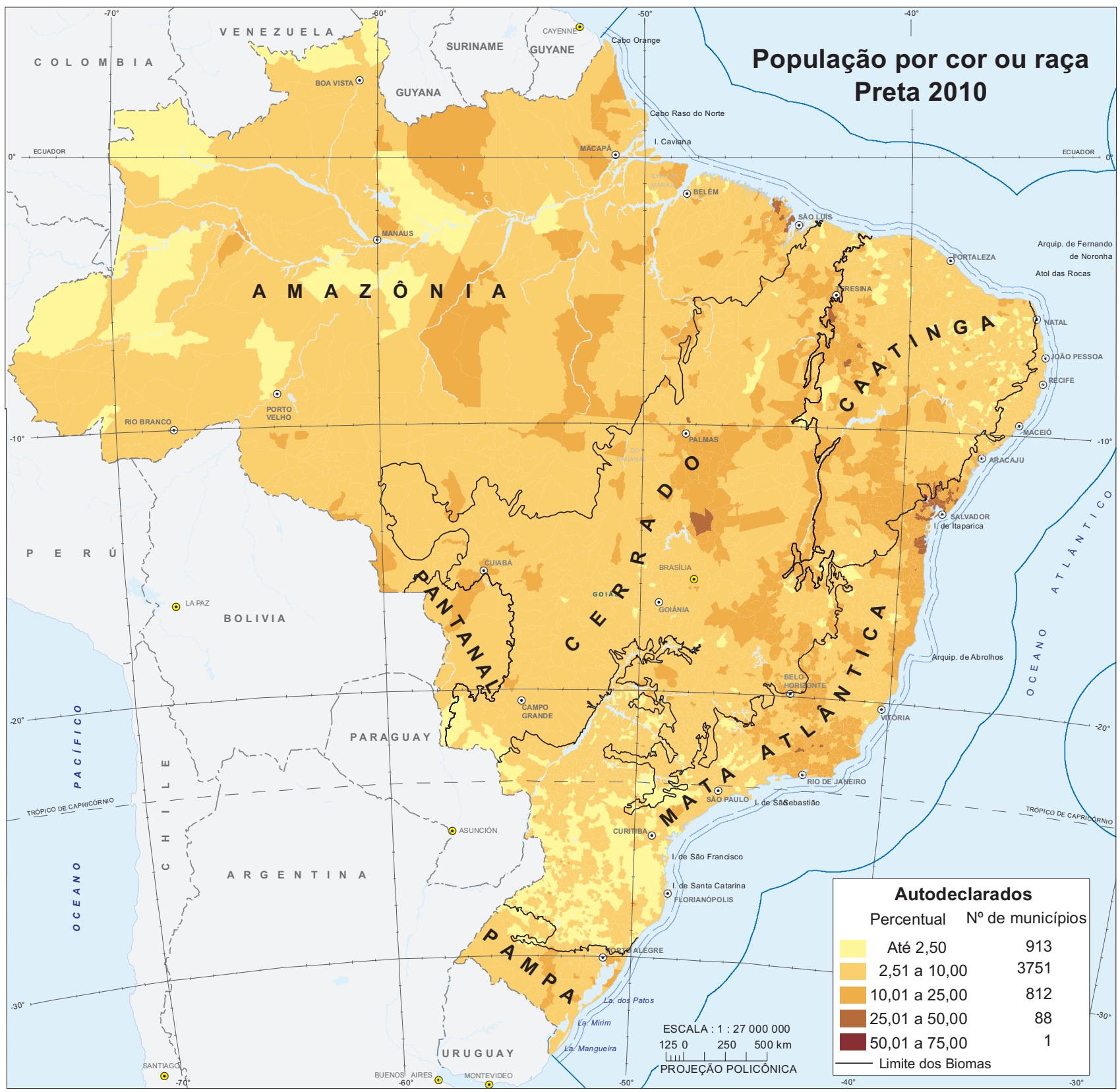

Fonte: Censo Demográfico 2010. Características da população e dos domicílios: resultados do universo. Rio de Janeiro: IBGE, 2011. Disponível em: <http:// www.ibge.gov.br/home/estatistica/populacao/censo2010/caracteristicas_da_populacao/default_caracteristicas_da_populacao.shtm>. Acesso em: jan. 2016. 
Mapa 5 - População, por cor ou raça - Indígena - 2010

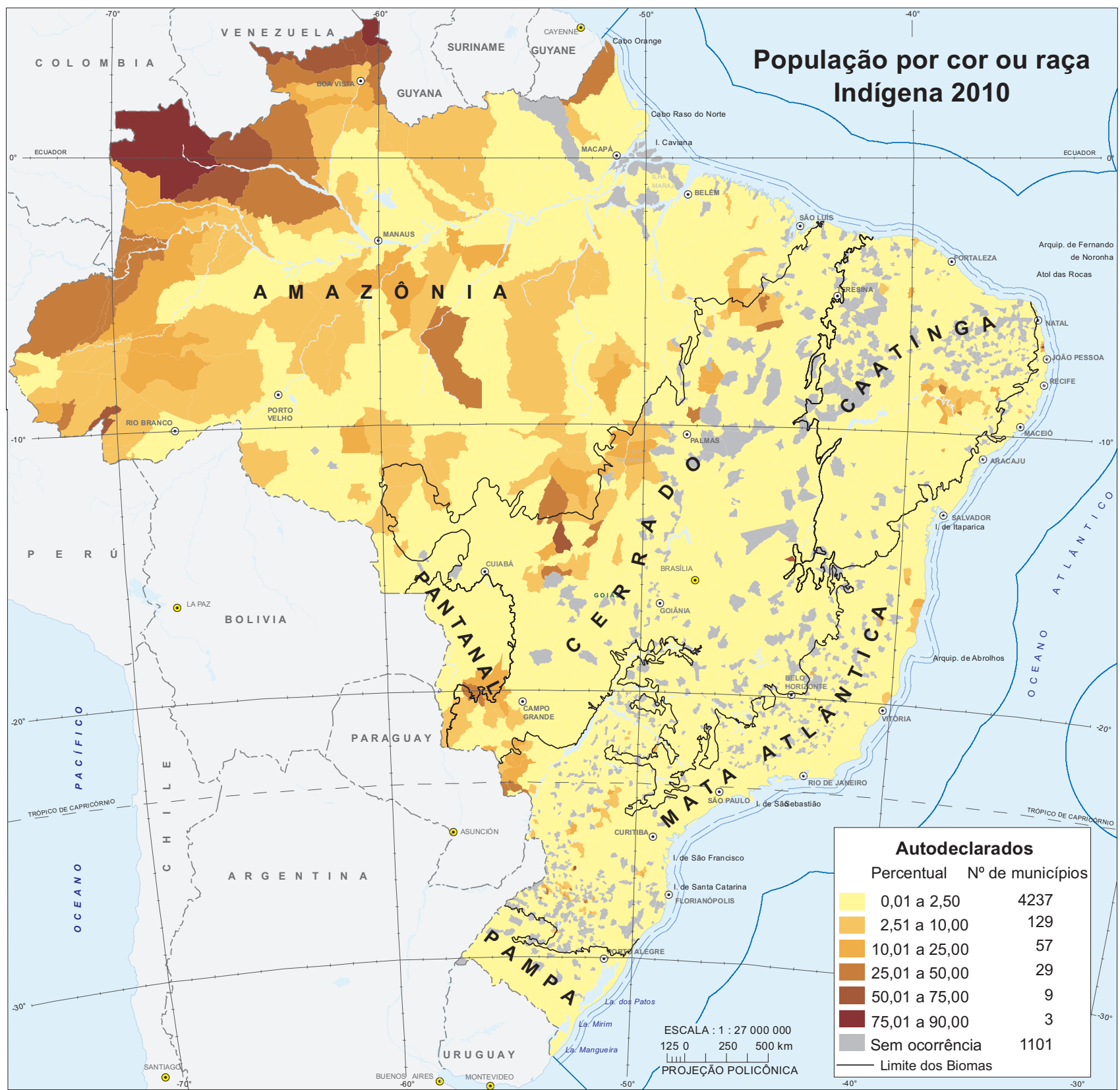

Fonte: Censo Demográfico 2010. Características da população e dos domicílios: resultados do universo. Rio de Janeiro: IBGE, 2011. Disponível em: <http:/ www.ibge.gov.br/home/estatistica/populacao/censo2010/caracteristicas_da_populacao/default_caracteristicas_da_populacao.shtm>. Acesso em: jan. 2016. 
Em 2010, a população brasileira que se autodeclarava parda predominava na maior parte do Brasil, especialmente nos Biomas Amazônia, Cerrado, Caatinga e Pantanal, enquanto a população autodeclarada branca era dominante no Pampa e no sul da Mata Atlântica, e a proporção de pessoas que se autodeclararam pretas tem sua presença em todos os biomas, alcançando, em pontos dispersos do Território Nacional, uma proporção acima de $25 \%$ do total. A presença de diversas comunidades quilombolas, que vêm obtendo crescente reconhecimento legal quanto à posse de seus territórios, responde, por vezes, pelo percentual mais elevado da população autodeclarada preta na população municipal. ${ }^{3}$

A população autodeclarada indígena em 2010 se concentrava em municípios localizados no Bioma Amazônia, especialmente na porção ocidental, e, secundariamente, no Cerrado, onde se encontravam algumas concentrações significativas de autodeclarados indígenas, ainda esparsamente distribuídos em pequenos espaços dos outros biomas, com exceção do Bioma Pampa, onde é quase imperceptível a presença de autodeclarados indígenas.

Outra dimensão da diversidade sociocultural do Brasil se revela na sua diversidade linguística, que abriga o português como idioma predominante e línguas minoritárias, como o pomerano, falado por comunidades da Região Sul e do interior do Estado do Espírito Santo (ROCHE, 1968), além de mais de 200 troncos e famílias linguísticas indígenas faladas no domicílio por $37 \%$ das pessoas indígenas com 5 anos ou mais de idade (CENSO DEMOGRÁFICO 2010, 2011).

Tabela 2 - Pessoas indígenas de 5 anos ou mais de idade, segundo a condição de falar língua indígena no domicílio - Brasil - 2010

\begin{tabular}{|c|c|c|}
\hline \multirow{2}{*}{$\begin{array}{c}\text { Condição de falar } \\
\text { íngua indígena no domicílio }\end{array}$} & \multicolumn{2}{|c|}{ Pessoas indígenas de 5 anos ou mais de idade } \\
\hline & Total & \\
\hline Total & & 100,0 \\
\hline Falavam & & 37,4 \\
\hline Não falavam & & 57,1 \\
\hline Sem declaração & & 5,5 \\
\hline
\end{tabular}

Fonte: Censo Demográfico 2010. Características da população e dos domicílios: resultados do universo. Rio de Janeiro: IBGE, 2011. Disponível em: <http://www.ibge.gov.br/home/estatistica/populacao/censo2010/caracteristicas_da_populacao/default caracteristicas_da_populacao.shtm >. Acesso em: jan. 2016.

Nota: Adaptada da Tabela 1.7 - Pessoas indígenas de 5 anos ou mais de idade, por sexo, condição de falar português no domicílio e localização do domicílio, segundo os grupos de idade e a condição de falar língua indígena no domicílio - Brasil - 2010 Disponível em: <http://biblioteca.ibge.gov.br/visualizacao/periodicos/95/cd_2010_indigenas_universo.pdf>. Acesso em: jan. 2016

\footnotetext{
3 O Decreto n. 4.887, de 20.11.2003, regulamentou o procedimento para identificação, reconhecimento, delimitação, demarcação e titulação das terras ocupadas por remanescentes das comunidades dos quilombos. O seu Art. 20 considera "remanescentes das comunidades dos quilombos [...] os grupos étnico-raciais, segundo critérios de auto-atribuição, com trajetória histórica própria, dotados de relações territoriais específicas, com presunção de ancestralidade negra relacionada com a resistência à opressão histórica sofrida".
} 
É raramente lembrado que o uso das línguas indígenas foi proibido nos domínios portugueses da América, no fim do Século XVIII, e mesmo a diversidade linguística expressa nos nomes de lugares foi afetada quando o governo promoveu, na atual Região Norte, a substituição sistemática dos nomes geográficos de origem indígena por nomes transplantados da toponímia portuguesa. A política de Portugal foi menos eficiente em outras partes do Brasil, onde, na época, havia mais falantes da língua geral, difundida pelos missionários jesuítas (FREIRE, 2004). Os nomes geográficos da região onde o tupi predominou emprestam identidade a serras, rios, lugares que não tiveram o nome alterado e ainda hoje formam uma rica amostra do uso da língua geral na descrição de elementos naturais pelas populações, especialmente na atual Região Sudeste, onde era predominante (SAMPAIO, 1914).

\section{Diversidade natural e ocupação do território brasileiro}

Longe da visão determinista das relações entre população e recursos naturais, a abordagem aqui proposta relaciona biomas e diversidade sociocultural, e chama a atenção para uma das feições estruturantes da geografia brasileira, que é a rica diversidade coexistente em seu território e em sua sociedade. Para a formulação de políticas públicas que contemplam a diversidade biológica e a diversidade cultural, tendo em vista os parâmetros do desenvolvimento sustentável, o Mapa de biomas do Brasil ${ }^{4}$ (MAPA..., 2004a) tem sido um valioso instrumento, pois mostra a diversidade de áreas naturais e sua distribuição pelo território brasileiro, aí incluídos os limites político-administrativos de suas Unidades da Federação (Mapa 6). Conceituado como um conjunto de vida (vegetal e animal) constituído pelo agrupamento de tipos de vegetação contíguos e identificáveis em escala regional, o bioma apresenta condições geoclimáticas similares e história compartilhada de mudanças, o que resulta em uma diversidade biológica própria que, de diversas maneiras, condicionou e/ou influenciou o processo histórico de povoamento do Brasil e de seus estados.

\footnotetext{
4 O Mapa de biomas do Brasil, fruto da cooperação entre o IBGE e o Ministério do Meio Ambiente, baseia-se no Mapa de vegetação do Brasil (MAPA..., 2004b), utiliza um marco conceitual para mapeamento dos limites entre os biomas que foi objeto de ampla discussão em seminários que reuniram, além de técnicos e representantes regionais do IBGE, usuários potenciais tanto do governo quanto da comunidade científica e de organizações da sociedade civil atuantes no campo socioambiental. Um exemplo de utilização da abordagem por biomas na aplicação de leis federais é a exigência de reserva legal de vegetação em propriedades rurais que, a depender do bioma e do tipo de vegetação predominante, varia de $20 \%$ a $80 \%$ da área total do imóvel.
} 
Mapa 6 - Biomas - 2004

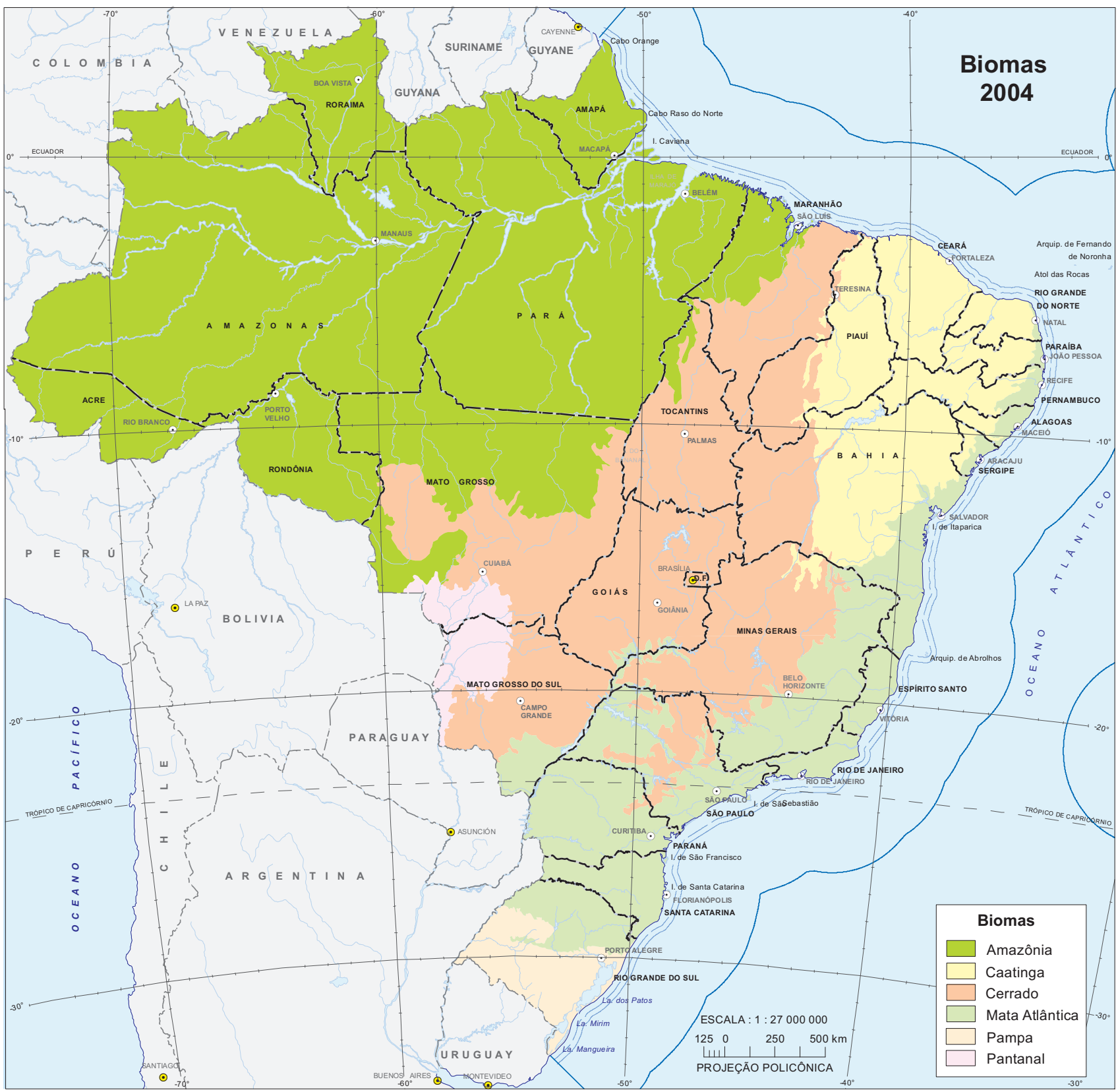

Fonte: Mapa de biomas do Brasil. Rio de Janeiro: IBGE, 2004. Disponível em: <ftp://ftp.ibge.gov.br/Cartas_e_Mapas/Mapas_Murais/>. Acesso em: jan. 2016. 
Os biomas foram designados a partir dos nomes mais usuais, em geral associados ao tipo de vegetação predominante e ao relevo. A área antropizada também é destacada na Tabela 3, pois a atividade humana no território, a depender dos recursos naturais e da densidade demográfica, pode resultar em grande impacto sobre o patrimônio ambiental, uma vez que a dinâmica da sociedade destaca elementos da paisagem e de seus atributos naturais e lhes dá uso e sentido, mas ao mesmo tempo pode alterá-la de modo mais ou menos reversível.

Tabela 3 - Biomas do Brasil, por área e por área antropizada - 2004

\begin{tabular}{|c|c|c|c|}
\hline Bioma & $\begin{array}{l}\text { Área aproximada } \\
\qquad\left(\mathrm{em} \mathrm{km}^{2}\right)(1)\end{array}$ & $\begin{array}{c}\text { Área } \\
(\%)\end{array}$ & $\begin{array}{l}\text { Área antropizada } \\
(\% \text { por Bioma) (2) }\end{array}$ \\
\hline Brasil (3) & 8514877 & 100,0 & 37,6 \\
\hline Amazônia & 4196943 & 49,3 & 16,0 \\
\hline Cerrado & 2036448 & 23,9 & 57,2 \\
\hline Mata Atlântica & 1110182 & 13,0 & 86,9 \\
\hline Caatinga & 176496 & 9,9 & 38,9 \\
\hline Pantanal & 150355 & 1,8 & 9,4 \\
\hline Pampa & 6608 & 2,1 & 33,2 \\
\hline
\end{tabular}

Fonte: Mapa de biomas do Brasil. Rio de Janeiro: IBGE, 2004. Disponível em: <ftp://ftp.ibge.gov.br/Cartas_e_Mapas/Mapas_ Murais/>. Acesso em: jan. 2016.

(1) Datas médias de referência: Regiões Norte e Centro-Oeste - 2000; Regiões Nordeste e Sul - 1996; Região Sudeste - 1982. (2) Área total do Brasil de acordo com a Resolução n. 5, de 10.10.2002, da Presidência do IBGE, segundo quadro territorial vigente em 01.01.2001.

De acordo com a Tabela 4, em números relativos, o Bioma Amazônia ocupa a totalidade de cinco Unidades da Federação (Acre, Amapá, Amazonas, Pará e Roraima), grande parte de Rondônia (99\%), mais da metade de Mato Grosso (54\%), além de parte de Maranhão (34\%) e Tocantins (9\%). Esse bioma é definido pela unidade de clima, fisionomia florestal e localização geográfica. Ao abrigar a maior reserva de diversidade biológica do mundo, ele é também o maior bioma brasileiro em extensão e ocupa quase metade do Território Nacional (49\%). Cerca de 16\% da área do Bioma Amazônia já se encontra alterada por atividades humanas.

Com $13 \%$ da área do território brasileiro, o Bioma Mata Atlântica se distribui por toda a faixa continental atlântica leste do País. Ele se estende ainda em direção ao interior, nas Regiões Sudeste e Sul, e é definido tanto pela vegetação florestal predominante quanto pelo relevo diversificado. É o bioma continental mais alterado pela presença humana, com mais de $86 \%$ de sua área antropizada. Em termos de sua presença no mapa político do Brasil, ele ocupa inteiramente três estados, Espírito Santo, Rio de Janeiro e Santa Catarina, e 98\% do Paraná, além de porções de outras 11 Unidades da Federação.

Segundo bioma do Brasil em extensão (ocupa quase 24\% do território brasileiro), o Bioma Cerrado deve seu nome à vegetação predominante e se estende desde o litoral maranhense até a Região Centro-Oeste. Com mais de 57\% de sua área antropizada, o Bioma Cerrado ocupa a totalidade do Distrito Federal, mais da metade dos Estados de Goiás (97\%), Maranhão (65\%), Mato Grosso do Sul (61\%), Minas Gerais (57\%) e Tocantins (91\%), além de porções de outros seis estados. 
Tabela 4 - Percentual aproximado de área ocupada por bioma, segundo as Unidades da Federação

\begin{tabular}{|c|c|c|c|c|c|c|}
\hline \multirow[b]{2}{*}{ Unidades da Federação } & \multicolumn{6}{|c|}{ Percentual aproximado de área ocupada por bioma (\%) } \\
\hline & Amazônia & $\begin{array}{c}\text { Mata } \\
\text { Atlântica }\end{array}$ & Caatinga & Cerrado & Pantanal & Pampa \\
\hline Acre & 100,0 & & & & & \\
\hline Alagoas & & 52,0 & 48,0 & & & \\
\hline Amapá & 100,0 & & & & & \\
\hline Amazonas & 100,0 & & & & & \\
\hline Bahia & & 19,0 & 54,0 & 27,0 & & \\
\hline Ceará & & & 100,0 & & & \\
\hline Distrito Federal & & & & 100,0 & & \\
\hline Espírito Santo & & 100,0 & & & & \\
\hline Goiás & & 3,0 & & 97,0 & & \\
\hline Maranhão & 34,0 & & 100,0 & 65,0 & & \\
\hline Mato Grosso & 54,0 & & & 39,0 & 7,0 & \\
\hline Mato Grosso do Sul & & 14,0 & & 61,0 & 25,0 & \\
\hline Minas Gerais & & 41,0 & 2,0 & 57,0 & & \\
\hline Pará & 100,0 & & & & & \\
\hline Paraíba & & 8,0 & 92,0 & & & \\
\hline Paraná & & 98,0 & & 2,0 & & \\
\hline Pernambuco & & 17,0 & 83,0 & & & \\
\hline Piauí & & 63,0 & 37,0 & & & \\
\hline Rio de Janeiro & & 100,0 & & & & \\
\hline Rio Grande do Norte & & 5,0 & 95,0 & & & \\
\hline Rio Grande do Sul & & 37,0 & & & & 63,0 \\
\hline Rondônia & 99,0 & & & 0,2 & & \\
\hline Roraima & 100,0 & & & & & \\
\hline Santa Catarina & & 100,0 & & & & \\
\hline São Paulo & & 68,0 & & 32,0 & & \\
\hline Sergipe & & 51,0 & 49,0 & & & \\
\hline Tocantins & 9,0 & & & 91,0 & & \\
\hline Em questão $\mathrm{Pl} \times \mathrm{CE}$ & & & 100,0 & & & \\
\hline
\end{tabular}

Fonte: Mapa de biomas do Brasil. Rio de Janeiro: IBGE, 2004. 1 mapa, color. Escala 1: 5.000.000; proj. policônica. Disponível em: <ftp://ftp.ibge.gov.br/Cartas_e_Mapas/Mapas_Murais/>. Acesso em: jan. 2016.

O Bioma Caatinga, típico da região de predomínio do clima semiárido do sertão nordestino, tem quase $40 \%$ de sua área antropizada e ocupa menos de $10 \%$ do território brasileiro. Ele se estende pela totalidade do Ceará (100\%) e mais de metade da Bahia (54\%), da Paraíba (92\%), de Pernambuco (83\%), do Piauí (63\%), do Rio Grande do Norte (95\%), quase metade de Alagoas (48\%) e de Sergipe (49\%), além de pequenas porções de Minas Gerais ( $2 \%$ ) e do Maranhão ( $1 \%)$.

O bioma de menor extensão no Brasil - mas que constitui a maior superfície inundável interiorana do mundo - é o Pantanal, que está presente em dois estados brasileiros (ocupa $25 \%$ de Mato Grosso do Sul e 7\% de Mato Grosso), enquanto o Bioma Pampa, que se define por um conjunto de vegetação de campo em relevo de planície, está restrito ao Rio Grande do Sul e ocupa $63 \%$ do território do estado. A área antropizada do Bioma Pampa chega a $33 \%$, enquanto o Bioma Pantanal é o que apresenta o menor percentual de alteração pelas atividades humanas (9\%). 
Especialistas como Oliveira (2004) destacam que os biomas podem ser muito diversos internamente em termos de vegetação e, se as florestas predominam na Amazônia e na Mata Atlântica, também estão presentes em menor proporção nos demais biomas do Brasil. No Cerrado e no Pantanal, a vegetação predominante é a savana, enquanto na Caatinga predomina a savana-estépica e, no Pampa, a estepe. A Mata Atlântica é o bioma com maior diversidade de tipos de vegetação, e o Bioma Amazônia é o único no Brasil onde se encontra o tipo de vegetação conhecido como campinarana, concentrado principalmente nas margens do Rio Negro.

\section{Diversidade cultural: povos e comunidades tradicionais e legislação}

Um quadro natural tão diverso oferece condições para o desenvolvimento de outros tipos de diversidade resultantes da interação dos habitantes com o meio, havendo mesmo populações tradicionais que se definem pelo próprio pertencimento ao bioma, como ocorre com os pantaneiros, os caatingueiros (Quadro 2); e outras, com seus recursos naturais, como os vazanteiros e piaçaveiros. A inclusão de dados relativos às populações tradicionais no quadro de diversidade social do Brasil se impõe desde 2007, quando o Decreto n. 6.040, de 07.02.2007, da Presidência da República, instituiu a Política Nacional de Desenvolvimento Sustentável dos Povos e Comunidades Tradicionais. Vale a pena destacar a formulação, por meio do referido Decreto, de três componentes para essa Política:

I - Povos e Comunidades Tradicionais: grupos culturalmente diferenciados e que se reconhecem como tais, que possuem formas próprias de organização social, que ocupam e usam territórios e recursos naturais como condição para sua reprodução cultural, social, religiosa, ancestral e econômica, utilizando conhecimentos, inovações e práticas gerados e transmitidos pela tradição;

II - Territórios Tradicionais: os espaços necessários à reprodução cultural, social e econômica dos povos e comunidades tradicionais, sejam eles utilizados de forma permanente ou temporária, observado, no que diz respeito aos povos indígenas e quilombolas, respectivamente, o que dispõem os arts. 231 da Constituição e 68 do Ato das Disposições Constitucionais Transitórias e demais regulamentações; e

III - Desenvolvimento Sustentável: o uso equilibrado dos recursos naturais, voltado para a melhoria da qualidade de vida da presente geração, garantindo as mesmas possibilidades para as gerações futuras (BRASIL, 2007).

Povos e Comunidades Tradicionais é um tema de seguidos decretos federais, que aos poucos promovem sua inclusão e sedimentam conceitos necessários para orientar as políticas públicas a serem criadas. Inicialmente, as comunidades tradicionais estavam no centro de uma política nacional de desenvolvimento sustentável, tema do Decreto de 27.12.2004, revogado pouco depois, com a edição do Decreto de 13.07.2006, sobre a Comissão Nacional de Desenvolvimento Sustentável dos Povos e Comunidades Tradicionais. Essa Comissão foi criada para coordenar a implementação da Política Nacional de Desenvolvimento Sustentável dos Povos e Comunidades Tradicionais, explicitada no Anexo do Decreto n. 6.040, de 2007. 
Quadro 2 - Populações tradicionais segundo direitos socioambiental e territorial associados

\begin{tabular}{|c|c|c|}
\hline $\begin{array}{c}\text { Povos e comunidades tradicionais citados } \\
\text { na composição da Comissão Nacional } \\
\text { de Desenvolvimento Sustentável } \\
\text { dos Povos e Comunidades Tradicionais }\end{array}$ & $\begin{array}{l}\text { Direito socioambiental } \\
\text { (Decreto n. 6.040/2007) }\end{array}$ & $\begin{array}{l}\text { Direito territorial } \\
\text { (Constituição Federal } \\
\text { do Brasil, de 1988) }\end{array}$ \\
\hline Povos indígenas & $x$ & $x$ \\
\hline Comunidades remanescentes de quilombos & $x$ & $x$ \\
\hline Ciganos & $x$ & - \\
\hline Comunidades de Terreiro & $x$ & - \\
\hline Pescadores artesanais & $x$ & - \\
\hline Caiçaras & $x$ & - \\
\hline Seringueiros & $x$ & - \\
\hline Agroextrativistas da Amazônia & $x$ & - \\
\hline Quebradeiras de coco-de-babaçu & $x$ & - \\
\hline Comunidades de fundo de pasto & $x$ & - \\
\hline Retireiros do Araguaia & $x$ & - \\
\hline Geraizeiros & $x$ & - \\
\hline Faxinais (ou faxinalenses) & $\mathrm{x}$ & - \\
\hline Pomeranos & $x$ & - \\
\hline Pantaneiros & $\mathrm{x}$ & - \\
\hline
\end{tabular}

Fontes: 1. Brasil. Constituição (1988). Constituição da República Federativa do Brasil. Brasília, DF, [2009]. Disponível em: $<$ http://www.presidencia.gov.br/legislacao> Acesso em: jan. 2016. 2. Brasil. Decreto n. 6.040, de 07.02.2007. Institui a Política Nacional de Desenvolvimento Sustentável dos Povos e Comunidades Tradicionais. Diário Oficial da União, Brasília, DF, ano 144, n. 28, 8 fev. 2007. Seção 1, p. 316-317. Disponível em: <http://www.presidencia.gov.br/legislacao>. Acesso em: jan. 2016.

Nota: Outra fonte, o Sistema Nacional de Informações e Indicadores Culturais, do IPHAN, inclui ainda outros povos, além dos citados, entre os quais: agricultores tradicionais, irmandades de negros, ribeirinhos, jangadeiros, campeiros, caatingueiros, açorianos, marisqueiras e caranguejeiras.

Incluídos no conceito de Povos e Comunidades Tradicionais, os povos e comunidades indígenas e quilombolas gozam de direitos especificados na Constituição Federal do Brasil de 1988 e em outras leis. Está definido constitucionalmente e pelas legislações infraconstitucionais que as populações tradicionais indígenas e quilombolas detêm o direito territorial. A Fundação Nacional do Índio - FunAl define legalmente as terras indígenas, e o Instituto Nacional de Colonização e Reforma Agrária - INCRA, as terras quilombolas. É importante compreender que há uma diferença conceitual e jurídica no tocante aos direitos socioambiental e territorial. O Decreto n. 6.040, de 07.02.2007, atribui aos povos e comunidades apenas direitos do primeiro tipo, o socioambiental, mas indica a existência do direito territorial para os povos indígenas e quilombolas. 


\section{Caminhos legais da conservação e populações tradicionais}

O socioambientalismo é um conceito surgido no Brasil, sem paralelo no ambientalismo internacional, que preconiza a integração de políticas setoriais, suas perspectivas e atores, num projeto de Brasil com um perfil próximo da realidade nacional; por isso, afirma a sustentabilidade e a busca de integração com os direitos humanos. Esse conceito, que vem sendo construído no Brasil desde a década de 1980, a partir de articulações políticas entre os movimentos sociais e ambientalista, identifica-se com o processo histórico de redemocratização do País, iniciado com o fim do regime militar, em 1984. Consagrado a partir da promulgação da nova Constituição Federal do Brasil, de 1988, o socioambientalismo trouxe contribuição também para legislações estaduais, em artigos referentes ao meio ambiente e à preservação cultural.

Em termos conceituais, o socioambientalismo se baseia na ideia de que as políticas públicas ambientais devem incluir e envolver as comunidades locais detentoras de conhecimentos e de práticas de manejo dos recursos naturais. Seu desenvolvimento se apoia na concepção de que, num país com tantas desigualdades sociais, um novo paradigma de desenvolvimento deve promover não só a sustentabilidade estritamente ambiental, ou seja, a sustentabilidade de espécies, ecossistemas e processos ecológicos, como também a sustentabilidade social, visando a uma gestão democrática do Território Nacional, portanto, em sintonia com as diversas culturas do País. Assim como prevê a Constituição Federal de 1988, o socioambientalismo vincula cultura e meio ambiente, ao promover a articulação das dimensões social, cultural, econômica, política e ambiental. Como noção jurídica, o socioambientalismo constitui uma construção derivada de interesses difusos que têm foco nos bens socioambientais.

Na década de 1990 e no início do Século XXI, o pensamento ambientalista avançou, no Brasil, numa direção voltada para a integração da sustentabilidade dos ecossistemas com a sobrevivência digna das populações neles instaladas historicamente. Os novos conceitos deram lastro para a criação, no Sistema Nacional de Unidades de Conservação - SNUC, instituído por meio da Lei n. 9.985, de 18.07.2000, de duas classes principais: as Unidades de Proteção Integral, que são para manutenção dos ecossistemas livres de alterações causadas por interferência humana, admitido apenas o uso indireto dos seus atributos naturais; e as Unidades de Uso Sustentável, em que a presença de populações humanas se alia à conservação da biodiversidade.

Os Parques Nacionais são um exemplo da categoria de proteção integral, cujo principal objetivo é a proteção da natureza, na qual é permitido apenas o uso indireto dos recursos naturais, para fins de recreação em contato com a natureza, pesquisa científica, turismo ecológico, educação ambiental e atividades similares que não envolvam consumo, coleta ou dano aos recursos naturais. As Unidades de Conservação de Uso Sustentável, alternativamente, são áreas que visam conciliar a conservação da natureza com o uso sustentável dos recursos naturais, desde que seja feito de forma a assegurar a perenidade dos recursos ambientais renováveis e dos processos ecológicos. Um exemplo são as Reservas Extrativistas da Amazônia, nas quais é permitida a atividade de seringueiros, e as Reservas Extrativistas 
Marinhas, onde pescadores e outros povos tradicionais podem extrair recursos naturais dentro de certos limites. Outras categorias de manejo desse Sistema Nacional, mesmo sem o objetivo explícito de proteger formas culturalmente diferenciadas de utilização dos recursos naturais, também abrigam experiências de manejo comunitário.

Com o SNUC, algo novo veio se conjugar com a visão preservacionista inicial, que por longo tempo orientou a criação de áreas protegidas, inspirada no conceito de "natureza intocada", do modelo adotado pelos Estados Unidos da América, sem considerar a realidade socioeconômica local e regional ou os povos e comunidades tradicionais instalados na área. O objetivo mais importante desse Sistema Nacional passou a ser a conservação da diversidade biológica, para a qual muitas vezes as comunidades tradicionais contribuem, com seu modo de vida e sua filosofia de utilização dos recursos naturais. Este é um dos motivos pelos quais os objetivos do SNUC, listados pelo Ministério do Meio Ambiente, responsável por sua gestão, incluem não apenas valorizar econômica e socialmente a diversidade biológica, mas proteger os recursos naturais necessários à subsistência de populações tradicionais, respeitando e valorizando seu conhecimento e sua cultura, além de promovê-las social e economicamente.

Tendo em vista a inclusão das famílias e grupos populacionais tradicionais, o Ministério do Desenvolvimento Social e Combate à Fome criou um manual de orientação para a inscrição no Cadastro Único para Programas Sociais do Governo Federal (Cadastro Único), o qual considera duas possibilidades de identificação, nele detalhadas. Em virtude de sua origem étnica, uma das classes do Cadastro permite identificar famílias que se autodeclararem como indígenas, quilombolas, ciganas e pertencentes a comunidades de terreiro. Em função de sua relação com o meio ambiente, identificam-se as famílias extrativistas, de pescadores artesanais e ribeirinhas. No meio rural, encontram-se os agricultores familiares. As informações sobre pertencimento a determinado grupo são autodeclaratórias, ou seja, a pessoa que se assume como responsável pela unidade familiar simplesmente identifica se a família pertence a determinado grupo. Quando possuem identificação própria, os grupos podem apresentar documentos, utilizados para dar mais qualidade às informações coletadas.

Povos tradicionais são, em geral, grandes conhecedores de possíveis fragilidades e potenciais de renovação dos recursos e, consequentemente, das técnicas de manejo e preservação dos ambientes em que se encontram. Em muitos casos, a identidade de comunidades extrativistas, que muito comumente vivem próximo ao local de ocorrência das espécies que mais utilizam, se atrela ao tipo de material coletado. Exemplos encontrados no Guia de cadastramento de grupos populacionais tradicionais e específicos (BRASIL, 2012), são andirobeiras, castanheiros, seringueiros, quebradeiras de coco-de-babaçu, apanhadores de flores sempre-vivas, catadoras de mangaba, cipozeiros, piaçaveiros, grupos que interagem com seus respectivos biomas e com eles são profundamente identificados em razão de sua atividade e principal meio de subsistência.

O surgimento das Reservas Extrativistas, no fim da década de 1980, respondeu à demanda dos seringueiros da Amazônia, em especial do Estado do Acre, de regularização fundiária das áreas de uso sustentável das populações tradicionais, onde se encontram os recursos florestais indispensáveis à sua sobrevivência, e depois passou a atender também 
outras populações. Diferentemente das Unidades de Proteção Integral, as Unidades de Uso Sustentável, entre as quais se encontram as Reservas Extrativistas, admitem a utilização direta do solo, incluindo o assentamento humano e as atividades agrícolas e extrativistas. A exploração dos recursos desta última unidade ocorre por meio de contrato de concessão de direito real de uso, tendo em vista que são áreas de domínio público, onde, no entanto, são vedadas as atividades econômicas incompatíveis com a preservação dos recursos naturais.

Nas Unidades de Conservação de Uso Sustentável, em especial as Reservas Extrativistas RESEX, Reservas de Desenvolvimento Sustentável - RDS e Florestas Nacionais - Flonas, todas elas áreas destinadas pelo Estado à proteção da biodiversidade, as populações tradicionalmente extrativistas têm garantido, por força de lei, o exercício das suas atividades, mas com o compromisso de conservação dos recursos florestais e de toda a biodiversidade relacionados com essas áreas. Tais condições também são observadas nos projetos de assentamento ambientalmente diferenciados, entre os quais se incluem os projetos de assentamento agroextrativista e os projetos de assentamento florestal, desenvolvidos no âmbito dos projetos de assentamento, sob a responsabilidade do INCRA. É grande a diversidade de populações tradicionais e de caminhos para a sua inclusão.

Povos tradicionais da Amazônia, os seringueiros são trabalhadores que extraem a resina da seringueira (Hevea brasiliensis), utilizada como matéria-prima na fabricação da borracha. Vivem, principalmente, nos Estados do Acre e do Amazonas. Os castanheiros coletam o fruto da castanheira-do-pará (Bertholletia excelsa), encontrada em toda a Região Amazônica, incluindo Rondônia, Acre, Amazonas, Pará, norte de Goiás e Mato Grosso. As andirobeiras extraem o óleo da semente da andiroba, historicamente utilizado como combustível e na fabricação de velas e sabonetes. A andiroba (Carapa guianensis Aublet), cujo óleo é aproveitado nas indústrias cosmética e farmacêutica, se encontra em praticamente todos os estados do Bioma Amazônia, especialmente nas várzeas e faixas alagáveis ao longo dos cursos d'água. Ainda na Amazônia, situados principalmente na região norte do Estado do Amazonas, os piaçabeiros são trabalhadores que extraem e comercializam a fibra da palmeira piaçava (Attalea funifera), em estado bruto ou beneficiado. Há registro também da exploração da piaçava no sul e no sudeste da Bahia.

Presentes, principalmente, nos Estados do Pará, do Maranhão, do Piauí e do Tocantins, em área dos Biomas Amazônia e Cerrado, as quebradeiras de coco-de-babaçu são trabalhadoras rurais que atuam na coleta e beneficiamento do coco da palmeira babaçu (Orbignya speciosa) e comercializam produtos como azeite, sabão, farinha e artesanato gerados a partir dessa coleta. Já as catadoras de mangaba comercializam, em feiras regionais, o fruto da mangabeira, que pode ser beneficiado e consumido na forma de polpas, doces e sorvetes. A mangabeira (Harconia speciosa) é encontrada no Cerrado e nas áreas de restinga, principalmente na Região Nordeste e na região Central do Brasil.

Entre as populações tradicionais do Cerrado, incluem-se ainda povos indígenas e também povos pretos ou pardos que ficaram por longo tempo em relativo isolamento e tiveram de adaptar seus modos de vida aos recursos naturais ali disponíveis. Assim, o Cerrado abriga quilombolas, geraizeiros, vazanteiros, sertanejos, ribeirinhos, que aprenderam, ao longo de séculos, a encontrar naquele bioma recursos para alimentação, utensílios e artesanato. 
É da região da Serra do Espinhaço, no Estado de Minas Gerais, o principal registro de ocorrência de apanhadores de sempre-vivas. As flores sempre-vivas são espécies de plantas herbáceas utilizadas na confecção de arranjos e outros enfeites. Os cipozeiros são grupos que extraem diferentes espécies de cipós e vendem em estado bruto ou utilizam na confecção de artesanato de cestas e balaios, chapéus, luminárias e outros objetos. Na Mata Atlântica, destaca-se a presença de diversas comunidades de cipozeiros nos Estados do Paraná e Santa Catarina. Na Amazônia, os cipozeiros se concentram na região norte do Estado do Amazonas.

Pescadores artesanais têm como principal atividade econômica a pesca artesanal, realizada por meio de conhecimento tradicional, repassado entre familiares, e da utilização sustentável dos recursos pesqueiros animais ou vegetais. Podem trabalhar desembarcados ou utilizar embarcação de pequeno porte, trabalhar com espécies diversas e utilizar várias técnicas. A pesca artesanal pode ser desenvolvida tanto no mar quanto nos rios e demais ambientes, como lagos, lagoas, açudes, represas, baías, enseadas, lagunas, estuários, manguezais etc. A categoria pescadores artesanais inclui caiçaras, marisqueiras e pantaneiros. Caiçaras são populações que vivem na zona litorânea, com maior representatividade nas Regiões Sul e Sudeste do Brasil. As marisqueiras são grupos de mulheres que assim se identificam e realizam, de forma artesanal, a coleta de mariscos (moluscos e crustáceos) em manguezais e bancos de areia. Os pantaneiros são os habitantes tradicionais do Bioma Pantanal.

Os pescadores artesanais ilustram bem a força econômica da produção das populações tradicionais, responsáveis por 60\% da pesca nacional em 2012, segundo o Ministério da Pesca de Aquicultura ${ }^{5}$. Mais de um milhão de pescadores sustentam suas famílias com o trabalho na captura dos peixes e frutos do mar, no beneficiamento e na comercialização do pescado. Desde 2004, esse Ministério emite o Registro Geral da Pesca, documento para caracterizar o pescador profissional e the prover acesso a programas sociais, como linhas de microcrédito e o Seguro-Defeso. O Seguro-Defeso é uma forma de seguro-desemprego, concedido pelo extinto Ministério do Trabalho e Emprego ${ }^{6}$ no período de paralisação temporária da pesca ou coleta de recursos pesqueiros, determinado pelos governos, visando à preservação das espécies.

Com distribuição geográfica semelhante à dos pescadores, os ribeirinhos são comunidades tradicionais agroextrativistas que vivem em regiões de várzea próximas de rio, cujo modo de organização, reprodução social, cultural e econômica se fundamenta na constante interação com o meio onde vivem, determinada pelo regime de cheias e vazantes e pelos recursos que o rio oferece. Nas regiões de planície e de baixa altitude no Pantanal e na Amazônia, áreas extensas são alagadas nos períodos chuvosos e provocam uma série de

\footnotetext{
5 Extinto a partir da Medida Provisória n. 696, de 02.10.2015. Suas competências foram transferidas para o Ministério da Agricultura, Pecuária e Abastecimento.

6 Foi extinto em 2015 após a criação do Ministério do Trabalho e Previdência Social, mediante a fusão do Ministério do Trabalho e Emprego com o Ministério da Previdência Social, oficializada por meio da Medida Provisória n. 696, de 02.10.2015.
} 
mudanças no modo de vida das populações. Nos períodos em que o rio diminui de volume, formam-se lagos que são importantes para a atividade de pesca. O terreno que foi alagado torna-se fértil na seca e propício ao plantio não só de espécies cultivadas em outras épocas, mas também abóbora, melancia e abacaxi. Algumas comunidades preservam formas de trabalho coletivo, como o mutirão, em que há o uso compartilhado da terra, ou a troca de serviços entre diferentes proprietários.

Outra população considerada tradicional, os agricultores familiares caracterizam-se pela forma como organizam a produção de alimentos, na qual os próprios componentes conduzem o processo produtivo. Apresentam características específicas de acordo com a região do País e o bioma natural onde se localizam, perpassando outras categorias de populações tradicionais, e, desse modo, mais do que um segmento econômico, representam um modo de vida ligado à realidade do local onde se encontram. Têm em comum a relação com o campo, por meio da atividade agrícola, na qual utilizam os recursos naturais da propriedade e a força de trabalho da família. Em geral, combinam a produção de várias culturas com a criação de animais e o beneficiamento de produtos, tanto para consumo da família quanto para comercialização. Para atender à demanda do Ministério do Desenvolvimento Agrário, o Censo Agropecuário 2006, do IBGE, adotou o conceito de "agricultura familiar", conforme a Lei n. 11.326, de 24.07.2006. Essa categoria vem chamando a atenção recentemente por se ligar à defesa das sementes crioulas e à proteção da agrobiodiversidade.

Mais um grupo para o qual se dirigem políticas públicas especiais, as comunidades de terreiro, de matriz africana, possuem uma cultura diferenciada e uma organização social própria, as quais constituem patrimônio cultural afro-brasileiro. As tradições de matriz africana são oriundas do continente africano, trazidas pelas pessoas traficadas para o Brasil que pertenciam a diversos grupos étnicos: Bantu, das regiões onde atualmente se localizam Moçambique, Angola e Congo; lorubá (denominados Nagôs ou Ketus); e Fon, do ocidente africano (Sudão, Nigéria e Benin). O terreiro congrega comunidades que possuem características comuns, tais como a manutenção das tradições de matriz africana, o respeito aos ancestrais, os valores de generosidade e solidariedade, o conceito amplo de família e uma relação próxima com o meio ambiente, além da oralidade, ou seja, o repasse de conhecimentos e da história dos povos pelo relato oral. Há uma grande diversidade de tradições de matriz africana no Brasil, como o Candomblé (com diferentes tipos), a Umbanda, o Batuque, o Tambor de Mina, a Quimbanda, a Jurema, entre outras. 
Quadro 3 - Manifestações religiosas afrobrasileiras e afroindígenas reportadas na Pesquisa Socioeconômica e Cultural de Povos e Comunidades Tradicionais de Terreiros, segundo as Regiões Metropolitanas

\begin{tabular}{|l|l|r|}
\hline Região Metropolitana & \multicolumn{1}{|c|}{ Denominação } & Casas praticantes \\
\hline \multirow{3}{*}{ Belém } & Umbanda & 533 \\
& Tambor de Mina & 523 \\
& Pena e Maracá & 402 \\
& Candomblé & 190 \\
& Nagô & 61 \\
& Mina de caboclo & 42 \\
& Pajeança & 10 \\
\hline \multirow{2}{*}{ Belo Horizonte } & Umbanda & 212 \\
& Candomblé & 163 \\
& Omolocô & 28 \\
\hline \multirow{2}{*}{ Porto Alegre } & Umbanda & 1003 \\
& Batuque & 830 \\
& Quimbanda & 777 \\
& Linha Cruzada & 72 \\
& Nagô & 32 \\
& Candomblé & 29 \\
\hline \multirow{2}{*}{ Recife } & Jurema & 896 \\
& Candomblé & 703 \\
& Umbanda & 365 \\
& Nagô & 181 \\
& Xangô & 10 \\
\hline
\end{tabular}

Fonte: Pesquisa Socioeconômica e Cultural de Povos e Comunidades Tradicionais de Terreiros: síntese de resultados. In: Alimento: direito sagrado. Pesquisa Socioeconômica e Cultural de Povos e Comunidades Tradicionais de Terreiros. Brasília, DF: Ministério do Desenvolvimento Social e Combate à Fome, 2011. p. 138. Disponível em: <http://www.ideiasnamesa.unb.br/upload/ bibliotecaldeias/04112015130257ok_Alimento_Direito_Sagrado_web.pdf>. Acesso em: jan. 2016.

\section{Leituras de avaliação da diversidade brasileira: Indicadores de Desenvolvimento Sustentável}

Os Indicadores de Desenvolvimento Sustentável - IDS - Brasil, de 2012 (Tabela 5), em sua dimensão ambiental, mostram que, no Brasil, nos anos recentes, houve forte crescimento tanto do número quanto da área das Unidades de Conservação federais, especialmente daquelas de uso sustentável, cujo número e proporção já superavam os das Unidades de Proteção Integral (173 e 139, respectivamente). Essa evolução representa o crescente reconhecimento pelo Estado das populações tradicionais como aliadas naturais e não obstáculo à conservação ambiental, tendo em vista que sua presença detém a degradação dos ambientes e dos recursos naturais.

Entre os biomas brasileiros, a Amazônia reúne a maior área protegida e a maior quantidade de Unidades de Conservação, com $14 \%$ de sua área total em unidades federais, distribuída igualmente entre Unidades de Proteção Integral e Unidades de Uso Sustentável, ainda que as últimas totalizem um número superior ao dobro das primeiras. A Amazônia 
também contém as maiores Unidades de Conservação em extensão, dado que reflete a ocupação humana menos densa observada nesse bioma. Pode-se mesmo dizer que o tamanho e o número dessas unidades, na Amazônia, distorce a interpretação do conjunto da realidade brasileira, pois, na maior parte dos biomas, a área protegida é relativamente pequena e fragmentada, inferior a $4 \%$ e, portanto, bem abaixo da média mundial, de 5\%. Excluindo-se o Bioma Amazônia, que eleva a média de área protegida do Brasil para 8,8\%, e a área total protegida para mais de 750000 quilômetros quadrados $(\mathrm{km} 2)$, os demais biomas continentais juntos detêm pouco mais de $150000 \mathrm{~km} 2$ de área protegida, dos quais a maior parte em uso sustentável.

Tabela 5 - Quantidade, área e participação relativa no bioma, das Unidades de Conservação federais, por tipo de uso - Brasil - 2012

\begin{tabular}{|c|c|c|c|c|c|c|c|c|c|}
\hline \multirow{2}{*}{ Bioma } & \multicolumn{3}{|c|}{$\begin{array}{l}\text { Número de Unidades } \\
\text { de Conservação federais } \\
\text { (unidades) }\end{array}$} & \multicolumn{3}{|c|}{$\begin{array}{c}\text { Área das Unidades } \\
\text { de Conservação federais } \\
\qquad\left(\mathrm{km}^{2}\right)\end{array}$} & \multicolumn{3}{|c|}{$\begin{array}{c}\text { Participação relativa } \\
\text { da área das Unidades } \\
\text { de Conservação federais } \\
\text { na área do bioma (\%) }\end{array}$} \\
\hline & Total & $\begin{array}{l}\text { Prote- } \\
\text { ção } \\
\text { integral }\end{array}$ & $\begin{array}{l}\text { Uso } \\
\text { susten- } \\
\text { tável }\end{array}$ & Total & $\begin{array}{l}\text { Prote- } \\
\text { ção } \\
\text { integral }\end{array}$ & $\begin{array}{l}\text { Uso } \\
\text { susten- } \\
\text { tável }\end{array}$ & Total & $\begin{array}{l}\text { Prote- } \\
\text { ção } \\
\text { integral }\end{array}$ & $\begin{array}{l}\text { Uso } \\
\text { susten- } \\
\text { tável }\end{array}$ \\
\hline Total & 312 & 139 & 173 & 750457 & 361807 & 388649 & 8,8 & 4,2 & 4,6 \\
\hline Amazônia & 117 & 38 & 79 & 596959 & 295808 & 301151 & 14,2 & 7,1 & 7,2 \\
\hline Cerrado & 47 & 22 & 25 & 65739 & 46314 & 19425 & 3,2 & 2,3 & 1,0 \\
\hline Caatinga & 25 & 13 & 12 & 31824 & 4939 & 26885 & 3,8 & 0,6 & 3,2 \\
\hline Mata Atlântica & 93 & 52 & 41 & 36473 & 10973 & 25501 & 3,3 & 1,0 & 2,3 \\
\hline Pampa & 4 & 2 & 2 & 3672 & 475 & 3197 & 2,1 & 0,3 & 1,8 \\
\hline Pantanal & 2 & 2 & - & 1472 & 1472 & - & 1,0 & 1,0 & - \\
\hline \multicolumn{10}{|c|}{ Unidades de Conservação } \\
\hline Marinhas & 24 & 10 & 14 & 14317 & 1827 & 12490 & - & - & - \\
\hline
\end{tabular}

Fontes: 1. Indicadores de desenvolvimento sustentável: Brasil 2012. Rio de Janeiro: IBGE, 2012. Disponível em: <http://www. ibge.gov.br/home/geociencias/recursosnaturais/ids/default_2015.shtm>. Acesso em: jan. 2016. 2. Áreas protegidas. Cadastro Nacional de Unidades de Conservação - CNUC. Brasília, DF: Ministério do Meio Ambiente, Sistema Nacional de Unidades de Conservação - SNUC 2014. Disponível em: <http://www.mma.gov.br/areas-protegidas>. Acesso em: jan. 2016.

Notas: 1. Dados atualizados em 12.12.2012.

2. Exclusive as áreas das Unidades de Conservação marinhas.

3. As áreas de sobreposição entre as Unidades de Conservação foram consideradas na categoria de maior restrição.

4. Unidades de Conservação que abarcam limites entre biomas foram contabilizadas no bioma predominante.

5. Foram consideradas as áreas dos biomas disponibilizadas pelo IBGE (ÁREA..., 2012, Tab. 3926).

No Cerrado, o percentual de área destinada à proteção integral é de apenas 2,3\%, mas o conjunto de Unidades de Uso Sustentável tem área ainda inferior e não chega a 1\% do total do bioma. Na Caatinga, na Mata Atlântica e no Pampa, ao contrário, as Unidades de Conservação de Uso Sustentável ocupam um percentual de área muito superior ao das Unidades de Conservação de Proteção Integral, ainda que os números globais pudessem ser bem mais expressivos. A Caatinga, único bioma exclusivamente brasileiro com 25 Unidades de Conservação, o Pampa, com quatro, e o Pantanal, com duas (ambas de proteção integral), 
são os que têm menor número. Nos biomas marinhos, as Unidades de Conservação chegam a 24, das quais 14 de uso sustentável. De maneira geral, relatórios do Ministério do Meio Ambiente apontam o problema, ainda sem solução satisfatória, das populações que tradicionalmente extraíam recursos em áreas tornadas Unidades de Conservação de Proteção Integral.

\section{Leituras cadastrais da diversidade brasileira: indicadores de patrimônio natural e cultural}

É importante incluir, no conjunto das iniciativas em favor da preservação da diversidade biológica e cultural brasileira, os vários programas e convenções mundiais que, de forma direta ou indireta, protegem os bens naturais. Alguns programas se articulam com o modelo brasileiro, como as Reservas da Biosfera, da UNESCO, incluídas no texto do SNUC e cujas áreas-núcleo muitas vezes são também Unidades de Conservação do sistema nacional. De acordo com a proposta do programa Homem e Biosfera (Man and the Biosphere - MaB) da UNESCO, todos os biomas estão representados nas Reservas da Biosfera no Brasil, que incluem os Biomas Cerrado, Caatinga, Pantanal, além da Amazônia Central e da Mata Atlântica, inclusive o Cinturão Verde de São Paulo e a Serra do Espinhaço. Como mencionado anteriormente, a UnESCO conduz também as atividades ligadas ao Patrimônio Cultural Mundial, cuja lista inclui bens naturais.

No Brasil, o primeiro bem natural (Unidade de Conservação) a receber a honraria mundial de ser declarado de importância para a humanidade foi o Parque Nacional do Iguaçu, em 1986. O título se encontrava seriamente ameaçado, segundo o relatório de 2014 do Comitê do Patrimônio Mundial (WORLD HERITAGE COMMITTEE) ${ }^{7}$ devido à construção de uma pequena hidrelétrica rio acima e à abertura de uma antiga estrada incompatível com as finalidades do Parque Nacional e Patrimônio Mundial, que agora pode ser retirado da lista principal para ingressar na lista dos bens em perigo ou em necessidade de salvaguarda urgente.

Assim, há várias formas de avaliar a diversidade cultural resultante das condições particulares do Brasil, já descritas, a qual idealmente deve estar representada primeiramente nos bens do patrimônio cultural tombados e registrados em escalas municipal, estadual e nacional. O Brasil tem, além disso, os bens reconhecidos em escala global, ou seja, bens expressivos da riqueza cultural de toda a humanidade. Desde a realização da Convenção para a Proteção do Patrimônio Mundial, Cultural e Natural de 1972, um comitê recebe e avalia as candidaturas de bens propostas pelos órgãos nacionais de cultura para formar a Lista Representativa do Patrimônio Cultural Mundial (Quadro 4), que é divulgada pela UNESCO.

O patrimônio mundial do Brasil incluído na lista - até 2013 estavam inscritos 23 bens culturais materiais, naturais e imateriais - se distribui entre quase todos os biomas e Grandes Regiões do País, mas, por ser ainda pouco numeroso, não contempla totalmente a grande diversidade de interações com o meio, representadas pelas populações tradicionais.

\footnotetext{
7 Para informações mais detalhadas, consultar: CONVENTION Concerning the Protection of the World Cultural and Natural Heritage. In: WORLD HERITAGE COMMITTEE, 38., Doha, 15-25 June 2014. Paris: United Nations Organization for Education, Science and Culture - Unesco, 2014. p. 135. Disponível em: <http://whc.unesco.org/archive/2014/whc14-38com-7B-en.pdf>. Acesso em: jan. 2016.
} 
Existem, no entanto, muitas outras expressões de populações já aprovadas para a lista indicativa e à espera de compor a lista representativa do Patrimônio Cultural da Humanidade. A lista distingue, além dos bens imateriais representativos da herança cultural da humanidade, também os bens culturais e os bens naturais, ainda que, devido à reconhecida dificuldade de encaixar certos bens em uma ou outra categoria, tenha sido aceito o conceito de bens "mistos", descritos tanto como bens naturais quanto bens culturais. Mais recentemente, tem sido proposto o conceito de "paisagem cultural", exemplificado pela inclusão de mais um bem cultural do Brasil na lista mundial, em 2012: o Rio de Janeiro: paisagens cariocas entre a montanha e o mar.

Quadro 4 - Patrimônio Mundial no Brasil - 2013

\begin{tabular}{|c|c|}
\hline Lista representativa & Ano de inscrição \\
\hline \multicolumn{2}{|l|}{ Bens culturais } \\
\hline Rio de Janeiro: paisagens cariocas entre a montanha e o mar & 2012 \\
\hline Praça de São Francisco, São Cristóvão, Sergipe & 2010 \\
\hline Centro Histórico da Cidade de Goiás, Goiás & 2001 \\
\hline Centro Histórico de Diamantina, Minas Gerais & 1999 \\
\hline Centro Histórico de São Luís, Maranhão & 1997 \\
\hline Conjunto Urbanístico de Brasília, Distrito Federal & 1987 \\
\hline Centro Histórico de Salvador, Bahia & 1985 \\
\hline Santuário do Senhor Bom Jesus de Matosinhos, Congonhas, Minas Gerais & 1985 \\
\hline Ruínas de São Miguel das Missões, Rio Grande do Sul & 1983 \\
\hline Centro Histórico de Olinda, Pernambuco & 1982 \\
\hline Conjunto Arquitetônico e Urbanístico de Ouro Preto, Minas Gerais & 1980 \\
\hline \multicolumn{2}{|l|}{ Bens naturais } \\
\hline Ilhas Atlânticas: Parque Nacional de Fernando de Noronha e Atol das Rocas, Pernambuco & 2001 \\
\hline Áreas protegidas do Cerrado: Parque Nacional dos Veadeiros e das Emas, Goiás & 2001 \\
\hline Complexo de Áreas Protegidas do Pantanal, Mato Grosso e Mato Grosso do Sul & 2000 \\
\hline Complexo de Áreas Protegidas da Amazônia Central (Parque Nacional do Jaú), Amazonas & 2000 \\
\hline Mata Atlântica, Reservas do Sudeste, São Paulo e Paraná & 1999 \\
\hline Costa do Descobrimento, Bahia e Espírito Santo & 1999 \\
\hline Parque Nacional da Serra da Capivara, Piauí & 1991 \\
\hline Parque Nacional do Iguaçu, Paraná & 1986 \\
\hline \multicolumn{2}{|l|}{ Bens imateriais } \\
\hline Círio de Nazaré em Belém do Pará & 2013 \\
\hline Frevo do carnaval de Recife & 2012 \\
\hline Expressão oral e gráfica dos Wajãpi & 2008 \\
\hline Samba de Roda do Recôncavo Baiano & 2008 \\
\hline \multicolumn{2}{|l|}{ Bens com necessidade urgente de salvaguarda } \\
\hline Yaokwa, ritual do povo Enawene Nawe & 2011 \\
\hline \multicolumn{2}{|l|}{ Melhores práticas } \\
\hline Financiamento de Projetos de Patrimônio Imaterial & 2011 \\
\hline Museu Vivo do Fandango & 2011 \\
\hline
\end{tabular}

Fonte: Patrimônio mundial no Brasil. Brasília, DF: Organização das Nações Unidas para a Educação, a Ciência e a Cultura Unesco Brasil, [2015]. Disponível em: <http://www.unesco.org/new/pt/brasilia/culture/world-heritage/list-of-world-heritagein-brazil/\#c1048555>. Acesso em: jan. 2016. 
O patrimônio cultural brasileiro na lista da UNESCO reunia, em 2013, 11 bens culturais, oito bens naturais, quatro bens imateriais, além de um bem imaterial declarado em necessidade de salvaguarda urgente. Incluía ainda dois projetos criados no Brasil entre as melhores práticas do mundo de fomento ao Patrimônio Cultural Mundial. O Brasil tem implementado políticas inovadoras, inclusive novos instrumentos para a ação local, como o inventário e a premiada prática de incentivo a projetos locais de patrimônio imaterial. Paralelamente, esforços no campo da educação patrimonial também contribuem para consolidar os novos conceitos, que cada vez mais permitem a inclusão da ampla diversidade social brasileira no quadro econômico, social e cultural que compõe o Brasil.

A dificuldade de monitoramento da diversidade cultural é reconhecida mundialmente, mas pode se valer de indicadores como os que aparecem na edição de 2014 dos Indicadores de Desenvolvimento Sustentável, publicação do IBGE que há 12 anos, bianualmente, recolhe e atualiza avaliações das dimensões econômica, social, ambiental e institucional da sustentabilidade. Sob o título de Patrimônio Cultural, a dimensão institucional dos indicadores passou a incluir quadros, tabelas e mapas sobre o patrimônio cultural brasileiro tombado e registrado pelo IPHAN, além da lista de bens incluídos pela UNESCO na lista representativa do patrimônio mundial.

Já na década de 1930, muito antes da Convenção para a Proteção do Patrimônio Mundial, Cultural e Natural de 1972 e da adoção de listas pela comunidade internacional, o Brasil iniciou sua política de identificação e preservação do Patrimônio Cultural Material. Em 1938, foram feitas as primeiras inscrições de bens materiais nos livros do tombo, que, em 2012, já reuniam mais de mil bens culturais materiais históricos e artísticos, mas também arqueológicos, etnográficos, paisagísticos. A criação do órgão nacional de patrimônio cultural em 1937 marca o início oficial da política nacional para o tema, da qual participam como protagonistas também outras instituições, como o Centro Nacional de Folclore e Cultura Popular, criado em 1958, o Centro Nacional de Referência Cultural, na década de 1970, e depois a Fundação Nacional Pró-Memória, além dos órgãos estaduais e locais.

Esses órgãos governamentais realizaram vários projetos que antecipavam ideias mais tarde abarcadas pelo conceito de patrimônio imaterial, ampliando a atuação do Estado em relação ao patrimônio vinculado às culturas populares, às culturas indígenas e aos cultos afro-brasileiros. Essa orientação conduziu ao tombamento de dois importantes bens de matriz africana, já em 1986: a Serra da Barriga, em Alagoas, local do Quilombo dos Palmares, e o Terreiro da Casa Branca, em Salvador, um dos mais antigos e atuantes centros de atividade do candomblé baiano. Em 2000, foram tombados mais quatro terreiros em Salvador e um no Maranhão. Assim, no Livro do Tombo Arqueológico, Etnográfico e Paisagístico, bem como no Histórico, são feitas as primeiras inscrições de bens culturais associados a populações tradicionais de matriz africana, os quais depois encontrariam lugar também nos livros de registro de bens imateriais. 
Quadro 5 - Alguns bens do Patrimônio Cultural Material do Brasil de matriz africana

\begin{tabular}{|c|c|c|c|}
\hline $\begin{array}{c}\text { Bem material } \\
\text { (nome de inscrição oficial) }\end{array}$ & Localização & Livro(s) do Tombo & Data da inscrição \\
\hline $\begin{array}{l}\text { Serra da Barriga (Quilombo } \\
\text { dos Palmares; República dos Palmares) } \\
\text { (Serra da Barriga, } \\
\text { parte mais acantilada, conforme } \\
\text { descrição constante na } \\
\text { Informação } \mathrm{n}^{\circ} \text { 123/85) }\end{array}$ & União dos Palmares (AL) & $\begin{array}{l}\text { Arqueológico/Etnográfico/ } \\
\text { Paisagístico e Histórico }\end{array}$ & 19.02.1986 \\
\hline $\begin{array}{l}\text { Terreiro da Casa Branca } \\
\text { (Terreiro da Casa Branca } \\
\text { constituído de uma área de } \\
\text { aproximadamente } 6.800 \mathrm{~m}^{2} \text {, } \\
\text { com as edificações, árvores e principais } \\
\text { objetos sagrados, } \\
\text { situado na Avenida Vasco } \\
\text { da Gama } \mathrm{s} / \mathrm{n}^{\circ} \text { ) }\end{array}$ & Salvador (BA) & $\begin{array}{l}\text { Arqueológico/Etnográfico/ } \\
\text { Paisagístico }\end{array}$ & 14.08.1986 \\
\hline $\begin{array}{l}\text { Morro do Pai Inácio: conjunto } \\
\text { paisagístico e Rio Mucugêzinho } \\
\text { (Conjunto paisagístico do Morro } \\
\text { do Pai Inácio) }\end{array}$ & Palmeiras (BA) & $\begin{array}{l}\text { Arqueológico/Etnográfico/ } \\
\text { Paisagístico }\end{array}$ & 05.05 .2000 \\
\hline $\begin{array}{l}\text { Terreiro de Candomblé do } \\
\text { Axé Opô Afonjá (Terreiro } \\
\text { do Axé Opô Afonjá) }\end{array}$ & Salvador (BA) & $\begin{array}{l}\text { Arqueológico/Etnográfico/ } \\
\text { Paisagístico e Histórico }\end{array}$ & 28.07.2000 \\
\hline $\begin{array}{l}\text { Terreiro de Candomblé llê lyá } \\
\text { Omim Axé Yiamassé (Terreiro } \\
\text { do Gantois - Ilê lyá Omim Axé } \\
\text { Yiamassé) }\end{array}$ & Salvador (BA) & $\begin{array}{l}\text { Arqueológico/Etnográfico/ } \\
\text { Paisagístico e Histórico }\end{array}$ & 02.02 .2005 \\
\hline $\begin{array}{l}\text { Terreiro do Bate-Folha (Terreiro } \\
\text { de Candomblé do Bate-Folha } \\
\text { Manso Banduquenqué) }\end{array}$ & Salvador (BA) & $\begin{array}{l}\text { Arqueológico/Etnográfico/ } \\
\text { Paisagístico e Histórico }\end{array}$ & 03.02 .2005 \\
\hline $\begin{array}{l}\text { Terreiro de Alaketo, Ilê Maroiá Láji } \\
\text { (Terreiro do Alaketo, Ilê Maroiá Láji) }\end{array}$ & Salvador (BA) & $\begin{array}{l}\text { Arqueológico/Etnográfico/ } \\
\text { Paisagístico e Histórico }\end{array}$ & 30.09 .2008 \\
\hline $\begin{array}{l}\text { Terreiro Casa das Minas Jeje (Terreiro } \\
\text { Casa das Minas Jeje, situado na Rua de } \\
\text { São Pantaleão n }{ }^{\circ} 857 \text { e } 857 \text { a) }\end{array}$ & São Luís (MA) & $\begin{array}{l}\text { Arqueológico/Etnográfico/ } \\
\text { Paisagístico e Histórico }\end{array}$ & 02.02 .2005 \\
\hline $\begin{array}{l}\text { Quilombo do Ambrósio: documentação } \\
\text { (Documentação referente ao Quilombo } \\
\text { do Ambrósio) }\end{array}$ & Ibiá (MG) & Histórico & 11.07.2002 \\
\hline $\begin{array}{l}\text { Quilombo do Ambrósio: remanescentes } \\
\text { (Remanescentes do antigo Quilombo do } \\
\text { Ambrósio) }\end{array}$ & Ibiá (MG) & Histórico & 11.07.2002 \\
\hline
\end{tabular}

Fonte: Lista dos bens culturais inscritos nos livros do tombo (1938-2012). Rio de Janeiro: Instituto do Patrimônio Histórico Artístico Nacional - IPHAN, 2013. Disponível em: <http://portal.iphan.gov.br/uploads/ckfinder/arquivos/guia\%20de\%20bens\% 20tombados\%20atualizado\%20em\%202012.pdf>. Acesso em: jan. 2016. 
Da mesma natureza cultural que o patrimônio material, cujo tombamento, no entanto, depende da iniciativa do IPHAN, o registro de bens imateriais é realizado pelo órgão nacional de patrimônio cultural como resultado de um processo que surge da iniciativa das pessoas reunidas em associações e organizações da sociedade civil. Por esse motivo, muitas vezes tem servido como canal de fortalecimento da identidade de populações tradicionais e tende a crescer à medida que recebe incentivo no âmbito de programas oficiais ${ }^{8}$.

Por fim, é preciso acrescentar que, ao contrário do que possa sugerir, o livro de tombo que diz respeito aos bens paisagísticos não se restringe a paisagens de pura beleza cênica ou ligados a eventos históricos, como a chamada Costa do Descobrimento, onde, como se sabe, conjugam-se critérios ligados à importância cultural para o País, mas também de diversidade biológica excepcional. Os bens que figuram nas listas do patrimônio mundial do Brasil atendem aos mesmos critérios utilizados para decidir sobre a criação de uma nova unidade de conservação para o sistema nacional, entre elas a diversidade biológica e a existência de espécies endêmicas, ou seja, de ocorrência restrita àquela área. O tombamento também pode se oferecer como alternativa para a conservação de áreas naturais ocupadas por populações tradicionais.

O Mapa 7 mostra que os três estados onde, em 2012, se encontravam mais de 150 bens materiais inscritos nos quatro livros do tombo são Rio de Janeiro, Bahia e Minas Gerais. Com 51 a 150 bens materiais tombados, os Estados de São Paulo, Pernambuco e Rio Grande do Sul também têm um patrimônio material expressivo. Com relação à distribuição dos bens ao longo do tempo, a análise de sua quantidade em cada livro do tombo revela um crescimento proporcional dos tombamentos de bens arqueológicos, etnográficos e paisagísticos, em relação aos bens históricos e artísticos no período entre 1938 e 2012. No primeiro ano, houve grande quantidade de inscrições de bens de belas artes e históricos (respectivamente $67 \%$ e $32 \%$ do total de tombamentos), concentrados principalmente nas regiões Nordeste e Sudeste, como reflexo do próprio processo de povoamento do Brasil, inicialmente concentrado nessas áreas. Desde o ano 2000, no entanto, vem crescendo a proporção de bens inscritos no Livro do Tombo Arqueológico, Etnográfico e Paisagístico, os quais representavam 1\% do total em 1938, mas chegaram a $11 \%$ em 2012, distribuídos principalmente pelas mesmas Regiões Nordeste e Sudeste, cada uma com 60 bens da categoria.

\footnotetext{
8 Outro canal de reconhecimento de direito coletivo de povos e comunidades tradicionais têm sido as chamadas Indicações Geográficas que, associadas a arranjos produtivos locais, podem ser registradas no Instituto Nacional de Propriedade Industrial - INPI, conforme a Lei da Propriedade Industrial n. 9.279, de 14.05.1996 em consonância com instrumentos internacionais da Organização Mundial do Comércio.
} 
Mapa 7 - Patrimônio Cultural Material do Brasil - 2012

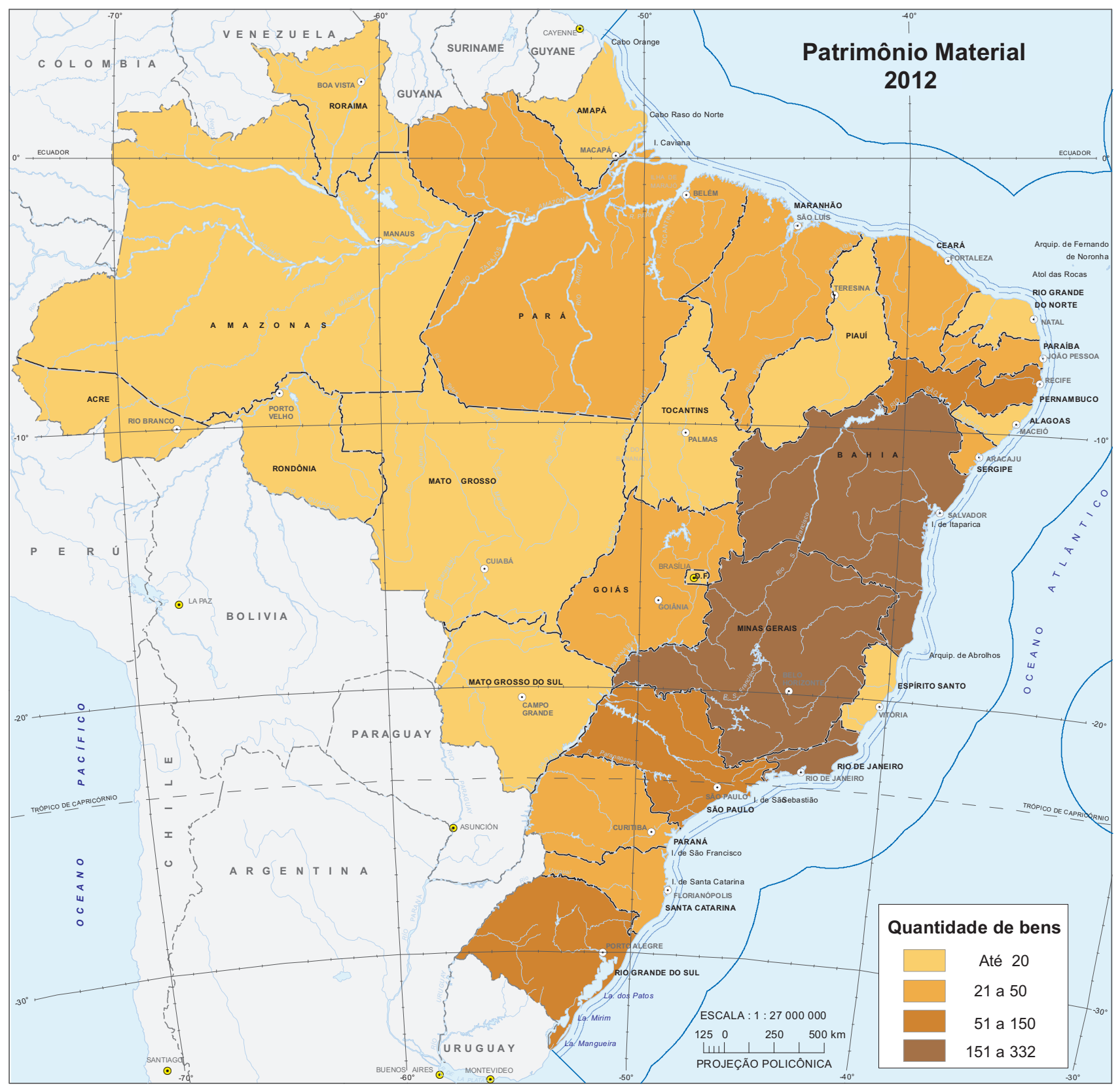

Fontes: 1. Lista dos bens culturais inscritos nos livros do tombo (1938 - 2012). Rio de Janeiro: Instituto do Patrimônio Histórico Artístico Nacional - IpHan, 2013. Disponível em: <http://portal.iphan.gov.br/uploads/ckfinder/arquivos/guia\%20de\%20bens\%20tombados $\% 20$ atualizado\%20em $\% 202012$.pdf>. Acesso em: jan. 2016. 2. Indicadores de desenvolvimento sustentável: Brasil 2015. Rio de Janeiro: IBGE, 2015. Disponível em: <http://www.ibge.gov.br/home/ geociencias/recursosnaturais/ids/default_2015.shtm>. Acesso em: jan. 2016. 


\section{Leituras cadastrais da diversidade brasileira: Indicadores de patrimônio imaterial}

Entre os bens do Patrimônio Imaterial do Brasil, em 2012, havia nove saberes, nove formas de expressão, seis celebrações e dois lugares. A inclusão, em 2013, de três celebrações e um saber, contribuiu para equilibrar o número de inscrições em três livros de registro. A inscrição de lugares foi criada para o registro de mercados, feiras, santuários, praças e demais espaços onde se concentram e se reproduzem práticas culturais coletivas, e pode, com seu crescimento, trazer maior contribuição para uma abordagem da diversidade cultural expressa em lugares que já incluem a cachoeira de lauaretê, lugar sagrado para indígenas de várias etnias do alto Rio Negro, na Amazônia, e a Feira de Caruaru, centro de divulgação de tradições nordestinas.

Quadro 6 - Patrimônio Imaterial - Brasil - 2002/2012

\begin{tabular}{|c|c|}
\hline Bens do Patrimônio Imaterial & $\begin{array}{l}\text { Ano de } \\
\text { inscrição }\end{array}$ \\
\hline \multicolumn{2}{|l|}{ Livro de Registro dos Saberes } \\
\hline Modo de fazer e práticas socioculturais associadas à cajuína & 2013 \\
\hline Saberes e Práticas Associados aos Modos de Fazer Bonecas Karajá & 2012 \\
\hline Sistema Agrícola Tradicional do Rio Negro & 2010 \\
\hline Modo de fazer Renda Irlandesa, tendo como referência este ofício em Divina Pastora (Sergipe) & 2009 \\
\hline Ofício de Sineiro & 2009 \\
\hline Modo artesanal de fazer Queijo de Minas, nas regiões do Serro e das serras da Canastra e do Salitre & 2008 \\
\hline Ofício dos Mestres de Capoeira & 2008 \\
\hline Modo de Fazer Viola-de-Cocho & 2005 \\
\hline Ofício das Baianas de Acarajé & 2005 \\
\hline Ofício das Paneleiras de Goiabeiras, Vitória (Espírito Santo) & 2002 \\
\hline \multicolumn{2}{|l|}{ Livro de Registro das Formas de Expressão } \\
\hline Rtixòkò: expressão artística e cosmológica do Povo Karajá & 2012 \\
\hline $\begin{array}{l}\text { Toque dos Sinos em Minas Gerais, tendo como referência São João del Rey e as cidades de Ouro Preto, Mariana, } \\
\text { Catas Altas, Congonhas, Diamantina, Sabará, Serro e Tiradentes }\end{array}$ & 2009 \\
\hline Roda de Capoeira & 2008 \\
\hline Frevo & 2007 \\
\hline Matrizes do Samba no Rio de Janeiro: Partido Alto, Samba de Terreiro e Samba-Enredo & 2007 \\
\hline Tambor de Crioula do Maranhão & 2007 \\
\hline Jongo no Sudeste & 2005 \\
\hline Samba de Roda do Recôncavo Baiano & 2004 \\
\hline Arte Kusiwa - Pintura Corporal e Arte Gráfica Wajãpi & 2002 \\
\hline \multicolumn{2}{|l|}{ Livro de Registro das Celebrações } \\
\hline Festa do Divino Espírito Santo de Paraty & 2013 \\
\hline Festa do Senhor Bom Jesus do Bonfim & 2013 \\
\hline São Sebastião na Região do Marajó & 2013 \\
\hline Fandango Caiçara & 2012 \\
\hline Complexo Cultural do Bumba-meu-boi do Maranhão & 2011 \\
\hline Festa de Sant' Ana de Caicó (Rio Grande do Norte) & 2010 \\
\hline Festa do Divino Espírito Santo de Pirenópolis (Goiás) & 2010 \\
\hline Ritual Yaokwa do povo indígena Enawene Nawe & 2010 \\
\hline Círio de Nossa Senhora de Nazaré & 2004 \\
\hline \multicolumn{2}{|l|}{ Livro de Registro dos Lugares } \\
\hline Cachoeira de lauaretê - Lugar sagrado dos povos indígenas dos Rios Uaupés e Papuri & 2006 \\
\hline Feira de Caruaru & 2006 \\
\hline
\end{tabular}

Fonte: Instituto do Patrimônio Histórico e Artístico Nacional - IPHAN. 
A partir da vinculação entre meio ambiente e cultura, é possível imaginar um indicador de diversidade cultural baseado na evolução da quantidade e da proporção de tombamentos de patrimônio material e registros de patrimônio imaterial, devendo, no entanto, necessariamente associá-los à sociodiversidade brasileira, possivelmente em articulação com a biodiversidade. Uma primeira abordagem mostra que, paralelamente à consolidação do pensamento socioambiental, nas três últimas décadas, ampliou-se no Brasil o leque de manifestações culturais representadas nos livros do tombo e de registro, e, consequentemente, também a visibilidade de vários segmentos da população que passaram a ter sua contribuição para a diversidade das expressões culturais no Brasil formalmente reconhecida.

O Fandango caiçara, por exemplo, se liga presumivelmente à população tradicional de mesmo nome, restrita ao litoral sul de São Paulo e norte do Paraná, mas nenhuma outra apresenta patrimônio imaterial mais numeroso, ainda que regionalmente restrito, que os povos indígenas. A compreensão da distribuição desses bens imateriais pode se apoiar na forte relação existente entre patrimônio cultural e populações tradicionais. Os povos poderão ser representados por seu patrimônio cultural quanto mais houver proximidade entre as instituições formais e os anseios de institucionalização da população organizada.

Remanescentes de antigos quilombos, as comunidades quilombolas estão encontrando seu caminho de reconhecimento e desenhando seu "mapa cultural", assim como já têm feito os indígenas que na atualidade habitam principalmente a parte ocidental do Brasil, delimitada pelos Estados do Pará, de Mato Grosso e de Mato Grosso do Sul, conforme o Mapa 8, justamente na região onde se encontrava, em 2012, a maior parte dos bens imateriais de origem indígena já incluídos nos quatro Livros de Registro do IPHAN: Livro de Registro dos Saberes; Livro de Registro das Celebrações; Livro de Registro das Formas de Expressão; e Livro de Registro dos Lugares ${ }^{9}$. Todos os livros de registro estão representados no conjunto do patrimônio imaterial indígena no Bioma Amazônia e áreas de transição com o Cerrado: 0 livro das celebrações registra o Ritual Yaokwa do Povo Indígena Enawene Nawe; o livro dos lugares registra a Cachoeira de lauaretê, lugar sagrado dos povos indígenas dos rios Uaupés e Papuri; o livro das formas de expressão inclui a Arte Kusiwa, que é a pintura corporal e arte gráfica dos Wajãpi; e o livro de saberes registra o Sistema Agrícola do Rio Negro. Dois outros bens imateriais se encontram no Bioma Cerrado - a expressão artística do povo Karajá, chamada Rtixòkò, registrada no livro das formas de expressão, e os saberes e práticas associados aos modos de fazer bonecas Karajá, no livro dos saberes.

\footnotetext{
9 Para informações mais detalhadas consultar o portal do IPHAN, no endereço: <http://portal.iphan.gov.br/pagina/detalhes/122>.
} 
Mapa 8 - Patrimônio Culłural Imaterial de origem indígena - 2012

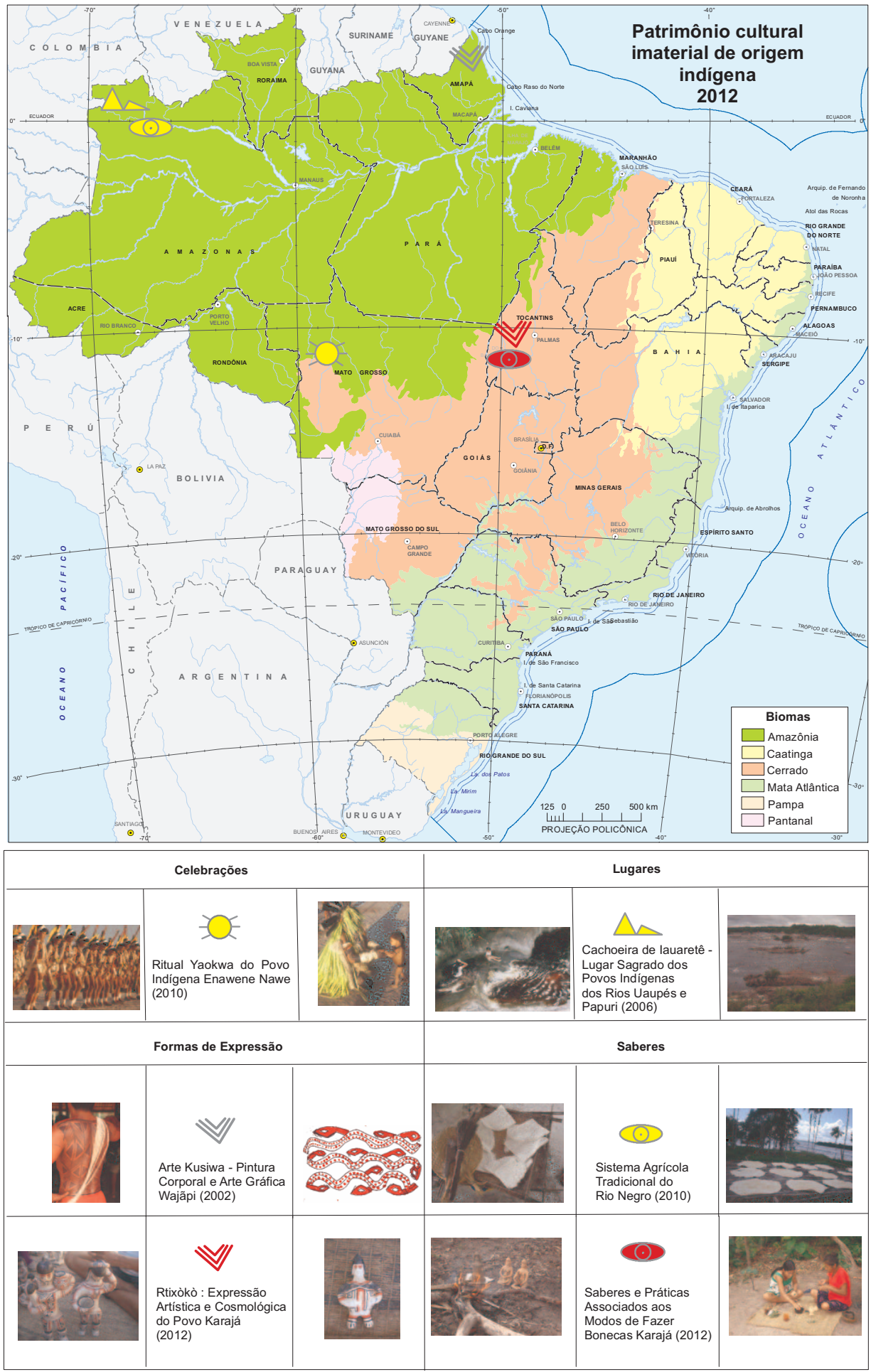

Fonte: Livros de registro. Rio de Janeiro: Instituto do Patrimônio Histórico e Artístico Nacional - IPHAN, 2016. Disponível em: <http://portal.iphan.gov.br/pagina/detalhes/122>. Acesso: jan. 2016.

Nota: Fotos: Acervo IPHAN. 
Em nível local, outros povos começam a promover sua identificação pelas expressões culturais, saberes e celebrações, além de lugares repletos de significados comuns, onde se renovam as tradições. À medida que se organizam e se fazem representar, outras populações podem enriquecer o indicador de patrimônio cultural, por meio da inscrição de novos bens materiais e imateriais. Quanto a um possível mapeamento da influência das culturas afro-brasileiras, a intensa miscigenação e o caldeirão cultural fazem com que alguns bens, de matriz africana, sejam considerados nacionais, como a capoeira, incluída com essa abrangência geográfica no Livro de Registro das Formas de Expressão, assim como o ofício do mestre de capoeira, incluído no Livro de Saberes do Patrimônio Imaterial do Brasil. A dimensão nacional da cultura das populações quilombolas também se revela na Constituição Federal de 1988, em seu Art. 216 (apresentado a seguir), item V, parágrafo 5, declara tombados "todos os documentos e os sítios detentores de reminiscências históricas dos antigos quilombos".

Atualmente, do Patrimônio Material do Brasil, quase metade (47\%) dos bens está inscrita no Livro do Tombo das Belas Artes, e $41 \%$ são bens históricos. O Livro do Tombo de Artes Aplicadas contém apenas cinco inscrições em todo o Brasil (quatro bens na Região Nordeste e um no Sul). Em comparação com o ano de 1938, o número de bens de belas artes tombados triplicou até 2012, totalizando 697, enquanto os bens históricos mais que quintuplicaram, chegando a 606 em 2012. Os bens da categoria arqueológico, etnográfico e paisagístico aumentaram bem mais significativamente, passando de quatro bens tombados no primeiro ano para 159 até 2012.

Já contemplados no anteprojeto da política de preservação de bens culturais elaborado, a pedido do governo federal por Mário de Andrade, escritor modernista e também pesquisador da cultura brasileira, no início do Século XX, os bens imateriais só passaram a ser objeto de registro a partir da edição do Decreto n. 3.551, de 04.08.2000. Mundialmente, a Convenção para a Salvaguarda do Patrimônio Cultural, da UNESCO, reconheceu, em 2006, não ser a cultura dos povos constituída só de aspectos físicos, abrindo espaço também para as tradições, o folclore, os saberes, as línguas, as festas, transmitidos oral ou gestualmente, ou seja, a porção intangível da cultura dos povos.

Os bens imateriais expressam uma visão mais ampla de patrimônio cultural, formalizada, no Brasil, nos Arts. 215 e 216 da Constituição Federal de 1988, que trouxeram um grande avanço ao estabelecer a necessidade de elaboração de outras formas de acautelamento e preservação, além do tombamento, para saberes tradicionais, incluindo formas de expressão, modos de criar, fazer e viver, obras, objetos, documentos, edificações e demais espaços destinados às manifestações artístico-culturais; sítios de valor histórico, paisagístico, artístico, arqueológico, paleontológico, ecológico e científico. O trecho referido da Constituição Federal de 1988 inclui, no conceito de cultura, as manifestações populares indígenas e afro-brasileiras, bem como de outros grupos dos diferentes segmentos étnicos da população "participantes do processo civilizatório nacional", abrindo novas possibilidades de monitoramento e de proteção da diversidade por sua expressão no patrimônio cultural.

Art. 215. O Estado garantirá a todos o pleno exercício dos direitos culturais e acesso às fontes da cultura nacional, e apoiará e incentivará a valorização e a difusão das manifestações culturais. 
$\S 1^{\circ} \mathrm{O}$ Estado protegerá as manifestações das culturas populares, indígenas e afro-brasileiras, e das de outros grupos participantes do processo civilizatório nacional.

$\S 2^{\circ}$ A lei disporá sobre a fixação de datas comemorativas de alta significação para os diferentes segmentos étnicos nacionais.

$\S 3^{\circ}$ A lei estabelecerá o Plano Nacional de Cultura, de duração plurianual, visando ao desenvolvimento cultural do País e à integração das ações do poder público que conduzem à:

I - defesa e valorização do patrimônio cultural brasileiro;

II - produção, promoção e difusão de bens culturais;

III - formação de pessoal qualificado para a gestão da cultura em suas múltiplas dimensões;

IV - democratização do acesso aos bens de cultura;

$\checkmark$ - valorização da diversidade étnica e regional.

Art. 216. Constituem patrimônio cultural brasileiro os bens de natureza material e imaterial, tomados individualmente ou em conjunto, portadores de referência à identidade, à ação, à memória dos diferentes grupos formadores da sociedade brasileira, nos quais se incluem:

I - as formas de expressão;

II - os modos de criar, fazer e viver;

III - as criações científicas, artísticas e tecnológicas;

IV - as obras, objetos, documentos, edificações e demais espaços destinados às manifestações artístico-culturais;

V - os conjuntos urbanos e sítios de valor histórico, paisagístico, artístico, arqueológico, paleontológico, ecológico e científico.

$\S 1^{\circ} \mathrm{O}$ poder público, com a colaboração da comunidade, promoverá e protegerá o patrimônio cultural brasileiro, por meio de inventários, registros, vigilância, tombamento e desapropriação, e de outras formas de acautelamento e preservação.

$\S 2{ }^{\circ}$ Cabem à administração pública, na forma da lei, a gestão da documentação governamental e as providências para franquear sua consulta a quantos dela necessitem.

$\S 3^{\circ} \mathrm{A}$ lei estabelecerá incentivos para a produção e o conhecimento de bens e valores culturais.

$\S 4^{\circ}$ Os danos e ameaças ao patrimônio cultural serão punidos, na forma da lei.

$\S 5^{\circ}$ Ficam tombados todos os documentos e os sítios detentores de reminiscências históricas dos antigos quilombos.

$\S 6^{\circ}$ É facultado aos Estados e ao Distrito Federal vincular a fundo estadual de fomento à cultura até cinco décimos por cento de sua receita tributária líquida, para o financiamento de programas e projetos culturais, vedada a aplicação desses recursos no pagamento de:

I - despesas com pessoal e encargos sociais;

II - serviço da dívida;

III - qualquer outra despesa corrente não vinculada diretamente aos investimentos ou ações apoiados. (BRASIL, 2009).

Assim como o Patrimônio Cultural Material informa sobre o povoamento e a colonização do Brasil, o Patrimônio Imaterial pode ser interpretado como o lugar natural de visibilidade das populações tradicionais, ainda que em alguns casos se tenha optado pelo tombamento 
como bens históricos; e arqueológicos, etnográficos e paisagísticos, como ocorreu com os bens de matriz africana entre 1986 e 2002. Os povos indígenas, por exemplo, em 2003, tiveram reconhecida a pintura corporal e arte gráfica Wajãpi, incluída primeiramente no Patrimônio Cultural Imaterial brasileiro. Sua visibilidade se ampliou quando esta forma de expressão foi declarada obra-prima da humanidade e, mais tarde, incluída na lista representativa do patrimônio mundial imaterial.

Quadro 7 - Patrimônio Imaterial, segundo os livros de registro de populações indígenas - Brasil - 2002/2012

\begin{tabular}{|l|c|}
\hline \multicolumn{1}{|c|}{ Patrimônio Imaterial } & Ano de inscrição \\
\hline Livro de Registro dos Saberes & 2010 \\
Sistema Agrícola Tradicional do Rio Negro & 2012 \\
Saberes e Práticas Associados aos Modos de Fazer Bonecas Karajá & 2002 \\
\hline$\quad$ Livro de Registro das Formas de Expressão & 2012 \\
Arte Kusiwa - Pintura Corporal e Arte Gráfica Wajãpi & 2010 \\
Rtixòkò: expressão artística e cosmológica do Povo Karajá & 2006 \\
\hline Livro de Registro das Celebrações & \\
Ritual Yaokwa do povo indígena Enawene Nawe & \\
\hline Livro de Registro dos Lugares & \\
Cachoeira de lauaretê - Lugar sagrado dos povos indígenas dos Rios Uaupés e Papuri & \\
\hline
\end{tabular}

Fonte: Instituto do Patrimônio Histórico Artístico Nacional - IPHAN.

Outros bens imateriais indígenas constituem sistemas profundamente enraizados na relação dessas populações com a natureza, mas em 2010, pela primeira vez, foi feito o registro de um sistema propriamente dito no Livro de Registro dos Saberes. O sistema agrícola tradicional do Rio Negro envolve cultura material, parentesco, rituais e celebrações, resultando em agrobioversidade, outra modalidade de diversidade que precisa encontrar seu caminho de preservação, diante da grave erosão genética causada pela homogeneização das espécies cultivadas (CUNHA, 2012).

Também o registro de dois bens distintos relacionados com os povos Karajá, do Brasil Central, em 2012, permitiu consagrar não apenas como conhecimentos os saberes e as práticas relacionadas ao modo de fazer bonecas Karajá, mas também incluiu no Livro de Registro das Formas de Expressão o próprio Rtixòkò: expressão artística e cosmológica dos Karajá, pois, em conjunto, esses bens constituem uma forma pela qual as crianças, novos membros da comunidade, aprendem o que é ser Karajá. As bonecas Karajá se integram ao cotidiano das populações indígenas das margens do Rio Araguaia e da Ilha do Bananal, confeccionadas a partir de conhecimentos tradicionais e recursos locais - como a argila, extraída de barreiros formados na vazante dos rios, e a tintura extraída do urucum, entre outras plantas envolvidas no processo, inclusive na produção das cinzas que se misturam à argila. 
A noção de patrimônio material e imaterial precisou ser diferenciada, como foi dito, mas não diferem verdadeiramente suas características de identificação, registro e conservação de bens em razão de sua representatividade e relação com identidades culturais nas respectivas escalas geográficas. Do mesmo modo, o patrimônio ambiental vem encontrando vários caminhos para aliar a conservação da diversidade biológica e cultural. Espera-se que a noção de sistema continue a orientar os encaminhamentos, tendo em vista o que preconiza o Plano Nacional de Cultura - PNC, instituído na Lei n. 12.343, de 02.12.2010, onde se recomenda a valorização da diversidade cultural e da cultura como vetor de desenvolvimento sustentável de um país cuja dimensão territorial e populacional contribui significativamente para torná-lo mais diverso e rico em termos de seu patrimônio cultural e natural da humanidade.

\section{Referências}

ALIMENTO: direito sagrado. Pesquisa Socioeconômica e Cultural de Povos e Comunidades Tradicionais de Terreiros. Brasília, DF: Ministério do Desenvolvimento Social e Combate à Fome, 2011. 200 p. Disponível em: <http://www.ideiasnamesa.unb.br/upload/bibliotecaldeias/ 04112015130257ok_Alimento_Direito_Sagrado_web.pdf>. Acesso em: jan. 2016.

ALTAFIN, I., VILAR, I. Novo Código Florestal mantém percentuais de reserva legal, mas isenta parte dos produtores da recomposição. Senado notícias, Brasília, DF: Senado Federal, 2011. Disponível em: <http://www12.senado.gov.br/noticias/materias/2011/12/07/novocodigo-florestal-mantem-percentuais-de-reserva-legal-mas-isenta-parte-dos-produtores-darecomposicao>. Acesso em: jan. 2016.

ANDRADE, M. de. Anteprojeto para a criação do Serviço do Patrimônio Artístico Nacional. Revista do Patrimônio Histórico e Artístico Nacional, Brasília, DF: IPHAN, n. 30, p. 270-287, 2002. Disponível em: <http://docvirt.no-ip.com/docreader.net/DocReader.aspx?bib=reviphan \&pagfis=10933 \&pesq=>. Acesso em: jan. 2016.

ÁREA dos biomas. In: IBGE. Sidra: sistema IBGE de recuperação automática. Rio de Janeiro, [2012]. IPCA dessazonalizado. tab. 3926. Disponível em: <http://www.sidra.ibge.gov.br/ bda/>. Acesso em: dez. 2012.

ÁREAS protegidas. Brasília, DF: Ministério do Meio Ambiente, Sistema Nacional de Unidades de Conservação - SNUC 2014. Disponível em: <http://www.mma.gov.br/areas-protegidas>. Acesso em: jan. 2016.

ÁREAS protegidas. Cadastro Nacional de Unidades de Conservação - CNUC. Brasília, DF: Ministério do Meio Ambiente, Sistema Nacional de Unidades de Conservação - SNUC 2014. Disponível em: <http://www.mma.gov.br/areas-protegidas>. Acesso em: jan. 2016.

BRASIL. Constituição (1988). Constituição da República Federativa do Brasil. Brasília, DF, [2009]. Disponível em: <http://www.presidencia.gov.br/legislacao> Acesso em: jan. 2016.

. Decreto n. 4.887, de 20 de novembro de 2003. Regulamenta o procedimento para identificação, reconhecimento, delimitação, demarcação e titulação das terras ocupadas por remanescentes das comunidades dos quilombos de que trata o art. 68 do Ato das 
Disposições Constitucionais Transitórias. Diário Oficial da União, Brasília, DF, ano 140, n. 227, 21. nov. 2003. Seção 1, p. 4-5. Disponível em: <http://www.presidencia.gov.br/ legislacao $>$. Acesso em: jan. 2016.

Decreto n. 6.040, de 7 de fevereiro de 2007. Institui a Política Nacional de Desenvolvimento Sustentável dos Povos e Comunidades Tradicionais. Diário Oficial da União, Brasília, DF, ano 144, n. 28, 8 fev. 2007a. Seção 1, p. 316-317. Disponível em: $<$ http://www.presidencia.gov.br/legislacao $>$. Acesso em: jan. 2016.

Lei n. 9.985, de 18 de julho de 2000. Regulamenta o artigo 225, parágrafo 1, incisos I, II, III e VII da Constituição Federal, institui o Sistema Nacional de Unidades de Conservação da Natureza e dá outras providências. Diário Oficial [da] República Federativa do Brasil, Brasília, DF, 19 jul. 2000. p. 1, c. 1. Disponível em: <http://www.presidencia.gov. br/legislacao>. Acesso em: jan. 2016.

Lei n. 12.343, de 2 de dezembro de 2010. Institui o Plano Nacional de Cultura PNC, cria o Sistema Nacional de Informações e Indicadores Culturais - SNIIC e dá outras providências. Diário Oficial da União, Poder Legislativo, Brasília, DF, ano 142, n. 231, 3 dez. 2010a. Seção 1, p. 1. Disponível em: <http://www.presidencia.gov.br/legislacao>. Acesso em: jan. 2016.

Ministério do Desenvolvimento Social e Combate à Fome. Guia de cadastramento de grupos populacionais tradicionais e específicos. Brasília, DF, 2012. Disponível em: <http:// mds.gov.br/assuntos/cadastro-unico/a-gestao-do-cadastro/processo-de-cadastramento/ cadastramento-diferenciado>. Acesso em: jan. 2016.

CENSO AGROPECUÁRIO 2006. Agricultura familiar: primeiros resultados. Brasil, grandes regiões e unidades da federação. Rio de Janeiro: IBGE, 2009. Disponível em: <http://www. ibge.gov.br/home/estatistica/economia/agropecuaria/censoagro/agri_familiar_2006_2/ apresentacao.shtm>. Acesso em: jan. 2016.

CENSO DEMOGRÁFICO 2010. Características da população e dos domicílios: resultados do universo. Rio de Janeiro: IBGE, 2011. Disponível em: <http://www.ibge.gov.br/home/ estatistica/populacao/censo2010/caracteristicas_da_populacao/default_caracteristicas_da_ populacao.shtm >. Acesso em: jan. 2016.

CONVENTION Concerning the Protection of the World Cultural and Natural Heritage. In: WORLD HERITAGE COMMITTEE, 38., Doha, 15-25 June 2014. Paris: United Nations Organization for Education, Science and Culture - Unesco, 2014. p. 135. Disponível em: <http://whc.unesco.org/archive/2014/whc14-38com-7B-en.pdf>. Acesso em: jan. 2016.

CUNHA, M. C. da. Questões suscitadas pelo conhecimento tradicional. Revista de Antropologia, São Paulo: Universidade de São Paulo - USP, v. 55, n. 1, p. 439-464, 06 nov. 2012. Disponível em: <http://www.revistas.usp.br/ra/article/view/46971/51311>. Acesso em: jan. 2016.

DECLARAÇÃO universal sobre a diversidade cultural. Brasília, DF: United Nations Organization for Education, Science and Culture - Unesco, 2002. Artigo 1. Disponível em: <http://unesdoc.unesco.org/images/0012/001271/127160por.pdf>. Acesso em: jan. 2016. 
DIEGUES, A. C. O mito moderno da natureza intocada. São Paulo: Hucitec, 1996. (Geografia: teoria e realidade; 35 ).

FLORESTAS tropicais, mitigação e adaptação às mudanças climáticas. Brasília, DF: Ministério do Meio Ambiente, Secretaria de Mudanças Climáticas e Qualidade Ambiental, abr. 2012. (Nota informativa n. 1). Disponível em: <http://www.mma.gov.br/redd/images/Publicacoes/ mma_notainformativa_01.pdf>. Acesso em: jan. 2016.

FREIRE, J. R. B. Rio Babel: a história das línguas na Amazônia. Rio de Janeiro: Ed. Uerj; Atlântica, 2004. (Coleção Brasilis).

GIESBRECHT, H. O.; SCHWANKE, F. H.; MÜSSNICH, A. G. Indicações geográficas Brasileiras. Brasília, DF: Serviço Brasileiro de Apoio às Micro e Pequenas Empresas - Sebrae: Instituto Nacional da Propriedade Intelectual - INPI, 2011.

INDICADORES de desenvolvimento sustentável: Brasil 2012. Rio de Janeiro: IBGE, 2012. Disponível em: <http://www.ibge.gov.br/home/geociencias/recursosnaturais/ids/ default_2015.shtm>. Acesso em: jan. 2016.

INDICADORES de desenvolvimento sustentável: Brasil 2015. Rio de Janeiro: IBGE, 2015. Disponível em: <http://www.ibge.gov.br/home/geociencias/recursosnaturais/ids/ default_2015.shtm>. Acesso em: jan. 2016.

LÉVI-STRAUSS, C. Raça e cultura. In: Raça e história. Lisboa: Presença, 1973. (Universidade hoje, 14). p. 66. Disponível em: <http://charlezine.com.br/wp-content/ uploads/Ra\%C3\%A7a-e-Hist\%C3\%B3ria-L\%C3\%A9vi-Strauss.pdf>. Acesso em: jan. 2016. .

LISTA dos bens culturais inscritos nos livros do tombo (1938 - 2012). Rio de Janeiro: Instituto do Patrimônio Histórico Artístico Nacional - IPHAN, 2013. 157 p. Disponível em: <http://portal. iphan.gov.br/uploads/ckfinder/arquivos/guia\%20de\%20bens\%20tombados\%20atualizado\%20 em\%202012.pdf>. Acesso em: jan. 2016.

LIVROS de registro. Rio de Janeiro: Instituto do Patrimônio Histórico e Artístico Nacional - IPHAN, 2016. Disponível em: <http://portal.iphan.gov.br/pagina/detalhes/122>. Acesso: jan. 2016.

MACHADO, A. B. M.; DRUMMOND, G. M.; PAGLIA, A. P. (Ed.). Livro vermelho da fauna brasileira ameaçada de extinção. Brasília, DF: Ministério do Meio Ambiente, 2008. 2 v. (Biodiversiadede, 19). Disponível em: $<$ http://www.mma.gov.br/publicacoes/biodiversidade/ category/55-especies-ameacadas-de-extincao >. Acesso em: jan. 2016.

MACHADO, A. B. M.; DRUMMOND, G. M.; PAGLIA, A. P. A fauna brasileira ameaçada de extinção: síntese taxonômica e geográfica. In: . (Ed.). Livro vermelho da fauna brasileira ameaçada de extinção. Brasília, DF: Ministério do Meio Ambiente; Belo Horizonte: Fundação Biodiversitas, 2008. (Biodiversidade, 19). V. 1. p. 63. Disponível em: <http://www. mma.gov.br/publicacoes/biodiversidade/category/55-especies-ameacadas-de-extincao $>$. Acesso em: jan. 2016. 
MAPA de biomas do Brasil. Rio de Janeiro: IBGE, 2004a. 1 mapa, color. Escala 1: 5.000.000; proj. policônica. Disponível em: <ftp://ftp.ibge.gov.br/Cartas_e_Mapas/Mapas_Murais/>. Acesso em: jan. 2016.

MAPA de vegetação do Brasil. Rio de Janeiro: IBGE, 2004b. 1 mapa, color. Escala 1:5 000 000. Projeção policônica. Disponível em: <ftp://ftp.ibge.gov.br/Cartas_e_Mapas/ Mapas_Murais/>. Acesso em: jan. 2016.

MEGADIVERSIDADE. Belo Horizonte: Conservação Internacional - Cl Brasil, v. 1-5, 20052009. Disponível em: <http://www.conservation.org/global/brasil/publicacoes/Pages/ revista-megadiversidade.aspx>. Acesso em: jan. 2016.

MORAES, A. C. R. Geografia: pequena história crítica. 13. ed. São Paulo: Hucitec, 1994. $138 \mathrm{p}$.

OLIVEIRA, L. Composição vegetal dos biomas continentais brasileiros, 2004. Quadro apresentado no material didático da disciplina "Vegetação e Biomas Brasileiros", ministrada no curso de Especialização em Análise Ambiental e Gestão do Território da Escola Nacional de Ciências Estatísticas - ENCE em 2004.

PÁDUA, J. A. Natureza e projeto nacional: as origens da ecologia política no Brasil. In: Ecologia e política no Brasil. 2. ed. Rio de Janeiro: Espaço e Tempo: Instituto Universitário de Pesquisas do Rio de Janieor - IUPERJ, 1987.

PATRIMÔNIO mundial no Brasil. Brasília, DF: Organização das Nações Unidas para a Educação, a Ciência e a Cultura - Unesco Brasil, [2015]. Disponível em: <http://www.unesco. org/new/pt/brasilia/culture/world-heritage/list-of-world-heritage-in-brazil/\#c1048555>. Acesso em: jan. 2016.

PESQUISA Socioeconômica e Cultural de Povos e Comunidades Tradicionais de Terreiros: síntese de Resultados. In: ALIMENTO: direito sagrado. Pesquisa Socioeconômica e Cultural de Povos e Comunidades Tradicionais de Terreiros. Brasília, DF: Ministério do Desenvolvimento Social e Combate à Fome, 2011. p. 138. Disponível em: <http://www.ideiasnamesa.unb. br/upload/bibliotecaldeias/04112015130257ok_Alimento_Direito_Sagrado_web.pdf>. Acesso em: jan. 2016.

POVOS do cerrado. Brasília, DF: Pesquisa e Conservação do Cerrado - PEQUI, [2006]. Disponível em: <http://www.pequi.org.br/povos.html>. Acesso em: jan. 2016.

RESERVA da biosfera. In: ÁREAS protegidas. Ações e iniciativas. Gestão territorial para a conservação. Brasília, DF: Ministério do Meio Ambiente, 2014. Disponível em: <http:// www.mma.gov.br/areas-protegidas $>$. Acesso em: jan. 2016.

RIBEIRO, D. O povo brasileiro: a formação e o sentido do Brasil. São Paulo: Companhia das Letras, 1995. $470 \mathrm{p}$.

ROCHE, J. A colonização alemã no Espírito Santo. São Paulo: Difusão Europeia do Livro: EdUSP, 1968. 367 p. (Corpo e Alma do Brasil, 28.).

SAMPAIO, T. O tupi na geografia nacional. 2. ed. São Paulo: Pensamento, 1914. 
SANTILLI, J. Socioambientalismo e novos direitos: proteção jurídica à diversidade biológica e cultural. São Paulo: Peirópolis: Instituto Socioambiental; Brasília, DF: Instituto Internacional de Educação do Brasil, 2005. 303 p. Originalmente apresentada como dissertação de Mestrado na Universidade de Brasília - UnB, Brasília, DF, 2004.

SANTILLI, J. Agrobiodiversidade e direitos dos agricultores. São Paulo: Peirópolis, 2009. 519 p. SHIRAISHI NETO, J. (Org.). Direito dos povos e das comunidades tradicionais no Brasil: declarações, convenções internacionais e dispositivos jurídicos definidores de uma política nacional. Manaus: Universidade Federal do Amazonas - UFAM, Programa de PósGraduação em Sociedade e Cultura na Amazônia - PPGSCA; Fundação Ford, 2007. 230 p. (Coleção documentos de bolso, n. 1). Disponível em: <http://novacartografiasocial.com/? wpdmact=process\&did=MjEuaG90bGluaw==>. Acesso em: jan. 2016.

SILVA, J. A. da. Direito ambiental constitucional. São Paulo: Malheiros, 2007. 6. ed.

UNIDADES de conservação. Brasília, DF: Ministério do Meio Ambiente, Instituto Chico Mendes de Conservação da Biodiversidade - ICMBio, 2014. Disponível em: <http://www. icmbio.gov.br/portal/biodiversidade/unidades-de-conservacao/biomas-brasileiros.html>. Acesso em: jan. 2016.

WAINER, A. H. Legislação ambiental brasileira, subsídios para a história do direito ambiental. 2. ed. Rio de Janeiro: Forense, 1999.

WANDSCHEER, C. B. Integração e proteção das comunidades de remanescentes de quilombos com base nos princípios e normas constitucionais brasileiras: uma questão de justiça social. In: LIBERATO, A. P. Direito socioambiental em debate. Curitiba: Juruá, 2006. p. 37-68. 


\section{Equipe técnica}

Nossa homenagem especial ao Professor Judicael Clevelário Júnior, que, durante os 13 anos em que atuou na Coordenação de Recursos Naturais e Estudos Ambientais da Diretoria de Geociências (2002 a 2015), deixou gravada na memória do IBGE a imagem de servidor exemplar, pesquisador acurado - entusiasta, principalmente, dos temas ligados à Ecologia e ao Meio Ambiente - e amigo inesquecível. Biólogo e Estatístico, graduou-se na Universidade Federal do Rio de Janeiro - UFRJ e na Escola Nacional de Ciências Estatísticas - ENCE, em 1983 e 1985, respectivamente, obtendo Mestrado em Geociências/Geoquímica na Universidade Federal Fluminense - UFF e Doutorado em Agronomia/Solos e Nutrição de Plantas na Universidade Federal de Viçosa - UFV, em 1988 e 1995, respectivamente, sendo um estudioso incansável.

Judicael ingressou no IBGE em 2002, como Tecnologista em Informações Geográficas e Estatísticas, trazendo experiência significativa, nos setores público e privado, com destaque na consultoria científica e no magistério. No Instituto, integrou variadas equipes de trabalho, sempre pronto a partilhar seus múltiplos e consistentes conhecimentos e ajudar a todos. Foi Gerente dos Indicadores de Desenvolvimento Sustentável - IDS, coordenando a Dimensão Ambiental desse estudo. Participante ativo de congressos nacionais e internacionais, com apresentação de trabalhos, colaborou em várias publicações acadêmicas e científicas, além de relatórios e estudos de impacto ambiental.

A Judicael (1961-2015), nossa saudade e nosso reconhecimento.

\section{Diretoria de Geociências}

\section{Coordenação de Geografia}

Claudio Stenner

\section{Organização geral da publicação}

Adma Hamam de Figueiredo 


\section{Elaboração dos textos}

Formação territorial

Adma Hamam de Figueiredo

Breve histórico do processo demográfico Celso Cardoso da Silva Simões

A delimitação legal dos espaços urbanos Maria Helena Palmer Lima

Padrões espaciais de serviços avançados de apoio às empresas na rede urbana brasileira Marcelo Paiva da Motta Ronaldo Cerqueira Carvalho

Evolução do espaço rural brasileiro Luiz Sérgio Pires Guimarães

Recursos naturais e questões ambientais Betânia Tarley Porto de Matos Góes

Elisabeth Kohnert Linhares

Eloísa Domingues

José Enilcio Rocha Collares

Judicael Clevelário Júnior (Coordenação do capítulo)

Lindinalva Mamede

Luiz Carlos Aveline

Mauro César Lambert de Brito Ribeiro

Paula Teresina Tudesco Macedo de Oliveira

Pedro Edson Leal Bezerra

Pedro Francisco Teixeira Kaul

Rogério de Oliveira Rosa

Ronaldo Marquete

Rosangela Garrido Machado Botelho (Coordenação do capítulo)

Virlei Álvaro de Oliveira

Uma contribuição à geografia dos recursos hídricos

Eugênio Antônio de Lima

Hellen Cano

José Antônio Sena do Nascimento

Desenvolvimento local sustentável e governança ambiental

Denise Maria Penna Kronemberger

Valéria Grace Costa

Diversidade e patrimônio cultural

Ana Maria Goulart Bustamante

Jorge Kleber Teixeira Silva

\section{Geoprocessamento}

Cleber de Azevedo Fernandes

Gustavo Medeiros de Pinho
Jorge Kleber Teixeira Silva

José Aldo Gonçalves Coutinho

José Carlos Louzada Morelli

Ricart Normandie Ribeiro Junior

\section{Colaboradores}

Ailton Antônio Baptista de Oliveira

Andrey Rosenthal Schlee (Diretor do Departamento de Patrimônio Material e Fiscalização, do Instituto do Patrimônio Histórico e Artístico Nacional - IPHAN)

Carlos José Galvão Corrêa (SEDuc-RJ)

Célia Maria Corsino (Diretora do Departamento de Patrimônio Imaterial, do IPHAN)

Claudia Lellis Callado Anciães

Glória Vanicore Ribeiro

Ingrid Souza de Freitas (Estagiária)

Jorge Kleber Teixeira Silva

Luciana Mara Temponi de Oliveira

Mônica Silvestrin (Coordenadora-Geral de Identificação e Registro, do IPHAN)

Patrícia Goulart Bustamante (Empresa Brasileira de Pesquisa Agropecuária - EMBRAPA-DF)

Rogério Botelho de Mattos

Roberto Augusto Soares Pereira Duarte

Thaynnah Santos Castro da Silva (Estagiária)

\section{Projeto Editorial}

\section{Centro de Documentação e Disseminação de Informações}

\section{Coordenação de Produção}

Marise Maria Ferreira

\section{Gerência de Editoração}

Estruturação textual, tabular e de gráficos Beth Fontoura

Katia Vaz Cavalcanti

Marisa Sigolo

Diagramação tabular e de gráficos Beth Fontoura

Mônica Pimentel Cinelli Ribeiro

Maria da Graça Fernades de Lima

Copidesque e revisão

Anna Maria dos Santos

Kátia Domingos Vieira

\section{Diagramação textual}

Solange Maria Mello de Oliveira 
Programação visual da publicação

Marisa Sigolo

Mônica Pimentel Cinelli Ribeiro

Tratamento de imagens

Fernanda Maciel Jardim

Produção do e-book

Roberto Cavararo

\section{Gerência de Documentação}

Pesquisa e normalização bibliográfica

Ana Raquel Gomes da Silva

Edgar de Albuquerque Santanna (Estagiário)

Elizabeth de Carvalho Faria

Karina Pessanha da Silva (Estagiária)

Lioara Mandoju

Nadia Bernuci dos Santos

Solange de Oliveira Santos

Vera Lúcia Punzi Barcelos Capone

Padronização de glossários

Ana Raquel Gomes da Silva

Elaboração de quartas capas

Ana Raquel Gomes da Silva

\section{Gerência de Gráfica}

Impressão e acabamento

Maria Alice da Silva Neves Nabuco

\section{Gráfica Digital}

Impressão

Ednalva Maia do Monte 


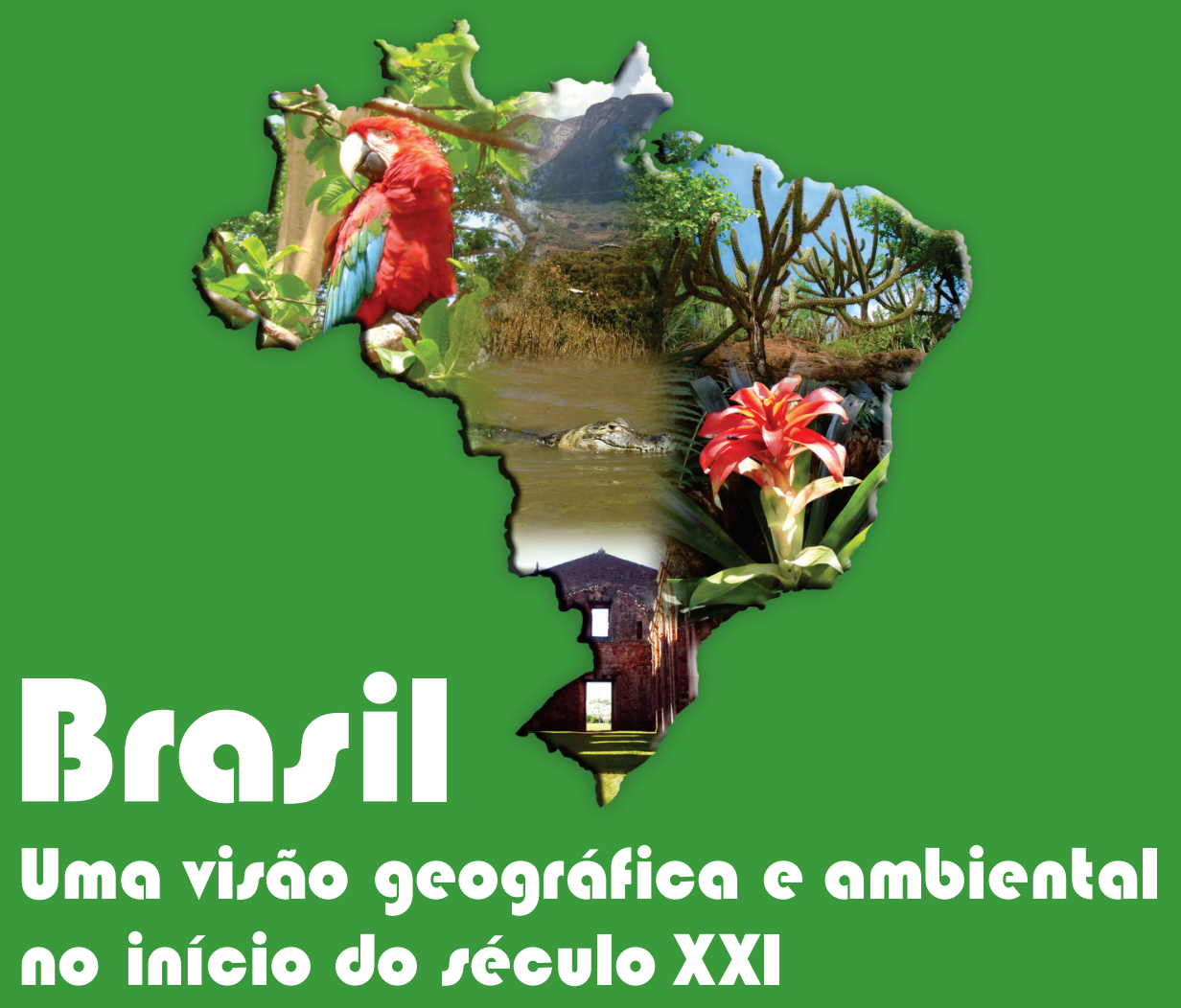

Se, até o Século XX, a análise do espaço geográfico brasileiro passava pelo grande movimento de estruturação do Território Nacional, marcado pelos processos de industrialização e urbanização e pela constituição de um sistema econômico nacionalmente integrado, atualmente essa análise percorre diversas perspectivas de observação, algumas das quais o IBGE tem a satisfação de oferecer ao público na presente obra.

Organizada em nove capítulos, a publicação reúne estudos que gravitam em torno da formação territorial do Brasil, de seu processo demográfico, da formação de suas cidades e da evolução do espaço rural e das atividades agropecuárias, da questão ambiental, bem como das formas contemporâneas de vivenciar e gerir as múltiplas diversidades que identificam o Brasil no mundo.

Tais são os olhares que ajudam a decifrar o Brasil contemporâneo, que tem seu território rearticulado e, ao mesmo tempo, fragmentado continuamente a partir de interesses de toda ordem, provenientes das escalas global, nacional, regional e local. São eles, também, que tornam o conhecimento geográfico imprescindivel para se entender o presente e para prospectar o futuro de um País de dimensões continentais, cuja análise impõe a releitura de realidades regionais em constante transformação.

Esta publicação, também disponibilizada no portal do IBGE na Internet, visa ampliar o conhecimento das expressivas alterações verificadas no território brasileiro como resultado das transformações econômicas, demográficas, políticas e ambientais ocorridas nas últimas décadas.
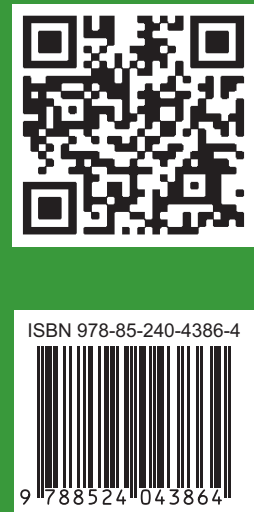